JOANNA STAWSKA

\title{
Stopy procentowe a inwestycje w Polsce i strefie euro
}


盗 


\section{JOANNA STAWSKA}

\section{Stopy procentowe a inwestycje w Polsce i strefie euro}


Joanna Stawska - Uniwersytet Łódzki, Wydział Ekonomiczno-Socjologiczny Instytut Finansów, Zakład Bankowości Centralnej i Pośrednictwa Finansowego 90-214 Łódź, ul. Rewolucji 1905 r. nr 39

\author{
RECENZENT \\ Mirostaw Wypych \\ SKŁAD KOMPUTEROWY \\ Monika Wolska \\ PROJEKT OKŁADKI \\ Barbara Grzejszczak
}

Wydrukowano z gotowych materiałów dostarczonych do Wydawnictwa UŁ
przez Wydział Ekonomiczno-Socjologiczny

Publikacja finansowana w ramach projektu na badania młodych naukowców i doktorantów numer projektu (545/1057) (B1311200000378.02)

C Copyright by Uniwersytet Łódzki, Łódź 2014

Wydane przez Wydawnictwo Uniwersytetu Łódzkiego

Wydanie I. W.06397.13.0.D

ISBN (wersja drukowana) 978-83-7969-062-6

ISBN (wersja elektroniczna) 978-83-7969-090-9
Wydawnictwo Uniwersytetu Łódzkiego
90-131 Łódź, ul. Lindleya 8
www.wydawnictwo.uni.lodz.pl
e-mail: ksiegarnia@uni.lodz.pl

tel. (42) 66558 63, faks (42) 6655862 


\section{SPIS TREŚCI}

Wstęp

Rozdział 1. Specyfika banku centralnego jako podmiotu badań ekonomicznych w kontekście polityki pieniężnej

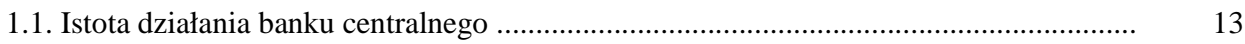

1.1.1. Europejski Bank Centralny w kontekście integracji monetarnej ......................... 14

1.1.2. Niezależność banku centralnego ...................................................................... 20

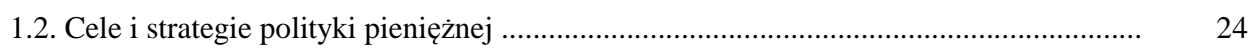

1.2.1. Strategia polityki pieniężnej Europejskiego Banku Centralnego .......................... 27

1.2.2. Strategia polityki pieniężnej Narodowego Banku Polskiego .............................. 31

1.3. Znaczenie procesów integracyjnych dla polityki pieniężnej NBP ................................ 36

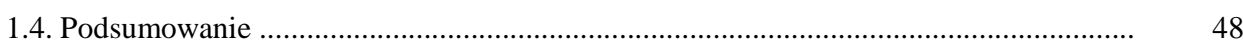

Rozdział 2. Oddziaływanie banku centralnego na sektor bankowy i gospodarkę w świetle badań

2.1. Mechanizm transmisji impulsów polityki pieniężnej

2.1.1. Kanał tradycyjny stóp procentowych mechanizmu transmisji impulsów polityki pieniężnej

2.1.2. Kanał kredytowy oraz bilansowy mechanizmu transmisji impulsów polityki pieniężnej

2.1.3. Kanał kursowy mechanizmu transmisji impulsów polityki pieniężnej ................ 57

2.1.4. Kanał giełdowy mechanizmu transmisji impulsów polityki pieniężnej ............... 59

2.1.5. Czynniki wpływające na mechanizm transmisji polityki pieniężnej .................... 61

2.2. Przegląd badań dotyczących wpływu polityki pieniężnej na gospodarkę ...................... 69

2.3. Metody realizacji polityki pieniężnej Europejskiego Banku Centralnego i Narodowego Banku Polskiego

2.3.1. Polityka operacji otwartego rynku Europejskiego Banku Centralnego i Narodowego Banku Polskiego

2.3.2. Polityka operacji depozytowo-kredytowych Europejskiego Banku Centralnego i Narodowego Banku Polskiego .....

2.3.3. Polityka rezerwy obowiązkowej Europejskiego Banku Centralnego i Narodowego Banku Polskiego 
Rozdział 3. Dorobek teoretyczny w naukach ekonomicznych dotyczący stóp procentowych

3.1. Teorie pieniądza i stóp procentowych w ujęciu chronologicznym

3.1.1. Teoria preferencji płynności pieniądza i stóp procentowych w ujęciu ekonomii keynesowskiej

3.1.2. Teoria monetarystyczna

3.1.3. Teoria funduszy pożyczkowych stóp procentowych 97

3.1.4. Teorie terminowej struktury stóp procentowych 99

3.2. Polityka stóp procentowych banku centralnego

3.2.1. Stopy procentowe Europejskiego Banku Centralnego oraz Narodowego Banku Polskiego

3.2.2. Znaczenie stóp procentowych w gospodarce

3.2.3. Stopa referencyjna jako podstawowa stopa banku centralnego oraz jej wpływ na poziom stóp rynku międzybankowego

3.3. Czynniki wpływające na wysokość stóp procentowych banku centralnego

3.3.1. Wpływ polityki fiskalnej na decyzje banku centralnego

3.3.2. Nadpłynność sektora bankowego jako czynnik utrudniający prowadzenie polityki pieniężnej

3.3.3. Wpływ inflacji na decyzje banku centralnego .....

3.4. Stopy procentowe a kurs walutowy

3.5. Stopy procentowe a kryzys finansowy

3.6. Podsumowanie

Rozdział 4. Istota inwestycji przedsiębiorstw i ich finansowanie za pomocą kredytu bankowego

4.1. Znaczenie przedsiębiorstw $\mathrm{w}$ gospodarce

4.2. Istota i poziom inwestycji przedsiębiorstw 136

4.2.1. Czynniki wpływające na poziom inwestycji przedsiębiorstw 141

4.2.2. Źródła finansowania inwestycji przedsiębiorstw

4.3. Kredyt bankowy jako forma finansowania przedsiębiorstw

4.4. Czynniki wpływające na ceny kredytów dla przedsiębiorstw.

4.5. Podsumowanie

Rozdział 5. Uwarunkowania i realizacja polityki pieniężnej a poziom inwestycji w latach 1998-2009 - studium przypadku

5.1. Polityka pieniężna Europejskiego Banku Centralnego na tle sytuacji gospodarczej w latach 1998-2009 
5.2. Zadłużenie kredytowe przedsiębiorstw w bankach komercyjnych oraz nakłady inwestycyjne podmiotów gospodarczych w strefie euro w latach 1998-2009

5.3. Polityka pieniężna Narodowego Banku Polskiego na tle sytuacji gospodarczej w latach 1998-2009

5.4. Zadłużenie kredytowe przedsiębiorstw w bankach komercyjnych oraz nakłady inwestycyjne podmiotów gospodarczych w Polsce w latach 1998-2009 .....

5.5. Podsumowanie

Rozdział 6. Analiza zależności inwestycji od stopy referencyjnej banku centralnego na podstawie badań empirycznych w latach 1998-2009 - studium przypadku

6.1. Metodyka badań empirycznych oraz specyfika metod badawczych

6.2. Źródła danych wykorzystanych w badaniach empirycznych

6.3. Weryfikacja empiryczna wpływu stopy referencyjnej EBC na inwestycje w strefie euro - modelowanie ekonometryczne

6.3.1. Estymacja oraz weryfikacja statystyczna (model 1 dla strefy euro)

6.3.2. Estymacja oraz weryfikacja statystyczna (model 2 dla strefy euro)

6.3.3. Analiza stacjonarności

6.4. Weryfikacja empiryczna wpływu stopy referencyjnej NBP na inwestycje w Polsce - modelowanie ekonometryczne

6.4.1. Estymacja oraz weryfikacja statystyczna (model 1 dla Polski)

6.4.2. Estymacja oraz weryfikacja statystyczna (model 2 dla Polski)

6.4.3. Estymacja oraz weryfikacja statystyczna (model 3 dla Polski)

6.4.4. Analiza stacjonarności zmiennych

6.5. Wnioski

Zakończenie

Bibliografia

Spis tabel

Spis rysunków

Spis wykresów

Spis schematów

Spis wzorów 



\section{WSTĘP}

Niniejsza monografia stanowi fragment pracy doktorskiej pt.: „Wpływ stóp procentowych NBP i EBC na inwestycje przedsiębiorstw w Polsce i strefie euro" napisanej pod kierunkiem prof. dr hab. Iwony Doroty Czechowskiej w Zakładzie Bankowości Centralnej i Pośrednictwa Finansowego Uniwersytetu Łódzkiego.

Polityka pieniężna jest istotnym elementem polityki gospodarczej, a stopy procentowe, na które wpływają władze monetarne pełnią w niej szczególną rolę. Jak wskazywał jeden z czołowych ekonomistów J. M. Keynes stabilne stopy procentowe stanowią zachętę do długoterminowych decyzji inwestycyjnych, chociażby poprzez ograniczenie niepewności na rynkach finansowych. Z kolei jego następcy - neokeynesiści eksponowali znaczenie stóp procentowych w gospodarce, podkreślając koszt użytkowania kapitału, który poprzez poziom stóp procentowych oddziałuje na wielkość inwestycji. Wpływ stóp procentowych banku centralnego na inwestycje w gospodarce stanowi przedmiot wielu kontrowersji. $Z$ jednej strony ekonomiści tacy jak np. J. Taylor, M. Keynes twierdzili, że związek ten jest istotny. $Z$ drugiej strony pojawili się zwolennicy teorii przekonujących o braku silnej zależności między inwestycjami przedsiębiorstw a kosztem kapitału (B. Bernanke, M. Gertler), którzy upatrywali występowania tych zależności wobec cen i płac. Oprócz rozważań teoretycznych prowadzono także badania empiryczne dotyczące zależności między poziomem stóp procentowych i inwestycji. I tak np. Ch. J. Erceg i A. T. Levin oraz K. Kuttner i P. Mosser wykazali, że stopy procentowe oddziałują silnie na budownictwo mieszkaniowe i słabiej na inwestycje przedsiębiorstw.

Kształtowanie stóp procentowych jest istotnym sposobem oddziaływania banku centralnego na sferę realną gospodarki. Analiza zależności inwestycji od stopy procentowej nie należy do prostych zadań, przede wszystkim z powodu braku jednoznacznych powiązań zmiennych. Wynika to z faktu, że na wyróżnione zjawisko wpływają różne przyczyny o mniejszej lub większej sile oddziaływania (np. poziom inflacji oraz oczekiwania inflacyjne, substytucja kredytu krajowego przez inne źródła finansowania inwestycji, stopień monetyzacji w gospodarce, system fiskalny, płynność sektora bankowego, przepływ kapitału pomiędzy krajami, poziom rozwoju rynku kapitałowego). Pomimo problemów 
dotyczących wielu parametrów wpływających jednocześnie na decyzje banku centralnego i na decyzje inwestycyjne podmiotów gospodarczych wydaje się, że warto zbadać, w jakim stopniu stopa referencyjna banku centralnego oddziałuje na inwestycje. Przedmiotem zainteresowania może być także analiza siły, kierunku oraz okresu opóźnień, po jakim widoczne jest oddziaływanie stopy referencyjnej na gospodarkę, w tym głównie na inwestycje.

Prowadzenie efektywnej polityki pieniężnej jest uwarunkowane szczególną znajomością mechanizmów oddziaływania i sprawnością działania banku centralnego. Dla zwiększenia tej skuteczności potrzebna jest analiza krajowych doświadczeń i doświadczeń strefy euro, także ze względu na ewentualne przystąpienie Polski do Eurosystemu i powierzenie Europejskiemu Bankowi Centralnemu (EBC) prowadzenia polityki pieniężnej.

Celem niniejszej monografii jest zbadanie wpływu realizacji polityki stopy referencyjnej banku centralnego na inwestycje przy uwzględnieniu uwarunkowań zewnętrznych i wewnętrznych polityki pieniężnej w Polsce i strefie euro w latach 1998-2009. Ponadto w pracy postawiono hipotezę, że stopa referencyjna banku centralnego wpływa odwrotnie proporcjonalnie na poziom inwestycji przedsiębiorstw, zarówno w Polsce jak i strefie euro.

W celu zbadania wpływu stopy procentowej na nakłady inwestycyjne przedsiębiorstw w Polsce oraz w strefie euro zostały wykorzystane dane za okres 1998-2009, pochodzące z opracowań EBC oraz NBP takich jak np.: Raport o inflacji, Raport o rozwoju systemu finansowego, Raport o stabilności systemu finansowego, Instrumenty polityki pieniężnej NBP, Sytuacja na rynku kredytowym, Założenia polityki pieniężnej oraz Strategia polityki pieniężnej, Sprawozdania $z$ wykonania założeń polityki pieniężnej oraz opracowań tematycznych zawartych w np.: „Materiały i Studia”, „Bank i Kredyt”, a także publikacji EBC (Biuletyn miesięczny EBC, Raport roczny). Ponadto zostały wykorzystane do badań roczniki statystyczne i biuletyny Głównego Urzędu Statystycznego, raporty Ministerstwa Finansów, raporty Polskiej Agencji Rozwoju Przedsiębiorczości, (takie jak: Raport o stanie sektora MSP w Polsce, czy Biuletyn Informacji Publicznej), opracowania Eurostatu, statystyki OECD oraz inne dostępne źródła statystyczne.

W pracy zastosowano modelowanie ekonometryczne. Estymacja parametrów modelu ekonometrycznego dokonana została metodą najmniejszych kwadratów. Wykorzystano jednorównaniowy, autoregresyjny model ekonometryczny, na podstawie kwartalnych danych statystycznych obejmujących lata 1998 -2009. W związku z występowaniem w rzeczywistości gospodarczej opóźnień w reakcji przedsiębiorstw na decyzje banku centralnego, w badaniu zostały wykorzystane przesunięcia czasowe. Stosując opóźnienia zbadana została m. in. zależność wzrostu realnych nakładów inwestycyjnych od nakładów inwestycyjnych z poprzednich kwartałów, ponieważ poziom inwestycji z przeszłości decyduje o realizowanych inwestycjach bieżących. Rozważono kilka wariantów 
równania w celu zaobserwowania wpływu zestawu różnych zmiennych objaśniających na zmienną objaśnianą. Ponadto przeprowadzono badanie współczynnika korelacji Pearsona oraz współczynnika determinacji $R^{2}$ pomiędzy odpowiednimi zmiennymi w Polsce i strefie euro.

W związku z tym, że w gospodarce występuje wiele zakłóceń, wzajemnych zależności pomiędzy poszczególnymi zmiennymi oraz opóźnień wynikających z mechanizmu transmisji polityki monetarnej do gospodarki, które utrudniają zbadanie bezpośredniej zależności nakładów inwestycyjnych od stopy referencyjnej banku centralnego, przeprowadzono analizę uwarunkowań polityki pieniężnej prowadzonej przez EBC i NBP w okresie 1998-2009.

Zakres czasowy badań obejmował okres od 1998 do 2009 r. i przedział podmiotowy. Za początek tego okresu badawczego przyjęto rok 1998, ponieważ na mocy Ustawy o NBP z 29 sierpnia 1997 r. (obowiązującej od 1998 r.), bank centralny ustala założenia polityki pieniężnej i mechanizmy działania podstawowych instrumentów polityki pieniężnej poprzez nowy organ - Radę Polityki Pieniężnej. Od tego momentu rośnie rola polityki pieniężnej w gospodarce. Okres badawczy zakończono w 2009 r., ponieważ w czasie prowadzenia analiz były to najnowsze dostępne dane. W celu dokonania porównań badań dla Polski i strefy euro, okres badawczy dla EBC rozpoczęto również od 1998 r., co wynikało z uchwalenia struktur EBC w 1998 r. (i ustalenia po raz pierwszy poziomów stóp procentowych EBC w grudniu 1998 r.) oraz rozpoczęcia działalności Eurosystemu w 1999 r. Badania, tak jak w przypadku NBP, zakończono w 2009 r. Analiza empiryczna obejmująca lata 1998-2009 została przeprowadzona w formie studium przypadku.

W celu zachowania przejrzystości rozważań praca została podzielona na dwie części - teoretyczną (rozdziały 1-4) oraz empiryczną (rozdziały 5-6).

$\mathrm{W}$ rozdziale 1 zaprezentowano pojęcia związane ze specyfiką polityki pieniężnej w Polsce i strefie euro. Przegląd teoretyczny rozpoczęto od przedstawienia istoty działania banku centralnego oraz uporządkowano pojęcia dotyczące strategii i celów polityki pieniężnej. W związku z integracją walutową, na której oparta jest strefa euro, podkreślono znaczenie procesów integracyjnych dla polityki pieniężnej.

W rozdziale 2 przedstawiono mechanizm transmisji impulsów polityki pieniężnej oraz czynniki mające wpływ na ten mechanizm. Ponadto ukazano metody realizacji polityki pieniężnej EBC oraz NBP. Opisano politykę operacji otwartego rynku, operacji depozytowo-kredytowych oraz rezerwy obowiązkowej stosowanych w strefie euro i Polsce.

Rozdział 3 poświęcono stopie procentowej, ze szczególnym uwzględnieniem stóp procentowych banków centralnych. Opisano teorie stóp procentowych w ujęciu ekonomii keynesowskiej i monetarystycznej, jak również teorie funduszy pożyczkowych oraz teorie terminowej struktury stóp procentowych. Zaprezentowano czynniki wpływające na wysokość stóp procentowych banku central- 
nego, takie jak: polityka fiskalna, nadpłynność sektora bankowego, poziom inflacji, kursy walutowe i inne.

W rozdziale 4 analizowano inwestycje przedsiębiorstw finansowane kredytem bankowym. Podkreślono znaczenie polityki pieniężnej banku centralnego w procesie ustalania oprocentowania kredytów z uwzględnieniem elementów wpływających na ceny kredytów oraz finansowanie aktywności inwestycyjnej przedsiębiorstw kredytem bankowym.

W rozdziale 5 przedstawiono uwarunkowania realizacji polityki pieniężnej w Polsce i strefie euro. W rozdziale tym zawarto również informacje dotyczące zadłużenia kredytowego przedsiębiorstw w bankach oraz poziomu nakładów inwestycyjnych w Polsce i Eurosystemie.

W rozdziale 6 wykorzystano teorię i problematykę zaprezentowaną w poprzednich rozdziałach książki. Ta część pracy prezentuje wyniki własnych badań empirycznych, wykorzystujących modele ekonometryczne i badania statystyczne. 


\title{
Rozdział 1
}

\section{SPECYFIKA BANKU CENTRALNEGO JAKO PODMIOTU BADAŃ EKONOMICZNYCH W KONTEKŚCIE POLITYKI PIENIĘŻNEJ}

\begin{abstract}
Współczesna polityka gospodarcza dąży do międzynarodowej integracji na wielu szczeblach swojej działalności. W związku z tym, że tematem niniejszej książki jest ocena wpływu polityki pieniężnej a dokładnie stóp procentowych na nakłady inwestycyjne w Polsce oraz w strefie euro, to szczególnie integracja monetarna nabiera w tym kontekście istotnego znaczenia, jako element międzynarodowej integracji gospodarczej. Ponadto polityka pieniężna w Polsce również może w przyszłości zależeć od decyzji na szczeblu międzynarodowym. Zatem warto podjąć próbę analizy oddziaływania polityki pieniężnej na gospodarkę szczególnie w warunkach integracji gospodarczej krajów. Procesy integracyjne w obszarze polityki pieniężnej oraz walutowej nie miałyby miejsca, gdyby nie działalność banków centralnych. Poza makroekonomiczną harmonizacją gospodarki polskiej z gospodarkami krajów Eurosystemu, istotnym warunkiem sprawnego włączenia i funkcjonowania w strukturze Unii Gospodarczej i Walutowej (UGiW) jest dostosowanie zasad funkcjonowania NBP do standardów obowiązujących w strefie euro. Dorównanie standardom i normom wypracowanym przez banki centralne Eurosystemu dotyczy dostosowań w obszarze organizacyjno-prawnym banków centralnych, jak również realizowanej przez nie polityki pieniężnej.
\end{abstract}

\subsection{Istota działania banku centralnego}

System bankowy pełni rolę jednego z najważniejszych segmentów systemu finansowego w gospodarce rynkowej. Rozwija się bardzo dynamicznie, szczególnie w polskiej gospodarce poddanej transformacji. Istotną rolę w systemie finansowym pełni bank centralny ${ }^{1}$. Model bankowości centralnej powstał

${ }^{1}$ Wł. Jaw orski, L., Zawadzka Z. (red.), Bankowość. Podręcznik akademicki, Poltext, Warszawa 2006, s. 30-31. 
w wyniku starań o utrzymanie równowagi pieniężnej oraz przeciwdziałania kryzysom finansowym gospodarki rynkowej. Banki centralne odpowiadają za stabilność i rozwój rynku pieniężno-kapitałowego, tworząc przez to warunki do sprawnej i efektywnej redystrybucji oszczędności w gospodarce ${ }^{2}$. Działalność banków centralnych oparta jest na relacjach między walutami krajowymi, stabilizacji kursów oraz zarządzaniu rezerwami dewizowymi ${ }^{3}$. W odniesieniu do pozostałych banków bank centralny ma nadrzędną pozycję i zazwyczaj posiada monopol na emisję pieniądza gotówkowego; dostarcza bankom komercyjnym pieniądza gotówkowego, udziela im pożyczek oraz reguluje rezerwy tych banków, prowadzi rozliczenia z rządem, obsługuje budżet państwa czy utrzymuje rezerwy państwowe, wpływa na stabilność rynków finansowych, występując jako kredytodawca ostatniej instancji, w sytuacji gdyby panika finansowa stanowiła zagrożenie dla stabilności całego systemu finansowego kraju udziela pożyczek bankom; odpowiada za realizację polityki pieniężnej danego kraju oddziałując na podaż pieniądza i kredytu w gospodarce ${ }^{4}$. Na przykładzie Europejskiego Banku Centralnego oraz Narodowego Banku Polskiego podjęto próbę przybliżenia działalności banku centralnego oraz jego znaczenia w gospodarce.

\subsubsection{Europejski Bank Centralny w kontekście integracji monetarnej}

Bankowość centralna państw Unii Europejskiej uległa zmianom w wyniku utworzenia wspólnego obszaru płatniczego opartego na integracji gospodarczej. Poprzez pojęcie międzynarodowej, a zarazem regionalnej integracji gospodarczej, rozumie się złożony proces powstawania pewnego organizmu gospodarczego, który obejmuje grupę krajów. Tak powiązane państwa, regiony czy nawet gałęzie gospodarki charakteryzują się wysokim stopniem wewnętrznych powiązań ekonomicznych. Osiągnięta przez nie wewnętrzna spoistość ekonomiczna wyróżnia je w wyraźny sposób z całokształtu gospodarki światowej ${ }^{5}$. Cel integracji gospodarczej sprowadza się nie tylko do decyzji politycznych, ideologicznych czy kulturalnych, ale do czysto ekonomicznych. Definicja integracji gospodarczej rozumiana jest jako proces oparty na rozwijaniu powiązań rzeczowych oraz instytucjonalno-instrumentalnych, w taki sposób, by wszystkim członkom danego ugrupowania integracyjnego przynosiły one korzyści w związ-

${ }^{2}$ A. Kaźmierczak, Polityka pieniężna $w$ gospodarce otwartej, Wydawnictwo Naukowe PWN, Warszawa 2008, s. 115.

${ }^{3}$ I. P y k a, Bank centralny na wspótczesnym rynku pieniężnym, dyscyplina regulacyjna, skuteczność, instrumenty, Wydawnictwo C. H. Beck, Warszawa 2010, s. 26-27.

${ }^{4}$ R. Milewski (red.), Podstawy ekonomii, Wydawnictwo Naukowe PWN, Warszawa 1999, s. 473.

${ }^{5}$ Z. K a me c ki, Pojecie i typy integracji gospodarczej, „Ekonomista” 1967, nr 1, s. 79. 
ku z racjonalizacją gospodarowania ${ }^{6}$. W literaturze wyróżnia się kilka etapów międzynarodowej, regionalnej integracji gospodarczej, np. B. Balassa wymienia następujące formy ${ }^{7}$ : strefa wolnego handlu, unia celna, wspólny rynek, unia walutowa i gospodarcza, unia polityczna.

Analizując fundamentalne podstawy unii gospodarczej i walutowej trzeba odwołać się do teorii optymalnych obszarów walutowych (optimum currency area), której istnienie zapoczątkował R. Mundell ${ }^{8}$. Rozważania na temat tej teorii kontynuowali między innymi R. I. McKinnon czy P. B. Kenen. Według teorii optymalnych obszarów walutowych, państwa, które zdecydują się zrezygnować $\mathrm{z}$ własnej narodowej waluty na rzecz waluty obowiązującej w danej unii monetarnej, powinny spełniać podstawowe warunki ekonomiczne. R. A. Mundell wymienia w ramach tych warunków przede wszystkim wysoki stopień elastyczności płac oraz wysoki stopień mobilności siły roboczej. Obszar walutowy spełniający powyższe warunki R. A. Mundell uważa za optymalny, ponieważ pozwala uniknąć trwałego wzrostu bezrobocia spowodowanego szokiem asymetrycznym ${ }^{9}$. Według niego gospodarka jest wtedy w stanie dostosować się do sytuacji szoku stabilizując zarówno poziom cen, jak i zatrudnienia ${ }^{10}$.

Współcześnie największym ugrupowaniem integracyjnym jest Unia Europejska (European Union - UE). W ramach jej struktur ustanowiono w 1999 r. Unię Gospodarczą i Walutową (UGiW - Economic and Monetary Union - EMU), rozpoczynając trzeci i ostatni etap tzw. Raportu Delorsa o stopniowej realizacji unii gospodarczej i walutowej. Jednak osiągnięcie tak zaawansowanego poziomu integracji poprzedzone było długoletnim procesem (traktat paryski, traktaty rzymskie) ${ }^{11}$. Istniała potrzeba silniejszej integracji gospodarczej głównie w sferze polityki pieniężnej oraz polityki fiskalnej, a także większej koordynacji polityk gospodarczych krajów członkowskich ${ }^{12}$. Pierwsze kroki ku tej koordynacji podjęto na szczycie Rady Europejskiej w 1969 r. w Hadze, deklarując wolę powołania na terenie Unii Europejskiej, Unii Gospodarczej i Walutowej. W tym

${ }^{6}$ J. Misala (red.), Proces integracji gospodarczej Polski z krajami członkowskimi Unii Europejskiej w świetle teorii, Wydawnictwo Politechniki Radomskiej, Radom 2001, s. 20.

${ }^{7}$ B. B a las s a, The theory of economic integration, George Allen and Unwin, London 1964, [za:] zasoby witryny internetowej: http://www.questia.com/PM.qst?a=o\&d=34589359 [10.10.2010].

${ }^{8}$ R. Mundell został uhonorowany Nagrodą Nobla w 1999 r. w dziedzinie ekonomii, za badania związane z teorią optymalnych obszarów walutowych.

${ }^{9}$ Szok asymetryczny - takie pogorszenie się sytuacji spowodowanej wahaniami koniunkturalnymi czy perturbacjami na rynkach światowych, które dotyka jeden tylko kraj z danego obszaru wspólnej waluty a pozostałe omija.

${ }^{10}$ R. A. Munde11, A Theory of Optimum Currency Areas, „The American Economic Review" 1961, vol. 9, s. 657.

${ }^{11}$ H. J. S ch eller, European Central Bank - history, role and functions, European Central Bank, Frankfurt n. Menem 2004, s. 16.

${ }^{12}$ K. Lutkowski, Od złotego do euro. Źródta obaw i nadziei, TWIGGER, Warszawa 2004, s. 9. 
celu została utworzona grupa ekspertów, która na czele z premierem i ministrem finansów Luksemburga, P. Wernerem miała przygotować plan stopniowego wprowadzania w życie unii gospodarczej i walutowej. W Raporcie Wernera ogłoszonym w 1970 r. planowano realizację wyżej wspomnianego celu w trzech etapach, w ciągu 10 lat, czyli do końca $1980 \mathrm{r}^{13}$

W wyniku pogorszenia koniunktury gospodarczej na świecie, na początku lat 70. XX w., załamania się systemu walutowego z Bretton Woods (1971 r.) oraz kryzysu naftowego (1973 r.), nie zrealizowano Planu Wernera. W praktyce istotnym rezultatem mającym swoje podstawy w Planie Wernera było utworzenie tzw. „węża walutowego"14, jako elementu systemu stabilizowania kursów między walutami państw EWG. Kolejnym krokiem ku integracji walutowej było powołanie przez Radę Europejską w 1978 r. w Brukseli, Europejskiego Systemu Walutowego (European Monetary System - ESW). Wprowadzono wtedy również wspólną jednostkę walutową - ECU ${ }^{15}$ (European Currency Unit), będącą pewnego rodzaju prekursorem wspólnej waluty - euro. Proces integracji walutowej został przyspieszony w momencie wejścia w życie 1 lipca 1987 r. Jednolitego Aktu Europejskiego - JAE (The Single European Act). Zakładano w nim, że do końca 1992 r. powstanie wspólnotowy Jednolity Rynek wśród krajów członkowskich EWG. W 1988 r. w Hanowerze, Rada Europejska powołała grupę specjalistów, którzy pod przewodnictwem J. Delorsa mieli opracować plan ${ }^{16}$ utworzenia unii gospodarczej i walutowej. Kolejnym aktem mającym istotne znaczenie dla integracji walutowej był Traktat o Unii Europejskiej z Maastricht. Powołano również Europejski Instytut Monetarny (European Monetary Institute - EMI), który był podstawą utworzenia Europejskiego Banku Centralnego (European Central Bank - ECB). Zadaniem Europejskiego Instytutu Monetar-

${ }^{13} \mathrm{~K} . \mathrm{S}$ ze l ą g, Integracja walutowa $w$ Europie Zachodniej w okresie powojennym, „Materiały i Studia" 2003, nr 166, s. 12-13.

14 „Wąż walutowy” opierał się na postanowieniu, że dopuszczalny przedział wahań kursów rynkowych będzie wynosił +/-2,25\% wokół kursów centralnych. Dodatkowo ustalono, że kursy walut krajów członkowskich w stosunku do dolara amerykańskiego będą w się wahać w przedziale 4,5\%, pozostając w tzw. „tunelu walutowym”. System stabilizowania kursów walutowych funkcjonował w latach 1972-1978, przy bardzo częstym składzie walut stabilizowanych w ramach tego systemu.

${ }^{15}$ Jednostka walutowa ECU, stanowiła koszyk składający się z określonej liczby walut krajów członkowskich. Jednocześnie wprowadzono również Europejski Mechanizm Kursowy (European Rate Mechanizm - ERM), w którym margines wahań między walutami wokół kursu centralnego ECU, określono w granicach $+/-2,25 \%$.

${ }^{16}$ Komitet Delorsa zdefiniował trzy etapy dochodzenia do unii gospodarczej i walutowej, jednak nie określił ram czasowych każdego etapu. Dopiero we wchodzącym w życie Traktacie o Unii Europejskiej z Maastricht, w dniu 1 stycznia 1993 r., określono terminy etapów integracji walutowej. Pierwszy etap rozpoczął się 1 lipca 1990 r. i trwał do 31 grudnia 1993 r. Drugi etap - od stycznia 1994 r. do 31 grudnia 1998 r., natomiast trzeci - od 1 stycznia 1999 r. do 30 czerwca $2002 \mathrm{r}$. 
nego było koordynowanie współpracy banków centralnych krajów członkowskich Europejskiego Systemu Walutowego ${ }^{17}$.

Trzeci etap tworzenia unii gospodarczej i walutowej rozpoczął się 1 stycznia 1999 r. Wtedy działalność rozpoczął Europejski Bank Centralny (EBC), który powołano jeszcze w czerwcu 1998 r. Utworzono w tym momencie również Europejski System Banków Centralnych (ESBC), którego centralną jednostką był EBC z siedzibą we Frankfurcie nad Menem, a uczestnikami banki centralne państw członkowskich Unii Europejskiej. Wraz z powstaniem od 1 stycznia 1999 r. Unii Gospodarczej i Walutowej wprowadzono jedną wspólną walutę - euro oraz zapoczątkowano prowadzenie ponadnarodowej polityki pieniężnej ${ }^{18}$.

Europejski Bank Centralny funkcjonuje zgodnie z Traktatem ustanawiającym Wspólnotę Europejską oraz Statutem Europejskiego Systemu Banków Centralnych i Europejskiego Banku Centralnego. W ten sposób powstała nowa struktura organizacyjna zwana Eurosystemem ${ }^{19}$, obejmująca kraje Unii Europejskiej, które weszły do UGiW. Strategie kształtowania polityki pieniężnej w strefie euro przejął EBC pozostawiając w gestii Narodowych Banków Centralnych ${ }^{20}$ wdrażanie decyzji EBC na szczeblach krajowych ${ }^{21}$. ESBC oraz Eurosystem nie posiadają osobowości prawnej, w przeciwieństwie do Europejskiego Banku Centralnego oraz Krajowych Banków Centralnych. Wśród zadań EBC wyróżniamy ${ }^{22}$ : formułowanie i realizację polityki pieniężnej UGiW (w ramach funkcji banku banków), prowadzenie wspólnej polityki emisyjnej (w ramach funkcji banku emisyjnego), dokonywanie operacji dewizowych, jak również przechowywanie i zarządzanie oficjalnymi rezerwami dewizowymi krajów Eurosystemu oraz wspieranie sprawnego funkcjonowania systemów płatniczych (jako bank banków). Dla EBC poza polityką pieniężną istotna jest również realizacja poli-

${ }^{17}$ E. Lato sze k, Etapy integracji walutowej w Unii Europejskiej, [w:] W. Pacho (red.), Europejska Integracja Monetarna od A do Z, Narodowy Bank Polski, Warszawa 2009, s. 44.

${ }^{18} \mathrm{R}$. Wi erzba, Euro - dziesięć lat funkcjonowania, [w:] W. Przybylska- Kapuścińska (red.), Studia z bankowości centralnej i polityki pieniężnej, Difin, Warszawa 2009, s. 259.

${ }^{19}$ Działanie ESBC ma charakter federalny, co oznacza, że instytucje pełniące funkcje banku centralnego wykonują swoje zadania na obszarze kilku suwerennych państw, a nie tylko na terenie jednego kraju federalnego [w:] I. P y k a, op. cit., s. 31.

${ }^{20}$ Warto wspomnieć w tym miejscu o zasadzie subsydiarności inaczej pomocniczości, która zgodnie $\mathrm{z}$ art. 5/3b Traktatu z Maastricht stanowi, iż w dziedzinach niepodlegających wyłącznej kompetencji Unii Europejskiej, Wspólnota podejmuje działania tylko wtedy, gdy na szczeblu państw członkowskich osiągnięcie danych celów nie jest możliwe lub niewystarczające [w:] I. P y k a, op. cit., s. 31.

${ }^{21}$ M. S o b o l, Dostosowanie ram operacyjnych polityki pieniężnej NBP do wymogów Eurosystemu, [w:] J. L. Bednarczyk (red.), Stopy procentowe a gospodarka. Dylematy Unii Gospodarczej $i$ Walutowej, Wydział Ekonomiczny Politechniki Radomskiej, Radom 2006, s. 174.

${ }_{22}^{2}$ M. S o b o l, Polityka pieniężna Narodowego Banku Polskiego w drodze do euro, Wydawnictwo Fachowe CeDeWu, Warszawa 2008, s. 186. 
tyki kursowej w strefie euro. Zasadniczo dla banku centralnego ma ona równie duże znaczenie jak i polityka pieniężna, jednak odpowiedzialność za kurs walutowy powierzono narodowym ministrom Eurosystemu zasiadającym w ECOFIN $^{23}$. Zgodnie z artykułem 111 TWE za zarządzanie kursem walutowym odpowiada EBC. Prace nad opracowywaniem kształtu polityki kursowej ECOFIN muszą być konsultowane z EBC, który ma możliwość sprzeciwu wobec polityki kursowej sprzecznej z celem stabilizacji cen. Kurs euro pozostaje płynny, co ułatwia EBC prowadzenie skutecznej polityki monetarnej. Wobec państw Unii Europejskiej, które znajdują się poza strefą euro polityka kursowa polega na zarządzaniu mechanizmem kursowym ERM II, którego zasady działania zatwierdzono w czerwcu 1997 r. w Amsterdamie. W ramach tego mechanizmu państwa członkowskie spoza strefy euro zobligowały się do powiązania swojej waluty z euro, w formie ustalonych dwustronnie stałych kursów centralnych, dostosowywanych wobec wspólnej waluty ze standardowym pasmem wahań $+/-15 \%$. Istnieje obowiązek interwencji walutowej w przypadku, gdy kurs waluty zbliży się wyraźnie do ustalonej granicy. Jednak interwencje te są rzadkie i przeprowadzane tylko, jeśli jest to konieczne dla zachowania stabilności systemu. Polityka kursowa EBC skupia się również na zarządzaniu rezerwami walutowymi krajów strefy euro. EBC gromadzi i utrzymuje rezerwy przekazane od państw członkowskich w celu ewentualnych interwencji walutowych. Rezerwy walutowe Eurosystemu składają się z euro, złota, dolara amerykańskiego, jena japońskiego oraz specjalnych praw ciągnienia (SDR). EBC tak zarządza rezerwami, by w odpowiednim momencie móc przeprowadzić interwencję walutową niwelując tym samym ryzyko zachwiania stabilności cen w obszarze euro ${ }^{24}$.

Istotny jest fakt, że kurs euro w stosunku do innych walut ma znaczenie dla rozwoju gospodarczego strefy euro. Szczególnie obserwowany jest przez podmioty i władze gospodarcze kurs euro do dolara amerykańskiego, ponieważ wysoki kurs euro sprawia, że produkty i usługi strefy euro są zbyt drogie dla kupujących ze Stanów Zjednoczonych. Drogie euro ma z drugiej strony zaletę, gdyż zwiększa siłę nabywczą obywateli ze strefy euro, którzy nabywają towary i usługi sprzedawane w dolarach ${ }^{25}$.

Sytuacja gospodarcza w strefie euro w dużej mierze uzależniona jest od polityki EBC. Istotne znaczenie mają tu stopy procentowe, poziom inflacji oraz polityka kursowa, na które EBC ma wpływ. Dodatkowo EBC jest jednym z największych banków centralnych na świecie, a PKB strefy euro jest zbliżone wiel-

${ }^{23}$ Rada ECOFIN - obraduje w składzie ministrów gospodarki i finansów oraz szefów państw lub rządów.

${ }^{24}$ M. Proczek, Polityka pieniężna $w$ strefie euro. Europejska integracja monetarna od A do Z, „Bank i Kredyt” 2008, nr 6, s. 25-28.

${ }^{25}$ K. C z ubo ch a, M. P a s zkow sk a, Rola Europejskiego Banku centralnego w integracji walutowej krajów członkowskich Unii Europejskiej, „eFinanse - Finansowy Kwartalnik Internetowy" 2009, nr 4, s. 6. 
kością do PKB Stanów Zjednoczonych. Suma tych dwóch PKB stanowi 40\% światowego PKB. Dlatego wysokość stóp procentowych ustalanych przez amerykańską Rezerwę Federalną i Europejski Bank Centralny tak istotnie oddziałuje na koniunkturę gospodarczą na całym świecie. Informacje dotyczące stóp procentowych EBC, ogłaszane na konferencjach prasowych przekładają się na ruchy indeksów giełdowych w wielu państwach. Stąd, pozytywne oceny decyzji EBC mają odzwierciedlenie we wzrostach giełdowych oraz skutkują wzmocnieniem euro w porównaniu do innych ważnych walut na świecie. Dlatego EBC jest instytucją o globalnym znaczeniu ${ }^{26}$.

EBC wpływa na kondycję gospodarczą państw strefy euro, a także odgrywa kluczową rolę w integracji walutowej krajów członkowskich Unii Europejskiej. Gospodarki państw strefy euro są jednak różne i często wymagana byłaby inna polityka gospodarcza wobec tych krajów. Przykładowo w połowie roku 2008 zanotowano deficyt w handlu zagranicznym Hiszpanii wynoszący $10,1 \%$ PKB, natomiast gospodarka niemiecka wykazała nadwyżkę na poziomie $7,7 \%$ PKB. Uznaje się, że niedopasowane stopy procentowe doprowadziły do „przegrzania” gospodarki hiszpańskiej. Niskie stopy procentowe i tanie kredyty wywołały w Hiszpanii „bańkę spekulacyjną” (bubble economy), szczególnie na rynku nieruchomości, na którym opiera się ta gospodarka. W związku z możliwością pozyskania w banku tanich kredytów, budowano dużo przy rosnących cenach nieruchomości. W obliczu światowego kryzysu finansowego doszło do pęknięcia „bańki” i recesji gospodarczej. Stopa bezrobocia wzrosła o 100\% stając się najwyższą w państwach Unii Europejskiej (15\%). Z drugiej strony doszło do obaw, że kryzys finansowy doprowadzi do takiego załamania gospodarczego, że niektóre kraje, jak chociażby Grecja ${ }^{27}$, a nawet Włochy, Portugalia czy Hiszpania zostaną usunięte ze strefy euro. Obecnie (lipiec 2013 r.) do tego nie doszło a EBC (wspólnie z UE, MFW i innymi instytucjami) interweniuje starając się nie dopuścić do załamania strefy euro. Paradoksalnie, europejski model gospo-

${ }^{26}$ Ibidem, s. 5.

${ }^{27}$ W I połowie $2010 \mathrm{r}$. jednym z krajów strefy euro dotkniętych kryzysem finansowym była Grecja, między innymi ze względu na niedostateczne przygotowanie tego państwa do integracji walutowej. Warto dodać, że u podstaw problemów greckich wymienia się słabości strukturalne skutkujące niższą konkurencyjnością międzynarodową, nierównowagą wewnętrzną oraz zewnętrzną. Ponadto niskooprocentowane środki uzyskane $\mathrm{z}$ emisji obligacji przeznaczano w większej mierze na konsumpcję. Grecja w okresie przedakcesyjnym skupiła się na tymczasowym wypełnieniu kryteriów konwergencji dodatkowo opierając obliczanie wskaźników gospodarczych na wątpliwych informacjach ekonomicznych. Dopiero ostatni kryzys ujawnił skalę nierównowagi fiskalnej w Grecji i podważył zdolność greckiego rządu do spłaty zadłużenia. Już jesienią 2009 r. odnotowano w Grecji znaczny wzrost rentowności bonów i obligacji skarbowych, w związku z czym pojawiło się zagrożenie wystąpienia spirali zadłużenia i przeniesienia fali kryzysu na inne kraje strefy euro. Instytucje UE oraz MFW podjęły decyzję o udzieleniu Grecji pakietów pomocowych w zamian za pakiet reform strukturalnych [w:] Kryzys grecki - geneza i konsekwencje, Dokument uzupełniający do ram strategicznych Narodowego Planu Wprowadzenia Euro, Ministerstwo Finansów, Warszawa 2010, s. 2-43. 
darczy, który dopuszcza do pewnego stopnia interwencjonizm państwowy okazuje się rozwiązaniem wykorzystywanym w skali światowej. W rezultacie w czasie kryzysu finansowego pozycja euro, jako waluty rezerwowej wśród wielu banków centralnych nie uległa osłabieniu. Strefa euro, pomimo wielu zagrożeń i trudnej sytuacji ma szanse wyjść z recesji, jednak pod warunkiem przeprowadzenia restrukturyzacji finansów publicznych poszczególnych krajów Eurosystemu $^{28}$.

Podsumowując, polityka pieniężna Europejskiego Banku Centralnego zależy od wielu różnych czynników leżących u podstaw danego systemu gospodarczego, od stopnia efektywności władz monetarnych, od jakości instrumentów polityki pieniężnej oraz od zachowania podmiotów gospodarczych i ich zdolności przystosowania się do decyzji podjętych przez władze w strefie euro ${ }^{29}$.

Rada Europejska w 1993 r. na szczycie w Kopenhadze zobowiązała kraje Europy Środkowej i Wschodniej do uczestnictwa w obszarze wspólnej waluty. Od momentu przystąpienia Polski do struktur Unii Europejskiej, władze gospodarcze starają się dotrzymać tzw. kryteriów kopenhaskich i dążą do kolejnego etapu integracji europejskiej, jakim jest UGiW. Wiąże się to z przyjęciem euro, jako prawnego środka płatniczego w Polsce. W momencie pomyślnej akcesji Polski do UGiW, złoty przestanie istnieć a prawa do emisji banknotów przejmie Europejski Bank Centralny, który odpowiada za prowadzenie polityki pieniężnej w obszarze euro. NBP będzie miał prawo do emisji monet euro ${ }^{30}$.

W działalności banku centralnego istotna jest kwestia niezależności od organów rządowych. Ma to znaczenie w mechanizmie oddziaływania banku centralnego na procesy gospodarcze, ponieważ stwarza możliwość uniknięcia politycznych wpływów na decyzje podejmowane przez władze monetarne, a tym samym przyczynia się do stabilizacji w gospodarce.

\subsubsection{Niezależność banku centralnego}

Niezależność banku centralnego jest istotną przesłanką sprzyjającą utrzymaniu inflacji na niskim poziomie, ponadto pozytywnie wpływa na długookresowe tempo wzrostu gospodarczego. Instytucja niezależnego banku centralnego przyczynia się również do rozwiązania problemu dynamicznej niespójności polityki pieniężnej. Poza tym niezależność banku centralnego związana jest z samodzielnym kształtowaniem i realizacją polityki pieniężnej oraz podejmowaniem decyzji dotyczących funkcji statutowych.

${ }^{28}$ K. Czubocha, M. Pas zkow ska, op. cit., s. 8.

${ }^{29} \mathrm{O}$. V lad, The use of the monetary policy instruments by central banks under globalization, Alexandru Ioan University, Iasi - Romania 2008, s. 164.

${ }^{30}$ M. S o b o 1, Polityka..., op. cit., s. 80. 
W Statucie Europejskiego Systemu Banków Centralnych oraz w Traktacie ustanawiającym Wspólnotę Europejską określono kwestie dotyczące niezależności Europejskiego Banku Centralnego oraz Narodowych Banków Centralnych ${ }^{31}$. T. Padoa-Schioppa podkreślał, że polityka pieniężna powinna być pozostawiona instytucji niezależnej i zarazem odpowiedzialnej, której zadania są jasno określone. Ma to również fundamentalne znaczenie dla integracji walutowej, ponieważ niezależność banku centralnego jest koniecznym warunkiem przystąpienia do struktur Unii Europejskiej. Jest to według tego autora nie tylko wymóg formalny, ale również istotny komponent potrzebny do prawidłowego funkcjonowania polityki gospodarczej ${ }^{32}$. Poza tym niezależny bank centralny, wolny od wszelkich nacisków politycznych, nie musi uwzględniać w swojej polityce celów doraźnych, ma wtedy możliwość skupienia się na podstawowym celu, jakim jest ochrona wartości pieniądza ${ }^{33}$. Niezależność EBC jest fundamentalnym elementem integracji walutowej, dla której stabilność cen jest głównym priorytetem.

Niezależność banku centralnego wynika z założenia, że stabilizacja wartości pieniądza jest elementem polityki nowoczesnego państwa. Inaczej ujmując, współcześnie dąży się do tego, by stabilność cen była efektem polityki pieniężnej bez względu na cele stawiane sobie przez rząd w innych segmentach tej polityki. Często na gruncie polityki banku centralnego i polityki rządu dochodzi do konfliktów ${ }^{34}$. Spowodowane one są tym, że rządy i parlamenty działają w okresie krótko- i średnioterminowym, zaś oddziaływanie polityki pieniężnej na gospodarkę ma charakter zdecydowanie długookresowy ${ }^{35}$. W powyższym kontekście w teorii występują wymiary niezależności politycznej oraz ekonomicznej, o których wspomina V. Grilli i in. Podają oni, że niezależność polityczna polega na zdefiniowaniu stosunków pomiędzy bankiem centralnym a rządem, określeniu procedur powoływania władz banku centralnego oraz sformalizowaniu sposobu ustalania celów banku centralnego odpowiadającego za prowadzenie polityki monetarnej. Z kolei niezależność ekonomiczna według V. Grillego i in. jest wyznaczona poprzez ramy prawne stosunków kredytowych $\mathrm{z}$ rządem oraz rolę, jaką bank centralny pełni w nadzorze bankowym. Według tych autorów bank centralny jest tym bardziej niezależny im ma bardziej ograni-

${ }^{31}$ Protocol on the Statute of the European Central Bank System and of the European Central Bank, Official Journal of the European Communities C 191, 29 July 1992, art. 14, pkt. 14.1-14.2., s. $71-72$.

${ }^{32}$ T. Padoa-Schioppa, Accession Countries on the Way to Euro: A Central Banker's View, speech at the conference on „Economic Policy Directions in the OECD Countries and Emerging Markets: Analysing the Experiences”, Warszawa 21.03.2002, s. 5.

${ }^{33}$ L. Oręzi ak, Polityczne i ekonomiczne uwarunkowania ustanowienia i funkcjonowania Unii Gospodarczej i Walutowej, „Bank i Kredyt” 1998, nr 12, s. 26.

${ }^{34}$ R. Ko k o s z c zy ń s ki, Współczesna polityka pieniężna w Polsce, PWE, Warszawa 2004, s. $159-161$.

${ }^{35}$ B. Pi etrzak, Z. Polań ski, B. Woźni ak, System finansowy w Polsce, Wydawnictwo Naukowe PWN, Warszawa 2008, s. 124. 
czone możliwości kredytowania rządu oraz im mniejsze jest jego zaangażowanie w nadzór nad bankami komercyjnymi ${ }^{36}$.

S. Fischer z kolei wprowadził rozróżnienie niezależności banku centralnego W zakresie formułowania celów polityki pieniężnej (goal independence) oraz w obszarze doboru i stosowania instrumentów polityki pieniężnej w dążeniu do osiągnięcia zamierzonych celów (instrument independence). Z niezależnością wytyczania celów polityki pieniężnej mamy do czynienia wtedy, gdy cele te są precyzyjnie ujęte w przepisach prawnych. Natomiast niezależność instrumentalna występuje, gdy bank centralny ma możliwość postępowania dyskrecjonalnego ${ }^{37}$ oraz posiada swobodę realizacji określonych celów ${ }^{38}$.

W teoretycznych rozważaniach na temat niezależności banku centralnego w wyznaczaniu celów, niezależności instrumentalnej czy instytucjonalnej można spotkać się z licznymi argumentami przemawiającymi zarówno za niezależnością banku centralnego, jak i przeciwko niej. S. Fisher przytacza argumenty przemawiające za niezależnością banku centralnego. Wywodząca się z badań nad niespójnością czasową oraz skrzywieniem inflacyjnym ${ }^{39}$ koncepcja niezależnego banku centralnego zapoczątkowana przez szkołę klasyczną, sprowadza się do stwierdzeń, że niezależność banku centralnego prowadzi do: niższej inflacji (ceteris paribus), większej wiarygodności banku centralnego, mniejszej zmienności poziomu inflacji oraz sprzyja wzrostowi gospodarczemu ${ }^{40}$. To właśnie najczęściej rządowi przypisuje się rolę tego, który dąży do zwiększenia

${ }^{36}$ R. Ko k o s z c z yń s ki, op. cit., s. 160.

37 Postępowanie dyskrecjonalne, czyli elastyczne, polega na dostosowaniu działań danego podmiotu do bieżących warunków, sytuacji rynkowej. W przypadku banku centralnego mamy do czynienia z polityką dyskrecjonalną wtedy, gdy władze monetarne reagują przy pomocy dostępnych instrumentów na zaistniałą sytuację na rynku.

38 S. Fis cher, Modern central banking, [w:] F. Capie, Ch. Godhart, S. Fisher, N. Schnadt, The Future of Central Banking, Cambridge University Press, Cambridge 1994, s. 301-302.

39 Problem dynamicznej niespójności polityki pieniężnej w czasie (time inconsistency problem) opisany został początkowo przez F. Kydlanda i E. Prescota w latach 70., a następnie przez R. Barro i D.Gordona. Zauważyli oni, że nie jest możliwe czerpanie korzyści z nieoczekiwanej inflacji w dłuższym terminie. Problem dynamicznej niespójności opiera się na tym, ze władze monetarne ogłaszając, że ich celem jest zerowa inflacja, po pewnym czasie z zamiarem osiągnięcia korzyści uruchamiają niespodziewaną inflację, by w krótkim czasie doprowadzić do wzrostu poziomu produkcji. W momencie, gdy podmioty gospodarcze racjonalnie działając przewidzą taką sytuację formułując oczekiwania inflacyjne, wtedy pojawia się tzw. skrzywienie inflacyjne (inflationary bias), które powoduje tylko wzrost inflacji bez wzrostu produkcji w gospodarce. Skrzywienie to będzie tym wyższe im podmioty gospodarcze będą bardziej przekonane o możliwościach proinflacyjnych banku centralnego. Generalnie im wyższa wiarygodność antyinflacyjna banku centralnego tym mniejsze skrzywienie inflacyjne, [w:] C. Wój cik, Przesłanki wyboru reżimu kursu walutowego $w$ teorii i badaniach empirycznych, s. 44-45, [za:] zasoby witryny internetowej: http://akson.sgh.waw.pl/ cwojcik/research/Wybor\%20rezimu.pdf [12.12.2011].

${ }^{40}$ S. Fischer, Modern Approach to Central Banking, „NBER Working Paper” 1995, no. 5064 , s. 3 . 
dochodów z renty menniczej, dewaluacji nominalnej wartości deficytu budżetowego, czy dynamicznej niespójności polityki pieniężnej lub obciążenia banku centralnego zbyt dużą ilością celów ${ }^{41}$.

Wśród zwolenników niezależności banku centralnego panuje pogląd, że bank państwa jest bardziej odporny na naciski polityczne niż rząd, który w celu osiągnięcia krótkookresowego wzrostu zatrudnienia mógłby wywierać presje na obniżanie stóp procentowych i wzrost podaży pieniądza ${ }^{42}$. Wśród argumentów na rzecz niezależności banku centralnego wymienia się także znaczne skrócenie procesu decyzyjnego wprowadzania uchwał i innych dokumentów prawnych, co ma istotne znaczenie dla skuteczności polityki monetarnej. Kolejnym argumentem przemawiającym za autonomią banku centralnego jest ujemna korelacja pomiędzy niezależnością banku a deficytem budżetowym. Wiąże się to z możliwością odmowy finansowania deficytu budżetowego przez bank centralny, co zmusza rząd do rozwagi przy planowaniu wydatków budżetowych ${ }^{43}$.

Podjęto również próby wykazywania korelacji pomiędzy stopniem niezależności banku centralnego a stabilnością cen, wzrostem gospodarczym i deficytem budżetowym. Przykładowo Niemcy i Szwajcaria, których banki centralne miały dużą niezależność, odnotowywały najniższy poziom inflacji w latach 1973-1988. Z kolei Hiszpania, Nowa Zelandia, Australia czy Włochy charakteryzowały się najwyższą stopą inflacji przy niskim poziomie niezależności banku centralnego ${ }^{44}$.

A. S. Posen po zbadaniu 17 najbardziej rozwiniętych gospodarek państw świata doszedł do wniosku, że nie może wskazać jednoznacznie mechanizmu, który posłużyłby wyjaśnieniu antyinflacyjnego efektu niezależności banku centralnego. Według A. S. Posen nie można upatrywać w niezależności banku centralnego przyczyny niskiej inflacji, co jest jednym $\mathrm{z}$ argumentów przeciwko niezależności banku ${ }^{45}$. Jednak przesłanką niezależności banku centralnego jest walka z inflacją, a w celu skuteczności dezinflacji dąży się do zmniejszenia zależności banków centralnych od decyzji zewnętrznych (politycznych) ${ }^{46}$.

Wśród przeciwników niezależności banku centralnego najczęściej przytaczanym argumentem jest pogląd, że nie powinien istnieć organ władzy o zbyt

${ }^{41}$ A. Wojtyn a, Szkice o niezależności banku centralnego, Wydawnictwo Naukowe PWN, Warszawa-Kraków 1998, s. 22.

${ }^{42}$ A. S. B linder, Bankowość centralna $w$ teorii $i$ praktyce, Wydawnictwo CeDeWu, Warszawa 2001, s. 78.

${ }^{43}$ M. S o b o 1, Polityka ..., op. cit., s. 90.

${ }^{44}$ F. S. Mi s h ki n, Ekonomika pieniądza, bankowości i rynków finansowych, Wydawnictwo Naukowe PWN, Warszawa 2002, s. 517.

${ }^{45}$ A. S. Pos en, Why central bank independence does not cause low inflation: There is no institutional fix for policy, Finance and the International Economy, Oxford University Press, Oxford 1993, s. 7.

${ }^{46} \mathrm{M}$. Kow alak, Jakościowe aspekty polityki wspótczesnego banku centralnego, „Bank i Kredyt” 2006, nr 3, s. 5. 
dużych kompetencjach, niepodlegający demokratycznej legitymizacji. Dodatkowo uważają oni, że nie jest wskazane by polityka gospodarcza była prowadzona przez niezależne od siebie organa, szczególnie w przypadku, gdy zarówno rząd jak i bank centralny oddziałują na wspólny obszar odpowiedzialności, czyli gospodarkę $^{47}$. Ponadto, jak podaje A. Cukierman, również banki centralne o małej niezależności doprowadzały do niskiej inflacji w kraju ${ }^{48}$.

Narodowy Bank Polski jest instytucją o wysokim stopniu niezależności od organów władzy i administracji państwowej, zarówno na płaszczyźnie instytucjonalnej, funkcjonalnej, personalnej oraz finansowej. W Konstytucji Rzeczpospolitej Polskiej ${ }^{49}$ widnieje zapis będący podstawą niezależności NBP. Przejawia się to w sformułowaniu informującym o tym, że NBP ma wyłączne prawo emisji pieniądza oraz ustalania i realizowania polityki pieniężnej. NBP informuje jednak Sejm o założeniach polityki pieniężnej na każdy następny rok, przedkłada mu sprawozdania z realizacji założeń polityki pieniężnej za rok ubiegły. Dodatkowo Prezes NBP przedstawia Sejmowi kwartalne informacje o bilansie płatniczym, jak również roczne bilanse należności i zobowiązań płatniczych państwa. Niezależność NBP od władzy rządowej nie ogranicza współpracy między tymi instytucjami. Przeciwnie, właśnie warunkiem skutecznej polityki pieniężnej NBP oraz polityki gospodarczej rządu jest ich współpraca ${ }^{50}$.

Podsumowując, nie jest łatwo jednoznacznie opowiedzieć się za całkowitą autonomią banku centralnego lub jej brakiem. Najważniejszym aspektem w tej kwestii powinno być zachowanie równowagi w konkretnych rozwiązaniach władz monetarnych oraz politycznych państwa. Jednak na podstawie teorii i doświadczeń, które zostały opisane w literaturze, autorka zgadza się z ekonomistami, którzy opowiadają się za niezależnością banku centralnego. Głównie dlatego, że to właśnie niezależny bank centralny gwarantuje długookresowe nastawienie polityki monetarnej oraz często przyczynia się do niższego poziomu inflacji.

\subsection{Cele i strategie polityki pieniężnej}

Bank centralny prowadząc politykę pieniężną działa w ramach pewnego systematycznego procesu analizowania uzyskanych informacji, podejmowania decyzji, wykorzystywania odpowiednich instrumentów oraz komunikowania się

${ }^{47}$ Wł. B a ka, Bankowość centralna, funkcje - metody - organizacja, Biblioteka Menedżera i Bankowca, Warszawa 2001 s. 85.

${ }^{48}$ A. C u ki e r man, Central bank strategy, credibility, and independence, MIT Press, Cambridge 1992, s. 415-437.

${ }^{49}$ Konstytucja Rzeczpospolitej Polskiej dnia 2 kwietnia 1997 r., DzU 1997, nr 78, poz. 483 z późn. zm., art. 227, par. 1.

${ }^{50}$ Wł. B a k a, op. cit., s. 99. 
z otoczeniem, w taki sposób, żeby jego polityka pozostawała zrozumiała i czytelna dla społeczeństwa. Sposobem określającym politykę banku centralnego jest strategia polityki pieniężnej ${ }^{51}$. Wybór najlepszej strategii ma istotne znaczenie dla skuteczności działania banku centralnego, który dąży do osiągnięcia ostatecznych celów polityki pieniężnej za pomocą instrumentów swojej polityki ${ }^{52}$. Istotne dla władz monetarnych jest wyznaczenie w ramach strategii polityki pieniężnej takich celów, które można osiągnąć i które są zarazem pomocne w realizacji celu finalnego ${ }^{53}$.

W różnych okresach zmieniała się hierarchia celów i strategii realizowania polityki pieniężnej. Wynikało to $\mathrm{w}$ pewnym stopniu ze zmian ustroju gospodarczego, innych sposobów realizacji polityki monetarnej czy zmiennych w czasie preferencji wyborców. W latach 1950-1960 główną uwagę skupiano na parametrach wzrostu gospodarczego, w mniejszym stopniu interesując się inflacją. Uznawano wtedy, że istnieje dodatnia korelacja pomiędzy inflacją a produkcją oraz przywiązywano istotną wagę do krzywej Philipsa i tzw. efektu Tobina $^{54}$. Efekt ten dotyczy przekonania, że inflacja obniża popyt na pieniądz, co prowadzi do wzrostu popytu na kapitał i przyczynia się do korzystnych zmian w strukturze aktywów i akumulacji kapitału ${ }^{55}$. Już w końcu lat 60. XX w., w związku ze wzrostem cen, w teorii ekonomii zaczęły przeważać nurty akcentujące znaczenie stabilności cen dla sprawnego funkcjonowania gospodarki. W debatach intelektualnych zaczął dominować monetaryzm a potem nowa ekonomia klasyczna wypierając założenia keynesizmu. Miało to odzwierciedlenie w hierarchii celów polityki gospodarczej, gdyż za najważniejszy cel uznawano inflację, stopniowo nakładając realizację tego zadania na banki centralne ${ }^{56}$.

Występujące w latach 70. XX w. szoki podażowe oraz nasilające się procesy inflacyjne przyczyniły się do wzrostu znaczenia stabilności cen w polityce gospodarczej. Zaczęto doceniać fakt, że niska inflacja a tym samym stabilna siła nabywcza pieniądza sprzyja wzrostowi gospodarczemu. Do powyższego wniosku doszło wielu autorów opracowań ekonomicznych, chociażby R. Barro ${ }^{57}$,

${ }^{51}$ M. Musielak-Lin kow ska, Cel inflacyjny w Polsce. Założenia i realizacja, Wydawnictwo Fachowe CeDeWu, Warszawa 2007, s. 7.

${ }^{52} \mathrm{Z}$. Knaki ewicz (red.), Wspótczesny pieniądz w teorii i praktyce, Wydawnictwo Akademii Ekonomicznej w Poznaniu, Poznań 2006, s. 90.

53 L. E. Svensson, Monetary Policy and Real Stabilization, Stockholm University, „National Bureau of Economic Research Working Paper” 2003, Issue 9486, s. 263.

${ }^{54}$ P. Fort in, Can Monetary Policy Make a Difference for Economic Growth and Inequality, Canadian Institute for Advanced Research, Ottawa, January 2001, s. 4-5.

${ }^{55} \mathrm{Z}$. Knaki ewicz (red.), op. cit., s. 75-76.

${ }^{56}$ A. Wojtyn a, Ewolucja keynesizmu a główny nurt ekonomii, Wydawnictwo Naukowe PWN, Warszawa 2000, s. 119-122, 135.

${ }^{57}$ R. B arro, Inflation and Economic Growth, „NBER Working Papers” 1995, no. 5326, Cambridge. 
S. Fischer ${ }^{58}$, K. Johnson, D. Small czy R. Tryon ${ }^{59}$. Zauważono wiele korzyści płynących ze stabilnych cen. L. Balcerowicz zaprezentował pogląd, że niska inflacja sprzyja prawidłowej alokacji kapitału, wpływa na lepszą komunikację między podmiotami, zwiększa przewidywalność oraz ogranicza niepewność, co ułatwia podejmowanie decyzji w dłuższym horyzoncie czasowym ${ }^{60}$. W. Wilczyński zajął podobne stanowisko, podkreślając, że niska stopa inflacji wiąże się z niższymi kosztami kredytu, co skutkuje większą skłonnością do inwestowania $^{61}$. Potwierdzenie słuszności powyższych poglądów można znaleźć w praktyce gospodarczej. J. Taylor opublikował badanie, z którego wynika, że w Japonii w latach 1978-1987, a w USA w latach 1987-1999, wzrost gospodarczy był najbardziej stabilny w okresach niskiej przeciętnej inflacji ${ }^{62}$.

F. S. Mishkin zwrócił uwagę również na fakt, że kryzys finansowy rozprzestrzenia się znacznie wolniej w warunkach stabilnego poziomu cen. Dominują wtedy kredyty długoterminowe w walucie krajowej. Natomiast w warunkach wysokiej oraz zmiennej stopy inflacji przeważają kredyty krótkoterminowe, indeksowane i zaciągane w walucie obcej ${ }^{63}$. Również C. Borio oraz P. Lowe potwierdzili, że niski oraz stabilny poziom inflacji przyczynia się do stabilności finansowej w przeciwieństwie do niespodziewanych wahań tempa inflacji, które najczęściej zwiększają podatność na kryzysy ${ }^{64}$. Warto podkreślić, że utrzymanie stabilnego poziomu cen jest głównym celem wielu banków centralnych, miedzy innymi: banków centralnych Eurosytemu, Banku Rezerwy Nowej Zelandii, Narodowego Banku Węgier, Narodowego Banku Polskiego czy Narodowego Banku $\mathrm{Czech}^{65}$. Poza tym strategię bezpośredniego celu inflacyjnego (BCI) stosują banki centralne w Australii, Chile, Kanadzie, Norwegii, Szwecji i Wielkiej Bry$\operatorname{tanii}^{66}$.

${ }^{58}$ S. Fi is che r, Why Are Central Banks Pursuing Long-run Price Stability, Federal Reserve Bank of Kansas City, 1996.

${ }^{59}$ K. J o h n s o n, D. S mal1, R. Try o n, Monetary Policy and Price Stability (unpublished), Board of Governors of the Federal Reserve System, „International Finance Discussion Papers” 1999, no. 641.

${ }^{60}$ Z. Kn akiewicz (red.), op. cit., s. 77.

${ }^{61} \mathrm{~W}$. Wilczyńs ki, Rynek i polityka pieniężna w Polsce u progu XXI wieku, Wydawnictwo WSB, Poznań 2001, s. 166.

${ }^{62}$ J. T a y lor, Low Inflation, Deflation, and Policies for Future Price Stability, „Monetary and Economic Studies" 2001, vol. 2 (Special Edition), s. 35-51.

${ }^{63}$ F. S. Mi sh ki n, The Cause and Propagation of Financial Instability: Lessons for Policymakers, Federal Reserve Bank of Kansas City, 1997, s. 55-96.

${ }^{64}$ C. B or i o, P. Low e, Asset Proces, Financial and Monetary Stability: Exploring the Nexus, „BIS Working Papers” 2002, no. 114, s. 18.

${ }^{65} \mathrm{Z}$. Kn aki e wic z (red.), op. cit., s. 80.

${ }^{66}$ Narodowy Bank Polski 2001-2006, Narodowy Bank Polski, Warszawa, [za:] zasoby witryny internetowej: http://www.nbp.pl/Home.aspx?f=publikacje/plan_dzialalnosci/nbp_0106.html [06.01.2010]. 


\subsubsection{Strategia polityki pieniężnej Europejskiego Banku Centralnego}

Polityka pieniężna spełnia istotną rolę w łagodzeniu zaburzeń w gospodarce. Władze monetarne za pomocą narzędzi polityki pieniężnej mają możliwość przywracania gospodarki do stanu równowagi po szokach w strefie realnej, przy odpowiednim nastawieniu władz fiskalnych (policy mix). EBC prowadzi politykę na podstawie następujących przesłanek dotyczących polityki pieniężnej ${ }^{67}$ :

- w krótkim okresie obniżka stóp procentowych banku centralnego przyczynia się do spadku realnych krótkookresowych stóp procentowych i deprecjacji waluty zwiększając tym samym popyt i produkcję w gospodarce,

- w długim okresie bank centralny dąży do tego, by krótkookresowa realna stopa procentowa była równa przeciętnej naturalnej stopie procentowej, przy której produkcja rzeczywista równa jest produkcji potencjalnej, przy jednoczesnym założeniu elastyczności cen,

- utrzymywanie krótkookresowej realnej stopy procentowej zbyt długo poniżej naturalnej przyczynia się do przekroczenia potencjalnej produkcji przez łączny popyt, a tym samym do przegrzania gospodarki i wzrostu inflacji,

- w długim okresie polityka pieniężna nie jest w stanie zmienić wielkości realnych.

Cel Europejskiego Banku Centralnego oraz Narodowych Banków Centralnych działających w strefie euro, sprowadza się do utrzymania stabilności cen. Został on określony w Artykule 105 Traktatu WE, który stanowi również o tym, że EBC dbając o cel podstawowy, powinien mieć na względzie przyczynianie się do osiągnięcia celów Wspólnoty. Wspieranie przez EBC ogólnej polityki gospodarczej Wspólnoty i jej celów, czyli wysokiego poziomu zatrudnienia oraz trwałego i bezinflacyjnego wzrostu, powinno odbywać się bez uszczerbku dla stabilności cen ${ }^{68}$.

W Traktacie przedstawiono hierarchię celów EBC. Nadrzędnym celem EBC jest stabilność cen, głównie ze względu na następujące przesłanki teoretyczne ${ }^{69}$ :

- przekonanie o neutralności pieniądza w długim okresie, według którego zmiana ilości pieniądza przyczyni się w długim okresie do zmiany ogólnego poziomu cen, nie oddziałując jednak na zmienne realne (produkt, zatrudnienie),

- przekonanie, że inflacja to zjawisko monetarne, ponieważ w okresach wysokiej inflacji zwykle wzrastała tylko stopa podaży pieniądza (inne czynniki,

${ }^{67}$ P. Gierałtowski, Polityka pieniężna $w$ unii walutowej, [w:] P. Kowalewski, W. Ko zińs ki (red.), Mechanizmy funkcjonowania strefy euro, Narodowy Bank Polski, Warszawa 2010, s. 84.

${ }^{68}$ The Monetary Policy of the ECB, European Central Bank, Frankfurt n. Menem 2004, s. 42.

${ }^{69}$ P. Gierałt ow ski, op. cit., s. 84. 
jak szoki popytowe czy podażowe wpływały na ceny w krótkim okresie, które $\mathrm{z}$ kolei można neutralizować zmianami polityki monetarnej w długim okresie),

- przekonanie, że w długim okresie bank centralny może wpłynąć na przyspieszenie wzrostu gospodarczego tylko poprzez stabilność cen.

Polityka pieniężna ukierunkowana na utrzymanie stabilności cen poparta została wieloma doświadczeniami praktycznymi oraz pracami teoretycznymi. Udowadniają one, że takie właśnie podejście banku centralnego przyczynia się do poprawy perspektyw gospodarczych i wpływa na podniesienie standardu życia obywateli. Stabilność cen przede wszystkim sprzyja podejmowaniu przez przedsiębiorstwa oraz osoby fizyczne trafnych decyzji inwestycyjnych i konsumpcyjnych. Pozwala to na mniejsze wahanie ogólnego poziomu cen, gdy ceny relatywne są bardziej stabilne dla podmiotów gospodarczych. Dodatkowo inwestorzy, którzy mają podstawy uważać, że ceny w przyszłości pozostaną stabilne, nie wymagają premii za ryzyko inflacyjne, jako części swojego wynagrodzenia za ryzyko ponoszone w czasie utrzymywania aktywów nominalnych w długim okresie. Wiarygodne utrzymanie stabilnych cen zwiększa również prawdopodobieństwo, że podmioty gospodarcze przeznaczą swoje zasoby na cele produkcyjne zamiast gromadzić je w postaci aktywów w celu zabezpieczenia przed inflacją $^{70}$. Uznano, że utrzymanie stałej, niskiej stopy inflacji przez bank centralny będzie najbardziej korzystne (przykładowo, niska stopa inflacji ogranicza sztywność płac i cen nominalnych, co wpływa na dobre funkcjonowanie rynku pracy, oddziałuje to również na wyższy poziom zatrudnienia i produkcji) ${ }^{71}$. Wielu ekonomistów ma jednak odmienne zdania, co do wysokości stopy inflacji przyjętej za cel główny. L. Summers stwierdził np., że najlepsza jest inflacja na poziomie $2-3 \%{ }^{72}$. Inflacja zaproponowana przez P. Krugmana wynosi $3-4 \%^{73}$, a Ch. Wypłosz uważa, że cel inflacyjny EBC powinien oscylować na poziomie $4-10 \%{ }^{74}$.

Rada Prezesów EBC, w październiku 1998 r. przedstawiła ilościową definicję stabilności cen, jako „,roczny wzrost cen Zharmonizowanego Wskaźnika Cen Konsumpcyjnych (HICP - Harmonised Index of Consumer Prices) dla strefy euro o mniej niż 2\%”, dodając, że stabilność cen „,należy utrzymać w średnim okresie". W 2003 r. Rada Prezesów sprecyzowała, że będzie się starała utrzymać stopę inflacji poniżej $2 \%$, ale blisko tego poziomu. Oznacza to, że $2 \%$ stanowi górną granicę wskaźnika HICP. Ponadto dodatni, bliski 2\% poziom ogólnego

${ }^{70}$ The Monetary..., op. cit., s. 42.

${ }^{71}$ R. Kokos zcz yń s ki, op. cit., s. 23.

${ }^{72}$ L. Summers, How Should Long-term Monetary Policy de Determined?, ,Journal of Money, Credit and Banking" 1991, vol. 13, s. 627.

${ }^{73}$ P. Krugman, Stable Proces and Fast Growth: Just Say No, „The Economist”, 03.08.1996, s. 19-21.

${ }^{74}$ Ch. W y pło s z, Do We Know, [w:] Z. Kn a ki e w i c z (red.), Wspótczesny pieniądz w teorii $i$ praktyce, Wydawnictwo Akademii Ekonomicznej w Poznaniu, Poznań 2006, s. 85. 
wskaźnika cen, pozwala uniknąć ryzyka deflacji. Sformułowanie „w średnim okresie" wynika stąd, że niemożliwe jest dokładne ukształtowanie stopy inflacji w krótkim horyzoncie czasowym. Przyczyną tej sytuacji jest brak możliwości zneutralizowania przez politykę pieniężną w krótkim okresie nieoczekiwanych wstrząsów cenowych bez opóźnień czasowych. Zatem krótkotrwała zmienność inflacji jest $\mathrm{w}$ pewnym stopniu uzasadniona ${ }^{75}$. Ogłoszenie ilościowej definicji stabilności cen zapewnia większą przejrzystość polityki monetarnej oraz daje pewien punkt odniesienia dla oceny przez opinię publiczną czy EBC wywiązuje się z założonego celu. Ponadto celem tej definicji było również kształtowanie oczekiwań rynków finansowych i opinii publicznej dotyczących rozwoju sytuacji cenowej. Ustabilizowanie długookresowych oczekiwań inflacyjnych zapobiega kalkulacji wyższej inflacji w cenach i płacach ustalanych przez podmioty gospodarcze ${ }^{76}$.

W celu utrzymania stabilności cen w średnim okresie, EBC oddziałuje na poziom cen za pośrednictwem mechanizmu transmisji monetarnej, wpływając na poziom stóp procentowych rynku pieniężnego. Proces transmisji monetarnej jest złożoną siecią interakcji gospodarczych. EBC działa w warunkach jeszcze większej niepewności niż poszczególne banki centralne, ponieważ odpowiada za wielonarodowy obszar walutowy. Dlatego istotne jest określenie kierunku polityki pieniężnej, który pozwoli utrzymać stabilne ceny w przyszłości, skutecznie ograniczając wpływ nieoczekiwanych wstrząsów cenowych. Stąd przyjęcie średniookresowego horyzontu utrzymania stabilnych cen wiąże się z określeniem polityki pieniężnej prowadzonej przez EBC w dłuższej perspektywie. Pozwala to uniknąć wprowadzenia elementów zmienności do sfery realnej gospodarki oraz nadmiernego aktywizmu gospodarczego. Europejski Bank Centralny opiera prowadzenie polityki pieniężnej na dwóch podstawowych płaszczyznach analizy, zwanych filarami ${ }^{77}$. Główne elementy tej analizy zostały ustalone już w 1998 r., natomiast dopiero w maju 2003 r. zostały zatwierdzone przez Radę Prezesów. Te dwa filary polityki pieniężnej EBC to: analiza makroekonomiczna $\mathrm{i}$ analiza monetarna ${ }^{78}$.

Analiza makroekonomiczna to inaczej ocena bieżącej sytuacji gospodarczofinansowej przeprowadzana przez EBC. Analiza ta uwzględnia wszystkie czynniki, które stanowią zagrożenie dla stabilności cen w średnim okresie. EBC, w celu podjęcia odpowiednich decyzji ocenia dynamikę aktywności realnej oraz prawdopodobieństwo zmian cen, monitorując wzajemne relacje popytu i podaży na rynkach towarów, usług i kapitału. Regularnie przeprowadza moni-

${ }^{75}$ The Monetary..., op. cit., s. 42.

${ }^{76}$ Ibidem, s. 42-43.

${ }^{77}$ O. Is s ing, The ECB`s Monetary Policy Strategy: Why did we choose a two Pillar Approach?, $4^{\text {th }}$ ECB Central Banking Conference, Frankfurt, 10 November 2006, 06.11.10 EBC Conference, s. 1-10.

${ }^{78}$ The Monetary..., op. cit., s. 42-43. 
toring wskaźników produkcji całkowitej, popytu oraz warunków na rynku pracy. Analizuje ceny aktywów, zachowania uczestników rynków finansowych, politykę fiskalną, poziom kursów walutowych, a także bilanse płatnicze strefy euro. Analiza makroekonomiczna jest narzędziem, które służy EBC do zrozumienia sytuacji gospodarczej w perspektywie krótko- i średniookresowej oraz określenia rodzaju i skali zakłóceń gospodarczych wpływających na stabilność $\operatorname{cen}^{79}$.

Analiza monetarna związana jest z analizą podaży pieniądza i zjawiskiem inflacji w średnim i długim okresie. EBC podejmując decyzje dotyczące kierunku polityki pieniężnej wykorzystuje dane monetarne i płynnościowe w perspektywie średnio- i długoterminowej. Poziomem odniesienia dla oceny sytuacji monetarnej jest wprowadzona przez EBC wartość referencyjna wzrostu szerokiego agregatu pieniądza M3. Jest to stopa wzrostu, która umożliwia utrzymanie stabilnego poziomu cen w średnim okresie. Wartość referencyjna została ustalona przez Radę Prezesów już 1998 r. w wysokości 4,5\% rocznie (uwzględnia ona roczny wzrost realnego PKB w wysokości $2 \%$ do $2,5 \%$ oraz spadek szybkości obiegu pieniądza między $0,5 \%$ a $1 \%$ ).Wartość referencyjna jest punktem odniesienia dla EBC, który informuje o zmianach podaży pieniądza w obszarze euro w średniej oraz długiej perspektywie czasowej. W momencie krótkookresowych zmian podaży pieniądza od wartości referencyjnej, EBC nie reaguje automatycznie na te odchylenia. Analiza monetarna obejmuje także badanie poszczególnych składników szerokiego pieniądza, jak ilości gotówki w obiegu lub depozytów terminowych ${ }^{80}$.

Przyjęcie w strategii EBC dwóch filarów, czyli kontrolowanie podaży pieniądza oraz średniookresowy cel inflacyjny miało swoje uzasadnienie. Mianowicie monitorowanie podaży pieniądza zapobiega pieniężnym impulsom inflacyjnym (w wyniku badań wskazujących na istnienie związku pomiędzy wielkością agregatu M3 a inflacją w strefie euro), a z kolei stosowanie bezpośredniego celu inflacyjnego ma oddziaływać na czynniki psychologiczne, stabilizując oczekiwania inflacyjne ${ }^{81}$. Wykorzystywanie podejścia dwóch filarów ma swoje uzasadnienie w przeprowadzaniu szerszej analizy sytuacji gospodarczej i wykorzystywaniu większej liczby wskaźników do podejmowania konkretnych decyzji.

\footnotetext{
${ }^{79}$ Ibidem, s. 42-44.

${ }^{80}$ Ibidem.

${ }^{81}$ I. P s z c zół k a, Zmiany cen akcji poszczególnych branż $w$ strefie euro a polityka pieniężna Europejskiego Banku Centralnego, [w:] J. L. B edn arczyk (red.), Stopy procentowe a gospodarka. Dylematy Unii Gospodarczej i Walutowej, Wydział Ekonomiczny Politechniki Radomskiej,
} Radom 2006, s. 247. 


\subsubsection{Strategia polityki pieniężnej Narodowego Banku Polskiego}

Strategia bezpośredniego celu inflacyjnego, którą stosuje NBP, jest używana powszechnie przez banki centralne, które wykorzystują dostępne informacje ekonomiczne o gospodarce oraz instrumenty potrzebne do realizacji celu dotyczącego stopy inflacji. Do cech tej strategii zalicza się: stabilny poziom cen jako główny cel polityki monetarnej, ilościowo ustalony i publicznie ogłoszony cel inflacyjny, przejrzystość oraz demokratyczną odpowiedzialność banku centralnego, jak również niezależność banku centralnego, chociażby w zakresie wykorzystywanych instrumentów ${ }^{82}$.

W październiku 1998 r. przyjęto w Polsce średniookresową strategię polityki pieniężnej na lata 1999-2003, była to tzw. strategia bezpośredniego celu inflacyjnego (direct inflation targeting). Jej głównym celem było obniżenie przez władze monetarne stopy inflacji do poziomu poniżej $4 \%{ }^{83}$. W Ustawie z 29 sierpnia 1997 r. o Narodowym Banku Polskim znajdujemy informacje, że ,podstawowym celem działalności NBP jest utrzymanie stabilnego poziomu cen, przy jednoczesnym wspieraniu polityki gospodarczej Rządu, o ile nie ogranicza to podstawowego celu NBP",84. Głównym celem polityki pieniężnej jest wiec stabilizowanie poziomu cen. Bank centralny dąży do utrzymania niskiej dynamiki stopy inflacji albo do jej obniżania. Dla władz monetarnych ważnym celem jest nie tylko ograniczanie inflacji, ale również zapobieganie deflacji.

Rada Polityki Pieniężnej stosuje strategię BCI od 1999 r. Po ogłoszeniu liczbowego celu inflacyjnego bank centralny dąży do jego realizacji poprzez wykorzystywanie instrumentów polityki pieniężnej, głównie operacji otwartego rynku, polityki stóp procentowych oraz operacji depozytowo-kredytowych. W swojej polityce NBP nie koncentruje się na pojedynczym wskaźniku, ale rozważa dostępne na rynku informacje w celu uniknięcia długotrwałych odchyleń od przyjętego celu inflacyjnego ${ }^{85}$.

Rada Polityki Pieniężnej opierając politykę pieniężną na strategii bezpośredniego celu inflacyjnego bazuje na doświadczeniach międzynarodowych, które dowodzą skuteczności tej strategii w zapewnieniu stabilności cen w gospodarce. Pierwszy cel średnioterminowy wyznaczono na lata 1999-2003, z tym, że w latach 1999-2001 wyznaczano cele roczne, bez wskazywania środ-

${ }^{82}$ Ch. Wy płosz, op. cit., s. 92.

${ }^{83}$ Raport roczny 1998, Narodowy Bank Polski, Warszawa 1999, s. 20-21.

${ }^{84}$ Ustawa z dnia 29 sierpnia 1997 r. o Narodowym Banku Polskim, tekst ujednolicony - stan na dzień 22 czerwca 2010 r., DzU 2005, nr 1, poz. 2., art. 3 oraz Sprawozdanie z wykonania zatożeń polityki pieniężnej w 2006 roku, Narodowy Bank Polski, Warszawa 2007, s. 3.

${ }^{85}$ Narodowy Bank Polski 2001-2006, op. cit., [za:] zasoby witryny internetowej: http://www.nbp.pl/Home.aspx?f=publikacje/plan_dzialalnosci/nbp_0106.html [07.01.2010]. 
kowej wartości pasma docelowej inflacji ${ }^{86}$. Od roku 2002 r. cele były wytyczane punktowo z dopuszczalnym pasmem wahań. Od 2004 r. przyjęto długookresowy ciągły cel inflacyjny na poziomie $2,5 \%$ z przedziałem odchyleń $+/-1$ punkt procentowy. Postanowiono zwiększyć horyzont czasowy realizacji celu polityki pieniężnej, między innymi dlatego że opóźnienia reakcji gospodarki na działania banku centralnego uległy zwiększeniu (zgodnie z przewidywaniami NBP) wraz z obniżaniem stopy inflacji i rozwojem rynków finansowych. Strategia BCI realizowana jest $\mathrm{w}$ warunkach płynnego kursu walutowego. RPP dążąc do zapewnienia stabilności makroekonomicznej kraju nie wyklucza przeprowadzenia interwencji na rynku walutowym w celu realizacji przyjętych wytycznych. Założenia celu inflacyjnego i sposób jego realizacji przedstawiają się następująco ${ }^{87}$ :

- cel ciągły oznacza, że inflację mierzy się roczną zmianą cen towarów i usług konsumpcyjnych w danym miesiącu w relacji do analogicznego miesiąca roku poprzedniego;

- rozwiązania BCI ukierunkowane są na utrzymanie inflacji jak najbliżej poziomu $2,5 \%$, a nie tylko wewnątrz przedziału, dzięki czemu polityka pieniężna jest bardziej odporna na wstrząsy i nie wymaga częstych zmian stóp procentowych, a jeśli już to mają one mniejszy wymiar;

- w przypadku zaistnienia wstrząsów w gospodarce, które są nieuniknione, władze monetarne reagują w zależności od siły i okresu odchylenia inflacji od założonego celu. Jeśli odchylenie to jest uznane za przejściowe oraz mieści się w przedziale wahań to bank centralny nie musi nawet podejmować działań interwencyjnych;

- ważne są również przyczyny wstrząsów z punktu widzenia decyzji podejmowanych przez RPP. Wstrząsy popytowe są względnie mniejszym problemem niż wstrząsy podażowe. Podwyższenie stóp procentowych w przypadku wstrząsu popytowego prowadzi do osłabienia aktywności gospodarczej, a tym samym do zmniejszenia presji inflacyjnej. Natomiast neutralizowanie wstrząsu podażowego poprzez restrykcyjną politykę pieniężną najczęściej prowadzi do wzrostu cen i spadku produkcji, a co się z tym wiąże, wyższej inflacji i obniżenia tempa wzrostu gospodarczego, dlatego ważne jest określenie trwałości wstrząsu;

- część wstrząsów podażowych ma charakter przejściowy i jakakolwiek restrykcyjna reakcja władz monetarnych może doprowadzić do wzrostu cen, który mógłby przerodzić się $\mathrm{w}$ trwały wzrost oczekiwań inflacyjnych, a następnie wzrost inflacji spowodowany żądaniami płacowymi. Na polityce pieniężnej spoczywa zadanie zapobiegania takim właśnie wtórnym skutkom wstrząsów

${ }^{86}$ M. Musi elak-Linkowska, Cel...,op. cit., s. 69-72.

${ }^{87}$ Uchwała Rady Polityki Pieniężnej z dnia 30 września 2009 r. w sprawie ustalenia zatożeń polityki pieniężnej (M.P. z dnia 17 września 2007 r.), zmiany w tekście jednolitym w DzU 2005, nr 167, poz. 1398; DzU 2006, nr 157, poz. 1119 oraz DzU 2007, nr 25, poz. 162 i nr 61, poz. 410. 
podażowych, tzw. efektów drugiej rundy. W celu rozróżnienia przejściowych od trwałych skutków presji inflacyjnej stosuje się miary inflacji bazowej ${ }^{88}$;

- bieżące decyzje banku centralnego mają swoje odzwierciedlenie w realnej sferze gospodarki dopiero kilka kwartałów później, podobnie bieżąca inflacja jest reakcją na zmiany polityki monetarnej kilka kwartałów wcześniej. Opóźnienia reakcji inflacji i produkcji nie są stałe i zależą od zmian strukturalnych $\mathrm{i}$ instytucjonalnych $\mathrm{w}$ gospodarce;

- również utrzymywanie inflacji na określonym poziomie przez kilka okresów niesie za sobą konsekwencje dla gospodarki w postaci stopniowego zamykania albo otwierania się luki popytowej;

- polityka pieniężna jest prowadzona w warunkach niepewności, która jest wynikiem niedoskonałości modeli prognozujących poziom inflacji, w obliczu ciągłych zmian strukturalnych. Stąd przy podejmowaniu decyzji istotne jest wykorzystanie jak najwięcej informacji, a nie tylko wyników projekcji inflacji, oraz ukazanie polityki pieniężnej w świetle dążenia do realizacji celu inflacyjnego, a nie tylko sprawowania kontroli procesów gospodarczych;

- oceniając restrykcyjność polityki pieniężnej oprócz wysokości stóp procentowych nie należy zapominać o kursie walutowym, ponieważ dopiero tak pojmowana restrykcyjność w połączeniu z realizowaną polityką fiskalną wpływa na agregatową restrykcyjność całej gospodarki. Zbyt ekspansywna polityka fiskalna implikuje konieczność utrzymania stóp procentowych na wyższym poziomie;

- w oparciu o projekcję inflacji, ocenę rzeczywistego przebiegu procesów gospodarczych często odbiegających od tych w projekcji i innych informacji nieujętych w projekcji powstaje bilans czynników, które wpływają na określenie prawdopodobieństwa utrzymania się inflacji powyżej lub poniżej celu.

Strategia bezpośredniego celu inflacyjnego stwarza pewne ograniczenia, które Rada Polityki Pieniężnej stara się uwzględnić przy podejmowaniu decyzji gospodarczych. Zarówno utrudnienia towarzyszące prowadzeniu polityki pieniężnej opartej na BCI jak i zalety tej strategii zostały umieszczone w tab. 1.1. Po analizie mocniejszych oraz słabszych stron strategii BCI, można wnioskować, że przeważają zalety tej strategii, przede wszystkim ze względu na jasno określony cel polityki pieniężnej, co zwiększa wiarygodność banku oraz większą elastyczność w stosowaniu instrumentów polityki pieniężnej, co umożliwia odpowiednią reakcję na różne rodzaje szoków gospodarczych.

${ }^{88}$ Inflacja bazowa powstaje poprzez eliminację przy jej szacowaniu towarów i usług podlegających silnym wahaniom sezonowym, regulacjom o charakterze administracyjnym oraz wahaniom wywołanym przejściowymi szokami podażowymi. Od marca 2009 r. NBP publikuje cztery miary inflacji bazowej: inflację po wyłączeniu cen administrowanych, cen najbardziej zmiennych, cen żywności i energii oraz 15\% średnia obcięta. 
Wady i zalety strategii BCI

\begin{tabular}{|c|c|}
\hline Zalety & Wady \\
\hline $\begin{array}{l}\text { Możliwość względnie szybkich dostosowań do } \\
\text { zaburzeń występujących w gospodarce za pomo- } \\
\text { cą instrumentów polityki pieniężnej. Docelowy } \\
\text { przedział inflacji pozwala uniknąc zbyt dużych } \\
\text { kosztów ograniczenia inflacji (mierzonych utratą } \\
\text { PKB), bez uszczerbku na wiarygodności prowa- } \\
\text { dzenia polityki pieniężnej. }\end{array}$ & $\begin{array}{l}\text { Zbyt duża dyskrecjonalność strategii. } \\
\text { Władze monetarne mają zbyt duże po- } \\
\text { le manewru, jeśli chodzi o reagowanie } \\
\text { na zmiany sytuacji gospodarczej kraju. }\end{array}$ \\
\hline $\begin{array}{l}\text { Możliwość wykorzystania szerokiego zakresu } \\
\text { informacji i w związku z tym brak konieczności } \\
\text { reakcji na zmianę jednego parametru, bez wzglę- } \\
\text { du na całościową ocenę sytuacji. Reakcja banku } \\
\text { centralnego nie musi następować w razie odchy- } \\
\text { lenia od pożądanej ścieżki tylko jednego parame- } \\
\text { tru - np. podaży pieniądza - jak miałoby to miej- } \\
\text { sce w przypadku wyboru tego parametru za je- } \\
\text { dyny cel pośredni polityki pieniężnej. }\end{array}$ & $\begin{array}{l}\text { Słaba odpowiedzialność banku central- } \\
\text { nego wobec instytucji demokratycz- } \\
\text { nych, ponieważ inflacja jest trudna } \\
\text { do kontroli i istnieją duże opóźnienia } \\
\text { w efektach zastosowania instrumen- } \\
\text { tów polityki pieniężnej. }\end{array}$ \\
\hline $\begin{array}{l}\text { Wskazywanie bezpośrednio na cel finalny polityki } \\
\text { daje bankowi centralnemu przejrzystość w od- } \\
\text { biorze zewnętrznym (przez społeczeństwo), } \\
\text { a dalej również większą wiarygodność. }\end{array}$ & $\begin{array}{l}\text { Płynny kurs walutowy wymagany przez } \\
\text { cel inflacyjny może spowodować } \\
\text { nadmierną i trwałą aprecjację oraz } \\
\text { wywołać perturbacje w sferze realnej } \\
\text { gospodarki. }\end{array}$ \\
\hline $\begin{array}{l}\text { Eksponowanie celu inflacyjnego ogranicza prowa- } \\
\text { dzenie przez władze monetarne polityki antycy- } \\
\text { klicznej, która zawsze osłabiała autorytet i pozycję } \\
\text { banku centralnego. Zmniejsza to również naciski } \\
\text { rządu na bank centralny i dyscyplinuje go przed } \\
\text { prowadzeniem zbyt luźnej polityki fiskalnej. }\end{array}$ & \multirow[t]{2}{*}{$\begin{array}{l}\text { Może prowadzić do niskiego wzrostu } \\
\text { produkcji i zatrudnienia*. }\end{array}$} \\
\hline $\begin{array}{l}\text { Strategia pozwala na pełniejszą ocenę polityki } \\
\text { pieniężnej ex post. }\end{array}$ & \\
\hline
\end{tabular}

* Redukowaniu inflacji towarzyszy obniżony wzrost zatrudnienia, kiedy jednak inflacja zostanie sprowadzona do docelowego poziomu, wzrost zatrudnienia powraca przynajmniej do poziomu poprzedniego.

Ź ródło: W. Przybylska-Kapuścińska (red.), Polityka pieniężna. Cele, strategie $i$ instrumenty, Wydawnictwo Akademii Ekonomicznej w Poznaniu, Poznań 2002.

Podsumowując, strategia bezpośredniego celu inflacyjnego została zastosowana w krajach rozwiniętych ad hoc, ponieważ na początku lat 90. w teorii ekonomii nie było informacji jakoby strategia ta była optymalna dla istniejących warunków gospodarczych. W literaturze brakowało wskazówek, kiedy najlepiej wdrożyć w polityce pieniężnej strategię BCI. Wykorzystanie tej strategii znalazło zatem swe podstawy w subiektywnych ocenach profesjonalistów. W tym przypadku praktyka bankowości centralnej dała podstawy teorii ekonomii, 
tym bardziej, że strategia BCI okazała się skuteczna w osiąganiu i utrzymywaniu niskiej inflacji oraz obniżaniu oczekiwań inflacyjnych ${ }^{89}$.

W celu ilustracji strategii banku centralnego $\mathrm{w}$ tab. 1.2 została zaprezentowana polityka antyinflacyjna w Polsce na podstawie porównania zakładanej oraz rzeczywistej stopy inflacji CPI. Analizując dane informacje można wnioskować, że niełatwym zadaniem było osiągnięcie wskaźnika inflacji odpowiadającego wartości planowanej.

T a b e la 1.2

Zakładana i rzeczywista stopa inflacji CPI w Polsce w latach 1998-2009

\begin{tabular}{|c|c|c|c|}
\hline \multicolumn{4}{|c|}{ Stopa inflacji CPI (a) } \\
\hline Rok & $\begin{array}{l}\text { założona stopa inflacji } \\
(\mathrm{w} \%)\end{array}$ & $\begin{array}{c}\text { faktyczna stopa inflacji } \\
(\mathrm{w} \%)\end{array}$ & $\begin{array}{c}\text { odchylenie } \\
\text { (w pkt. proc.) }\end{array}$ \\
\hline 1998 & 9,5 & 8,6 & $-0,9$ \\
\hline 1999 & $6,6-7,8^{(\mathrm{b})}$ & 9,8 & 2,0 \\
\hline 2000 & $5,4-6,8$ & 8,5 & 1,7 \\
\hline 2001 & $6,0-8,0$ & 3,6 & $-2,4$ \\
\hline 2002 & $3,0^{(\mathrm{c})}$ & 0,8 & $-1,2$ \\
\hline 2003 & 3,0 & 1,7 & $-0,3$ \\
\hline 2004 & $2,5^{(\mathrm{d})}$ & 4,4 & 0,9 \\
\hline 2005 & 2,5 & 0,7 & $-0,8$ \\
\hline 2006 & 2,5 & 1,4 & $-0,1$ \\
\hline 2007 & 2,5 & 4,0 & 0,5 \\
\hline 2008 & 2,5 & 4,8 & 1,3 \\
\hline 2009 & 2,5 & 3,5 & 0,0 \\
\hline
\end{tabular}

(a) wskaźnik cen towarów i usług CPI mierzony metodą grudzień do grudnia, od 2008 r. metodą lipiec do lipca;

(b) początkowo ustalono przedział 8,0-8,5\%, zmieniono 24 marca 1999 r.;

(c) początkowo ustalono jako 5\% +/-1,0 punkt procentowy, zmieniono 26 czerwca 2002 r.;

(d) od 2004 r. ustalono cel ciągły na poziomie $2,5 \%+/-1 \%$.

Ź r ó d ł o: opracowanie własne na podstawie Sprawozdań z wykonania założeń polityki pieniężnej w poszczególnych latach 1998-2009, Narodowy Bank Polski, Warszawa.

Najniższe odchylenia od założonej wartości inflacji (nie większe od 1 pkt. proc.) osiągnięto w roku 1998, w latach 2002-2007 oraz w 2009 r. Pomimo tych

${ }^{89}$ G. P a u l in, Credibility with Flexibility: The Evolution of Inflation - Targeting Regimes, 1990-2006, „Bank of Canada Review” 2006, s. 16-17. 
odchyleń polityka pieniężna realizowana w latach 1998-2009 w istotnym stopniu przyczyniła się do spadku inflacji. Odchylenia w górę od zakładanego poziomu miały miejsce w latach 1999-2000 (wpływ szoków zewnętrznych, zaburzeń na rynkach finansowych), a następnie po przystąpieniu Polski do Unii Europejskiej oraz w latach 2007-2008, czyli od momentu pojawienia się pierwszych symptomów globalnego kryzysu finansowego ${ }^{90}$.

Po analizie zawartości tab. 1.2, wydaje się, że strategia bezpośredniego celu inflacyjnego jest strategią słusznie stosowaną, ponieważ pomimo odchyleń od założonej stopy inflacji, faktyczny poziom inflacji sukcesywnie ulegał obniżeniu albo pozostawał zbliżony do celu inflacyjnego lub jego granic. W kontekście tematu niniejszej pracy dotyczącym wpływu stóp procentowych na inwestycje przedsiębiorstw, niska inflacja jest korzystnym zjawiskiem, ponieważ bank centralny utrzymuje stopy procentowe na niższym poziomie, co wpływa stymulująco na wielkość inwestycji w gospodarce. Z perspektywy kilkunastu lat stosowania strategii BCI można stwierdzić, że strategia ta przyczyniła się do zmniejszenia stopnia niepewności otoczenia gospodarczego co do reakcji banku centralnego na różnego rodzaju szoki, przede wszystkim poprzez jasne przedstawianie kwestii celów długookresowych, sposobu ich realizacji i interpretacji rozwoju sytuacji gospodarczej.

\subsection{Znaczenie procesów integracyjnych dla polityki pieniężnej NBP}

Gospodarka polska znajdując się na drodze do strefy euro dąży do spełnienia kryteriów konwergencji nominalnej. Jednak szanse i zagrożenia związane $\mathrm{z}$ procesem integracji walutowej zależą $\mathrm{w}$ istotnym stopniu od poziomu konwergencji realnej, związanej ze stopniem strukturalnego podobieństwa polskiej gospodarki do Eurosystemu oraz zbliżonym przebiegiem cykli koniunkturalnych ${ }^{91}$. Warunki konieczne do uczestnictwa w Unii Gospodarczej

${ }^{90}$ M. S o b o 1, Polityka ..., op. cit., s. 161-162.

${ }^{91}$ M. Frenkel, Ch. Nickel i G. Schmidt podają, że występuje wysoka korelacja pomiędzy szokami podażowymi oraz popytowymi w Polsce a Niemcami i Francją [w:] M. Frenkel, Ch. Nickel, G. Schmidt, Some Shocking Aspects of EMU Enlargement, Research Note no. 1999/99-4; Podobnie J. Borowski pisze, że cykliczne komponenty PKB, produkcja przemysłowa, jak również poziom inflacji i bezrobocia w Polsce, w Niemczech a nawet w całej strefie euro są istotnie skorelowane [w:] J. B oro w s ki, Podatność na szoki asymetryczne i proces przystapienia do Unii Monetarnej, „Bank i Kredyt” 2001, nr 11-12. Informacje te potwierdza Bank Rozrachunków Międzynarodowych, według którego produkcja przemysłowa oraz eksport w krajach kandydujących jest silnie skorelowany z tymi wskaźnikami w strefie euro [w:] BIS Working Party on Monetary Policy in Central and Eastern Europe, Mimeo 2003. 
i Walutowej to tzw. kryteria konwergencji ${ }^{92}$ określone w Traktacie o Unii Europejskiej z Maastricht ${ }^{93}$.

Kwestia kryteriów konwergencji wywołuje wśród ekonomistów wiele kontrowersji. P. De Grauwe wyraził pogląd, że dążenie do spełnienia kryteriów konwergencji z Maastricht, szczególnie dotyczących finansów publicznych było przyczyną zjawisk deflacyjnych. W konsekwencji mogło to przyczynić się do obniżenia wzrostu gospodarczego w Unii Europejskiej oraz zwiększenia poziomu bezrobocia ${ }^{94}$. Odmienne zdanie na ten temat zaprezentował między innymi T. Padoa-Schioppa, który podkreślił, że starania mające na celu wypełnienie kryteriów konwergencji przez kraje przystępujące do strefy euro wspierają proces konwergencji realnej ${ }^{95}$. Oznacza to, że kraje o słabszych wskaźnikach makroekonomicznych mają możliwość osiągnięcia w szybszym tempie poziomu gospodarczego prezentowanego przez kraje relatywnie lepiej rozwinięte (bogatsze). Zatem T. Padoa-Schioppa zauważył, że kryteria konwergencji z Maastricht przyczyniają się do wyrównania poziomu dochodu narodowego w państwach Unii Europejskiej ${ }^{96}$. Zdaniem autorki niniejszej książki pogląd T. Padoa-Schioppa jest słuszny, ponieważ kryteria konwergencji pozwalają na ustabilizowanie sytuacji finansów publicznych krajów UE oraz mobilizują do utrzymania niskiego poziomu inflacji, który w perspektywie długookresowej przyczynia się do wzrostu gospodarczego.

W kontekście procesów integracyjnych istotne jest również zjawisko, które miało miejsce głównie w piętnastu państwach (tzw. krajów transformujących się), które przechodziły w latach 90., transformację gospodarczą, ubiegając się

${ }^{92}$ Poziom cen - w ciągu roku poprzedzającego badanie stopa inflacji nie może przekraczać stopy granicznej plus 1,5 punktu procentowego, będącej średnią z trzech najniższych stóp inflacji państw UE, które ratyfikowały traktat; finanse publiczne - również w ciągu roku poprzedzającego badanie relacja długu publicznego do PKB nie może przekraczać $60 \%$ oraz stosunek deficytu budżetowego do PKB nie może przekraczać 3\%; kurs walutowy - w ciągu dwóch lat poprzedzających badanie, waluta kraju UE powinna być włączona do Europejskiego Mechanizmu Kursowego ERM II na okres co najmniej 2 lat, przy zachowaniu odchyleń od kursu centralnego w przedziale $+/-15 \%$; długoterminowe stopy procentowe - wartość długoterminowej stopy procentowej kraju UE nie może przekroczyć wartości granicznej o więcej niż 2 punkty procentowe, czyli średniej stopy procentowej trzech krajów UE, które mają najniższy wskaźnik inflacji [w:] Protocol on the Convergence Criteria Referred to in Article 109j of the Treaty Establishing European Community, „Official Journal of the European Communities C 191", 29 July 1992, s. 85; Protocol on the Excessive Deficit Procedure, „Official Journal of European Communities C 191”, 29 July 1992, s. 84-85.

${ }^{93}$ Treaty on European Union, ECSC-EEC-EAEC, Brussels, Luxemburg 1992.

${ }^{94}$ P. De Grauwe, Unia walutowa. Funkcjonowanie $i$ wyzwania, PWE, Warszawa 2003, s. $150-154$.

${ }^{95}$ Konwergencja realna - oznacza wyrównanie poziomów rozwoju gospodarczego, mierzonego poziomem PKB per capita, według parytetu siły nabywczej. Konwergencja realna ma miejsce wtedy, gdy państwa słabsze gospodarczo dzięki szybkiemu rozwojowi zaczynają dorównywać krajom relatywnie bogatszym.

${ }^{96}$ T. Padoa-Schioppa,op. cit., s. 3. 
następnie (w tym Polska) o przystąpienie do Unii Europejskiej. Temat ten poruszany jest także ze względu na proces realnej konwergencji, który pojawił się z chwilą otworzenia gospodarek transformujących się na handel międzynarodowy. Jest to zagadnienie związane z problemem realnej aprecjacji kursów walutowych spowodowane silnym wzrostem produktywności w sektorze dóbr wymienialnych (towarów), według tzw. efektu Samuelsona-Balassy ${ }^{97}$. Chociaż C. Grafe i Ch. Wypłosz konstatują, że przyczyna tego zjawiska leży w tzw. odwrotnym efekcie Samuelsona-Balassy, który odnosi się do stwierdzenia, że to realna aprecjacja prowadzi do wzrostu produktywności a nie odwrotnie ${ }^{98}$. Według hipotezy Samuelsona-Balassy przyczyną trwałego zróżnicowania inflacji w państwach rozwiniętych i tzw. doganiających (catching-up) jest odmienny wzrost produktywności w sektorach dóbr wymienialnych z zagranicą i dóbr niewymienialnych (usług) ${ }^{99}$. Kwestia ta polega na tym, że w krajach o niższych dochodach różnica produktywności pomiędzy tymi dwoma sektorami jest wyższa niż w krajach o wyższych dochodach (zakładając, że wzrost produktywności w sektorze dóbr wymienialnych jest wyższy niż w sektorze dóbr niewymienialnych), stąd stopa inflacji w krajach bogatszych jest niższa niż w krajach biedniejszych. Z kolei wyższa inflacja jest powodem realnej aprecjacji kursu walutowego danego kraju ${ }^{100}$.

Temat kryteriów konwergencji ma istotne znaczenie w dziedzinie polityki pieniężnej z powodu zainteresowania poszerzeniem strefy euro, krajów Unii Europejskiej, które jeszcze nie spełniły warunków przystąpienia do UGiW. F. Schardax opisuje kwestię adekwatności kryterium kursu walutowego oraz kryterium inflacji w kontekście integracji krajów głównie z Europy Środkowo-Wschodniej. Istotne jest to $\mathrm{z}$ tego względu, że różnice stóp inflacji w ramach unii walutowej oddziałują na realny kurs walutowy ${ }^{101}$ i przyczyniają się do

${ }^{97}$ Efekt Samuelsona-Balassy - to zjawisko wpływu wymiany międzynarodowej na ogólny poziom cen oraz na kurs walutowy. Efekt ten występuje w przypadku, kiedy wzrost produktywności w sektorze krajowym jest wolniejszy niż w sektorze międzynarodowym.

${ }^{98}$ C. Grafe, Ch. Wy płosz, The Real Exchange Rate in Transition Economies, artykuł zaprezentowany na konferencji „Third Dubrovnik Conference on Transition Economies in Dubrovnik", Chorwacja, czerwiec 1997, s. 25-28.

${ }^{99}$ G. Palu s za k, Spór o stabilność cen w euroobszarze, [za:] zasoby witryny internetowej: www.konferencja.edu.pl/ref8/pdf/pl/Paluszak-Poznanpolski.pdf [12.12.2010].

${ }^{100} \mathrm{C}$. W ó j c i k, Źródta zmian cen relatywnych i dynamiki realnego kursu walutowego - przegląd badań teoretycznych, „Bank i Kredyt” 2005, nr 9, s. 17-30.

${ }^{101} \mathrm{~W}$ tym kontekście najczęściej chodzi o efekt Balassy-Samuelsona, który dotyczy relacji pomiędzy realną konwergencją a realnymi kursami walutowymi. Zgodnie z efektem B-S w państwach, które dążą do konwergencji wydajność w sektorze dóbr handlowych, czyli wymienialnych, rośnie szybciej niż w sektorze dóbr niehandlowych, czyli niewymienialnych. Z kolei w sektorze dóbr wymienialnych płace realne determinowane są krańcowym produktem pracy. W momencie międzysektorowego wyrównywania się płac w sektorze dóbr niewymienialnych płace kształtują się w ślad za płacami w sektorze dóbr wymienialnych. Wydajność wzrasta wolniej niż płace w sektorze dóbr niehandlowych, stąd inflacja w sektorze dóbr niehandlowych jest wyż- 
względnej zmiany konkurencyjności krajów członkowskich. Bez mechanizmu korekcyjnego w postaci nominalnego kursu walutowego, kraje te stałyby się mniej konkurencyjne w wyniku aprecjacji ich realnego kursu walutowego ${ }^{102}$. Stąd pojawiły się dyskusje na temat sprzeczności między kryterium kursu walutowego a kryterium inflacji, szczególnie dla krajów, które realizowały przekształcenia gospodarcze. Jest to jednak temat wymagający głębszej analizy, która nie jest celem niniejszej pracy.

W 1998 r. Rada Europejska uznała, że 11 państw UE spełniło niezbędne kryteria konwergencji i w związku tym ich gospodarki są gotowe do wprowadzenia wspólnej waluty. Do państw tych należały: Austria, Belgia, Finlandia, Francja, Hiszpania, Holandia, Irlandia, Luksemburg, Niemcy, Portugalia i Włochy ${ }^{103}$. Przyglądając się jednak bliżej wskaźnikom makroekonomicznym tych krajów, można zauważyć, że 8 państw nie spełniało wszystkich kryteriów, a mimo wszystko zostały zakwalifikowane do strefy euro ${ }^{104}$. Dania oraz Wielka Brytania biorące udział w negocjacjach dotyczących ustanowienia UE, nie weszły do UGiW, zapewniając sobie jednak status tzw. opting-out, który oznacza że mogą one wejść do strefy euro, ale nie muszą. W przypadku Szwecji przyjęto deklarację o nieuczestniczeniu Szwecji w obszarze euro, chociaż zdaniem P. De Grauwego, Wielka Brytania, Dania i Szwecja spełniły kryteria konwergencji, pomimo tego postanowiły pozostać poza Unią Walutową ${ }^{105}$. Po spełnieniu kryteriów konwergencji do Unii Gospodarczej i Walutowej przystąpiła Grecja 1 stycznia 2001 r., Słowenia 1 stycznia 2007 r. ${ }^{106} 1$ stycznia 2008 r. w strefie euro znalazły się Cypr i Malta, od stycznia 2009 r. Słowacja, z kolei od stycznia 2011 r. Estonia ${ }^{107}$. Podsumowując, Prezes Europejskiego Banku Centralnego, J.-C. Trichet, stwierdził, że moment utworzenia UGiW był elementem przełomowym w procesie integracji walutowej w Unii Europejskiej. Natomiast strefa euro oparta na wiarygodnej polityce monetarnej przyczynia się do ekonomicznej i monetarnej równowagi w Europie ${ }^{108}$.

sza niż w sektorze dóbr handlowych. Różnica w zakresie wydajności jest wyższa w krajach dążących do zbieżności w stosunku do krajów ogólnie o wysokim poziomie wydajności, co jest przyczyną aprecjacji realnej tych pierwszych krajów.

${ }^{102} \mathrm{~F}$. S c h a rd ax, Realna konwergencja, realne kursy walutowe oraz inflacja $w$ krajach Europy Środkowo-Wschodniej, referat przygotowany na konferencję „Polska droga do euro”, Oesterreichische Nationalbank, październik 2001, s. 1-17.

${ }^{103}$ Council Decision (98/317/EC) of 3 May 1998 in Accordance with Article 109(4) of the Treaty, „Official Journal of the European Communities L 139”, 11 May 1998, s. 30.

${ }^{104}$ Ch. W y płos z, op. cit., s. 300.

${ }^{105}$ P. De Grauwe, op. cit., s. 142.

${ }^{106}$ R. W i er zba, Europejski Bank Centralny, [w:] R. Kokoszczyński, B. Pietrzak (red.), Bankowość centralna od A do Z, Narodowy Bank Polski, Warszawa 2006, s. 152.

${ }^{107}$ K. C z u boch a, M. P a s zkow ska,op. cit., s. 7.

108 J.-C. Trichet, The euro after two years, ,Journal of Common Market Studies” 2001, vol. 39 , no. 1 , s. 1 . 
Polska znajduje się na etapie tzw. procesu doganiania zwanego beta-konwergencją, co oznacza wyższy wzrost gospodarczy i niższy PKB per capita w danym kraju w odniesieniu do państw strefy euro. Stąd wyższe tempo wzrostu gospodarczego oraz realna aprecjacja złotego mogą przyczynić się do niskich stóp procentowych w Polsce wyznaczanych przez EBC. Zbyt niski poziom stóp procentowych przyjęty w momencie wejścia do Eurosystemu mógłby przyczynić się do inflacji lub boomu kredytowego ${ }^{109}$.

W Raporcie na temat petnego uczestnictwa Rzeczypospolitej Polskiej $w$ trzecim etapie Unii Gospodarczej $i$ Walutowej podkreślono, że koszty dotyczące rezygnacji z autonomicznej polityki pieniężnej w istotnym stopniu będą uzależnione od adekwatności polityki pieniężnej EBC do polskiej gospodarki, ponadto od stopnia autentyczności krajowej polityki pieniężnej oraz poziomu skuteczności nominalnego kursu walutowego w absorbowaniu szoków. W zależności od kursu konwersji oraz stopnia elastyczności rynków ukształtują się ryzyko i zagrożenia wynikające $\mathrm{z}$ utraty międzynarodowej konkurencyjności polskiej gospodarki. Zbyt wysoki kurs konwersji może przyczynić się do osłabienia tempa wzrostu gospodarczego, z kolei niedowartościowanie kursu może wpłynąć na wzrost inflacji. Ryzyko związane z utratą autonomiczności polityki pieniężnej NBP może być przyczyną wzrostu cen i płac, a w konsekwencji wyższych kosztów pracy, co może doprowadzić do osłabienia konkurencyjności polskiej gospodarki. Od polityki pieniężnej zależą również ceny nieruchomości, które są uzależnione od skali spadku stóp procentowych, poziomu akcji kredytowej i fazy cyklu na rynku nieruchomości w momencie przystąpienia Polski do strefy euro ${ }^{110}$.

Według R. Barczyka poziom stóp procentowych w gospodarce jest istotny, ponieważ to stabilna stopa procentowa ogranicza wahania realnego popytu na pieniądz, co przyczynia się do mniejszych wahań globalnego popytu i podaży rynkowej. Ponadto stabilizacji ulegają dochody realne społeczeństwa, a osiągniecie celu stabilności nominalnych stóp procentowych służy minimalizacji inflacji $\mathrm{w}$ gospodarce ${ }^{111}$. Procesy integracyjne $\mathrm{w}$ sferze polityki pieniężnej mają istotne znaczenie dla polskiej gospodarki, ponieważ dąży się do tego by cele pieniężnej polityki stabilizacji w Polsce były zbieżne z celami ESBC. Problemem jest natomiast kwestia odmiennych warunków realizacji tego celu. W polskim sektorze bankowym występuje nadpłynność rynku pieniądza w przeci-

${ }^{109}$ J. Stryjek, Konwergencja nominalna a konwergencja realna - kiedy będzie możliwe wprowadzenie euro?, Informator Euro w Polsce w roku 20?? Ekonomiczne, polityczne i społeczne aspekty rezygnacji z waluty narodowej, Szkoła Główna Handlowa, Warszawa, s. 1-5.

${ }^{110}$ Raport na temat uczestnictwa Rzeczypospolitej Polskiej w trzecim etapie Unii Gospodarczej i Walutowej, Projekty badawcze część IV, Narodowy Bank Polski, Warszawa 2009, s. 342.

${ }^{111}$ R. B a rc z y k, Rola pieniężnej polityki stabilizacji w procesie wchodzenia Polski do Unii Gospodarczej $i$ Walutowej, rozdział 10, [za:] zasoby witryny internetowej: http://mikro.univ.szczecin.pl/bp/pdf/61/9.pdf [15.10.2010]. 
wieństwie do gospodarki krajów euro, gdzie dominuje strukturalny niedobór płynności. Zatem powstaje pytanie, czy polityka EBC może nie być w pełni dostosowana do potrzeb polskiej gospodarki ${ }^{12}$. Dodatkowo sytuacja w Polsce będzie miała zdecydowanie mniejszy wpływ na poziom stóp procentowych EBC w porównaniu do sytuacji obecnej, gdy Rada Polityki Pieniężnej prowadzi politykę pieniężną w sposób autonomiczny. Zatem nieadekwatność polityki pieniężnej EBC w odniesieniu do gospodarki polskiej miałaby miejsce w obszarze strukturalnego niedopasowania poziomu stóp procentowych w związku z różnym rozwojem gospodarczym w Polsce i strefie euro oraz z niedopasowaniem cyklicznym, czyli brakiem pełnej synchronizacji cykli koniunkturalnych ${ }^{113}$.

M. Brzoza-Brzezina podaje, że naturalna stopa procentowa jest w Polsce prawdopodobnie wyższa niż w Eurosystemie. Stąd w momencie przystąpienia Polski do strefy euro naturalna stopa procentowa przyjmie niższą wartość niż miałoby to miejsce w warunkach niezależnej polityki pieniężnej prowadzonej przez NBP. W konsekwencji można by oczekiwać wyższych nakładów inwestycyjnych związanych z niższym kosztem kapitału, ale jednocześnie tańszy kredyt mógłby przyczynić się do wzrostu konsumpcji. W tym miejscu pojawia się procykliczny wpływ realnej stopy procentowej, który powoduje nadmierny wzrost popytu a następnie zwiększenie presji inflacyjnej. Warto podkreślić jednak, że wyższe ceny to mniejsza konkurencyjność producentów krajowych, co oddziałuje na realną aprecjację kursu walutowego i przyczynia się do spadku popytu na dane produkty. Ma to związek z niższą dynamiką produkcji, spadkiem dochodów, ograniczeniem popytu i presji inflacyjnej. Na podstawie tych rozważań można jednak wyciągnąć wniosek, że równowaga makroekonomiczna zostanie przywrócona pomimo niższego poziomu realnej stopy procentowej EBC obowiązującej również w Polsce po wstąpieniu do strefy euro ${ }^{114}$.

Warto podkreślić, że w polskiej gospodarce konwergencja nominalna została osiągnięta w znacznym stopniu, co wiąże się ze zbliżonym poziomem stóp inflacji oraz niewielkim dysparytetem stóp procentowych w Polsce i strefie euro. Daje to podstawy ku stwierdzeniu, że w momencie przystąienia Polski do UGiW, spadek kosztu kapitału będzie niższy w porównaniu do wielu dotychczasowych krajów członkowskich Eurosystemu. Wspólna polityka pieniężna będzie tym bardziej adekwatna do uwarunkowań polskiej gospodarki im większe będzie podobieństwo w obszarach synchronizacji cykli koniunkturalnych oraz podobieństwo dotyczące stopnia symetryczności występujących szoków. Jest to istotne, ponieważ różnice w fazie cyklu koniunkturalnego doprowadziłyby do różnych zmian stóp inflacji oraz niezgodnego poziomu realnych stóp procentowych

112 Ibidem, s. 1-6.

${ }^{113}$ Raport na temat petnego uczestnictwa Rzeczypospolitej Polskiej $w$ trzecim etapie Unii Gospodarczej i Walutowej, Narodowy Bank Polski, Warszawa 2009, s. 152-153.

${ }^{114}$ Ibidem, s. 152-155. 
w krajach strefy euro, co oznaczałoby, że wspólna polityka pieniężna byłaby procykliczna $^{115}$. Ryzyko słabej reakcji wspólnej polityki pieniężnej w stosunku do warunków polskiej gospodarki na wstrząsy jest ograniczone. Wynika to głównie z faktu, że reakcja gospodarek Polski i strefy euro na zachwiania gospodarcze jest zbliżona, zaś synchronizacja cykliczna z Eurosystemem przewyższa w Polsce wiele państw regionu ${ }^{116}$.

Podsumowując, trudno przewidzieć wstrząsy asymetryczne w gospodarce, jednak opierając się na analizie podobieństwa struktur produkcji i popytu w Polsce i strefie euro oraz stopniu realnej konwergencji można wywnioskować, że wystąpią pewne koszty utraty autonomicznej polityki pieniężnej w Polsce. Pozostaje jedynie pytanie o wysokość tych kosztów, które można zminimalizować poprzez staranne przygotowanie się do momentu przyjęcia euro. Polska, jako jeden z krajów akcesyjnych ma możliwość wejścia do strefy euro, jednak pojawia się pytanie czy bilans korzyści i kosztów z tym związanych jest dla Polski dodatni, tzn. czy państwo polskie powinno wejść do systemu ERM2 i strefy euro, czy też nie, lub powinno się wstrzymać od podejmowania takiego kroku (szczególnie w momencie kryzysu strefy euro).

Wśród argumentów za przystąpieniem Polski do strefy euro znajdują się przede wszystkim: eliminacja ryzyka kursowego, z czym wiąże się zwiększenie przewidywalności eksportu i importu, redukcja kosztów transakcyjnych oraz zwiększenie porównywalności cen w krajach strefy euro ${ }^{117}$. Bezpośrednią korzyścią przyjęcia euro jest redukcja ryzyka kursowego związanego z niepewnością uczestników rynku, co do kształtowania się kursów walutowych w przyszłości. Ryzyko kursowe jest czynnikiem ograniczającym i utrudniającym planowanie aktywności gospodarczej, w tym inwestycji. Dodatkowo materializacja ryzyka kursowego stwarza podmiotom niepewne warunki funkcjonowania, przynosząc zamiennie straty i korzyści ${ }^{118}$. Wejście Polski do strefy euro wyeliminuje również koszty transakcyjne, które dzielą się na bezpośrednie (finansowe) i pośrednie (administracyjne). Koszty finansowe to koszty prowadzenia rachunków bankowych, kupna i sprzedaży walut, operacje zabezpieczające przed ryzykiem kursowym, czy opłaty bankowe związane z płatnościami transgranicznymi. Koszty administracyjne związane są z zasobami w gospodarce, zaangażowanymi w dokonywanie operacji walutowych, sprawozdawczości finansowej czy trans-

115 Ibidem, s. 154-155. fy euro.

${ }^{116}$ Chociaż w Polsce występuje wyższa amplituda wahań cyklicznych w porównaniu do stre-

${ }^{117}$ W. Mrocze k, Wptyw wprowadzenia euro na stopień otwartości i zmiany strukturalne w handlu krajów strefy euro, [w:] Raport na temat uczestnictwa Rzeczpospolitej Polskiej trzecim etapie Unii Gospodarczej $i$ Walutowej, Projekty badawcze część IV, Narodowy Bank Polski, Warszawa 2009, s. 6.

${ }^{118}$ A. Wi e czorkiewicz, K. Dąbrowska, M. Gruszczyński, Integracja walutowa Polski w ramach Europejskiego Systemu Walutowego na tle doświadczén unijnych, „Studia Europejskie” 2005, nr 1, Centrum Europejskie Uniwersytetu Warszawskiego, s. 3-4. 
akcji zabezpieczających, zarazem stanowią koszt utraconych możliwości innego wykorzystania tych zasobów. Zatem potencjalne korzyści z przyjęcia wspólnej waluty dla podmiotów gospodarczych to obniżenie kosztów działalności gospodarczych w związku z redukcją kosztów transakcyjnych, bardziej precyzyjne szacowanie rentowności przedsięwzięć inwestycyjnych, a także poprawa międzynarodowej pozycji Polski w charakterze partnera handlowego. Rozważając występowanie potencjalnych korzyści wprowadzenia euro w dłuższym terminie, często wymienia się spadek nominalnych stóp procentowych ${ }^{119}$, ze względu na spadek premii za ryzyko, w konsekwencji wzrost inwestycji, intensyfikację wymiany handlowej, jak również w dalszych etapach wzrost tempa PKB i ogólnie poziomu dobrobytu ${ }^{120}$.

Ponadto, do bezpośrednich korzyści rezygnacji z własnej waluty zalicza się również mniejsze ryzyko gwałtownych przepływów kapitałowych, wywołanych spekulacjami walutowymi, czy zmiennym zaufaniem inwestorów, co w konsekwencji wpływa na gospodarkę destabilizująco. W tym kontekście skutkiem przystąpienia do strefy euro może być ograniczenie ryzyka wystąpienia kryzysu walutowego i zwiększenie długoterminowej stabilności makroekonomicznej kraju $^{121}$. Do korzyści przyjęcia wspólnej waluty euro zalicza się również uproszczenie i ułatwienie inwestowania $\mathrm{w}$ akcje $\mathrm{i}$ inne papiery wartościowe, co stwarza nowe perspektywy dla funduszy inwestycyjnych, banków i osób fizycznych ${ }^{122}$. Dodatkowo wraz z przyjęciem danego państwa do UGiW następuje import wiarygodności polityki pieniężnej EBC. Powinno to również mieć związek ze wzrostem wiarygodności polityki fiskalnej, w większym stopniu przestrzeganej w ramach dyscypliny finansowej wynikającej z Paktu Stabilności i Wzrostu.

Zatem stabilność i wiarygodność makroekonomiczna, jak również większa przejrzystość cen i konkurencji mogą mieć pozytywny wpływ na stabilność gospodarczą Polski w długim okresie ${ }^{123}$. To właśnie stabilność i wiarygodność makroekonomiczna mają znaczenie w procesie podejmowania decyzji inwestycyjnych i alokacji zasobów gospodarczych przez inwestorów. W dłuższym okresie po przystąpieniu do strefy euro spodziewana jest intensyfikacja wymiany handlowej, wzrost inwestycji oraz wzrost integracji rynków finansowych, które mogą przełożyć się na większe tempo wzrostu gospodarczego, wzrost zatrudnienia, dochodów i wzrost dobrobytu. W dłuższym okresie powinien pojawić się

${ }^{119}$ Do obliczenia oczekiwanego spadku nominalnych stóp procentowych w Polsce po wstąpieniu do strefy euro wykorzystano nieubezpieczony parytet stóp procentowych (Uncovered Interest Rate Parity - UIP). Oszacowano w ten sposób wysokość premii za ryzyko kursowe zawarte w długoterminowych stopach procentowych na około 2,3-2,4 punktów procentowych (więcej na ten temat w: Raport na temat uczestnictwa ..., op. cit. s. 101-106).

${ }^{120}$ Raport na temat uczestnictwa..., op. cit., s. 92-95.

${ }^{121}$ Ibidem, s. 96-98.

${ }^{122}$ A. Wieczorkiewicz, K. Dąbrowska, M. Gruszczyński, op. cit., s. 5.

${ }^{123}$ Raport na temat uczestnictwa..., op. cit., s. 96-98. 
efekt intensywniejszej wymiany handlowej w postaci napływu nowych technologii, efektywniejszego wykorzystania czynników produkcji poprzez specjalizację i zwiększenie skali produkcji oraz wzrostu inwestycji komplementarnych w stosunku do produkcji eksportowej. Istotnym skutkiem uczestnictwa Polski w UGiW byłby wzrost inwestycji krajowych poprzez obniżenie kosztów pozyskania kapitału oraz poszerzenia perspektyw działania. Spodziewany jest także wzrost inwestycji zagranicznych poprzez eliminację ryzyka kursowego i stabilniejsze otoczenie ekonomiczne. Korzystne dla Polski będzie również uniezależnienie gospodarki od krajowego zasobu oszczędności i stabilizacyjne oddziaływanie na gospodarkę przez mechanizm dyspersji ryzyka (risk sharing) ${ }^{124}$. A. Sławiński wymienia czynniki stabilizujące kurs złotego, takie jak chociażby rosnąca integracja polskiej gospodarki $\mathrm{z}$ europejską (dilerzy postrzegają złoty jako walutę powiązaną coraz silniej z euro). Ponadto od momentu wejścia Polski do Unii Europejskiej zaczęto częściej wyceniać polską walutę w euro a nie w dolarze, którego zmienność do euro była źródłem zmienności kursu złotego do euro. Istotna jest również kwestia umacniania wiarygodności banku centralnego dla ograniczania wahań kursu walutowego ${ }^{125}$.

Powołując się na argumenty przeciwko uczestnictwu Polski w strefie euro można odwołać się do stanowiska E. Łona. Unia walutowa, jako zaawansowana forma międzynarodowej integracji wiąże się z przenoszeniem wielu suwerennych praw na szczebel ponadnarodowy. E. Łon wskazuje na fakt, że wprowadzenie jednej waluty w pewnych krajach nie jest warunkiem koniecznym gospodarczej integracji. Zauważa, że istnieją międzynarodowe organizacje, oparte na integracji gospodarczej, ale zachowujące prawo do prowadzenia własnej polityki pieniężnej. E. Łon, dokonał obliczeń w celu porównania średniego tempa wzrostu PKB w strefie euro ze średnim tempem wzrostu PKB w każdej grupie krajów tworzących następujące organizacje: MERCOSUR ${ }^{126}$, ASEAN $^{127}$, NAFTA ${ }^{128}$

${ }^{124}$ Ibidem, s. 91-92.

${ }^{125}$ A. Sławiński, Znaczenie czynników ryzyka towarzyszacych wchodzeniu Polski do ERM2 i do strefy euro, Kongres Ekonomistów Polskich, Warszawa 29-30 listopad 2007, s. 3-16.

${ }^{126}$ MERCOSUR - (hiszp. Mercado Komun del Sur - Wspólny Rynek Południa), jest to międzynarodowa organizacja gospodarcza, która powołana została na mocy traktatu z Asuncion (Paragwaj) w 1991 r. Należą do niej takie państwa jak: Argentyna, Brazylia, Paragwaj, Urugwaj, Wenezuela. Zadaniem MERCOSUR jest wzmocnienie współpracy gospodarczej i zniesienie barier handlowych. Stanowi on najsilniejszą strefę wolnego handlu w Ameryce Południowej.

${ }^{127}$ ASEAN - (Association of South East Asian Nations - Stowarzyszenie Narodów Azji Południowo-Wschodniej), jest to organizacja polityczno-gospodarcza powstała w 1967 r. w Bangkoku, z siedzibą w Dżakarcie. Zrzesza takie kraje jak: Filipiny, Indonezja, Malezja, Singapur, Tajlandia, Brunei, Wietnam, Laos, Birma, Kambodża. Do zadań tej organizacji należy między innymi współpraca gospodarcza, polityczna, kulturalna oraz naukowo-techniczna. Od 2005 r. ASEAN wprowadził na obszarze swojego działania strefę wolnego handlu, do której dołączyła w 2009 r. również Australia oraz Nowa Zelandia.

${ }^{128}$ NAFTA - (North American Free Trade Agreement - Północnoamerykański Układ Wolnego Handlu lub Północnoamerykańska Strefa Wolnego Handlu), jest to organizacja stowarzysza- 
oraz EFTA $^{129}$. Badanie to zostało przeprowadzone dla lat 1999-2006. Jak wynika $\mathrm{z}$ przeprowadzonych obliczeń realne tempo zmian PKB strefy euro $(2,1 \%)$ było niższe od średniego realnego tempa zmian PKB w grupie krajów tworzących ASEAN (5,2\%), NAFTA (3,1\%) oraz EFTA (2,7\%). Jedynie średnie tempo zmian PKB w grupie krajów członkowskich MERCOSUR $(1,9 \%)$ było niższe od tempa PKB w strefie euro w latach 1999-2006. Wnioski, jakie na podstawie tych obliczeń wyciągnął E. Łon można zaliczyć do argumentów przeciw przystąpieniu Polski do UGiW. Podkreśla on, że kraj, który chce uczestniczyć w korzystnym dla siebie modelu integracji gospodarczej nie musi likwidować swej waluty narodowej i rezygnować z suwerenności prowadzenia własnej polityki pieniężnej ${ }^{130}$. Jak wynika z powyższych rozważań rozwój gospodarczy państw wcale nie musi być rezultatem likwidacji ich walut narodowych. K. Rybiński wskazuje na fakt, że kraje wschodzące, którym zalecone zostało przestrzeganie zasad tzw. Konsensusu Waszyngtońskiego ${ }^{131}$ autorstwa Międzynarodowego Funduszu Walutowego, wcale nie przyczyniły się do poprawy ich perspektyw wzrostu. K. Rybiński podkreśla, że nawet szybciej rozwijały się kraje, które nie wdrożyły wielu z sugerowanych reform. Szczególnie kraje azjatyckie jak Chiny, Tajwan, Korea, Malezja, Singapur, czy Indie rozwijały się bardzo dynamicznie, osiągając wysokie wskaźniki wzrostu gospodarczego, nie likwidując swoich walut narodowych i zachowując prawo do prowadzenia własnej polityki monetarnej ${ }^{132}$.

R. Barro oraz X. Sala-i-Martin podkreślają, że zgodnie ze współczesną teorią wzrostu (endogenicznego) to nie rynki pozostawione same sobie, lecz działa-

jąca USA, Kanadę i Meksyk. Powstała w roku 1994 i tworzy pomiędzy tymi państwami strefę wolnego handlu.

${ }^{129}$ EFTA - (European Free Trade Association - Europejskie Stowarzyszenie Wolnego Handlu), to międzynarodowa organizacja gospodarcza powstała w 1960 r. na mocy konwencji sztokholmskiej, której celem jest strefa wolnego handlu na obszarze państw członkowskich. Kraje założycielskie to: Austria, Dania, Norwegia, Portugalia, Szwajcaria, Szwecja i Wielka Brytania. Natomiast obecnie członkami EFTA są: Islandia, Lichtenstein, Norwegia i Szwajcaria.

${ }^{130}$ E. Ł o n, Dlaczego Polska nie powinna wchodzić do strefy euro?, Wydawnictwo Fundacja im. Bolesława Chrobrego, Poznań 2007, s. 33-34.

${ }^{131}$ Konsensus Waszyngtoński - jest to dokument zaprezentowany przez amerykańskiego ekonomistę Johna Williamsona w latach 80 . XX w., jako podstawa poprawnie prowadzonej polityki gospodarczej Stanów Zjednoczonych. Obecnie założenia Konsensusu Waszyngtońskiego są kanonem polityki gospodarczej Międzynarodowego Funduszu Walutowego oraz Banku Światowego. Polska w czasie transformacji gospodarczej także korzystała z jego postulatów. Wśród założeń Konsensusu znajdują się następujące punkty: dyscyplina finansowa, wzmacnianie systemu finansowego w celu zwiększania jego odporności na kryzysy walutowe, liberalizacja rynków finansowych oraz handlu wraz z ujednoliceniem stóp procentowych, utrzymanie jednolitego kursu walutowego, deregulacja rynków w obszarze wchodzenia na rynek, gwarancja praw własności, prywatyzacja przedsiębiorstw państwowych, zniesienie barier dla bezpośrednich inwestycji zagranicznych, reformy podatkowe, jak również zwiększenie nakładów na edukację.

${ }^{132} \mathrm{~K}$. R y bińs ski, Globalizacja w trzech odstonach, offshoring - globalne nierównowagi - polityka pieniężna, Difin, Warszawa 2007, s. 122. 
nia rządu coraz bardziej wpływają na długookresowe stopy wzrostu gospodarczego (regulacje handlu międzynarodowego oraz rynków finansowych). Natomiast wprowadzanie jednolitej waluty w celu pogłębienia integracji gospodarczej nie w każdym przypadku prowadzi do wyższych stóp wzrostu. Synchronizacja cykli koniunkturalnych związana $\mathrm{z}$ teorią optymalnego obszaru walutowego $^{133}$ jest warunkiem koniecznym w celu osiągnięcia wyższej stopy wzrostu $\mathrm{w}$ procesie międzynarodowej integracji gospodarczej ${ }^{134}$.

Kolejne argumenty przeciwko przystąpieniu Polski do strefy euro, które wysunął E. Łon wynikały z analizy związku pomiędzy polityką EBC a polityką innych banków centralnych. Zbadał on korelację pomiędzy zmianą realnej stopy krótkoterminowej w strefie euro a zmianą realnej stopy krótkoterminowej w takich krajach, jak Szwecja, Dania, Wielka Brytania, Islandia, Szwajcaria, oraz Norwegia. Okazało się, że w latach 1999-2006 wyżej wspomniany wskaźnik korelacji w przypadku Danii (około 0,8) oraz Szwajcarii (około 0,9) jest wysoki, co oznacza, że decyzje banków centralnych tych państw były istotnie powiązane z decyzjami Europejskiego Banku Centralnego. Z kolei dla banków Szwecji (powyżej 0,3), Wielkiej Brytanii (powyżej 0,5), Islandii (około 0,4), jak również Norwegii (około 0,05) opisywany wskaźnik był zdecydowanie niższy, co świadczy o bardziej elastycznej polityce banków centralnych tych państw. Dodatkowo podkreślono fakt, że w badanym okresie kraje (wyżej wspomniane) o bardziej suwerennej polityce pieniężnej osiągały wyższe średnie tempo wzrostu gospodarczego niż kraje, których banki centralne podążały za decyzjami EBC (jak Dania i Szwajcaria). Zatem okazuje się, że możliwość prowadzenia polityki pieniężnej na szczeblu narodowym często bardziej sprzyja wzrostowi gospodarczemu niż sterowanie polityką przez ponadnarodowy bank centralny ${ }^{135}$.

A. Sławiński skoncentrował się na analizie czynników ryzyka związanych z wchodzeniem Polski do ERM2 oraz strefy euro. Czynnikiem stwarzającym pewnego rodzaju ryzyko uczestniczenia w UGiW dla kraju wschodzącego, jakim jest Polska, jest zmienność kursu złotego. Wśród elementów destabilizujących polską walutę należy wymienić przekształcenia instytucjonalne na globalnym rynku walutowym (banki, fundusze arbitrażowe zajmujące się spekulacjami walutowymi), a także zmienność indeksu S\&P500 na rynku amerykańskim, który oddziałuje na zmienność kursów walut gospodarek wschodzących ${ }^{136}$.

Polska przystępując do strefy euro narażona może być na ryzyko procyklicznego wpływu polityki pieniężnej EBC. Jest to potencjalny koszt uczestnictwa w unii monetarnej dla krajów członkowskich, dla których wspólna polityka pieniężna może okazać się procykliczna, ze względu na niedostateczną synchro-

${ }^{133}$ Teoria optymalnych obszarów walutowych wyjaśniona została na stronie 15 .

${ }^{134}$ M. I wanicz-Drozdowska, Integracja rynków finansowych $w$ Unii Europejskiej od A do Z, Narodowy Bank Polski, Warszawa 2009, s. 54.

${ }^{135}$ E. Ło n, op. cit., s. 28-29.

${ }^{136}$ A. S ł a wińs ki, op. cit., s. 3-16. 
nizację ich cykli koniunkturalnych w unii walutowej. Zjawisko procykliczności określa się, jako „krytyka Waltersa” (od nazwiska doradcy ekonomicznego M. Thatcher). Związana jest z niewystarczającą synchronizacją cykli koniunkturalnych, która zazwyczaj prowadzi do różnicowania się oczekiwanych stóp inflacji, a tym samym realnych stóp procentowych w poszczególnych krajach członkowskich. Najczęściej w wyniku procykliczności następuje przegrzanie gospodarki, po którym zwykle pojawia się długotrwałe spowolnienie wzrostu gospodarczego. Takie zjawisko ma podłoże w rosnących, jednostkowych kosztach pracy i inflacji w czasie ekspansji gospodarczej, co przyczynia się do wzrostu realnego efektywnego kursu walutowego REER ${ }^{137}$ (Real Effective Exchange Rate) i osłabienia konkurencyjności danej gospodarki w stosunku do innych krajów unii walutowej. Względnie wysokie tempo wzrostu wydajności produkcji może przyczynić się do obniżenia jednostkowych kosztów pracy i odzyskania konkurencyjności. W warunkach polskich problem ten ma trochę inne podłoże, które ma związek z czynnikami zmniejszającymi ryzyko procykliczności polityki pieniężnej EBC w stosunku do Polski. Wśród takich elementów jest realna konwergencja przynosząca względnie wysokie tempo wydajności pracy, a także niski poziom inflacji oraz stóp procentowych zbliżony do poziomu w strefie euro ${ }^{138}$.

Wejście do strefy euro wiąże się również z zagrożeniem wystąpienia szoku asymetrycznego w kraju przystępującym. Takim przykładem mogą być Włochy, które doświadczyły konkurencji taniego eksportu tradycyjnych towarów przemysłowych z Chin i Azji Południowo-Wschodniej, w warunkach aprecjacji euro do dolara. Według K. Rybińskiego jest to, szczególnie dla Polski, wariant raczej mało prawdopodobny, ale istnieje takie ryzyko. Głównie dlatego, że przystępując do strefy wspólnej waluty znacznie ogranicza się zakres narzędzi, które mogłyby być użyte w celu łagodzenia wpływu tego rodzaju szoków. Dopóki w Polsce istnieje narodowa waluta, władze mogą wykorzystać instrumenty polityki monetarnej oraz fiskalnej do stymulowania popytu oraz redukcji wpływu szoków na produkcję i poziom bezrobocia. Dodatkowo w przypadku szoku asymetrycznego deprecjacja kursu walutowego przyczynia się do zwiększenia konkurencyjności eksportu. Od momentu przystąpienia do strefy euro, kanał stopy procentowej i kursu walutowego przestanie oddziaływać na gospodarkę. Narodowy Bank Polski nie będzie miał możliwości obniżenia stóp procentowych w celu pobudzenia popytu, jak również przestanie istnieć możliwość dostosowywania kursu walutowego do warunków gospodarczych. Polska gospodarka jest silnie zintegrowana ze strefą euro, poprzez eksport w dużej mierze powiązany z walutą europejską, co zmniejsza ryzyko wystąpienia szoku asymetryczne-

${ }^{137}$ REER - realny efektywny kurs walutowy to ważona średnia krajowej waluty w stosunku do innych walut jednocześnie uwzględniająca efekty inflacji.

${ }^{138}$ A. Sławińs ki, op. cit., s. 3-16. 
go, jednak go nie wyklucza ${ }^{139}$. Bardziej dynamiczny postęp w procesie integracji europejskiej poprzez pełne otwarcie rynków pracy i usług oraz większa skala redystrybucji dochodów w skali międzynarodowej przyczynią się do obniżenia kosztów mechanizmów dostosowawczych w przyszłych krajach członkowskich Unii Gospodarczej i Walutowej. W kontekście wpływu stopy procentowej NBP na inwestycje, wejście Polski do strefy euro może przyczynić się do niższego kosztu finansowania, a przez to do akumulacji kapitału i rozszerzenia działalności inwestycyjnej w wyniku spadku nominalnych stóp procentowych.

Wydaje się, że przeważają korzyści i szanse uczestnictwa Polski w UGiW nad kosztami i zagrożeniami, jednak w czasie obecnego osłabienia gospodarczego i niepewności na rynkach finansowych należy w pierwszej kolejności skupić się na utrzymaniu stabilności gospodarki. Podsumowując, należy dokonać bilansu kosztów i korzyści przystąpienia Polski do strefy euro po to, by w momencie podjęcia ewentualnej decyzji o dacie przyjęcia euro, być w pełni gospodarczo przygotowanym.

\subsection{Podsumowanie}

Polityka pieniężna pozostaje obok polityki fiskalnej kluczową metodą polityki gospodarczej państwa. Bank centralny poprzez realizację polityki pieniężnej dąży do osiągnięcia wybranych celów, które zmieniają się wraz z rozwojem myśli ekonomicznej. Ostatecznie zaakceptowano pogląd, że długookresowym celem polityki pieniężnej jest osiągnięcie i utrzymanie stabilności cen, która w dłuższej perspektywie sprzyja stabilizacji gospodarczej i stwarza warunki do wzrostu gospodarczego.

$\mathrm{Na}$ podstawie przedstawionego $\mathrm{w}$ tym rozdziale przeglądu literatury przedmiotu można stwierdzić, że elastyczna strategia bezpośredniego celu inflacyjnego banku centralnego w strefie euro i w Polsce przyczynia się do niższego poziomu inflacji $\mathrm{w}$ gospodarce i stabilizacji rynkowych stóp procentowych, co stymuluje decyzje inwestycyjne podmiotów gospodarczych. Ponadto wdrożenie strategii BCI zapewnia jasność i przejrzystość polityki banku centralnego, mając istotne znaczenie z punktu widzenia integracji Polski w ramach UGiW. W celu wypełnienia przez Polskę kryteriów konwergencji konieczne jest również zwiększenie dyscypliny państwa w obszarze finansów publicznych przy jednoczesnej niezależności banku centralnego.

Podsumowując, NBP odgrywa istotną rolę w procesie dostosowywania polityki pieniężnej i walutowej do norm obowiązujących w strefie euro. Wprowadzenie euro w Polsce wiąże się z szeregiem działań wymuszających bezpieczeństwo

${ }^{139}$ K. R y b ińs ki, The Euro adoption: Assessing benefits and costs, Narodowy Bank Polski, Warszawa 2007, s. 3-4. 
całej gospodarki w okresie bezpośrednio poprzedzającym członkostwo w obszarze wspólnej waluty europejskiej. Odpowiedzialność w tym względzie spoczywa nie tylko na władzach monetarnych, ale również fiskalnych i tylko odpowiedzialna koordynacja prowadzonych przez nie polityk umożliwi uniknięcie zagrożeń związanych z tym procesem. Dążąc do spełnienia kryteriów z Maastricht niezbędne jest kontynuowanie antyinflacyjnej polityki pieniężnej w warunkach płynnego kursu walutowego (chociaż do momentu wejścia do systemu ERM II). 



\section{Rozdział 2}

\section{ODDZIAŁYWANIE BANKU CENTRALNEGO NA SEKTOR BANKOWY I GOSPODARKE W ŚWIETLE BADAŃ}

\subsection{Mechanizm transmisji impulsów polityki pieniężnej}

Mechanizm transmisji impulsów polityki pieniężnej (MTM - Monetary Transmission Mechanizm) opisuje sposób, w jaki decyzje banku centralnego wpływają na sferę realną gospodarki. Mechanizm ten przedstawia się jako przyczynowo-skutkowe powiązania pomiędzy decyzjami banku centralnego a zmianami podstawowych wielkości makroekonomicznych. Zachowania instytucji i jednostek ekonomicznych stanowią kanał, poprzez który polityka monetarna banku centralnego oddziałuje na decyzje cenowe oraz produkcyjne podmiotów gospodarczych ${ }^{1}$. Z kolei pojęcie impulsów pieniężnych związane jest ze zmianami cen (stóp procentowych, innych stóp dochodowości, kursu walutowego) oraz wielkości podaży instrumentów finansowych istniejących w gospodarce. Impulsy monetarne są wynikiem zastosowania narzędzi polityki pieniężnej w działalności banku centralnego ${ }^{2}$.

W literaturze przedmiotu wskazuje się na kilka kanałów transmisji, opartych na odmiennych czynnikach ekonomicznych uznawanych przez twórców koncepcji za istotne dla całego mechanizmu przenoszenia impulsów polityki pieniężnej do sfery realnej gospodarki. Rozpoznanie mechanizmu transmisji jest ważne, ponieważ ułatwia wybór celu polityki monetarnej (stopy procentowe, agregaty pieniężne, poziom cen, czy inne), na którym bank centralny powinien się skupić w realizacji swoich działań ${ }^{3}$. Wyróżnia się następujące kanały transmisji impulsów polityki monetarnej ${ }^{4}$ : tradycyjny, kredytowy, bilansowy, kursowy, giełdowy.

${ }^{1}$ A. Kaźmierczak, Polityka pieniężna $w$ gospodarce otwartej, Wydawnictwo Naukowe PWN, Warszawa 2008, s. 117-118.

${ }^{2}$ R. Kokoszczyński, T. Łyziak, M. Pawłowska, J. Przystupa, E. Wróbel, Mechanizm transmisji polityki pieniężnej - wspótczesne ramy teoretyczne, nowe wyniki empiryczne dla Polski, „Materiały i Studia” 2002, nr 151, Warszawa.

${ }^{3}$ W. Przybylska-Kapu ścińska (red.), Wspótczesna polityka pieniężna, Difin, Warszawa 2008, s. 165-166.

${ }^{4}$ G. Pi e tr z y k, Nadptynność krajowego sektora banków komercyjnych w roli czynnika zakłócającego transmisję impulsów polityki pieniężnej do sfery realnej, Akademia Ekonomiczna 


\subsubsection{Kanał tradycyjny stóp procentowych mechanizmu transmisji impulsów polityki pieniężnej}

Za kanał tradycyjny transmisji impulsów polityki pieniężnej uznaje się mechanizm transmisji stóp procentowych. Polega on na tym, że bank centralny zmieniając poziom bazowych stóp procentowych wysyła impuls pieniężny do gospodarki, co ma na celu spowodowanie zmiany stóp procentowych na międzybankowym rynku pieniężnym. To z kolei wywołuje zmianę poziomu stóp procentowych kredytów i depozytów w bankach komercyjnych, które oferują swoje produkty podmiotom gospodarczym. W przypadku wzrostu płynnych rezerw banków komercyjnych, a więc zwiększenia poziomu podaży pieniądza i przez to wzmożonej ekspansji kredytowej sektora bankowego, następuje spadek stóp procentowych w sferze realnej. Mechanizm ten w konsekwencji prowadzi do zmiany realnych długookresowych stóp procentowych mających wpływ na popyt globalny, który jest sumą popytu konsumpcyjnego i inwestycyjnego. Następnie ma to odzwierciedlenie w decyzjach dotyczących konsumpcji, inwestycji oraz oszczędności podejmowanych przez przedsiębiorstwa i gospodarstwa domowe. $Z$ powodu niższej ceny pieniądza rośnie poziom inwestycji i konsumpcji finansowanej kredytem, co przyczynia się do wzrostu produkcji i zatrudnienia. $Z$ drugiej strony wzrost stóp procentowych spowodowany impulsem polityki pieniężnej hamującym ekspansję kredytową banków objawia się wzrostem ceny pieniądza. Większy koszt kapitału to spadek produktu krajowego brutto i zachęta do oszczędzania ${ }^{5}$. Tradycyjny kanał stopy procentowej według poglądu keynesowskiego można przedstawić za pomocą schematu 2.16

Schemat. 2.1. Kanał stopy procentowej

$$
\mathrm{M} \uparrow \rightarrow \mathrm{i} \downarrow \rightarrow \mathrm{I} \uparrow \rightarrow \mathrm{Y} \uparrow
$$

gdzie:

M - ekspansywna polityka pieniężna,

i - realna stopa procentowa,

I - wydatki inwestycyjne,

Y - zagregowany nominalny produkt krajowy brutto.

\footnotetext{
w Katowicach, ,eFinanse - finansowy kwartalnik internetowy”, [za:] zasoby witryny internetowej: www.e-finanse.com [15.09.2009].

${ }^{5}$ Ibidem, s. 2.

${ }^{6} \mathrm{~A}$. K a ź mi e r c z a k, Monetary policy in market economy, Szkoła Główna Handlowa, Warszawa 2004, s. 75.
} 
Ekspansywna polityka pieniężna przyczynia się zatem do spadku realnych stóp procentowych, który prowadzi do obniżenia kosztu kapitału i wzrostu wydatków inwestycyjnych, co w konsekwencji powoduje wzrost zagregowanego produktu krajowego. Warto dodać, że w mechanizmie transmisji polityki pieniężnej stóp procentowych to nie nominalne a realne stopy procentowe mają istotny wpływ na decyzje konsumentów i przedsiębiorstw ${ }^{7}$. Należy podkreślić, że to, w jakim stopniu zmiana stóp procentowych banku centralnego wpłynie na poziom globalnego popytu jest również uzależnione od stanu gospodarki po stronie podażowej. W sytuacji istnienia $\mathrm{w}$ gospodarce wolnych mocy produkcyjnych, w momencie wzrostu popytu pojawi się wzrost produkcji i niewielki (o ile w ogóle) wzrost poziomu cen. Natomiast przy spadku popytu nastąpi spadek produkcji oraz pojawi się mniejsza presja inflacyjna. Zmiany stóp procentowych odbywają się poprzez tzw. impuls monetarny, transmitowany kanałem stopy procentowej, kanałem kredytowym oraz kanałem papierów wartościowych. Podsumowując, impulsy pieniężne przekazywane przez kanał stóp procentowych mają istotny wpływ na sferę realną gospodarki oraz na poziom cen ${ }^{8}$.

A. Kaźmierczak podaje, że w krajach uprzemysłowionych stopa inflacji nie jest wysoka i oscyluje zazwyczaj wokół 5\%, stąd kredyt bankowy nie jest warunkiem podstawowym rozpoczęcia inwestycji przez przedsiębiorstwa. $\mathrm{Z}$ tego powodu w tych państwach wpływ rynkowej stopy procentowej na poziom inwestycji przedsiębiorstw nie jest silny, a cena pożyczonego kapitału nie jest głównym składnikiem kosztów realizowanego przedsięwzięcia'. Inaczej sytuacja wyglądała w Polsce, szczególnie w latach 90. XX w., kiedy rynkowe stopy procentowe $\mathrm{w}$ silnym stopniu były współzależne $\mathrm{z}$ decyzjami inwestycyjnymi przedsiębiorstw ${ }^{10}$.

\subsubsection{Kanał kredytowy oraz bilansowy mechanizmu transmisji impulsów polityki pieniężnej}

W przypadku kanału kredytowego mechanizmu transmisji polityki pieniężnej bank centralny wpływa na podaż kredytu bankowego w gospodarce. W przypadku restrykcyjnej polityki monetarnej, bank centralny wykorzystując operacje otwartego rynku może doprowadzić do spadku bazy monetarnej i zmniejszyć ilość pieniądza rezerwowego w bankach komercyjnych. Mniejsza

\footnotetext{
${ }^{7}$ A. K a źmi e r c z a k, Polityka pieniężna w gospodarce otwartej, op. cit., s. 117-118.

${ }^{8} \mathrm{~A}$. R u bry ck a - D et t l a ff, Polityka stóp procentowych narodowego banku polskiego i jej implikacje makroekonomiczne $w$ latach 1999-2004, [za:] zasoby witryny internetowej: http://pecunia.ue.poznan.pl/pien_ryn_inw/7_A.Rubrycka.pdf [20.01.2010].

${ }^{9}$ A. K a źmi e r c z a k, Polityka pieniężna w gospodarce otwartej, op. cit., s. 118-119.

${ }^{10}$ Procesy restrukturyzacji dużych przedsiębiorstw, Instytut Nauk Ekonomicznych PAN, Warszawa 1998, s. 1-5.
} 
ilość płynnych rezerw banków komercyjnych powoduje, że stawki na rynku międzybankowym rosną. Zmienia się struktura aktywów banków komercyjnych, która przejawia się we wzroście papierów wartościowych oraz spadku wolnych środków na rachunkach banków komercyjnych w banku centralnym. W momencie niemożności skompensowania spadku płynnych rezerw bankowych przez zamianę papierów wartościowych na środki służące do ekspansji kredytowej lub braku innych możliwości, ograniczona zostaje podaż pieniądza. Zwykle wiąże się to ze wzrostem stopy procentowej, a tym samym z niższym poziomem inwestycji i konsumpcji, spadkiem produkcji oraz mniejszą presją inflacyjną. Należy jednak podkreślić, że proces dostosowywania gospodarki do wyższych stóp procentowych istotniej wpływa na ograniczenie popytu konsumpcyjnego niż popytu inwestycyjnego. Popyt inwestycyjny uzależniony jest bardziej od długoterminowych stóp procentowych, które zależą w większej mierze od przewidywań inflacyjnych niż krótkotrwałych zmian na rynku pieniądza ${ }^{11}$. Kanał kredytu bankowego odgrywa znaczącą rolę w systemie finansowym wtedy, gdy banki są jedynym źródłem finansowania dla części kredytobiorców oraz bank centralny ma wpływ na zmiany podaży kredytów. Kanał kredytów bankowych przedstawia się następująco ${ }^{12}$ :

Schemat 2.2. Kanał kredytowy

$\mathrm{M} \uparrow \rightarrow$ depozyty bankowe $\uparrow \rightarrow$ kredyty bankowe $\uparrow \rightarrow \mathrm{I} \uparrow \rightarrow \mathrm{Y} \uparrow$

gdzie:

M - ekspansywna polityka pieniężna,

I - wydatki inwestycyjne,

Y - zagregowany nominalny produkt krajowy brutto.

Ekspansywna polityka pieniężna poprzez wzrost rezerw i depozytów bankowych pozwala na rozszerzenie akcji kredytowej i przez to na większą liczbę udzielonych kredytów inwestycyjnych. To prowadzi do wzrostu poziomu inwestycji, a co się z tym wiąże, również produktu globalnego.

W tym miejscu warto podkreślić fakt, że inwestycje w gospodarce mogą rosnąć nawet, jeśli stopa procentowa nie spada, jak również poziom inwestycji może maleć, pomimo że stopa procentowa ulega obniżeniu ${ }^{13}$ :

${ }^{11}$ G. Pietrzyk, op. cit., s. 2.

${ }^{12}$ F. S. M i s h k in, The Channels of Monetary Transmission. Lessons for Monetary Policy, „National Bureau of Economic Research Working Paper” 1996, no. 5464, s. 37.

${ }^{13}$ A. K a ź mi e r c z a k, Polityka pieniężna w gospodarce otwartej, op. cit., s. 117-119. 
Schemat 2.3. Dostępność kredytów a inwestycje

$$
\begin{aligned}
& \mathrm{M} \uparrow \rightarrow \mathrm{V} \uparrow \rightarrow \mathrm{I} \uparrow \rightarrow \mathrm{Y} \uparrow \\
& \mathrm{M} \downarrow \rightarrow \mathrm{V} \downarrow \rightarrow \mathrm{I} \downarrow \rightarrow \mathrm{Y} \downarrow
\end{aligned}
$$

gdzie:

M - podaż pieniądza,

V - wolumen kredytów,

I - wydatki inwestycyjne,

Y - zagregowany nominalny produkt krajowy brutto.

To, w jakim stopniu powyżej przedstawiony mechanizm transmisji impulsów polityki pieniężnej wpływa na gospodarkę, zależy od siły związku pomiędzy wartością kredytów bankowych a wielkością inwestycji. Nie jest łatwo określić, czy to dostępność kredytu oddziałuje na rozmiary inwestycji czy też wartość realizowanych projektów inwestycyjnych wpływa na rozmiary działalności kredytowej ${ }^{14}$.

Oprócz kanału kredytów bankowych, istotną rolę w mechanizmie transmisji polityki pieniężnej odgrywa również kanał bilansowy. Pośrednictwo bilansowe wiąże się $\mathrm{z}$ problemem asymetrii informacji na finansowych rynkach kredytowych, gdzie jedna ze stron transakcji nie posiada dostatecznych informacji o drugiej stronie. Banki pełnią istotną rolę w systemie finansowym, gdyż są przystosowane do rozwiązywania problemów asymetrii informacyjnej na rynkach kredytowych. Pożyczkobiorcy mający szczególne kontakty z bankami, którzy często korzystają z kredytu bankowego jako najlepszego źródła kapitału, w przypadku ekspansywnej polityki pieniężnej mają zwiększony dostęp do kredytów bankowych. W przypadku pośrednictwa bilansowego problem asymetrii informacji częściej spotyka przedsiębiorstwa o niższej wartości netto, znajdując odzwierciedlenie w negatywnej selekcji i ryzyku nadużycia. Negatywna selekcja to szczególna sytuacja, w której asymetria informacji prowadzi do zawodności rynku oraz błędnych decyzji kredytowych banków, opartych często na informacjach historycznych o kliencie a nie stricte ekonomicznych. Z kolei ryzyko nadużycia występuje wtedy, gdy przedsiębiorstwo prowadzi nieetyczną grę wobec banku i wykorzystuje na swoją korzyść umowę bankową, nie respektując swoich zobowiązań. Ma to odzwierciedlenie w procesie kredytowania, gdy klient przeznacza zaciągnięty kredyt na cele niezgodne z przeznaczeniem. Poniższe równanie przedstawia pierwszy kanał pośrednictwa bilansowego ${ }^{15}$.

\footnotetext{
${ }^{14}$ Ibidem, s. 119.

${ }^{15}$ F. S. M is h kin, The channels..., op. cit., s. 38.
} 
Schemat 2.4. Kanał bilansowy związany z ceną kapitału

$$
\begin{aligned}
\mathrm{M} \uparrow \rightarrow \mathrm{P}_{\mathrm{e}} \uparrow \rightarrow & \text { negatywna selekcja } \downarrow \\
\rightarrow \text { kredytowanie } \uparrow & \rightarrow \mathrm{I} \uparrow \rightarrow \mathrm{Y} \uparrow
\end{aligned}
$$

gdzie:

M - ekspansywna polityka pieniężna,

$\mathrm{P}_{\mathrm{e}} \quad-$ ceny akcji,

I - wydatki inwestycyjne,

Y - zagregowany nominalny produkt krajowy brutto.

Schemat 2.4 obrazuje sytuację, kiedy ekspansywna polityka pieniężna powoduje wzrost cen akcji $\left(\mathrm{P}_{\mathrm{e}}\right)$ i prowadzi do zwiększenia wartości netto przedsiębiorstw, większych wydatków inwestycyjnych oraz większego popytu zagregowanego. Wyższy poziom cen aktywów wzmacnia zdolność kredytobiorców do pożyczania. To z kolei pozwala im więcej wydawać i inwestować, gdyż wzrost cen osłabia ich realną wartość zaległych zobowiązań. Z drugiej strony wyższy produkt zagregowany jest wynikiem osłabienia problemów negatywnej selekcji i ryzyka nadużycia wynikających z podniesienia ceny kapitału podmiotów gospodarczych oraz ich możliwości rozwoju ${ }^{16}$.

W ramach drugiego kanału bilansowego, związanego tym razem ze strumieniem pieniądza, główną rolę odgrywają krótkoterminowe, nominalne stopy procentowe $^{17}$.

Schemat 2.5. Kanał bilansowy związany ze strumieniem pieniądza

$$
\begin{gathered}
\mathrm{M} \uparrow \rightarrow \mathrm{i} \downarrow \text { strumień pieniadza } \uparrow \rightarrow \text { negatywna selekcja } \downarrow \rightarrow \\
\quad \rightarrow \text { ryzyko nadużycia } \downarrow \rightarrow \text { kredytowanie } \uparrow \rightarrow \mathrm{I} \uparrow \rightarrow \mathrm{Y} \uparrow
\end{gathered}
$$

gdzie:

M - ekspansywna polityka pieniężna,

i - stopa procentowa,

I - wydatki inwestycyjne,

Y - zagregowany nominalny produkt krajowy brutto.

W wyniku ekspansywnej polityki monetarnej nominalne stopy procentowe ulegają obniżeniu, co wpływa korzystnie na bilans przedsiębiorstwa, zwiększając jego płynność i ułatwiając pożyczkodawcom weryfikację zdolności przedsiębiorstwa do zaciągnięcia zobowiązania. To prowadzi do osłabienia proble-

\footnotetext{
${ }^{16}$ M. I a covi ello, House Prices, Borrowing Constraints and Monetary Policy in the Business Cycle, Boston College, Boston, 06.12.2004, s. 3.

${ }^{17}$ F. S. M i s h kin, The Channels..., op. cit., s. 38.
} 
mów negatywnej selekcji i ryzyka nadużycia, a przez to do zwiększenia akcji kredytowania podmiotów gospodarczych, wyższych wydatków inwestycyjnych i następnie wzrostu produktu globalnego ${ }^{18}$.

Natomiast $\mathrm{w}$ przypadku trzeciego kanału bilansowego przedsiębiorstw główną rolę odgrywa ogólny poziom cen $(\mathrm{P})$. Polega on na tym, że zobowiązania przedsiębiorstw są wyrażone $\mathrm{w}$ ujęciu nominalnym i w momencie wzrostu poziomu cen, wartość płatności z tytułu zadłużenia ulega obniżeniu w wyrażeniu realnym. Proces ten został zilustrowany poniżej ${ }^{19}$ :

Schemat 2.6. Kanał bilansowy przedsiębiorstw związany z ogólnym poziomem cen

$$
\begin{aligned}
& \mathrm{M} \uparrow \rightarrow \text { nieoczekiwany } \mathrm{P} \uparrow \rightarrow \text { negatywna selekcja } \downarrow \rightarrow \\
& \rightarrow \text { ryzyko nadużycia } \downarrow \rightarrow \text { kredytowanie } \uparrow \rightarrow \mathrm{I} \uparrow \rightarrow \mathrm{Y} \uparrow
\end{aligned}
$$

gdzie:

M - ekspansywna polityka pieniężna,

P - ogólny poziom cen,

I - wydatki inwestycyjne,

Y - zagregowany nominalny produkt krajowy brutto.

W powyższym schemacie ekspansywna polityka pieniężna banku centralnego, poprzez obniżenie stóp procentowych, w dalszej perspektywie skutkuje wzrostem cen na rynku, powodując wzrost realnej wartości aktywów netto przedsiębiorstw, co w konsekwencji łagodzi problem negatywnej selekcji i ryzyka nadużycia oraz prowadzi do wzrostu wydatków inwestycyjnych i zagregowanego produktu krajowego.

Podsumowując, w szczególności to ekspansywna polityka monetarna przyczynia się bezpośrednio do wzrostu popytu na kredyty bankowe poprzez kanał kredytowy lub pośrednio przez polepszenie wartości netto przedsiębiorstw i redukcję kosztów związanych z osłabieniem asymetrii informacji ${ }^{20}$.

\subsubsection{Kanał kursowy mechanizmu transmisji impulsów polityki pieniężnej}

Kanał kursowy jest uznawany za najszybszy kanał transmisji polityki pieniężnej i stanowi ważny element $\mathrm{w}$ typowych, makroekonomicznych modelach gospodarek otwartych. Łańcuch transmisji prowadzi tutaj od stóp procentowych

${ }^{18}$ A. Ka źmi e r c za k, Polityka pieniężna w gospodarce otwartej, op. cit., s. 120-122.

${ }^{19}$ F. S. Mis h ki in, The Channels..., op. cit., s. 38.

${ }^{20}$ A. Maddaloni, J. L. Peydro, S. Sope 1, Does Monetary Policy Affect Bank Credit Standards, European Central Bank, Frankfurt n. Menem 2008, s. 2. 
do kursu walutowego. Wzrost krajowych stóp procentowych przyczynia się do umocnienia waluty krajowej i ograniczenia zarówno eksportu netto i całkowitego poziomu zagregowanego popytu ${ }^{21}$. Mechanizm transmisji polityki pieniężnej poprzez kanał kursu walutowego składa się z dwóch etapów. Pierwszy etap opiera się na wspomnianym wyżej założeniu, że stopy procentowe wpływają na kurs walutowy. Im wyższe stopy, tym większa atrakcyjność krajowych w stosunku do zagranicznych papierów wartościowych, czego konsekwencją jest napływ kapitału portfelowego oraz aprecjacja kursu. Jednak nie należy zapominać, że związek pomiędzy kursem walutowym i stopami procentowymi jest zakłócany przez wiele procesów ekonomicznych, jak chociażby przepływy finansowe związane $\mathrm{z}$ handlem zagranicznym ${ }^{22}$.

Drugi etap kanału kursowego dotyczy wpływu zmian kursu walutowego na inflację ${ }^{23}$. Siła oddziaływania kursu walutowego na poziom inflacji zależy między innymi od otwartości danej gospodarki. Banki centralne wykorzystują możliwość bezpośredniego sterowania kursem w celu stabilizowania poziomu inflacji. Aprecjacja czy deprecjacja waluty ma wpływ na poziom cen towarów importowanych, co jest przykładem bezpośredniego związku pomiędzy kursem walutowym a inflacją. W przypadku osłabienia waluty krajowej, czyli jej deprecjacji, towary sprowadzone do danego kraju drożeją po przeliczeniu na jego walutę. Konsekwencją tego procesu jest wpływ deprecjacji na krajową inflację, ponieważ towary importowane są składnikami koszyka CPI (Customer Price Index $)^{24}$. Inaczej jest w przypadku towarów importowanych, które nie są bezpośrednio przeznaczone do konsumpcji, tylko są elementem dalszej produkcji. Zmiana kursu w tym przypadku będzie widoczna dopiero w zmianie cen dóbr finalnych. Kurs walutowy wpływa również na inflację za pośrednictwem eksportu netto. W przypadku deprecjacji drożeją towary importowane do danego kraju w przeliczeniu na jego walutę oraz tanieją towary tego kraju sprzedawane za granicą. Efektem jest spadek popytu importowanego oraz wzrost popytu na towary eksportowane, a zatem wzrost eksportu netto. Ten składnik popytu glo-

${ }^{21}$ K. N. K u t tn er, P. C. Mos s e r, The Monetary Transmission Mechanism: Some Answers and Further Questions, „FRBNY Economic Policy Review” 2002, vol. 5, s. 17.

${ }^{22}$ W. Przybylska-Kapuścińska (red.), Polityka pieniężna. Cele, strategie i instrumenty, Wydawnictwo Akademii Ekonomicznej w Poznaniu, Poznań 2002, s. 60.

${ }^{23}$ Wskaźnik pass-through, znany jest jako łączny efekt przenoszenia zmian czynników zewnętrznych na CPI. Zawiera on w sobie nie tylko zmiany kursu (szok kursowy), ale również zmiany cen zewnętrznych (szoki podażowe), jak i luki popytowej (szok popytowy). Zmiany kursu walutowego wpływając na poziom wyrażonych w walucie krajowej cen towarów importowanych oddziałują na zmiany wskaźnika CPI, zarówno bezpośrednio przez ceny importowanych dóbr konsumpcyjnych, jak i pośrednio poprzez zmiany cen produkcji sprzedanej przemysłu (PPI) wywołane wahaniami cen importu zaopatrzeniowego, [w:] R. Kokoszczyński, T. Łyziak, M. P a włow ska, J. Przy st u pa, E. W róbe 1, op. cit., s. 30.

${ }^{24}$ A. K a ź mi e r c z a k, Polityka pieniężna w gospodarce otwartej, op. cit., s. 124-125. 
balnego w przypadku wzrostu popytu prowadzi do zwiększenia presji inflacyjnej, a spadek do jej obniżenia ${ }^{25}$.

$$
\begin{gathered}
\text { Schemat 2.7. Kanał kursowy } \\
\mathrm{M} \uparrow \rightarrow \mathrm{i} \downarrow \rightarrow \mathrm{E} \downarrow \rightarrow \mathrm{NX} \uparrow \rightarrow \mathrm{Y} \uparrow
\end{gathered}
$$

gdzie:

M - ekspansywna polityka pieniężna,

i - realna stopa procentowa,

E - kurs waluty krajowej,

NX - eksport netto,

Y - zagregowany nominalny produkt krajowy brutto.

Podsumowując, wpływ efektu stóp procentowych poprzez kanał kursowy widoczny jest $\mathrm{w}$ momencie spadku realnych krajowych stóp procentowych, gdy następuje spadek atrakcyjności depozytów krajowych w porównaniu do depozytów w walutach obcych. Spada wartość depozytów krajowych, co prowadzi do deprecjacji waluty krajowej (E). Następnie wiąże się to $\mathrm{z}$ potanieniem dóbr krajowych w stosunku do dóbr zagranicznych, co dalej skutkuje wzrostem eksportu netto (NX) i zagregowanego produktu (Y).

\subsubsection{Kanał giełdowy mechanizmu transmisji impulsów polityki pieniężnej}

Kanał giełdowy transmisji polityki pieniężnej opiera się na założeniu, że rezultatem impulsów ekspansywnej polityki monetarnej banku centralnego jest wzrost cen aktywów giełdowych. Istnieje zależność pomiędzy wielkością inwestycji przedsiębiorstw a polityką pieniężną wpływającą na giełdowe ceny akcji. Niskie ceny akcji to niska wartość rynkowa jednostki wobec jej wartości odtworzeniowej. Koszty zakupu nowych składników kapitału rzeczowego finansowanych zewnętrznym kapitałem własnym wiążą się z emisją dużej ilości ak$\mathrm{cji}^{26}$. Taka sytuacja ma miejsce $\mathrm{w}$ przypadku korzystania przedsiębiorstw z emisji akcji i obligacji. Wpływ polityki pieniężnej przejawia się $\mathrm{w}$ tym przypadku w postaci zwiększenia płynnych rezerw banków, czyli wzrostu ekspansji kredytowej banków. Podmioty gospodarcze z racji większej dostępności środków finansowych zwiększają wydatki, co ma odzwierciedlenie we wzroście popytu globalnego. W rezultacie rosną ceny akcji, zwiększają się wydatki inwestycyjne, rośnie $\mathrm{PKB}^{27}$. Zależność ta została przedstawiona na schemacie $2.8^{28}$.

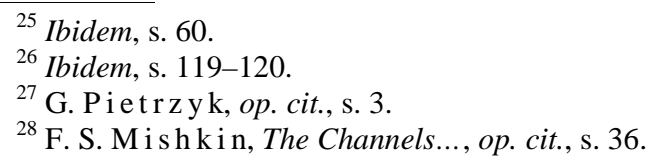


Schemat 2.8. Kanał giełdowy

$$
\mathrm{M} \uparrow \rightarrow \mathrm{P}_{\mathrm{e}} \uparrow \rightarrow \mathrm{q} \uparrow \rightarrow \mathrm{I} \uparrow \rightarrow \mathrm{Y} \uparrow
$$

gdzie:

M - ekspansywna polityka pieniężna,

$\mathrm{P}_{\mathrm{e}}-$ ogólny poziom cen,

q - współczynnik Tobina,

Y - wydatki inwestycyjne,

Y - zagregowany nominalny produkt krajowy brutto.

W teorii q Tobina ujęty został mechanizm oddziaływania polityki pieniężnej na gospodarkę poprzez jej wpływ na cenę akcji przedsiębiorstw $\left(\mathrm{P}_{\mathrm{e}}\right)$. Współczynnik q to wartość rynkowa firm podzielona przez koszt odnowienia kapitału. Wysokie q oznacza, że cena akcji jest wysoka w stosunku do kosztu odnowienia jej kapitału, a co się z tym wiąże, stosunkowo tani jest kapitał na nowe inwestycje. Przedsiębiorstwa emitują akcje za wysoką cenę i inwestują ${ }^{29}$.

Decyzje banku centralnego mają odzwierciedlenie w sferze realnej gospodarki poprzez mechanizm przenoszenia impulsów polityki pieniężnej złożony $\mathrm{z}$ wielu kanałów transmisji. W tab. 2.1 zaprezentowano różne kanały oddziaływania banku centralnego na produkt krajowy brutto poprzez mechanizm transmisji impulsów. Zachowania podmiotów finansowych i niefinansowych, które uczestniczą $\mathrm{w}$ procesie przekazywania impulsów przez bank centralny, mogą prowadzić do osłabienia, zniekształcenia, opóźnienia, a nawet zahamowania mechanizmu transmisji polityki pieniężnej. Skuteczność instrumentów zastosowanych w obszarze polityki monetarnej będzie niższa, a czas uzyskania pożądanych efektów dłuższy, jeśli system ekonomiczno-finansowy będzie wykazywał się niską wrażliwością na zmiany impulsów banku centralnego. Istotne jest zatem prawidłowe rozpoznanie mechanizmu transmisji polityki pieniężnej oraz wpływu na niego zakłóceń w postaci opóźnień w przełożeniu impulsu monetarnego na zmienne w sferze realnej gospodarki ${ }^{30}$.

W kontekście niniejszej pracy, istotne znaczenie mają kanał tradycyjny stóp procentowych oraz kanał kredytowy mechanizmu transmisji impulsów polityki pieniężnej. Bank centralny spełnia ważną rolę w procesie stwarzania korzystnych warunków do podejmowania decyzji inwestycyjnych przez podmioty gospodarcze. Niższe stopy procentowe oraz wyższa podaż kredytów bankowych powinny mieć odzwierciedlenie $\mathrm{w}$ wyższym poziomie inwestycji.

\footnotetext{
${ }^{29}$ Ibidem, s. 36.

${ }^{30}$ W. Pr z y b y lsk a - Ka pu śc iń s ka (red.), Wspótczesna..., op. cit., s. 197-201.
} 
T a b e 1 a 2.1

Progi oddziaływania polityki pieniężnej na produkt krajowy brutto

\begin{tabular}{|c|c|c|c|c|c|c|c|c|}
\hline \multicolumn{9}{|c|}{ Polityka pieniężna } \\
\hline \multicolumn{4}{|c|}{ Ceny pozostałych aktywów } & \multicolumn{5}{|c|}{ Stanowisko kredytowe } \\
\hline 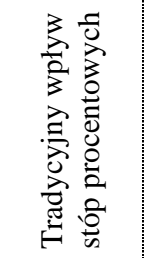 & 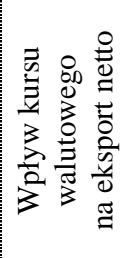 & 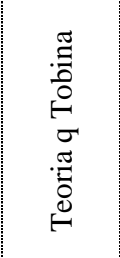 & 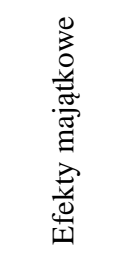 & 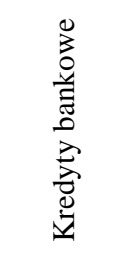 & $\stackrel{\text { : }}{\frac{0}{n}}$ & 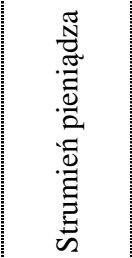 & 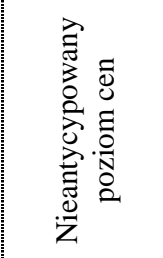 & 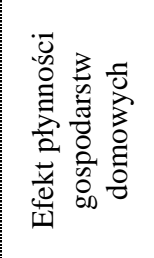 \\
\hline $\begin{array}{c}\text { Polityka } \\
\text { pieniężna }\end{array}$ & $\begin{array}{c}\text { Polityka } \\
\text { pieniężna }\end{array}$ & $\begin{array}{c}\text { Polityka } \\
\text { pieniężna }\end{array}$ & $\begin{array}{l}\text { Polityka } \\
\text { pieniężna }\end{array}$ & $\begin{array}{c}\text { Polityka } \\
\text { pieniężna }\end{array}$ & $\begin{array}{c}\text { Polityka } \\
\text { pieniężna }\end{array}$ & $\begin{array}{c}\text { Polityka } \\
\text { pieniężna }\end{array}$ & $\begin{array}{c}\text { Polityka } \\
\text { pieniężna }\end{array}$ & $\begin{array}{c}\text { Polityka } \\
\text { pieniężna }\end{array}$ \\
\hline$\downarrow$ & $\downarrow$ & $\downarrow$ & $\downarrow$ & $\downarrow$ & $\downarrow$ & $\downarrow$ & $\downarrow$ & $\downarrow$ \\
\hline $\begin{array}{c}\text { Stopy } \\
\text { procentowe }\end{array}$ & $\begin{array}{c}\text { Stopy } \\
\text { procentowe }\end{array}$ & Ceny akcji & Ceny akcji & $\begin{array}{c}\text { Kredyty } \\
\text { bankowe }\end{array}$ & Ceny akcji & $\begin{array}{c}\text { Stopy } \\
\text { procentowe }\end{array}$ & $\begin{array}{c}\text { Ryzyko nad- } \\
\text { użycia selekcja } \\
\text { negatywna }\end{array}$ & Ceny akcji \\
\hline$\downarrow$ & $\downarrow$ & $\downarrow$ & $\downarrow$ & $\downarrow$ & $\downarrow$ & $\downarrow$ & $\downarrow$ & $\downarrow$ \\
\hline $\begin{array}{l}\text { Inwestycje } \\
\text { budownictwo } \\
\text { mieszka- } \\
\text { niowe }\end{array}$ & $\begin{array}{c}\text { Kurs } \\
\text { walutowy }\end{array}$ & q Tobina & $\begin{array}{c}\text { Majątek } \\
\text { finansowy }\end{array}$ & Inwestycje & $\begin{array}{c}\text { Ryzyko } \\
\text { nadużycia } \\
\text { selekcja } \\
\text { negatywna }\end{array}$ & $\begin{array}{l}\text { Strumień } \\
\text { pieniądza }\end{array}$ & $\begin{array}{l}\text { Działalność } \\
\text { kredytowa }\end{array}$ & $\begin{array}{l}\text { Zamożność } \\
\text { (majątek } \\
\text { kredytowy) }\end{array}$ \\
\hline$\downarrow$ & $\downarrow$ & $\downarrow$ & $\downarrow$ & $\downarrow$ & $\downarrow$ & $\downarrow$ & $\downarrow$ & $\downarrow$ \\
\hline \multirow[t]{4}{*}{$\begin{array}{l}\text { Wydatki } \\
\text { konsumpcyj- } \\
\text { ne na dobra } \\
\text { trwałe }\end{array}$} & $\begin{array}{l}\text { Eksport } \\
\text { netto }\end{array}$ & Inwestycje & $\begin{array}{l}\text { Konsump- } \\
\text { cja }\end{array}$ & $\begin{array}{l}\text { Budownic- } \\
\text { two miesz- } \\
\text { kaniowe }\end{array}$ & $\begin{array}{c}\text { Działal- } \\
\text { ność } \\
\text { kredytowa }\end{array}$ & $\begin{array}{l}\text { Ryzyko } \\
\text { nadużycia, } \\
\text { selekcja } \\
\text { negatywna }\end{array}$ & Inwestycje & $\begin{array}{l}\text { Prawdopodo- } \\
\text { bieństwo } \\
\text { wystąpienia } \\
\text { trudnej } \\
\text { sytuacji } \\
\text { finansowej }\end{array}$ \\
\hline & & & & & $\begin{array}{c}\downarrow \\
\text { Inwestycje }\end{array}$ & $\begin{array}{c}\downarrow \\
\qquad \\
\text { Działalność } \\
\text { kredytowa }\end{array}$ & & $\begin{array}{c}\downarrow \\
\text { Budownictwo } \\
\text { mieszkaniowe }\end{array}$ \\
\hline & & & & & & $\downarrow$ & & $\downarrow$ \\
\hline & & & & & & Inwestycje & & $\begin{array}{l}\text { Wydatki } \\
\text { konsumpcyjne } \\
\text { na dobra } \\
\text { trwałe }\end{array}$ \\
\hline & & & & $₫ \mathrm{KI} a$ & brutto & & & \\
\hline
\end{tabular}

Ź ró d ło: F. S. Mis h ki in, Ekonomika pieniądza, bankowości i rynków finansowych, Wydawnictwo Naukowe PWN, Warszawa 2002, s. 799.

\subsubsection{Czynniki wpływające na mechanizm transmisji polityki pieniężnej}

H. Berger, M. Hermann oraz M. Fratzscher doszli do wniosku, że bardzo istotnym czynnikiem, który ma wpływ na mechanizm transmisji impulsów monetarnych EBC do strefy realnej są oczekiwania panujące na rynku. Z kolei 
zmiany stóp procentowych EBC oddziałują na rynkowe stopy procentowe oraz oczekiwania rynku na ich zmiany. Dodatkowo EBC ma utrudnione zadanie, ponieważ prowadząc swoją działalność $\mathrm{w}$ heterogenicznym środowisku, musi brać pod uwagę wpływ swoich decyzji na konsekwencje w poszczególnych krajach strefy euro, które mają zróżnicowane możliwości gospodarcze ${ }^{31}$. B. Bernanke oraz A. Blinder stwierdzili, że restrykcyjna polityka pieniężna ma istotny wpływ na zmniejszenie podaży kredytów bankowych, co negatywnie oddziałuje na działalność gospodarczą ${ }^{32}$.

M. Brzoza-Brzezina przeprowadził badanie na temat przyczyn przyspieszenia akcji kredytowej w państwach, które przygotowywały się do przystąpienia do strefy euro, tj. w: Portugalii, Irlandii oraz Grecji ${ }^{33}$. Jednym z głównych powodów boomu kredytowego w tych krajach było znaczne obniżenie realnych stóp procentowych. Było to wywołane konwergencją w ramach wspólnego obszaru walutowego. Jest to historyczny przykład działania mechanizmu transmisji polityki pieniężnej poprzez obniżenie realnych stóp procentowych i wpływ na ekspansję kredytową podmiotów gospodarczych ${ }^{34}$. Ponadto, pomimo silnego wzrostu poziomu kredytów w gospodarce, nie zauważono negatywnych konsekwencji tego zjawiska w sektorze bankowym ${ }^{35}$.

Podstawowe stopy procentowe polityki pieniężnej oddziałują na kształtowanie się bankowych stóp procentowych dla kredytów i pożyczek, głównie kanałem stóp procentowych oraz kanałem kredytowym. Jest to podstawowy mechanizm strefy euro, poprzez który EBC wywiera istotny wpływ na realną gospodarkę i inflację, ze względu na główną rolę sektora bankowego w finansowaniu sektora przedsiębiorstw prywatnych (non-financial private sektor). Obniżenie przez Radę Prezesów podstawowych stóp procentowych przekłada się na zmiany rynkowych stóp procentowych, głównie krótkoterminowych. Następnie bankowe stopy procentowe ustalane są z reguły na bazie krótko- bądź długoterminowych rynkowych stóp procentowych. Dlatego korekty podstawowych stóp procentowych decydują w dużej mierze o kosztach finansowania bankowego dla

${ }^{31}$ H. B erger, M. Ehrmann, M. Fratzscher, Forecasting ECB monetary policy. Accuracy is (still) a matter of geography, Working Paper no. 578, EVB, 05/2006, s. 23.

${ }^{32} \mathrm{~B}$. B e rn an ke, A. B inder, The federal fund rate and the channels of monetary transmission, „American Economic Review” 1992, vol. 82(4), s. 920.

${ }^{33}$ Portugalia i Irlandia przystąpiły do strefy euro w 1999 r., boom kredytowy w Portugalii rozpoczął się w latach 1995-1996, ze szczytowym momentem w 1999 r.; w Irlandii ekspansja kredytowa zaczęła się w 1995 r., natomiast Grecja weszła do strefy euro w 2001 r., a ekspansja kredytowa zapoczątkowana została w 1995 r., i po przejściowym okresie stabilizacji i niewielkich wahań wzrosła gwałtowanie w $2002 \mathrm{r}$.

${ }^{34}$ M. B r zo za-B r ze z in a, J. Ni ed ź wi ed zińs ka, Ekspansja kredytowa w nowych państwach cztonkowskich Unii Europejskiej a przystapienie do wspólnego obszaru walutowego, [w:] J. L. Bednarczyk (red.), Stopy procentowe a gospodarka. Dylematy Unii Gospodarczej $i$ Walutowej, Wydział Ekonomiczny Politechniki Radomskiej, Radom 2006, s. 25-26.

${ }^{35} \mathrm{M}$. B rzoza-B rzezin a, Lending booms in the new UE member states. Will euro adoption matter?, Working Paper Series no. 543, EBC, Frankfurt 2005, s. 5. 
podmiotów gospodarczych. Zwykle w praktyce bankowej banki stopniowo przenoszą zmiany podstawowych stóp procentowych banku centralnego oraz stóp rynkowych na wysokość oprocentowania depozytów i kredytów bankowych. Mówi się nawet o pewnej lepkości oraz asymetryczności cen produktów bankowych oferowanych klientom przez banki. Wiąże się to z tym, że bankowe stopy procentowe zazwyczaj szybciej dostosowuja się do podwyżek podstawowych stóp procentowych EBC niż do ich obniżek ${ }^{36}$. Z powodu niedoskonałości konkurencji w sektorze bankowym oraz tzw. kosztów „menu”, czyli nominalnej korekty, banki wolniej reagują na zmiany podstawowych stóp procentowych przez Radę Prezesów oraz stóp rynkowych, decydując się na opóźnienia korekt stóp kredytów i pożyczek. Wśród innych czynników wpływających na opóźnienia w dostosowywaniu bankowych stóp procentowych do zmian podstawowych stóp procentowych wymienia się koszty związane z ryzykiem stopy procentowej i ryzykiem kredytowym, jednostkowe koszty działalności, płynność sektora bankowego lub stopień awersji banków do ponoszenia ryzyka. EBC przeprowadził badania transmisji podstawowych stóp procentowych przenoszonych przez rynkowe stopy na bankowe stopy procentowe przy użyciu modelowania za pomocą mechanizmu korekty błędem (error-correction modelling framework). W rezultacie badania dowiedziono, że w pierwszym miesiącu spadek rynkowych stóp procentowych jest przeniesiony na stopy kredytów i pożyczek oferowanych przedsiębiorstwom w $69 \%{ }^{37}$.

Decyzje władz monetarnych mają znaczenie dla oczekiwań uczestników rynku co do przyszłego poziomu inflacji, oddziałując tym samym na zmiany cen w gospodarce ${ }^{38}$. Bank centralny, jako instytucja o wysokim stopniu wiarygodności, ma wpływ na oczekiwania dotyczące stabilności cen. Władze monetarne, poprzez wpływ na gospodarkę i na oczekiwania rynkowe, mogą prowadzić do zmiany cen aktywów (np. cen akcji) oraz kursu walutowego. Zmiany kursu walutowego mogą oddziaływać bezpośrednio na poziom inflacji, o ile importowane towary bezpośrednio wykorzystywane są do konsumpcji ${ }^{39}$. Na rys. 2.1 zmiany kursów walutowych wpływają bezpośrednio na ceny towarów importowanych. Następnie, poprzez ceny surowców importowanych, przekładają się na ceny dóbr finalnych wyprodukowanych przy użyciu dóbr zagranicznych oraz oddziałują na popyt wewnętrzny, na produkty krajowe w wyniku zmian konkurencyjności dóbr krajowych w stosunku do zagranicznych ${ }^{40}$.

\footnotetext{
s. $93-105$.

${ }^{37}$ Annual Report 2009, European Central Bank, Frankfurt n. Menem 2010, s. 49-52.

${ }^{38}$ Monetary policy transmission in the euro zone, „EBC Monthly Bulletin” 2000, vol. 7 , s. $43-58$.

${ }^{39}$ Monetary Policy, Transmission mechanizm of monetary policy, EBC, [za:] zasoby witryny internetowej: http://www.ecb.europa.eu/mopo/intro/transmission/html/index.en.html [15.08.2010].

${ }^{40}$ P. Gierałtowski, Polityka pieniężna $w$ unii walutowej, [w:] P. Kowalewski, W. Ko zińs ki (red.), Mechanizmy funkcjonowania strefy euro, Narodowy Bank Polski, Warszawa 2010, s. 93.
}

${ }^{36}$ Monthly Bulletin August 2008, European Central Bank, Frankfurt n. Menem, August 2009, 


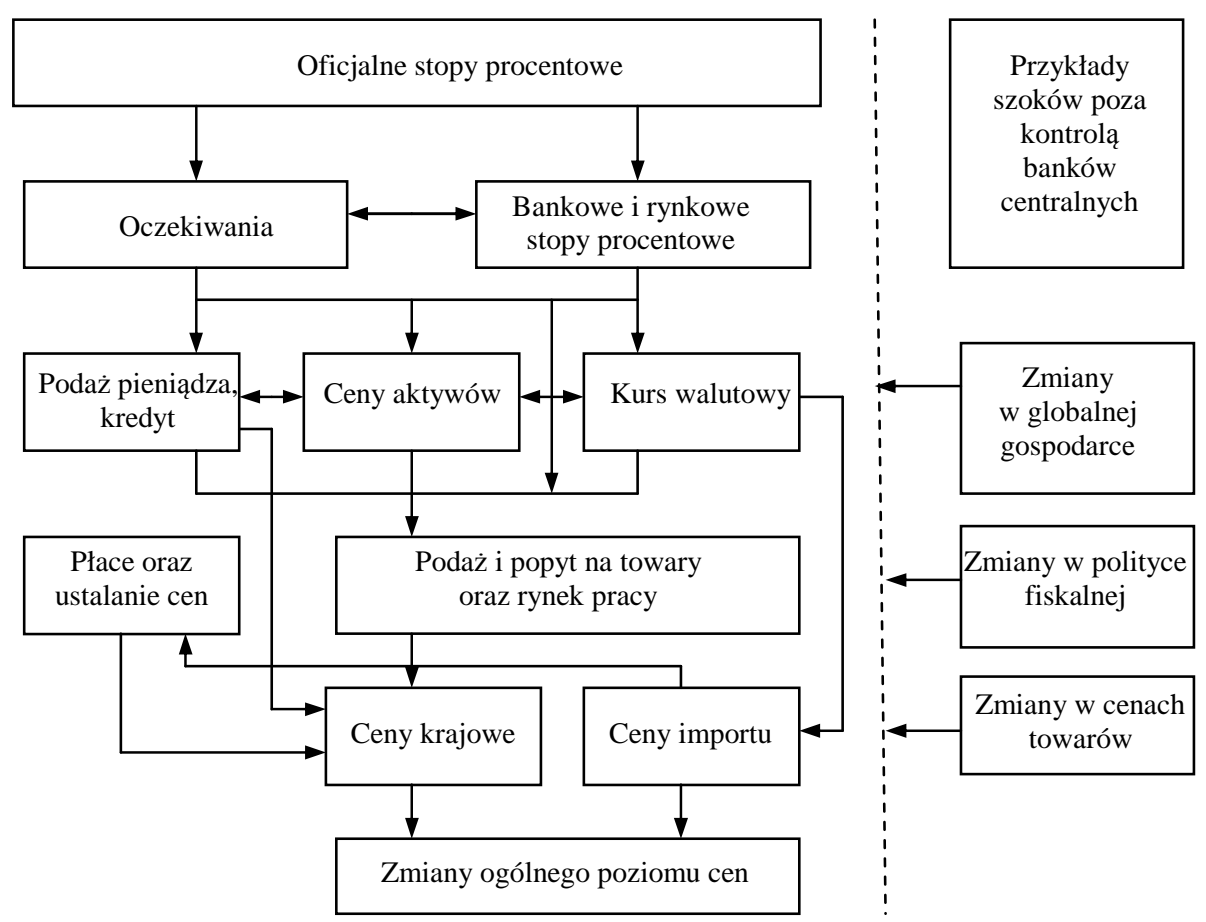

Rys. 2.1. Mechanizm transmisji impulsów stóp procentowych polityki pieniężnej EBC

Ź r ó d ł o: tłumaczenie własne, Monetary Policy, Transmission mechanism of monetary Policy, EBC [za:] zasoby witryny internetowej: http://www.ecb.europa.eu/mopo/intro/transmission/ html/index.en.html [30. 09. 2010].

Zgodnie z mechanizmem transmisji impulsów polityki pieniężnej prezentowanym przez EBC na rys. 2.1, oficjalne stopy procentowe mają wpływ na poziom konsumpcji oraz inwestycji. W dodatku ceny aktywów, poprzez efekt majątkowy (bogactwa) i efekt wartości zabezpieczeń, oddziałują na poziom cen w gospodarce. Jeśli rośnie wartość kapitału własnego, właściciele akcji stają się bogatsi i wydają więcej środków pieniężnych na konsumpcję. Z kolei wyższe ceny aktywów, poprzez większą wartość zabezpieczeń, umożliwiają kredytobiorcom zaciąganie większej liczby pożyczek a zarazem banki obciążają ich niższą premią za ryzyko ${ }^{41}$.

Wyższe stopy procentowe zwiększają ryzyko niespłacenia kredytów przez pożyczkobiorców. Banki mogą na tej podstawie zmniejszyć fundusze przeznaczone na kredyty dla gospodarstw domowych i firm, co redukuje konsumpcję

${ }^{41}$ Monetary policy transmission in the euro area, a decade after the introduction of the euro, „Monthly Bulletin” 2010, vol. 5, European Central Bank, s. 85-98. 
i inwestycje podmiotów gospodarczych. Zmiany w poziomie konsumpcji i inwestycji w gospodarce zmieniają popyt na towary i usługi w stosunku do ich podaży. Jeśli popyt przekroczy podaż pojawia się duże prawdopodobieństwo presji cenowej w górę. W dodatku zagregowany popyt może przełożyć się na zmienne warunki na rynku pracy i produktów, co wpływa na ceny i politykę płacową w gospodarce ${ }^{42}$. Poza tym zmiany oficjalnych stóp procentowych oddziałują na krańcowy koszt kapitału pozyskiwanego przez bank, który zależy w dużej mierze od własnych zasobów i kapitału banków. Ten kanał jest bardzo istotny, szczególnie w czasie kryzysów finansowych, kiedy bankom trudniej zdobyć środki na akcję kredytową, czy na podniesienie kapitału własnego ${ }^{43}$. Mechanizm transmisji impulsów polityki pieniężnej jest procesem złożonym, co jest przyczyną opóźnień występujących między decyzją o zmianie stóp procentowych banku centralnego a pojawieniem się jej skutków w gospodarce.

Proces ten ma niezwykle duże znaczenie dla instytucji prowadzącej politykę pieniężną, ponieważ tempo dostosowań stóp procentowych oraz skala przenoszenia zmian stóp procentowych na oprocentowanie produktów bankowych oferowanych przez banki komercyjne określa tempo i poziom zagregowanego popytu oraz inflacji. Poza tym dostosowanie stóp procentowych depozytów i kredytów do odpowiednich wielkości rynkowych stóp procentowych wiąże się z opóźnieniami. Przyczyny tego typu zjawisk to ${ }^{44}$ :

- niedoskonała konkurencja - efekt przenoszenia zmian bazowych stóp procentowych banku centralnego na ceny produktów bankowych zależy od konkurencyjności w sektorze bankowym, jak również od konkurencji pomiędzy rynkiem pieniężnym a kapitałowym. Efekt przenoszenia jest tym większy im lepiej jest rozwinięty rynek kapitałowy i produkty bankowe można łatwo zamieniać na produkty rynku kapitałowego;

- koszty zmian cen produktów - zmiany cen produktów bankowych wiążą się dla banku z pewnymi kosztami, jeśli zmiany te są niewielkie, ale częste, banki komercyjne stosują wtedy zasadę unikania kosztów i zmieniają ceny produktów rzadziej, ale silniej; stąd reakcja cen produktów bankowych jest opóźniona w stosunku do zmiany podstawowych stóp procentowych;

- niepewność decyzji banku centralnego w zakresie kierunku przyszłej polityki pieniężnej - w przypadku niepewności banków komercyjnych co do przyszłej polityki banku centralnego, mogą one opóźniać decyzje dotyczące cen swoich produktów dla podmiotów gospodarczych;

${ }^{42}$ Monetary Policy, Transmission mechanizm..., op. cit.

${ }^{43}$ Monetary policy transmission in the euro area..., op. cit., 85-98.

${ }^{44}$ G. Grabek, B. Kło s, R. Kokoszczyński, T. Łyziak, J. Przystupa, E. Wróbel, Porównanie podstawowych cech mechanizmu transmisji monetarnej $w$ Polsce $i w$ strefie euro, Narodowy Bank Polski, Warszawa, kwiecień 2008, s. 15. 
- trudności wynikające z wyboru odpowiedniej stopy procentowej do badań empirycznych - w praktyce bardzo trudno jest precyzyjnie ustalić, na podstawie których stóp rynkowych banki kształtują ceny swoich produktów.

W literaturze przedmiotu wyróżnia się następujące czynniki strukturalne wpływające na mechanizm transmisji impulsów polityki pieniężnej: skala monetyzacji, struktura popytu krajowego, stopień otwartości gospodarki, struktura źródeł finansowania przedsiębiorstw oraz gospodarstw domowych, struktura własnościowa systemu bankowego, stopień jego koncentracji i struktura bilansów banków ${ }^{45}$.

Skala monetyzacji rozumiana jest jako relacja podaży pieniądza do PKB. Niski poziom monetyzacji cechuje głównie kraje rozwijające się, często o reglamentowanych rynkach finansowych lub nieformalnych rynkach kredytowych i depozytowych. W krajach o niskim stopniu monetyzacji, siła transmisji impulsów polityki pieniężnej jest mniejsza niż w krajach rozwiniętych, a główną rolę w tym procesie pełni system bankowy. W Polsce można zaobserwować relatywnie niski stopień monetyzacji, co wyjaśnia słabszą reakcję głównych zmiennych makroekonomicznych na impulsy polityki monetarnej. Pomimo wzrostu efektywności przenoszenia impulsów polityki pieniężnej mechanizm ten nadal wydaje się słaby i charakteryzuje się opóźnieniami ${ }^{46}$.

Kolejnym ważnym elementem w mechanizmie transmisji impulsów polityki pieniężnej jest zależność wynikająca z kontaktów gospodarki z zagranicą, a dokładnie wpływ kursu walutowego na inflację. Po pierwsze, wpływ otwartości gospodarki na inflację przejawia się w udziale dóbr importowanych w spożyciu, których ceny wchodzą w skład indeksu cen konsumpcyjnych. Po drugie, krajowa produkcja oraz luka popytowa, które zależą od popytu zagranicznego oraz kursu walutowego, pojawiające się w przypadku gospodarki otwartej, odgrywają istotną rolę $\mathrm{w}$ mechanizmie transmisji polityki pieniężnej. Na indeks cen konsumpcyjnych wpływ ma również stopień substytucji między dobrami krajowymi a zagranicznymi. W przypadku dominacji w imporcie dóbr o charakterze zaopatrzeniowym, które są podstawowym elementem wykorzystywanym w procesie produkcji, wpływ zmian kursu walutowego przekłada się w pierwszej kolejności na krajową lukę popytową, a dopiero potem oddziałuje na inflację. Na mechanizm ten istotny wpływ mają ceny proponowane przez zagranicznych eksporterów, którzy ustalają je w walucie lokalnej kraju importera i stąd kurs walutowy wpływa na marżę zysku krajowych eksporterów tylko w przypadku ustalania przez nich ceny swoich towarów w walucie zagranicznej ${ }^{47}$.

Znaczną rolę $\mathrm{w}$ mechanizmie transmisji impulsów polityki pieniężnej odgrywa struktura systemu finansowego. To, w jakim stopniu oprocentowanie

${ }^{45}$ R. Kokoszczyński, T. Łyziak, E. Wróbel, Czynniki strukturalne we wspótczesnych teoriach mechanizmów transmisji polityki pieniężnej, XXII Konferencja naukowa NBP „Reformy strukturalne a polityka pieniężna”, Falenty 2002, s. 2.

${ }^{46}$ Ibidem, s. 3.

${ }^{47}$ Ibidem, s. 8. 
depozytów i kredytów jest wrażliwe na zmiany stóp procentowych rynku pieniężnego zależy od liczby banków, jako miary konkurencyjności w systemie bankowym. Struktura systemu finansowego ma również znaczenie w działaniu kanału kredytowego mechanizmu transmisji polityki pieniężnej, który składa się z kanału kredytów bankowych oraz kanału bilansowego. Oddziaływanie kanału bilansowego zależy od relacji długu przedsiębiorstw do ich kapitału netto. Im relacja ta jest mniejsza, tym restrykcyjna polityka pieniężna $\mathrm{w}$ mniejszym stopniu ograniczy zdolność kredytową przedsiębiorstw niż w gospodarkach, gdzie współczynnik ten jest wyższy. Ekonomiści, jak wspomniany wyżej L. Guiso, podkreślają również znaczenie wielkości przedsiębiorstwa w kanale bilansowym. Ponieważ banki zwykle od mniejszych firm żądają większych zabezpieczeń, dlatego restrykcyjna polityka banku centralnego ma silniejszy wpływ na te właśnie przedsiębiorstwa. Następnym elementem mającym znaczenie w mechanizmie oddziaływania polityki pieniężnej poprzez kanał bilansowy jest zadłużenie przedsiębiorstw w relacji do ich dochodów do dyspozycji. Im bardziej restrykcyjna polityka pieniężna tym mniejsze dochody przedsiębiorstw do dyspozycji i mniejsza zdolność kredytowa podmiotów gospodarczych. W przypadku kanału kredytowego główne założenie opiera się na tym, że polityka pieniężna ma wpływ na bilanse banków komercyjnych. W momencie ograniczania przez bank centralny podaży kredytu, przedsiębiorstwa, które utrzymują relację z jednym bankiem są bardziej narażone na efekty restrykcyjnej polityki pieniężnej i ograniczanie dostępu do kapitału niż firmy, które współpracują z wieloma bankami, mając dzięki temu zdywersyfikowane źródła finansowania zewnętrznego ${ }^{48}$.

Do innych wskaźników strukturalnych określających znaczenie kanału kredytowego w mechanizmie transmisji polityki monetarnej należy wielkość rynku kapitałowego. Odgrywa on relatywnie dużą rolę ze względu na dostępność alternatywnych źródeł finansowania zewnętrznego w stosunku do kredytów bankowych. Im jest on bardziej rozwinięty, tym restrykcyjna polityka banku centralnego ma słabszy oddźwięk w gospodarce. Kolejny wskaźnik funkcjonowania kanału kredytów bankowych to wielkość banku. Banki mniejsze, których wielkość jest mierzona sumą całkowitych aktywów, są bardziej wrażliwe na zmiany stóp procentowych banku centralnego w porównaniu do banków większych. Również struktura aktywów banków komercyjnych jest istotna w mechanizmie transmisji impulsów polityki pieniężnej, chociażby ze względu na stopień płynności tych aktywów ${ }^{49}$. Na tym etapie analizy pojawia się pojęcie efektu poduszki

\section{${ }^{48}$ Ibidem, s. 9.}

49 M. Ehrmann i inni otrzymali wyniki, według których zacieśnianie polityki pieniężnej ogólnie redukuje akcję kredytową banków w większości krajów strefy euro, natomiast wielkość banku nie wyjaśnia ich reakcji dotyczących udzielania kredytów, w przeciwieństwie do płynności banku. Analiza wpływu polityki pieniężnej w krajach strefy euro opiera się na niejednorodności ich reakcji na decyzje banku centralnego. Przykładowo, przedsiębiorstwa we Włoszech rzadziej korzystają z własnych papierów dłużnych niż firmy we Francji, natomiast częściej z kredytów 
płynnościowej (buffer-stock behaviour). Zjawisko to polega na utrzymywaniu akcji kredytowej przez banki komercyjne ze względu na szczególne kontakty z kredytobiorcami, kosztem dostosowywania portfela aktywów płynnych jak: bony i obligacje skarbowe oraz bony pieniężne NBP. Tak dzieje się w bankach, które posiadają duże portfele aktywów o wysokim stopniu płynności. Badania M. Ehrmanna świadczą o tym, że impuls polityki pieniężnej na podaż kredytu zależy od stopnia płynności banku komercyjnego ${ }^{50}$. Banki o większej płynności reagują słabiej aniżeli banki o mniejszej płynności ${ }^{51}$.

W Polsce pomimo rozwoju rynku kapitałowego nadal banki pełnią rolę najważniejszych pośredników finansowych. Rynek obligacji czy bonów komercyjnych nie jest tak rozwinięty jak w innych państwach europejskich, a rynek kapitałowy jest właściwie osiągalny $\mathrm{w}$ większości dla dużych przedsiębiorstw ${ }^{52}$. Poza tym mimo przewagi rynku bankowego nad rynkiem kapitałowym w finansowaniu przedsiębiorstw, tylko około połowy przedsiębiorstw korzysta z kredytu bankowego jako źródła finansowania inwestycji, co nie jest relatywnie wysoką statystyką ${ }^{53}$. Dodatkowo banki komercyjne w Polsce utrzymują dość duże portfele aktywów o wysokim stopniu płynności, co ułatwia im postępowanie zgodnie ze schematem poduszki płynnościowej. To osłabia działanie mechanizmu impulsów polityki pieniężnej $\mathrm{w}$ momencie podjęcia przez bank centralny restrykcyjnych kierunków w polityce, w celu ograniczania podaży kredytów bankowych ${ }^{54}$.

Według T. Chmielewskiego na efekt przenoszenia impulsów polityki pieniężnej w Polsce wpływają przede wszystkim dwie cechy, mianowicie: sytuacja finansowa banków (wskaźnik ROA) oraz jakość portfela kredytów. Banki o lepszej kondycji finansowej dostosowują oprocentowanie kredytów i depozytów bankowych o długich okresach zapadalności dużo szybciej i w większym

bankowych (zatem banki włoskie silniej reagują na decyzje banku centralnego). Również zapadalności kredytów bankowych we Włoszech są krótsze niż we Francji. Krótszy termin zapadalności kredytów bankowych wpływa na wzmocnienie mechanizmu transmisji impulsów polityki pieniężnej, ponieważ kredyty muszą być częściej odnawiane. Kolejny przykład to niejednorodność koncentracji rynku mierzona wskaźnikiem HHI (Herfindahl-Hirschman Index). Wskaźnik Herfindahla będący miarą koncentracji rynku i poziomu konkurencji jest niższy w Niemczech niż we Francji, co oznacza, że niemiecki system bankowy charakteryzuje się większą liczbą małych banków oraz silniejszą konkurencyjnością. Zatem mechanizm transmisji polityki pieniężnej może mieć większy wpływ w Niemczech [w:] M. Ehrmann, L. Gambacorta, J. Martinez-Pages, P. S e ve stre, A. W or m s, Financial system and the role of banks in monetary policy transmission in the euro area, European Central Bank, Working Paper no. 105, 2001, s. 6-34.

${ }^{50}$ M. Ehrmann, L. Gambacorta, J. Martinez-Pages, P. Sevestre, A. Worms, op. cit., s. 34 .

${ }^{51}$ R. Kokoszczyński, T. Łyziak, E. Wróbel, op. cit., s. 10-11.

${ }^{52}$ Ibidem, s. 11.

${ }^{53}$ Wstępna informacja o kondycji sektora przedsiębiorstw ze szczególnym uwzględnieniem stanu koniunktury w IV kwartale 2006 roku, [za:] zasoby oficjalnej witryny internetowej Narodowego Banku Polskiego: http://www.nbp.pl/home.aspx?f=publikacje/koniunktura/koniunktura.html [06.06.2011].

${ }^{54}$ G. Grabek, B. Kłos, R. Kokoszczyński, T. Łyziak, J. Przystupa, E. Wróbel, op. cit., s. 18. 
zakresie niż banki o gorszej sytuacji finansowej. T. Chmielewski podkreśla, że banki o gorszych portfelach kredytowych szybciej niż inne banki dostosowują oprocentowanie kredytów do zmian rynkowych stóp procentowych. Zaś dostosowanie oprocentowania depozytów tych od 3 do 12 miesięcy odbywa się z większym opóźnieniem w bankach o gorszych portfelach kredytowych ${ }^{55}$.

Podsumowanie rozważań na temat wpływu polityki pieniężnej poprzez mechanizm transmisji na $\mathrm{m}$. in. rynkowe stopy procentowe, kurs walutowy, kredyty bankowe, poziom cen czy bilanse przedsiębiorstw zostało zaprezentowane w tab. 2.2. Jest to mechanizm transmisji według podejścia kredytowego postulowany przez szkołę keynesowską czy neokeynesowską ${ }^{56}$. Przedstawia sposób wywołania przez bank centralny zmian wielkości poziomu cen, zagregowanego popytu, produkcji czy zatrudnienia za pomocą impulsów polityki pieniężnej, poprzez fazy procesu transmisyjnego. Zaletą tego modelu jest całościowy obraz funkcjonowania gospodarki, podkreślający wpływ pieniądza na wielkości makroekonomiczne. Jest to jednak tylko schemat, który nie uwzględnia czynników zakłócających transmisje impulsów polityki do sfery realnej gospodarki.

W mechanizmie transmisji impulsów polityki pieniężnej uczestniczą banki komercyjne, przedsiębiorstwa i gospodarstwa domowe, których celem jest utrzymanie się na rynku i optymalizacja swoich korzyści. Podmioty te nie koncentrują działalności na osiągnięciu celu inflacyjnego i dlatego często ich działania są czynnikami zakłócającymi transmisję impulsów polityki banku centralnego do sfery realnej. Istotne jest zatem, by władze monetarne koncentrowały się na tworzeniu właściwych systemów prognostycznych, określaniu skali i momentów przełożenia swoich decyzji na gospodarkę, przy uwzględnieniu możliwych opóźnień i czynników zaburzających impulsy polityki pieniężnej.

\subsection{Przegląd badań dotyczących wpływu polityki pieniężnej na gospodarkę}

W badaniach siły mechanizmu transmisji impulsów polityki pieniężnej banku centralnego istotne znaczenie ma struktura popytu krajowego. Wpływ stóp procentowych na inwestycje, konsumpcję (z podziałem na wydatki mieszkaniowe i wydatki na dobra trwałego użytku) oraz eksport netto w sposób obszerny przedstawiony jest w opracowaniach L. Mahadeva i P. Sinclaira ${ }^{57}$.

${ }^{55}$ T. Chmielewski, Interest rate pass-through in the Polish banking sektor and bankspecific financial disturbances, MPRA Paper no 5133, 2003, [za:] zasoby witryny internetowej: http://mpra.ub.uni-muenchen.de/5133/ [12.04.2011], [w:] G. Grabek, B. Kłos, R. Kokoszc zyński, T. Łyziak, J. Przystu pa, E. Wróbel, op. cit., s. 18-19.

${ }^{56}$ P. N. Ireland, The Monetary Transmission Mechanism, Boston College and NBER, 2005, s. 1.

${ }^{57}$ L. Mahadeva, P. S in clair, The transmission mechanism of monetary policy, materiał przygotowany na Central Bank Governors' Symposium, Bank Anglii, 08.06.2001. 
T a b e 1 a 2.2

Mechanizm transmisji zmian polityki pieniężnej na gospodarkę w wersji „koszt i dostępność kredytu”

\begin{tabular}{|c|c|c|c|c|}
\hline Faza & Impuls & Faza I & Faza II & Faza III \\
\hline $\begin{array}{l}\text { Podmioty } \\
\text { gospodarcze } \\
\text { (regulujące } \\
\text { lub } \\
\text { działające) } \\
\end{array}$ & Bank centralny & $\begin{array}{l}\text { Banki } \\
\text { komercyjne }\end{array}$ & \begin{tabular}{|l|} 
Przedsiębior- \\
stwa \\
niebankowe \\
i gospodarstwa \\
domowe \\
\end{tabular} & $\begin{array}{l}\text { Przedsiębior- } \\
\text { stwa } \\
\text { niebankowe } \\
\text { i gospodarstwa } \\
\text { domowe }\end{array}$ \\
\hline \multirow[t]{2}{*}{$\begin{array}{l}\text { Proces } \\
\text { transmisyjny }\end{array}$} & $\begin{array}{l}\text { Ekspansywny } \\
\text { charakter } \\
\text { polityki } \\
\text { pieniężnej } \\
\text { - obniżka stopy } \\
\text { redyskontowej } \\
\text { - zwiększenie } \\
\text { kwot redyskonto- } \\
\text { wych } \\
\text { - obniżka stóp } \\
\text { rezerw obowiąz- } \\
\text { kowych }\end{array}$ & $\left|\begin{array}{l}\text { Wzrost wol- } \\
\text { nych rezerw } \\
\text { płynnych } \\
\text { Zwiększenie } \\
\text { podaży kredytu } \\
\vdots \\
\text { Tendencja do } \\
\text { spadku stóp \% }\end{array}\right|$ & $\begin{array}{l}\text { Wzrost popytu na } \\
\text { kredyt } \\
\text { Wzrost wydatków } \\
\text { finansowanych } \\
\text { kredytem (zwłasz- } \\
\text { cza inwestycyj- } \\
\text { nych) } \\
\text { Ekspansywne } \\
\text { procesy mnożni- } \\
\text { kowe i akcelera- } \\
\text { cyjne } \\
\text { Wzrost globalnego } \\
\text { popytu }\end{array}$ & $\mid \begin{array}{l}\text { Zmniejszenie się } \\
\text { deficytu popy- } \\
\text { towego } \\
\text { Wzrost produkcji } \\
\text { Wzrost zatrud- } \\
\text { Zmniejszenie się } \\
\text { wielkości bezro- } \\
\text { bocia koniunktu- } \\
\text { ralnego }\end{array}$ \\
\hline & \begin{tabular}{|l|} 
Restrykcyjny \\
charakter polityki \\
pieniężnej \\
- podwyższenie \\
stopy dyskonto- \\
wej \\
- ograniczenie \\
kwot redyskonto- \\
wych \\
- podwyższenie \\
stóp rezerw obo- \\
wiązkowych
\end{tabular} & \begin{tabular}{|l|} 
Zmniejszenie \\
się wolnych \\
rezerw płyn- \\
nych \\
Ograniczenie \\
podaży kredytu \\
Tendencja do \\
wzrost stóp \%
\end{tabular} & $\begin{array}{l}\text { Spadek popytu na } \\
\text { kredyt } \\
\text { Zmniejszenie się } \\
\text { wydatków finan- } \\
\text { sowanych kredy- } \\
\text { tem (zwłaszcza } \\
\text { inwestycyjnych) } \\
\text { Restrykcyjne } \\
\text { procesy mnożni- } \\
\text { kowe i akcelera- } \\
\text { cyjne } \\
\text { Zmniejszenie } \\
\text { wielkości global- } \\
\text { nego popytu }\end{array}$ & $\begin{array}{l}\text { Zmniejszenie się } \\
\text { nadwyżki popy- } \\
\text { towej } \\
\text { Ograniczenie } \\
\text { luki inflacyjnej } \\
\text { Ograniczenie } \\
\text { inflacji popyto- } \\
\text { wej }\end{array}$ \\
\hline $\begin{array}{l}\text { Wskaźniki } \\
\text { gospodarcze }\end{array}$ & $\begin{array}{l}\text { Zmienne } \\
\text { instrumentalne } \\
\text { jak wyżej }\end{array}$ & $\begin{array}{l}\text { Wolne rezerwy } \\
\text { płynne } \\
\text { i poziom stóp } \\
\text { procentowych }\end{array}$ & \begin{tabular}{|l|} 
Popyt, \\
produkcja, dochód \\
narodowy
\end{tabular} & $\begin{array}{l}\text { Zatrudnienie, } \\
\text { poziom cen }\end{array}$ \\
\hline
\end{tabular}

Ź r ó d ł o: J. L. B ed n ar c zy k, Polityka pieniężna przeciw inflacji, Wydawnictwo Naukowe PWN, Warszawa 1990. 
Z przeprowadzonych przez tych autorów badań wynika, że wzrost nominalnych stóp procentowych wywiera hamujący wpływ na konsumpcję, z kolei wzrost realnych stóp procentowych w przeszłości powoduje wzrost konsump$\mathrm{cji}^{58}$. W jeszcze innych badaniach, np. Ch. J. Ercega i A. T. Levina zastosowano podział wydatków konsumpcyjnych na dobra trwałego użytku i inne dobra nietrwałe. Wyniki badań pokazały, że wpływ polityki pieniężnej na wydatki na dobra trwałe jest nawet kilkakrotnie większy niż na dobra nietrwałe ${ }^{59}$. Podobnie G. Peersman i F. Smets wnioskują, że branże przemysłu zajmujące się produkcją wyrobów trwałego użytku są dużo bardziej wrażliwe na impulsy polityki pieniężnej niż inne branże ${ }^{60}$.

Rozpatrując szerzej strukturę popytu krajowego należy podkreślić co najmniej trzy aspekty wpływu stóp procentowych na inwestycje. Pierwszy odnosi się do kosztu użytkowania kapitału, jako podstawowego elementu transmisji polityki banku centralnego w przypadku inwestycji. Zależy on nie tylko od kosztów finansowania, na który wpływa przede wszystkim stopa procentowa. Na koszt użytkowania kapitału wpływ mają również: deprecjacja, podatki, ceny względne kapitału do produkcji. Drugi aspekt wiąże się z tym, że zmiany stóp procentowych mogą być powodowane wzrostem popytu inwestycyjnego, co jest utrudnieniem w rozróżnieniu wpływu na inwestycje wzrostu popytu inwestycyjnego czy malejących stóp procentowych. Trzeci aspekt dotyczy składowych inwestycji (akcji, maszyn, urządzeń), na których kształtowanie ma również wpływ kurs walutowy i ich ceny zagraniczne, ponieważ wiele takich inwestycji jest przedmiotem handlu międzynarodowego. Badania empiryczne wskazują, że istnieje relatywnie słaby bezpośredni wpływ stóp procentowych na inwestycje ogółem. Dlatego podjęto badania, które mierzą wpływ stóp procentowych na poszczególne składowe inwestycji. Wyniki, do jakich doszli chociażby

${ }^{58}$ Wyniki dekompozycji strukturalnej dla Polski (E. Wróbel, B. Kłos) w latach 1995-2000 pokazały, że zmiany stóp procentowych oraz wybranych zmiennych nominalnych oddziałują na inflację w podobny sposób jak w gospodarkach o rozwiniętych rynkach finansowych. Warto podkreślić, że niektóre zmienne realne, jak produkcja, zmieniała się w sposób niezgodny z oczekiwaniami, tzn. po zacieśnieniu polityki pieniężnej początkowo następował wzrost produkcji (output puzzle). E. Wróbel oraz M. Pawłowska rozszerzyły to badanie otrzymując następujące wyniki; w rezultacie zacieśnienia polityki pieniężnej następuje spadek inflacji oraz tymczasowy spadek produkcji przemysłowej i sprzedaży detalicznej; natomiast reakcja produkcji i wskaźnika CPI w Polsce jest słabsza niż w krajach strefy euro, [w:] E. Wróbel, M. P a wło w ska, Monetary transmission in Poland: Some evidence on interest rate and credit channles, ,Materiały i studia” 2002, nr 24, s. 7-26.

Dekompozycja strukturalna to metoda umożliwiająca wyróżnienie głównych przesunięć wewnątrz gospodarki poprzez środki porównawczych statystycznych zmian w kluczowych dla danego zjawiska grupach parametrów, [w:] J. S kolk a, Input-output structural decompsition analysis for Austria, ,Journal of Policy Modeling” 1989.

${ }^{59}$ Ch. J. Erceg, A. T. Le vin, Optimal Monetary Policy with Durable and Non-Durable Goods, referat przedstawiony na konferencji „International Research Forum on Monetary Policy”, ECB, 5-6.07.2002.

${ }^{60}$ G. Peersman, F. S mets, The Industry Effects of Monetary Policy in the Euro Area, Working Paper no. 165, European Central Bank, Frankfurt 2002, s. 1-24. 
Ch. J. Erceg i A. T. Levin oraz K. N. Kuttner i P. C. Mosser przedstawiają silny wpływ stóp procentowych na budownictwo mieszkaniowe oraz słabszy na inwestycje przedsiębiorstw $^{61}$. Natomiast L. Guiso w swoich badaniach wykorzystał dane mikroekonomiczne opisujące inwestycje indywidualnych przedsiębiorstw ${ }^{62}$. Otrzymał dość precyzyjne szacunki kosztu użytkowania kapitału i na tej podstawie zaobserwował większą siłę wpływu zmiany stóp procentowych na poziom tego kosztu niż w badaniach opartych na danych zagregowanych.

Podobnie J. Taylor przedstawił dowody empiryczne na temat istnienia znaczącego wpływu stóp procentowych na wydatki inwestycyjne za pośrednictwem kosztu kapitału ${ }^{63}$. Odmienne zdanie mieli B. Bernanke oraz M. Gertler, którzy na podstawie badań empirycznych doszli do wniosku, że koszt kapitału nie ma silnego wpływu na mechanizm oddziaływania stóp procentowych na inwestycje. Uznali, że podstawowy koszt podejmowanych inwestycji nie składa się głównie z ceny pożyczonego kapitału w banku. Wytłumaczeniem tego faktu może być zjawisko niskiej inflacji i rynkowej stopy procentowej w krajach wysoko rozwiniętych ${ }^{64}$.

W Polsce na podstawie przeprowadzonych badań, między innymi przez A. Szymczak, wynika, że w latach 1995-2002 istniała ujemna umiarkowana zależność stopy wzrostu realnych nakładów inwestycyjnych od realnej stopy procentowej. Otrzymany przez A. Szymczak współczynnik korelacji Pearsona bez opóźnień czasowych wyniósł $\left(r_{x y}=-0,59\right)$. Do opisywanego badania wykorzystano stopę redyskontową Narodowego Banku Polskiego. Dodatkowo posłużono się współczynnikiem determinacji, który wskazał, że 35\% zmienności nakładów inwestycyjnych wyjaśniają zmiany stopy procentowej. Dopiero po opóźnieniu zmiennych o 4 kwartały współczynnik determinacji wzrósł do $60 \%{ }^{65}$.

M. Kowalski podaje wyniki współczynnika korelacji pomiędzy realną stopą referencyjną a nakładami inwestycyjnymi przy rocznym opóźnieniu na poziomie $\left(r_{x y}=-0,80\right) \mathrm{w}$ latach 1998-2003. Świadczy to o tym, że inwestycje reagują z opóźnieniem na zmiany stóp procentowych NBP w Polsce, czego powodem jest wydłużony proces decyzyjny i organizacyjny związany z inicjatywą inwestycyjną ${ }^{66}$.

${ }^{61}$ K. N. Kuttner, P. C. Mosse r, op. cit., s. 15-26.

${ }^{62}$ L. Guis o, A. K. Kashyap, F. Panet ta, D. Terlizzese, How Interest Sensitive is Investment?, [w:] R. Kokoszczyński, T. Łyziak, E. Wróbel, Czynniki strukturalne we wspótczesnych teoriach mechanizmów transmisji polityki pieniężnej, XXII Konferencja Naukowa NBP „Reformy strukturalne a polityka pieniężna”, Falenty 2002, s. 26.

${ }_{63}^{3}$ J. T a y lor, Monetary Transmission Mechanism: An Empirical Framework, ,Journal of Economic Perspectives" 1995, vol. 9, s. 1-26.

${ }^{64}$ B. B e rn an ke, M. Gertl er, Inside the Black Box: The Credit Channel of Monetary Policy Transmission, ,Journal of Economic Perspectives” 1995, vol. 9, s. 1-48.

${ }^{65}$ A. S z y mczak, Krótkookresowe i dtugookresowe efekty wptywu stopy procentowej na aktywność inwestycyjna przedsiębiorstw w Polsce, [za:] zasoby witryny internetowej: http://mikro. univ.szczecin.pl/bp/pdf/41/17.pdf [12.11.2009].

${ }^{66} \mathrm{M}$. K o w als ki, Wptyw polityki pieniężnej na inwestycje przedsiębiorstw, [za:] zasoby witryny internetowej http://Kowalski_2003_Wplyw\%20NBP\%20na\%20inwestycje.pdf [07.09.2009]. 


\subsection{Metody realizacji polityki pieniężnej Europejskiego Banku Centralnego i Narodowego Banku Polskiego}

Przedmiotem zainteresowania banku centralnego jest zachowanie wewnętrznej oraz zewnętrznej równowagi finansowej kraju, a jednocześnie dbanie o płynność i stabilność sektora bankowego. Dlatego bank centralny, aby zapewnić gospodarce krajowej zrównoważony rozwój wyznacza cele, które ujęte są w założeniach polityki pieniężnej. Bank centralny zorientowany jest na realizację postawionego celu finalnego, którym zazwyczaj jest cel inflacyjny, w ramach opracowanej strategii polityki pieniężnej, mającej mu pomóc w osiągnięciu zaplanowanych zamierzeń. Żeby mieć wpływ na cel podstawowy władze monetarne muszą mieć opracowany zestaw narzędzi służących do oddziaływania na sferę realną gospodarki.

Realizacja nadrzędnego celu polityki pieniężnej i przyjęcie określonej strategii jego wykonania jest możliwa tylko przy zastosowaniu odpowiednich instrumentów $^{67}$. Instrumenty polityki pieniężnej to narzędzia, za pomocą których władze monetarne dokonują zmian w podaży i cenie pieniądza. W związku z tym, że zadania instrumentów polityki pieniężnej ulegają zmianom, wybór odpowiedniego zestawu narzędzi pieniężnej polityki procesowej zależy od wyznaczonych celów i przyjętej strategii realizacji celu nadrzędnego władz mone$\operatorname{tarnych}^{68}$.

Poprzez te instrumenty bank centralny ma wpływ na poziom krótkoterminowych stóp procentowych na rynku międzybankowym. W strefie euro praktyczne wykorzystywanie instrumentów służących realizacji polityki pieniężnej należy do obowiązków narodowych banków centralnych Eurosystemu. Zatem pomimo tego, iż proces decyzyjny został scentralizowany, to jednak funkcje wykonawcze pozostały zdecentralizowane. Stąd banki komercyjne, które biorą udział w operacjach z bankiem centralnym nadal współpracują ze swoim narodowym bankiem. Wymaga to jednak stosowania jednolitego systemu instrumentów, aby postanowienia Zarządu EBC były wprowadzane we wszystkich krajach strefy euro na tych samych zasadach. Jednolity system instrumentów (zgodny $\mathrm{z}$ art. 105 Traktatu z Maastricht) ${ }^{69}$ jest niezbędny w celu prowadzenia przez EBC wspólnej polityki pieniężnej ${ }^{70}$. W krajach rozwiniętych gospodarczo banki centralne, w tym EBC oraz NBP, których głównym celem polityki monetarnej jest utrzymanie stabilnego poziomu cen w gospodarce, wykorzystują trzy podsta-

${ }^{67}$ W. Przybylska-Kapuścińska (red.), Polityka...,op. cit., s. 62.

${ }^{68}$ W. Pr z yb yl sk a-Ka pu ścińs k a (red.), Wspótczesna..., op. cit., s. 100-101.

${ }^{69}$ M. S o b o l, Dostosowanie ram operacyjnych polityki pieniężnej NBP do wymogów Eurosystemu, [w:] J. L. B e d n a c z y k (red.), Stopy procentowe a gospodarka. Dylematy Unii Gospodarczej i Walutowej, Wydział Ekonomiczny Polityki Radomskiej, Radom 2006, s. 175.

${ }^{70}$ O. S zczep ań ska, Instrumenty polityki pieniężnej Eurosystemu, Euro od A do Z, [za:] zasoby oficjalnej witryny internetowej Narodowego Banku Polskiego: www.nbp.pl [24.09.2010]. 
wowe instrumenty polityki pieniężnej, a mianowicie: operacje otwartego rynku, operacje depozytowo-kredytowe oraz rezerwę obowiązkową ${ }^{71}$.

Decyzja władz monetarnych dotycząca wyboru instrumentów polityki pieniężnej zależy od stopnia rozwoju systemu finansowego danego kraju, pozycji jaką bank centralny posiada w systemie oraz od jego niezależności i celów (np. inflacyjnych) do jakich dąży ${ }^{72}$.

\subsubsection{Polityka operacji otwartego rynku Europejskiego Banku Centralnego i Narodowego Banku Polskiego}

Operacje otwartego rynku (OOR) to nowoczesny, rynkowy instrument aktywnego oddziaływania banku centralnego na system bankowy ${ }^{73}$. Pełnią one znaczącą rolę w polityce monetarnej banków centralnych, w tym EBC oraz NBP. Operacje te mają duże znaczenie wśród instrumentów polityki pieniężnej, ponieważ umożliwiają utrzymanie krótkoterminowych stóp procentowych na poziomie spójnym $\mathrm{z}$ realizacją ustalonego celu inflacyjnego ${ }^{74}$. Polegają one na kupnie i sprzedaży papierów wartościowych oraz walut na rynku pieniężnym. Banki centralne dopuszczają stosowanie w ramach operacji otwartego rynku bonów pieniężnych, weksli skarbowych, depozytów w banku centralnym oraz swapów walutowych ${ }^{75}$.

Stopa podstawowych operacji otwartego rynku bezpośrednio oddziałuje na poziom oprocentowania depozytów na rynku międzybankowym, szczególnie tych, których termin zapadalności jest zbliżony do długości transakcji zawieranych $\mathrm{w}$ ramach operacji otwartego rynku. Zatem przeprowadzanie operacji otwartego rynku umożliwia bankowi centralnemu szybką reakcję na zmiany stóp procentowych rynku międzybankowego ${ }^{76}$. Te następnie wpływają na poziom stóp procentowych instrumentów mających dłuższy okres zapadalności, na kurs walutowy lub oczekiwania inflacyjne. Bank centralny wykorzystuje operacje otwartego rynku do sterowania ilością pieniądza w obiegu, a także aktywnego zarządzania płynnością sektora bankowego ${ }^{77}$.

${ }^{71}$ D. Ty m o c z k o, Ewolucja systemu finansowego a skuteczność instrumentów polityki pieniężnej, „Bank i Kredyt” 2002, nr 3, Narodowy Bank Polski, Warszawa, s. 5.

${ }^{72} \mathrm{O}$. V lad, The use of the monetary policy instruments by central banks under globalization, Alexandru Ioan University, Iasi - Romania 2008, s. 164.

${ }^{73}$ W. Przybylska-Kapuścińs ka (red.), Wspótczesna..., op. cit., s. 121.

${ }^{74}$ I. P y k a, Bank centralny na współczesnym rynku pieniężnym, dyscyplina regulacyjna, skuteczność, instrumenty, Wydawnictwo C. H. Beck, Warszawa 2010, s. 91.

${ }^{75}$ Instrumenty Polityki Pieniężnej Narodowego Banku Polskiego w 2006 roku. Ptynność sektora bankowego, Raport NBP, Warszawa 2006, s. 19.

${ }^{76}$ Sprawozdanie z działalności NBP w 2004 r., Narodowy Bank Polski, Warszawa 2004, s. 50.

${ }^{77}$ P. S c h a a l, Pieniądz i polityka pieniężna, PWE, Warszawa 1996, s. 393. 
Jednym z czynników decydujących o tym, jaki typ oraz kierunek operacji otwartego rynku wybierze bank centralny jest stan płynności na rynku, czyli pozycja strukturalna systemu bankowego wobec banku centralnego. Pozycja strukturalna wyznaczona jest poprzez sumę środków na rachunkach banków w banku centralnym (RB) oraz sumę operacji absorbujących, którą pomniejsza się o kwotę zadłużenia banków komercyjnych w banku centralnym. Przyjmując uproszczony bilans banku centralnego ustalamy, że operacje banku centralnego z bankami komercyjnymi składają się z operacji refinansujących (OR) - strona aktywna bilansu banku centralnego oraz operacji absorbujących (OA) - po stronie pasywnej banku centralnego. W przypadku $(\mathrm{RB}+\mathrm{OA})-\mathrm{OR}>0$, występuje nadwyżka płynności na rynku pieniężnym. $Z$ kolei, gdy $(R B+O A)-O R<0$, na rynku pojawi się niedobór płynnych rezerw ${ }^{78}$. Bank centralny może występować jako kredytobiorca netto w stosunku do systemu bankowego w momencie, gdy saldo operacji banku centralnego jest dodatnie, czyli $(\mathrm{OA}-\mathrm{OR}>0)$. Jest to przykład sytuacji, kiedy bank centralny absorbuje środki z rynku, które w innym przypadku stanowiłyby płynne rezerwy banków. Zatem bank centralny ,pożycza" płynne rezerwy banków. W drugim przypadku, bank centralny występuje jako kredytodawca netto, czyli saldo operacji OA - OR < 0, jest ujemne. Środki ściągnięte z rynku przez bank centralny poprzez operacje absorbujące są mniejsze niż kredyt zaciągnięty przez banki w banku centralnym ${ }^{79}$.

Wymienia się następujące rodzaje instrumentów wykorzystywanych do prowadzenia polityki operacji otwartego rynku ${ }^{80}$ :

- operacje warunkowe (reverse transactions), czyli operacje warunkowego zakupu (repurchase agreement) i warunkowej sprzedaży (reverse repurchase agreement $^{81}$,

${ }^{78}$ W. Przybylska-Kapuścińska, Operacje otwartego rynku w absorpcji nadptynności, [w:] W. Przy bylsk a-Ka puścińska (red.), Studia z bankowości centralnej, Wydawnictwo Akademii Ekonomicznej w Poznaniu, Poznań 2005, s. 108-109.

${ }^{79} \mathrm{O}$. S z c ze pańs ka, Operacje otwartego rynku jako element systemu operacyjnego EBC i banków centralnych w krajach kandydujących do Unii Europejskiej, „Bank i Kredyt” 2002, nr 4, s. 8 .

${ }^{80}$ W. Pr z yb ylsk a - Ka pu ścińs k a (red.), Wspótczesna...,op. cit., s. 121-127.

${ }^{81}$ Operacje warunkowe kupna i sprzedaży papierów wartościowych polegające na tym, że w ściśle określonym terminie następuje transakcja odwrotna do pierwotnej po określonej cenie, to znaczy, że zawierane są jednocześnie dwie transakcje. W przypadku operacji repo (repurchase agreement) następuje warunkowe kupno przez bank centralny papierów wartościowych od banków komercyjnych, przez co system bankowy zostaje zasilony w środki. Przeprowadzając operacje repo bank centralny wpływa również na poziom stóp procentowych, gdyż wysokość oprocentowania transakcji repo jest uzależniona od cen, po jakich bank centralny sprzedaje zakupione od banków komercyjnych papiery wartościowe. Tym samym bank centralny określając wysokość cen odsprzedaży kupionych od banków papierów, wyznacza oprocentowanie kredytów o takim samym terminie zapadalności jak termin zapadalności operacji repo. Z kolei operacje reverse repo (reverse repurchase agreement) wiążą się ze sprzedażą przez bank centralny papierów wartościowych bankom komercyjnym, co absorbuje płynność sektora bankowego, [w:] O. Szczepańska, Operacje..., op. cit., s. 7-8. 
- operacje bezwarunkowe (outright transactions), czyli operacje bezwarunkowego zakupu (outright purchase) i bezwarunkowej sprzedaży (outright sale) ${ }^{82}$,

- swapy walutowe (foreign exchange swaps) ${ }^{83}$,

- emisja certyfikatów dłużnych (debt certificates) ${ }^{84}$, sits $)^{85}$.

- depozyty terminowe o stałym terminie zapadalności (fixed-term depo-

Wyodrębniając kryterium celu oraz sposobu regulowania płynności rynku pieniężnego, operacje otwartego rynku można zakwalifikować do następujących kategorii $^{86}$ :

- podstawowych operacji refinansujących (main refinancing operations),

- dłuższych operacji refinansujących (longer-term refinancing operations) ${ }^{87}$,

- operacji dostrajających (fine-tuning operations $)^{88}$,

- operacji strukturalnych (structural operations) ${ }^{89}$.

${ }^{82}$ Operacje bezwarunkowe polegają na kupnie lub sprzedaży papierów wartościowych na stałe, czyli operacje te nie podlegają odwróceniu (zawierana jest jedna transakcja: kupna bądź sprzedaży), stąd absorpcja lub ograniczenie płynności w sektorze bankowym są równe terminowi zapadalności papierów wartościowych. W tym przypadku następuje nieodwracalne przeniesienie prawa własności sprzedającego papiery wartościowe. Bank centralny kupuje (outright purchase) od banków komercyjnych lub sprzedaje im (outright sale) papiery wartościowe, [w:] W. Przyb yls k a - Ka pu śc iń ska (red.), Wspótczesna..., op. cit., s. 124.

${ }^{83}$ Operacje swap są to operacje walutowe oparte na transakcjach kupna lub sprzedaży walut, pod warunkiem odsprzedaży bądź odkupienia ich w ściśle określonym terminie w przyszłości po ustalonym wcześniej kursie, jednocześnie na rynku kasowym i terminowym, [w:] J. O s t a s ze w s k i, Finanse, Difin, Warszawa 2008, s. 356.

${ }^{84}$ Certyfikaty dłużne emitowane są w celu skorygowania strukturalnej pozycji banku centralnego na rynku finansowym oraz regulacji płynności na rynku. Najczęściej certyfikaty emituje się w celu absorpcji płynności z rynku, [w:] Realizacja polityki pieniężnej w strefie euro. Dokumentacja ogólna instrumentów i procedur polityki pieniężnej w Eurosystemie, European Central Bank, Frankfurt, luty 2005, s. 18-20.

${ }^{85}$ Depozyt terminowy składany jest przez banki komercyjne w banku centralnym. Depozyt ten nie jest zabezpieczony, co ogranicza znacznie formalności związane z wykorzystaniem tego instrumentu. Bank centralny stwarzając bankom możliwość deponowania określonymi środkami, na znany z góry okres o ustalonym oprocentowaniu, może jedynie absorbować płynność sektora bankowego. Depozyt znajduje się w katalogu instrumentów dostrajających EBC, [w:] W. Przy b y lska-Ka puścińska (red.), Wspótczesna..., op. cit., s. 126-127.

${ }^{86}$ Ibidem, s. 8.

${ }^{87}$ Dłuższe operacje refinansujące również przeprowadzane są regularnie, co miesiąc w formie przetargów standardowych. Charakteryzują się 3-miesięcznym okresem zapadalności, [w:] The Implementation of Monetary Policy in the Euro Area. General Documentation on Eurosystem Monetary Policy Instruments and Procedures, European Central Bank, Frankfurt n. Menem 2008, s. 8.

${ }^{88}$ Operacje dostrajające bank centralny stosuje w momencie niespodziewanych i krótkotrwałych wahań płynności na rynku pieniężnym. Ich zadaniem jest krótkoterminowe regulowanie podaży płynności. Przeprowadzane są ad hoc, sporadycznie, jako operacje uzupełniające w stosunku do operacji podstawowych [w:] M. S o bo 1, Polityka pieniężna Narodowego Banku Polskiego w drodze do euro, Wydawnictwo Fachowe CeDeWu, Warszawa 2008, s. 194.

${ }^{89}$ Operacje strukturalne wykorzystywane są w momencie zaistnienia sytuacji długotrwałej zmiany skali płynności, czyli niedoboru płynności lub jej nadmiaru w dłuższym okresie, a ich 
Operacje podstawowe ${ }^{90}$ sa to operacje przeprowadzane systematycznie w celu regulacji płynności rynku w ustalonych odstępach czasowych, stosowane w standardowej sytuacji płynnościowej. Oprocentowanie operacji podstawowych wiąże się z podstawową stopą polityki pieniężnej, gdyż wyznaczając poziom stopy podstawowej, bank centralny określa poziom, jaki powinny mieć stopy rynkowe dla transakcji o terminach zbliżonych do zapadalności podstawowych OOR. Rentowność operacji podstawowych określana jest na przetargach, ale nie może być niższa niż stopa referencyjna, która ma bezpośrednio oddziaływać na oprocentowanie depozytów o tygodniowym terminie zapadalności. W Eurosystemie do realizacji podstawowych operacji otwartego rynku wykorzystuje się podstawową stopę refinansowania, natomiast w Polsce - stopę referencyjną ${ }^{91}$.

Mechanizm oddziaływania zasilających operacji otwartego rynku wskazuje na osiągnięty przez bank centralny efekt procentowy, w tym przypadku spadek stóp procentowych oraz efekt płynnościowy, czyli wzrost płynności sektora bankowego. W przypadku mechanizmu oddziaływania absorbujących operacji otwartego rynku, bank centralny również doprowadza do efektu procentowego (wzrost stóp procentowych) oraz płynnościowego (ograniczenie nadpłynności sektora bankowego), tylko o odwrotnym kierunku zmian do skutków operacji zasilających. Ponadto bank centralny poprzez oddziaływanie cenowe (tzw. efekt

celem jest trwałe regulowanie długookresowej płynności sektora bankowego, [w:] The Implementation..., op. cit., s. 8.

${ }^{90}$ Podstawowe operacje refinansujące przeprowadzano początkowo w formie przetargów o stałej stopie procentowej, zmieniono ją jednak na zmienną stopę procentową, ponieważ banki komercyjne stosowały tzw. taktykę overbidding, zarówno w Eurosystemie jak i w Polsce. Taktyka ta polegała na tym, że banki składały wysokie i wciąż rosnące oferty w ramach podstawowych operacji refinansujących. Powodowało to występowanie zjawiska zbyt dużego popytu na płynność w stosunku do przyznanej kwoty przydziału. Takie sytuacje miały miejsce w okresach, kiedy banki oczekiwały podwyżki podstawowych stóp procentowych EBC w bieżącym okresie utrzymywania rezerwy obowiązkowej. Oczekując wzrostu stóp procentowych, rynkowa stopa procentowa typu overnight rzeczywiście rosła powyżej stałej stopy, która obowiązywała w podstawowych operacjach refinansujących. W związku z tym, banki preferowały pozyskiwanie funduszy w banku centralnym niż na rynku międzybankowym. Wprowadzenie nowej procedury przetargowej o zmiennej stopie procentowej w Eurosystemie oraz Polsce rozwiązało problem overbidding, jednak nie uchroniło systemu bankowego od taktyki odwrotnej, tzw. underbidding. Polega ona na tym, że łączna wartość zgłaszanego popytu na płynność jest niższa od przewidywanej kwoty przydziału. W wyniku tego, banki stoją przed zagrożeniem nie uzyskania odpowiedniej płynności w operacjach otwartego rynku i konieczności uzupełnienia swoich potrzeb przy wykorzystaniu kredytu na koniec dnia w banku centralnym. W momencie oczekiwania spadku stóp procentowych banku centralnego w danym okresie utrzymywania rezerwy obowiązkowej, rynkowa stopa procentowa typu overnight obniżała się w istocie poniżej minimalnej oferowanej stopy podstawowej operacji refinansujących. Wtedy banki preferowały zaopatrzenie się w płynność na rynku międzybankowym a nie korzystanie z operacji otwartego rynku, [w:] Komunikat Narodowego Banku Polskiego $w$ sprawie przyczyn utrzymywania się na wysokim poziomie stóp rynku pieniężnego w okresie 26.10.2001-22.11.2001, Narodowy Bank Polski, Warszawa, s. 1-3 oraz Monthly Bulletin 10. anniversary EBC, European Central Bank, Frankfurt n. Menem 2008, s. 58-59.

${ }^{91}$ W. Pr z y b y lska-Ka pu ścińs ka (red.), Wspótczesna...,op. cit., s. 128. 
cenowy) podstawowych operacji otwartego rynku, podając do publicznej wiadomości wysokość podstawowej stopy procentowej, wyznacza poziom, jaki według niego powinny mieć stopy rynkowe (o terminie zapadalności zbliżonym do ORR $)^{92}$. Jest to również funkcja informacyjna operacji otwartego rynku.

W strefie euro, bank centralny tak steruje polityką pieniężną by stopa overnight ${ }^{93}$ - EONIA ${ }^{94}$ rynku międzybankowego oscylowała wokół poziomu oficjalnej stopy repo ${ }^{95}$. Podobnie w Polsce NBP wpływa na poziom stóp dla porównywalnych transakcji na rynku międzybankowym oddziałując jednocześnie na płynność systemu bankowego tak, by na rynku występował stan równowagi i stopa overnight POLONIA kształtowała się wokół stopy referencyjnej ${ }^{96}$. Polityka otwartego rynku jest najczęściej stosowana w krajach o rozwiniętych rynkach finansowych, głównie tam gdzie jest rozbudowany obrót papierami wartościowymi. Szerokie zastosowanie OOR występuje w Stanach Zjednoczonych, a za początek ich wykorzystywania przyjmuje się już lata $30 . \mathrm{XX} \mathrm{w.}{ }^{97}$

Porównując procedury oraz instrumenty, jakimi dysponuje NBP oraz Eurosystem, widoczne są różnice, które w istotnej mierze spowodowane są odmienną sytuacją rynkową w Polsce i strefie euro. EBC działa w warunkach strukturalnego niedoboru płynności. Stąd banki komercyjne w strefie euro są uzależnione od refinansowania banku centralnego, dlatego w systemie bankowym Eurosystemu przeważają operacje zasilające banki w płynność ${ }^{98}$. Odmienna sytuacja występuje w Polsce, ponieważ NBP funkcjonuje w warunkach nadpłynności na rynku pieniężnym. W związku z tym Narodowy Bank Polski stosuje odmienną od EBC formę instrumentów, które wykorzystywane są głównie w celu absorpcji płynności z systemu ${ }^{99}$. W celu ujednolicenia zasad operacji otwartego rynku z wymogami obowiązującymi w Eurosystemie, NPB podejmuje działania zmierzające do usunięcia istniejących rozbieżności. Różnice te wynikają z odmiennego środowiska, w którym funkcjonują banki w Polsce i strefie euro. Z porównania zasad operacji otwartego rynku przeprowadzanych przez NBP i EBC wynika, że $\mathrm{w}$ ramach operacji strukturalnych nie ma emisji certyfikatów dłużnych ${ }^{100}$. W tab. 2.3 przedstawione zostały rozwiązania dotyczące operacji otwartego rynku w Polsce oraz w strefie euro.

${ }^{92}$ Ibidem, s. 128-129.

${ }^{93}$ Stopa overnight - stopa operacji jednodniowych.

${ }^{94}$ Pojęcie stopy EONIA zostało rozszerzone na stronie 115.

${ }^{95}$ O. S z c ze pań s k a, Operacje..., op. cit., s. 10.

${ }^{96}$ M. Cendal, Wptyw instrumentów banku centralnego na kształtowanie się krótkoterminowych stop procentowych rynku pieniężnego, [w:] J. L. B e d n a r c z y k (red.), Stopy procentowe a gospodarka. Dylematy Unii Gospodarczej $i$ Walutowej, Wydawnictwo Instytutu Technologii Eksploatacyjnej Państwowego Instytutu Badawczego, Radom 2006, s. 164.

${ }_{97}^{97}$ A. K a ź mi e r c z a k, Polityka pieniężna w gospodarce otwartej, op. cit., s. 155.

${ }^{98}$ Rola Narodowego Banku Polskiego w procesie integracji europejskiej, Narodowy Bank Polski, Warszawa 2003, s. 16.

${ }^{99}$ M. S o b o 1, Dostosowanie..., op. cit., s. 181.

${ }^{100}$ Ibidem, s. 182 
Operacje otwartego rynku w Eurosystemie i w Polsce

\begin{tabular}{|c|c|}
\hline Eurosystem & Polska \\
\hline $\begin{array}{l}\text { Podstawowe operacje refinansujące - } \\
\text { dostarczające płynność, przeprowadzane } \\
\text { regularnie przy wykorzystaniu transakcji } \\
\text { odwracalnej, repurchase agreement; }\end{array}$ & $\begin{array}{l}\text { Operacje podstawowe - } \\
\text { absorbujące płynność, przeprowadzane regu- } \\
\text { larnie poprzez emisję bonów pieniężnych } \\
\text { NBP; }\end{array}$ \\
\hline $\begin{array}{l}\text { Dłuższe operacje refinansujące - } \\
\text { zapewniające płynność, przeprowadzane } \\
\text { regularnie, raz w miesiącu z terminem zapa- } \\
\text { dalności } 3 \text { miesiące, na zasadzie transakcji } \\
\text { odwracalnej, repurchase agreement; }\end{array}$ & $\begin{array}{l}\text { Operacje długoterminowe - } \\
\text { NBP ma możliwość wykorzystania tych } \\
\text { operacji absorbujących płynność emitując } \\
\text { bony pieniężne z terminem zapadalności } \\
3 \text { miesiące; }\end{array}$ \\
\hline $\begin{array}{l}\text { Operacje dostrajające - } \\
\text { zapewniające lub absorbujące płynność; } \\
\text { - nadpłynność w systemie bankowym - } \\
\text { EBC wykorzystuje operacje reverse repo; } \\
\text { transakcje swap lub przyjmuje depozyty } \\
\text { o stałym oprocentowaniu; } \\
\text { - } \text { brak płynności w systemie bankowym - } \\
\text { EBC może zastosować operacje typu repo, } \\
\text { operacje outright lub operacje swap; }\end{array}$ & $\begin{array}{l}\text { Operacje dostrajające - } \\
\text { zapewniające lub absorbujące płynność; } \\
\text { - w sytuacji nadpłynności w systemie ban- } \\
\text { kowym - NBP emituje bony pieniężne; } \\
\text { - w sytuacji braku płynności w systemie } \\
\text { bankowym - NBP może wykorzystać ope- } \\
\text { racje typu repo lub przedterminowy wykup } \\
\text { bonów pieniężnych; }\end{array}$ \\
\hline $\begin{array}{l}\text { Operacje strukturalne - } \\
\text { zapewniające lub absorbujące płynność; } \\
\text { - nadpłynność w systemie bankowym - } \\
\text { EBC stosuje operacje outright sale oraz } \\
\text { emituje certyfikaty dłużne EBC o dowol- } \\
\text { nym terminie zapadalności; } \\
\text { - brak płynności w systemie bankowym - } \\
\text { EBC ma do dyspozycji operacje repo } \\
\text { agreement lub operacje outright. }\end{array}$ & $\begin{array}{l}\text { Operacje strukturalne - } \\
\text { zapewniające bądź absorbujące płynność; } \\
\text { - nadpłynność w systemie bankowym - } \\
\text { NBP ma możliwość wykorzystania emisji } \\
\text { długoterminowych papierów wartościo- } \\
\text { wych NBP; } \\
\text { - brak płynności w systemie bankowym - } \\
\text { może zastosować operacje przedtermino- } \\
\text { wego wykupu obligacji NBP. }\end{array}$ \\
\hline
\end{tabular}

Ź r ó d ł o: opracowane na podstawie: M. S obol, Dostosowanie ram operacyjnych polityki pieniężne NBP do wymogów Eurosystemu, [w:] J. L. B ednarczyk (red.), Stopy procentowe gospodarka. Dylematy Unii Gospodarczej $i$ Walutowej, Wydział Ekonomiczny Politechniki Radomskiej, Radom 2006, s. 185-186; Realizacja polityki pieniężnej w strefie euro. Dokumentacja ogólna instrumentów i procedur polityki pieniężnej w Eurosystemie, European CentralBank, Frankfurt, luty 2005 oraz Rola Narodowego Banku Polskiego w procesie integracji europejskiej, Narodowy Bank Polski, Warszawa 2003.

Wśród operacji dostrajających NBP w tab. 2.3 nie zostały uwzględnione swapy walutowe, ponieważ dopiero 13 października 2008 r. bank centralny w Polsce wprowadził transakcje swapów walutowych w ramach „Pakietu zaufania”. Zatem w czasie kryzysu finansowego, kiedy system bankowy powinien zostać zasilony w płynność, NBP umożliwił wykorzystywanie przez banki do- 
datkowego instrumentu $\mathrm{w}$ ramach dostrajających operacji otwartego rynku ${ }^{101}$. W związku z poprawą sytuacji na rynkach finansowych NBP zrezygnował $\mathrm{z}$ operacji zasilających rynek typu swapy walutowe ${ }^{102}$.

Proces harmonizacji instrumentów polityki pieniężnej NBP do rozwiązań obowiązujących w Eurosystemie postępuje z upływem czasu. Jednak stosowanie instrumentów polityki monetarnej w Polsce, w takiej postaci jak w strefie euro, jest na razie niemożliwe ze względu na nadpłynność krajowego rynku pieniężnego.

\subsubsection{Polityka operacji depozytowo-kredytowych Europejskiego Banku Centralnego i Narodowego Banku Polskiego}

Operacje depozytowo-kredytowe zwane również standing facilities to instrument dający możliwość zaciągania kredytu na okres jednego dnia $(\mathrm{O} / \mathrm{N})$ lub składania depozytu w banku centralnym na koniec dnia. Operacje kredytowo-depozytowe przeprowadzane są w celu łagodzenia wahań krótkookresowych stóp rynku międzybankowego. W przeciwieństwie do operacji otwartego rynku, których inicjatorem jest bank centralny, operacje depozytowo-kredytowe przeprowadzane są z inicjatywy banków komercyjnych. Do tych operacji zaliczamy ${ }^{103}$ : depozyt na koniec dnia oraz kredyt na koniec dnia (w Polsce kredyt lombardowy).

Banki, które na koniec dnia dysponują niezagospodarowanymi środkami pieniężnymi, mają możliwość zdeponowania ich w banku centralnym, wykorzystując instrument depozyt na koniec dnia (deposit facility) ${ }^{104}$. Jest to forma absorpcji nadmiernej płynności na rynku, a jednocześnie sposób wyznaczania dolnej granicy dla wahań jednodniowych rynkowych stóp procentowych (EONIA, POLONIA $)^{105}$. Oprocentowanie depozytu na koniec dnia jest zazwyczaj niższe od właściwej stopy rynkowej. Depozyt kontrahenta składany w banku centralnym nie otrzymuje zabezpieczenia. W Eurosystemie dostępu do depozytu udziela bank centralny państwa członkowskiego, w którym znajduje się siedziba instytucji kredytowej - deponenta. Nie ma ograniczeń, co do

${ }^{101}$ Instrumenty wykorzystane przez NBP oraz EBC w okresie kryzysu finansowego zostały dokładniej opisane w rozdziale 5.

${ }^{102}$ Raport o stabilności systemu finansowego czerwiec 2009, Narodowy Bank Polski, Warszawa, czerwiec 2009, s. 13.

${ }^{103} \mathrm{~W}$. B ogu sła w s ka, Instrumenty polityki pieniężnej NBP $w$ kontekście dostosowań do wymogów ESBC, Uniwersytet Szczeciński, Szczecin, [za:] zasoby witryny internetowej: www.konferencja.edu.pl/ref8/pdf/pl/Boguslawska-Szczecin-polski.pdf [09.04.2011].

${ }^{104}$ The Implementation..., op. cit., s. 55.

${ }^{105}$ M. S o b o 1, Polityka.., op. cit., s. 195. 
kwoty depozytu, a terminem zapadalności depozytów jest następny dzień roboczy $^{106}$.

W Polsce cenę jednodniowego depozytu środków banków komercyjnych w banku centralnym wyznacza stopa depozytowa ${ }^{107}$. NBP wprowadził stopę depozytową banku centralnego 1 grudnia 2001 r., która określa dolną granicę wahań dla stóp procentowych rynku międzybankowego o terminie zapadalności ograniczonym do jednego dnia. Oprocentowanie depozytu mieści się poniżej stopy lombardowej (górnego pułapu wahań stóp procentowych) oraz stopy referencyjnej $^{108}$. Z tego depozytu mogą korzystać wszystkie banki, które mają rachunek w NBP. Depozyt składa się przed końcem dnia operacyjnego a zwracany jest na początku następnego dnia operacyjnego ${ }^{109}$.

$\mathrm{Z}$ kolei kredyt na koniec dnia (credit facility), jest przyznawany bankom, które na koniec dnia muszą uzupełnić środki na swoich rachunkach w banku centralnym. Bank centralny nie ogranicza dostępu do tego kredytu, jedynym warunkiem jest posiadane przez banki zabezpieczenie w postaci papierów wartościowych. Kredyt na koniec dnia zaopatruje banki w płynność w czasie końcowych rozliczeń między bankami określając tym samym górny pułap dla stopy rynkowej overnight. Stopa oprocentowania takich kredytów jest wyższa niż rynkowa, ze względu na brak limitów kredytowych i innych ograniczeń ich dostępności (poza obowiązkiem przedstawienia aktywów zabezpieczających). Jedną z form udzielania kredytów banku centralnego na koniec dnia, może być umowa z przyrzeczeniem odkupu z terminem overnight. Wtedy własność aktywów będących zabezpieczeniem kredytu, przechodzi na kredytodawcę ${ }^{110}$. Bank centralny państwa członkowskiego udziela dostępu do kredytu na koniec dnia instytucji kredytowej ustanowionej w danym kraju. Oprocentowanie tego kredytu wyznaczone jest przez stałą stopę marginal lending rate ${ }^{111}$.

Kredyt lombardowy, jako instrument umożliwiający zaciąganie krótkoterminowych pożyczek gotówkowych przez banki komercyjne w banku centralnym jest kredytem udzielanym pod zastaw papierów wartościowych, których oprocentowanie wyznacza stopa lombardowa. Od 2001 r. horyzont czasowy dla kredytu lombardowego zmniejszono do jednego dnia, a jego udzielenie uzależniono od spłaty kredytu zaciągniętego w poprzednim dniu operacyjnym. Banki komercyjne mogą zadłużyć się $\mathrm{z}$ tytułu kredytu lombardowego tylko do pewnej

${ }^{106}$ B. Mucha-Leszko, Strefa euro. Wprowadzenie. Funkcjonowanie. Międzynarodowa rola euro, Wydawnictwo Uniwersytetu Marii Curie-Skłodowskiej, Lublin 2007, s. 141-142.

${ }^{107}$ A. K a ź mi e r c z a k, Polityka pieniężna w gospodarce otwartej, op. cit., s. 153.

${ }^{108}$ Sprawozdanie z wykonania założeń polityki pieniężnej w 2006 roku, Narodowy Bank Polski, Warszawa 2007, s. 24.

${ }^{109}$ Raport roczny 2001, Narodowy Bank Polski, Warszawa 2002, s. 28.

${ }^{110}$ M. S o b o 1, Polityka..., op. cit., s. 195.

${ }^{111}$ Ibidem, s. 196. 
wyznaczonej kwoty, np.: do $80 \%$ wartości zastawionych papierów wartościowych. Od 27 października 2008 r., zgodnie z uchwałą nr 44 Zarządu NBP ${ }^{112}$ rozszerzono zakres zabezpieczeń kredytu lombardowego o następujące papiery wartościowe zdeponowane w Krajowym Depozycie Papierów Wartościo$\mathrm{wych}^{113}$ : obligacje Europejskiego Banku Inwestycyjnego, listy zastawne, obligacje komunalne i obligacje korporacyjne emitentów krajowych.

Bank centralny stosuje stopę kredytu lombardowego, jako góry pułap zmian krótkoterminowych stóp rynku międzybankowego. W sytuacjach nadzwyczajnych jest to limit ograniczający większe wahania stóp procentowych. Kredyty lombardowe są jednak wykorzystywane sporadycznie przez banki komercyjne, jedynie w momentach występowania krótkoterminowych dużych niedoborów płynności. Ten instrument banku centralnego traktuje się jako kredyt ostatniej instancji i jest wykorzystywany przez banki komercyjne do zachowania bezpieczeństwa finansowego oraz minimalizacji ryzyka utraty płynności ${ }^{114}$.

Do innych elementów oddziaływania NBP na rynek pieniężny należy zaliczyć kredyt techniczny w złotych (intraday credit) oraz kredyt techniczny w euro (kredyt śróddzienny w euro (euro intraday credit) $)^{115}$. Nie należą one jednak do operacji depozytowo-kredytowych, ani nie są podstawowymi instrumentami należącymi do triady narzędzi polityki pieniężnej.

Zasady operacji depozytowo-kredytowych (standing facilities) w Polsce zostały $\mathrm{w}$ istotnym stopniu dostosowane do sposobu ich przeprowadzania przez EBC. Od kwietnia 2000 r. skrócono horyzont czasowy dla kredytu lombardowego do 1 dnia w celu harmonizacji z zasadami obowiązującymi w strefie euro. Kredyt lombardowy NBP, tak jak w EBC, zabezpieczany jest skarbowymi papierami wartościowymi. Od grudnia 2001 r. NBP wprowadził możliwość składania depozytu na koniec dnia przez banki komercyjne w banku centralnym, dostosowując w ten sposób regulacje NBP dotyczące depozytu do obowiązujących w strefie euro. W Polsce i strefie euro stopa lombardowa oraz depozytowa stanowią korytarz dla wahań jednodniowych stóp procentowych $(\text { overnight })^{116}$.

${ }^{112}$ Uchwała Zarządu Narodowego Banku Polskiego z dnia 13 października 2008 r. zmieniajaca uchwate $w$ sprawie wprowadzenia „Regulaminu refinansowania banków kredytem lombardowym przez Narodowy Bank Polski”, DzU NBP nr 16, 15 października 2008 r. oraz Instrumenty Polityki Pieniężnej Narodowego Banku Polskiego w 2008 roku. Ptynność sektora bankowego, Raport NBP, Warszawa 2009, s. 28.

${ }_{113}^{113}$ J. O st a s zew ski, op. cit., s. 360.

${ }^{114}$ Ibidem, s. 360-361.

115 Instrumenty polityki pieniężnej Narodowego Banku Polskiego w 2008 roku, op. cit., s. 24-25.

${ }^{116}$ M. S o b o 1, Polityka..., op. cit., s. 203. 


\subsubsection{Polityka rezerwy obowiązkowej Europejskiego Banku Centralnego i Narodowego Banku Polskiego}

Rezerwa obowiązkowa stanowi odsetek bilansowych zwrotnych zobowiązań (bieżących i terminowych) banków wobec sektora niefinansowego, która podlega odprowadzeniu i utrzymaniu w postaci środków pieniężnych ulokowanych na rachunkach w banku centralnym lub w postaci innych aktywów (jak gotówka w kasach banków lub określonych rodzajów papierów wartościowych $)^{117}$. Rezerwa obowiązkowa obliczana jest jako ustalony procent od wkładów ulokowanych w banku. Jest to instrument wpływający na strukturalną płynność banków komercyjnych, służący pośrednio do określania możliwości udzielania kredytów ${ }^{118}$. Rezerwa obowiązkowa formalnie weszła do zestawu narzędzi EBC na mocy Regulacji Rady - „Council Regulation” 2531/98 z 23 listopada 1998 r. oraz Regulacji EBC 2818/98 z 1 grudnia 1998 r. ${ }^{119}$

Utrzymywanie rezerwy obowiązkowej pełni funkcję stabilizatora stóp procentowych rynku pieniężnego. Jest to możliwe, ponieważ rezerwy gromadzone przez banki utrzymywane są według uśrednionej zasady, co pozwala na łagodzenie skutków krótkotrwałych zmian w poziomie płynności ${ }^{120}$. Zatem banki są zobligowane do takiego zarządzania środkami pieniężnymi, aby średnio w okresie rezerwowym (trwającym jeden miesiąc ${ }^{121}$ ) kwota rezerw odpowiadała wielkości wymaganej (system rezerwy uśrednionej). Jeszcze inną funkcją rezerwy obowiązkowej w Eurosystemie jest regulowanie stanu płynności na rynku pieniężnym. W przypadku systemu bankowego strefy euro jest to strukturalny brak płynności. Zatem EBC wpływa na wzrost płynności w systemie, jako kredytodawca dla banków komercyjnych, co umacnia jego rolę i zwiększa efektywność prowadzonej przez niego polityki pieniężnej ${ }^{122}$.

${ }^{117}$ W. Przybylska-Kapuścińs ka (red.), Wspótczesna..., op. cit., s. 110.

${ }^{118}$ R. B arc zy k, Rola pieniężnej polityki stabilizacji w procesie wchodzenia Polski do Unii Gospodarczej $i$ Walutowej, [za:] zasoby witryny internetowej: http://mikro.univ.szczecin.pl/bp/ pdf/61/9.pdf.

${ }^{119}$ Council Regulation (EC) concerning the application of minimum reserves by the European Central Bank, Official Journal of the European Communities, no 2531/98 of 23 November 1998; oraz Rozporzadzenie EBC $w$ sprawie rezerw minimalnych $n r$ 2818/98, DzU L 356 z 30.12.1998, art. 8, s. 1 .

${ }^{120}$ Monthly Bulletin 10. anniversary ..., op. cit., s. 52-53.

${ }^{121}$ Od stycznia 1999 r. do lutego 2004 r. okres rezerwowy rozpoczynał się 24. dnia każdego miesiąca i kończył 23. dnia miesiąca kolejnego. Natomiast od 10 marca 2004 r. okres naliczania rezerwy rozpoczyna się w dniu rozrachunku głównych operacji refinansujących, które mają miejsce po pierwszym posiedzeniu danego miesiąca Rady Zarządzającej EBC, w czasie którego dokonuje ona analizy sytuacji polityki monetarnej w Eurosystemie i na tej podstawie decyduje o zmianach poziomu stóp procentowych. Kalendarz okresów utrzymywania rezerwy publikowany jest przez EBC przynajmniej na trzy miesiące przed początkiem danego roku.

${ }^{122}$ O. S z c z e p ań s k a, Instrumenty..., op. cit., s. 63. 
Rezerwa obowiązkowa jest utrzymywana przez instytucje kredytowe w ich narodowych bankach centralnych. Za podstawę wyliczenia rezerwy obowiązkowej mogą być uznawane pasywa powstające $w$ wyniku przejęcia przez instytucje kredytowe środków pieniężnych, a także pasywa pozabilansowe. W strefie euro podstawą naliczenia rezerwy objęte są depozyty i wyemitowane papiery dłużne ${ }^{123}$. W celu wyliczenia podstawy naliczenia rezerwy obowiązkowej, którą banki będą musiały odłożyć w okresie utrzymywania, wykorzystuje się dane bilansowe na koniec bieżącego miesiąca kalendarzowego. Okres utrzymywania rezerwy jest opóźniony w stosunku do czasu objętego procedurą naliczania rezerwy o dwa miesiące. Na przykład podstawa naliczenia rezerwy oszacowana na podstawie bilansu na koniec marca będzie stosowana do obliczania poziomu rezerwy danej instytucji $\mathrm{w}$ okresie jej utrzymywania rozpoczynającym się w maju ${ }^{124}$.

W Eurosytemie funkcjonują następujące stawki naliczania rezerwy obowiązkowej: pozycje objęte stawką procentową równą $2 \%$, oraz stawką $0 \%$, a ponadto środki nieobjęte obowiązkiem rezerwy. Pozycje objęte $2 \%$ stopą oprocentowania rezerwy obowiązkowej to: depozyty o terminie zapadalności do 2 lat, depozyty „za wypowiedzeniem” z okresem zapadalności do 2 lat, papiery dłużne z terminem do 2 lat oraz papiery rynku pieniężnego. Pozycje, dla których obowiązuje $0 \%$ stopa rezerwy obowiązkowej to: depozyty o terminie zapadalności ponad 2 lata, depozyty „za wypowiedzeniem” z terminem do wygaśnięcia ponad 2 lata, papiery dłużne $\mathrm{z}$ terminem ponad 2 lata oraz transakcje repo. Pozycje nieobjęte obowiązkiem odprowadzania rezerwy obowiązkowej to: zobowiązania wobec Europejskiego Banku Centralnego i Narodowych Banków Centralnych oraz zobowiązania wobec innych instytucji objętych obowiązkiem rezerwy obowiązkowej. Istotne jest również, szczególnie dla mniejszych instytucji kredytowych, że od wyliczonej należnej kwoty rezerwy obowiązkowej, instytucje odliczają zryczałtowaną sumę 100000 euro (lump sum). Dodatkowo środki rezerwy, które zgromadzone są na rachunkach krajowych banków centralnych, są oprocentowane według stawki zbliżonej do rynkowej. W praktyce odsetki wyliczane są według średniej ważonej stopy podstawowych operacji refinansujących z okresu utrzymywania środków (wagą są dni kalendarzowe), pomnożone przez kwotę rezerwy obowiązkowej $w$ danym okresie ${ }^{125}$. Zaletą oprocentowania rezerwy jest to, że nie stanowi ona kosztu dla banków, a przede wszystkim instytucje finansowe nie próbują ominąć obowiązku rezerwowego ${ }^{126}$.

${ }^{123}$ Regulation (EC) No 1745/2003 of the European Central Bank of 12 September 2003 on the application of minimum reserves, Official Journal of the European Communities, 2 October 2003, art. 3, ust. 2.

${ }^{124}$ P. Gierałtowski, op. cit., s. 88.

${ }^{125}$ I. P i e tr y k a, Harmonizacja instrumentów NBP ze standardami europejskimi - rezerwa obowiazkowa, [w:] M. Nog a (red.), Ponadnarodowa i narodowa polityka monetarna na świecie, CeDeWu, Warszawa 2009, s. 141.

${ }^{126}$ O. S z c z e pań s k a, Instrumenty..., op. cit., s. 65. 
W Polsce rezerwa obowiązkowa została wprowadzona w 1989 r. wraz $\mathrm{z}$ dwuszczeblowym sektorem bankowym. Banki komercyjne utrzymują rezerwę obowiązkową na rachunkach bieżących w NBP albo na specjalnych rachunkach rezerwy obowiązkowej. Rezerwę nalicza i przechowuje się w złotych. Od stycznia 1999 r. wprowadzono system naliczania rezerwy obowiązkowej oparty na średniej arytmetycznej ze wszystkich dni roboczych danego miesiąca, czyli tzw. uśredniony system naliczania rezerwy ${ }^{127}$. W Polsce stosuje się, tak jak w Eurosystemie, uśredniony sposób utrzymywania rezerwy obowiązkowej, co oznacza, że średnia suma ze wszystkich dni danego okresu utrzymywania rezerwy musi być równa rezerwie naliczonej. Uśrednienie to nie zobowiązuje banków do utrzymywania na koniec każdego dnia środków pieniężnych równych rezerwie wymaganej. Istotne jest, by średni stan środków w okresie utrzymywania rezerwy obowiązkowej równał się wymaganej sumie. Stosowany jest również tzw. opóźniony okres utrzymywania rezerwy. Oznacza to, że od momentu naliczenia rezerwy mija określony czas do momentu, w którym ta rezerwa ma być utrzymana w banku centralnym. Zatem okres utrzymywania rozpoczyna się po zakończeniu okresu naliczania rezerwy. Od 30 września 2003 r. banki pomniejszają kwotę naliczonej rezerwy obowiązkowej o równowartość 500000 euro, obliczaną według kursu średniego NBP z ostatniego dnia miesiąca będącego podstawą naliczenia rezerwy obowiązkowej ${ }^{128}$.

Rada Polityki Pieniężnej określa poziom stopy rezerwy obowiązkowej. Od 31 października 2003 r. stopa rezerwy obowiązkowej została ustalona na poziomie 3,5\% dla wszystkich rodzajów depozytów z wyłączeniem zobowiązań wynikających z transakcji repo ${ }^{129}$. Stopa ta obowiązywała do czerwca 2009 r., ponieważ od 30 czerwca tego roku obniżono stopę rezerwy obowiązkowej do poziomu $3 \%{ }^{130}$, ze względu na kryzys finansowy w gospodarce światowej. Od 31 grudnia 2010 r. powrócono do stopy rezerwy obowiązkowej równej $3,5 \%{ }^{131}$. Dla środków pozyskanych ze sprzedaży papierów wartościowych z przyrzeczeniem odkupu od 30 czerwca 2004 r. stopa rezerwy wynosi $0 \%$. Od 1 maja 2004 r. środki rezerwy obowiązkowej zostały oprocentowane ${ }^{132}$. Wysokość tego oprocentowania jest równa 0,9 stopy redyskonta weksli (obowiązuje od 1 stycznia 2005 r., obecnie oprocentowanie środków rezerwy obowiązkowej

${ }^{127}$ Uchwała nr 15/2004 Zarzadu Narodowego Banku Polskiego z dnia 13 kwietnia 2004 r. w sprawie zasad i trybu naliczania oraz utrzymywania przez banki rezerwy obowiazkowej, $\mathrm{nr} 3$, poz. 4.

${ }^{128}$ Instrumenty Polityki Pieniężnej Narodowego Banku Polskiego w 2006 roku, op. cit., s. 20.

${ }^{129}$ Narodowy Bank Polski, Wydawnictwo NBP, Warszawa 2005, s. 9.

${ }^{130}$ Uchwata nr 9/2009 Rady Polityki Pieniężnej z dnia 27 maja 2009 r. zmieniajaca uchwate w sprawie stóp rezerwy obowiąkowej banków i wysokości oprocentowania rezerwy obowiąkowej, DzU NBP nr 10, Warszawa 2009.

${ }^{131}$ Informacja po posiedzeniu Rady Polityki Pieniężnej w dniach 26-27 października 2010, Narodowy Bank Polski, Rada Polityki Pieniężnej, Warszawa, październik 2010, s. 1.

${ }^{132}$ Narodowy..., op. cit., s. 9. 
wynosi $2,475 \%)^{133}$. Tylko środki do wysokości rezerwy wymaganej podlegają oprocentowaniu $^{134}$.

Polityka rezerwy obowiązkowej polega na możliwości wpływania władz monetarnych na poziom krótkoterminowych stóp procentowych na rynku międzybankowym, głównie stopy overnight (EONIA, POLONIA) ${ }^{135}$. System rezerwy opóźnionej i uśrednionej sprzyja zmniejszeniu wahań krótkoterminowych stóp procentowych, które poprzez impuls polityki monetarnej przenoszone są na stopy depozytowo-kredytowe banków komercyjnych. W systemie opóźnionym banki już od początku okresu utrzymywania wiedzą, jaką kwotę muszą odprowadzić do banku centralnego, co umożliwia im zarządzanie swoją płynnością i eliminuje zmienność rynkowych stóp procentowych. Podobnie system uśrednionej rezerwy wygładza wahania krótkoterminowych stóp procentowych poprzez wpływ na płynność systemu bankowego ${ }^{136}$.

System rezerwy obowiązkowej w Polsce został w wielu kwestiach zbliżony do rozwiązań Europejskiego Banku Centralnego, chociażby w kwestii oprocentowania środków rezerwy. $\mathrm{W}$ tab. 2.4 przedstawiono różnice pomiędzy systemem rezerwy obowiązkowej panującym w strefie euro i w Polsce. Istnieje różnica w sposobie obliczania odsetek od kwoty rezerwy obowiązkowej. Poprzez nowelizację Ustawy o NBP z dnia 18 grudnia 2003 r., wprowadzono zmiany dotyczące oprocentowania środków z tytułu rezerwy obowiązkowej, jak również zrezygnowano $\mathrm{z}$ wymogu ustalania stopy rezerwy $\mathrm{w}$ stosunku do średniomiesięcznych stanów środków. W Polsce wysokość oprocentowania wynosi 0,9 stopy redyskonta weksli, a w strefie euro jest ono równe średniej stopie operacji refinansujących. Zagwarantowano również możliwość różnicowania rezerwy ze względu na rodzaj przeprowadzanej operacji finansowej będących źródłem pozyskiwania środków pieniężnych przez banki. Ponadto wprowadzono zasadę pomniejszania naliczonej rezerwy obowiązkowej o 500000 euro $^{137}$.

Jedną z różnic jest wyłączenie standardowe, którego kwota w Polsce jest pięciokrotnie wyższa. Nie jest to niedostosowanie, które znacznie oddala polskie rozwiązania w zakresie instrumentów polityki pieniężnej od obowiązującego w strefie euro. Różnica związana ze stopą rezerwy obowiązkowej, która powstała między stawką 3,5\% w Polsce i 2\% w Eurosystemie, jest w polskim systemie bankowym uzasadniona, ze względu na nadpłynność sektora bankowego.

${ }^{133}$ Zasoby oficjalnej witryny internetowej Narodowego Banku Polskiego, Warszawa 2007: www.nbp.pl/Home.aspx?f=publikacje/plan_dzalalnosci/nbp_0106.html [04.07.2013]; stopa redyskonta weksli wynosi 2,75\% (od 04.072013 ).

${ }^{134}$ Od 2007 r. banki otrzymują całość oprocentowania, ponieważ wcześniej część tej kwoty przekazywana była na Fundusz Poręczeń Unijnych.

${ }^{135}$ I. P y k a, op. cit., s. 95-97.

${ }^{136}$ D. Ty moc zk o, Ewolucja..., op. cit., s. 6-8.

${ }^{137}$ Ustawa z dnia 29 sierpnia 1997 r. o Narodowym Banku Polskim, tekst ujednolicony - stan na dzień 22 czerwca 2010 r., art. 39. 
Rezerwa obowiązkowa w Eurosystemie i w Polsce (stan na lipiec 2013 r.)

\begin{tabular}{|l|l|}
\hline \multicolumn{1}{|c|}{ Eurosystem } & \multicolumn{1}{c|}{ Polska } \\
\hline \hline Rezerwa obowiązkowa w Eurosystemie & Rezerwa obowiązkowa w Polsce \\
- 2\% - od depozytów bieżących, depozytów & $-3,5 \%$ - od wszystkich rodzajów depozy- \\
terminowych z okresem wypowiedzenia & tów; \\
do 2 lat, od wyemitowanych papierów & $-0 \%-$ od transakcji repo; \\
wartościowych z terminem zapadalności & - rezerwą nie są objęte środki z papierów \\
do 2 lat; & wartościowych zabezpieczonych hipotecz- \\
0\% - od transakcji repo, od depozytów & nie o terminie wykupu powyżej 5 lat, \\
z terminem wymagalności powyżej 2 lat, & listów zastawnych o okresie wykupu po- \\
od wyemitowanych dłużnych papierów & wyżej 5 lat oraz środki uzyskane na pod- \\
wartościowych z terminem zapadalności & stawie umów o prowadzenie indywidual- \\
powyżej 2 lat; & nych kont emerytalnych; \\
kwota pomniejszająca bazę naliczonej & - kwota pomniejszająca bazę naliczonej \\
rezerwy obowiązkowej - 100 tys. euro. & rezerwy obowiązkowej - 500 tys. euro. \\
\hline
\end{tabular}

Źr ódło: opracowane na podstawie: M. Sobol, Dostosowanie..., op. cit., s. 185-186; Realizacja..., op. cit. oraz Rola Narodowego..., op. cit.

Perspektywa przystąpienia do strefy euro będzie dla NBP oznaczać istotne zmiany dotyczące Konstytucji i ustaw bankowych. Zmiany obejmą cel, zadania NBP, inne będą kompetencje jego poszczególnych organów. Różnice będą związane z funkcją emisyjną, zasadami przeprowadzania operacji otwartego rynku, polityką kredytową, polityką rezerw obowiązkowych, funkcjonowaniem systemu płatności i rozliczeń, a także normami ostrożnościowymi.

\subsection{Podsumowanie}

Na podstawie przedstawionej specyfiki polityki pieniężnej banków centralnych EBC oraz NBP można zauważyć, że banki te wykorzystując triadę instrumentów, tj.: operacje otwartego rynku, operacje depozytowo-kredytowe oraz rezerwy obowiązkowe, wpływają poprzez mechanizm transmisji impulsów polityki pieniężnej na poziom i zmienność stóp procentowych na rynku międzybankowym. Z kolei stopy rynku międzybankowego mają cenotwórcze znaczenie dla gospodarki, ponieważ stopa rynku pieniężnego jest podstawą oprocentowania depozytów i kredytów w bankach komercyjnych, oddziałuje także na oczekiwania inflacyjne i kurs walutowy. Podmioty gospodarcze uzależniają swoje decyzje odnośnie konsumpcji, oszczędności, czy inwestycji między innymi od oprocentowania depozytów i kredytów w bankach komercyjnych, co odzwierciedla spo- 
sób funkcjonowania kanałów mechanizmu impulsów polityki pieniężnej na sferę realną gospodarki.

Na postawie przeprowadzonej analizy porównawczej rozwiązań instrumentalnych w ramach polityki pieniężnej w Polsce i strefie euro można zauważyć, że pomimo różnic pomiędzy polityką banków centralnych w Polsce i strefie euro, wynikających między innymi z różnego poziomu płynności sektora bankowego, instrumenty wykorzystywane w polityce pieniężnej obu tych banków są zbliżone, jednak nie takie same. Różnice wynikają głównie z innej sytuacji rynkowej w Polsce i strefie euro. Dla sprawnego włączenia się NBP do UGiW i funkcjonowania w ramach wspólnej polityki monetarnej istotne jest nie tylko dorównanie standardom i zasadom opracowanym przez ESBC, ale również przeprowadzenie dostosowań natury organizacyjno-prawnej NBP, a także makroekonomicznej harmonizacji gospodarki polskiej z gospodarkami krajów strefy euro wyrażonej zbieżnością w zakresie kryteriów zapisanych w Traktacie z Maastricht. 


\section{Rozdział 3}

\section{DOROBEK TEORETYCZNY W NAUKACH EKONOMICZNYCH DOTYCZĄCY STÓP PROCENTOWYCH}

\subsection{Teorie pieniądza i stóp procentowych w ujęciu chronologicznym}

Dotychczasowy dorobek teoretyczny ekonomii zawiera wiele prób formułowania tez dotyczących wpływu pieniądza na zachowania ekonomiczne podmiotów gospodarczych. Poniżej przedstawiono zarys ewolucji różnych poglądów związanych z teoriami pieniądza oraz stóp procentowych, których wpływ na decyzje podejmowane $\mathrm{w}$ polityce ekonomicznej jest widoczny również współcześnie. Szczególnie teorie stóp procentowych mają istotne znaczenie w kontekście tematu niniejszej pracy dotyczącej wpływu stóp banku centralnego NBP i EBC na inwestycje w Polsce i strefie euro. W książce podjęto starania zbadania skali oddziaływania stóp procentowych na inwestycje w gospodarce, stąd w celu dokładniejszej analizy przybliżone zostały teorie stóp procentowych.

\subsubsection{Teoria preferencji płynności pieniądza i stóp procentowych w ujęciu ekonomii keynesowskiej}

Kryzys gospodarczy w latach 1929-1933, który wywołał recesję na świecie dał podstawy ku stwierdzeniu, że założenia teorii ilościowej pieniądza odbiegają od rzeczywistości. Występowało masowe bezrobocie, niewykorzystane czynniki produkcji, mniejsze dochody i sprzedaż. W 1936 r. w pracy pt. Ogólna teoria zatrudnienia, procentu i pieniądza J. M. Keynes przedstawił teorię podważającą założenia klasycznej teorii równowagi. Zakładał między innymi, że $\mathrm{e}^{1}$ : podaż pieniądza zależy od popytu, nie ma więc charakteru niezależnego; szybkość krążenia pieniądza ulega dużym zmianom, więc nie jest stała; mechanizm dostoso-

${ }^{1}$ T. Grus ze cki, Teoria pieniądza i polityka pieniężna. Rys historyczny i praktyka gospodarcza, Oficyna Ekonomiczna, Kraków 2004, s. 110-111. 
wawczy w gospodarce nie występuje, ponieważ ceny i płace w fazie recesji nie zmniejszają się w identycznym stopniu jak produkcja, czyli wykazują tzw. mała elastyczność cen i płac w dół.

J. M. Keynes wprowadził nową kategorię, jaką jest ,,preferencja płynności”, opisująca skłonność społeczeństwa do gromadzenia części dochodu w postaci płynnej (pieniężnej), tzw. sald pieniężnych. Większa skłonność do inwestowania w aktywa finansowe, czyli do oszczędzania, pojawia się wraz ze wzrostem dochodu, więc preferencja płynności czy krańcowa skłonność do oszczędzania rośnie wraz z dochodem. Jednak popyt na pieniądz nie zależy tylko od dochodu, ale również od stopy procentowej, która kształtuje się w zależności od popytu i podaży pieniądza. Keynes wychodzi z założenia, że podaż w danym czasie jest stała, a decydującą rolę spełnia popyt na pieniądz. Według Keynesa popyt na pieniądz zależy od następujących czynników ${ }^{2}$ : motywu transakcyjnego ${ }^{3}$, motywu przezornościowego ${ }^{4}$, motywu spekulacyjnego 5 .

Warto dodać, że Keynesiści nie traktują kontroli podaży pieniądza jako instrumentu osiągania stabilności finansowej, w przeciwieństwie do stopy procentowej. Według nich oddziaływanie na rynkowe stopy procentowe warunkuje równowagę na rynku finansowym ${ }^{6}$.

J. M. Keynes odrzucając zasadę neutralności pieniądza (pieniądz nie wpływa na kształtowanie się poziomu produktu globalnego) stwierdził, że rola pieniądza w gospodarce jest aktywna, a zmiana podaży pieniądza ma odbicie w zmianie stopy procentowej. Według keynesistów, jeśli wzrośnie zasób pieniądza to spadnie stopa procentowa, co wpłynie na wzrost inwestycji, a następnie produkcji. Stopa procentowa wpływa na rynkową cenę obligacji. Wzrost stopy procentowej prowadzi do spadku rynkowej ceny obligacji i odwrotnie. Wpływ na lokowanie majątku ma nie tylko jego dochodowość, ale i oddziaływanie stopy procentowej na rynkową wartość kapitału ${ }^{7}$. Każdy uczestnik rynku finansowego ma pewien pogląd na poziom rynkowej stopy procentowej, jak również na

\footnotetext{
${ }^{2}$ Ibidem, s. 110-111.

${ }^{3}$ Motyw transakcyjny określa skłonność podmiotów gospodarczych do gromadzenia pewnego poziomu salda pieniężnego, w celu finansowania stałych wydatków; salda te są tym większe im wyższy jest dochód podmiotu.

${ }^{4}$ Motyw przezornościowy oparty jest na szacowaniu przez jednostki ryzyka, jakie może wystąpić w przyszłości i odkładaniu funduszy przeznaczonych na nieprzewidziane wydarzenia.

${ }^{5}$ Motyw spekulacyjny przejawia się oszczędnościami podmiotów gospodarczych w postaci papierów wartościowych lub gotówki, a decyzja, jaka część tych oszczędności zostanie podzielona na salda gotówkowe, a jaka na inwestycje finansowe zależy od wysokości stopy procentowej - im wyższa stopa procentowa tym więcej oszczędności zostanie w postaci aktywów finansowych.

${ }^{6}$ A. K aźmi e r c z a k, Polityka pieniężna w gospodarce w otwartej, Wydawnictwo Naukowe PWN, Warszawa 2008, s. 236-238.

${ }_{7}$ A. K aź mi e rc zak, Polityka pieniężna $w$ gospodarce rynkowej, Wydawnictwo Naukowe PWN, Warszawa 2003, s.126-129.
} 
wysokość normalnej, standardowej (naturalnej) stopy ukształtowanej w ustabilizowanych warunkach gospodarowania ${ }^{8}$.

Stopa procentowa odgrywa w poglądach Keynesa podstawową rolę. W przeciwieństwie do klasyków postrzega ją jako kategorię pieniężną. Stopa procentowa według Keynesa „(...) jest nagrodą za wyrzeczenie się płynności, jest miarą niechęci osób posiadających pieniądze do wyrzeczenia się dysponowania nimi w formie płynnej". Keynes przedstawia mechanizm transmisji oparty na stopie procentowej, zaczynając od zewnętrznie określonej podaży pieniądza wraz z możliwością jej zmiany przez władze monetarne. Wyjaśnia mechanizm w następujący sposób: ,gdy bowiem można się spodziewać, że wzrost ilości pieniądza obniża, ceteris paribus, stopę procentową, to obniżka stopy procentowej nie nastąpi, gdy preferencja płynności będzie się zwiększała bardziej niż ilość pieniądza. Następnie spadek stopy procentowej, ceteris paribus, zwiększa rozmiary inwestycji, nie nastąpi to jednak, jeżeli krzywa krańcowej efektywności kapitału przesunie się w dół gwałtowniej, niż spada stopa procentowa (...) wzrost inwestycji, ceteris paribus, wpływa na zwiększenie zatrudnienia, może to nie nastąpić, jeśli zmniejsza się skłonność do konsumpcji"9. Teoria Keynesa służy wyjaśnieniu zmian stóp procentowych przy pomocy dwóch głównych czynników, a mianowicie podaży pieniądza oraz skłonności do utrzymywania rezerw pieniężnych w gospodarce, inaczej ujmując preferencji płynności. Wraz ze wzrostem stóp procentowych maleje preferencja płynności, czyli utrzymywanie majątku w najpłynniejszym elemencie aktywów, czyli gotówce ${ }^{10}$.

Różne stanowiska zwolenników ekonomii keynesowskiej zilustrowano przy pomocy tzw. diagramu Hiksa opracowanego w oparciu o analizy J. M. Keynesa, zwanego modelem IS-LM (Investment-Savings $i$ Liquidity-Money) ${ }^{11}$. Keynesowski model IS-LM opisuje dwie krzywe IS, czyli inwestycje-oszczędności oraz LM, tj. krzywą płynności pieniądza. Krzywa IS opisuje warunki równowagi na rynku produktów w zależności od poziomu realnej stopy procentowej oraz wielkości realnego dochodu. Przedstawia punkty, w których inwestycje równe są oszczędnościom przy danej wielkości dochodu i danym poziomie stopy procentowej. O tym jak może fluktuować poziom inwestycji czy oszczędności pod wpływem zmian dochodu i stopy procentowej decyduje elastyczność funkcji IS, czyli inwestycji i oszczędności. Natomiast krzywa LM ilustruje warunki równowagi na rynku pieniężnym. Obrazuje wszystkie punkty, dla których popyt na pieniądz jest równy podaży przy danym dochodzie i wielkości stopy procentowej. O zmianach krzywej LM decyduje elastyczność popytu na pieniądz pod

\footnotetext{
${ }^{8}$ Pojęcie stopy naturalnej szerzej zostało opisane w dalszej części tego rozdziału.

${ }^{9}$ J. M. Ke y nes, Ogólna teoria zatrudnienia, procentu i pieniądza, [tłum.] M. Kale c ki, St. R a c zk o w ski, Wydawnictwo Naukowe PWN, Warszawa 1985, s. 29-196.

${ }^{10}$ M. S o bo l, Polityka pieniężna Narodowego Banku Polskiego w drodze do euro, Wydawnictwo Fachowe CeDeWu, Warszawa 2008, s. 33.

${ }^{11}$ R. Milewski (red.), Podstawy ekonomii, Wydawnictwo Naukowe PWN, Warszawa 1999, s. 611.
} 
wpływem zmian stopy procentowej oraz dochodu ${ }^{12}$. Model IS-LM jest wykorzystywany do analiz wielu zależności makroekonomicznych, ponieważ pokazuje jak pod wpływem zmiany parametrów gospodarka przechodzi od jednego do innego stanu równowagi ${ }^{13}$. Na rys. 3.1 zaprezentowano różne stany równowagi pod wpływem zmian krzywej LM.

Punkt przecięcia się krzywej IS z krzywą LM wyznacza punkt równowagi makroekonomicznej (E) zarówno na rynku dóbr i usług oraz na rynku pieniądza przy danej kombinacji stopy procentowej i dochodu narodowego ${ }^{14}$. W tym przypadku równowaga nie oznacza jednak pełnego wykorzystania siły roboczej oraz zdolności wytwórczych maszyn i urządzeń. Jeśli władze w danym państwie chcą zmniejszyć bezrobocie i zwiększyć wykorzystanie zdolności wytwórczych, to mają taką możliwość poprzez realizację ekspansywnej polityki pieniężnej bądź przez zwiększenie deficytu budżetowego ${ }^{15}$.

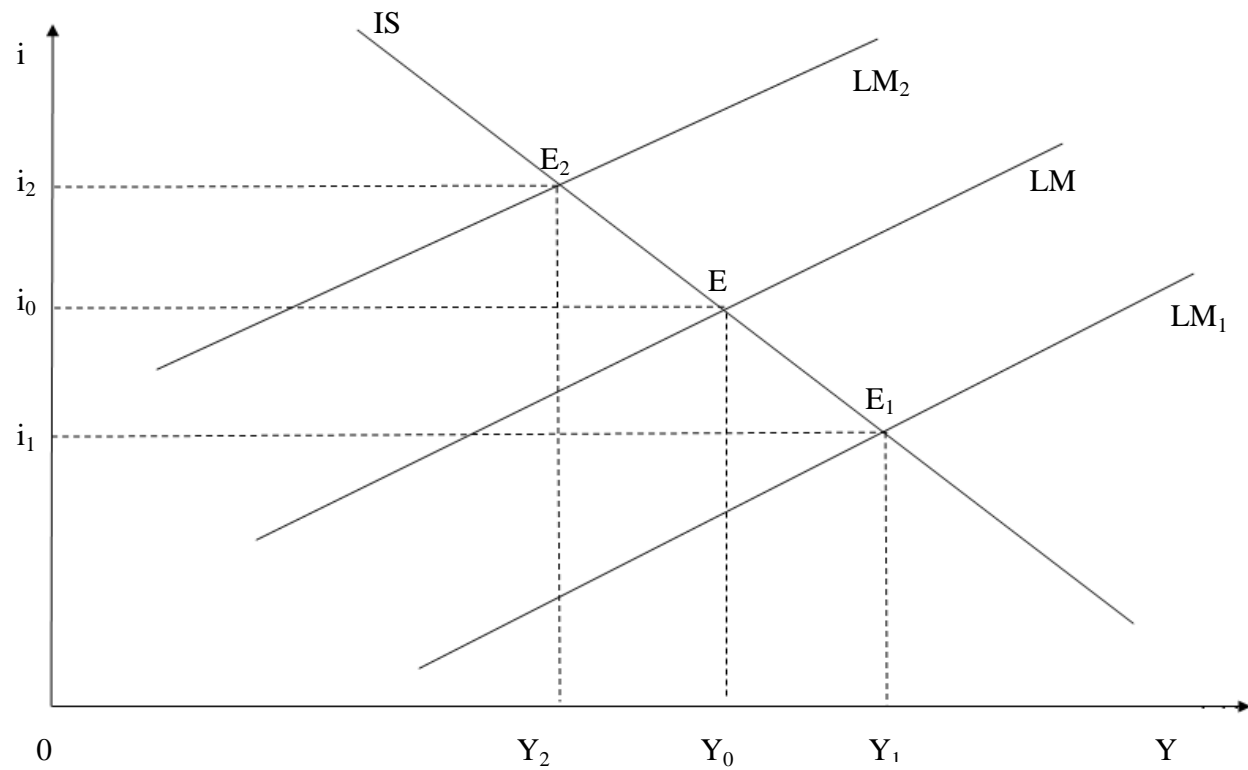

E - punkty równowagi, Y - dochód narodowy, i - stopa procentowa

Rys. 3.1. Konsekwencje realizowanej polityki pieniężnej w modelu IS-LM

Źr ódło: A. Kaźmi erczak, Polityka pieniężna w gospodarce otwartej, Wydawnictwo Naukowe PWN, Warszawa 2008, s. 165.

${ }^{12}$ F. S. M is h ki n, Ekonomika pieniądza, bankowości i rynków finansowych, Wydawnictwo Naukowe PWN, Warszawa 2002, s. 727-729.

${ }^{13} \mathrm{~K}$. B arteczko, A. B oci a n, Modelowanie polityki makroekonomicznej, PWE, Warszawa 1996, s. 52.

${ }^{14}$ R. Milewski (red.), op. cit., s. 611-615.

${ }^{15}$ R. B arczy k, Teoria i praktyka polityki antycyklicznej, Wydawnictwo Akademii Ekonomicznej w Poznaniu, Poznań, 2004, s.198-199. 
Bank centralny może zwiększyć ilość pieniądza na rynku przez udzielenie bankom komercyjnym dodatkowych kredytów, co przyczyni się do zwiększenia płynności na rynku oraz przyspieszenia akcji kredytowej przez banki. Wtedy nastąpi przesunięcie krzywej LM w prawo do poziomu $\mathrm{LM}_{1}$. W efekcie takiej decyzji banku centralnego równowaga ekonomiczna z punktu E przesunie się do punktu $E_{1}$, a dochód narodowy wzrośnie do poziomu $0 \mathrm{Y}_{1} \mathrm{z}$ wcześniejszego $0 \mathrm{Y}_{0}$, który odpowiadał początkowej równowadze. Dodatkowo przesunięcie krzywej LM w prawo i wzrost podaży pieniądza przyczyni się do spadku stopy procentowej z $0 \mathrm{i}_{0}$ do $0 \mathrm{i}_{1}$. Właśnie $\mathrm{w}$ wyniku nadwyżki podaży pieniądza w gospodarce w stosunku do popytu następuje spadek ceny pieniądza, czyli stopy procentowej. Z kolei restrykcyjna polityka pieniężna polega na zmniejszeniu ilości pieniądza $\mathrm{w}$ gospodarce i przesunięciu krzywej LM w lewo do położenia $\mathrm{LM}_{2}$. W tym przypadku równowaga makroekonomiczna $\mathrm{z}$ punktu $\mathrm{E}$ przesunie się do punktu $\mathrm{E}_{2}$, a dochód narodowy spadnie z poziomu $0 \mathrm{Y}_{0}$ do $0 \mathrm{Y}_{2}$. W tym czasie stopa procentowa wzrośnie na skutek spadku podaży pieniądza $\mathrm{w}$ stosunku do popytu, z początkowej wartości $0 \mathrm{i}_{0}$ do $0 \mathrm{i}_{2}{ }^{16}$.

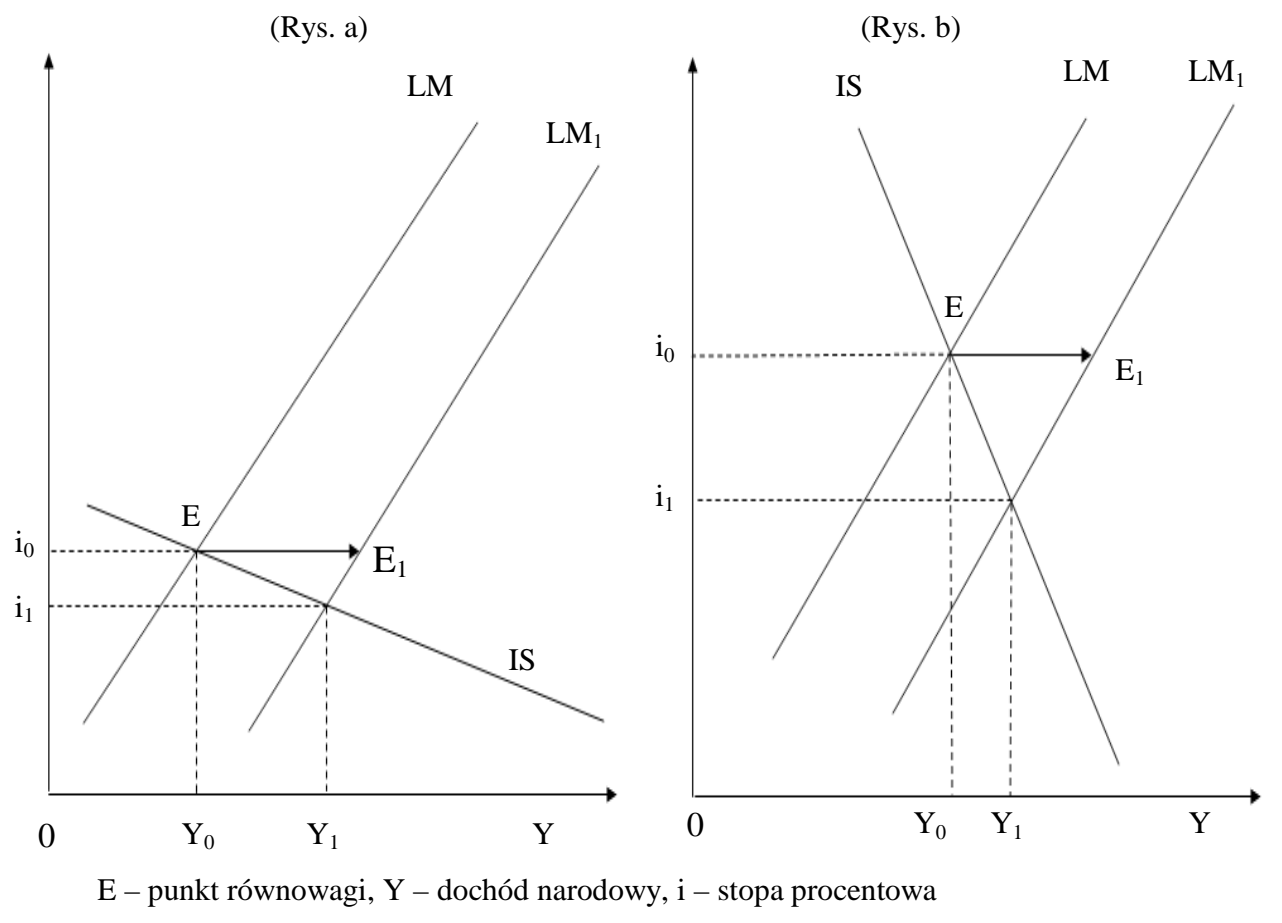

Rys. 3.2. Efekty polityki pieniężnej przy średnim nachyleniu linii LM i płaskiej lub stromej linii IS Ź r ó d ło: Z. Fe d o r o w i c z, Polityka pieniężna, Poltext, Warszawa 1993, s. 56.

${ }^{16}$ Ibidem, s.198-199. 
Rysunek 3.2 przedstawia efekty polityki pieniężnej uwzględniające elastyczność krzywej LM względem popytu na pieniądz.

Bank centralny wpływając na podaż pieniądza powoduje zmiany realnego dochodu oraz stopy procentowej. Siła wpływu banku centralnego na stope procentową i dochód zależy od położenia krzywych IS i LM, ujmując to graficznie chodzi o kąty nachylenia tych krzywych do osi odciętych ${ }^{17}$. W przypadku krzywej LM, jej kąt nachylenia zależy od wrażliwości popytu na pieniądz na zmiany stopy procentowej. Natomiast kąt nachylenia linii IS uzależniony jest od wartości współczynnika wrażliwości popytu inwestycyjnego na zmiany stopy procentowej. Rysunek 3.2 obrazuje sytuację na rynku i efekty wpływu polityki pieniężnej na parametry w gospodarce. Zakładamy, że krzywa LM ma przeciętne nachylenie, czyli wrażliwość popytu na pieniądz na zmiany stopy procentowej jest średnia ${ }^{18}$. Natomiast linia IS jest bardziej płaska, czyli inwestycje są bardzo wrażliwe na zmiany stopy procentowej. W takiej sytuacji wzrost podaży pieniądza o $\Delta \mathrm{M}_{\mathrm{S}}$ przyczyni się do niewielkiego spadku stóp procentowych i szybkiego wzrostu dochodu narodowego - rys. 3.2(a).

Z kolei, gdy linia LM będzie słabo nachylona do osi odciętych a krzywa IS będzie stroma to można wnioskować, że inwestycje mają niską wrażliwość na zmiany stopy procentowej ${ }^{19}$. W takich warunkach wzrost podaży pieniądza spowoduje niewielki wzrost dochodu narodowego i stosunkowo szybki spadek stopy procentowej - rys. 3.2(b). Podsumowując należy podkreślić, że polityka pieniężna jest bardziej skuteczna względem dochodu, jeśli występuje większa wrażliwość inwestycji na zmiany stopy procentowej (płaska krzywa IS) oraz jest skuteczniejsza względem stóp procentowych, jeśli występuje mniejsza wrażliwość inwestycji na stopy procentowe (stroma krzywa IS) ${ }^{20}$.

Istotne jest również pokazanie jak zmiany czynników podażowych i popytowych oddziałują na ceny i produkcję ${ }^{21}$. Zależność pomiędzy zmianami produkcji, cen, podaży globalnej oraz popytu globalnego przedstawia model AS-AD (aggregate supply-aggregate demand), czyli podaży globalnej i globalnego popytu ${ }^{22}$, który uwidacznia spór pomiędzy keynesowską a monetarystyczną koncepcją polityki pieniężnejej. Zwolennicy Keynesa uważają, że należy stymulować produkcję poprzez zwiększanie popytu globalnego. Jednak wyższy popyt globalny można osiągnąć przede wszystkim poprzez dodatkową emisję pieniądza i wzrost deficytu budżetowego ${ }^{24}$. Zwolennicy aktywnej roli banku

\footnotetext{
${ }^{17}$ M. S o b o 1, Polityka..., op. cit., s. 28-29.

${ }^{18}$ R. Milewski (red.), op. cit., s. 611-630.

${ }^{19}$ F. S. Mi s h ki in, Ekonomika..., op. cit., s. 727-729.

${ }^{20}$ R. Milewski (red.), op. cit., s. 611-631.

${ }^{21}$ M. S o b o 1, Polityka...,op. cit., s.44.

${ }^{22}$ Więcej na temat modelu AS-AD [w:] F.S. M is h k in, Ekonomika..., op. cit., s. 884.

${ }^{23}$ A. K aź mi e r c z a k, Polityka pieniężna w gospodarce otwartej, op. cit., s. 170.

${ }^{24}$ M. S o bo 1, Polityka..., op. cit., s. 33-36.
} 
centralnego w gospodarce akceptują wyższe ceny na rzecz zwiększenia poziomu produkcji oraz zatrudnienia nawet przejściowo $\mathrm{W}$ konsekwencji wzrostu koniunktury gospodarczej zwiększają się żądania płacowe, rosną płace a zarazem koszty całkowite i następuje spadek rentowności produkcji. Zwolennicy monetaryzmu są przeciwni aktywnej polityce pieniężnej, ponieważ prowadzi ona do wzrostu inflacji ${ }^{25}$. W praktyce spory dotyczące wielkości oddziaływania władz gospodarczych wciąż występują, jednak wszystko zależy od stopnia wykorzystania zdolności produkcyjnych oraz kwestii kreowania popytu w gospodarce.

\subsubsection{Teoria monetarystyczna}

Za początek teorii monetarystycznej przyjmuje się moment przedstawienia przez M. Friedmana $\mathrm{z}$ Uniwersytetu w Chicago teorii popytu na pieniądz w $1956 \mathrm{r}^{26}$ Teoria monetarystyczna nabrała znaczenia na przełomie lat 60 . i 70., natomiast największy wpływ na politykę gospodarczą miała w końcu lat 70 . i w pierwszej połowie lat 80. Dla kontrrewolucji monetarystycznej drogą do istotnego znaczenia w teorii ekonomii była stagflacja lat 70., która spowodowała odwrót od ortodoksji keynesowskiej ${ }^{27}$. Zwolennicy monetaryzmu przyjmują, że głównym celem polityki ekonomicznej państwa jest zapewnienie wzrostu gospodarczego poprzez zapewnienie stabilności cen. To znaczy, że za główny cel polityki pieniężnej uważali walkę $\mathrm{z}$ inflacją, która jest zjawiskiem pieniężnym. Podstawowym narzędziem do walki z inflacją powinna być kontrola podaży pieniądza $^{28}$. Dla monetarystów podaż pieniądza odgrywała istotną rolę w gospodarce i nie powinno się jej ograniczać tylko do roli utrzymywania stałości stopy procentowej $^{29}$.

M. Friedman jak i A. Meltzer podkreślali, że nominalne stopy procentowe nie są dobrym wskaźnikiem, na którym powinna opierać się polityka pieniężna, ponieważ stopy te wskazują zacieśnianie lub łagodzenie polityki monetarnej tylko zależnie od oczekiwań inflacyjnych ${ }^{30}$. Dla M. Friedmana istotnym czynnikiem wpływającym na poziom działalności gospodarczej była zmiana zasobów

\footnotetext{
${ }^{25}$ A. Kaźmi e rc z a k, Polityka pieniężna w gospodarce otwartej, op. cit., s. 170.

${ }^{26}$ Termin monetaryzm będący określeniem doktryny makroekonomicznej został jednak wprowadzony dopiero w $1968 \mathrm{r}$. przez Karla Brunnera.

${ }^{27}$ H. Landreth, D. C. Colan de r, Historia myśli ekonomicznej, Wydawnictwo Naukowe PWN, Warszawa 2005, s. 557.

${ }_{28}$ M. Friedman, R. Friedman, Wolny wybór, Wydawnictwo Kraków, Kraków 1988, s. $33-35$.

${ }^{29}$ H. Landreth, D. C. Colander, op. cit., s. 505.

${ }^{30}$ B. S. B e rn a n k e, Friedman's Monetary Framework: Some Lessons, On Milton Friedman's Ninetieth Birthday, University of Chicago, Chicago 2002, s. 207-214, [za:] zasoby witryny internetowej: www.federalreserve.gov/boarddocs/speeches/2002/20021108/default.htm [10.10.2009].
} 
pieniądza. Podkreślał także znaczenie polityki pieniężnej, gdyż zmiany pieniądza w obiegu istotnie wpływają na gospodarkę i nie można nimi dowolnie manipulować $^{31}$. Według M. Friedmana istnieje związek pomiędzy podażą pieniądza a nominalnym dochodem, jednak relacja ta jest zaburzona przez opóźnienia reakcji pomiędzy zmiennymi. Wzrost dochodów ma odzwierciedlenie w pierwszej kolejności $\mathrm{w}$ produkcji, dopiero $\mathrm{w}$ dłuższej perspektywie $\mathrm{w}$ cenach. Poziom podaży pieniądza wpływa na produkcję w krótkim okresie, natomiast w długim produkcja zdeterminowana jest przez czynniki realne jak inwestycje czy oszczędności ${ }^{32}$. Charakterystyczne zagadnienia związane $\mathrm{z}$ tą teorią można ująć w następujących punktach ${ }^{33}$ :

- na poziom inflacji w długim okresie wpływają zmiany podaży pieniądza, a długi czas reakcji sektora realnego na politykę pieniężną jest spowodowany stopniem jej antycypacji, czyli przewidywań uczestników gry rynkowej,

- ilościowa teoria pieniądza jest podstawą mechanizmu transmisji pieniądza, a kanały kredytowe mają mniejsze znaczenie niż kanały pieniężne, natomiast zmienność długoterminowych stóp procentowych jest wynikiem wahań premii za oczekiwaną inflację a nie zmiany stopy realnej,

- polityka pieniężna powinna być oparta na sztywnych regułach albo prowadzona w kierunku ogłaszanych wcześniej celów ilościowych.

Zwolennicy poglądów Friedmana twierdzili, że w długim okresie państwo nie oddziałuje na rozmiary produkcji i zatrudnienia, gdyż wymaga to ciągłego wzrostu podaży pieniądza, co nieuchronnie przyspiesza inflację. Jedynie przy stopie bezrobocia zbliżonej do naturalnej jest możliwe osiągnięcie stabilnego poziomu inflacji w długim okresie, a dokładnie przy stopie wzrostu podaży pieniądza odpowiadającej długoterminowej stopie wzrostu realnej produkcji ${ }^{34}$. Według zwolenników monetaryzmu, stałe tempo wzrostu podaży pieniądza powinno być na poziomie 3-4\% rocznie, ponieważ tyle właśnie wynosi naturalna stopa wzrostu potencjału podażowego gospodarki. Zatem jeśli ilość pieniądza w obiegu rośnie w tym samym tempie co produkcja, to przeciętny poziom cen nie ulega zmianom i nie występują procesy inflacyjne ${ }^{35}$.

Inflacja według M. Friedmana jest zjawiskiem tylko i wyłącznie pieniężnym oraz może być wywołana raczej przez szybszy wzrost podaży pieniądza niż produkcji. Monetaryści postulują by twórcy polityki pieniężnej dążyli do stabilności monetarnej, gdyż stabilna polityka pieniężna pobudza efektywność i wzrost

${ }^{31}$ S. Marciniak (red.), Makro- $i$ mikroekonomia. Podstawowe problemy, Wydawnictwo Naukowe PWN, Warszawa 2005, s. 50.

${ }^{32}$ B. S. B e r n a n ke, Friedman's Monetary..., op. cit. [16.10.2009].

${ }^{33}$ R. Ko kos z c z y ń s ki, Wspótczesna polityka pieniężna w Polsce, PWE, Warszawa 2004, s. 35 .

${ }^{34}$ H. Ćwikliński, Polityka gospodarcza, Wydawnictwo Uniwersytetu Gdańskiego, Gdańsk 2004, s. 38.

${ }^{35}$ R. Milewski (red.), op. cit., s. 86. 
gospodarki ${ }^{36}$. Banki centralne powinny unikać nadmiernie ambitnych prób kierowania lub wpływania na realne wielkości w gospodarce. Sugerują, że niższy i stabilny poziom inflacji nie tylko prowadzi do wzrostu i produkcyjności w gospodarce, ale również redukuje jej wrażliwość na szoki zewnętrzne i wewnętrzne $^{37}$. Biorąc zatem pod uwagę, że inflacja jest zjawiskiem wyłącznie pieniężnym a pieniądz jest neutralny, zmiany ilości pieniądza wpłyną na kształtowanie wielkości nominalnych, tj. cen. Z tego wynika, że głównym celem polityki pieniężnej powinno być zapewnienie stabilności cen, a przez to zapewnienie harmonijnego wzrostu gospodarczego ${ }^{38}$.

\subsubsection{Teoria funduszy pożyczkowych stóp procentowych}

Teoria funduszy pożyczkowych opiera się na założeniu, że stopa procentowa kształtując się na rynku stanowi cenę równowagi pomiędzy popytem na pieniądz a jego podażą. Uczestnicy rynku, którzy mają preferencję nabyć dane dobro w określonym momencie tworzą popyt na pieniądz ${ }^{39}$. Podmioty te zakładają, że satysfakcja z konsumpcji lub oczekiwana stopa zwrotu z inwestycji będzie wyższa niż koszt kredytu. Mają one niedobór środków finansowych i dlatego zgłaszają popyt na środki pieniężne. Z kolei podaż pieniądza generują podmioty gospodarcze, które w danym momencie preferują oszczędzanie i dochód z procentu, by w przyszłości spożytkować te środki na konsumpcję lub inwestycję. W ten sposób tworzą na rynku fundusze pożyczkowe, które są oferowane innym podmiotom za opłatą ${ }^{40}$.

Na rys. 3.3 została przedstawiona sytuacja, w której z jednej strony występuje podaż funduszy pożyczkowych (S), a z drugiej popyt na kredyt (D). Przy stopie procentowej wyznaczającej punkt równowagi (E), popyt na kredyt ilustruje krzywa D, a podaż krzywa S. W przypadku, gdy stopa procentowa będzie niższa niż w punkcie równowagi na rynku pojawi się nadwyżka popytu nad podażą, co spowoduje tendencję wzrostową stopy procentowej ${ }^{41}$.

${ }^{36}$ R. B arro, Milton Friedman: Perspectives, Particularly on Monetary Policy, Harvard University, Harvard 2006, s. 1-10.

${ }^{37}$ B. S. B ern an ke, Friedman's Monetary..., op. cit. [19.12.2009].

${ }^{38}$ J. K. Galbraith, The Collapse of Monetarism and the Irrelevance of the New Monetary Consensus, 25th Annual Milton Friedman Distinguished Lecture at Marietta College, Marietta, Ohio 31 marzec 2008, s. 2.

${ }^{39}$ A. Ka ź mi e r c z a k, Polityka pieniężna w gospodarce otwartej, op. cit., s. 45-47.

${ }^{40}$ T. Gruszecki, op. cit., s. 117-118.

${ }^{41}$ N. G. Manki w, M. P. T a y lor, Makroekonomia, PWE, Warszawa 2009, s. 1-491. 


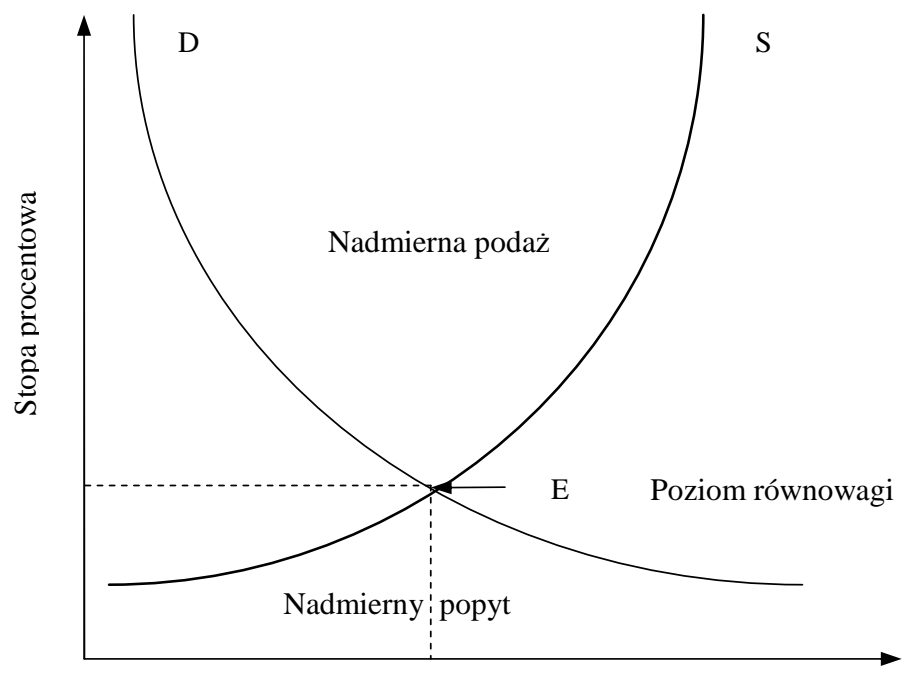

Popyt i podaż funduszy pożyczkowych

$\mathrm{S}$ - podaż funduszy pożyczkowych, D - popyt na kredyt, E - poziom równowagi

Rys. 3.3. Popyt i podaż funduszy pożyczkowych

Ź r ó d ło: A. Kaźmi e r c z a k, Polityka pieniężna w gospodarce otwartej, op. cit., s. 46.

Ta tendencja wzrostowa będzie bodźcem do dodatkowego oszczędzania przez uczestników rynku, aż do momentu, gdy stopa procentowa wróci do poziomu równowagi. Odwrotna sytuacja ma miejsce w przypadku wyższej stopy procentowej niż stopa równowagi, gdyż następuje wtedy nadmiar podaży funduszy pożyczkowych. Taka sytuacja stymuluje obniżkę stopy procentowej, a co się z tym wiąże, ograniczenie oszczędności w bankach, co w późniejszym okresie prowadzi do obniżki podaży funduszy pożyczkowych. Oczywiście nie tylko stopa procentowa wpływa na popyt i podaż kapitału pożyczkowego, ale również dochód narodowy danego kraju. W bogatszych krajach występuje większa skłonność do oszczędzania niż w krajach mniej zamożnych. Wyższy dochód jest źródłem większej akumulacji kapitału, który jest źródłem inwestycji i wzrostu gospodarczego. Podobny wpływ na popyt i podaż funduszy pożyczkowych ma stabilność ekonomiczna oraz polityczna kraju. Chociażby w przypadku wysokiej inflacji, której stopa przewyższa nominalną stopę rynkową, skłonność do oszczędzania ulega obniżeniu. Podsumowując, teoria funduszy pożyczkowych wyjaśnia krótkookresowe przyczyny wahan stóp procentowych wykorzystując do tego kategorię podaży i popytu ${ }^{42}$.

\footnotetext{
${ }^{42}$ A. Kaźmi e r c z a k, Polityka pieniężna w gospodarce rynkowej, op. cit., s. 46.
} 


\subsubsection{Teorie terminowej struktury stóp procentowych}

Teorie terminowej struktury stóp procentowych tworzą podstawy do prognozowania stóp procentowych, ponieważ umożliwiają objaśnienie mechanizmów kształtujących ich poziom oraz opis czynników wpływających na ich zróżnicowanie czasowe ${ }^{43}$. W wyjaśnieniu tych teorii pomogło sformułowanie linii dochodowości, która jest związkiem pomiędzy wysokością stóp procentowych różnych aktywów finansowych a długością czasu do chwili ich wykupu. Ogólnie zakłada się, że im dłuższy termin lokaty, tym stopa dochodu jest wyższa, ponieważ wiąże się to z pewnym ryzykiem. Krzywa dochodowości była przedmiotem badań ekonomistów przez większą część XX w. Jednak pierwsze modele matematyczne powstały dopiero w latach 70., natomiast modele bazujące już na stopie forward dopiero w latach $90{ }^{44}$ Graficzna prezentacja terminowej struktury stóp procentowych, czyli krzywa dochodowości przybiera różne kształty (rys. 3.4). Wśród najbardziej podstawowych wyróżnia się kształty ${ }^{45}$ : normalny, czyli rosnący (normal); płaski (flat), odwrócony, czyli malejący (inverted) oraz zgarbiony (hump-shaped). Kształt krzywej dochodowości określa różnica pomiędzy jednookresową stopą procentową a stopami o dłuższych terminach zapadalności (czyli wartość spread) ${ }^{46}$.

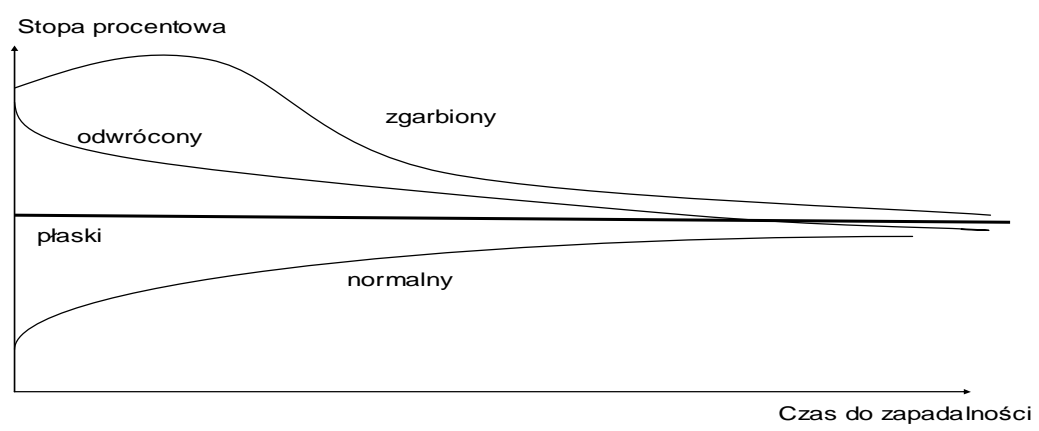

Rys. 3.4. Podstawowe kształty krzywej dochodowości

Ź r ód ło: opracowanie własne na podstawie: M. Świętoń, Terminowa struktura dochodowości skarbowych papierów wartościowych w Polsce w latach 1998-2001, „Materiały i Studia” 2002, z. 150, s. 16.

${ }^{43}$ A. Ge mzik-S alwach, Analiza komparatywna koncepcji czasowej struktury stóp procentowych. Podejście analityczne i krytyczne, „Finanse - Finansowy kwartalnik internetowy” 2010, vol. 6, no. 2, s. 40.

${ }^{44}$ Ibidem, s. 40.

${ }^{45}$ M. Ś w i ę to ń, Terminowa struktura dochodowości skarbowych papierów wartościowych w Polsce w latach 1998-2001, „Materiały i Studia” 2002, z. 150, s. 15-16.

${ }^{46}$ Ibidem, s. 16. 
W przypadku normalnego kształtu krzywej, wartość spreadu jest duża i krzywa rośnie. Kształt płaski jest czysto teoretyczny, nie występuje w praktyce, oznacza, że wartość spreadu nie istnieje. Kształt odwrócony to odzwierciedlenie malejących wartości spreadu dla rosnących wartości czasu zapadalności. Kształt zgarbiony lub inaczej łukowaty, dla pewnego czasu zapadalności spread osiąga wielkość maksymalną, a spready stóp dla pozostałych czasów zapadalności są dodatnie, ale niższe od tego w punkcie najwyższym ${ }^{47}$.

Wyróżniono następujące terminowe teorie struktury stóp procentowych: teoria oczekiwań, teoria segmentacji rynków oraz teoria preferowanego środowiska i premii za płynnośćc ${ }^{48}$. Wśród teorii oczekiwań wyróżniamy teorię racjonalnych oczekiwań oraz teorię oczekiwań adaptacyjnych. Ta pierwsza przyjmuje, że uczestnicy rynku formułują swoje oczekiwania na temat przyszłości opierając się na informacjach minionych, obecnych oraz przewidywanych w przyszłym okresie. Teoria oczekiwań adaptacyjnych opiera się na założeniu, że podmioty gospodarcze tworzą swoje oczekiwania związane z przyszłością wykorzystując do tego informacje wyłącznie obecne i przyszłe ${ }^{49}$. Według teorii oczekiwań poziom długoterminowej stopy dochodowości kształtuje się zgodnie z przewidywaniami, co do wysokości krótkoterminowych stóp procentowych w przyszłości ${ }^{50}$.

Teoria oczekiwań wywodzi się od I. Fishera, a następnie rozwijana była przez F. A. Lutza i D. Meiselmana. Do warunków, na których jest ona oparta należy założenie, że podmioty gospodarcze postępują w sposób racjonalny, dążąc do maksymalizacji zysków i każdy inwestor dysponuje pełnym dostępem do informacji. Ponadto zakłada się, że instrumenty finansowe o tym samym, kontraktowym okresie trwania są homogeniczne, a na rynku nie występują bariery wejścia i wyjścia na jego różne segmenty. Poniższe równanie prezentuje zależność pomiędzy krótko- i długoterminowymi stopami procentowymi ${ }^{51}$ :

Wzór 3.1. Zależność między stopami o różnym stopniu terminowości (1)

$$
y_{n, t}=\frac{1}{n}\left(y_{1}+f_{1, t+1}+\ldots . .+f_{1, n+t-1}\right)
$$

gdzie:

$y_{n, t} \quad-n$-okresowa stopa procentowa obserwowana w momencie $t$,

$f_{1, t+1}, f_{1, t+2}, f_{1, t+n-1} \quad$ - oczekiwane roczne stopy procentowe rozpoczynające się w kolejnych okresach $t+1, t+2, \ldots$ aż do $t+n-1$.

${ }^{47}$ Ibidem, s. 16-17.

${ }^{48}$ A. Ka źmi e r c z a k, Polityka pieniężna w gospodarce otwartej, op. cit., s. 52-55.

${ }^{49} \mathrm{M}$. C z a p l u k, Racjonalne oczekiwania a polityka państwa, Uniwersytet Zielonogórski, nr 3, Zielona Góra 2002, s. 1.

${ }^{50}$ F. M. Mis h ki n, Ekonomika..., op. cit., s. 204.

${ }^{51}$ A. Ge mzik-S alwa ch, op. cit., s. 41. 
Stopy długoterminowe stanowią średnią arytmetyczną oczekiwanych krótkoterminowych stóp procentowych o zbliżonym terminie wykupu aktywów finansowych. Inwestorzy muszą przewidywać jak będą kształtować się stopy krótkoterminowe w przyszłości i na tej podstawie będą oczekiwać określonej długoterminowej stopy procentowej. Jeżeli krótkookresowe stopy są w danym momencie niskie, to inwestorzy oczekują ich wzrostu w przyszłości i dlatego te spekulacje odzwierciedlone są w wyższej długookresowej stopie procentowej. Stąd, jeśli większość inwestorów oczekuje wzrostu krótkoterminowych stóp procentowych, to stopa długoterminowa będzie wyższa od stopy krótkoterminowej. Wtedy krzywa dochodowości będzie rosnąca, a w przypadku oczekiwań spadku stóp krótkoterminowych, krzywa ta będzie miała przebieg malejący ${ }^{52}$.

Inaczej jest w przypadku teorii segmentacji rynków (teorii preferowanych habitatów). Powstała ona przy udziale J. M. Culbertsona, S. Homera i R. L. Johannesena. Habitat to taki segment rynku, na którym określone instytucje kupują lub sprzedają papiery wartościowe o terminach zapadalności, które odpowiadają okresom zmian stawek procentowych posiadanych już aktywów i pasywów. Inwestorzy próbują utrzymać się na rynku zabezpieczając się przed ryzykiem stóp procentowych, utrzymując takie struktury portfela aktywów finansowych, by ich średni ważony termin zapadalności był możliwie jak najbardziej zbliżony do średniego ważonego terminu wymagalności pasywów. Część inwestorów, którzy decydują się wyjść z danego bezpiecznego dla nich habitatu decydują się na podjęcie ryzyka inwestowania w zamian za premię. Polega to na tym, że jeśli aktywa o innych terminach zapadalności oferują względnie wysoką stopę zwrotu, wtedy instytucje finansowe angażują swoje środki właśnie w te aktywa przynoszące wyższe dochody. Tak więc, możliwość osiągnięcia premii pojawia się przy terminach wykupu o niższym popycie, co skłania inwestorów do wyjścia z preferowanego środowiska ${ }^{53}$. Teorię tę nazywa się również teorią segmentacji rynków, ponieważ według niej, ceny i stopy dochodu $\mathrm{z}$ aktywów finansowych o różnych terminach wykupu zależą wyłącznie od relacji między popytem a podażą. Zwykle popyt na walory krótkookresowe jest wyższy niż na długookresowe, dlatego ceny aktywów krótkookresowych są wyższe, a na długoterminowe niższe w zamian za większą dochodowość tych ostatnich ${ }^{54}$.

$\mathrm{W}$ trzeciej teorii terminowej struktury stóp procentowych połączono nurty dwóch wcześniejszych. $\mathrm{Z}$ połączenia obu powyższych teorii powstała teoria

${ }^{52}$ J. C. C o x, J. E. In ger s o 11, Jr. S. A. Ros s, The Theory of the Term Structure of Interest Rate, „Econometrica” 1985, vol. 53, no. 2, s. 385.

${ }_{53}$ A. Ge m zik-S a lwa ch, op. cit., s. 41-43.

${ }^{54}$ A. K a ź mi e r c z a k, Polityka pieniężna w gospodarce otwartej, op. cit., s. 52-55. 
preferowanego środowiska i premii za płynność (inaczej teoria naturalnych preferencji), oparta na założeniu, że długoterminowe stopy procentowe równają się średniej oczekiwanych stóp krótkookresowych oraz premii terminowej za płynność. Inwestorzy mają preferowane przez siebie środowisko i są zdolni do zmiany swoich preferencji w celu uzyskania wyższego dochodu ${ }^{55}$. Za twórcę tej teorii uważa się J. R. Hicksa, chociaż on przede wszystkim zajmował się głównym nurtem tej hipotezy, czyli teorią preferencji płynności. Pozostali ekonomiści zajmujący się tą teorią to: R. A. Kassel, F. Modigliani, R. Sutch, E. J Kane oraz B. G. Malkiel. Poniższe równanie przedstawia relację pomiędzy stopami krótkoi długoterminowymi ${ }^{56}$ :

Wzór 3.2. Zależność między stopami o różnym stopniu terminowości (2)

$$
y_{n, t}=\frac{1}{n}\left(y_{1}+f_{1, t+1}+L_{1}+\ldots . .+f_{1, n+t-1}+L_{n-1}\right)
$$

gdzie:

$L_{n} \quad-$ premia za ryzyko,

pozostałe oznaczenia jak wyżej.

Według tego podejścia, stopa zysku z instrumentu wynika z zależności między popytem a podażą. Inwestorzy preferują instrumenty o najkorzystniejszym dla nich terminie wykupu, dlatego instrumenty, które mają różne terminy wykupu nie są idealnymi substytutami. Uczestnicy rynku rezygnując z preferowanego okresu inwestycyjnego wymagają rekompensaty w postaci premii, związanej z niepewnością co do kształtowania się stawek procentowych w przyszłości oraz czasem trwania transakcji. Teorie te umożliwiają określenie na podstawie kształtu krzywej stóp procentowych oczekiwań, co do krótkookresowych stóp procentowych w przyszłości ${ }^{57}$.

W literaturze ekonomii istnieje wiele teorii dotyczących sposobu prowadzenia polityki gospodarczej, jej wpływu na wielkości makroekonomiczne, na ogólny stan ekonomiczny danego kraju. Wraz ze zmianami gospodarczo-politycznymi tworzono nowe idee i teorie ekonomiczne, których wykorzystanie miało prowadzić do stanu równowagi lub wzrostu gospodarczego. Wiele $\mathrm{z}$ tych teorii rzeczywiście ma ponadczasowy wymiar i można je z powodzeniem stosować we współczesnej polityce gospodarczej.

\footnotetext{
${ }^{55}$ Ibidem, s. 52-55.

${ }^{56}$ A. Ge mzik-S alw a ch,op. cit., s. 42.

${ }^{57}$ F. S. M is h ki n, Ekonomika..., op. cit., s. 204-206.
} 


\subsection{Polityka stóp procentowych banku centralnego}

Jak ujmuje I. Pyka stopa procentowa jest parametrem współczesnego rynku pieniężnego, który reguluje poziom inwestycji i oszczędności w gospodarce, oddziałuje na poziom zatrudnienia i dochodu narodowego, ma wpływ na popyt konsumpcyjny, inflację oraz kurs walutowy ${ }^{58}$. Stopa procentowa jest uznawana za rynkową cenę pieniądza. Z perspektywy pożyczkobiorcy jest to cena, którą skłonny jest on zapłacić za dysponowanie przez określony czas pożyczonym pieniądzem. $Z$ punktu widzenia pożyczkodawcy jest ceną, za jaką jest on skłonny zrezygnować $z$ władania swoimi środkami pieniężnymi ${ }^{59}$. Jak podają A. Bień i W. Bień, to cena, jaką dłużnik musi zapłacić za pożyczenie kapitału. Stopa procentowa to składowa poziomu inflacji, wynagrodzeń dla wierzycieli kapitałów, kosztu ryzyka, dostępności oraz zyskowności potencjalnych inwestycji ${ }^{60}$. Jest ceną dysponowania pożyczonym kapitałem finansowym, a jednocześnie stopą zwrotu funduszy pożyczkowych. Inaczej ujmując, stopa procentowa jest współczynnikiem dochodowości za czasową rezygnację $\mathrm{z}$ dysponowania kapitałem finansowym ${ }^{61}$. Stopa procentowa, jako cena kapitału jest jednym z najważniejszych parametrów zarządzania układami gospodarczymi w gospodarce rynkowej. Wpływa na działalność i efektywność podmiotów gospodarczych oraz na koniunkturę gospodarczą danego kraju. Poziom stopy procentowej wykorzystuje się przy wyznaczaniu ceny kapitału własnego oraz inwestycji finansowych w celu wyznaczenia poziomu opłacalności tych przedsięwzięć ${ }^{62}$.

Istnieje wiele czynników, które wpływają na kształt i strukturę stóp procentowych, są to między innymi ${ }^{63}$ : wysokość stóp bazowych ${ }^{64}$ banku centralnego, powiązana z poziomem stóp stosowanych przez władze monetarne w operacjach repo i reverse repo; popyt i podaż płynnych środków na rynku; w określonych warunkach może to być również rentowność weksli skarbowych.

${ }^{58}$ I. P y k a, Bank centralny na wspótczesnym rynku pieniężnym, dyscyplina regulacyjna, skuteczność, instrumenty, Wydawnictwo C. H. Beck, Warszawa 2010, s. 70.

${ }^{59}$ Wł. L. J a w or s ki (red.), Wspótczesny bank, Poltext, Warszawa 2002, s. 163.

${ }^{60}$ A. B i eń, W. B i én, Kalkulacja ceny pieniadza w lokatach, pożyczkach i kredytach, Difin, Warszawa 1999.

${ }^{61}$ A. K a ź mi e r c z a k, Polityka pieniężna w gospodarce otwartej, op. cit., s. 44.

${ }^{62} \mathrm{~W}$. D ę b s ki, Rynek finansowy i jego mechanizmy. Podstawy teorii i praktyki, Wydawnictwo Naukowe PWN, Warszawa 2005, s. 103.

${ }^{63}$ Wł. L. J a w orski (red.), op. cit., s. 163.

${ }^{64}$ Bazowe stopy procentowych to cena pieniądza banku centralnego, ustalana arbitralnie przez NBP. Inaczej są to podstawowe stopy procentowe, jakie bank centralny ustala w zależności od przyjętej polityki pieniężnej. 
Praktycznym odzwierciedleniem stopy procentowej jest oprocentowanie wkładów bankowych, wkładów w innych instytucjach finansowych oraz oprocentowanie kredytów. Im dłuższy okres lokaty bądź pożyczki, tym oczekiwany jest większy dochód z procentu, w pierwszym przypadku dla depozytariusza, a w drugim dla kredytodawcy. Jednak w rzeczywistości gospodarczej nie jest to regułą i w momencie, gdy na rynku oczekuje się spadku stóp procentowych, to potencjalni kredytobiorcy odkładają decyzję zaciągnięcia kredytów na długi termin i na wysoki procent. W zamian będą zaciągać krótkoterminowe pożyczki, oczekując refinansowania swoich potrzeb $\mathrm{w}$ momencie spadku stóp procentowych. Dlatego według tego schematu długoterminowe stopy procentowe będą miały tendencje spadkową. Istotnym również wyznacznikiem stóp procentowych jest produktywność kapitału rzeczowego. To właśnie rentowność inwestycji rzeczowych realizowanych $\mathrm{z}$ pożyczonych funduszy jest najlepszym wyznacznikiem granicznego kosztu uzyskania środków finansowych. Zakłada się, że koszt pożyczonych funduszy na cele inwestycyjne nie może przekraczać stopy zysku z realizowanego przedsięwzięcia. Ważnym również elementem, który bezpośrednio wiąże się ze stopą procentową jest ryzyko. Zależność jest następująca - im wyższe ryzyko kredytowe, tym wyższa stopa zwrotu z pożyczonego kapitału. W rzeczywistości gospodarczej występują również pożyczki o mniejszym ryzyku udzielane skarbowi państwa. Są one udzielane w postaci emisji rządowych instrumentów dłużnych, najczęściej krótkoterminowych weksli skarbowych, które są atrakcyjną formą krótkoterminowej lokaty kapitału. Odgrywają one ważną rolę na rynku finansowym, ponieważ oddziałują na kształtowanie się stopy dochodowości od innych rodzajów lokat na rynku finansowym ${ }^{65}$.

Istotną kwestią w rozważaniach na temat stóp procentowych jest ustalenie definicji różnych stóp procentowych, które mają duże znaczenie dla podmiotów gospodarczych. Wyróżniamy efektywną (rzeczywistą) stopę procentową, uwzględniającą wszystkie koszty obsługi długu, łącznie z prowizją oraz różnymi okresami kapitalizacji odsetek. W przypadku kredytów w walutach obcych efektywna stopa procentowa obejmuje również dodatkowy koszt, jakim jest spread walutowy, czyli różnica pomiędzy ceną zakupu a sprzedaży walut obcych ${ }^{66}$. $\mathrm{W}$ definicji realnej stopy procentowej została uwzględniona siła nabywcza pieniądza w okresie trwania umowy pożyczki bądź depozytu. Stopa realna informuje o jednakowej sile nabywczej pożyczonego kapitału w różnych okresach. Jest ona istotną determinantą dla inwestycji i oszczędności podmiotów gospodarczych, dlatego ma kluczowe znaczenie w warunkach cyklicznego rozwoju i długoterminowego wzrostu gospodarczego. Realna stopa procentowa zawiera wiele

\footnotetext{
${ }^{65}$ A. K a ź mi e r c z a k, Polityka pieniężna w gospodarce otwartej, op. cit., s. 44.

${ }^{66}$ M. G ór s k i, Rynkowy system finansowy, PWE, Warszawa 2007, s. 60-64.
} 
informacji o warunkach inwestowania na rynku kapitałowym ${ }^{67}$. Z kolei nominalna stopa procentowa, będąca stawką określającą oprocentowanie instrumentu, jest sumą stopy realnej oraz premii inflacyjnej, która jest rekompensatą utraty wartości kapitału dla pożyczkodawców z powodu wzrostu cen konsumpcyjnych. Premia za ryzyko inflacyjne wynika stąd, że w momencie zawierania umowy strony nie wiedzą, jaki będzie poziom inflacji w trakcie jej trwania ${ }^{68}$.

W teorii pieniądza występuje również pojęcie naturalnej stopy procentowej, która ma istotne znaczenie dla prowadzenia polityki pieniężnej banku centralnego. Naturalna stopa procentowa (NSP), inaczej stabilna lub neutralna, to stopa, przy której inflacja jest stabilna. W przypadku, gdy realna stopa procentowa będzie na wyższym poziomie od stopy naturalnej wtedy nastąpi spadek inflacji i odwrotnie - inflacja wzrośnie, gdy realna stopa procentowa będzie niższa od stopy neutralnej. Stopa ta jest uzależniona od warunków i struktury danej gospodarki oraz jest różna w wielu gospodarkach. T. Gruszecki prezentuje sposób ustalania przez bank centralny stóp nominalnych i pośrednio realnych w odniesieniu do neutralnej stopy procentowej. Przykładowo, jeśli przy określonej przez bank centralny nominalnej stopie procentowej (np. 7\%) nie następuje spadek inflacji tylko jej wzrost (np. do 8\%), to można podejrzewać, że stopa wyznaczona przez bank jest zbyt niska. Z tego wynika, ze stopa inflacji jest faktycznie wyższa (np. 7,5\%) i stopa realna była za niska by obniżyć poziom inflacji. Spadek stopy inflacji może nastąpić dopiero, gdy bank centralny ustali stopę realną powyżej poziomu stopy naturalnej (np. 9\%). Zatem skuteczna polityka antyinflacyjna banku centralnego powinna dążyć do utrzymania realnej stopy procentowej na wyższym poziomie niż stopa naturalna ${ }^{69}$.

\subsubsection{Stopy procentowe Europejskiego Banku Centralnego oraz Narodowego Banku Polskiego}

Europejski Bank Centralny wyznaczając krótkoterminowe stopy procentowe dla państw strefy euro oddziałuje na funkcjonowanie całego rynku finansowego, jak i na inne warunki makroekonomiczne. Wyróżnia się trzy kluczowe stopy procentowe EBC, są to ${ }^{70}$ :

- krańcowa stopa pożyczkowa (marginal lending facility rate), to stopa, po jakiej wszystkie krajowe banki centralne strefy euro oferują pożyczki bankom

${ }^{67}$ Real Interest Rate: Movements and Determinants, „Deutsche Bundesbank Monthly Report" 2001, no. 7, s. 31.

${ }^{68}$ W. Dę b s ki, op. cit., s. 106.

${ }^{69}$ T. Gruszecki, op. cit., s. 180. s. 194-195.

${ }^{70}$ P. Temperton, S J. A. Felberg (red.), Euro Wspólna Waluta, Warszawa 2001, 
charakteryzującym się w danym momencie niskim stanem płynności, jest to zarazem górny próg stóp procentowych dla pożyczek overnight;

- stopa depozytowa (deposit facility rate), jest to stopa, jaką narodowe banki centralne strefy euro oferują bankom za złożenie depozytu jednodniowego, poza tym określa ona minimalny poziom stóp procentowych overnight;

- stopa repo podstawowych operacji refinansowych (main refinancing operations rate), to stopa siedmiodniowych papierów wartościowych podstawowych operacji refinansowych przeprowadzanych przez EBC. Zatem stopa repo jest minimalną stopą procentową, po której składane są oferty w ramach podstawowych operacji refinansowych ${ }^{71}$.

Istotnym jest fakt, że gospodarki krajów euro różnie reagują na politykę stóp procentowych EBC. Ze względu na różny poziom inflacji w krajach UGiW, podstawowe stopy procentowe wyznaczane przez EBC oznaczają różne realne stopy procentowe w poszczególnych krajach ${ }^{72}$. Po decyzjach Rady Prezesów dotyczących poziomu podstawowych stóp procentowych w strefie euro, Zarząd EBC odpowiada za wdrażanie podjętych decyzji w kwestii polityki pieniężnej. Realizacja ustaleń podjętych przez Radę odbywa się poprzez sterowanie krótkoterminowymi stopami procentowymi oraz przez zarządzanie płynnością na rynku pieniężnym. Działalność EBC związana z prowadzeniem polityki stóp procentowych odbywa się w oparciu o ramy operacyjne. Jest to zbiór instrumentów i procedur, przy pomocy których bank centralny wdraża decyzje Rady Prezesów. Do takich instrumentów należą operacje otwartego rynku, przy pomocy których EBC zarządza płynnością w sektorze bankowym strefy euro i stara się zbliżyć krótkoterminowe stopy procentowe rynku pieniężnego do poziomu podstawowych stóp procentowych wyznaczanych przez Radę. Wśród instrumentów wykorzystywanych do sterowania krótkoterminowymi stopami procentowymi znajdują się, poza operacjami otwartego rynku, również wymóg utrzymania rezerwy obowiązkowej oraz operacje banku centralnego na koniec dnia ${ }^{73}$.

Instrumenty operacji depozytowo-kredytowych oraz operacje refinansujące EBC wyznaczają korytarz zmian dla rynkowych krótkoterminowych stóp procentowych. Rada Zarządzająca EBC wyznaczyła korytarz, w którym rynkowa stopa typu overnight - EONIA może fluktuować. Od stycznia 1999 r. podsta-

${ }^{71}$ I. P s z c zół k a, Zmiany cen akcji poszczególnych branż $w$ strefie euro a polityka pieniężna Europejskiego Banku Centralnego, [w:] J. L. B ednarczyk (red.), Stopy procentowe a gospodarka. Dylematy Unii Gospodarczej $i$ Walutowej, Wydział Ekonomiczny Politechniki Radomskiej, Radom 2006, s. 247.

72 A. Kosztowniak, Polityka stóp procentowych Europejskiego Banku Centralnego a problem wzrostu gospodarczego w krajach strefy euro, [w:] J. L. B e d n a r c z y k (red.), Stopy procentowe a gospodarka. Dylematy Unii Gospodarczej $i$ Walutowej, Wydział Ekonomiczny Politechniki Radomskiej, Radom 2006, s. 253.

${ }^{73}$ Monthly Bulletin, 10. anniversary EBC, European Central Bank, Frankfurt n. Menem 2008, s. 52-53. 
wowe stopy procentowe EBC wyznaczają „sufit” - stopa kredytu na koniec dnia i ,podłogę" - stopa depozytu na koniec dnia dla rynkowej, krótkoterminowej stopy EONIA. Stopa repo oraz stopa depozytu i kredytu na koniec dnia to oficjalne stopy Eurosystemu ${ }^{74}$.

Z kolei NBP wśród podstawowych instrumentów realizacji założeń polityki monetarnej wyróżnia następujące stopy procentowe ${ }^{75}$ :

- stopa referencyjna (interwencyjna), która wyznacza minimalną rentowność instrumentów dłużnych, bonów pieniężnych banku centralnego sprzedawanych w ramach operacji otwartego rynku oraz wpływa na poziom oprocentowania lokat na rynku niezabezpieczonych depozytów międzybankowych;

- stopa lombardowa, która jest górnym pułapem wzrostu rynkowych stóp overnight, a zarazem określa koszt pieniądza oferowanego przez bank centralny, gdyż według tej stopy oprocentowane są pożyczki banków komercyjnych w NBP udzielane na jeden dzień pod zastaw papierów wartościowych. Inaczej ujmując, jest miarą maksymalnego kosztu pozyskania pieniądza przez banki komercyjne, wyznaczając górny limit wahań stóp rynkowych;

- stopa depozytowa to z kolei dolny pułap spadku cen rynkowych stóp overnight, jest oprocentowaniem jednodniowych depozytów banków komercyjnych składanych w banku centralnym;

- stopa redyskontowa (redyskonta weksli) jest oprocentowaniem weksli handlowych, które banki komercyjne oferują bankowi centralnemu do redyskonta, a które wcześniej uzyskały w czasie operacji kredytowania swoich klientów w zamian za dyskonto; posługując się stopą redyskonta, kontyngentami oraz warunkami przyjmowania weksli do redyskonta, bank centralny ma możliwość oddziaływania na system bankowy; banki komercyjne jednak niechętnie korzystają z tej możliwości kredytowania, ponieważ stopa redyskontowa jest zwykle wyższa niż stopa rynkowa, a dodatkowo banki komercyjne muszą dzielić się zyskiem z bankiem centralnym płacąc mu redyskonto;

- stopa kredytu refinansowego - jest to stopa oprocentowania kredytów udzielanych przez bank centralny bankom komercyjnym w rachunku kredytowym. Przy jego udzielaniu bank centralny nie wymaga zabezpieczenia w przeciwieństwie do kredytu lombardowego, czy redyskontowego. Kredyt ten może być udzielony na finansowanie inwestycji centralnych (rządowych), a także programów naprawczych banków komercyjnych, które zagrożone są upadłością. Stopa oprocentowania kredytu refinansowego na finansowanie inwestycji rządowych osiąga poziom stopy procentowej kredytu lombardowego, natomiast w przypadku finansowania programów naprawczych, stopa ta zwykle jest o 1 punkt procentowy wyższa od stopy kredytu lombardowego.

\footnotetext{
${ }^{74}$ The Monetary Policy of the ECB, European Central Bank, Frankfurt n. Menem 2004.

${ }^{75}$ Instrumenty Polityki Pieniężnej Narodowego Banku Polskiego w 2008 roku. Ptynność Sektora bankowego, Raport NBP, Warszawa 2009, s. 21.
} 
Zgodnie z Ustawa z dnia 29 sierpnia 1997 r. o Narodowym Banku Polskim, Rada Polityki Pieniężnej, jako główny organ NBP, ustala wysokość podstawowych stóp procentowych (stopy lombardowej, referencyjnej, depozytowej) ${ }^{76}$. RPP poprzez politykę stóp procentowych reguluje wysokość wielu rodzajów stóp procentowych w sposób pośredni lub bezpośredni. Podstawowe stopy procentowe banku centralnego wpływają na rynkowe stopy procentowe, oddziałując przez to na warunki działalności podmiotów gospodarczych oraz ich zachowania ekonomiczne. Od 1998 r. jako główne stopy banku centralnego traktuje się: stopę referencyjną, która określała pożądany poziom stóp na rynku międzybankowym, stopę oprocentowania kredytu lombardowego, a następnie stopę depozytową, którą zastosowano po raz pierwszy w grudniu 2001 r. jako instrument dostosowania polityki NBP do standardów $\mathrm{EBC}^{77}$. Na podstawie stopy referencyjnej kształtują się stopy rynku międzybankowego WIBOR 1M, WIBOR 3M, na bazie których wyznaczane jest oprocentowanie kredytów banków komercyjnych, co następnie ma odzwierciedlenie w koszcie kredytu i decyzjach inwestycyjnych.

Zwykle różnica wielkości miedzy stopą depozytową a referencyjną jest taka sama jak między stopą lombardową a referencyjną ${ }^{78}$. Wyjaśniając dokładniej, w momencie wprowadzenia przez RPP stopy depozytowej, ustalono, że w normalnych warunkach funkcjonować będzie korytarz stóp procentowych banku centralnego. Oznacza to, że różnica w punktach procentowych między stopą depozytową i stopą referencyjną będzie równa różnicy pomiędzy stopą kredytu lombardowego a poziomem oprocentowania stopy referencyjnej. Zastrzeżono, że różnica ta, przy niższych stopach procentowych NBP może ulec zmniejszeniu, ale przy zachowaniu symetrycznego korytarza stóp procentowych ${ }^{79}$.

Według J. Żyżyńskiego wprowadzenie stopy depozytowej budzi wiele zastrzeżeń. Przede wszystkim celem jej stosowania ma być ograniczanie od dołu wahań stóp procentowych, czyli hamowanie spadku stóp rynkowych poniżej określonego stopą depozytową poziomu. W sytuacji nadpłynności sektora bankowego, banki komercyjne posiadają nadwyżki płynności, dla których mogą nie znaleźć w krótkim terminie lokat na rynku międzybankowym. Wtedy deponują te środki na rachunku w banku centralnym według stopy depozytowej. Jest to dla banków komercyjnych korzystniejsza oferta niż utrzymywanie nadwyżki pieniądza $w$ formie nieoprocentowanych rezerw. Zatem bank centralny, który powinien pełnić rolę kredytodawcy ostatniej instancji zaczyna być depozytariu-

${ }^{76}$ Ustawa z dnia 29 sierpnia 1997 r. o Narodowym Banku Polskim, tekst ujednolicony - stan na dzień 22 czerwca 2010 r., art. 3.

${ }^{77}$ Rola Narodowego Banku Polskiego w procesie integracji europejskiej, Narodowy Bank Polski, Warszawa 2003, s. 12-19.

${ }^{78}$ M. S o b o l, Dostosowanie ram operacyjnych polityki pieniężnej NBP do wymogów Eurosystemu, [w:] J. L. B e d n ar c zy k (red.), Stopy procentowe a gospodarka. Dylematy Unii Gospodarczej $i$ Walutowej, Wydział Ekonomiczny Politechniki Radomskiej, Radom 2006, s. 121.

${ }^{79}$ Informacja z posiedzenia Rady Polityki Pieniężnej dniach w 27-28 listopada 2001, Narodowy Bank Polski, Warszawa 2001. 
szem ostatniej instancji. J. Żyżyński wysunął wnioski, że bank centralny poprzez stopę depozytową zachęca banki do lokowania środków pieniężnych na rachunku w NBP, zamiast udzielać kredytów przedsiębiorcom, inwestować w obligacje państwa lub na rynku międzybankowym ${ }^{80}$.

Wysokość stóp procentowych jest istotna dla pojedynczych podmiotów gospodarczych, jak również dla całej gospodarki. Zbyt wysoki poziom stóp procentowych może ograniczać aktywność inwestycyjną i dostęp do kredytów. W strefie euro nominalne stopy procentowe są niższe niż w Polsce, która znajduje się w fazie przygotowywania do przyjęcia wspólnej waluty. Różne realne stopy procentowe w Polsce i strefie euro wiążą się ze zróżnicowanym poziomem nominalnych stóp procentowych oraz stóp inflacji. Ma to podłoże w strukturalnych rozbieżnościach tych gospodarek. Wyższa dynamika wydajności pracy w Polsce (w wyniku fazy doganiania - konwergencji) w stosunku do gospodarek wysoko rozwiniętych prowadzi do wyższej dynamiki wynagrodzeń, która jest czynnikiem generującym presję inflacyjną. NBP chcąc utrzymać stopę inflacji w pobliżu celu inflacyjnego decyduje się na wyższe stopy procentowe. Dlatego poziom stóp procentowych w Polsce jest wyższy niż w strefie euro. Jeszcze inną przyczyną tego zjawiska jest ryzyko, które ma swoje odzwierciedlenie w poziomie rynkowych stóp procentowych w postaci tzw. premii za ryzyko. Składa się ona z ryzyka płynności, ryzyka niewypłacalności (default risk) oraz ryzyka kursowego. W krajach strefy euro składnik ryzyka kursowego został wyeliminowany, a na pozostałe elementy pozytywnie oddziałuje wzrost wiarygodności i stabilności makroekonomicznej ${ }^{81}$ tych państw $^{82}$.

\subsubsection{Znaczenie stóp procentowych $w$ gospodarce}

Obserwowanie stóp procentowych oraz wiedza na temat możliwości ich wpływania na gospodarkę jest trudną, ale niezbędną umiejętnością, szczególnie, że na ich kształt oddziałuje różnorodna gama czynników, często niezależnych od polityki pieniężnej.

Skutki zmian spadku oraz wzrostu stóp procentowych zostały przedstawione na rys. 3.5. $\mathrm{Z}$ informacji tam zawartych wynika, że zmiany stóp procento-

${ }^{80}$ J. Żyżyński, Problemy polityki pieniężnej, [za:] zasoby witryny internetowej: www.wydawnictwo.wz.uw.edu.pl/wpdownload.php?file=workingpaper022005.pdf\&paper=33 [01.12.2009], s. 6.

${ }^{81}$ W II połowie 2011 r. sytuacja ekonomiczna krajów strefy euro uległa znacznemu pogorszeniu w wyniku kryzysu długów publicznych. Światowe agencje ratingowe obniżyły standingi wielu krajów, co stwarzało zagrożenie finansowania się tych państw na rynku obligacji (rynku finansowym).

${ }^{82}$ Raport na temat petnego uczestnictwa Rzeczypospolitej Polskiej w trzecim etapie Unii Gospodarczej i Walutowej, Narodowy Bank Polski, Warszawa 2009, s. 96-98. 
wych oddziałują na istotne wielkości makroekonomiczne w gospodarce. Stopę procentową kwalifikuje się do podstawowych kategorii rynku finansowego, głównie $\mathrm{z}$ tego powodu, że wywiera wpływ na realne procesy gospodarowania podmiotów gospodarczych ${ }^{83}$. Wzrost stopy procentowej stymuluje wzrost oszczędności i spadek popytu na pieniądz, na inwestycje, spadek inflacji i niższy wzrost gospodarczy. Natomiast jej spadek zachęca jednostki gospodarcze do inwestowania a zniechęca do oszczędzania, przez co następuje poprawa koniunktury, która może doprowadzić do wzrostu inflacji.

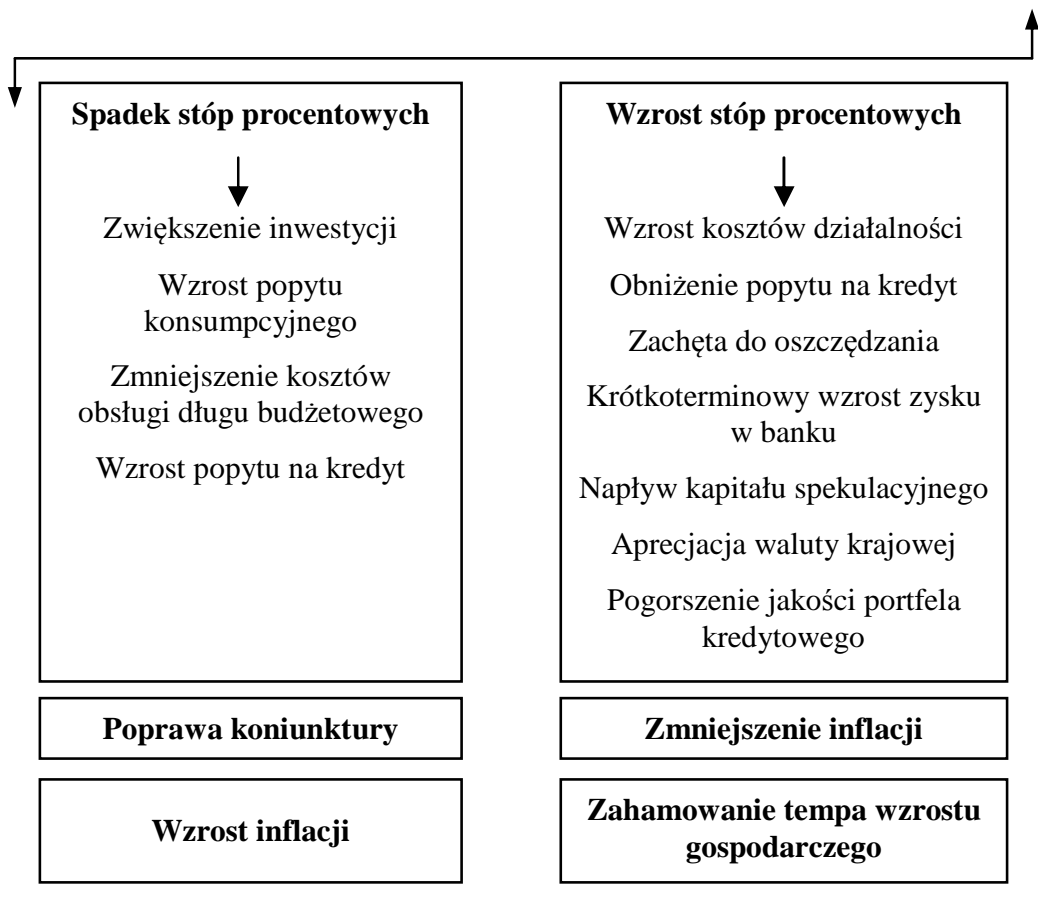

Rys. 3.5. Skutki zmian stopy procentowej

Źr ódło: W. Wąs o wski, Ekonomika i finanse banku komercyjnego, Difin, Warszawa 2004, s. 27.

Kończąc opis dotyczący szerokiego pojęcia stóp procentowych przytoczona zostanie jeszcze kwestia związana ze współczesną regułą stopy procentowej zaproponowaną przez J. B. Taylora. Jest ona istotna dla niniejszej pracy, ponieważ zwraca uwagę na stopę procentową jako ważny instrument polityki pieniężnej. Została ona wyrażona w formie równania, które później przyjęło w literaturze nazwę „reguła Taylora” (Taylor rule lub Taylor principle). Odnosi się ona do wysokości krótkoterminowych stóp procentowych, które

\footnotetext{
${ }^{83}$ W. W ą s o w s k i, Ekonomika i finanse banku komercyjnego, Difin, Warszawa 2004, s. 27.
} 
wiążą się z odchyleniem inflacji od celu inflacyjnego oraz poziomu PKB od docelowego, potencjalnego $\mathrm{PKB}^{84}$. Reguła ta dotyczyła początkowo polityki monetarnej Systemu Rezerwy Federalnej po 1986 r., a przedstawiał ją następujący wzór $^{85}$ :

Wzór 3.3. Reguła Taylora

$$
i_{t}=\mathbb{I}_{t}+0,5 y_{t}+0,5\left(\mathbb{I}_{t}-\mathbb{I}^{*}\right)+r^{*}
$$

gdzie:

$i_{t} \quad-$ nominalna stopa funduszy federalnych w okresie $t$,

Il $\quad$ - stopa inflacji w okresie $t$ (rocznie $\mathrm{w} \%$ ),

$\mathbb{I}^{*} \quad-$ cel inflacyjny w okresie $t(\mathrm{w} \%)$,

$y_{t} \quad-$ luka PKB (popytowa) w okresie $t$ (odchylenie PKB od poziomu potencjalnego, w \%),

$r^{*} \quad$ - realna stopa procentowa odpowiadająca stanowi pełnego zatrudnienia (naturalna stopa procentowa).

J. B. Taylor na podstawie przeprowadzonych badań wysunął kilka istotnych wniosków ${ }^{86}$. Przede wszystkim stwierdził, że polityka monetarna powinna reagować nie tylko na zmiany aktywności gospodarczej, ale również na poziom inflacji, a podstawowym instrumentem oddziaływania banku centralnego na gospodarkę powinna być nie podaż pieniądza a stopa procentowa. Dodatkowo J. B. Taylor uznał, że dążenie polityki pieniężnej do stabilizacji kursu walutowego może przeszkodzić władzom gospodarczym w osiągnięciu ustabilizowanej stopy inflacji i wysokiego tempa wzrostu PKB. Reguła Taylora jest tzw. regułą elastyczną, a oparta na niej polityka pieniężna nazywana jest polityką zamkniętej pętli (closed loop policy), gdyż bierze pod uwagę najbardziej aktualne informacje i dane o kondycji gospodarki ${ }^{87}$. Reguła opracowana przez J. B. Taylora opiera się na odpowiednim kształtowaniu poziomu stóp procentowych w celu stabilizowania inflacji.

${ }^{84} \mathrm{P}$. B a ran ow ski, Wykorzystanie danych typu real time do oszacowania parametrów reguty Taylora dla Polski, praca powstała w ramach projektu badawczego pt. Polityka fiskalna i monetarna w okresie akcesji do strefy euro - scenariusze $i$ wyzwania, finansowego ze środków na naukę w latach 2006-2008, s. 2.

${ }^{85}$ Z. Knaki ewicz (red.), Wspótczesny pieniądz w teorii i praktyce, Wydawnictwo Akademii Ekonomicznej w Poznaniu, Poznań 2006, s. 94.

${ }^{86}$ Reguła Taylora w wersji opisowej odnosi się do podnoszenia stopy funduszy federalnych o $0,5 \%$ wtedy, gdy realny PKB wzrasta o $1 \%$ ponad PKB potencjalny. Z kolei, jeśli inflacja wzrasta o $1 \%$ ponad cel wynoszący $2 \%$, to wtedy stopa funduszy federalnych powinna zostać podniesiona o $0,5 \%$. Natomiast w przypadku, gdy realny PKB jest równy potencjalnemu PKB, a inflacja równa jest celowi, który wynosi $2 \%$, to wtedy stopa funduszy federalnych powinna wynosić około $4 \%$, przy realnej stopie funduszy federalnych równej $2 \%$.

${ }^{87} \mathrm{M}$. Nog a, Inflacja a wzrost gospodarczy - ujęcie teoretyczne $i$ zastosowania $w$ polityce makroekonomicznej, [za:] zasoby witryny internetowej: http://mikro.univ.szczecin.pl/bp/pdf/ 88/6.pdf [01.02.2011], s. 70. 


\subsubsection{Stopa referencyjna jako podstawowa stopa banku centralnego oraz jej wpływ na poziom stóp rynku międzybankowego}

Podstawowa stopa banku centralnego ma istotny wpływ na wielkości ekonomiczne $\mathrm{w}$ gospodarce ${ }^{88}$. Zmiana stopy procentowej przez bank jest transmitowana do gospodarki poprzez jej wpływ na oprocentowanie depozytów międzybankowych, stopę dochodowości bonów skarbowych, czy oprocentowanie depozytów i kredytów w bankach komercyjnych (schemat 3.2). Jeśli w gospodarce nie występuje nadpłynność finansowa wtedy stopa oprocentowania kredytu redyskontowego lub lombardowego jest rzeczywistą ceną pieniądza na rynku i oddziałuje na stopy procentowe w operacjach międzybankowych oraz w depozytowo-kredytowej działalności banków komercyjnych. Z kolei w przypadku nadpłynności w systemie bankowym, bank centralny jest w stanie kształtować rynkowe stopy procentowe za pomocą operacji otwartego rynku. Oprocentowanie kredytów i depozytów banków komercyjnych jest zatem uzależnione nie tylko od stopy banku centralnego, ale również od rentowności bonów skarbowych oraz oprocentowania depozytów na rynku międzybankowym (rys. 3.6). Wysokość oprocentowania depozytów oraz kredytów wpływa na wielkość zaciąganych kredytów i utrzymywanych depozytów, to z kolei ma odzwierciedlenie w poziomie inwestycji przedsiębiorstw i stanie oszczędności czy konsumpcji gospodarstw domowych ${ }^{89}$. Decyzje konsumentów oraz producentów podejmowane są na bazie stopy realnej a nie nominalnej, co jest ważne w interpretacji mechanizmu wpływania stopy procentowej banku centralnego na zachowania podmiotów gospodarczych. Generalnie niższe stopy procentowe generują wzrost inwestycji przedsiębiorstw w środki trwałe, w budownictwo mieszkaniowe czy wydatków na konsumpcyjne dobra trwałe ${ }^{90}$.

Na schemacie 3.2 zaznaczono również wpływ luki popytowej na stopę inflacji, a dokładniej zależność pomiędzy inwestycjami a luką popytową. Luka popytowa to różnica między produkcją rzeczywistą a potencjalną. Jeśli poziom produkcji przewyższa jej potencjalną wielkość wtedy pojawia się w gospodarce presja inflacyjna. $\mathrm{W}$ takim przypadku przedsiębiorcy produkują $\mathrm{w}$ warunkach rosnących kosztów albo zatrudniają nowych pracowników, co w konsekwencji prowadzi do wzrostu cen i płac. Z kolei, gdy wielkość produkcji jest

${ }^{88}$ J. B u kow sk a, Polityka stóp procentowych Europejskiego Banku Centralnego a inflacja w obszarze euro w latach 1999-2008, [w:] M. N og a (red.), Ponadnarodowa i narodowa polityka monetarna na świecie, CeDeWu, Warszawa 2009, s. 97.

${ }^{89} \mathrm{~W}$. Przybylska-Kapúcińs ka, Spory wokót polityki stóp procentowych w Polsce, [w:] J. L. B ednarczyk (red.), Stopy procentowe a gospodarka. Dylematy Unii Gospodarczej $i$ Walutowej, Wydział Ekonomiczny Politechniki Radomskiej, Radom 2006, s. 122.

${ }^{90}$ Ibidem, s. 122. 
niższa od poziomu potencjalnego wtedy istnieje zagrożenie zjawiskiem deflacji w gospodarce ${ }^{91}$.

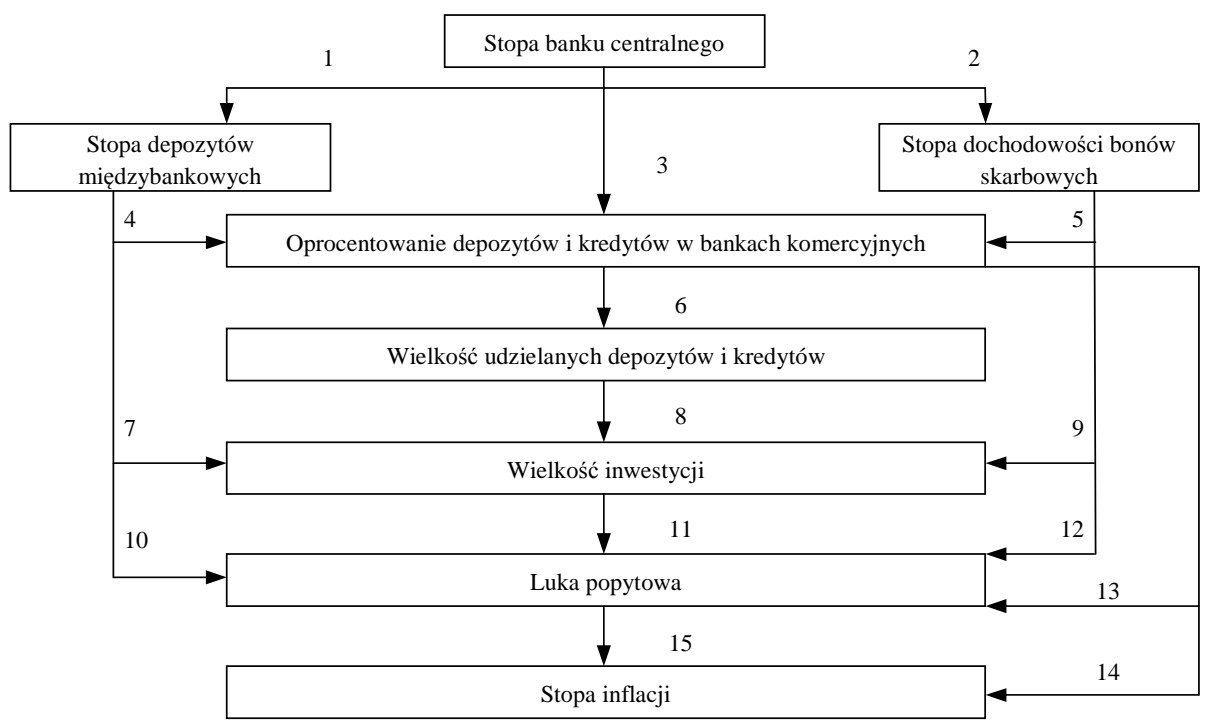

Rys. 3.6. Wpływ podstawowej stopy banku centralnego na wielkości ekonomiczne

Źródło: W. Przybylska-Kapuścińska, Spory wokót polityki stóp procentowych $w$ Polsce, [w:] J. L. B ednarczyk (red.), Stopy procentowe a gospodarka. Dylematy Unii Gospodarczej $i$ Walutowej, Wydział Ekonomiczny Politechniki Radomskiej, Radom 2006, s. 121.

Rynek pieniężny obejmuje transakcje krótkoterminowe, czyli od jednego dnia do jednego roku. Wśród instrumentów rynku pieniężnego wyróżniamy rynek depozytów (lokat i pożyczek) międzybankowych oraz rynek krótkoterminowych papierów wartościowych (bonów skarbowych, bonów pieniężnych, certyfikatów depozytowych, bankowych papierów wartościowych albo krótkoterminowych papierów komercyjnych). Do instrumentów rynku pieniężnego zalicza się również operacje warunkowe, operacje typu sell - buy - back oraz swapy walutowe. Rynek niezabezpieczonych lokat międzybankowych należy do najważniejszych segmentów rynku finansowego. Banki komercyjne wykorzystują ten rynek do zarządzania swoją płynnością, pożyczając sobie wzajemnie tzw. płynne rezerwy, czyli pieniądze na rachunkach w banku centralnym. Transakcje, których dokonują banki komercyjne dają możliwość wyrównania codziennych dysproporcji między wpłatami i wypłatami banków na rachunku w banku centralnym. Banki komercyjne prowadzą prognozy przyszłych wpłat i wypłat

${ }^{91}$ L. E. S ven s s o n, Monetary Policy and Real Stabilization, Stockholm University, „National Bureau of Economic Research Working Paper" 2003, W9486, s. 265. 
w celu ograniczenia występujących niedostosowań. Przyszłe strumienie pieniężne są dzielone na terminy, co ułatwia oszacowanie okresów, w których będą występowały nadwyżki i niedobory środków pieniężnych, jest to tzw. metoda luki. Takie prognozowane, przyszłe luki płynności są z wyprzedzeniem domykane na rynku międzybankowym przez banki komercyjne, które pożyczają bądź lokują odpowiednie kwoty na stosowne terminy ${ }^{92}$.

Rynek lokat międzybankowych to nieregulowany rynek typu over the counter (OTC). Banki zatrudniają dealerów, którzy bezpośrednio poprzez telefon, elektroniczną platformę Reuters Direct albo system Bloomberg inicjują transakcje z wybranymi bankami, podając tylko kwotę i termin transakcji. Zapytane banki odpowiadają poprzez podanie kwotowania czyli stopy procentowej po jakiej chcą pożyczyć środki (offer) i przyjąć środki na lokatę (bid). Transakcje, które zostają zawarte są zapisywane na rachunku bieżącym banku w banku centralnym prowadzonym przez Departament Systemu Płatniczego (DSP). Na rynku lokat międzybankowych wprowadzono limity kredytowe (zaangażowania), które ustala dany bank dla innych banków. Ma to na celu ograniczenie ryzyka kredytowego w związku z niezabezpieczeniem lokat międzybankowych. Wysokość limitów kredytowych zależy od wysokości funduszów własnych banku, od jego ratingu, pozycji na rynku czy jego wiarygodności ${ }^{93}$.

W celu ograniczania barier związanych z limitami kredytowymi umożliwiono zaciąganie pożyczek zabezpieczonych. Do takich instrumentów rynku pieniężnego zalicza się transakcje warunkowe typu repo (repurchase agreement, tj. warunkowy zakup/sprzedaż papierów wartościowych) oraz sell - buy - back (SBB) na skarbowych papierach wartościowych. Jeśli chodzi o transakcje sell - buy - back, to są to również umowy kupna/sprzedaży papierów wartościowych przy równoczesnym zobowiązaniu kontrahenta w oddzielnej umowie o dokonaniu transakcji odwrotnej polegającej na sprzedaży/kupnie tych samych papierów po ustalonej cenie i określonym terminie. Stopa procentowa na rynku repo jest różnicą między ceną zakupu a ceną sprzedaży papierów wartościowych. Różnica między transakcjami repo i SBB polega na innej formie prawnej, różnych zasadach księgowania, odmiennym sposobie przekazywania korzyści z nabytych papierów oraz obliczania ceny ich odkupu. W rezultacie rynek transakcji typu sell - buy - back jest lepiej rozwinięty niż transakcji typu repo. Stopy rynku międzybankowego są podstawowym punktem odniesienia przy określaniu oprocentowania pozostałych instrumentów rynku pieniężnego ${ }^{94}$. W literaturze podaje się trzy główne determinanty stóp procentowych rynku międzybankowego, są to $^{95}$ : wysokość stóp procentowych, które ustala bank centralny; podaż i popyt na

${ }^{92}$ B. Pietrzak, Z. Polań ski, B. Woźni ak, System finansowy w Polsce, Wydawnictwo Naukowe PWN, Warszawa 2008, s. 202.

${ }^{93}$ Ibidem, s. 202.

${ }^{94}$ Ibidem.

${ }^{95}$ W. D ę b s k i, op. cit., s. 27. 
pieniądz w gospodarce oraz wiarygodność kontrahenta transakcji na rynku międzybankowym.

Stopy procentowe, które ustala bank centralny (stopy bazowe), to cena pieniądza uzyskiwanego w banku centralnym, głównie w rezultacie finansowania się banków komercyjnych. Dla banków to refinansowanie jest z reguły drogie, stąd stopy bazowe są górną granicą ceny pieniądza na rynku międzybankowym. Na wysokość stóp rynku międzybankowego istotny wpływ mają także popyt i podaż pieniądza. Wzrost popytu zwykle prowadzi do wyższego poziomu stóp procentowych, natomiast nadwyżka podaży zwykle do spadku tych stóp $\mathrm{p}^{96}$.

Poziom stóp rynkowych mieści się pomiędzy kwotowaniami stóp bid i offer $\mathrm{w}$ danym terminie. $\mathrm{W}$ związku $\mathrm{z}$ istotnym znaczeniem cenotwórczym lokat międzybankowych określa się stawki referencyjne odzwierciedlające stopy rynkowe. $\mathrm{Na}$ polskim rynku rolę tę pełnią stopy $\mathrm{WIBOR}^{97}$ (Warsaw Interbank Offered Rate) i WIBID (Warsaw Interbank Bid Rate). Sa to średnie stawki na bazie 365-dniowego roku. Stawka WIBOR jest średnią stopą po jakiej banki są gotowe udzielić pożyczki, a WIBID to średnia stopa jaką banki płacą za środki przyjęte w depozyt od innych banków. Od $1991 \mathrm{r}$. stosuje się w Polsce system kwotowania stawek WIBOR/WIBID (tzw. fixing). Pod względem technicznym system ten jest obsługiwany przez Reuters, a nadzór merytoryczny pełni Polskie Stowarzyszenie Dealerów Bankowych FOREX Polska. Stawki WIBID/WIBOR ustalane są codziennie o godz. 11 i oblicza się je jako średnią arytmetyczną stawek uczestników po odrzuceniu dwóch najniższych i dwóch najwyższych kwotowań. Uczestnicy mają według regulaminu 15 minut na podjęcie decyzji o przyjęciu bądź udzieleniu depozytu po oficjalnym ogłoszeniu stawek BID/WIBOR.

Stawka POLONIA (Polish Overnight Index Average) została wprowadzona przez NBP w 24 stycznia 2005 r., jako średnia stawka overnight $(\mathrm{O} / \mathrm{N})$, ważona wielkością transakcji na rynku depozytów międzybankowych. Indeks POLONIA powstał z inicjatywy ACI POLSKA, który współpracując z NBP stworzył stawkę odzwierciedlającą wahania cen depozytów $\mathrm{O} / \mathrm{N}$ na rynku międzybankowym $^{98}$. Uważa się, że wskaźnik ten lepiej odzwierciedla rzeczywistą cenę pieniądza o terminie overnight niż stawka WIBOR O/N. NBP publikuje wysokość stawki POLONIA codziennie o godzinie 17 na stronie serwisu informacyjnego Reuters. Poziom tej stawki wyznacza rzeczywiste oprocentowanie krótkoterminowych lokat międzybankowych ${ }^{99}$. EBC z kolei publikuje w celach informacyjnych poziom stopy EONIA (Euro Overnight Index Average) ${ }^{100}$. EONIA jest

\footnotetext{
${ }^{96}$ Ibidem, s. 27.

${ }^{97}$ B. Pietrzak, Z. Polański, B. Woźni ak, op. cit., s. 209.

${ }^{98}$ Zasoby oficjalnej witryny internetowej Stowarzyszenia ACI POLSKA (Stowarzyszenie Rynków Finansowych ACI POLSKA): http://www.acipolska.pl/polonia.html [10.10.2010].

${ }^{99}$ Instrumenty Polityki Pieniężnej Narodowego Banku Polskiego w 2008 r...., op. cit., s. 25.

${ }^{100}$ O. S z z ze pań ska, Operacje otwartego rynku jako element systemu operacyjnego EBC i banków centralnych w krajach kandydujących do Unii Europejskiej, „Bank i Kredyt” 2002, nr 4, s. 10.
} 
stopą referencyjną dla jednodniowych, międzybankowych operacji depozytowych. Obliczana jest po uwzględnieniu wszystkich dziennych stóp procentowych i faktycznych dziennych obrotów na rynku pieniężnym, jako średnia ważona kwotami transakcji ${ }^{101}$. EBC nie wyznacza bezpośrednio konkretnej stopy rynku międzybankowego, a jedynie określa, że ta krótkoterminowa stopa overnight powinna oscylować wokół oficjalnej stopy operacji typu repo ${ }^{102}$. EONIA pełni istotną rolę, ponieważ sygnalizuje o sytuacji na rynku pieniężnym.

\subsection{Czynniki wpływające na wysokość stóp procentowych banku centralnego}

W celu zrozumienia decyzji podejmowanych przez bank centralny warto przyjrzeć się czynnikom wpływającym na stopy procentowe w gospodarce. Ocena skutków polityki stóp procentowych nie jest łatwym zadaniem, głównie z powodu występowania wielu zmieniających się czynników, zarówno zagranicznych jak i krajowych, na które bardzo często bank centralny nie ma większego wpływu. W Polsce po 1998 r. nastąpiło wiele zmian systemowych w gospodarce, pojawiły się niesprzyjające warunki przebiegu cyklu koniunkturalnego, a na świecie występowały kryzysy finansowe, które zagrażały polskiemu systemowi finansowemu. Podobne czynniki gospodarcze miały swoje odzwierciedlenie w kształtowaniu się polityki stóp procentowych zarówno w Polsce, jak i w strefie euro. Szczególnie należy podkreślić, że istotny wpływ na zmiany polityki stóp procentowych ma sytuacja w sektorze finansów publicznych oraz wielkość deficytu budżetowego ${ }^{103}$. Na skuteczność polityki pieniężnej oddziałuje wiele zmiennych, chociażby mechanizm koordynacji polityki monetarnej z innymi częściami polityki ekonomicznej, a także integracja rynków finansowych, jako element otoczenia zewnętrznego ${ }^{104}$. W literaturze przedmiotu można wyróżnić następujące czynniki oddziałujące na politykę stóp procentowych banku centralnego: polityka fiskalna, nadpłynność sektora bankowego, inflacja, kurs walutowy i inne.

${ }^{101}$ U. Hassler, D. Naucz, On the Persistence of the Eonia Spread, Goethe University, Frankfurt 2007, s. 1-2.

${ }^{102}$ O. S z c ze pańs k a, Operacje..., op. cit., s. 10.

${ }^{103}$ W. Pr zy by lska-Ka pu ścińs ka, Polityka stóp procentowych $w$ Polsce i makroekonomiczne skutki, [w:] P. K a r p uś, J. W ę c ł a w s k i (red.), Problemy rozwoju rynku finansowego w aspekcie wzrostu gospodarczego, Wydawnictwo Uniwersytetu Marii Curie-Skłodowskiej, Lublin 2007, s. 50.

${ }^{104}$ A. Wojtyna, Kontrowersje wokót skuteczności polityki pieniężnej, „Bank i Kredyt” 2000, nr 7-8, s. 127. 


\subsubsection{Wpływ polityki fiskalnej na decyzje banku centralnego}

Polityka fiskalna oraz polityka pieniężna mają istotne znaczenie w gospodarce, wpływając równocześnie na siebie. Po drugiej wojnie światowej wprowadzono nawet do literatury ekonomii pojęcie policy mix, jako kombinację polityki fiskalnej i pieniężnej. K. Kuttner poddając te interakcje pieniężno-fiskalne głębszej analizie, wyodrębnił trzy główne ich obszary, tj. ${ }^{105}$ : interakcje, które odnoszą się do struktury finalnej popytu i produkcji; interakcje oparte na międzyokresowych ograniczeniach budżetowych oraz interakcje strategiczne spowodowane różnymi celami i preferencjami niezależnych władz odpowiedzialnych za prowadzenie polityki pieniężnej i fiskalnej.

Biorąc pod uwagę kwestię stabilnego poziomu cen, szczególne znaczenie mają dwa pierwsze obszary interakcji fiskalno-monetarnych, czyli te związane ze strukturą popytu i podaży oraz ograniczeniami budżetowymi. T. J. Sargent i N. Wallace sformułowali „teorię nieprzyjemnej arytmetyki monetarystycznej” (unpleasant monetarist arithmetic), opartej na poglądzie, że w momencie występowania dominacji fiskalnej, władze monetarne nie są już w stanie utrzymać inflacji pod kontrolą, niezależnie od strategii, jaką stosują. Z kolei w przypadku interakcji związanych $\mathrm{z}$ międzyokresowymi ograniczeniami budżetowymi (intertemporal budget constraint) uważano, że formą finansowania deficytu budżetowego może być zarówno emisja pieniądza, obligacji lub kombinacja ich obu. Sądzono, że emisja obligacji nie prowadzi do wzrostu poziomu cen, co nie jest prawdą, ponieważ w momencie uwzględnienia racjonalnych oczekiwań okazuje się, że emisja obligacji może mieć również następstwa inflacyjne. Stąd wniosek, że polityka fiskalna ogranicza podejmowanie decyzji przez bank centralny i w związku z tym utrudnia stabilizowanie poziomu cen. Różnica celów lub preferencji banku centralnego i władz fiskalnych utrudnia stabilizację gospodarki w krótkim okresie. Obie władze wyznaczają cele swojej polityki oraz preferencje, które odzwierciedlają ich dążenia. Poszczególnym celom przyporządkowywane są wagi, które są formalnym wyrazem preferencji rządu i banku centralnego. Uzgodnienie działań jest właściwym wyborem dla obu władz. Konflikt obu polityk prowadzi do wzrostu stopy procentowej i deficytu budżetowego. Harmonizacja obu polityk niweluje źródła konfliktów, prowadzi do minimalizacji kosztów utrzymania stabilnego poziomu cen oraz łagodzi krytykę rządu związaną z działaniem banku centralnego. Koordynacja polityki pieniężnej oraz polityki fiskalnej przyczynia się do większej stabilności systemu finansowego ${ }^{106}$. W modelu prowadzenia polityki pieniężnej wprowadzonym w 1999 r. w Pol-

${ }^{105}$ K. N. Kuttne r, The Monetary - Fiscal Policy Mix: perspectives from the U. S., „Bank i Kredyt" 2002, nr 11-12, s. 208-209.

${ }^{106} \mathrm{Z}$. Kn aki e wicz (red.), op. cit., s. 111-112. 
sce $^{107}$, polityka fiskalna ma pełnić rolę wzmacniającą wiarygodność strategii deziflacyjnej, szczególnie poprzez przestrzeganie zbieżności polityki fiskalnej $\mathrm{z}$ celem inflacyjnym realizowanym przez bank centralny ${ }^{108}$.

Współzależności pomiędzy polityką pieniężną a fiskalną zaczęto badać dokładnej skupiając się na skutkach potencjalnych konfliktów między nimi, jak i na korzyściach z koordynacji działań decydentów odpowiedzialnych za politykę gospodarczą. Opracowano wiele modeli opartych na teorii gier, która posłużyła do badania interakcji monetarno-fiskalnych oraz do zaprezentowania implikacji, które powstają w wyniku wykorzystania gier dla projektowania i realizacji polityki gospodarczej. Pomimo wielu przeciwników stosowania teorii gier w kontekście koordynacji policy mix, to jednak modele te bardzo wyraźnie uwidaczniają problemy powstające wskutek konfliktu banku centralnego i rządu. Jak wskazali T. Sargent oraz N. Wallace, niezdyscyplinowanie polityki fiskalnej oddziałuje na presję zaostrzenia polityki monetarnej, co może pogorszyć sytuację na rynku. Z kolei zbyt restrykcyjna polityka pieniężna banku centralnego może przyczynić się do podniesienia kosztów dezinflacji i zwiększenia obciążenia prowadzenia polityki fiskalnej. Wśród przesłanek, które można odczytać z modeli opartych na teorii gier wynika, że koordynacja polityk przyniosłaby korzyści obu decydentom ${ }^{109}$. W celu przybliżenia znaczenia współpracy pomiędzy władzami monetarnymi a fiskalnymi, przedstawiony zostanie przykład prostej gry macierzowej, tzw. dylemat więźnia. Jest to gra o sumie niezerowej, posiadająca tzw. równowagę Nasha.

Polega ona na tym, że żaden z graczy nie zamierza rezygnować ze swojej strategii, dążąc do maksymalizacji korzyści, przy jednoczesnym oczekiwaniu decyzji współgracza. Jest to pewnego rodzaju impas, ponieważ w równowadze Nasha $^{110}$ żaden $\mathrm{z}$ uczestników gry nie jest w stanie jednostronnie poprawić swojej sytuacji, gdyż każdy gracz uważa, że jego strategia jest dla niego optymalna (znana dla wszystkich graczy) ${ }^{111}$. Strategia luźnej polityki fiskalnej jest najbar-

${ }^{107}$ Uchwała Rady Polityki Pieniężnej z dnia 29 września 1998 r. w sprawie założeń polityki pieniężnej na 1999 r., Monitor Polski z 1998 r., nr 36, poz. 501.

${ }^{108}$ D. Gotz-Kozierki ewicz, Polityka pieniężna a polityka fiskalna, „Bank i Kredyt”, lipiec-sierpień 2000, s. 38.

${ }^{109}$ P. Marszałek, Zastosowanie teorii gier do badania koordynacji polityki pieniężnej i polityki fiskalnej, [w:] W. Przy bylska-Ka puścińs ka (red.), Studia z bankowości central$n e j$, ,Zeszyty Naukowe Akademii Ekonomicznej w Poznaniu” 2005, nr 56, s. 223.

${ }^{110}$ Gra często wykorzystywana do badania interakcji monetarno-fiskalnych nazywa się grą Nasha, inną równie popularną jest gra Stackelberga. Są to gry dwuosobowe o sumie niezerowej, niekooperacyjne. Wykorzystana w tej pracy gra Nasha cechuje się jednakowym statusem graczy, którzy wybierają strategię jednocześnie traktując strategię współuczestnika jako daną. W grze monetarno-fiskalnej może wystąpić więcej niż jedna równowaga Nasha i wtedy pojawia się problem, którą z nich wybrać.

${ }^{111}$ H. B e n nett, N. Lo a y za, Policy biases when the monetary and fiscal authorities have different objectives, „Central Bank of Chile Working Papers” 2001, no. 66, s. 301. 
dziej preferowaną przez rząd, a twarda polityka monetarna przez bank centralny. Bank centralny otrzymuje następujące wypłaty za odpowiednio osiągniętą inflację: niską (6), średnią (4), wysoką (1), natomiast władze fiskalne dostawały za inflację niską (3), średnią (2), a wysoką (1). Z kolei bank centralny otrzymywał następujące wypłaty za poziom zatrudnienia: niski (1), średni (2), wysoki (3), a władze fiskalne dostawały za zatrudnienie niskie (1), średnie (4), wysokie (6) ${ }^{112}$.

\begin{tabular}{|c|c|c|}
\hline & $\begin{array}{c}\text { Twarda polityka monetarna } \\
\text { banku centralnego }\end{array}$ & $\begin{array}{l}\text { Luźna polityka monetarna } \\
\text { banku centralnego }\end{array}$ \\
\hline $\begin{array}{c}\text { Twarda } \\
\text { polityka } \\
\text { fiskalna rządu }\end{array}$ & $\begin{array}{ll}\text { Wynik: } & \begin{array}{l}\text { niska inflacja } \\
\text { i niskie zatrudnienie }\end{array} \\
\text { Wypłata: } & \text { bank centralny: } 6+1=7 \\
& \text { władze fiskalne: } 3+1=4\end{array}$ & $\begin{array}{ll}\text { Wynik: } & \begin{array}{l}\text { średnia inflacja } \\
\text { i średnie zatrudnienie }\end{array} \\
\text { Wypłata: } & \begin{array}{l}\text { bank centralny: } 4+2=6 \\
\text { władze fiskalne: } 2+4=6\end{array}\end{array}$ \\
\hline $\begin{array}{c}\text { Luźna } \\
\text { polityka } \\
\text { fiskalna rządu }\end{array}$ & $\begin{array}{ll}\text { Wynik: } & \begin{array}{l}\text { średnia inflacja } \\
\text { i średnie zatrudnienie }\end{array} \\
\text { Wypłata: } & \begin{array}{l}\text { bank centralny: } 4+2=6 \\
\text { władze fiskalne: } 2+4=6\end{array}\end{array}$ & $\begin{array}{ll}\text { Wynik: } & \begin{array}{l}\text { wysoka inflacja } \\
\text { i wysokie zatrudnienie }\end{array} \\
\text { Wypłata: } & \begin{array}{l}\text { bank centralny: } 1+3=4 \\
\text { władze fiskalne: } 1+6=7\end{array}\end{array}$ \\
\hline
\end{tabular}

Rys. 3.7. Macierz gry monetarno-fiskalnej (dylemat więźnia)

Źr ódło: opracowanie na podstawie: H. B ennett, N. Loay za, Policy biases when the monetary and fiscal authorities have different objectives, „Central Bank of Chile Working Papers” 2001, vol. 66, s. 301.

Jeśli bank wybierze ekspansywną politykę, to rząd zrobiłby to samo, a bank centralny otrzymałby najniższą z not. Dlatego bank przewidując strategię rządu wybiera politykę twardą. W tej sytuacji władze fiskalne, by postawić się w korzystniejszej sytuacji zdecydują się na politykę luźną. Wybory te nie są optymalne, a władze preferowałyby inne pola. Zatem powyższa macierz obrazuje problem braku komunikacji i współpracy władz fiskalnych i monetarnych, który wynika z ich odmiennych preferencji gospodarczych ${ }^{113}$.

\footnotetext{
112 Ibidem, s. 301.

${ }^{113}$ P. Mars załe k, op. cit., s. 223-234.
} 


\subsubsection{Nadpłynność sektora bankowego jako czynnik utrudniający prowadzenie polityki pieniężnej}

Zdecydowanie największą trudność w prowadzeniu polityki pieniężnej w Polsce sprawia nadpłynność sektora bankowego ${ }^{114}$. Wyróżnia się strukturalną nadpłynność, czyli długookresowe zadłużenie netto banku centralnego w bankach komercyjnych, oraz operacyjną nadpłynność sektora bankowego. Ta ostatnia oznacza, że bank centralny pozostaje dłużnikiem netto banków z tytułu operacji krótkoterminowych. W związku z tym, bank centralny musi rolować absorbujące płynność operacje otwartego rynku w następujących po sobie okresach utrzymywania rezerwy obowiązkowej ${ }^{115}$. To właśnie nadpłynność w sektorze bankowym jest jedną z głównych przyczyn inflacji, ponieważ ułatwia bankom komercyjnym kreację pieniądza poprzez dodatkową akcję kredytową. W szerokim ujęciu pojęcie płynności ogólnogospodarczej określa się jako wskaźnik płynności banków komercyjnych, gdyż to właśnie one mają wpływ na obieg pieniądza $\mathrm{w}$ gospodarce, umożliwiając płynność finansową podmiotom gospodarczym. Z kolei przez płynność banku należy rozumieć jego zdolność do wywiązywania się z bieżących zobowiązań, możliwość udzielania kredytów oraz poziom posiadanych przez banki rezerw. Najczęściej w definicji nadpłynności banków przyjmuje się stan rezerw posiadanych przez dany bank, którego głównym zadaniem jest pośrednictwo w przepływie środków pieniężnych. Do rezerw banków zalicza się: pieniądz gotówkowy, środki wykorzystywane do rozrachunków międzybankowych plus środki utrzymywane jako rezerwa obowiązkowa ${ }^{116}$.

Istnieje wiele czynników, które wpływają na zmniejszenie płynności w sektorze bankowym, są to przede wszystkim ${ }^{117}$ : przyrost pieniądza gotówkowego w obiegu; zwiększenie rezerwy obowiązkowej banków; wykorzystanie depozytu na koniec dnia; spłata kredytu refinansowego; operacje swap walutowy; niższe wykorzystanie kredytu lombardowego. Z kolei do przyczyn zwiększających płynność sektora bankowego zaliczamy ${ }^{118}$ : operacje zasilające repo; spadek depozytów złotowych sektora publicznego; wpłata zysku banku centralnego do budżetu państwa; wypłata dyskonta bonów pieniężnych banku centralnego; wypłata odsetek od rezerwy obowiązkowej; wypłata odsetek od obligacji; skup walut netto przez bank centralny; pozostałe pozycje netto (np. wypłaty z odsetek

${ }^{114}$ W. Przybylska-Kapuścińs ka, Operacje otwartego rynku $w$ absorpcji nadptynności, [w:] W. Pr z y bylska-Ka pu ściń ska (red.), Studia z bankowości centralnej, Wydawnictwo Akademii Ekonomicznej w Poznaniu, Poznań 2005, s. 105.

${ }^{115}$ R. Ko ko s zc zyń ski, Wspótczesna..., op. cit., s. 134.

${ }_{116} \mathrm{Z}$. Fe do row i c z, Stopa procentowa w polityce banku centralnego, [w:] J. Głu c how s ki, I. Ohl (red.), Bankowe i pozabankowe źródta finansowania gospodarki, Konferencja Katedr Finansów - Ciechocinek 1995, Wydawnictwo Uniwersytetu M. Kopernika, Toruń 1997, s. 64.

${ }^{117}$ Instrumenty polityki pieniężnej Narodowego Banku Polskiego w 2008 roku..., op. cit., s. 11.

${ }^{118}$ Ibidem, s. 11. 
lokat terminowych Ministerstwa Finansów w NBP lub zmniejszenie środków na rachunkach ZUS).

Nadpłynność sektora bankowego utrudnia bankowi centralnemu normalne oddziaływanie na gospodarkę poprzez wykorzystanie kredytu refinansowego ${ }^{119}$. W warunkach braku płynności banków komercyjnych to bank centralny jest główną instytucją uzyskania dodatkowych rezerw wykorzystującą kredyty refinansowe jako źródło kredytów dla banków. Sytuacja wygląda zupełnie inaczej w momencie nadpłynności w systemie bankowym. Wtedy banki komercyjne nie potrzebują dodatkowej płynności i nie korzystają z kredytów refinansowych banku centralnego. Jedynie oprocentowanie operacji otwartego rynku ma znaczenie dla decyzji banków komercyjnych związanych z alternatywnym zyskiem w stosunku do kredytów. Gdy rośnie rentowność papierów wartościowych emitowanych przez NBP, co związane jest również ze zmianą stopy referencyjnej, banki podnoszą oprocentowanie kredytów lub kosztem ograniczenia akcji kredytowej, zwiększają inwestycje w papiery wartościowe. Najczęściej w przypadku obniżania rentowności papierów wartościowych NBP, banki komercyjne obniżają oprocentowanie depozytów tak, by marża pomiędzy stopą referencyjną i oprocentowaniem depozytów nie zmieniła się znacząco. Natomiast podaż kredytów ulegnie zwiększeniu w momencie niższej rentowności papierów wartościowych banku centralnego ${ }^{120}$.

Zatem podniesienie stóp procentowych ma dychotomiczny wpływ na nadpłynność sektora bankowego. W pierwszej kolejności wyższe stopy procentowe wpłyną na wzrost oprocentowania depozytów i kredytów w bankach komercyjnych. Wyższe oprocentowanie depozytów oznacza większy popyt na tę formę oszczędzania, natomiast wzrost oprocentowania kredytów ogranicza popyt na kredyty. Oba zjawiska prowadzą do wzrostu wolnych rezerw banków komercyjnych, gdyż oznaczają więcej środków z depozytów i ograniczenie ich wykorzystania podczas akcji kredytowej. Wyższy poziom rezerw banków komercyjnych to nadpłynność sektora bankowego. Z drugiej strony podniesienie oprocentowania operacji otwartego rynku zwiększa rentowność papierów wartościowych emitowanych przez NBP i zachęca banki komercyjne do kupna tych papierów ${ }^{121}$.

Dla banków komercyjnych inwestycja w akcję kredytową jest mniej bezpieczna niż w papiery wartościowe. Banki kupując papiery wartościowe osiągają również zysk, a dodatkowo ograniczają ryzyko bankowe, rezygnując w to miejsce z kredytów. Papiery wartościowe pomagają w utrzymaniu płynności banku, gdyż są aktywami najłatwiejszymi do sprzedania. Są korzystniejsze dla banków, które muszą utrzymywać określony współczynnik wypłacalności. Papiery war-

${ }^{119}$ W. Prz y b y 1 s k a - Ka pu śc ińs ka, Operacje...,op. cit., s. 105-107.

${ }^{120}$ Z. Fe d o r o w i c z, Polityka pieniężna, Poltext, Warszawa 1993, s. 64.

${ }^{121}$ M. Jaremko, M. Wi śniewski, Wptyw polityki stóp procentowych na nadptynność sektora bankowego $w$ Polsce, [w:] W. Pr zy b y l s k a - K a p u śc iń s k a (red.), Polityka pieniężna i rynek, „Zeszyty naukowe Akademii Ekonomicznej w Poznaniu” 2003, nr 26, s. 49-51. 
tościowe umożliwiają bankom aktywne zrządzanie portfelem aktywów ${ }^{122}$. W przypadku, gdy bank centralny obniży oprocentowanie operacji otwartego rynku, bankom nie będzie się opłacało inwestować w papiery wartościowe. Spadnie oprocentowanie depozytów i kredytów, zmniejszy się skłonność do oszczędzania ludności oraz wzrośnie popyt na kredyty, co przyczyni się do zmniejszenia nadpłynności banków komercyjnych ${ }^{123}$. W przypadku braku płynności bank centralny ma większy wpływ na decyzje banków komercyjnych, ponieważ muszą się one liczyć z ceną pieniądza wyznaczoną przez władze monetarne $^{124}$. Natomiast $\mathrm{w}$ warunkach nadpłynności w systemie bankowym impuls monetarny banku centralnego poprzez tradycyjny kanał stóp procentowych do banków komercyjnych jest utrudniony.

Czynnikiem, który najczęściej prowadzi do zakłócenia poziomu płynności sektora bankowego jest kryzys finansowy. Taka sytuacja miała miejsce w Polsce, gdzie kryzys na światowych rynkach finansowych widoczny już pod koniec 2007 r., a pogłębiony w 2008 r. spowodował spadek płynności sektora bankowego w Polsce. I tak, w 2008 r. krótkoterminowa płynność sektora bankowego ${ }^{125}$ wyniosła 10,96 mld zł w porównaniu do 19,81 mld zł w roku 2007 (nastąpiło więc obniżenie nadpłynności w ujęciu średniorocznym o $8,85 \mathrm{mld} \mathrm{zl})^{126}$. W związku z tym wprowadzono w październiku 2008 r. tzw. „Pakiet zaufania" ${ }^{\text {, }}$, na podstawie, którego bank centralny przeprowadzał operacje repo zasilające w płynność sektor bankowy oraz umożliwił bankom komercyjnym pozyskiwanie środków walutowych poprzez transakcje typu swap walutowy. W rezultacie poziom krótkoterminowej płynności sektora bankowego w 2009 r. wynosił 23,94 mld zł, czyli był o 12,97 mld zł wyższy w porównaniu do roku poprzedniego ${ }^{128}$.

\subsubsection{Wpływ inflacji na decyzje banku centralnego}

Bank centralny dbając o stabilność cen w gospodarce, w swoich badaniach i prognozach zwraca szczególną uwagę na istotny parametr oddziałujący na stopy procentowe, a mianowicie - poziom inflacji. Inflacja to stan stałego wzro-

${ }^{122}$ B. La ch i e w i c z, Stopa procentowa NBP a stopy procentowe w bankach komercyjnych, [w:] J. L. B ednarczyk (red.), Stopy procentowe a gospodarka. Dylematy Unii Gospodarczej $i$ Walutowej, Wydawnictwo Politechniki Radomskiej, Radom 2006, s.194.

${ }^{123}$ M. J a r e m k o, M. W iśn i e w s ki, op. cit., s. 49-51.

${ }^{124}$ W. W ą s o w s ki, op. cit., s. 27.

${ }^{125}$ Krótkoterminowa płynność sektora bankowego - liczona jako saldo operacji podstawowych, operacji typu repo, operacji typu swap walutowy oraz operacji depozytowo-kredytowych.

${ }^{126}$ Instrumenty polityki pieniężnej Narodowego Banku Polskiego w 2008 roku..., op. cit., s. 6-8.

${ }^{127}$ Pakiet zaufania NBP opisany został szerzej w dalszej części pracy, w rozdziale 5.

${ }^{128}$ Raport roczny Ptynność sektora bankowego. Instrumenty polityki pieniężnej NBP, Narodowy Bank Polski, Warszawa 2009, s. 6-14. 
stu poziomu cen w danej gospodarce ${ }^{129}$. Inflacja jest procesem, który oznacza, że wzrost cen występuje przez pewien okres w sposób względnie stały. Skokowy wzrost cen, po którym następuje stabilizacja cenowa nie jest inflacją ${ }^{130}$. Zatem inflacja, jak pisze E. Kwiatkowski, to proces wzrostu ogólnego poziomu cen ${ }^{131}$. G. Kołodko rozszerza definicję inflacji podając, że ,inflacja to proces wzrostu ogólnego poziomu cen lub presja na ten wzrost" ${ }^{\prime 32}$. W inny sposób definicję inflacji ujął A. Hagger, piszac, że inflacja to stan, w którym pojawia się nadwyżka globalna popytu na dobra ${ }^{133}$. Zjawisko inflacji ma istotne znaczenie z punktu widzenia polityki pieniężnej banku centralnego, ponieważ kształtuje wiele procesów, które są ważne dla całej gospodarki ${ }^{134}$. Zarówno poziom inflacji wpływa na kierunek polityki banku centralnego, jak i polityka monetarna oddziałuje na inflację $e^{135}$. Oto kilka przykładów negatywnych skutków inflacji w gospodarce ${ }^{136}$ :

- wysoki poziom inflacji prowadzi do niejednakowego wzrostu cen, co utrudnia kalkulację producentom i konsumentom, ceny przestają dla uczestników rynku pełnić funkcję informacyjną,

- w związku z zakłóceniami informacyjnymi podmioty gospodarcze dokonują nieracjonalnych decyzji, mających negatywne skutki w przyszłości, dodatkowo występują błędy w alokacji zasobów,

- wzrost poziomu inflacji jest trudny do przewidzenia, więc inwestorzy podejmują się tylko krótkookresowych inwestycji, co w konsekwencji zmniejsza udział inwestycji w PKB i rośnie bezrobocie,

- maleje poziom oszczędności podmiotów gospodarczych na skutek niepewności lokowania pieniędzy, gdy towary i usługi z dnia na dzień są coraz droższe, a pieniądze tracą na wartości,

- jednostki gospodarcze postępują według tzw. oczekiwań inflacyjnych, które przyczyniają się do utrwalania inflacji, ponieważ w kalkulacjach uwzględ-

${ }^{129}$ F. S. M is h ki in, Ekonomika..., op. cit., s. 815.

${ }^{130}$ Istnieją następujące klasyfikacje inflacji: inflacja pełzająca (gdzie roczna stopa inflacji znajduje się w przedziale (0-5\%), inflacja umiarkowana (5-10\%), inflacja galopująca (10-150\%), hiperinflacja (powyżej 150\%) [za:] P. B a r a n o w s ki, Problem optymalnej stopy inflacji w modelowaniu wzrostu gospodarczego, Wydawnictwo Biblioteka, Łódź 2008, s. 13.

${ }^{131}$ R. Mile w ski (red.), op. cit., s. 558.

${ }^{132}$ P. B ar a now s ki, Problem..., op. cit., s. 13.

${ }^{133}$ Ibidem, s. 13.

${ }^{134} \mathrm{~W}$ gospodarce światowej silne zjawiska inflacyjne występowały od początku lat 70 . XX w., czego przykładem jest fakt, że wiele krajów OECD notowało w latach 70. i w pierwszej połowie lat 80. średnią inflację odpowiednio na poziomie $10,2 \%$ oraz $9,2 \%$, w drugiej połowie lat 80 . spadła ona do poziomu $5,1 \%$, a w latach 90 . wynosiła już tylko $2,8 \%$.

${ }^{135}$ C. Alt avilla, M. Cicc a relli, Inflation Forecasts, Monetary Policy and Unemployment Dynamics. Evidence from US and the Euro Area, ,Working Paper Series” European Central Bank 2007, no. 725, s. 7.

${ }^{136}$ T. Gruszecki, op. cit., s. 172-173. 
nia się poziom inflacji z przeszłości do wyznaczania cen w przyszłości, np. pracownicy domagają się indeksacji płac o wskaźnik inflacji,

- inflacja przyczynia się do zwiększenia ciężarów podatkowych, ponieważ rząd na podstawie oczekiwań inflacyjnych włącza przewidywaną stopę inflacji do obciążeń podatkowych, sam w związku ze wzrostem cen ponosi większe wydatki budżetowe, następnie zwiększa obciążenia podatkowe i tak pojawia się spirala opodatkowania podmiotów.

E. Kwiatkowski podkreśla, że wysoka inflacja potęguje zjawisko „ucieczki od pieniądza", która polega na gwałtownym spadku popytu na pieniądz w ujęciu realnym, czyli w celu minimalizacji ponoszonych strat korzystniej jest utrzymywać aktywa chociażby w formie lokat oszczędnościowych niż w gotówce. Ponadto inflacja może wywołać niekorzystne zmiany w bilansie płatniczym. Przejawia się to w mniejszej konkurencyjności dóbr eksportowanych z krajów o wyższej inflacji do tych o niższym wskaźniku inflacji. Prowadzi to do spadku eksportu i wzrostu importu, co w rezultacie wpływa na pogorszenie bilansu płatniczego państwa o wyższej stopie inflacji ${ }^{137}$. Ogólnie silne procesy inflacyjne zwiększają niepewność w zakresie prognoz zmian cen, co w rezultacie przyczynia się do osłabienia działalności inwestycyjnej i hamowania tempa wzrostu gospodarczego $^{138}$.

Wzrost cen w gospodarce generuje dodatkowe koszty związane $\mathrm{z}$ obsługą procesów gospodarczych, takich jak np. drukowanie nowych kart w restauracjach, cenników w sklepach, czy przestawianie liczników na parkingach (menu costs). W skali całej gospodarki takie koszty spowodowane inflacją absorbują znaczne zasoby, które zmniejszają poziom dochodu narodowego. Istotną kwestią w przypadku określania skutków inflacji jest fakt, czy jest to zjawisko antycypowane przez podmioty gospodarcze, czy całkowicie niespodziewane. Inflacja antycypowana, którą jednostki przewidują jest łagodniejsza w negatywnych skutkach dla gospodarki od inflacji niespodziewanej ${ }^{139}$.

W pracach J. Galbraitha można znaleźć trzy zasady polityki pieniężnej zebrane przez B. Bernanke, dotyczące walki władz monetarnych ze zjawiskiem inflacji w aspekcie współczesnych zmian ekonomiczno-gospodarczych. Pierwsza z zasad traktuje o tym, że polityka pieniężna jest w stanie sama zredukować niepożądany poziom inflacji kosztem produkcji i zatrudnienia. Druga zasada wiąże się ze zdecydowanie niezależnym bankiem centralnym, który może zdobyć wiarygodność podmiotów gospodarczych, utrzymując niski poziom inflacji bez instytucjonalnej pomocy rządu. Trzecia zasada dotyczy stosowania odpowiednio restrykcyjnego kursu polityki pieniężnej poprzez utrzymywanie wymie-

${ }^{137}$ R. Mile w ski (red.), op. cit., s. 563-565.

${ }^{138}$ P. B ł a s z z y k, Stabilność cen - sposoby definicji oraz wyzwania dla polityki pieniężnej, „Materiały i Studia” 2010, z. 249, s. 11-19.

${ }^{139}$ Ibidem, s. 566. 
rzonego poziomu stóp procentowych, który redukując oczekiwania inflacyjne może zahamować inflację bez recesji w gospodarce. Zatem powyższe zasady potwierdzają słuszność wykorzystywania strategii celu inflacyjnego, ponieważ polityka, która nakierowana jest na inflację, ma istotny wkład w stabilizowanie produkcji i zatrudnienia $^{140}$. Na zakończenie warto przytoczyć zdanie A. Greenspana na temat stabilności cen wypowiedziane w 1989 r., który stwierdził, że ,ze stabilnością cen mamy do czynienia, kiedy inflacja nie jest brana pod uwagę w decyzjach gospodarstw domowych i przedsiębiorstw" ${ }^{141}$. Oznacza to, że niski poziom inflacji nie jest brany pod uwagę przy podejmowaniu decyzji przez uczestników rynku.

\subsection{Stopy procentowe a kurs walutowy}

W krótkim i średnim okresie istotnymi czynnikami wpływającymi na kurs walutowy są miedzy innymi: zmiany stóp procentowych, poziom inflacji, stosowana polityka monetarna i fiskalna, krótkoterminowe zmiany w bilansie płatniczym oraz zmiany w koniunkturze gospodarczej, jak również spekulacja, ryzyko, jak i wydarzenia polityczne. Z kolei w długim okresie kurs walutowy kształtowany jest głównie przez czynniki o charakterze strukturalnym i instytucjonalnym. Teoria parytetu stóp procentowych wyjaśnia między innymi zmienność kursu walutowego w krótkim i średnim okresie ${ }^{142}$. Zgodnie z teorią parytetu stóp procentowych realna stopa procentowa $\mathrm{w}$ skali międzynarodowej nie zmienia się. Oznacza to, że dochód otrzymany z jednostki pieniądza jest taki sam, bez względu na to, w jakim kraju i walucie inwestuje się dany pieniądz. Stąd wynika, że zależność pomiędzy realnym kursem waluty danego kraju a stopą procentową tego kraju, jest proporcjonalna ${ }^{143}$.

Istota parytetu stóp procentowych opiera się na zależności pomiędzy różnicą stóp procentowych w kraju i za granicą a oczekiwaną zmianą kursu waluty danego kraju. Stąd wynika, że jeśli w określonym kraju występują wysokie stopy procentowe to muszą one ulec w przyszłości wyrównaniu poprzez deprecjację waluty tego kraju. Inaczej, jeśli w danym kraju stopy procentowe są niskie, wtedy będą musiały być wyrównane przez aprecjację danej waluty ${ }^{144}$. W celu

${ }^{140}$ J. K. Galbraith, op. cit., s. 6.

${ }^{141}$ P. B ła s zczy k, op. cit., s. 11.

${ }^{142} \mathrm{~S}$. B u kow s ki, Stopy procentowe a ksztattowanie się kursu walutowego euro w latach 1999-2004, [w:] J. L. Bednarczyk (red.), Stopy procentowe a gospodarka. Eseje z teorii i polityki stóp procentowych, Wydawnictwo Politechniki Radomskiej, Radom 2004, s. 163-164.

${ }^{143} \mathrm{P}$. M is ztal, Teoria parytetu stóp procentowych a ksztattowanie się kursu złotego $w$ latach 1995-2002, [w:] J. L. B e d n ar c z y k (red.), Stopy procentowe a gospodarka. Eseje z teorii i polityki stóp procentowych, Wydawnictwo Politechniki Radomskiej, Radom 2004, s. 172.

${ }^{144}$ Ibidem, s. 172-173. 
szerszego wyjaśnienia zależności kursu walutowego i stóp procentowych, można jeszcze przybliżyć koncepcję tzw. efektu I. Fishera, opartą na teorii racjonalnych oczekiwań. Zgodnie z tym twierdzeniem, przy określonej realnej stopie procentowej, różnica między nominalną stopą procentową w danym kraju a nominalną stopą procentową za granicą jest tym większa, im istnieje większa różnica pomiędzy krajową stopą inflacji a stopą inflacji za granicą ${ }^{145}$. Zgodnie z efektem Fishera, jeśli wzrośnie inflacja w danym kraju to nastąpi wzrost nominalnych stóp procentowych i kursu walutowego. Jak wynika z powyższych rozważań, zmianę kursu walutowego determinuje zmiana relacji między krajową i zagraniczną stopą procentową. Tak też, odchylenie się w górę od parytetu krajowej stopy procentowej przyczyni się do napływu kapitału z zagranicy, aprecjacji waluty krajowej oraz deprecjacji waluty zagranicznej ${ }^{146}$.

Zmiany kursu walutowego oraz stóp procentowych mają zastosowanie również $\mathrm{w}$ analizach stopnia restrykcyjności polityki pieniężnej przy wykorzystaniu indeksu MCI (Monetary Condition Index) ${ }^{147}$. Indeksem tym szczególnie zainteresowane są banki centralne, które stosują strategię bezpośredniego celu inflacyjnego. Poniżej przedstawiono równanie opisujące prezentowany indeks ${ }^{148}$.

Wzór 3.4. Indeks MCI

$$
M C I_{t}=\alpha_{1}\left(r_{t}-r_{0}\right)+\alpha_{2}\left(q_{t}-q_{0}\right)
$$

gdzie:

$r_{t} \quad$ - realna stopa procentowa w okresie $t$,

$r_{0} \quad$ - realna stopa procentowa w okresie bazowym,

$q_{t} \quad$ - logarytm realnego kursu walutowego w okresie $t$,

$q_{0} \quad$ - logarytm realnego kursu walutowego w okresie bazowym.

Indeks MCI oparty jest na średniej ważonej zmian realnego kursu walutowego i zmian stopy procentowej w odniesieniu do okresu bazowego. Wykorzystując indeks restrykcyjności polityki pieniężnej w postaci przedstawionej w równaniu można wnioskować, że polityka pieniężna ma istotny wpływ na gospodarkę poprzez kanał stopy procentowej i kursu walutowego. W praktyce stosuje się również wskaźnik $M C I$ - ratio, który informuje o ile procent zmieni

${ }^{145}$ S. B u kow sk i, op. cit., s. 164-166.

${ }^{146}$ Ibidem, s. 164-166.

${ }^{147}$ MCI zaczął być stosowany w praktyce od drugiej połowy lat 80 . XX w.

${ }^{148}$ L. K u c har s ki, Polityka pieniężna a wzrost gospodarczy i bezrobocie $w$ Polsce $w$ latach 1998-2009, [w:] J. L. Bednarczyk (red.), Finansowe determinanty wzrostu $w$ gospodarce globalnej, Wydawnictwo Fachowe CeDeWu, Warszawa 2010, s. 237-239. 
się realny kurs walutowy w efekcie zmiany realnej stopy procentowej o 1 punkt procentowy $^{149}$.

Wzór 3.5. Wskaźnik $M C I$ - ratio

$$
M C I-\text { ratio }=\frac{\alpha_{1}}{\alpha_{2}}
$$

Wartość parametrów $\alpha_{1}$ oraz $\alpha_{2}$ szacowana jest na bazie modeli makroekonomicznych, strukturalnych, modeli $\mathrm{VAR}^{150}$, krzywej IS lub krzywej Philipsa. Im wyższy wskaźnik MCI - ratio, tym bardziej zamknięta jest dana gospodar$\mathrm{ka}^{151}$. Warto podkreślić, że zależność kursu walutowego i stóp procentowych jest istotna $\mathrm{w}$ procesie podejmowania decyzji dotyczących polityki pieniężnej i jej wpływu na gospodarkę.

\subsection{Stopy procentowe a kryzys finansowy}

Kwestia kryzysu finansowego jest zjawiskiem, które w istotnym stopniu oddziałuje na gospodarkę, szczególnie w obecnych czasach globalizacji. W teorii ekonomii keynesowski mechanizm transmisji polityki stóp procentowych ma względnie największą skuteczność w fazie osłabienia koniunktury oraz w końcowej fazie jej ożywienia. W pierwszym przypadku ekspansywna polityka stóp procentowych jest uzupełnieniem narzędzi polityki fiskalnej. Natomiast w drugiej sytuacji w celu kontynuowania fazy ożywienia koniunktury, najlepszym rozwiązaniem jest zwiększenie podaży pieniądza i zahamowanie przez to wzrostu stóp procentowych ${ }^{152}$.

Zmiany stóp procentowych we wczesnej fazie recesji często są zakłócane negatywnymi informacjami o stanie gospodarki i jej perspektyw do tego stopnia, że osłabiają ich wpływ na sferę realną. Przykładem takiej sytuacji jest kryzys finansowy, który pojawił się w połowie 2007 r., głównie w gospodarkach krajów uprzemysłowionych. Początku tego kryzysu upatruje się na rynku kredytów subprime. W wyniku perturbacji na rynku hipotecznym wiele instytucji finan-

${ }^{149}$ Ibidem, s. 238-239.

${ }^{150}$ Modele VAR (wektorowo-autoregresyjne).

${ }^{151}$ A. Kot, Metody kwantyfikacji restrykcyjności polityki monetarnej, fiskalnej oraz Policy mix $w$ krajach akcesyjnych, „Bank i Kredyt” 2003, nr 6.

${ }^{152}$ J. L. B ednarczyk, Stopa procentowa jako narzędzie polityki banku centralnego, [w:] W. Przybylska-Kapuścińska (red.), Studia z bankowości centralnej i polityki pieniężnej, Difin, Warszawa 2009, s. 171. 
sowych, szczególnie w Stanach Zjednoczonych oraz Wielkiej Brytanii, miało poważne problemy z wypłacalnością. W celu uniknięcia paraliżu sektora bankowego z czasów Wielkiego Kryzysu, postanowiono wykorzystać narzędzia polityki pieniężnej by zapobiec ówczesnej sytuacji ograniczenia finansowania sektora realnego gospodarki przez banki. Banki centralne dążyły do zabezpieczenia płynności sektorów bankowych oraz dostarczenia gospodarkom pieniądza po możliwie najniższym koszcie. Wprowadzono bez precedensu zmiany w polityce refinansowej banków centralnych, obniżając jednocześnie stopy procentowe. Skutkiem tych działań był znaczny wzrost podaży pieniądza. W USA baza monetarna powiększyła się o $78 \%$ od grudnia 2007 r. do grudnia 2008 r., podaż pieniądza M1 wzrosła o 11,5\%, a M2 o 7,2\%. Zatem wchodząc w fazę recesji gospodarka amerykańska odnotowała znaczną ekspansję monetarną przy malejącym popycie transakcyjnym. System Rezerwy Federalnej od września 2007 r. rozpoczął fazę obniżania podstawowej stopy procentowej, przeprowadzając w sumie do grudnia 2008 r. 10 obniżek oprocentowania funduszy federalnych (federal funds rate) ${ }^{153}$. W rezultacie w końcu 2008 r. podstawowa stopa procentowa w Stanach Zjednoczonych oscylowała na poziomie $0-0,25 \%{ }^{154}$. Europejski Bank Centralny również rozpoczął od lipca 2008 r. serię obniżek stóp procentowych, redukując podstawową stopę procentową z 5,25 do 2,5\% w końcu $2008 \mathrm{r}$. Jednak największy wpływ na efektywność mechanizmu transmisyjnego stóp procentowych miała rosnąca dysproporcja pomiędzy zmianami oficjalnych stóp procentowych a zmianami krótkoterminowych stóp rynkowych. Zjawisko narastania tych różnic zaobserwowano w USA i Unii Europejskiej już wcześniej, a kryzys finansowy zaostrzył te dysproporcje. W rezultacie wzrósł koszt refinansowania się banków w banku centralnym w stosunku do kosztów, które banki ponoszą korzystając ze środków dostępnych na rynku międzybankowym. Natomiast koszty pozyskania kapitałów, ponoszone przez banki na rynku międzybankowym, wpływają na warunki finansowania podmiotów gospodarczych spoza sektora bankowego ${ }^{155}$.

W związku z narastającymi dysproporcjami w wysokości stóp procentowych banku centralnego i rynku międzybankowego, znaczna część zasobów pieniądza wprowadzona do sektora bankowego przeznaczona została głównie na zabezpieczenie jego płynności, a nie do finansowania sfery realnej. Było to przyczyną obniżenia sprawności przepływu sygnałów rynkowych pobudzanych obniżaniem stóp procentowych, czy refinansowaniem sektora finansowego przez

${ }^{153}$ J. B. Taylor, Zrozumieć kryzys finansowy, Wydawnictwo Naukowe PWN, Warszawa 2010, s. 9-79.

${ }^{154}$ A. W i ęz now ski, Monetarne przyczyny kryzysu finansowego w USA 2007/2008, [w:] M. Nog a, M. K. S t a w i ck a (red.), Ponadnarodowa i narodowa polityka monetarna na świecie, CeDeWu, Warszawa 2009, s. 155-162.

155 J. B. T a y lo r, op. cit., s. 9-79. 
bank centralny. Jest to przypadek prowadzenia polityki stóp procentowych w warunkach tzw. pułapki płynności (liquidity trap) ${ }^{156}$.

Na rys. 3.8 zobrazowana została sytuacja, która zaistniała od połowy 2007 r. w gospodarkach krajów uprzemysłowionych, w wyniku redukcji stopy procentowej $^{157}$.

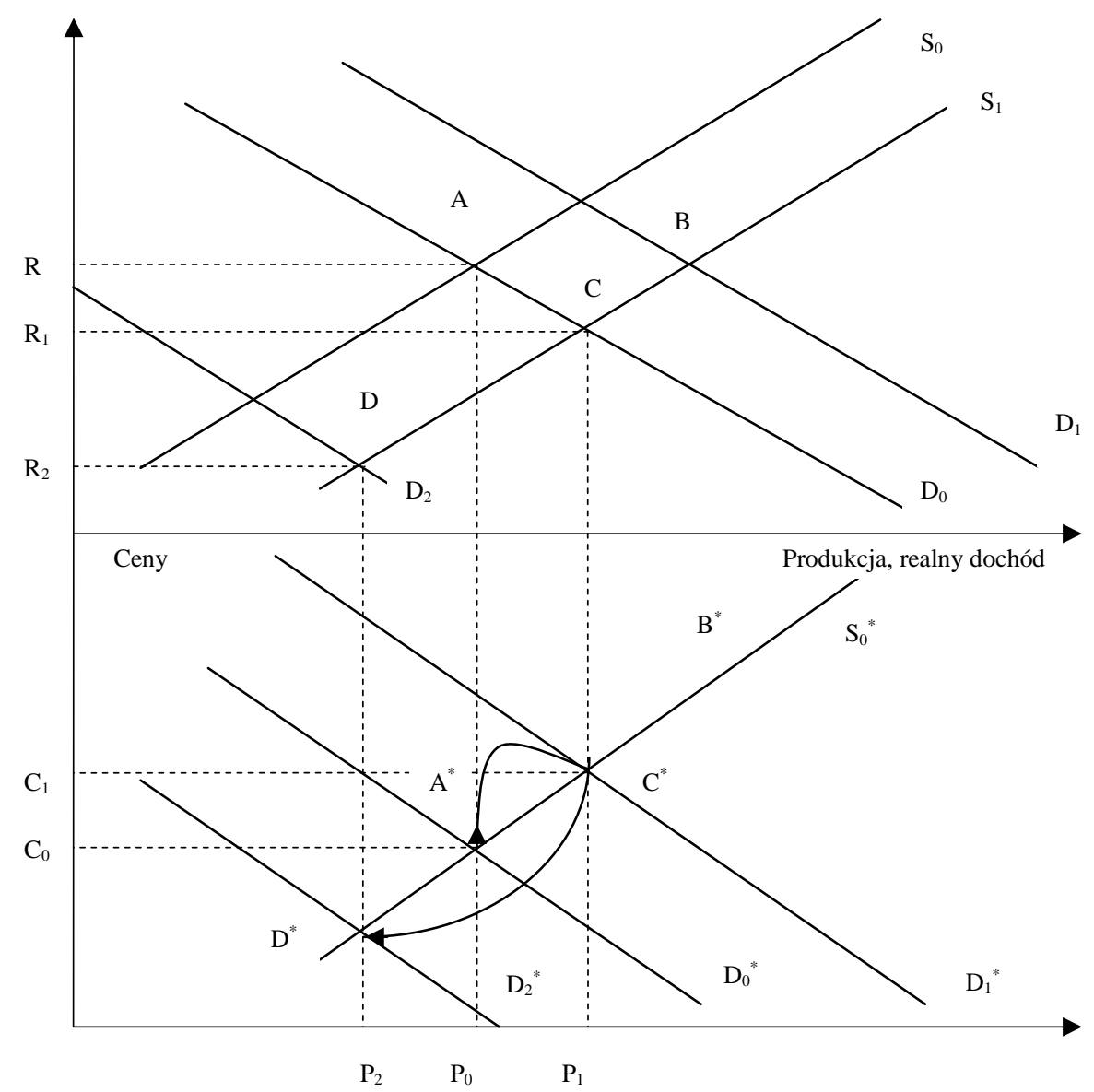

Rys. 3.8. Redukcja stopy procentowej jako narzędzie przeciwdziałania pogłębianiu się recesji gospodarczej

Ź ród ło: J. L. B ed narczy k, Stopa procentowa jako narzędzie polityki banku centralnego, [w:] W. Przybylska-Kapuścińska (red.), Studia z bankowości centralnej i polityki pieniężnej, Difin, Warszawa 2009, s. 171.

${ }^{156}$ Więcej na temat pułapki płynności [w:] A. Kaźmi e r c z a k, Polityka pieniężna w gospodarce otwartej, op. cit., s. 93.

${ }^{157}$ J. L. B ed narc zy k, Stopa..., op. cit., s. 171-172. 
Górna część rysunku dotyczy warunków równowagi na rynku finansowym, natomiast dolna - równowagi na rynku dóbr i usług. Punkt A obrazuje stan równowagi przy niewykorzystanych $\mathrm{w}$ pełni możliwościach produkcyjnych oraz innych problemach charakterystycznych dla gospodarki w początkowej fazie recesji. Są to wysokie bezrobocie, ograniczony poziom inwestycji w kapitale trwałym oraz wydatków konsumpcyjnych ${ }^{158}$. Decyzje banku centralnego dążącego do zwiększenia dostępności pieniądza, spowodują przesunięcie poziomu równowagi do punktu B, głównie w wyniku wzrostu popytu transakcyjnego na pieniądz. Przyrost zasobów pieniądza częściowo wykorzystany został do zakupu papierów wartościowych (obligacji), co w konsekwencji przyczyniło się do obniżenia ich cen oraz spadku stóp procentowych.

Punkt równowagi na rynku finansowym przesunie się do punktu $\mathrm{C}$, o wyższym poziomie produkcji i cen $\left(\mathrm{C}_{1}\right)$. Gdy nastąpiłaby szybka reakcja sektora realnego na obniżki stóp procentowych, równowaga w punkcie $\mathrm{C}$ mogłaby utrzymać się przez dłuższy czas. W przeciwnym przypadku podmioty gospodarcze oczekując jeszcze niższego poziomu stóp procentowych zaczną kupować papiery wartościowe, prowadząc do dalszego wzrostu ich cen i spadku stóp procentowych. Dodatkowo w warunkach obniżającego się popytu inwestycyjnego oraz popytu na dobra i usługi, mogą pojawić się w gospodarce tendencje deflacyjne (spadek cen w USA w ostatnich miesiącach 2008 r.). Deflacja przyczynia się do wzrostu realnych stóp procentowych, który niweluje pozytywne następstwa obniżki stóp nominalnych. W związku z tym równowaga przesunie się do punktu $\mathrm{D}^{*}$, który charakteryzuje się niskim poziomem produkcji, wysokim bezrobociem, przy niskich stopach procentowych i niskiej inflacji ${ }^{159}$.

\subsection{Podsumowanie}

Odmienne teorie stóp procentowych w ujęciu klasycznym, keynesowskim czy monetarystycznym umożliwiają szerszy pogląd na zjawisko wpływu stóp procentowych banków centralnych na inwestycje przedsiębiorstw w Polsce i strefie euro. Na podstawie przedstawionego powyżej dorobku teoretycznego dotyczącego stóp procentowych można wysunąć wnioski, że pomimo sporów w teorii ekonomii odnośnie ich znaczenia w gospodarce przypisuje się im istotną rolę w procesach gospodarczych.

Podsumowując, można zauważyć, że większość banków centralnych używa krótkoterminowej stopy procentowej jako kluczowego instrumentu polityki pieniężnej. Szczególne znaczenie przypisywane jest stopom rynku międzybanko-

\footnotetext{
${ }^{158}$ Ibidem, s. 171.

159 Ibidem.
} 
wego. Zwykle podmioty gospodarcze kojarzą zacieśnianie polityki monetarnej ze wzrostem międzybankowych stóp procentowych, a łagodzenie polityki ze spadkiem tych stóp. Oczekiwania inflacyjne społeczeństwa, niespójna z polityką monetarną polityka fiskalna, czy nadpłynność sektora bankowego utrudniają bankowi centralnemu utrzymanie krótkoterminowych stóp procentowych wokół stopy referencyjnej. Jednak wykorzystując instrumenty polityki pieniężnej, szczególnie operacje otwartego rynku, bank centralny ma możliwość ustabilizowania stóp rynku międzybankowego wokół stopy podstawowej. Jest to istotne, ponieważ stopy rynku międzybankowego oddziałują na stopy oprocentowania kredytów i depozytów w bankach komercyjnych oraz na długoterminowe stopy aktywów finansowych. Stopy te mają swoje odzwierciedlenie w wielkości inwestycji, oszczędności, konsumpcji czy poziomie inflacji w gospodarce. Zatem umiejętność prognozowania i odpowiedniego reagowania władz monetarnych na zmienność stóp procentowych jest istotnym zadaniem banku centralnego, który przyczynia się do utrzymania stabilności cen według strategii bezpośredniego celu inflacyjnego, a przez to stabilizacji systemu finansowego. 



\section{Rozdział 4}

\section{ISTOTA INWESTYCJI PRZEDSIĘBIORSTW I ICH FINANSOWANIE ZA POMOCĄ KREDYTU BANKOWEGO}

\subsection{Znaczenie przedsiębiorstw $w$ gospodarce}

Polityka pieniężna poprzez dbałość o stabilność cen, ma istotne znaczenie dla wielkości makroekonomicznych wchodzących w skład miernika wzrostu gospodarczego. Oddziałując między innymi na poziom inwestycji, a przez to na rozwój przedsiębiorstw, wpływa na tempo wzrostu PKB. Zadanie banku centralnego polega na odpowiednim sterowaniu stopami procentowymi w celu kontroli podaży pieniądza przy użyciu dostępnych instrumentów polityki pieniężnej. Działanie to zmierza do utrzymania odpowiedniego poziomu inflacji, w taki sposób, by nie szkodziła ona gospodarce. Władze monetarne przy współpracy z rządem (odpowiadającym za prowadzenie polityki fiskalnej) są w mocy efektywnie wpływać na decyzje podejmowane przez podmioty gospodarcze funkcjonujące na rynku finansowym ${ }^{1}$. Istotne są zatem zależności, jakie występują pomiędzy przedsiębiorstwami i bankami komercyjnymi, a głównie aspekt wykorzystywania przez przedsiębiorstwa finansowania zewnętrznego w postaci kredytów bankowych przeznaczonych na inwestycje. Ważna pozostaje również kwestia dostępności kredytów inwestycyjnych dla podmiotów gospodarczych oraz wpływu polityki banku centralnego na ceny tych kredytów dla przedsiębiorstw.

Przedsiębiorstwa mają istotne znaczenie dla rozwoju gospodarczego, ponieważ przyczyniają się do zrównoważonego funkcjonowania gospodarki oraz do przyspieszonego wzrostu gospodarczego. Uważa się, że sektor przedsiębiorstw stanowi największe źródło nowych miejsc pracy, co ma szczególne znacznie w wielu krajach europejskich, które walczą ze zbyt wysoką stopą bezrobocia (zwłaszcza w następstwie ostatniego kryzysu finansowego). Sektor

${ }^{1}$ J. Tre mbińska, Polityka pieniężna i jej wptyw na gospodarkę w Polsce po 1990 roku w warunkach nadptynności sektora bankowego, [w:] M. Marcinkowska, St. Wieteska (red.), Harmonizacja bankowości i ubezpieczeń w skali narodowej i europejskiej, Difin, Warszawa 2007, s. 399. 
przedsiębiorstw charakteryzuje szybka reakcja na potrzeby rynku, dynamiczne podejście do otoczenia, otwartość na postęp techniczny i organizacyjny oraz możliwość występowania we wszystkich działach gospodarki ${ }^{2}$. W niniejszej pracy część informacji dotyczących przedsiębiorstw przedstawiono według podziału na mikro, małe, średnie i duże przedsiębiorstwa zgodnie z definicją Komisji Europejskiej w celu podkreślenia istotnego wkładu sektora MMSP w rozwój gospodarki.

W Unii Europejskiej sam sektor MMSP reprezentuje 99\% wszystkich przedsiębiorstw dostarczając około 65 milionów miejsc pracy (na 130 milionów osób pracujących w przedsiębiorstwach). Wśród krajów o największym wkładzie w liczbę pracujących w przedsiębiorstwach znajdują się następujące państwa: Niemcy (26,2 mln osób), Wielka Brytania (17,7 mln), Włochy (15,3 mln), Francja $(15,2)$ oraz Hiszpania $(10,1 \mathrm{mln})$, co stanowi około dwóch trzecich łącznej liczby pracujących w przedsiębiorstwach w UE - 28 ( $85 \mathrm{mln}$ osób). W pozostałych 22 krajach członkowskich UE w przedsiębiorstwach pracuje $46 \mathrm{mln}$ osób, przy czym Polska jest liderem w tej grupie $(8,4 \mathrm{mln} \text { osób })^{3}$. W krajach o rozwiniętej gospodarce rynkowej istotną większość w liczebności stanowią właśnie mikro, małe i średnie przedsiębiorstwa. To właśnie sektor małych i średnich przedsiębiorstw stanowi źródło innowacji w gospodarce oraz w istotnym stopniu przyczynia się do rozwoju gospodarczego ${ }^{4}$. Według danych Eurostatu w krajach Unii Europejskiej (UE - 27) w 2010 r. mikroprzedsiębiorstwa wytworzyły $21,2 \%$ wartości dodanej brutto przedsiębiorstw, małe i średnie firmy po $18,2 \%$, natomiast duże $42,4 \%$ (porównując, duże firmy w Polsce wytworzyły $49,4 \%)^{5}$. Uważa się, że firmy z sektora MMSP są twórcami nowych rozwiązań, ponadto postrzegane są jako źródło konkurencyjności oraz czynnik wpływający na dywersyfikację rynku ${ }^{6}$. Dynamiczny rozwój przedsiębiorstw przyczynia się do wzrostu zatrudnienia, nieustannych innowacji i inwestycji, co z kolei prowadzi do większego ich udziału we wzroście produktywności gospodarki ${ }^{7}$. W literaturze wymienia się jednak nie tylko pozytywne aspekty tzw. ,,małej przedsiębiorczości”. Głównie ze względu na bariery, na jakie napotykają w swojej dzia-

${ }^{2}$ Z. D a ch, Sektor matych i średnich przedsiębiorstw $w$ perspektywie przystapienia do Unii Europejskiej, ,Zeszyty Naukowe AE Kraków", 2001.

${ }^{3}$ Raport o stanie sektora matych $i$ średnich przedsiębiorstw w Polsce w latach 2011-2012, Polska Agencja Rozwoju Przedsiębiorczości, Warszawa 2013, s. 24-28.

${ }^{4} \mathrm{P}$. V an d e n berg, Micro, Small and Medium-sized Enterprises and the Global Economic Crisis, Impact and Policy Responses, International Labour Organization, 2009, s. 1-5.

${ }^{5}$ Raport o stanie sektora matych i średnich przedsiębiorstw w Polsce $w$ latach 2011-2012, op. cit., s. 16.

${ }^{6}$ B. Mikołajczyk, M. Krawczyk, Sektor przedsiębiorstw mikro, matych i średnich w krajach Unii Europejskiej, „Studia Europejskie” 2006, nr 2, s. 68-69.

7 M. Chądzyński, Wptyw matych i średnich przedsiębiorstw na wzrost gospodarczy w Polsce w latach 1995-2005, Stowarzyszenie Ekonomistów Rolnictwa i Agrobiznesu, Roczniki Naukowe, t. X, z. 3, s. 57. 
łalności, istnieją również inne ich charakterystyki. Przedsiębiorstwa MMSP dysponują zwykle niższym poziomem aktywów trwałych do ich ogólnego stanu aktywów oraz mają wyższy stosunek bieżących zobowiązań do ogólnego poziomu aktywów (w szczególności w krótkim okresie polegają na bankowych kredytach w celu finansowania swoich aktywów). Poza tym są finansowo ryzykowne, co odzwierciedla wskaźnik zadłużenia i wyższa stopa bankructwa, a ich produkty mają słabszą pozycję rynkową w porównaniu do produktów dużych przedsiębiorstw. Oprócz tego firmy te cierpią na finansowe niekorzyści skali, związane z mniejszym zróżnicowaniem źródeł finansowania, relatywnie słabszymi perspektywami wzrostu oraz mniej rozwiniętą dywersyfikacją produktu ${ }^{8}$.

W Polsce ilość mikro i małych przedsiębiorstw od początku 1998 r. do 2012 r. właściwie się nie zmieniła, stanowiąc odpowiednio 99\% w 1998 r. i 98,9\% ogółu firm w 2012 r. Średnie przedsiębiorstwa stanowią w 2012 r. około $0,9 \%$ wszystkich przedsiębiorstw, natomiast duże podmioty około $0,2 \%$. Ze względu na formę prawną badanych w 2012 r. jednostek - 91,6\% przedsiębiorstw należało do osób fizycznych ${ }^{9}$. Przykładowo, według GUS udział przedsiębiorstw w tworzeniu PKB w Polsce wynosi około 71,8\%, z czego ponad 47,3\% generują firmy kategorii MMSP, zaś duże 24,5\% (dane za 2011 r.). Liczba pracujących w przedsiębiorstwach wynosi ponad $9 \mathrm{mln}$ osób, z czego w podmiotach z sektora MMSP pracuje $70 \%$ zatrudnionych $(6,3 \mathrm{mln}$ osób), natomiast firmy duże zatrudniają około $30 \%$ pracujących w sektorze przedsiębiorstw (dane za $2011 \mathrm{r}$.) ${ }^{10}$.

Również eksport ma istotne znaczenie w rozwoju gospodarki, a przedsiębiorstwa w wysokim stopniu wpływają na jego wielkość. Charakteryzując sektor przedsiębiorstw w Polsce można stwierdzić, że duże firmy wykazują większe powiązania z rynkami zagranicznymi. Według wskaźnika udziału eksporterów w ogólnej liczbie firm, w 2012 r. najwięcej eksporterów jest wśród firm dużych - 66,9\%, następnie średnich - 45\%, a najmniej wśród przedsiębiorstw małych $-28,6 \%^{11}$.

Statystyki wyraźnie wskazują, że przedsiębiorstwa traktowane są jako siła napędowa gospodarki. Sektor przedsiębiorstw generuje istotny udział w tworzeniu PKB kraju. To właśnie wśród przedsiębiorstw rośnie zatrudnienie i eksport. Natomiast inwestycje przedsiębiorstw przyczyniają się do innowacyjności, konkurencyjności na rynku, a przede wszystkim do wzrostu gospodarczego.

${ }^{8}$ R. Cross y, Ch. Ol of s s on, European SME Financing: An Overview, „Small Business Economics", Springer, 1997, s. 87-96.

${ }^{9}$ Działalność przedsiębiorstw niefinansowych w 2012 roku, Główny Urząd Statystyczny, Warszawa 2013, s. 1.

${ }^{10}$ Raport o stanie sektora matych $i$ średnich przedsiębiorstw w Polsce w latach 2011-2012, op. cit., s. 4-27.

${ }^{11}$ Ibidem, s. 76-77. 


\subsection{Istota i poziom inwestycji przedsiębiorstw}

Do najczęściej przytaczanych w literaturze pojęć inwestycji zaliczamy to, według którego inwestycje to wszystkie środki i oszczędności w gospodarce przeznaczone na rozwój produkcji i usług w danym kraju ${ }^{12}$. E. Kwiatkowski podkreśla, że inwestycje odgrywają istotną rolę w analizach makroekonomicznych, ponieważ są one częścią agregatowego popytu na towary, a ich zmiany oddziałują na popyt i dochód narodowy. Ponadto w dłuższym terminie inwestycje przyczyniają się do zwiększenia mocy produkcyjnych gospodarki i wzrostu produkcji potencjalnej ${ }^{13}$. Inwestycje wiążą się z długoterminowym zaangażowaniem środków finansowych oraz z tym, że nakłady na inwestycje są znacznie większe niż wydatki na operacyjną działalność przedsiębiorstwa. Inwestycje powinny mieć istotny wpływ na działanie, efektywność, czy konkurencyjność przedsiębiorstwa w przyszłości. Posiadają ponadto cechy, które charakteryzują ich specyfikę i wyróżniają je spośród innych działań przedsiębiorstw ${ }^{14}$. Przede wszystkim przy realizowaniu inwestycji pojawia się ryzyko i brak pewności, co do ich rezultatów. Wiążą się one również z procedurami wykonania kosztochłonnego rachunku inwestycyjnego, który opisuje możliwości finansowe oraz rezultaty inwestycji w przyszłości. Pomimo trudności związanych z procesem inwestycyjnym istnieje potrzeba inwestowania przedsiębiorstw $\mathrm{w}$ celu ich dalszego rozwoju i przetrwania na rynku ${ }^{15}$.

Przedsiębiorstwo wykorzystuje inwestycje do dostosowania aktualnego zasobu kapitału do jego poziomu pożądanego. Dodatkowy zysk jest motywem prowadzącym do zwiększenia zasobu kapitału. Natomiast pożądany zasób kapi-

${ }^{12} \mathrm{~W}$ związku z teorią, że w gospodarce zamkniętej oszczędności są równe inwestycjom, a w gospodarce otwartej różnica inwestycji i oszczędności ma odzwierciedlenie w bilansie obrotów bieżących nasuwa się paradoks Feldsteina-Horioki. W momencie, gdy kapitał jest mobilny pomiędzy państwami i może przepływać bez przeszkód, wyrównując jednocześnie zyski inwestorów, wtedy nie powinna występować korelacja pomiędzy inwestycjami a oszczędnościami. Oznacza to, że oszczędności zgromadzone w jednym kraju nie muszą w nim pozostawać, mogą być wykorzystane w innym. W przeciwnym razie występuje wysoka korelacja pomiędzy inwestycjami i oszczędnościami. Według badań empirycznych, właśnie w gospodarkach otwartych istnieje duża korelacja pomiędzy stopą oszczędności i inwestycji, co mogłoby świadczyć o niskiej mobilności kapitału. Jednak dla większości autorów silny efekt F-H nie oznacza niskiej mobilności kapitału, [w:] M. J a ku bi a k, Oszczędności, inwestycje, integracja finansowa i bezpośrednie inwestycje zagraniczne w Europie Środkowo-Wschodniej, [w:] B. Lib erd a (red.), Determinanty oszczędzania w Polsce, Raport Centrum Analiz Społeczno-Ekonomicznych, CASE, nr 28, Warszawa 1999, s. 23-39.

${ }^{13}$ R. Milewski (red.), Podstawy ekonomii, Wydawnictwo Naukowe PWN, Warszawa 1999, s. 364.

${ }^{14}$ J. Ró żań s ki (red.), Inwestycje rzeczowe i kapitałowe, Difin, Warszawa 2006, s. 13.

${ }^{15} \mathrm{R}$. W olański, Wspieranie inwestycji prowadzonych przez małe i średnie przedsiębiorstwa, [za:] zasoby witryny internetowej: http://ekonom.univ.gda.pl/mikro/konferencja/pdf/Wolanski.pdf [20.10.2010]. 
tału zależy od wielkości popytu na produkty przedsiębiorstwa w przyszłości, czyli od poziomu przyszłej produkcji oraz różnicy pomiędzy marginalną produkcyjnością kapitału, a kosztem jego pozyskania do użytkowania ${ }^{16}$. Pożądany zasób kapitału jest uzależniony od kosztu użytkowania kapitału oraz od poziomu produkcji, co zostało zilustrowane na rys. 4.1.

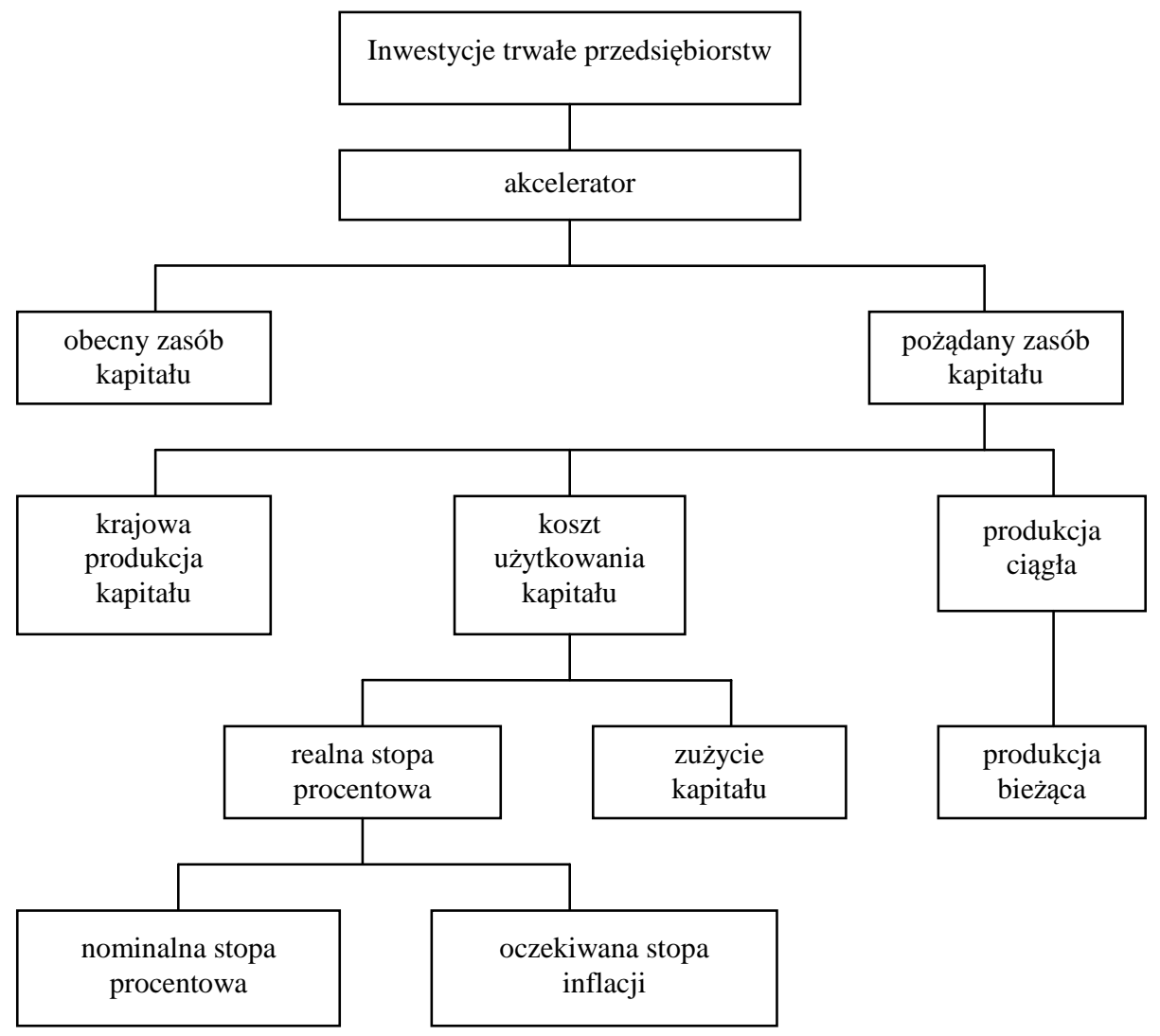

Produkcja ciągła - produkcja o przepływie ciągłym, przepływ materiału w procesie produkcyjnym jest ciągły.

Rys. 4.1. Podstawowe czynniki determinujące inwestycje trwałe przedsiębiorstw

Ź r ó d ł o: M. Nog a (red.), Makroekonomia, Akademia Ekonomiczna im. Oskara Langego, Wrocław 1995, s. 53.

${ }^{16}$ Ibidem, s. 53. 
Koszt użytkowania kapitału zależy natomiast od realnej stopy procentowej oraz od stopnia zużycia kapitału. Z kolei na realną stopę procentową wpływa nominalna stopa procentowa oraz oczekiwana stopa inflacji. Zależność tę przedstawia poniższe równanie ${ }^{17}$ :

Wzór 4.1. Koszt użytkowania kapitału

$$
i_{c}=i_{r}+d
$$

gdzie:

$i_{c} \quad$ - koszt użytkowania (pozyskania) kapitału,

$i_{r} \quad$ - realna stopa procentowa

(gdzie $i_{r}=i-I$, czyli $i$ - nominalna stopa procentowa,

II-oczekiwana stopa inflacji),

$d$ - stopa amortyzacji.

Im niższa jest realna stopa procentowa, tym niższy jest koszt użytkowania kapitału, a tym samym pożądany zasób kapitału staje się zbliżony do oczekiwanego. To pozwala na zwiększenie poziomu produkcji i zasobu kapitału przybliżając go do pożądanego poziomu. Dlatego dla przedsiębiorstw istotny jest poziom stóp procentowych, ponieważ ma on odzwierciedlenie w decyzjach inwestycyjnych podmiotów gospodarczych.

W tabeli 4.1 zaprezentowano dane dotyczące nakładów inwestycyjnych w Polsce w latach 1998-2012, ze szczególnym wskazaniem na poziom inwestycji przedsiębiorstw w gospodarce. Nakłady inwestycyjne przedsiębiorstw w latach 1998-2000 z roku na rok rosły (z 88 mld zł do 106 mld zl), jednak w okresie spowolnienia gospodarczego (lata 2001-2003) istotnie spadły (z około 93 mld zł do 77 mld zł). W latach 2001-2003 procesy inwestycyjne w gospodarce uległy znacznemu osłabieniu, głównie ze względu na pogarszającą się koniunkturę w kraju i za granicą. Trudna sytuacja finansowa przedsiębiorstw, brak środków z zewnętrznych źródeł finansowania oraz niski poziom bezpośrednich inwestycji nie sprzyjały zwiększaniu nakładów inwestycyjnych przez firmy. Było to zjawisko niekorzystne, ponieważ niższe zdolności inwestycyjne gospodarki oznaczają wolniejszy postęp procesów restrukturyzacyjnych i modernizacyjnych oraz spadek konkurencyjności gospodarki. W konsekwencji mogło mieć to wpływ na spowolnienie procesu likwidowania przez Polskę luki technologicznej w stosunku do krajów rozwiniętych ${ }^{18}$. Największy udział w inwestycjach przedsiębiorstw ogółem w 1998 r. miały firmy duże $(55,8 \%)$, natomiast przedsiębiorstwa mikro i małe $(22,24 \%)$ miały wkład w inwestycjach w gospodarce

${ }^{17}$ Ibidem, s. 54.

${ }^{18}$ Raport o stanie sektora matych i średnich przedsiębiorstw w Polsce w latach 1999-2000, Polska Agencja Rozwoju Przedsiębiorczości, Warszawa 2001, s. 23. 
na porównywalnym poziomie ze średnimi (21,96\%). W kolejnych latach 1999 -2000 wzrósł udział nakładów inwestycyjnych przedsiębiorstw mikro i małych (1999 r. - 25,13\%, 2000 r. - 26,91\%) kosztem firm dużych (odpowiednio $53,20 \%$ i $49,98 \%)^{19}$.

$\mathrm{T}$ a b e 1 a 4.1

Nakłady inwestycyjne przedsiębiorstw w Polsce w latach 1998-2012 w mln zł, ceny bieżące

\begin{tabular}{|c|c|c|c|c|c|}
\hline Rok & $\begin{array}{c}\text { Nakłady inwe- } \\
\text { stycyjne ogółem }\end{array}$ & $\begin{array}{c}\text { Ogółem } \\
\text { przedsiębiorstwa }\end{array}$ & $\begin{array}{c}\text { Mikro i małe } \\
(0-49)\end{array}$ & $\begin{array}{c}\text { Średnie } \\
(50-249)\end{array}$ & $\begin{array}{c}\text { Duże } \\
(\geq 250)\end{array}$ \\
\hline \hline 1998 & 112813 & 88080,57 & 19592,86 & 19339,78 & 49147,92 \\
\hline 1999 & 126803 & 101099,61 & 25406,58 & 21908,24 & 53784,79 \\
\hline 2000 & 133160 & 106328,33 & 28611,64 & 24578,76 & 53137,93 \\
\hline 2001 & 121363 & 93259,66 & 25955,31 & 19019,88 & 48284,47 \\
\hline 2002 & 109266 & 72229,05 & 18260,08 & 13352,77 & 40616,20 \\
\hline 2003 & 110860 & 77397,00 & 20768,00 & 16259,00 & 40370,00 \\
\hline 2004 & 120467 & 90030,00 & 22932,00 & 21708,90 & 45389,10 \\
\hline 2005 & 131055 & 99418,20 & 22241,00 & 21384,30 & 55792,90 \\
\hline 2006 & 154880 & 113895,10 & 26845,60 & 27647,70 & 59247,60 \\
\hline 2007 & 191714 & 144279,60 & 34147,00 & 34759,20 & 75373,00 \\
\hline 2008 & 217260 & 160540,00 & 39367,00 & 34942,00 & 86230,00 \\
\hline 2009 & 218581 & 143751,00 & 38269,00 & 30806,00 & 74675,00 \\
\hline 2010 & 217287 & 141939,00 & 41725,00 & 29598,00 & 70616,00 \\
\hline 2011 & 243346 & 161240,00 & 47039,00 & 33785,00 & 80416,00 \\
\hline 2012 & 237627 & b.d. & b.d. & b.d. & b.d. \\
\hline
\end{tabular}

Ź r ó d ł o: opracowanie własne na podstawie: Raportów o stanie sektora matych i średnich przedsiębiorstw w Polsce, raporty od 1998 do 2012 r., Polska Agencja Rozwoju Przedsiębiorczości, Warszawa 1999-2013 oraz danych statystycznych GUS (Tablice: Roczne wskaźniki makroekonomiczne - część IV - Inwestycje), [za:] zasoby witryny internetowej: www.stat. gov.pl.

Z kolei korzystna sytuacja gospodarcza w latach 2004-2008 miała istotny wpływ na wielkość nakładów inwestycyjnych w sektorze przedsiębiorstw (wzrost inwestycji z 90 mld zł do 160,5 mld zł ${ }^{20}$. Największy udział w inwestycjach przedsiębiorstw ogółem zanotowały w tym okresie firmy duże (w 2008 r. - 53,71\%),

${ }^{19}$ Raport o stanie sektora matych i średnich przedsiębiorstw w Polsce w latach 2008-2009, Polska Agencja Rozwoju Przedsiębiorczości, Warszawa 2010, s. 57-60.

${ }^{20}$ Raport o stanie sektora matych i średnich przedsiębiorstw w Polsce $w$ latach 2007-2008, Polska Agencja Rozwoju Przedsiębiorczości, Wydawnictwo Naukowe Instytutu Technologii Eksploatacji - PIB, Radom 2009, s. 11. 
a najniższy podmioty średnie (w 2008 r. - 21,77\%). Już od 2008 r. zaczęły pojawiać się oznaki globalnego kryzysu, który rozpoczął się na rynku światowym w II połowie 2007 r. ${ }^{21}$ Skutki kryzysu finansowego przyczyniły się miedzy innymi do spadku wielkości nakładów inwestycyjnych przedsiębiorstw w 2009 r. w gospodarce polskiej. W latach 2009-2010, w wyniku skutków kryzysu finansowego, inwestycje przedsiębiorstw uległy obniżeniu (do 141,9 mld zł w 2010 r.).

W $2011 \mathrm{r}$. zanotowano wzrost inwestycji przedsiębiorstw do $161 \mathrm{mld} \mathrm{zł}$, co było wynikiem wysokiego stopnia wykorzystania mocy produkcyjnych, realizacji odkładanych we wcześniejszych latach inwestycji oraz poprawy sytuacji gospodarczej w Polsce.

Z powodu kryzysu finansowego w Unii Europejskiej wartość inwestycji sektora prywatnego $\mathrm{w}$ relacji do PKB wyniosła w 2009 r. 16,3\% w porównaniu do $18,4 \%$ PKB w 2008 r. W Polsce wartość wskaźnika inwestycji sektora prywatnego w stosunku do PKB wyniosła 15,7\%, a rok wcześniej 17,5\%. Wśród liderów znalazły się w 2009 r.: Słowacja (21,3\%), Rumunia (20,2\%), Hiszpania (20,0\%) oraz Bułgaria (19,9\%). Kraje o najniższej relacji inwestycji do PKB w tym czasie to Wielka Brytania $(12,2 \%)$, Malta $(12,0 \%)$ oraz Irlandia $(11,0 \%)^{22}$. W strefie euro relacja inwestycji do PKB wynosiła średnio około $20 \%$.

Inwestycje przedsiębiorstw w Polsce były finansowanie głównie z wygospodarowanych środków własnych, pochodzących z zysku i amortyzacji. Oszacowano, że udział kredytu bankowego, jako źródła finansowania inwestycji wynosił 13-17\%. Również leasing stanowił tylko około 5\% ogółu inwestycji firm, gdzie dla porównania w krajach Europy Zachodniej ten sposób finansowania wykorzystywano do realizacji $30 \%$ nowych inwestycji (dane za 2000 r.) ${ }^{23}$. Warto dodać, że w 2011 r., podobnie jak w latach poprzednich, dominującym źródłem finansowania inwestycji MSP w Polsce pozostawały środki własne (63,4\%), a na drugim miejscu angażowano środki pochodzące $\mathrm{z}$ kredytów bankowych $(17,5 \%)$. Ponadto im większe przedsiębiorstwo, tym wykorzystanie środków własnych na finansowanie inwestycji było większe (małe firmy $-59,44 \%$, średnie $-65,58 \%$, duże $-73,72 \%)^{24}$.

Przedsiębiorstwa potrzebują odpowiednich warunków, które zachęcą je do podjęcia ryzyka osiągnięcia dodatkowego dochodu przez zwiększanie aktywności inwestycyjnej. Warto podkreślić, że inwestycje firm są istotnym elementem kształtującym gospodarkę, jednak uzależnione są od wielu czynników, które często ograniczają decyzje inwestycyjne przedsiębiorstw.

${ }^{21}$ Ibidem, s. 11.

${ }^{22}$ Raport o stanie sektora matych i średnich przedsiębiorstw w Polsce w latach 2008-2009, op. cit., s. 24.

${ }^{23}$ Raport o stanie sektora matych i średnich przedsiębiorstw w Polsce w latach 1999-2000, op. cit., s. 23.

${ }^{24}$ Raport o stanie sektora matych i średnich przedsiębiorstw w Polsce w latach 2011-2012, op. cit., s. 41 . 


\subsubsection{Czynniki wpływające na poziom inwestycji przedsiębiorstw}

Na inwestycje przedsiębiorstw, a przez to na realizację ich celów, wpływ ma wiele, najczęściej niezależnych od firm, czynników gospodarczych. E. Kwiatkowski wymienia kilka czynników, od których zależy poziom inwestycji. Zalicza do niech stopę procentową, zmiany popytu konsumpcyjnego, koszty i efektywność wyposażenia kapitałowego oraz oczekiwania inflacyjne ${ }^{25}$. Na podstawie modeli ekonomicznych wyodrębniono trzy główne determinanty poziomu inwestycji, takie jak ${ }^{26}$ : koszt kapitału ze szczególnym uwzględnieniem stopy procentowej i efektów podatkowych, zmiany produkcji i sprzedaży oraz dostępność firm do kapitału. W literaturze ekonomicznej wspomniano również o tym, że siła oddziaływania tych zmiennych na wysokość inwestycji uzależniona jest od fazy cyklu koniunkturalnego w danym momencie w gospodarce. D. Jorgenson zaproponował odmienną grupę czynników wpływających na poziom inwestycji opartą na tzw. neoklasycznym modelu inwestycji. Według jego teorii największy wpływ na decyzje przedsiębiorstw związanych z zatrudnieniem, inwestycjami czy produkcją ma maksymalizacja zysku. Decyzje te determinowane są przez ceny rynkowe i bariery technologiczne. $Z$ kolei ceny rynkowe zawierają stopy procentowe oraz czynniki oddziałujące na koszt kapitału tj. amortyzacja, oczekiwania inflacyjne czy obciążenia podatkowe.

Determinanty inwestycji podane przez E. Kwiatkowskiego są istotne dla przeprowadzonych w dalszej części pracy badań empirycznych. Stopa procentowa oddziałując na koszty finansowania inwestycji wpływa na opłacalność projektu inwestycyjnego. Im stopa procentowa jest wyższa, tym droższe staje się finansowanie inwestycji. Zatem, jak podkreśla E. Kwiatkowski, inwestycje są malejącą funkcją stopy procentowej. Uważa się, że inwestycje prowadzą do rozbudowy zdolności wytwórczych. Zwiększanie zdolności wytwórczych jest niezbędne w momencie wzrostu popytu na produkty wytwarzane w danych obiektach produkcyjnych. Stąd im popyt konsumpcyjny jest większy, czyli im wyższa jest skala jego przyrostu, tym wyższy jest poziom inwestycji. Następnie, rozmiar inwestycji uzależniony jest również od kosztów i efektywności wyposażenia kapitałowego. Im koszty wyposażenia kapitałowego są niższe, tym inwestycje są wyższe. Natomiast, jeśli maszyny i urządzenia, czyli wyposażenie kapitałowe staje się bardziej efektywne to przedsiębiorstwo więcej inwestuje. $\mathrm{Na}$ wielkość inwestycji oddziałują również oczekiwania uczestników rynku dotyczące wielkości popytu, cen oraz kosztów. W przypadku optymistycznych ocze-

${ }^{25}$ R. Milewski, op. cit., s. 365.

${ }^{26}$ L. P a w ło w i c z, R. W i e r zb a (red.), Finanse przedsiębiorstw wobec procesów globalizacji, Gdańska Akademia Bankowa, Gdańsk-Jurata 2003, s. 11. 
kiwań zauważyć można zwiększenie rozmiarów bieżących inwestycji z kolei ich spadek przy prognozach pesymistycznych ${ }^{27}$.

Teoria I. Fishera, według której poziom realnych stóp procentowych jest względnie stały i nie jest uzależniony od inflacji pozwala pośrednio wytłumaczyć spadek inwestycji w gospodarce w warunkach wzrostu inflacji. Jeśli stopa inflacji wzrośnie o 1 punkt procentowy to stopa nominalna również wzrośnie o 1 punkt procentowy, a nominalny wzrost stóp procentowych wpłynie na zwiększenie kosztu wynajmu kapitału ${ }^{28}$. D. Romer oraz B. Snowdon i inni, podkreślają, że niepewność wywołana przez inflację jest istotnym czynnikiem negatywnie wpływającym na inwestycje. Niepewność ogranicza oczekiwania uczestników rynku co do przyszłych zysków, co zmniejsza poziom inwestycji oraz tłumaczy ich zmienność. Ponadto, jak postuluje J. Temple, inflacja utrudnia rachunek ekonomiczny, głównie w wyniku nieodpowiedniej wyceny aktywów, nawet $\mathrm{w}$ przypadku uwzględniania jej w rachunkach księgowych przedsiębiorstw. Wiąże się to $\mathrm{z}$ utrudnieniami w ocenie sytuacji na rynku i występowaniem niespodzianki cenowej, o której pisał R. Lucas. Nieoczekiwany wzrost inflacji przyczynia się głównie tylko do przejściowego wzrostu produkcji i inwestycji. Gdy okaże się, że decyzje zostały podjęte błędnie, inwestycje zostają natychmiast wstrzymane i często przedsiębiorcy mogą do nich nie wracać przez długi okres ${ }^{29}$.

Poniżej zaprezentowano uproszczony przykład równowagi w gospodarce zamkniętej w celu podkreślenia złożoności inwestycji i czynników oddziałujących na ich poziom. W tym miejscu należy podkreślić, że rozpatrywane będą inwestycje o charakterze autonomicznym $\left(I=I_{a}\right)^{30}$. W warunkach równowagi poziom dochodu narodowego jest równy sumie planowanych wydatków konsumpcyjnych $(C)$ oraz inwestycyjnych $(I)$, czyli $Y=\mathrm{C}+I$. Wiemy, że poziom dochodu narodowego $(Y)$ w stanie równowagi wyznacza warunek równości agregatowego popytu i produkcji. Przechodzenie zaś od jednego stanu równowagi do drugiego oznacza, że zmiany dochodu $(\Delta Y)$ są równe zmianom agregatowego popytu $\left(\triangle A P_{p}\right)$, czyli $\Delta Y=\Delta A P_{p}$. Ponadto równowaga na rynku towarów występuje wtedy, gdy łączne zamierzone wydatki będą równe faktycznie wytworzonemu dochodowi narodowemu, co zapisujemy poniższym równaniem ${ }^{31}$ :

$$
Y=\Delta A P_{p}=C+I
$$

${ }^{27}$ R. Mile w ski, op. cit., s. 365.

${ }^{28} \mathrm{P}$. B aranowski, Problem optymalnej stopy inflacji $w$ modelowaniu wzrostu gospodarczego, Wydawnictwo Biblioteka, Łódź 2008, s. 43.

${ }^{29}$ Ibidem, s. 43-44.

${ }^{30}$ Inwestycje autonomiczne to inwestycje, które nie są zależne od sytuacji w gospodarce, a szczególnie od popytu konsumpcyjnego. W stosunku do procesów zachodzących w gospodarce mają charakter ekonomiczny. Zazwyczaj wiążą się z przyrostem naturalnym ludzkości, z inwestycjami publicznymi oraz z nowymi wynalazkami wdrażanymi do produkcji.

${ }^{31}$ R. Milews ki, op. cit., s. 365-367. 
Z kolei zamierzone inwestycje są równe różnicy pomiędzy dochodem narodowym a konsumpcją w stanie równowagi: $I=Y-C$, a planowane oszczędności są częścią dochodu narodowego, które nie są przeznaczane na wydatki konsumpcyjne: $S=Y-C$. Stąd wynika, że w warunkach równowagi planowane inwestycje są równe planowanym oszczędnościom: $I=S$. Oczywiście taka sytuacja $\mathrm{w}$ gospodarce nie jest łatwa do osiągnięcia, ponieważ podmioty zachowują się bardzo różnie (jedne podmioty inwestują, z kolei inne oszczędzają, poza tym odmienne są determinanty oszczędzania i inwestycji). Jeśli inwestycje są większe od oszczędności $(I>S)$, wtedy łączne planowane wydatki inwestycyjne i konsumpcyjne przeważają poziom wytworzonej produkcji. Ta nadwyżka popytu przyczyniłaby się do wzrostu produkcji i dochodu narodowego prowadząc do zwiększenia oszczędności aż do zrównania ich z inwestycjami. W przeciwnym wypadku, gdy poziom planowanych inwestycji byłby mniejszy niż poziom oszczędności $(I<S)$, wtedy nadwyżka podaży towarów wpłynęłaby na spadek wielkości produkcji i dochodu narodowego ${ }^{32}$.

Jeśli rosną wydatki autonomiczne w wyniku zmiany wydatków inwestycyjnych, wtedy prowadzi to do wzrostu produkcji dóbr inwestycyjnych w celu zaspokojenia dodatkowego popytu, a tym samym do wzrostu dochodu narodowego. Jednak to nie jest koniec tego procesu. W warunkach niepełnego wykorzystania zdolności wytwórczych następuje pełniejsze wykorzystanie tych istniejących mocy wytwórczych, wzrasta produkcja, rośnie sprzedaż i dochód, który trafia do gospodarstw domowych. Te ostatnie z kolei przeznaczają go na zakup dóbr konsumpcyjnych. W zależności od krańcowej skłonności do konsumpcji $\left(k_{s k}\right)$ rośnie lub spada wysokość dodatkowych wydatków konsumpcyjnych. Im wskaźnik ten jest wyższy, tym większy jest przyrost popytu konsumpcyjnego. Zatem przyrost wydatków inwestycyjnych zapoczątkował ciąg wtórnych wydatków konsumpcyjnych. Ustalono również wzór określający mnożnik inwestycyjny ${ }^{33}: m_{i}=\frac{1}{1-k_{s k}}$. Natomiast łączny przyrost dochodu narodowego w wyniku pierwotnego wzrostu wydatków inwestycyjnych przedstawia się następująco:

Wzór 4.2. Przyrost dochodu narodowego

$$
\Delta Y=m_{i} * \Delta I, \text { czyli: } \Delta Y=\frac{1}{1-k_{s k}} * \Delta I,
$$

gdzie:

$\Delta Y$ - przyrost dochodu narodowego,

$\Delta I-$ przyrost autonomicznych wydatków inwestycyjnych,

$k_{s k} \quad$ - krańcowa skłonność do konsumpcji.

${ }^{32}$ Ibidem, s. 365-370.

${ }^{33}$ Ibidem, s. 365-372. 
Mnożnik inwestycyjny pozwala oszacować, o ile zmieni się dochód narodowy pod wpływem zmian autonomicznych wydatków inwestycyjnych. Przykładowo, jeśli $m_{i}=5$, to przyrost wydatków inwestycyjnych o 1000 przyczyni się do wzrostu dochodu narodowego o 5000. Z teorii ekonomii wynika, że suma przyrostów konsumpcji i oszczędności jest równa przyrostowi dochodu narodowego $^{34}: \Delta C+\Delta S=\Delta Y$, a suma krańcowej skłonności do konsumpcji i krańcowej skłonności do oszczędzania wynosi 1 , co przedstawia wzór: $k_{s k}+k_{s o}=1$. Formułę mnożnika inwestycyjnego można zapisać w inny sposób, korzystając z przekształcenia wzoru $4.2^{35}$ :

$$
k_{s o}=1-k_{s k}, \operatorname{stąd} m_{i}=\frac{1}{1-k_{s k}}=\frac{1}{k_{s o}} .
$$

Wynika z tego, że mnożnik inwestycyjny jest odwrotnością krańcowej skłonności do oszczędzania. Zatem im skłonność do oszczędzania jest wyższa, tym mnożnik inwestycyjny jest niższy. Nasuwa się tutaj stanowisko keynesistów, którzy w przeciwieństwie chociażby do ekonomistów klasycznych i neoklasycznych uważają, że większe oszczędności to mniejsze wydatki inwestycyjne i konsumpcyjne, niższa produkcja i spadek dochodu narodowego. Szerzej i w sposób bardzo dostępny mechanizm ten został opisany przez E. Kwiatkowskiego ${ }^{36}$.

Działalność, szczególnie inwestycyjna, przedsiębiorstw wiąże się z wieloma ograniczeniami i barierami funkcjonowania ${ }^{37}$. Zakumulowany własny majątek oraz oszczędności przedsiębiorców często nie są wystarczające do rozpoczęcia działalności na szeroką skalę. Dodatkowo, zachowawcza polityka kredytowa banków w stosunku do firm potęguje sytuację braku płynności, zatorów płatniczych, opóźnień w regulacjach podatkowych. Przedsiębiorstwa nie posiadają wtedy wystarczających środków na rozwój, inwestycje, wdrażanie nowych technologii. Wszystkie te elementy zagrażają egzystencji firmy, nie wspominając już

${ }^{34}$ Ibidem, s. 363-364.

${ }^{35}$ Ibidem, s. 363-374.

${ }^{36}$ Formuła mnożnika inwestycyjnego została również rozszerzona o podatki w gospodarce, jest on niższy od mnożnika nie uwzględniającego opodatkowania, co oznacza, że każdy wzrost wydatków inwestycyjnych generuje również wzrost dochodu, jednak ten dochód wpływa również na wzrost podatków, co osłabia wzrost wydatków konsumpcyjnych:

$$
m_{i}=\frac{1}{1-k_{s k}(1-t)}, \text { [w:] R. Mile w ski, op. cit., s. } 379 .
$$

${ }^{37}$ T. P. Korkeamaki, M. Rutherford, Industry Effects and Banking Relationship as Determinants of Small Firm Capital Structure Decisions, Gonzaga University, Virginia Commonwealth University, 2006, s. 3-7. 
o osłabieniu zdolności kredytowej przedsiębiorstwa w ocenie banku ${ }^{38}$. Ponadto przedsiębiorstwa borykają się z niewystarczającym poziomem zdolności akumulacyjnych firm, który gwarantowałby zwrot zainwestowanych kapitałów. Jako bariery działalności przedsiębiorstw wymienia się również zbyt wysokie koszty działalności, a przez to niski poziom rentowności, niesprzyjający akumulacji środków. Co więcej, wyszczególnia się również wysokie koszty finansowania środkami z sektora bankowego, podobnie jak z innych zewnętrznych źródeł, wymagane zabezpieczenia, następnie skomplikowane i czasochłonne procedury związane ze zdobyciem środków pieniężnych ze źródeł zewnętrznych. Przeszkodą jest również niewystarczający poziom środków publicznych na wsparcie przedsiębiorstw. W procesie przeprowadzania przez firmę inwestycji istotna jest także wiedza i umiejętności zarządcze kadr kierowniczych oraz właścicieli firm, a ponadto kwalifikacje i świadomość stosowania nowoczesnych instrumentów finansowania i zarządzania kapitałem przedsiębiorstwa oraz wykorzystywanie informacji o dostępnych funduszach czy programach. Poza tym ważna jest także kreatywność w stosowaniu różnych kombinacji źródeł finansowania w zależności od kondycji finansowej firmy i warunków zewnętrznych poprzez ciągłą obserwację szeroko rozumianego środowiska biznesowego ${ }^{39}$.

Ponadto do elementów, które mają hamujący wpływ na prowadzenie działalności, w tym inwestycyjnej, przedsiębiorstw zaliczamy między innymi: nadmiernie zbiurokratyzowany system zakładania nowych przedsiębiorstw, rozbudowany system koncesji i zezwoleń na prowadzenie różnej działalności, skomplikowaną sprawozdawczość oraz niejasne przepisy podatkowe. Są to czynniki ograniczające przedsiębiorczość, mające swoje źródło w polityce gospodarczej państwa. Często firmy, jako główną barierę rozwoju działalności, wymieniają system fiskalny, uważając go nawet za większą przeszkodę niż wysokość stóp procentowych oraz trudności kredytowe (skomplikowane procedury kredytowe, wymagany wysoki poziom zdolności kredytowej i stan zabezpieczeń). Przepisy podatkowe powinny być stabilne w dłuższej perspektywie czasowej, by przedsiębiorca miał poczucie stabilności finansowej, prowadzące do zmniejszenia ryzyka operacyjnego jego działalności oraz zachęcające go do zwiększania zadłużenia poprzez wykorzystywanie kapitałów obcych ${ }^{40}$.

${ }^{38}$ Krajowy Fundusz Kapitatowy jako uzupetnienie systemu finansowania rozwoju sektora MSP, Ministerstwo Gospodarki i Pracy, Departament Polityki Regionalnej, Warszawa 2005, s. 2.

${ }^{39}$ A. S k o wro n e k-M i l c z a rek, Mate i średnie przedsiębiorstwa. Źródta finansowania, Wydawnictwo C. H. Beck, Warszawa 2003, s. 9.

${ }^{40}$ W. J a nik, Stopy procentowe a zapotrzebowanie na obce źródła finansowania przedsiębiorstw, [w:] J. L. B e d n ar c z y k (red.), Stopy procentowe a gospodarka. Eseje z teorii i polityki stóp procentowych, Politechnika Radomska, Radom 2004, s. 98-102. 
Państwo może być również stymulatorem rozwoju przedsiębiorstw poprzez odpowiednie wykorzystanie instrumentów polityki fiskalnej, czego przykładem mogą być ulgi podatkowe, np. ulgi inwestycyjne. Są one jednym z czynników oddziaływania państwa poprzez system fiskalny na proces kreowania i pobudzania aktywności przedsiębiorstw. Istotnym elementem sytemu podatkowego danego państwa jest wysokość stawek podatkowych. Odpowiednio uregulowane prawo w tej kwestii może stymulująco wpływać na rozwój przedsiębiorstw ${ }^{41}$. W Polsce w roku 2010 stawka podatku dochodowego od osób prawnych (CIT) wynosiła 19\% i w ciągu ostatniej dekady (2000-2010) została obniżona z $40 \%$. W Europie w ciągu dekady występowała tendencja spadkowa wysokości stawek podatkowych CIT. Miało to miejsce w Niemczech (z 51,6\% do 29,8\%), Bułgarii (z $32,5 \%$ do 10\%), Grecji (z $40 \%$ do $24 \%$ ), Islandii (z 30\% do 18\%), w Czechach (z 31\% do 19\%) czy Luksemburgu (z 37,5\% do 28,6\%). Statystycznie europejska średnia stawka CIT wynosi $23,2 \%$, co plasuje stawkę podatku dochodowego w Polsce wyraźnie poniżej średniej ${ }^{42}$. Biorąc pod uwagę stawkę podatku dochodowego od osób prawnych można wysunąć wniosek, że polityka fiskalna w Polsce w większym stopniu niż w wielu krajach unijnych stymuluje rozwój przedsiębiorstw.

Na skłonność firm do inwestowania, oprócz poziomu podatków dochodowych i pośrednich, mogą oddziaływać jeszcze takie czynniki jak: poziom deficytu finansów publicznych, jego wpływ na wysokość rynkowych stóp procentowych, zasady stosowania odpisów amortyzacyjnych, dopłaty do kredytu inwestycyjnego, czy współfinansowanie inwestycji ze środków publicznych ${ }^{43}$. Pożądaną formą pomocy dla przedsiębiorstw przez władze fiskalne jest idea Specjalnych Stref Ekonomicznych (SSE). Zasady i warunki powstawania SSE oraz korzyści z faktu prowadzenia działalności na ich obszarze określa Ustawa z dnia 20 października 1994 r. o specjalnych strefach ekonomicznych ${ }^{44}$. Przedsiębiorcy przeprowadzający inwestycje na terenie SSE są zwolnieni z podatku dochodowego z tytułu kosztów nowej inwestycji lub kreowania nowych miejsc pracy. W Polsce istnieje 14 Specjalnych Stref Ekonomicznych (stan na lipiec 2010 r.) ${ }^{45}$.

${ }^{41}$ E. Pohulak-Żołędowska, Zastosowanie ulg i zwolnień $w$ podatkach dochodowych a rozwój MSP ocena, prezentacja wyników badań, [w:] D. K o p y c i ń s k a (red.), Funkcjonowanie gospodarki polskiej w warunkach integracji i globalizacji, Katedra Mikroekonomii Uniwersytetu Szczecińskiego, Szczecin 2005, s. 156.

${ }^{42}$ J. F i s ze r, Polska nie musi obniżać CIT jak inne kraje Unii Europejskiej, „Dziennik Gazeta Prawna", 07.11.2011.

${ }^{43}$ M. S o s now s ki, Podatkowe instrumenty polityki fiskalnej państwa a rozwój przedsiębiorczości, [w:] D. K o p y c iń s k a (red.), Funkcjonowanie gospodarki polskiej w warunkach integracji i globalizacji, Katedra Mikroekonomii Uniwersytetu Szczecińskiego, Szczecin 2005, s. 181.

${ }_{44}$ Ustawa z dnia 20 października 1994 roku o specjalnych strefach ekonomicznych, DzU 2007, nr 42, poz. 274 i DzU 2008, nr 118, poz. 746.

${ }^{45}$ Zasoby oficjalnej witryny internetowej Ministerstwa Gospodarki: http://www.mg.gov.pl/ Przedsiebiorcy/Specjalne+strefy+ekonomiczne [07.07.2010]. 
Uważa się, że rozwój przedsiębiorstw zależy w dużej mierze od czynników makroekonomicznych, takich jak ${ }^{46}$ : popyt wewnętrzny oraz zewnętrzny, poziom stóp procentowych, poziom inflacji, kursy walut. Odnosząc się do powyższego wyszczególnienia, niewystarczający popyt wewnętrzny oraz zewnętrzny może przyczynić się do osłabienia rozwoju przedsiębiorstw. W latach lepszej koniunktury rynkowej przedsiębiorstwa wykazują wyższą dynamikę swojej działalności rozwojowej. Niesprzyjającym czynnikiem dla aktywności inwestycyjnej firm jest również niestabilność finansowa w gospodarce przejawiająca się wysokim poziomem inflacji i znacznymi wahaniami kursów walutowych ${ }^{47}$.

\subsection{2. Źródła finansowania inwestycji przedsiębiorstw}

Wśród wielu zróżnicowanych źródeł pozyskiwania kapitału wyróżnia się dwa główne, wyodrębnione ze względu na pochodzenie pozyskiwanych środków pieniężnych, a mianowicie: finansowanie wewnętrzne i zewnętrzne ${ }^{48}$. Wśród źródeł finansowania zewnętrznego istotne znaczenie ma długoterminowy kredyt inwestycyjny z punktu widzenia przedsiębiorstwa, które podejmuje się realizacji inwestycji. Zapotrzebowanie inwestowania na rzeczowe aktywa trwałe, głównie w przypadku, gdy składniki majątku są niewystarczające do pokrycia potrzeb produkcyjnych przedsiębiorstwa, ma również związek z efektywnością produkcyjną firmy. Im działalność przedsiębiorstwa przynosi wyższe zyski, tym konieczność finansowania zewnętrznego jest mniejsza. Często kolejne zobowiązania finansowe wymagane w przyszłych okresach powstają w związku z zaciągniętymi wcześniej przez przedsiębiorstwa kredytami, pożyczkami, leasingiem finansowym ${ }^{49}$.

Jak podaje F. S. Mira, dopiero po wyczerpaniu kapitałów własnych należy bazować na obcych źródłach ${ }^{50}$. Inne podejście w kwestii finansowania zaprezentowali nobliści F. Modigliani oraz M. H. Miller. Według nich zewnętrzne źródła finansowania są tańsze, głównie ze względu na efekt tarczy podatkowej. Przed-

${ }^{46} \mathrm{~K}$. Ł a ch, Rozwój sektora matych i średnich przedsiębiorstw w Polsce i determinanty tego rozwoju, [za:] zasoby witryny internetowej www.univ.gda.pl/mikro/konferencja/pdf/Lach.pdf [08.07.2010].

${ }^{47} \mathrm{P} . \mathrm{Ciżkowicz,} \mathrm{K}$. R y biński, The role of banking and financial policies in promoting micro, small, and medium enterprises, artykuł przygotowany na konferencję „Macroeconomic Stability: Towards High Growth and Unemployment”, Bank Indonezji, Bali 2007, s. 186.

${ }^{48} \mathrm{M}$. K u row s ka, Ocena zdolności kredytowej matych i średnich przedsiębiorstw, Wydawnictwo Uniwersytetu Łódzkiego, Łódź 2005, s. 25.

${ }^{49}$ A. K u s a k, Jak określić potrzeby finansowe firmy, „ABC finansów” - dodatek do Serwisu Finansowo-Księgowego nr 10(464), 9 marca 2004, s. 2.

${ }^{50}$ F. S. Mira, On Capital Structure in the Small and Medium Enterprises: The Spanish Case, Universidad Cardenal Herrera, Elche 2001, s. 8. 
siębiorstwo finansowane obcym kapitałem wykorzystuje dźwignię finansową, przez co zwrot z zaangażowanego kapitału własnego jest wyższy ${ }^{51}$. Kapitał obcy umożliwia optymalizację struktury kapitału firmy, kiedy wartość przedsiębiorstwa jest największa przy najmniejszej wielkości średniego ważonego kosztu kapitału $^{52}$. Przedsiębiorstwo korzystające $\mathrm{z}$ kapitałów obcych ma możliwość odnoszenia korzyści podatkowych, ponieważ oprocentowanie zobowiązań stanowi koszt pozyskania przychodów (koszt finansowy), który pomniejsza podstawę opodatkowania podatkiem dochodowym ${ }^{53}$.

Struktura źródeł finansowania przedsiębiorstw ma istotny wpływ na koszt kapitału oraz na ryzyko ich działalności. Największe źródło finansowania inwestycji to środki własne (2007 r. - 70,4\%, 2008 r.- 71,4\% ${ }^{54}, 2011$ r. - 69,96\%). Natomiast jako drugie źródło finansowania przedsiębiorstwa najczęściej wykorzystują krajowe kredyty i pożyczki (2007 r. - 13,5\%, 2008 r. - 12,8\%, 2011 r. $-10,21 \%)^{55}$.

W praktyce przedsiębiorstwa w celu wyboru najlepszych źródeł finansowania biorą pod uwagę głównie kryteria wzrostu stopy rentowności kapitałów własnych oraz zapewnienie płynności finansowej przedsiębiorstwa i optymalizację ryzyka finansowego ${ }^{56}$. W przypadku kierowania się strategią wzrostu stopy rentowności kapitałów własnych, przedsiębiorcy biorą również pod uwagę efekt dźwigni finansowej w procesie szacowania opłacalności wykorzystania kapitałów obcych do finansowania firmy. Z punktu widzenia efektywności kapitałów własnych dodatni efekt dźwigni finansowej występuje do momentu zrównania się stopy rentowności majątku z krańcowym kosztem kapitału. Efekt ten uzależniony jest od ceny tych kapitałów, chociażby od poziomu stopy procentowej, ponadto od wielkości zysku ze sprzedaży produktów, usług, towarów, a także od obrotu tym kapitałem. Istotnym czynnikiem wpływającym na zapotrzebowanie na kapitał obcy przedsiębiorstw, o którym wspomina W. Janik, jest sytuacja ekonomiczna państwa. Jeśli $w$ danym kraju ogólne warunki prowadzenia działalności gospodarczej są niesprzyjające, to nawet w przypadku niskich stóp procentowych zainteresowanie rozwojem firm może być niewielkie ${ }^{57}$.

${ }^{51}$ M. Kow alski, Analiza źródet finansowania inwestycji przedsiębiorstw w Polsce, [za:] zasoby witryny internetowej: http://www.wsei.edu.pl/ mkowalski/Kowalski_2004_Analiza\%20 Zrodel\%20Finansowania\%20Inwestycji.pdf [12.09.2010].

${ }^{52}$ Ibidem, s. 7.

${ }^{53}$ A. Dulin i e, Determinanty polityki finansowej przedsiębiorstwa, eFinanse - finansowy kwartalnik internetowy, [za:] zasoby witryny internetowej: www.e-finanse.com [12.02.2011], s. 8-9.

${ }^{54}$ Raport o stanie sektora matych i średnich przedsiębiorstw w Polsce w latach 2008-2009, op. cit., s. 60.

${ }^{55}$ Raport o stanie sektora matych i średnich przedsiębiorstw w Polsce w latach 2011-2012, op. cit., s. 175.

${ }^{56}$ W. J a n i k, op. cit., s. 97.

${ }^{57}$ Ibidem, s. 98-102. 
W związku z występującym w gospodarce powiązaniem wysokości stóp procentowych banku centralnego z poziomem oprocentowania kredytów dla przedsiębiorstw przybliżona została kwestia kredytu bankowego jako częstej formy finansowania zewnętrznego wykorzystywanej przez przedsiębiorstwa.

\subsection{Kredyt bankowy jako forma finansowania przedsiębiorstw}

Kredyt staje się coraz ważniejszym instrumentem w obszarze działalności bieżącej i inwestycyjnej firm. Skala zadłużenia długoterminowego firm w bankach w Polsce z pewnością jest istotna dla gospodarki. W 2008 r. znacznie wzrosły zobowiązania długoterminowe przedsiębiorstw, osiągając poziom $226,8 \mathrm{mld}$ zł (wzrost o $15,6 \%$ w stosunku do roku 2007). Był to wyraźny skok wartości zobowiązań długoterminowych firm w stosunku do lat 2003-2007. Znacznie szybszy wzrost zobowiązań długoterminowych odnotowano w 2008 r. wśród przedsiębiorstw dużych (o 23,1\% w porównaniu do roku wcześniejszego). Natomiast przedsiębiorstwa małe i średnie zwiększyły zobowiązania wobec banków o odpowiednio 8,5\% i 5,1\% ${ }^{58}$. Również w 2009 r. nastąpił wzrost zobowiązań długoterminowych $(254,6 \mathrm{mld}$ zł) przedsiębiorstw (istotny wzrost zadłużenia dużych przedsiębiorstw o $21,9 \%$ oraz firm małych o $10,6 \%{ }^{59}$ ). W latach 2010-2011 zobowiązania długoterminowe przedsiębiorstw ogółem wyniosły odpowiednio 267,7 mld zł i 319, 16 mld zł. ${ }^{60}$ Zapotrzebowanie na kapitał, którego wyrazem jest poszukiwanie dostępu do obcego finansowania, w tym do kredytu bankowego, wynika z potrzeb bieżącej działalności przedsiębiorstw i konieczności realizacji ich projektów inwestycyjnych ${ }^{61}$. Poszukiwanie przez firmy obcych źródeł finansowania jest sposobem na przełamanie bariery niedoboru środków pieniężnych. Brak zasobów finansowych staje się przeszkodą w dynamizacji i ekspansji działalności oraz wzroście efektywności ${ }^{62}$. Jedną z form finansowania przedsiębiorstw przez banki są kredyty gospodarcze. Kredyty te przeznaczone są na finansowanie potrzeb przedsiębiorstw związanych z prowadzoną przez nie dzia-

${ }^{58}$ Raport o stanie sektora matych i średnich przedsiębiorstw $w$ Polsce w latach 2008-2009, op. cit., s. 54.

${ }^{59}$ Dane te odnoszą się do zobowiązań na jedno przedsiębiorstwo, [w:] Raport o stanie sektora małych i średnich przedsiębiorstw w Polsce w latach 2009-2010, Polska Agencja Rozwoju Przedsiębiorczości, Warszawa 2011, s. 26-27.

${ }^{60}$ Raport o stanie sektora matych i średnich przedsiębiorstw $w$ Polsce $w$ latach 2011-2012, op. cit., s. 174.

${ }^{61}$ T. Ł u c z k a, Kapitat obcy w matym i średnim przedsiębiorstwie, Wydawnictwo Naukowe PWN, Warszawa-Poznań 2001, s. 33.

${ }^{62}$ A. S z c z ę s n a, Ryzyko i mechanizm dźwigni w działalności przedsiębiorstwa, [w:] Zarzadzanie finansami. Wspótczesne tendencje w teorii i praktyce, Uniwersytet Szczeciński, Szczecin 2000, s. 359. 
łalnością gospodarczą. Kredyty gospodarcze dzielą się na: ${ }^{63}$ kredyty obrotowe oraz kredyty inwestycyjne.

Kredyty inwestycyjne wykorzystywane przez przedsiębiorstwa związane są najczęściej z nakładami na wzrost produkcji, optymalizację kosztów czy wzrost jakości wyrobów. M. J. Barclay i C. W. Smith zauważyli, że przedsiębiorstwa o dużym potencjale wzrostu preferują raczej kredyty krótkoterminowe na rozwój działalności niż długoterminowe długi. Wynika to głównie z chęci utrzymania płynności finansowej przez przedsiębiorstwa ${ }^{64}$. Banki komercyjne przedstawiają szeroką ofertę kredytów inwestycyjnych nie tylko we własnym zakresie, ale również w porozumieniu z Europejskim Bankiem Inwestycyjnym, Unią Europejską czy Radą Europy. Banki oferują różny okres kredytowania (od 5 do 25 lat), kwoty kredytów w kilku walutach zależne od wartości inwestycji oraz umożliwiają przeznaczenie kredytów na różne cele związane z działalnością gospodarczą.

W celu minimalizacji ryzyka zaistnienia niekorzystnej dla banków sytuacji, dokonują one selekcji wśród podmiotów gospodarczych ubiegających się o kredyt ${ }^{65}$. Stąd istotne znaczenie ma rodzaj i jakość posiadanych przez przedsiębiorcę zabezpieczeń, które dzielimy na ${ }^{66}$ : zabezpieczenia ekonomiczne, zabezpieczenia psychologiczne oraz zabezpieczenia prawne. R. Inders i H. M. Mueller zwrócili uwagę na fakt, że oferowanie bankom odpowiedniego zabezpieczenia, daje firmom możliwość negocjowania niższej ceny kredytu ${ }^{67}$, chociaż posiadanie przez firmy odpowiednich form zabezpieczenia nie jest wystarczającym warunkiem uzyskania kredytu ${ }^{68}$. Banki w ramach weryfikacji kredytowej wymagają od przedsiębiorstw wielu dokumentów oraz dowodów ich wiarygodności

${ }^{63}$ M. Gó r s ki, Rynkowy system finansowy, PWE, Warszawa 2007, s. 149.

${ }^{64}$ J. M. B arclay, C. W. S mith Jr., The capital structure puzzle: Another look at the evidence, ,Journal of Applied Corporate Finance”, Spring 1999, vol. 12, no. 1, s. 8-20.

${ }^{65}$ J. R. B o ot, L. C. B o ot, Loan Collateral Decisions and Corporate Borrowing Costs, „Journal of Money, Credit and Banking” 2006, vol. 38, s. 67-90.

${ }^{66} \mathrm{~T}$. N a r o ż n y, Czynności kredytowe banku, Biblioteka Menedżera i Bankowca, Warszawa 2000, s. 56.

${ }^{67}$ R. Ind e r s, H. M. Muelle r, A Lender-Based Theory of Collateral, ,Journal of Financial Economics" 2007, s. 3-5.

${ }^{68}$ Kryzys finansowy wzmaga występowanie problemu asymetrii informacji. Mishkin podaje czynniki, które dodatkowo wpływają na nasilenie sytuacji kryzysowych, jak: wzrost stóp procentowych, spadek cen giełdowych, nieoczekiwanie niższa inflacja, większa niepewność oraz panika w sektorze bankowym. W rezultacie asymetria informacji prowadzi do racjonowania kredytu, a restrykcje kredytowe w postaci zabezpieczeń kredytowych łagodzą tę asymetrię. A. N. Berger i G. F. Udell oraz A. Chakraborty i C. X. Hu podają, że zabezpieczenie kredytu działa dyscyplinująco na kredytobiorców. Natomiast M. Śpiewak, W. Thor oraz Ł. Witkowski kontestują, że zabezpieczenie kredytu może oddziaływać na wyższą podaż kredytu, co ogranicza prawdopodobieństwo wystąpienia jego racjonowania, [za:] P. W d o w i ń s ki, Ekonometryczna analiza popytu na kredyt w polskiej gospodarce, Urząd Komisji Nadzoru Finansowego, Warszawa 2011/DAR/ A/J/2011/00, s. 6. 
i zdolności kredytowej. Na podstawie systemów weryfikacji kredytowej klientów, banki mają możliwość oszacowania ryzyka, na które są narażone decydując się na finansowanie potencjalnego kredytobiorcy.

Banki komercyjne uzależniają swoje ceny kredytów dla podmiotów gospodarczych również od norm, jakie nakłada na nie nadzór bankowy, który zajmuje się sprawą bezpieczeństwa ekonomicznego wkładów oszczędnościowych i lokat depozytariuszy. Wyróżnia się wiele form regulacji ostrożnościowych, jak chociażby tych związanych z zasadami określania wymogów kapitałowych, lokalowych, kadrowych, ochrony depozytów czy norm wskaźnikowych ${ }^{69}$. Wśród czynności regulacyjnych wyróżnia się między innymi: ustalanie norm płynności finansowej, minimum kapitału własnego banku, mierników dotyczących pokrycia aktywów banku funduszami własnymi. Obejmują one również regulacje ryzyka dopuszczalnego w banku, a także zabezpieczeń materialnych i prawnych. Normy ostrożnościowe ustalane dla banków odnoszą się do takich obszarów jak: fundusze własne ${ }^{70}$, koncentracja wierzytelności ${ }^{71}$, adekwatność kapitałowa ${ }^{72}$.

Regulacje ostrożnościowe w procesie dostępności kredytów dla przedsiębiorstw mają istotne znaczenie za pośrednictwem mechanizmu cenowego, który odnosi się głównie do adekwatności kapitałowej oraz zasad tworzenia rezerw przez banki. Zmiany regulacji ostrożnościowych wpływają na ceny kredytów, a przez to na ich dostępność dla klientów ${ }^{73}$. Chociaż niechęć banków do finansowania MMSP, ze względu na wyższe ryzyko niż w przypadku dużych korporacji, stopniowo ustępuje, jednak wciąż można mówić o procyklicznej ocenie ryzyka przez banki. Odnosi się ona do tego, że w okresie dobrej koniunktury banki częściej angażują się w działalność kredytową dla

${ }^{69}$ A. I wańczuk, Zarzadzanie ryzykiem $w$ banku jako przedmiot regulacji zewnętrznych, [w:] M. Marcinkowska, St. Wieteska (red.), Harmonizacja bankowości i ubezpieczeń w skali narodowej i europejskiej, Difin, Warszawa 2007, s. 200-205.

${ }^{70}$ Fundusze własne banku powinny być utrzymywane na poziomie nie mniejszym niż $5 \mathrm{mln}$ euro, w tym aporty rzeczowe nie powinny przekraczać $15 \%$ funduszy zasadniczych, fundusze własne i kapitał krótkoterminowy pomniejszony o wartość przekroczenia progu koncentracji kapitałowej nie powinny być mniejsze niż suma wymogów kapitałowych, tak by współczynnik wypłacalności był nie niższy niż $8 \%$.

71 Koncentracja wierzytelności nie powinna przekraczać progu 20\% funduszy własnych w stosunku do podmiotów powiązanych z bankiem, 25\% funduszy własnych w stosunku do podmiotów niepowiązanych, natomiast suma znaczących zaangażowań banku tj. powyżej $10 \%$ nie może przekraczać $800 \%$ funduszy własnych.

${ }^{72}$ Współczynnik wypłacalności powinien znajdować się na poziomie co najmniej 8\%, a bank rozpoczynający działalność operacyjną na poziomie co najmniej 15\% przez pierwsze 12 miesięcy działalności, a przez następne 12 miesięcy działalności chociaż $12 \%$.

${ }^{73}$ W. W a t a n a e, How Do Relationship Lenders Price Loans to Small Firms?, „Hold-up”, Costs, Transparency, and Private and Public Security, Faculty of Business and Commerce, Keio University, September 2007, s. 5. 
przedsiębiorstw, natomiast w czasie recesji raczej skłaniają się do ograniczania dostępności kredytów dla firm ${ }^{74}$.

Według badań przeprowadzonych przez C. Cottarellego, G. Dell’Ariccia i I. Vladkova-Hollar na grupie krajów, które przeszły transformację systemową, Polska należy do grupy tzw. rannych ptaszków (early birds), czyli państw, które notują wzrost wartości współczynnika kredytów bankowych dla sektora prywatnego do PKB. Wyniki zostały opracowane dla Polski w latach 1998-2002 - zaobserwowano wzrost tego współczynnika o 1,5 punktu procentowego powyżej przyrostu $\mathrm{PKB}^{75}$. Jednak właściwie od momentu zachwiania spowodowanego kryzysem finansowym, który pojawił się na rynku światowym już w II połowie 2007 r., można było zauważyć stopniowy spadek wielkości kredytów dla sektora prywatnego. Spowolnienie gospodarcze było jeszcze pogłębiane poprzez restrykcyjne zachowanie polskich banków komercyjnych, które znacząco podniosły koszty kredytów i zaostrzyły warunki pożyczania pieniędzy. Takie decyzje banków komercyjnych były spowodowane raczej warunkami zewnętrznymi niż wewnętrznymi, niemniej jednak międzynarodowy kryzys został przeniesiony na polski rynek międzybankowy ograniczając liczbę transakcji i prowadząc do znacznych wzrostów spread. W rezultacie zaostrzenia standardów kredytowych, jak chociażby wymogów dotyczących ich zabezpieczeń, spowodowały, że wielkość kredytów dla przedsiębiorstw wyraźnie spadła w 2009 r. $^{76}$

Jednym z istotnych ograniczeń dla przedsiębiorstw w kwestii dostępności kredytów jest wysokość stopy oprocentowania kredytów. Środowisko przedsiębiorców oczekuje od Rady Polityki Pieniężnej, że poprzez ekspansywną politykę stóp procentowych stworzy możliwości uzyskania tańszego kredytu inwestycyjnego. Bank centralny ustalając poziom stóp procentowych bierze pod uwagę przede wszystkim cel inflacyjny i dlatego wielokrotnie decyduje się na wyższe stopy procentowe, by ograniczyć wzrost inflacji, nawet kosztem mniej dostępnych kredytów ${ }^{77}$. W przypadku kredytów banki komercyjne przy ustalaniu ich ceny głównie kierują się wysokością oprocentowania 1-miesięcznej stopy WIBOR, która jest uzależniona od krótkoterminowych operacji otwartego ryn-

${ }^{74}$ M. I w a n i c z-Dro z d o w s k a, Wptyw zmian w regulacjach ostrożnościowych na dostępność kredytów dla matych i średnich przedsiębiorstw. Wyniki badań ankietowych, „Bank i Kredyt", marzec 2006, s. 67.

${ }^{75}$ C. Cottarelli, G. De11' Ariccia, I. V ladkova-Hollar, Early Birds, Late Riders, and Sleeping Beauties: Bank Credit Growth to the Private Sector in Central and Eastern Europe and the Balkans, „IMF Working Paper”, November 2003, s. 8, [w:] M. Iwanicz- Drozdowska, Wptyw zmian w regulacjach ostrożnościowych na dostępność kredytów dla matych i średnich przedsiębiorstw. Wyniki badań ankietowych, „Bank i Kredyt”, marzec 2006.

${ }^{76}$ M. B rzoza-Brzezina, K. Makarski, Credit Crunch in Small Open Economy, Narodowy Bank Polski, listopad 2009, s. 2.

${ }_{77}$ A. S. Krysiak, Stopy procentowe a polityka kredytowa wobec matych i średnich przedsiębiorstw w Polsce, [w:] J. L. B e d n arc z y k (red.), Stopy procentowe a gospodarka. Dylematy Unii Gospodarczej $i$ Walutowej, Radom 2006, s.139. 
$\mathrm{ku}^{78}$ (w przypadku niektórych kredytów inwestycyjnych banki biorą również jako podstawę stopę oprocentowania WIBOR $3 \mathrm{M}$ ). Z kolei oprocentowanie kredytów i depozytów banków oddziałuje na poziom konsumpcji oraz inwestycji $^{79}$.

W zależności od wahań stóp procentowych zmieniają się decyzje podmiotów gospodarczych, które kalkulując cenę kredytu szacują, czy dana inwestycja przyniesie im korzyści finansowe. Podmioty gospodarcze zachowują się zazwyczaj zgodnie z prawami ekonomicznymi. W przypadku wzrostu stóp procentowych zwykle poziom udzielonych przez banki kredytów spada, zaś depozytów rośnie. Z kolei spadek stóp procentowych przyczynia się do większej liczby udzielonych przez banki kredytów i ograniczania przez jednostki gospodarcze poziomu depozytów ${ }^{80}$. Potwierdzają to badania przeprowadzone dla Polski przez E. Wróbel, M. Pawłowską i T. Chmielewskiego, które potwierdzają, że restrykcyjna polityka pieniężna oddziałuje na ograniczenie podaży kredytu (głównie w odniesieniu do banków mniejszych o niskiej kapitalizacji ${ }^{81}$.

Bank centralny może wpływać na akcję kredytową banków komercyjnych emitując bony pieniężne, które mają na celu absorbowanie nadwyżki płynności i tym samym ograniczają podaż kredytów na rynku. Bank centralny może również wzmocnić kondycję finansową systemu bankowego poprzez wpływ na stopę procentową ${ }^{82}$. Dodatkowo obniżając rentowność papierów wartościowych (wzrost cen papierów, spadek ich oprocentowania) bank centralny wpływa na obniżenie skłonności do oszczędzania. Dla banków komercyjnych korzystniej jest wtedy zwiększyć podaż kredytów, co następnie przyczynia się do pobudzenia popytu wewnętrznego oraz do wzrostu gospodarczego ${ }^{83}$.

W przypadku dekoniunktury i niskiej stopy zwrotu jednostki gospodarcze często rezygnują z finansowania inwestycji kredytami, między innymi z powodu wzrostu ceny tych kredytów (chociaż nie zawsze w okresie dekoniunktury ceny

${ }^{78}$ M. S o b o 1, Polityka pieniężna Narodowego Banku Polskiego w drodze do euro, Wydawnictwo Fachowe CeDeWu, Warszawa 2008, s. 138.

${ }^{79}$ A. Sławiński, J. O siński, Operacje otwartego rynku banku centralnego, Fundacja Edukacji i Badań Bankowych, Warszawa 1995, s. 49.

${ }^{80} \mathrm{~A} . \mathrm{S} \mathrm{zel}$ ąg o w s ka, Interest rates as a factor impacting the price of basic bank products, [w:] J. L. Bednarczyk (red.), Stopy procentowe a gospodarka. Eseje z teorii i polityki stóp procentowych, Wydawnictwo Politechniki Radomskiej, Radom 2004, s. 128.

${ }^{81}$ E. W ró be l, M. P a wło w s ka, Monetary transmission in Poland: Some evidence on interest rate and credit channles, „Materiały i Studia” 2002, nr 24; oraz T. Ch mi e l e w s k i, Bank Risk and Credit Rationing, ,Quarterly Journal of Economics” 2005, vol. 74(2), s. 258-278.

${ }^{82}$ I. D. Czechowska, Wykorzystanie bonów pieniężnych $w$ ramach polityki pieniężnej, [w:] J. L. B ednarczyk (red.), Stopy procentowe a gospodarka. Dylematy Unii Gospodarczej $i$ Walutowej, Wydawnictwo Instytutu Technologii Eksploatacyjnej Państwowego Instytutu Badawczego, Radom 2006, s. 151.

${ }^{83}$ M. J a r e m k o, M. W i śn i e w s ki, Wptyw polityki stóp procentowych na nadptynność sektora bankowego w Polsce, [w:] W. Przybylska-Kapuścińska (red.), Polityka pieniężna i rynek, ,Zeszyty naukowe Akademii Ekonomicznej w Poznaniu” 2003, nr 26, s. 50-52. 
kredytów rosną) i niestabilnej sytuacji gospodarczej. Istotnym czynnikiem niesprzyjającym zwiększeniu akcji kredytowej banków komercyjnych jest również inflacja. A. Wojtyna podkreśla, że w sytuacji wzrostu inflacji mamy do czynienia z restrykcyjną polityką pieniężną, która przejawia się podwyższaniem stóp procentowych banku centralnego. $\mathrm{Z}$ kolei wysokie stopy procentowe prowadzą do spadku poziomu inwestycji i dodatkowo przez proces akceleracji utrwalają inflację w krótkim okresie ${ }^{84}$.

\subsection{Czynniki wpływające na ceny kredytów dla przedsiębiorstw}

Banki komercyjne dążąc do optymalizacji zysków oraz minimalizacji ryzyka swojej działalności szacują cenę kredytu, traktując ją jako jeden z najważniejszych elementów w polityce bankowej, który ma wpływ na poziom ryzyka ponoszonego przez bank. Cena kredytu zależy od wielu czynników takich jak ${ }^{85}$ : polityka cenowa banku, rynkowe uwarunkowania funkcjonowania banku, rodzaj instrumentu kredytowego.

Polityka cenowa banku uzależniona jest od jego strategii, która opiera się na kształtowaniu wiodącej pozycji rynkowej w zakresie bankowości korporacyjnej albo banku o dominującej pozycji na rynku określonych produktów i usług. Polityka cenowa zależy także od wewnętrznych możliwości i warunków, jakimi dysponuje bank, między innymi: poziomu aktywów, pasywów czy kosztów własnych. Elementy te wpływają na politykę cenową banku, która ma odzwierciedlenie w cenach kredytów. Z kolei rynkowe uwarunkowania funkcjonowania banku zależne są od zewnętrznych czynników, na które bank nie ma wpływu, a ich oddziaływanie przejawia się $\mathrm{w}$ jego polityce cenowej. Wśród tych zewnętrznych czynników wyróżniamy głównie zmienne makroekonomiczne takie jak: podaż pieniądza i inflacja oraz te parametry, które wyrażają stopień konkurencyjności pomiędzy bankami na szczeblu krajowym jak i światowym, według charakteru ich działalności. Rodzaj instrumentu kredytowego to kolejny czynnik w procesie szacowania ceny kredytu. Podstawą ustalania ceny instrumentów kredytowych są następujące dane: czas trwania transakcji oraz stopień bezpieczeństwa, który z kolei zależy od poziomu i jakości zabezpieczeń. W procesie ustalania ceny kredytu uwzględnia się jeszcze czynniki dodatkowe, a mianowicie tzw. koncepcje ustalania ceny kredytu do których należą ${ }^{86}$ : metoda kosztowa, metoda relacyjna, metoda rynkowa.

${ }^{84}$ A. Wojty na, Skuteczność polityki pieniężnej w warunkach niskiej inflacji: Problem zerowej granicy nominalnych stop procentowych, „Bank i Kredyt” 2001, nr 7, s. 47.

${ }^{85}$ D. Gątarek, R. Maksymiuk, M. Krysiak, Ł. Witkowski, Nowoczesne metody zarzqdzania ryzykiem finansowym, WIG Press, Warszawa 2001, s. 104-107.

${ }^{86}$ Ibidem, s. 104-108. 
Stosując metodę kosztową bank uwzględnia koszty własne w cenie kredytu. Koszty własne banku zawarte są w marży odsetkowej, w prowizjach i opłatach bankowych. Wyróżnić można wiele kosztów związanych z różnymi kredytami, są to: koszty kapitału banku, koszty wynikające z pracy personelu bankowego oraz związane z ryzykiem transakcji. W celu precyzyjnego oszacowania ceny kredytu należy wcześniej określić oprocentowanie depozytów. Bierze się również pod uwagę fakt, że cena kredytu powinna wygenerować nie tylko środki do pokrycia kosztów własnych banku, ale również zysk. Przy ustalaniu oprocentowania uwzględnia się również stopę inflacji i koszt alternatywny pozyskania pieniądza. Następnie szacuje się współczynnik określający wielkość pasywów wykorzystywanych w akcji kredytowej, uwzględniając przy tym koszty związane z utrzymaniem rezerw obowiązkowych oraz ustalonego poziomu gotówki w kasie i na rachunku bieżącym w banku centralnym. Innymi elementami cenotwórczymi są: koszty związane z obsługą klienta, koszty ogólnego ryzyka, koszty własne, niepokryte przez prowizje i opłaty, stopa zysku, koszty związane $\mathrm{z}$ ryzykiem specyficznym klienta, tj. prawdopodobieństwa utraty jego zdolności kredytowe $^{87}$. Zatem ustalenie ceny kredytu i zarazem ograniczanie ryzyka kredytowego jest zadaniem skomplikowanym i wymagającym szerokiej analizy wielu przypadków i elementów mających istotny wpływ na ostateczne decyzje.

Metoda relacyjna polega na wycenie relacji banku z przedsiębiorstwem, a dokładniej na ocenie rentowności współpracy banku z klientem. Ponadto metoda ta zawiera w sobie również wycenę kredytu w ramach relacji, tzn. określenie ceny kredytu w nawiązaniu do kosztów i dochodów dotyczących powiązań banku z przedsiębiorstwem. Należy w tym miejscu podkreślić, że metoda ta oparta jest na uznaniowych decyzjach kierownictwa banku. Często bank wymaga zakładania przez firmę salda kompensacyjnego będącego nieoprocentowanym depozytem w wysokości około 10-20\% nominalnej wartości kredytu. Jest to dla banku zabezpieczenie, a zarazem źródło finansowania kredytu zwiększające efektywną stopę oprocentowania tego kredytu. Celem wyceny kredytu na podstawie metody relacyjnej, oprócz możliwości uzyskania jego niższej ceny, będącej wynikiem wkładu przedsiębiorstwa do funduszy banku w postaci depozytu, są korzyści z długoterminowej współpracy ze stałymi klientami ${ }^{88}$.

Natomiast metoda rynkowa, według której ryzyko kredytowe nie ma bezpośredniego wpływu na cenę kredytu, oparta jest na przesłankach rynkowych i zależy od popytu i podaży na rynku kredytowym. Ustalając ceny kredytów metodą rynkową $\mathrm{w}$ warunkach asymetrii informacji, mającej wpływ na równowagę na rynku kredytowym, uwzględnia się takie czynniki jak: polityka kredytowa banku i jego ogólna strategia cenowa, stopa inflacji, segment rynku i stra-

${ }^{87} \mathrm{Cz} . \mathrm{Mes} \mathrm{j}$ a s z, L. Me s j a s z, Wycena kredytu dla przedsiębiorstwa - założenia teoretyczne i przeglad metod, „Bank i Kredyt”, wrzesień 2000, s. 62-64.

${ }^{88}$ Ibidem, s. 68-69. 
tegia $\mathrm{w}$ danym segmencie oraz tzw. benchmarking cenowy, czyli porównanie $\mathrm{z}$ cenami oferowanymi w innych bankach. Wycena rynkowa opiera się na kosztach niezmiennych oraz zmiennych będących sumą wszystkich składników negocjowalnych. Istotną rolę $\mathrm{w}$ negocjacjach ceny kredytu pomiędzy bankiem a przedsiębiorstwem odgrywa podejście oparte na benchmarkingu cenowym. Istota benchmarkingu polega na analizie przez obie strony cen dla podobnych transakcji i zgodnie z tym wzorcem ustalaniu ceny kredytu. W tym przypadku ważne jest określenie źródła wzorców benchmarkingowych, które najczęściej obejmują: ceny kredytów należących do tej samej klasy ryzyka, ceny kredytów pomostowych oraz ceny obligacji emitowanych przez przedsiębiorstwa wykorzystywanych do porównań z cenami kredytów o stałej stopie procentowej ${ }^{89}$.

Bank w zamian za udzielenie kredytu pobiera wynagrodzenie w postaci odsetek, które pokrywają koszt pozyskania środków niezbędnych do jego udzielenia $^{90}$. Zgodnie $\mathrm{z}$ umową kredytową bank nalicza odsetki według stałej bądź zmiennej stopy procentowej. Poza odsetkami bank pobiera również prowizję, która jest częścią kosztu kredytu. Występują różne rodzaje prowizji, takie jak ${ }^{91}$ : prowizja przygotowawcza, płatna przed uruchomieniem kredytu; prowizja podstawowa, dotycząca obsługi kredytu przez bank; prowizja od zaangażowania w przypadku kredytu w rachunku bieżącym; prowizja od przedterminowej spłaty kredytu (banki często rezygnują z tej prowizji w celu eliminacji czynników zniechęcających klientów do zaciągania kredytów). Cenę kredytu dla kredytobiorcy można wyrazić za pomocą poniższego wzoru ${ }^{92}$ :

Wzór 4.3. Cena kredytu (1)

$$
R=R_{n}+\frac{P \times 12}{t_{k}}+\frac{O_{p} \times 100}{K}
$$

gdzie:

$R_{n}$ - oprocentowanie nominalne (według umowy),

$P$ - prowizja,

$t_{k}$ - okres kredytowania,

$O_{p}$ - inne opłaty ponoszone przez kredytobiorcę (koszty pośrednie),

$K$ - wielkość przyznanego kredytu.

\footnotetext{
${ }^{89}$ Ibidem, s. 68.

${ }^{90}$ W. W a t a n a be, How..., op. cit., s. 5.

${ }^{91}$ W. W ą s o w s k i, Ekonomika i finanse banku komercyjnego, Difin, Warszawa 2004, s. 69.

92 Ibidem, s. 69.
} 
Do kosztów pośrednich banki kwalifikują między innymi takie elementy jak: wycena nieruchomości, ubezpieczenie nieruchomości, czy maszyn będących zabezpieczeniem, koszty opracowań wymaganych przez bank, jak np. biznes- plan $^{93}$.

Według innej metody ustalania kosztu kredytu, ceną kredytu jest pierwszorzędna stopa procentowa (prime rate). Określa się ją jako stopę bazową albo referencyjną. Jest to stopa od krótkoterminowych kredytów, wymagana przez banki od najbardziej wiarygodnych klientów ${ }^{94}$. W metodzie tej wykorzystuje się następujące elementy ${ }^{95}$ : stawkę transferową oraz marże: na ryzyko kredytowe, na koszty operacyjne i na zysk. W celu wyznaczenia ceny kredytu przy zmiennej stopie procentowej wykorzystuje się stopę bazową oraz marże. Za stopę bazową przyjmuje się stawkę WIBOR bądź LIBOR w zależności od waluty kredytu, natomiast marża jest stałym elementem ceny kredytu. Sposób ustalenia ceny kredytu obrazuje poniższy wzór ${ }^{96}$ :

Wzór 4.4. Cena kredytu (2)

$$
R=R_{o}(1+\alpha)(1+\beta)(1+x)
$$

gdzie:

$R_{0}$ - stopa oprocentowania depozytów,

$\alpha$ - stopa rezerwy obowiązkowej,

$\beta$ - narzut na ryzyko kredytowe, szacowany jako rekompensata straty kredytów,

$x \quad$ - numer okresu (od 1 do $n)$.

Narzut na ryzyko kredytowe oraz inne narzuty wchodzą w skład marży banku, która powinna uwzględniać warunki występujące na rynku.

Należy dodać, że dwie metody szacowania ceny kredytu, jak: metoda kosztowa oraz metoda porównawcza mogą być wykorzystywane jednocześnie. Według metody kosztowej cena kredytu obliczana jest według następującego wariantu ${ }^{97}$ :

Wzór 4.5. Cena kredytu według metody kosztowej

$$
C=K+K d+M
$$

${ }^{93} \mathrm{~S}$. Fros t, The construction of price indexes for deposit and loan facilities, Australian Bureau of Statistics, Canberra 2001, s. 1-7.

${ }^{94} \mathrm{Cz}$. Mesjas z, L. Mesjas z, op. cit., s. 66.

${ }^{95} \mathrm{~W}$. W ą s o w s k i, op. cit., s. 70.

${ }^{96}$ Ibidem, s. 70.

${ }^{97}$ Ibidem. 
gdzie:

$K$ - koszt pozyskania kapitału (krańcowy koszt pozyskania),

$K d-$ koszt działania,

$M$ - marża zawierająca koszt ryzyka oraz zysk.

Z kolei metoda porównawcza wyznaczania ceny kredytu opiera się na porównaniu stopy procentowej dla transakcji alternatywnych (np. bony skarbowe) wraz z szacunkową oceną ryzyka oraz stopą konkurencji na rynku.

Kredytowanie przedsiębiorstw przez banki jest uzależnione od wielu czynników. M. A. Petersen i R. G. Rajan wymieniają przede wszystkim skłonność kredytobiorcy do spłacania zobowiązań na podstawie dotychczasowej historii kredytowej podmiotu oraz możliwości spłaty tego długu na podstawie sytuacji ekonomicznej podmiotu i warunków makroekonomicznych mających wpływ na prawdopodobieństwo uregulowania zobowiązań. Dużo zależy również od dostępności zabezpieczeń jakie kredytobiorca może przeznaczyć na spłatę zadłużenia oraz od kapitałów własnych przedsiębiorstwa ${ }^{98}$. Stąd banki weryfikują zdolność kredytową klientów, co ma również wpływ na cenę kredytu bankowego.

Zanim banki podejmą decyzję o podpisaniu umowy kredytu z klientem dokonują analizy dwóch podstawowych kategorii zdolności kredytowej. Pierwszą jest ocena sytuacji formalnoprawnej przedsiębiorcy, a druga dotyczy sprawdzenia zdolności kredytowej firmy pod względem merytorycznym, uwzględniając przy tym ryzyko kredytowe banku ${ }^{99}$. Początkowo w ramach oceny sytuacji formalnoprawnej weryfikowana jest zdolność przedsiębiorcy do podejmowania czynności prawnych, do zaciągania zobowiązań finansowych oraz wiarygodność informacji podanych przez potencjalnego kredytobiorcę. Następnie przeprowadzana jest ocena merytoryczna, obejmująca aspekt personalny i ekonomiczny. W przypadku analizy zdolności merytorycznej pod kątem personalnym, bank weryfikuje wiarygodność kredytową klientów oceniając elementy wpływające na zaufanie do kredytobiorcy. Natomiast mając na uwadze aspekt ekonomiczny banki podejmują się weryfikacji dokumentów i informacji źródłowych opisujących sytuację ekonomiczno-finansową przedsiębiorstwa. Dokonują oceny kondycji finansowej kredytobiorcy, oceniają zdolność kredytową, oszacowują klasę i kategorię ryzyka kredytowego banku oraz opracowują warunki kredytowania $^{100}$. Banki komercyjne nie udzielają kredytów bez odpowiedniej dokumentacji. Najczęściej wymaganymi dokumentami, które przedsiębiorcy są zobowiązani dostarczyć w celu uzyskania kredytu, są wszelkie dokumentacje potwierdza-

${ }^{98}$ M. A. Petersen, R. G. Rajan, The Benefis of Lending Relationships: Evidence from Small Business Data, „The Journal of Finance” 1994, vol. 49, no. 1, s. 3-37.

${ }^{99}$ W. L. J a w o r ski (red.), Wspótczesny bank, Poltext, Warszawa 2002, s. 370.

${ }^{100}$ T. Popow, Badanie wiarygodności kredytowej przedsiębiorstw przez bank, [w:] A. Kopczyk (red.), Wiarygodność ekonomiczna przedsiębiorstwa - ocena i ksztattowanie, Wyższa Szkoła Finansów i Zarządzania, Białystok 2004, s. 438. 
jące status prawny klienta, uprawniające go do prowadzenia działalności gospodarczej, informacje o majątku osobistym kredytobiorcy lub ewentualnego poręczyciela. Poza tym bank wymaga sprawozdań finansowych, również tych analitycznych, zaświadczeń o stanie zobowiązań podatkowych wobec budżetu państwa czy zakładu ubezpieczeń. Ponadto należy podać informacje związane z przedsięwzięciem inwestycyjnym, dokumenty dotyczące zabezpieczeń kredytu oraz umowy własności, najmu czy dzierżawy odnoszące się do miejsca prowadzenia działalności gospodarczej ${ }^{101}$.

Bardzo często banki podejmują decyzję odnośnie kredytowania przedsiębiorstw na podstawie współpracy transakcyjnej lub relacyjnej ${ }^{102}$. Współpraca transakcyjna wiąże się z tym, że relacje pomiędzy bankiem i kredytobiorcą są różne w zależności od wielkości firmy. Podmioty większe mają lepszy dostęp do kredytu ze względu na niższy koszt kredytu bankowego, a banki ponoszą niższy koszt pozyskania informacji o potencjalnych kredytobiorcach. Współpraca relacyjna dotyczy współpracy przedsiębiorstw z bankami. Długoletnia relacja z bankiem wpływa na skłonność banków do finansowania projektów tych podmiotów oraz jest jednym z czynników ograniczających cenę usług świadczonych przez bank $^{103}$. Współpraca nie musi dotyczyć tylko historii kredytowej, może to być tylko prowadzenie rachunków rozliczeniowych przez bank, które są źródłem wielu informacji o przedsiębiorstwie, takich jak: wolumen obrotów czy ilość i jakość kontrahentów. Z obserwacji przeprowadzonych przez A. W. Boot i A. V. Thakor ${ }^{104}$ wynika, że w badanej przez nich próbie małych przedsiębiorstw oprocentowanie kredytu spada wraz z długością okresu współpracy z bankiem. Dodatkowo banki obniżają swoje wymagania co do zabezpieczeń kredytów. Zauważyli również, że ceny kredytów ulegają obniżeniu w miarę długości trwania współpracy banku z przedsiębiorstwem bez względu na zakres informacji zebranych przez bank. Dzieje się tak głównie dlatego, że banki w momencie, kiedy uznają, że dany podmiot jest w stanie zrealizować dany projekt, nie analizują jeszcze nowych informacji, bazując na tych, które zawsze były dostarczane przez przedsiębiorstwo.

M. A. Petersen i R. G. Rajan zaobserwowali, że wraz z wydłużeniem okresu współpracy banku z przedsiębiorstwem oprocentowanie kredytu może również

${ }^{101}$ Zobacz np.: zasoby oficjalnej witryny internetowej Banku PKO BP: http://www.pkobp.pl/ index.php/id=oferta/grupa=5/podgrupa $=5 /$ section=misp [28.07.2009].

102 A. N. B e r g e r, G. F. U d e 11, Small business credit availability and relationship lending: The importance of bank organizational structure, „Economic Journal” 2002, vol. 112, no.477, s. F32-F53.

${ }^{103}$ G. J i m e n e z, J. S a u ri n a, Collateral, Type of Lender and Relationship Banking as Determinants of Credit Risk, Bank of Spain, Directorate - General of Banking Regulation, May 2003, s. 16.

${ }^{104}$ A. W. A. B o ot, A. V. Thak or, Can relationship Banking survive Competition?, „The Journal of France" 2000, vol. 55, no. 2, s. 679-713. 
rosnąć. Przyczyną takiego typu zjawiska jest to, że banki rekompensują sobie bardziej ryzykowne finansowanie nieznanych firm we wcześniejszych okresach ich istnienia. Polega to na tym, że banki dostarczają przedsiębiorstwom względnie taniego kapitału w początkowych fazach ich funkcjonowania w celu osiągnięcia $w$ przyszłości korzyści z kredytowania takich podmiotów ${ }^{105}$. Według między innymi J. Peek i E. Rosengreen na dostępność kredytu dla przedsiębiorstw istotny wpływ mają również procesy łączenia i przejęć w sektorze bankowym. Jeśli procesy konsolidacyjne dotyczą dużych banków to ograniczony zostaje dostęp do kredytowania mniejszych przedsiębiorstw. W przypadku zaś łączenia się małych banków wzrasta dostępność kredytu bankowego dla małych i średnich przedsiębiorstw ${ }^{106}$.

Z badań przeprowadzonych przez PARP $^{107}$ w latach 2000-2001wynika, że główną barierą dostępu przedsiębiorstw MMSP do kapitału zewnętrznego był wysoki poziom stóp procentowych. Ponadto utrudnienia w dostępie kredytów są również spotęgowane poprzez złożone procedury bankowe, żądania banków co do wysokich i skomplikowanych zabezpieczeń. Przygotowanie obszernej dokumentacji jest dla przedsiębiorstw również czasochłonnym, a często kosztownym problemem. Dodatkowo banki komercyjne stosują dość wysokie prowizje, co także ogranicza dostęp firm do tego finansowania ${ }^{108}$.

Makroekonomiczna sytuacja oraz coraz większy poziom konkurencji na rynku bankowym ma istotny wpływ na politykę kredytową banków komercyjnych w Polsce. Obniżenie podstawowej stopy procentowej NBP z poziomu $21,5 \%$ w 2000 r. do $3,5 \%$ w 2010 r. (3,75\% w styczniu $2011,4,5 \%$ w czerwcu 2011, 2,50\% w lipcu 2013 r.) jest krokiem ku większej dostępności kredytów dla przedsiębiorstw. Jednak Polska wciąż jest w grupie państw, w których dostęp do kredytów jest niewystarczający w porównaniu do innych krajów rozwiniętych. Wśród barier wpływających na zmniejszenie akcji kredytowej banków komercyjnych znajdują się przede wszystkim: niestabilność prawa i niezadowalający poziom jego wdrażania, głównie trudności

${ }^{105}$ M. A. Pe ter s e n, R. G. R a j a n, The Effect of Credit Market Competition on Lending Relationships, „The Quarterly Journal of Economics” 1995, vol. 110(2), s. 407-443.

${ }^{106}$ J. P e e k, E. Ros en gre e n, The Evaluation of Small Business Lending, ,New England Economic Review" 1998, Federal Reserve Bank of Boston, [w:] I. Tymoczko, M. P awłowska, Uwarunkowania dostępności kredytu bankowego - analiza polskiego rynku, „Bank i Kredyt”, czerwiec 2007, s. 49.

${ }^{107}$ PARP - Polska Agencja Rozwoju Przedsiębiorczości, jest to agencja rządowa, która podlega Ministrowi właściwemu do spraw gospodarki, powstała w 2000 r. Jej zadanie polega na zarządzaniu funduszami z budżetu państwa oraz Unii Europejskiej, które przeznaczane są na wspieranie przedsiębiorczości, innowacyjności i rozwój zasobów ludzkich.

${ }^{108}$ B. La c hi e w i c z, Stopa procentowa NBP a stopy procentowe w bankach komercyjnych, [w:] J. L. B ednarczyk (red.), Stopy procentowe a gospodarka. Dylematy Unii Gospodarczej $i$ Walutowej, Wydawnictwo Politechniki Radomskiej, Radom 2006, s. 192. 
banków z wyegzekwowaniem swoich należności w przypadku niewypłacalności kredytobiorcy, także częste zmiany regulacji prawnych w celu dostosowania praw do międzynarodowych standardów ${ }^{109}$.

\subsection{Podsumowanie}

Przedsiębiorstwa generują znaczną część produktu PKB i stanowią miejsce zatrudnienia dla wielu pracowników. Ponadto wykorzystując kredyty bankowe lokują je w inwestycjach, co jest istotnym elementem wzrostu gospodarczego w kraju. W wyniku analizy literatury przedmiotu ustalono, że cena kredytów ma istotne znaczenie $\mathrm{w}$ procesie podejmowania decyzji inwestycyjnych przedsiębiorstw. Na poziom oprocentowania kredytów ustalany przez banki komercyjne, oprócz stopy rynku międzybankowego, składa się kilka elementów, jak: prowizja, marża zawierająca koszt ryzyka kredytowego oraz zysk, jak również koszty działalności. Cena kredytów pozostaje istotnym parametrem kosztu pozyskania kapitału dla przedsiębiorstw, dlatego podmioty gospodarcze szczegółowo rozpatrują wielkość oprocentowania kredytów przed rozpoczęciem inwestycji. W tym miejscu warto podkreślić, że dynamika inwestycji w dużej mierze jest również uzależniona od pozycji finansowej przedsiębiorstwa. Ponadto istnieje wiele czynników wpływających na poziom inwestycji przedsiębiorstw, które wzajemnie się nakładają i dlatego nie jest łatwo określić ich siłę. Inwestycje są istotne dla rozwoju gospodarczego, dlatego należy stwarzać korzystne warunki inwestowania przedsiębiorstwom, które generują większą część inwestycji w gospodarce. Bank centralny dysponuje instrumentarium, za pomocą którego ma możliwość stymulowania akcji kredytowej skierowanej do przedsiębiorstw. Oddziaływanie to jest możliwe poprzez mechanizm transmisji impulsów polityki pieniężnej do sfery realnej gospodarki za pośrednictwem banków komercyjnych, których polityka kredytowa w istotnym stopniu zależy między innymi od stóp procentowych banku centralnego.

${ }^{109}$ P. Augustynowicz, Lending Activity of Polish Banks, [w:] H. Żukowska, M. Żu kowski (red.), The Banking System in Poland, Maria Curie-Skłodowska Press, Lublin 2008, s. 172-174. 



\section{Rozdział 5}

\section{UWARUNKOWANIA I REALIZACJA POLITYKI PIENIĘŻNEJ A POZIOM INWESTYCJI W LATACH 1998-2009 - STUDIUM PRZYPADKU}

\subsection{Polityka pieniężna Europejskiego Banku Centralnego na tle sytuacji gospodarczej w latach 1998-2009}

Problematyka realizacji polityki pieniężnej i jej wpływ na inwestycje ma istotne znaczenie w kontekście przystąpienia Polski do Eurosystemu i prowadzenia polityki monetarnej przez EBC. Od momentu wejścia Polski do strefy euro to między innymi decyzje Europejskiego Banku Centralnego będą miały wpływ na wielkość kredytów dostępnych dla przedsiębiorstw oraz poziom inwestycji w gospodarce. Stąd warto zastanowić się, w jaki sposób EBC oddziałuje na gospodarkę Eurosystemu poprzez realizację polityki pieniężnej z uwzględnieniem jej uwarunkowań wewnętrznych i zewnętrznych oraz dokonać porównania z rozwiązaniami stosowanymi przez NBP.

W pierwszym etapie kształtowania Unii Gospodarczej i Walutowej, czyli od połowy 1998 r. do połowy 1999 r., stopy inflacji utrzymywały się na niskim poziomie. Wahania na rynkach finansowych, które pojawiły się w związku z kryzysami finansowymi w 1997 r. w Azji i w 1998 r. w Rosji oraz upadkiem w 1998 r. funduszu hedgingowego LTCM (Long-Term Capital Management), wpłynęły na perspektywy wzrostu w strefie euro zdominowanej zjawiskiem niepewności ${ }^{1} .22$ grudnia 1998 r. ustalono po raz pierwszy poziomy stóp procentowych EBC. Stopa podstawowych operacji refinansujących wynosiła 3\%, stopa kredytu na koniec dnia 4,5\%, a depozytu na koniec dnia $2 \%$ (wykres 5.1 ) $^{2}$.

Na początku działalności w 1999 r., Rada Prezesów odebrała sygnały z rynku, które mogły wpłynąć na wzrost cen. Były to wzrastające ceny ropy naftowej od lutego 1999 r. oraz deprecjacja euro w warunkach pojawiającego się

${ }^{1}$ Monthly Bulletin 10. anniversary EBC, European Central Bank, Frankfurt n. Menem 2008, s. $40-43$.

${ }^{2}$ Annual Report 1999, European Central Bank, Frankfurt n. Menem 2000, s. 8. 
spowolnienia gospodarczego. Pomimo, że stopa wzrostu agregatu $\mathrm{M}^{3}$ przekroczyła wartość referencyjną osiągając poziom $5 \%^{4}$, Rada Prezesów nie interpretowała tego jako czynnika mogącego przyczynić się do wzrostu cen w średniej i długiej perspektywie. Ponadto 8 kwietnia 1999 r. EBC obniżył stałą stopę głównych operacji refinansujących z $3 \%$ do 2,5\%, stopę kredytu na koniec dnia do 3,5\%, a depozytu na koniec dnia do 1,5\% (wykres 5.1). Był to krok, który przyczynił się do wykorzystania potencjału wzrostu gospodarki w strefie euro ${ }^{5}$. W 1999 r. sytuacja azjatyckich gospodarek ustabilizowała się, a aktywność gospodarcza w Stanach Zjednoczonych trwale wykazywała oznaki wzrostu. Również w strefie euro zaobserwowano poprawę w poziomie zaufania inwestorów na rynku ${ }^{6}$.

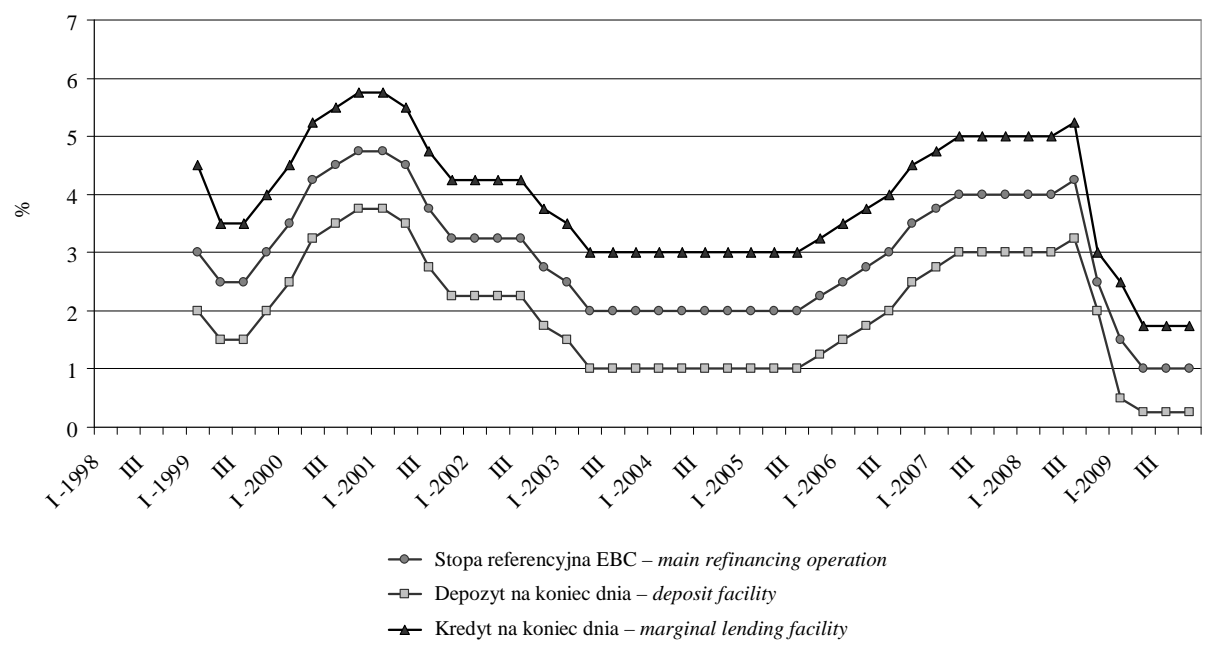

Wykres 5.1. Podstawowe stopy procentowe EBC w latach 1998-2009

Ź r ód ł o: opracowanie własne na podstawie danych z Biuletynów Miesięcznych EBC.

Od połowy 1999 r. do końca roku 2000, znacznie wzrastały ceny ropy naftowej oraz ceny importu, co w warunkach wzrostu gospodarczego zwiększyło ryzyko występowania efektów drugiej rundy ${ }^{7}$. Efekty te stwarzały obawy

${ }^{3} \mathrm{~W}$ strefie euro poszczególne agregaty pieniężne mają trochę inny skład niż w Polsce. Więcej na ten temat [w:] Annual Report 2007, European Central Bank, Frankfurt n. Menem 2008, s. 279.

${ }^{4}$ Wartość referencyjna M3 ustalona w grudniu 1998 r. wynosiła 4,5\%.

${ }^{5}$ Monthly Bulletin 10. anniversary..., op. cit., s. 40-43.

${ }^{6}$ Annual Report 1999, op. cit., s. 10.

${ }^{7}$ Efekty drugiej rundy - czyli spirala cenowo-płacowa, spowodowana bieżącym wzrostem cen. Bank centralny podejmując decyzje związane z polityką stóp procentowych, obserwuje nie tylko dane bieżące dotyczące inflacji, ale również statystyki z rynku pracy. Informują one bowiem jakie jest ryzyko wystąpienia efektów drugiej rundy. 
o wzrost inflacji poprzez politykę płacową. Dodatkowo, deprecjonująca się waluta euro zagrażała stabilności cen $\mathrm{w}$ średnim okresie. W związku z przeprowadzanymi przez EBC analizami makroekonomicznymi i monetarnymi, w warunkach rosnącej presji inflacyjnej, Rada Prezesów zdecydowała o podwyżce stóp procentowych. Jeszcze w listopadzie 1999 r. główna stopa referencyjna wzrosła do $3 \%$, depozytowa do $2 \%$, a kredytowa do $4 \%$ (wykres 5.1). Podwyżka ta miała powstrzymać zbyt duży wzrost płynności na rynku, który przełożyłby się na wzrost cen w średnim okresie, a tym samym miała przyczynić się do utrzymania oczekiwań inflacyjnych poniżej $2 \%{ }^{8}$.

Pomimo tego, że roczne tempo wzrostu gospodarczego w 1999 r. spadło do 2,2\% (według późniejszych danych do 2,5\%) z 2,8\% w 1998 r., to szczególnie od połowy 1999 r. utrzymywało się ożywienie gospodarcze. Istotny udział we wzroście PKB miał rosnący popyt wewnętrzny, a w wyniku deprecjacji euro, również wzrost eksportu dóbr i usług. Wzrost zaufania konsumentów przejawiał się przez cały 1999 r. wysoką konsumpcją wewnętrzną, która była rezultatem spadku bezrobocia, rosnących płac realnych, niskich stóp procentowych i stabilności inflacji w gospodarce?.

W 1999 r. stopa międzybankowych operacji typu overnight EONIA oscylowała wokół głównej stopy operacji refinansujących, odchylając się w granicach 3 punktów bazowych. Również od początku roku nachylenie krzywej dochodowości rynku pieniężnego nie wykazywało zbyt dużych wahań, odnotowując fluktuacje stóp procentowych EURIBOR o terminach zapadalności od 1 miesiąca do 12 miesięcy, między $3,21 \%$ do 3,26\%. Dopiero w wyniku reakcji rynku pieniężnego na decyzje EBC odnośnie stóp procentowych w kwietniu i listopadzie 1999 r. oraz ze względu na obawy związane z rokiem 2000, doszło do krótkotrwałych większych odchyleń stóp rynku międzybankowego od stopy podstawowych operacji refinansujących ${ }^{10}$. W 1999 r. EBC dostarczył do sektora finansowego w ramach podstawowych operacji refinansujących płynności, przeprowadzając 52 operacje, których przydziały wahały się od 39 mld do $102 \mathrm{mld}$ euro. EBC wykorzystał również w tym czasie 14 dłuższych operacji refinansujących, które również ułatwiły przejście do roku 2000 zasilając rynek w płynność. W 1999 r. EBC nie przeprowadzał operacji dostrajających oraz strukturalnych. Natomiast w ciągu roku banki dziennie, średnio korzystały z instrumentu kredytu i depozytu na koniec dnia odpowiednio w wysokości 1 mld oraz 0,8 mld euro $^{11}$.

\footnotetext{
${ }^{8}$ Monthly Bulletin 10. anniversary..., op. cit., s. 43-44.

${ }^{9}$ Annual Report 1999, op. cit., s. 28-31.

${ }^{10}$ Ibidem, s. $17-18$.

${ }^{11}$ Ibidem, s. 48-52.
} 
W pierwszej połowie 2000 r. odnotowano wzrost zagrożenia stabilności cen. Ceny ropy naftowej w dalszym ciągu rosły, ponadto kurs walutowy euro ulegał dalszej deprecjacji aż do początku maja. W rezultacie wskaźnik inflacji wzrósł i utrzymywał się na poziomie $2 \%$ przez większość pierwszej połowy 2000 r. Ponadto wzrost cen importu przyczynił się do rosnących kosztów produkcji, co prawdopodobnie pośrednio mogło mieć przełożenie na wzrost cen z pewnym opóźnieniem. Natomiast w dłuższej perspektywie utrzymująca się presja wzrostu inflacji z powodu wyższych cen energii mogła doprowadzić do zwiększenia ryzyka efektów drugiej rundy poprzez wzrost płac. Dane dotyczące wzrostu gospodarczego oraz innych wskaźników, takich jak: produkcja przemysłowa, zaufanie konsumentów do rynku, wskazywały na istotną aktywność gospodarczą na początku 2000 r. Również czynniki spoza strefy euro, dotyczące wychodzenia państw Azji Wschodniej z kryzysu oraz silnego tempa wzrostu gospodarczego w Stanach Zjednoczonych, wpływały pozytywnie na PKB Eurosystemu. W pierwszym półroczu $2000 \mathrm{r}$. wzrost podaży pieniądza M3 (w kwietniu 2000 r. agregat M3 zwiększył się już o 6,4\%) przekroczył wartość referencyjną ustaloną na poziomie $4,5 \%{ }^{12}$.

Sugerując się wynikami analiz przeprowadzonych w ramach I i II filaru, Rada Zarządzająca postanowiła podnieść podstawowe stopy procentowe EBC. W pierwszej połowie $2000 \mathrm{r}$. decyzja o podwyżce podstawowych stóp procentowych miała miejsce czterokrotnie. W rezultacie 8 czerwca stopa podstawowych operacji refinansujących wyniosła $4,25 \%$, stopa depozytu na koniec dnia $3,25 \%$, a kredytu - 5,25\% (wykres 5.1). W wyniku decyzji EBC podjętych w 2000 r. o zacieśnianiu polityki pieniężnej pojawiły się pierwsze sygnały w postaci spowolnienia wzrostu agregatu pieniężnego M3 oraz akcji kredytowej. Jednak wciąż dochodziły z rynku sygnały zagrażające stabilności poziomu cen w dłuższym okresie (deprecjacja waluty, dalszy wzrost cen ropy naftowej). W związku z powyższym, EBC zdecydował się na kolejne podniesienie głównych stóp procentowych, ustalając w wyniku dwóch podwyżek (31 sierpnia i 5 października) minimalną oferowaną stopę podstawowych operacji refinansujących na poziomie $4,75 \%$, depozytu na koniec dnia $-3,75 \%$, a kredytu $-5,75 \%$ (wykres 5.1) ${ }^{13}$. W 2000 r. inflacja średnio wyniosła 2,3\% (1,9\% w styczniu; 2,9\% listopadzie; $2,6 \% \mathrm{w}$ grudniu). Tempo wzrostu gospodarczego według danych z Eurostat kształtowało się średnio w 2000 r. na poziomie 3,4\% (w stosunku do 2,5\% w 1999 r. $)^{14}$.

Europejski Bank Centralny w 2000 r. przeprowadził 51 podstawowych operacji refinansujących, których kwoty przydziałów wahały się od 35 mld euro do 128 mld euro, dostarczając w ten sposób $74 \%$ płynności. Istotny wzrost ofert

\footnotetext{
${ }^{12}$ Annual Report 2000, European Central Bank, Frankfurt n. Menem 2001, s. 10-12.

${ }^{13}$ Ibidem, s. 13.

${ }^{14}$ Ibidem, s. 30,36
} 
składanych przez banki, szczególnie w pierwszej połowie 2000 r., wiązał się z oczekiwaniami uczestników rynku pieniężnego, dotyczącymi podwyższenia głównych stóp procentowych przez EBC. Krótkoterminowe stopy procentowe rynku międzybankowego przewyższały stopę podstawowych operacji refinansujących, stąd banki preferowały zasilanie w płynność w banku centralnym. W 2000 r. EBC przeprowadził 12 dłuższych operacji refinansujących, z których pierwsze sześć ustalono na kwotę 20 mld euro, a kolejne sześć na kwotę 15 mld euro. W tym czasie w Eurosystemie dokonano również dwóch operacji dostrajających, pierwsza polegała na absorpcji płynności z systemu bankowego, a druga na zasileniu rynku w płynnośćc ${ }^{15}$.

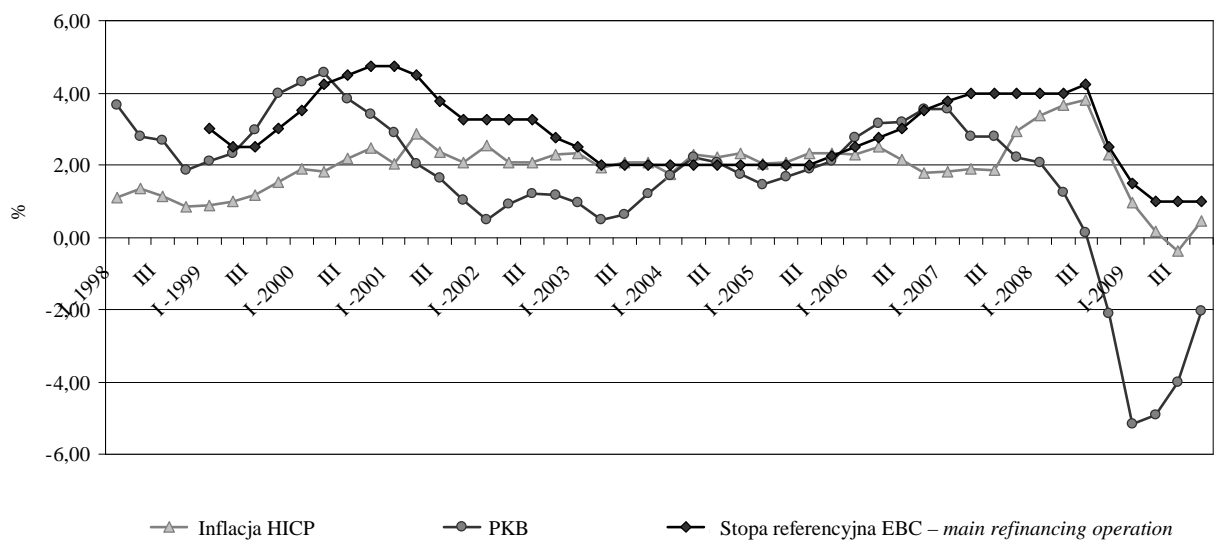

Wykres 5.2. Poziom inflacji, tempo wzrostu PKB w strefie euro oraz stopa referencyjna EBC w latach 1998-2009

Źr ódło: opracowanie własne na podstawie danych z: EBC Statistical Data Warehouse oraz Biuletynów Miesięcznych EBC; PKB wyrażone jest w rocznych zmianach procentowych, kwartał do kwartału.

W 2000 r. ceny rosły aż do pierwszej połowy 2001 r., co odzwierciedlał wzrost rocznego wskaźnika inflacji HICP, który w okresie od stycznia 2001 do maja tego samego roku wzrósł odpowiednio z 2,4\% do 3,1\%. Powodem tych wzrostów były rosnące ceny energii oraz żywności nieprzetworzonej w związku z epidemią chorób zwierzęcych w krajach strefy euro. Wzrost agregatu M3 wyniósł w 2001 r. średnio 5,4\%. Dodatkowo w analizach makroekonomicznych EBC uwzględniano ataki terrorystyczne w Stanach Zjednoczonych z 11 września 2001 r., które pogłębiały niepewność ekonomiczną. Dopiero z końcem 2001 r.

\footnotetext{
${ }^{15}$ Ibidem, s. 58-62.
} 
presja inflacyjna ustąpiła, a średnioroczna inflacja w 2001 r. wyniosła 2,3\% (wykres 5.2) ${ }^{16}$.

W czasie zwiększonej niepewności na rynkach finansowych, począwszy od połowy 2001 r., nastąpił wzrost agregatu pieniężnego M3, głównie na skutek występowania zmian struktury portfeli inwestorów, którzy odchodzili od akcji i długoterminowych instrumentów na rzecz bardziej płynnych aktywów pieniężnych. Rada Prezesów uznała to zjawisko za przejściowe, które po unormowaniu warunków gospodarczych, finansowych i geopolitycznych powinno ustąpić. Ponadto, uczestnicy rynku na podstawie stosunkowo płaskiej krzywej dochodowości w tamtym czasie (niski koszt alternatywny utrzymywania gotówki) skłaniali się bardziej do posiadania krótkoterminowych aktywów pieniężnych niż ryzykownych instrumentów długoterminowych. Wzrost M3 wiązał się również $\mathrm{z}$ większym zapotrzebowaniem podmiotów gospodarczych na środki konieczne do prowadzenia regularnej działalności w związku z dostosowaniami do wcześniejszych podwyżek cen energii i żywności. Dodatkowo roczne tempo wzrostu kredytów dla sektora prywatnego, w tym szczególnie dla przedsiębiorstw, malało w czasie niewielkiej aktywności gospodarczej, co również przemawiało za tym, że wzrost M3 nie jest oznaką presji inflacyjnej w średnim i długim okre$\operatorname{sie}^{17}$. W wyniku powyższych wydarzeń gospodarczych, władze polityki pieniężnej strefy euro postanowiły obniżyć stopy procentowe aż czterokrotnie w ciągu 2001 r. (10 maja, 30 sierpnia, 17 września oraz 8 listopada). W rezultacie minimalna stopa podstawowych operacji refinansujących ukształtowana została na poziomie $3,25 \%$, stopa kredytu i depozytu na koniec dnia odpowiednio $4,25 \%$ i $2,25 \%$ (wykres 5.1$)^{18}$.

W 2001 r. EBC przeprowadził 52 podstawowe operacje refinansujące, których kwoty przydziałów wahały się od 5 mld euro do 172 mld euro. Przeprowadzono również dłuższe operacje refinansujące dostarczające płynności, o wcześniej ogłoszonych kwotach przydziału równych 20 mld euro w formie przetargów o zmiennej stopie procentowej, których zadaniem był wpływ na stopę procentową, a nie dostarczenie dodatkowej płynności. W celu ułatwienia funkcjonowania rynków i dostarczenia płynności po atakach terrorystycznych w $2001 \mathrm{r}$. przeprowadzono również 2 operacje dostrajające oraz 2 operacje strukturalne ${ }^{19}$.

Średnioroczna inflacja w 2002 r. wyniosła 2,2\%. Zaobserwowano również w tym czasie osłabienie aktywności gospodarczej w strefie euro, co także miało wpływ na osłabienie presji inflacyjnej. Generalnie realny wzrost PKB w strefie euro spadł z poziomu 1,6\% w $2001 \mathrm{r}$. do $0,9 \%$ w 2002 r. Na podstawie analiz monetarnych oraz ekonomicznych Rada Zarządzająca zdecydowała o obniżce

\footnotetext{
${ }^{16}$ Monthly Bulletin 10. anniversary..., op. cit., s. 44.

17 Ibidem, s. 44.

${ }^{18}$ Annual Report 2001, European Central Bank, Frankfurt n. Menem 2002, s. 10-11.

${ }^{19}$ Ibidem, s. 66.
} 
stóp podstawowych w grudniu 2002 r. tak, że stopa podstawowych operacji refinansujących była na poziomie $2,75 \%$, a stopa kredytu i depozytu na koniec dnia odpowiednio $3,75 \%$ i $1,75 \%$. Średnia roczna stopa wzrostu agregatu pieniężnego w 2002 r. przekroczyła wartość referencyjną 4,5\% osiągając 7,4\% (wykres $5.1)^{20}$. EBC przeprowadził również 53 podstawowe operacje refinansujące o średniej kwocie przydziału $67 \mathrm{mld}$ euro oraz dłuższe operacje refinansujące o kwotach przydziału 20 mld euro oraz 15 mld euro, których zadaniem było ustabilizowanie stóp procentowych na rynku międzybankowym. W związku z wysokim zapotrzebowaniem uczestników rynku na płynność przeprowadzono również dwie operacje dostrajające na kwoty 25 mld euro oraz 40 mld euro ${ }^{21}$.

Niższa aktywność gospodarcza w strefie euro (realny roczny wzrost PKB na poziomie $0,4 \%$ ) spadek presji inflacyjnej, jak również wydarzenia geopolityczne związane z sytuacją w Iraku w 2003 r., przyczyniły się do niepewności na rynkach finansowych i zawirowań na rynku ropy naftowej. Średnie roczne tempo wskaźnika inflacji HICP utrzymywało się na poziomie 2,1\%. Pomimo, że w 2003 r. wciąż utrzymywał się znaczny poziom płynności w systemie finansowym (wzrost agregatu M3 - 8\%), to jednak nie uznano zagrożenia dla stabilności cen w dłuższym okresie (aprecjacja waluty oraz umiarkowany wzrost kredytów w gospodarce). W obliczu powyższych wydarzeń EBC w okresie od początku 2001 r. do połowy roku 2003 zdecydował się na obniżki podstawowej stopy procentowej do poziomu $2 \%{ }^{22}$. Decyzje te podjęte zostały na posiedzeniach Rady Zarządzającej w marcu i czerwcu 2003 r. Zredukowano stopy procentowe w sumie o 75 punktów bazowych. Stopę minimalnej oferty w podstawowych operacjach refinansujących obniżono do historycznie niskiego poziomu $2 \%$, stopę kredytu na koniec dnia do $3 \%$, a depozytu na koniec dnia do $1 \%$ (wykres 5.1) ${ }^{23}$.

$\mathrm{W}$ ramach operacji otwartego rynku EBC zasilano rynek przeprowadzając podstawowe operacje refinansujące o kwotach przydziałów od 38 mld euro do 150 mld euro, gdzie średnia wartość wyniosła 95,9 mld euro. Eurosystem w 2003 r. dokonał również 12 dłuższych operacji refinansujących, każda o przydziale 15 mld euro. W maju zdecydowano o przeprowadzeniu operacji dostrajającej o charakterze absorbującym płynność, w celu stabilizacji poziomu płynności na rynku, o wykorzystanej przez banki wartości 3,9 mld euro (oferowana kwota przydziału 5 mld euro) ${ }^{24}$.

Od czerwca 2003 r. do końca 2005 r., Rada Prezesów postanowiła pozostawić stopy procentowe na niezmienionym poziomie, czyli minimalna stopa podstawowych operacji refinansujących utrzymana została na poziomie $2 \%$ przez

\footnotetext{
${ }^{20}$ Annual Report 2002, European Central Bank, Frankfurt n. Menem 2003, s. 8-9.

${ }^{21}$ Ibidem, s. 70-74.

${ }^{22}$ Monthly Bulletin 10. anniversary..., op. cit., s. 46.

${ }^{23}$ Annual Report 2003, European Central Bank, Frankfurt n. Menem 2003, s. 8-9.

${ }^{24}$ Ibidem, s. 76-77.
} 
2,5 roku. Ta decyzja EBC była podyktowana tym, że pomimo znacznego wzrostu cen żywności, ropy naftowej oraz podatków pośrednich w 2004 roku oraz znaczną część 2005 r., stopa inflacji HICP wynosiła 2,2\% w 2005 r. Zatem było to niewiele więcej w porównaniu do wskaźnika HICP na poziomie $2,1 \%$ w dwóch poprzednich latach (wykres 5.2). Od połowy 2003 r. poprawiła się sytuacja ekonomiczna, głównie ze względu na niskie stopy procentowe i korzystne warunki finansowania. Pozytywnie na prognozy makroekonomiczne wpływały również oczekiwania co do korekty w sektorze przedsiębiorstw, której celem miała być poprawa ich rentowności i wydajności. Dodatkowo w wyniku poprawy dynamiki gospodarki światowej, wzrósł eksport strefy euro, co również przyczyniło się między innymi do lepszych prognoz i wyników związanych $\mathrm{z}$ umocnieniem wzrostu realnego $\mathrm{PKB}^{25}$.

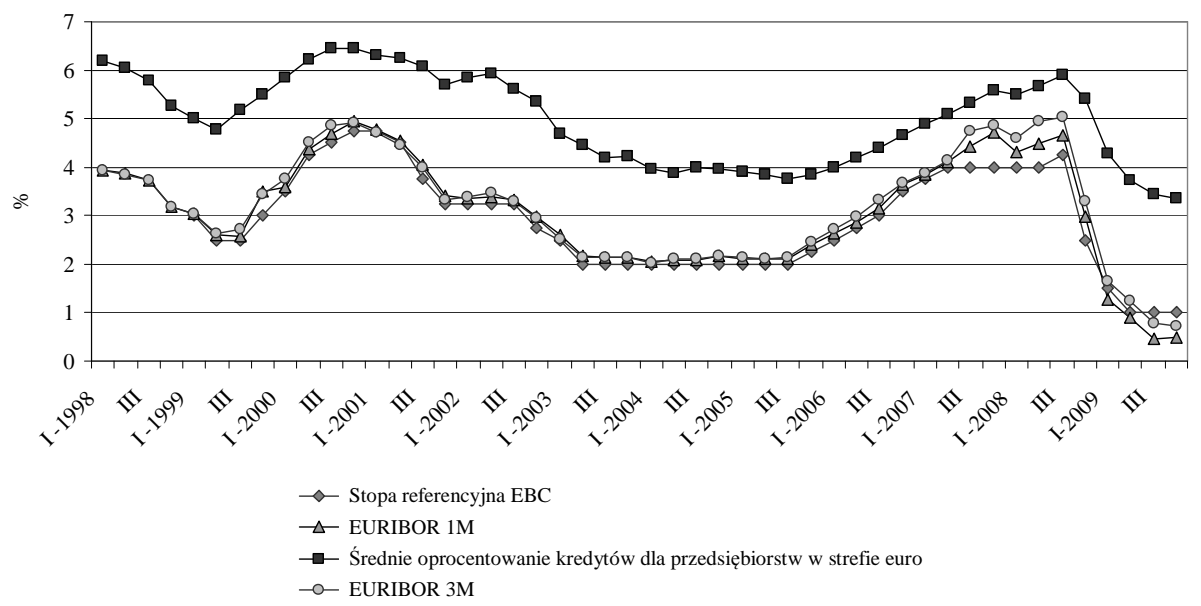

Wykres 5.3. Stopa referencyjna EBC, średnie nominalne oprocentowanie kredytów dla przedsiębiorstw w strefie euro, EURIBOR 3M oraz EURIBOR 1M w latach 1998-2009

Ź r ó d ł o: opracowanie własne na podstawie danych z EBC Statistical Data Warehouse oraz Biuletynów Miesięcznych EBC.

Rozpoczęte w drugiej połowie 2003 r. ożywienie gospodarcze w strefie euro utrzymywało się do połowy 2004 r., dopiero w drugiej połowie aktywność ta uległa niewielkiemu osłabieniu, głównie z powodu wzrostu cen ropy naftowej. W ujęciu realnym PKB w 2004 r. wzrósł o 1,8\% w stosunku do 0,5\% w 2003 r. i 0,9\% w 2002 r. W 2004 r. presja inflacyjna była niewielka, głównie z powodu niskiego wzrostu płac. Natomiast istotny wpływ na stopę inflacji miał wzrost cen kontrolowanych oraz podatków pośrednich. W drugiej połowie roku wyższe

\footnotetext{
${ }^{25}$ Monthly Bulletin 10. anniversary..., op. cit., s. 46-47.
} 
ceny ropy naftowej oddziaływały na wskaźnik inflacji HICP, który w 2004 r. wynosił $2,1 \%$ nie zmieniając się względem roku poprzedniego. Rada Prezesów zdecydowała, że pozostawi podstawowe stopy procentowe EBC na niezmienionym poziomie. Krańcowa stopa kredytowa wynosiła 3\%, minimalną stopę podstawowych operacji refinansujących EBC utrzymano w wysokości 2\%, zaś stopę depozytową pozostawiono na poziomie $1 \%$ (wykres 5.1) ${ }^{26}$. Generalnie w $2004 \mathrm{r}$., EONIA - stopa rynku międzybankowego strefy euro, mierzona jako uśredniona stopa procentowa transakcji jednodniowych typu overnight, zanotowała spadek w porównaniu do lat wcześniejszych. Mniejsza zmienność, czyli odchylenie rozpiętości pomiędzy minimalną oferowaną stopą podstawowych operacji refinansujących a stopą EONIA wyniosła 9 punktów bazowych w stosunku do 16 punków w 2003 r. i 13 punktów w 2002 r. ${ }^{27}$

Od połowy 2003 r. do czerwca 2004 r. roczny wzrost M3 uległ spowolnieniu (w czerwcu 2004 r. osiągnął poziom 5,3\%), jednak nie oznaczało to dla Rady Prezesów mniejszej presji inflacyjnej w perspektywie średnio- i długookresowej. Wynikało to głównie z przewidzianego przez EBC spadku poziomu niepewności i niechęci do ryzyka w instrumenty długoterminowe i związanym $\mathrm{z}$ tym przesunięciem w strukturze portfela na rynku finansowym. Dodatkowo w drugiej połowie 2003 r. zwiększyła się roczna stopa wzrostu kredytów przeznaczona dla sektora prywatnego. Następnie począwszy od połowy 2004 r. przez cały 2005 r. dynamika monetarna przejawiająca się wzrostem agregatu M3 uległa znacznemu wzmocnieniu (na koniec 2004 r. agregat M3 wzrósł do 6,4\%), co było sygnałem o zagrożeniu dla stabilności cen. Zjawisko to było potęgowane silną ekspansją kredytową od połowy 2004 r. przy niskich stopach procentowych i rosnącej dynamice gospodarczej w strefie euro ${ }^{28}$. Rada Prezesów była jednak w stanie zareagować na jakiekolwiek zagrożenia dla stabilności cen, które mogły pojawić się również ze strony polityki fiskalnej ${ }^{29}$, stanowiącej część środowiska, w którym realizowana jest polityka monetarna.

W marcu 2004 r. zmieniły się zasady prowadzenia operacji otwartego rynku w strefie euro. Zdecydowano o skróceniu terminu zapadalności podstawowych operacji refinansujących $\mathrm{z}$ dwóch tygodni do jednego tygodnia. W lutym zmieniono również termin przydzielania dłuższych operacji refinansujących, który ustalono na ostatnią środę miesiąca, a nie jak było wcześniej w pierwszą środę utrzymywania rezerwy obowiązkowej ${ }^{30}$.

${ }^{26}$ Annual Report 2004, European Central Bank, Frankfurt n. Menem 2005, s. 18.

${ }^{27}$ Ibidem, s. 93.

${ }^{28}$ Monthly Bulletin 10. anniversary..., op. cit., s. 46-47.

${ }^{29}$ Rozpatrując sytuację budżetową strefy euro w 2004 r., według danych Komisji Europejskiej, deficyt budżetowy wynosił $2,7 \%$ PKB, zaś wskaźnik zadłużenia w strefie euro wzrósł do 71,3\% PKB [w:] Annual Report 2004, op. cit., s. 64-65.

${ }^{30}$ Annual Report 2004, op. cit., s. 90-92. 
W sytuacji silnego wzrostu gospodarczego oraz dynamicznej ekspansji kredytowej i monetarnej Rada Prezesów pod koniec 2005 r. zdecydowała się na serię podwyżek stóp procentowych. Od połowy 2004 r. coraz silniejszy wzrost podaży wpływał na zwiększanie poziomu płynności w strefie euro, co stanowiło zagrożenie dla stabilności cen w średnim i długim okresie. Na posiedzeniu Rady Zarządzającej EBC dnia 4 października 2005 r., Prezes EBC, J. C. Trichet stwierdził, że stopy procentowe są na historycznie niskim poziomie i powinny zostać podniesione $^{31}$. 1 grudnia 2005 r. Rada Prezesów postanowiła dokonać korekty łagodnego nastawienia w polityce pieniężnej, podnosząc podstawowe stopy procentowe o 25 punktów bazowych (przez 2,5 roku nie dokonywano zmian stóp procentowych). W rezultacie minimalna stopa podstawowych operacji refinansujących wyniosła $2,25 \%$, natomiast stopy depozytów i kredytów na koniec dnia $\mathrm{w}$ banku centralnym ustalono na poziomach odpowiednio $1,25 \%$ i 3,25\% (wykres 5.1$)^{32}$.

W strefie euro agregat M3 osiągnął w $2006 \mathrm{r}$. najwyższy poziom od $2001 \mathrm{r}$. $\mathrm{W}$ tamtym czasie silny wzrost podaży pieniądza spowodowany był również niskimi stopami procentowymi, co znalazło odzwierciedlenie w silnym wzroście najbardziej płynnych składników M3 i zwiększeniu popytu na kredyty. Władze monetarne musiały znaleźć wyjście, by uniknąć wzrostu inflacji w efekcie dynamicznego wzrostu podaży ${ }^{33}$. W wyniku wahań cen ropy naftowej, stopa inflacji HICP ulegała w ciągu roku znacznym zmianom, jednak średnioroczna inflacja w 2006 r. wyniosła 2,2\%, a w 2007 r. 2,1\%. Pomimo wysokich oraz ulegających ciągłym zmianom cen ropy naftowej, wzrost gospodarczy nabierał coraz większego tempa. Tendencja ta była zauważalna od połowy $2006 \mathrm{r}$. W porównaniu do 2005 r., kiedy realny PKB oscylował na poziomie 1,6\%, w 2006 r. zanotowano wzrost gospodarczy na poziomie 2,8\%. Podobnie w roku 2007 gospodarka strefy euro mierzona realnym $\mathrm{PKB}^{34}$ rozwijała się w tempie $2,7 \%$ (wykres 5.2). Takie rezultaty $w$ istotnej mierze były wynikiem rosnącego popytu krajowego $^{35}$.

W ciągu 2006 r. utrzymywał się silny wzrost podaży pieniądza oraz kredytów, czego przyczyną były między innymi niskie stopy procentowe i aktywna działalność gospodarcza. W związku z tymi danymi, Rada Prezesów uznała, że rośnie zagrożenie dla stabilności cen w długim i średnim okresie i zdecydowała się na podwyżki stóp procentowych EBC (pięciokrotnie w ciągu roku). W wyni-

${ }^{31}$ D. Fil a r, Przymiarki do europejskich stóp, ,,Rzeczpospolita” 2005, nr 242, 14-15.10.2005.

${ }^{32}$ Annual Report 2005, European Central Bank, Frankfurt n. Menem 2006, s. 18.

${ }^{33}$ Annual Report on the Euro Area 2006, „European Economy” 2006, No. 3, European Commission, Luxembourg 2007, s. 15.

${ }^{34}$ Po okresie spowolnienia gospodarczego, tempo wzrostu PKB w strefie euro zaczęło wzrastać, ulegając pojedynczym wahaniom, utrzymując ten trend wzrostowy do połowy 2007 r. przy ogólnie niskiej realnej stopie referencyjnej EBC.

${ }^{35}$ Annual Report 2004, op. cit., s. 47-48. 
$\mathrm{ku}$ tych decyzji, minimalna stopa podstawowych operacji refinansujących w grudniu 2006 r. wyniosła 3,5\%, stopa depozytów na koniec dnia 2,5\%, a stopa kredytów 4,5\% (wykres 5.1)

W 2007 r. według EBC nadal utrzymywało się średniookresowe zagrożenie inflacyjne dla stabilności cen, stąd Rada Prezesów postanowiła podnieść stopy procentowe ogółem o 50 punktów bazowych, ustalając, że podstawowa stopa operacji refinansujących będzie wynosić $4 \%$ (wykres 5.3 ) ${ }^{37}$.

W 2008 r., EBC prowadził politykę pieniężną w trudnych warunkach spowodowanych zaburzeniami finansowymi, które występowały już od sierpnia $2007 \mathrm{r}$. W pierwszej połowie $2008 \mathrm{r}$. nasiliła się presja inflacyjna spowodowana szybkim wzrostem cen surowców na rynkach światowych. W czerwcu i lipcu roczna inflacja HICP osiągnęła najwyższą wartość $4 \%$, ponadto nastąpiło zacieśnienie rynków pracy. W tych warunkach pojawiło się ryzyko wystąpienia efektów drugiej rundy. W związku z tym, Rada Prezesów jeszcze w lipcu postanowiła podnieść stopy procentowe o 25 punktów bazowych (podstawowa stopa operacji refinansujących - 4,25\%). Z kolei od września znacznie nasiliły się zaburzenia na rynkach finansowych, powodując zakłócenia i niedobór płynności, co doprowadziło do pogorszenia się perspektyw dla gospodarek wielu krajów na całym świecie. Odnotowano również spadek inflacji, której wskaźnik HICP w grudniu 2008 r. wynosił 1,6\%, a średnioroczna inflacja osiągnęła poziom 3,3\% (wykres 5.2). Rada Prezesów w odpowiedzi na słabnącą presję inflacyjną oraz spadek aktywności gospodarczej (wzrost realnego PKB strefy euro w $2008 \mathrm{r}$. wyniósł zaledwie $0,8 \%$ ), zdecydowała się na obniżkę stóp procentowych łącznie o 175 punktów bazowych. Ostatecznie na koniec roku 2008 stopę podstawo-

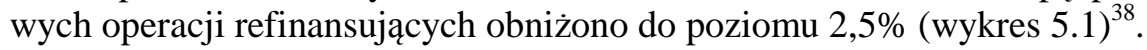

EBC zdecydował ponadto o wprowadzeniu programu ,nadzwyczajnego wsparcia kredytowego" w celu poprawy warunków finansowania oraz zwiększenia akcji kredytowej przy użyciu niestandardowych środków. Był on adresowany do banków, jako instytucji będących podstawowym źródłem finansowania realnej sfery gospodarki. Program ten składał się z następujących elementów ${ }^{39}$ :

- zasilanie banków strefy euro nieograniczonymi kwotami płynności za odpowiednim zabezpieczeniem według stałej stopy procentowej we wszystkich operacjach refinansujących,

- wydłużenie maksymalnej zapadalności operacji refinansujących z trzech miesięcy do jednego roku,

- powiększenie listy aktywów, które uznawane były jako zabezpieczenie,

\footnotetext{
${ }^{36}$ Annual Report 2006, European Central Bank, Frankfurt n. Menem 2007, s. 39.

${ }^{37}$ Annual Report 2007, op. cit., s. 18.

${ }^{38}$ Annual Report 2008, European Central Bank, Frankfurt n. Menem 2009, s. 10, 16.

${ }^{39}$ Ibidem, s. 19.
} 
- dostarczanie płynności w walutach obcych, głównie w dolarach amerykańskich,

- skupowanie na rynku obligacji zabezpieczonych w sposób bezpośredni.

Działania te zostały podjęte przez EBC w celu zmniejszenia niekorzystnego wpływu, jaki dysfunkcjonalny rynek pieniężny wywierał na sytuację płynnościową banków w Eurosystemie. Zgodnie z założeniem tego programu miało nastąpić zwiększenie napływu kredytów do firm i gospodarstw domowych. W rzeczywistości zastosowanie powyższych środków poprawiło dostęp sektora bankowego do płynności, napływ kredytów do gospodarki, przyczyniając się do polepszenia warunków finansowania oraz pobudzenia gospodarki strefy euro. Ponadto, skup obligacji zabezpieczonych wpłynął na zwiększenie emisji pierwotnych oraz zmniejszenie wysokich spreadów na tym rynku. Dodatkowo, w okresie od października 2008 r. do maja 2009 r., EBC znacznie obniżył poziom podstawowych stóp procentowych, co również miało wpływ na spadek stóp i spreadów na rynku pieniężnym oraz oprocentowanie kredytów bankowych (wykres 5.3). Rada Prezesów obserwując poprawę warunków na rynkach finansowych, postanowiła na początku grudnia 2009 r. o stopniowym wycofywaniu niektórych środków niestandardowych ${ }^{40}$.

Działania podjęte przez Europejski Bank Centralny okazały się konieczne, ponieważ efekty, które przyniosły nie zostałyby osiągnięte tylko poprzez samą obniżkę podstawowych stóp procentowych. Rozwiązania niestandardowe, których wprowadzenia podjął się EBC, doprowadziły do poprawy warunków finansowania, czego przykładem były spadki spreadów na terminowym rynku pieniężnym i ograniczenie zmienności na rynku finansowym. Świadczy to również o szczególnej roli, jaką EBC odgrywa w finansowaniu gospodarki w strefie euro.

W 2009 r. na decyzje EBC wpłynęły głównie informacje o niskiej presji inflacyjnej (średnioroczna stopa inflacji wyniosła $0,3 \%$ ) oraz o silnym załamaniu aktywności gospodarczej w strefie euro (łącznie realny PKB obniżył się o 4\%) ${ }^{41}$. W okresie od stycznia do maja 2009 r. Rada Prezesów zdecydowała o obniżeniu stóp procentowych łącznie o 150 punktów bazowych. W rezultacie oprocentowanie podstawowych operacji refinansujących wyniosło $1 \%$, stopa depozytu w banku centralnym $0,25 \%$, natomiast stopa kredytu w banku centralnym $1,75 \%$

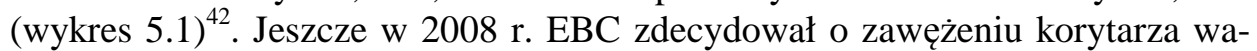
hań stóp procentowych na rynku międzybankowym do 1 punktu procentowego ${ }^{43}$,

${ }^{40}$ Ibidem, s. 19.
${ }^{41}$ Ibidem, s. $16-18$.
${ }^{42}$ Ibidem.
${ }^{43}$ Korytarz wahań krótkoterminowych stóp procentowych od 21 stycznia 2009 r. ponownie rozszerzono do 200 punktów bazowych. Następnie od 15 maja 2009 r. ustalono, że różnica pomiędzy stopą referencyjną EBC a depozytową będzie wynosić 75 punktów bazowych, [w:] D. Ty moc zk o, Reakcje wybranych banków centralnych (FED i EBC) na kryzys, [w:] J. O s iń - 
w celu ograniczenia zmienności krótkoterminowych stóp procentowych. Pomimo pojawiających się w drugim półroczu 2009 r. oznak stabilizacji gospodarczej w strefie euro (spadek niechęci inwestorów do podejmowania ryzyka, zanotowano niewielki kwartalny wzrost tempa wzrostu gospodarczego po pięciu kwartałach spadków) pozostawiono stopy procentowe na niezmienionym poziomie.

Uśredniona stopa procentowa transakcji jednodniowych typu overnight na rynku międzybankowym strefy euro utrzymywała się zasadniczo na poziomie zbliżonym do minimalnej stopy podstawowych operacji refinansujących (wykres 5.4).

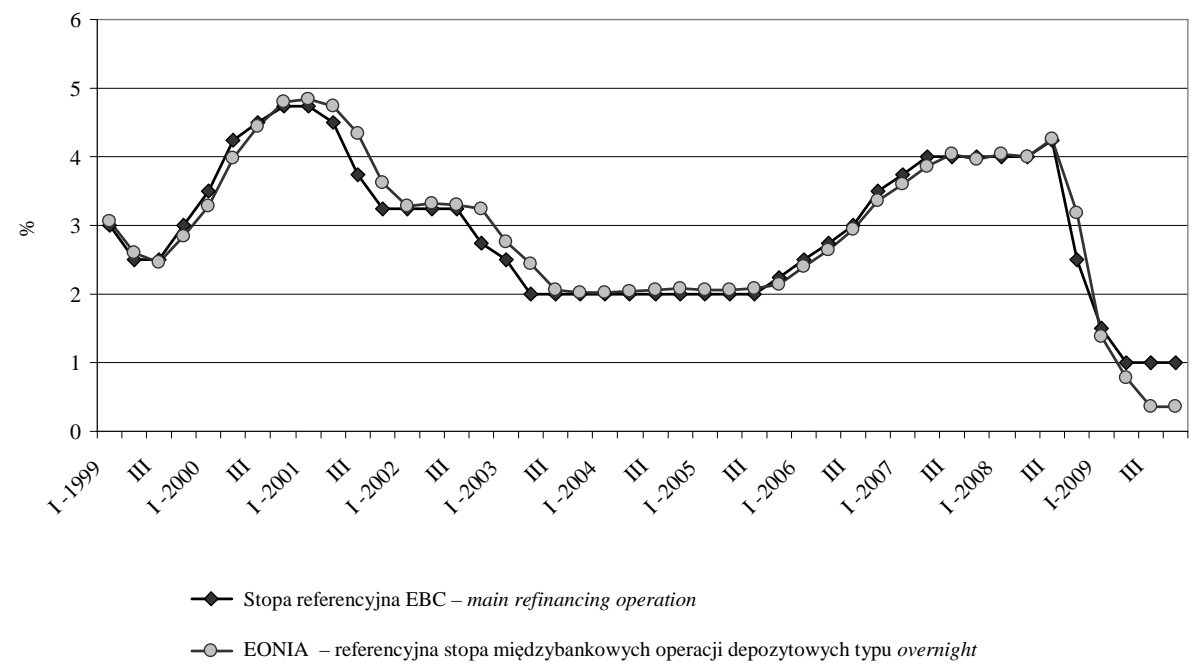

Wykres 5.4. Stopa referencyjna EBC oraz EONIA w strefie euro w latach 1999-2009

Ź ró d ło: opracowanie własne na podstawie danych z: EBC Statistical Data Warehouse, dane kwartalne opublikowane również w Biuletynach Miesięcznych EBC z lat 1999-2009.

W latach 2001-2003 średnia rynkowa stopa procentowa typu overnight kształtowała się powyżej podstawowej stopy procentowej EBC. Następnie od 2006 r. EONIA była średnio nieznacznie niższa od stopy podstawowych operacji refinansujących EBC. Natomiast w czasie kryzysu w 2008 r. EONIA notowała najczęściej wartości powyżej stopy podstawowych operacji refinansujących, a w 2009 r. z kolei poniżej głównej stopy EBC. Stawka EONIA, jako wskaźnik

s ki (red.), Banki centralne wobec kryzysu ekonomicznego, Szkoła Główna Handlowa, Warszawa 2010, s. 125-127. 
rzeczywistej ceny pieniądza, pełni istotną funkcję na rynku międzybankowym w strefie euro, jej znaczne wahania informują o zmianach poziomu płynności na rynku i o jego niestabilności (wykres 5.4).

Nawiązując do programu nadzwyczajnego wsparcia akcji kredytowej, w maju 2009 r., Rada zdecydowała o przeprowadzeniu w czerwcu, wrześniu i grudniu trzech dłuższych operacji zasilających w płynność z 12-miesięcznym terminem zapadalności. Pierwsza z tych operacji, która miała miejsce 24 czerwca 2009 r., udostępniła systemowi bankowemu strefy euro kwotę 442 mld euro po stałej stopie $1 \%$. Banki otrzymały na dłuższy czas dostęp do zasobów płynności, co miało odzwierciedlenie w obniżeniu stóp rynku pieniężnego, obniżeniu oprocentowania kredytów bankowych oraz zwiększeniu ich zdolności do finansowania gospodarki realnej. W następstwie dłuższych operacji refinansujących stopa EONIA uległa ustabilizowaniu (po wcześniejszym okresie wysokiej zmienności) na średnim poziomie około 10 punktów bazowych powyżej stopy depozytu na koniec dnia w banku centralnym. Od lipca 2009 r., Eurosystem przez 12 miesięcy prowadził skup denominowanych w euro obligacji zabezpieczonych o wartości 60 mld euro wyemitowanych w strefie euro ${ }^{44}$.

Sektor bankowy otrzymał w okresie kryzysu finansowego nie tylko wsparcie od Eurosystemu, ale również od rządów państw strefy euro. Pomoc ta opierała się na jednolitych zasadach przewodnich Unii Europejskiej, komunikatach Komisji Europejskiej ${ }^{45}$ oraz rekomendacjach $\mathrm{EBC}^{46}$. Przykładem aktywności rządów strefy euro $\mathrm{w}$ tej kwestii jest przyjęcie 12 października wspólnego europejskiego planu działania (European Action Plan). W ramach tego planu zdecydowano o podjęciu dodatkowych działań w celu wsparcia systemu finansowego na poziomie każdego kraju. Pomoc publiczna, która opierała się na uwzględnieniu interesu podatników dotyczyła zobowiązań bankowych obejmując $c^{47}$ : gwarancje rządowe dla pożyczek międzybankowych oraz nowo przeprowadzanych emisji dłużnych papierów wartościowych przez banki; dokapitalizowanie podmiotów finansowych poprzez zastrzyki kapitałowe, kredyty i pożyczki; objęcie większym zakresem ochrony ubezpieczeniowej depozytów detalicznych.

${ }^{44}$ Ibidem, s. 44.

${ }^{45}$ Wśród komunikatów Komisji Europejskiej znalazły się następujące dokumenty: Komunikat bankowy, DzU C 270 z 25 października 2008 r., Komunikat o dokapitalizowaniu, DzU C z 10 i 15 stycznia 2009 r., Komunikat w sprawie aktywów o obniżonej wartości, DzU C 72 z 26 marca 2009 r., jak również Komunikat w sprawie przywrócenia rentowności i oceny środków restrukturyzacyjnych stosowanych w sektorze finansowym, DzU C 195 z 19 sierpnia 2009 r.

${ }^{46}$ Do rekomendacji EBC dla rządów należy Zalecenie Rady Prezesów EBC w sprawie udzielania gwarancji państwa dla zadłużenia banków z 20 października 2008 r. oraz Zalecenie w sprawie ustalania cen środków stużących dokapitalizowaniu z 20 listopada $2008 \mathrm{r}$.

${ }^{47}$ Annual Report 2008, op. cit., s. 82-84. 
Rządy państw udzielając pomocy sektorowi bankowemu poniosły pewnego rodzaju ryzyko fiskalne, które w perspektywie średnio- lub długoterminowej mogło stanowić zagrożenie dla salda rachunków finansów publicznych. Rządy podjęły się zobowiązań warunkowych ryzykując, że w przyszłości może zaistnieć potrzeba wywiązania się z części udzielonych gwarancji lub udzielenia kolejnych $^{48}$. Ponadto, rządowe wsparcie dla sektora bankowego związane $\mathrm{z}$ dokapitalizowaniem banków czy zakupami aktywów i pożyczek, wpływa na wielkość i strukturę budżetu danego kraju. Zakładano, że interwencje te nie powinny mieć przełożenia na dług publiczny państwa, jednak rzeczywiste wpływy z przyszłej sprzedaży nabytych w czasie kryzysu aktywów mogą mieć wpływ na płynność finansową kraju ${ }^{49}$. Stabilność systemu finansowego została przywrócona wspólnym wysiłkiem władz monetarnych oraz fiskalnych. To właśnie jednym ze sposobów wychodzenia gospodarki światowej z kryzysu finansowego była współpraca w ramach polityki pieniężnej oraz fiskalnej.

Podsumowując, na podstawie powyżej zaprezentowanych informacji można przypuszczać, że wzrost gospodarczy w strefie euro reagował niższymi poziomami na decyzje w obszarze polityki pieniężnej z pewnym opóźnieniem, które wynika z naturalnego procesu mechanizmu transmisji polityki monetarnej do realnej gospodarki. Ponadto oprocentowanie kredytó $\mathrm{w}^{50} \mathrm{w}$ bankach komercyjnych wyraźnie podążało $\mathrm{w}$ omawianym okresie 1998-2009 za poziomem podstawowej stopy EBC oraz stóp rynku międzybankowego. Opisywane stopy rynku międzybankowego właściwie od początku ustanowienia minimalnej stopy podstawowych operacji refinansujących kształtowały się minimalnie powyżej tej stopy, z wyjątkiem okresu od połowy 2007 r. do III kwartału 2008 r. Powodem tego był istotny wpływ kryzysu finansowego, niepewności na rynkach i znacznych wahań międzybankowych stóp procentowych.

${ }^{48}$ Pod koniec 2009 r., zobowiązania warunkowe nieujawnione w bilansach państw (implicit contingent liabilities), które stanowiły zasoby przeznaczone na systemy gwarancji (za wyjątkiem gwarancji rządowych dla depozytów detalicznych) stanowiły 20,1\% PKB krajów strefy euro. Z kolei zobowiązania warunkowe ujawnione w bilansach (explicit contingent liabilities), które odnosiły się do gwarancji rzeczywiście wykorzystanych przez banki, stanowiły około 9,4\% PKB.

${ }^{49}$ Annual Report on the Euro Area 2009, „European Economy” 2009, No. 6, European Commission, Luxembourg 2009, s. 83-84.

${ }^{50}$ Od 1998 r. aż do końca 2003 r., oprocentowanie kredytów oscylowało pomiędzy 4\% a 6,5\%. Wyraźny trend spadkowy oprocentowania kredytów rozpoczął się jeszcze w $2001 \mathrm{r}$. i trwał właściwie do końca 2005 r. Oprocentowanie kredytów zaczęło wzrastać od roku 2006 i pozostawało w trendzie wzrostowym do III kwartału 2008 r. W 2009 r. w związku z kryzysem finansowym, niepewnością na rynkach finansowych, niższym poziomem podstawowych stóp procentowych EBC, średnie oprocentowanie kredytów zostało istotnie obniżone w celu zachęcenia podmiotów gospodarczych do zaciągania zobowiązań. Jednak pomimo niższego kosztu kredytu oferowanego przez banki, w warunkach zawirowań i niepewności na rynkach, przedsiębiorstwa rezygnowały lub zawieszały w czasie decyzje związane z wykorzystywaniem kredytów bankowych. 


\subsection{Zadłużenie kredytowe przedsiębiorstw w bankach komercyjnych oraz nakłady inwestycyjne podmiotów gospodarczych w strefie euro w latach 1998-2009}

W 1999 r. roczny wskaźnik wzrostu kredytów dla sektora prywatnego znajdował się w przedziale pomiędzy $10 \%$ a $11 \%$, zwiększając się w porównaniu do 8,3\% w 1998 r. ${ }^{51}$ Ta ekspansja kredytowa dla przedsiębiorstw i gospodarstw domowych była prawdopodobnie odzwierciedleniem niskich stóp oprocentowania kredytów w stosunku do lat wcześniejszych oraz wzrostu aktywności gospodarczej w strefie euro. Stopy oprocentowania długoterminowych kredytów dla przedsiębiorstw wykazały jednak trend wzrostowy, reagując z pewnym opóźnieniem na wzrost rynkowych stóp procentowych, który rozpoczął się w maju 1999 r. W odpowiedzi na zacieśnianie polityki pieniężnej przez EBC, banki zdecydowały się na umiarkowane podwyższenie stóp oprocentowania kredytów dla gospodarstw domowych i przedsiębiorstw. Pomimo tego nadal utrzymywał się wzrost kredytów dla przedsiębiorstw, który wynikał z większej aktywności gospodarczej (wykres 5.5) ${ }^{52}$.

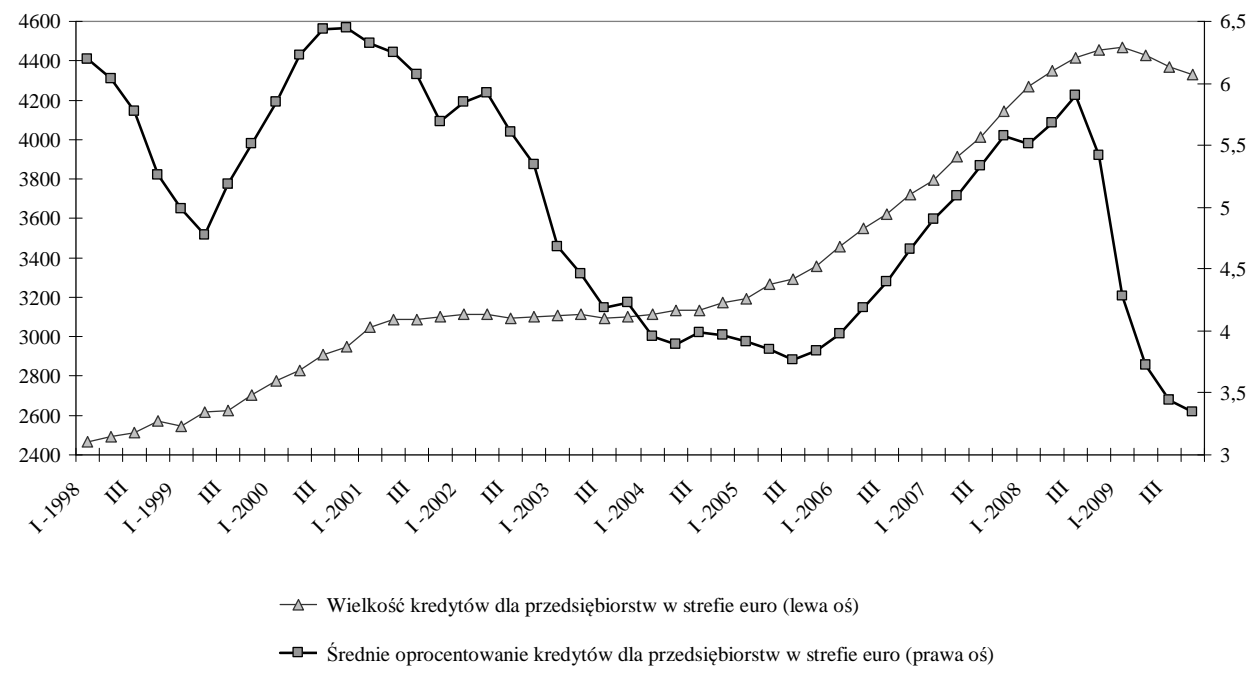

Wykres 5.5. Kredyty przedsiębiorstw w mld euro oraz średnie nominalne oprocentowanie kredytów dla przedsiębiorstw w strefie euro w latach 1998-2009

Ź r ó d ł o: opracowanie własne na podstawie danych z EBC Statistical Data Warehouse.

${ }^{51}$ Annual Report 2002, op. cit., s. 13.

${ }^{52}$ Annual Report 1999, op. cit., s. 13. 
Z kolei w 2000 r. roczne tempo wzrostu kredytów dla sektora prywatnego oscylowało pomiędzy $8,8 \%$ a 10,5\%, głównie w związku ze znaczącym wzrostem kredytów dla przedsiębiorstw, który wynikał z licznych fuzji i przejęć oraz wyższych cen nieruchomości (wykres 5.5) ${ }^{53}$. W 2002 r. roczna stopa wzrostu kredytów dla sektora prywatnego spadła do $4,8 \%$ w IV kwartale roku, w stosunku do poziomu 6,5\% tego samego kwartału $2001 \mathrm{r}^{54}$.

Warunki finansowania zewnętrznego w 2003 r. oraz 2004 r. pozostawały bardzo korzystne dla przedsiębiorstw. Istotnym jest fakt, że przedsiębiorstwa w znacznym stopniu korzystały $\mathrm{z}$ finansowania wierzycielskiego, głównie z powodu niskiej rentowności emitowanych przez nie obligacji, jak również niskich realnych kosztów dywidendy. Warunki udzielania kredytów przedsiębiorstwom przez monetarne instytucje finansowe także pozostawały korzystne dla kredytobiorców, głównie ze względu na niski i stabilny poziom stóp procentowych w strefie euro (wykres 5.6). Łatwiejszy dostęp firm do kredytów bankowych wiązał się również z łagodzeniem kryteriów ich przyznawania ${ }^{55}$.

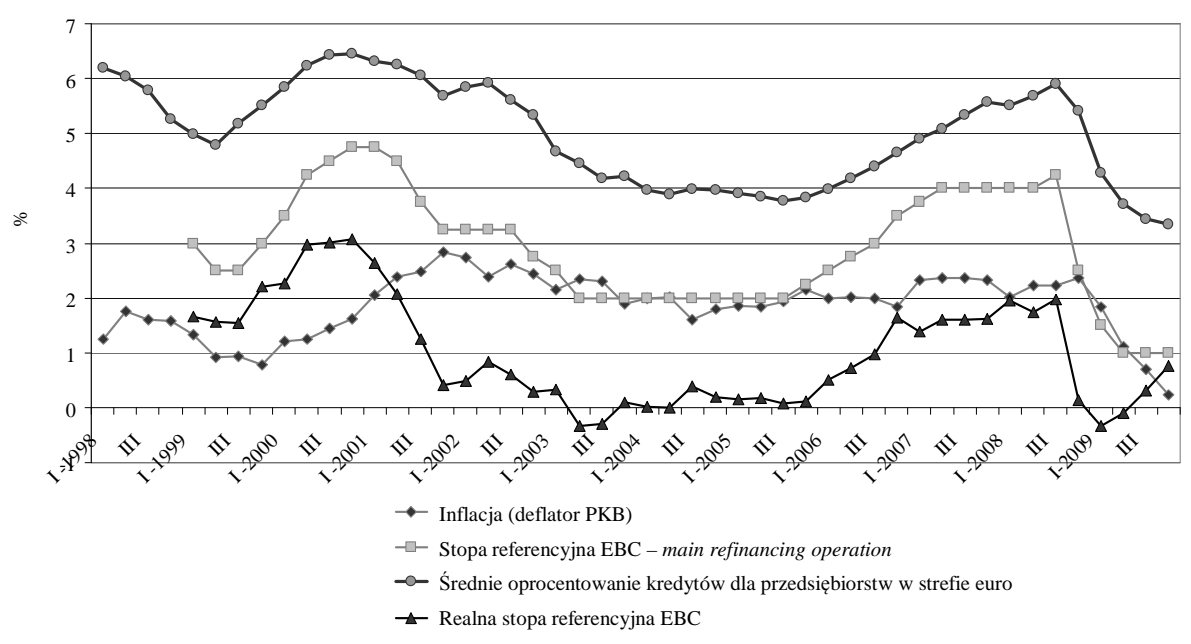

Wykres 5.6. Nominalna i realna stopa referencyjna EBC oraz średnie oprocentowanie kredytów dla przedsiębiorstw i inflacja w strefie euro w latach 1998-2009

Ź ró d ło: opracowanie własne na podstawie danych EBC pochodzących z Biuletynów Miesięcznych EBC oraz EBC Statistical Data Warehouse.

Stopa wzrostu kredytów monetarnych instytucji finansowych dla sektora przedsiębiorstw wzrosła z 3,5\% w 2003 r. do 5,4\% w 2004 r. (przy spadku stóp

\footnotetext{
${ }^{53}$ Annual Report 2000, op. cit., s. 17-18.

${ }^{54}$ Annual Report 2002, op. cit., s. 17.

${ }^{55}$ Annual Report 2004, op. cit., s. 42.
} 
nominalnych i realnych EBC - wykres 5.5). Interesujący jest fakt, że w 2004 r. przedsiębiorstwa $\mathrm{w}$ mniejszym stopniu zadłużały się poprzez emisję dłużnych papierów wartościowych, czego odzwierciedleniem była niższa stopa netto wzrostu emisji tych papierów, która w 2003 r. wynosiła 10,5\%, a w 2004 r. $2,4 \%$. Przyczyn takiego przebiegu wydarzeń upatrywano w poprawie rentowności firm (głównie tych dużych ujętych w indeksie Dow Jones EURO STOXX) oraz w ożywieniu gospodarczym ${ }^{56}$.

W 2005 r. roczna stopa wzrostu kredytów monetarnych instytucji finansowych strefy euro uległa zwiększeniu do $8 \% \mathrm{w}$ stosunku do poziomu $5,4 \%$ w 2004 r. Szczególnie w drugiej połowie roku 2005 istotnie wzrosła dynamika kredytów długoterminowych, które mają silniejszy związek z inwestycjami przedsiębiorstw, w przeciwieństwie do kredytów krótkoterminowych, które wykorzystywane są przez firmy głównie jako kapitał obrotowy. Według ankiety przeprowadzanej w październiku 2005 r. i na początku 2006 r., która dotyczyła akcji kredytowej wśród banków, wynikało, że popyt przedsiębiorstw na kredyty lub linie kredytowe wzrósł w wyniku zwiększenia nakładów na środki trwałe firm. Było to skutkiem wzrostu rocznej dynamiki nakładów brutto na środki trwałe szczególnie w drugim i trzecim kwartale 2005 r. (wykres 5.7) ${ }^{57}$.

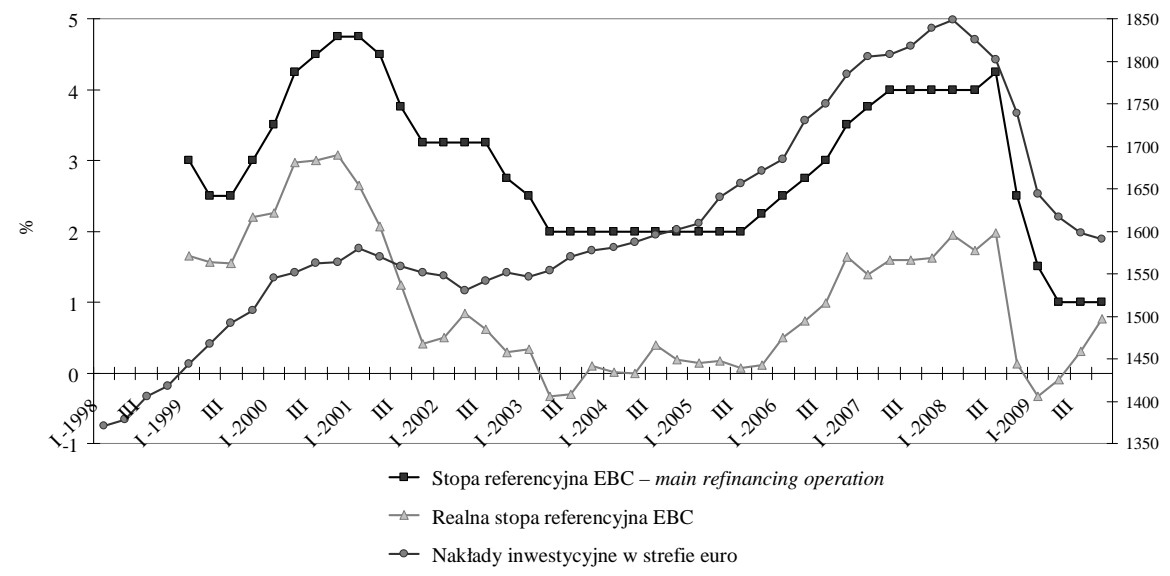

Wykres 5.7. Nominalna i realna stopa referencyjna EBC oraz realne nakłady inwestycyjne w mld euro, w strefie euro w latach 1998-2009

Źr ódło: opracowanie własne na podstawie danych z: EBC Statistical Data Warehouse oraz OECD National Accounts (www.oecd.org).

\footnotetext{
${ }^{56}$ Ibidem, s. $43-44$.

${ }^{57}$ Annual Report 2005, op. cit., s. 47.
} 
Niskie koszty finansowania oraz łagodne kryteria udzielania kredytów sprzyjały przedsiębiorstwom do przeprowadzania inwestycji przy korzystnych warunkach finansowania zewnętrznego.

Do trzeciego kwartału 2008 r. tempo wzrostu kredytów było bardzo silne, jednak po wrześniu 2008 r. tempo to znacznie się osłabiło. Roczne tempo wzrostu kredytów w sektorze prywatnym spadło do $1,5 \%$ w czerwcu 2009 r. ${ }^{58}$ Przyglądając się dokładniej informacjom dotyczącym poziomu kredytów i pożyczek dla przedsiębiorstw, można zauważyć zdecydowane wyhamowanie rocznej stopy wzrostu tego wskaźnika, z poziomu 9,5\% w grudniu 2008 r. (5,7\% po korekcie) do $-2,2 \%$ w grudniu 2009 r. ${ }^{59}$ Akcja kredytowa banków uległa istotnemu osłabieniu ze względu na zaostrzenie w 2009 r. warunków udzielania kredytów i pożyczek w wyniku ograniczeń bilansowych lub źródeł finansowania. Wiązało się to ze zmniejszeniem poziomu dostępnej płynności na rynku, jak również z pogorszeniem zdolności kredytowych kredytobiorców (wykres 5.5) ${ }^{60}$.

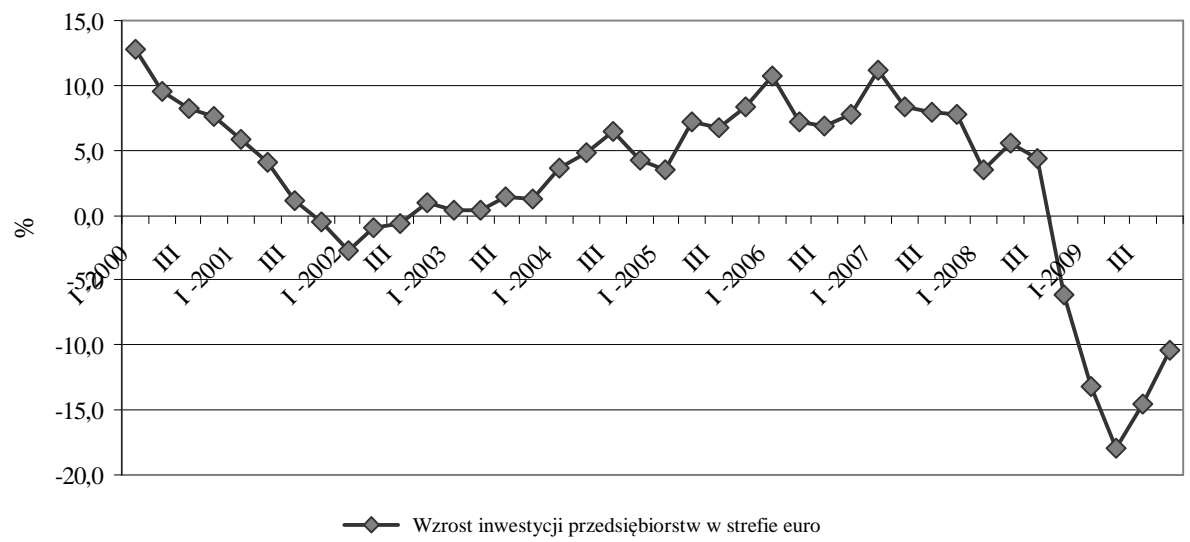

Wykres 5.8. Wzrost inwestycji przedsiębiorstw w strefie euro w latach 2000-2009

Ź ródło: opracowanie własne na podstawie danych z: EBC Statistical Data Warehouse. Dane dotyczące wzrostu nakładów inwestycyjnych brutto przedsiębiorstw w strefie euro liczone jako roczna zmiana procentowa zostały zaczerpnięte $\mathrm{z}$ bazy danych EBC oraz Eurostat, dane kwartalne ${ }^{61}$.

Nakłady brutto na środki trwałe w 1999 r. wzrosły utrzymując się na trochę wyższym poziomie niż w roku 1998 (według rocznej zmiany procentowej,

${ }^{58}$ Ibidem, s. 23.

${ }^{59}$ Annual Report 2009, Europejski Bank Centralny, Frankfurt n. Menem 2010, s. 34.

${ }^{60}$ Ibidem, s. 38.

${ }^{61} \mathrm{http} / / /$ epp.eurostat.ec.europa.eu/portal/page/portal/sector_accounts/documents/Charts\%20 and\%20Tables_EN_271010_wo_oldS13.xls\#'S11-4'!A1. 
w porównaniu do tego samego okresu rok wcześniej) ${ }^{62}$. Wydaje się, że przyczyną tych wzrostów były niskie stopy procentowe, które miały odzwierciedlenie w niższych kosztach pozyskania kapitału zewnętrznego podmiotów gospodarczych. W ciągu 2000 r. nakłady brutto na środki trwałe spadały w porównaniu do $1999 \mathrm{r}^{63}$

Na wykresie 5.8 zaprezentowano roczną zmianę procentową nakładów brutto na środki trwałe przedsiębiorstw w strefie euro, gdzie widoczny jest gwałtowany spadek inwestycji właściwie od połowy $2000 \mathrm{r}$. aż do połowy $2002 \mathrm{r}$. (II kwartał 2002 r. zmiana procentowa nakładów brutto na środki trwałe na poziomie -0,9\%). Dopiero od końca 2002 r. nakłady brutto na środki trwałe przedsiębiorstw weszły na ścieżkę trendu wzrostowego, z niewielkimi wahaniami do końca 2004 r. Wzrost nakładów na inwestycje miał swoje podłoże w wysokiej aktywności gospodarczej zarówno w strefie euro jak i poza jej granicami. Wysoka rentowność podmiotów gospodarczych szczególnie w sektorze produkcyjnym i korzystne warunki finansowe zapewniały firmom środki finansowe, które przeznaczano na inwestycje.

Wskaźnik nakładów brutto na środki trwałe w gospodarce strefy euro w I kwartale 2006 r. wynosił 10,7\% w porównaniu do 3,5\% w tym samym okresie 2005 r. Z kolei w IV kwartale 2007 r. wskaźnik ten ukształtował się na poziom 7,7\%, z tym, że jeszcze w pierwszym kwartale wynosił 11,1\%. W 2008 r. zaobserwowano dalszy spadek nakładów brutto na środki trwałe, który nadal wykazywał tendencję spadkową (roczna zmiana procentowa w porównaniu do analogicznego okresu roku poprzedniego wyniosła w IV kwartale 2008 r. $-6,1 \%)^{64}$. Ten gwałtowny spadek osiągnął najniższy punkt w II kwartale $2009 \mathrm{r}$. $(-17,9 \%)$ zmniejszając się nieznacznie w IV kwartale 2009 r. do poziomu $-10,5 \%$ (wykres 5.8). Skutki kryzysu okazały się tak istotne, że interwencja EBC $w$ postaci niskich stóp procentowych i dostarczania dodatkowej płynności na rynku nie uchroniły tak znacznego spadku nakładów inwestycyjnych przedsiębiorstw w strefie euro.

Według obliczeń Komisji Europejskiej, w I kwartale 2009 r. tempo wzrostu PKB spadło o 2,5\% kwartał do kwartału, a źródłem tego spadku był między innymi spadek nakładów brutto na środki trwałe. Ograniczenie inwestycji osłabiło wzrost gospodarczy o 1 punkt procentowy. W wyniku recesji spadł popyt, dochody firm kurczyły się, a banki zacieśniały politykę kredytową w stosunku do podmiotów gospodarczych ${ }^{65}$. Nakłady brutto na środki trwałe przedsiębiorstw obniżyły się w 2009 r. znacznie bardziej niż nawet inwestycje mieszkaniowe. Spadek ten w ujęciu rok do roku wyniósł około 14\%. Do przyczyn tak

${ }^{62}$ Annual Report 1999, op. cit., s. 31.

${ }^{63}$ Annual Report 2000, op. cit., s. 39.

${ }^{64} \mathrm{http}: / /$ epp.eurostat.ec.europa.eu/portal/page/portal/sector_accounts/documents/Charts\%20 and\%20Tables_EN_271010_wo_oldS13.xls\#'S11-4'!A1.

${ }^{65}$ Annual Report on the Euro Area 2009, op. cit., s. 18. 
gwałtownego spowolnienia inwestycyjnego zalicza się przede wszystkim: niepewność co do przyszłości na rynkach, znaczny spadek popytu, niskie wykorzystanie mocy produkcyjnych, ograniczona marża zysku, jak również zaostrzone warunki finansowania pomimo istotnego spadku stóp procentowych $\mathrm{EBC}^{66}$.

Zmiany stopy inwestycji w strefie euro w latach 2000-2009 odzwierciedlają reakcję podmiotów gospodarczych na zmiany wskaźników makroekonomicznych w gospodarce (wykres 5.9). Podsumowując, można wnioskować, że w momencie osłabienia gospodarczego, które pojawiło się w latach 2002-2003 oraz kryzysu finansowego w latach 2008-2009, zacznie słabła aktywność inwestycyjna przedsiębiorstw. Reakcja uczestników rynku następowała z pewnym opóźnieniem, co uwidocznione jest w przesuniętym w czasie spadku nakładów inwestycyjnych przedsiębiorstw. Decyzje EBC odnośnie podstawowych stóp procentowych przenoszone poprzez mechanizm transmisji polityki pieniężnej do realnej gospodarki były zauważalne w poziomie nakładów inwestycyjnych w badanym okresie.

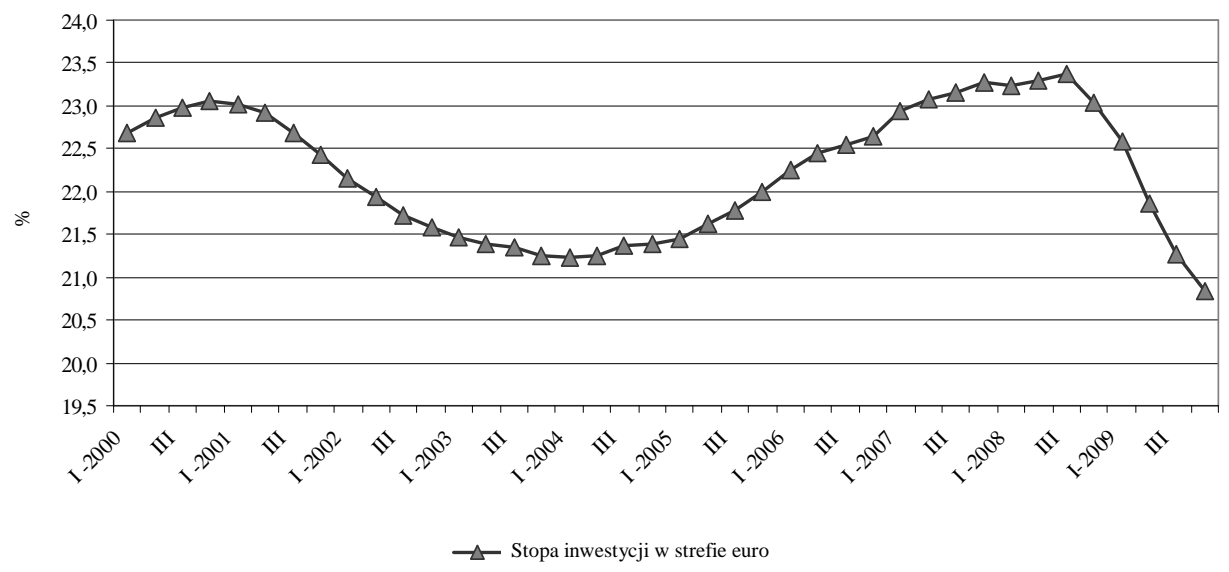

Wykres 5.9. Stopa inwestycji w strefie euro w latach 2000-2009

Źr ódło: opracowanie własne na podstawie danych z: EBC Statistical Data Warehouse. Dane dotyczące stopy inwestycji liczonej jako zmiana procentowa wartości dodanej brutto w strefie euro zostały zaczerpnięte z bazy danych EBC oraz Eurostat, są to dane kwartalne oparte na skumulowanej sumie $z$ czterech kwartałów ${ }^{67}$. Wartość dodana brutto opisuje przyrost wartości dóbr (wyrobów i usług) wytworzonych przez wszystkie krajowe podmioty w danym okresie pomniejszonej o koszty związane z ich wytworzeniem.

${ }^{66}$ Annual Report 2009, op. cit., s. 72.

${ }^{67}$ Zasoby witryny internetowej: http://epp.eurostat.ec.europa.eu/portal/page/portal/sector_accounts/documents/Charts\%20and\%20Tables_EN_271010_wo_oldS13.xls\#'S11-4'!A1 [08.08.2010]. 
W latach 2000-2001 EBC prowadził restrykcyjną politykę pieniężną (najwyższa wartość stopy referencyjnej wyniosła 4,25\%), przy stosunkowo wysokiej stopie inwestycji (23\% - wykres 5.9). Jednak wydaje się, że już w latach 2002 -2004 stopa inwestycji w strefie euro osłabła w rezultacie wyższych stóp procentowych we wcześniejszych latach oraz $w$ wyniku trwającego w tym czasie osłabienia gospodarczego. Wśród czynników, które wpłynęły na wzrost nakładów inwestycyjnych w strefie euro w latach 2006-2008, była ekspansywna polityka pieniężna EBC od połowy $2003 \mathrm{r}$. do połowy $2006 \mathrm{r}$. W czasie ostatniego kryzysu finansowego, pomimo że w IV kwartale 2008 r. EBC rozpoczął serię obniżek stóp procentowych do poziomu $1 \%$ w maju 2009 r., stopa inwestycji w strefie euro zaczęła gwałtownie spadać. Do głównych przyczyn spadku inwestycji i tempa wzrostu gospodarczego zalicza się światowy kryzys finansowy, który zaburzył funkcjonowanie gospodarek strefy euro. W czasach kryzysu, mimo niskiego poziomu nominalnej oraz realnej stopy referencyjnej banku centralnego i przez to korzystnych warunków inwestowania poprzez niski koszt kapitału obcego, podmioty gospodarcze ograniczały nakłady inwestycyjne.

\subsection{Polityka pieniężna Narodowego Banku Polskiego na tle sytuacji gospodarczej w latach 1998-2009}

Rok 1998 uznawany jest za początek funkcjonowania banku centralnego oraz całego sektora bankowego w nowych ramach instytucjonalno-prawnych. Zmiany te zostały zapoczątkowane $\mathrm{w}$ momencie przyjęcia $\mathrm{w}$ referendum 2 kwietnia 1997 r. Konstytucji Rzeczypospolitej Polskiej oraz Ustawy z dnia 29 sierpnia 1997 r. o Narodowym Banku Polskim i Prawa bankowego, które weszły w życie z początkiem 1998 r. Rozwiązania przyjęte w tych ustawach odpowiadają znacząco rozwiązaniom prawnym, które obowiązują banki centralne w krajach Unii Gospodarczej i Walutowej. Konieczność opracowania tych dokumentów przez Sejm RP wynikała również z podpisania przez Polskę Umowy Stowarzyszeniowej z Unia Europejska, czyli Układu Europejskiego (zobowiązującego stronę polską do przeprowadzenia harmonizacji ustawodawstwa krajowego z unijnym). Istotną zmianą było powierzenie podejmowania decyzji w zakresie polityki pieniężnej dziesięcioosobowej Radzie Polityki Pieniężnej i rozpoczęcie prac w obszarze nadzoru bankowego przez siedmioosobową Komisję Nadzoru Bankowego. Od 1998 r. celem NBP było utrzymanie stabilnego poziomu cen przy jednoczesnym wspieraniu polityki gospodarczej rządu, o ile nie ogranicza to podstawowego celu banku centralnego. Ponadto decyzja ${ }^{68}$

${ }^{68}$ Konstytucja Rzeczpospolitej Polskiej dnia 2 kwietnia 1997 r., DzU 1997, nr 78, poz. 483 z późn. zm., art. 220. 
o braku finansowania deficytu budżetowego przez bank centralny wzmocniła jego niezależność od zmian politycznych. W tym samym roku inflacja po raz pierwszy od osiemnastu lat osiągnęła poziom jednocyfrowy, co można było odbierać jako pewien krok ku stabilności finansowej. Poza tym można było już dostrzec, że gospodarka polska po dziesięciu latach transformacji ustrojowej kieruje się prawami rynkowymi ${ }^{69}$.

RPP rozpoczęła działalność od opracowania Założeń polityki pieniężnej na 1998 r. oraz przyjęcia Średniookresowej strategii polityki pieniężnej na lata 1999-2003. Głównym celem ogłoszonej strategii było zmniejszenie rocznego tempa inflacji do poziomu poniżej 4\% do końca 2003 r. ${ }^{70}$ Rok 1998 był również pierwszym rokiem przyjęcia przez RPP strategii bezpośredniego celu inflacyjnego i tym samym odejścia od wykorzystywania podaży pieniądza jako oficjalnego, pośredniego celu polityki monetarnej ${ }^{71}$. Głównym powodem takiej decyzji były coraz większe trudności w przewidywalności związku między agregatem pieniężnym M2 a inflacją ${ }^{72}$.

Warunki, w jakich NBP realizował politykę pieniężną w 1998 r. nie były łatwe, szczególnie w drugiej połowie roku. Nastąpiło wtedy osłabienie gospodarcze, w rezultacie czego PKB wzrósł o 4,8\%, czyli o 1,2 punktu procentowego poniżej prognozy. Dla porównania, w 1997 r. PKB wzrósł o 6,9\%. Pomimo tego, poziom cen towarów i usług konsumpcyjnych w ujęciu grudzień do grudnia w 1998 r. wyniósł 8,6\% obniżając się z poziomu 13,2\% w grudniu 1997 r. (wykres 5.10). Wśród przyczyn osłabienia gospodarczego wymieniano spadek tempa wzrostu popytu, w tym również zewnętrznego ${ }^{73}$. W związku z kryzysem na światowych rynkach finansowych, głównie kryzysu rosyjskiego, nastąpiło znaczne osłabienie wpływów z eksportu polskich towarów do krajów WNP (Wspólnota Niepodległych Państw), przede wszystkim do Rosji i Ukrainy. Niższy popyt przyczynił się do spadku produkcji przemysłowej oraz ograniczenia aktywności inwestycyjnej przedsiębiorstw ${ }^{74}$. Na warunki realizacji polityki pieniężnej wpływała również polityka fiskalna państwa. W roku 1998 relacja deficytu budżetowego do PKB wynosiła 2,4\%, kontynuując trend spadkowy deficytu, który sprzyjał realizacji celu inflacyjnego banku centralnego. Utrzymanie deficytu budżetowego pod kontrolą umożliwiło władzom monetarnym realizację polityki pieniężnej w warunkach przeniesienia większej restrykcyjności na poli-

\footnotetext{
${ }^{69}$ Raport roczny1998, Narodowy Bank Polski, Warszawa 1999, s. 13-27.

${ }^{70}$ Średniookresowa strategia polityki pieniężnej na lata 1999-2003, Rada Polityki Pieniężnej, NBP, Warszawa, wrzesień 1998, s. 9-10.

${ }^{71}$ Sprawozdanie z wykonania założeń polityki pieniężnej w 1998 roku, Narodowy Bank Polski, Warszawa 1999, s. 11-13.

${ }^{72}$ Raport roczny 1998, op. cit., s. 13-27.

${ }^{73}$ Raport o inflacji 1998 rok, Narodowy Bank Polski, Warszawa, czerwiec 1999, s. 8-9.

${ }^{74}$ M. S o b o 1, Polityka pieniężna Narodowego Banku Polskiego w drodze do euro, Wydawnictwo Fachowe CeDeWu, Warszawa 2008, s. 162.
} 
tykę fiskalną. Dobre wyniki budżetu państwa ułatwiły RPP prowadzenie polityki obniżania stóp procentowych (wykres 5.10) ${ }^{75}$.

W związku ze spodziewanym wzrostem oczekiwań inflacyjnych, spowodowanym zapowiadanymi podwyżkami cen regulowanych na początku 1998 r., a dokładnie 26 lutego NBP ustalił, że stopa operacji otwartego rynku będzie wynosić $24 \%$. Wysokość stopy lombardowej utrzymano na poziomie $27 \%$, natomiast stopę redyskonta weksli pozostawiono na poziomie $24,5 \%$. W II kwartale 1998 r. pojawiły się w gospodarce warunki dogodne do obniżenia stóp procentowych. Zaliczano do nich wygaszenie impulsu cenowego, obniżenie inflacji oraz dynamiki kredytów w wyrażeniu nominalnym, a także osłabienie popytu krajowego. W związku z tym Rada postanowiła pierwszy raz obniżyć stopę 28-dniowych operacji otwartego rynku do poziomu 23\%. W sumie w 1998 r., stopa operacji otwartego rynku została obniżona o 8,5 punktów procentowych do wysokości $15,5 \%$, stopa lombardowa o 7 punktów procentowych do poziomu $20 \%$, natomiast stopa redyskonta weksli została zredukowana o 6,25 punktów procentowych do $18,25 \%$ (wykres 5.10$)^{76}$.

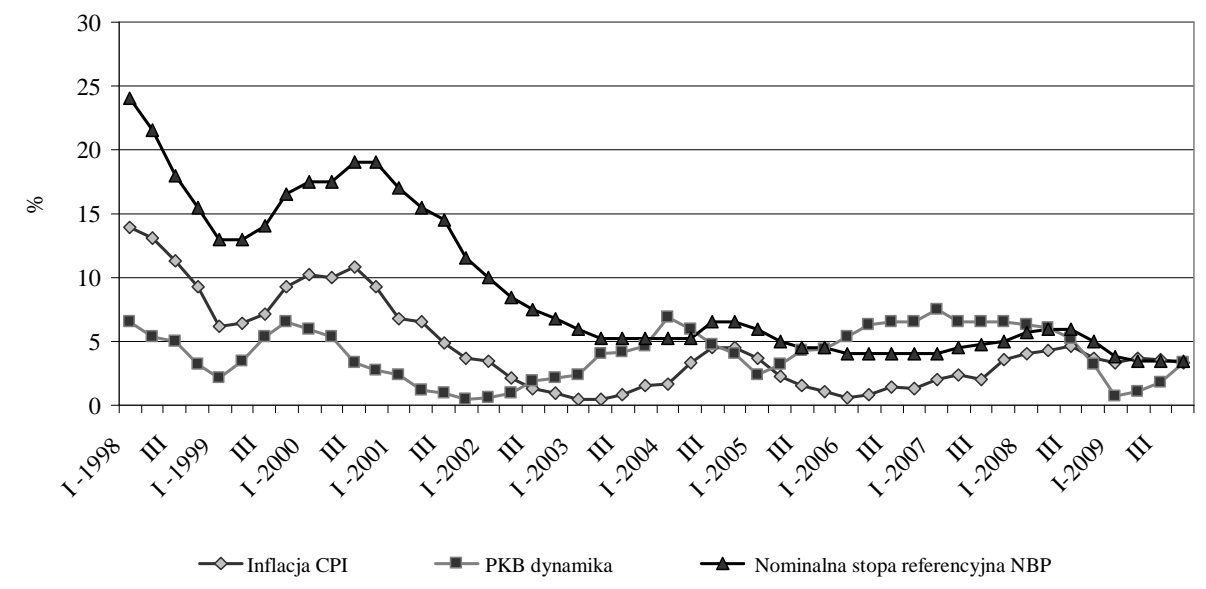

Wykres 5.10. Inflacja CPI, dynamika PKB, stopa referencyjna NBP w latach 1998-2009

Ź r ó d ł o: opracowanie własne na podstawie danych: Raporty roczne NBP z lat 1998-2009 oraz tabeli GUS - wybrane kwartalne wskaźniki makroekonomiczne.

Zgodnie z wytycznymi RPP emisja 28-dniowych bonów pieniężnych NBP była podstawowym rodzajem operacji otwartego rynku. Minimalna rentowność 28-dniowych bonów pieniężnych miała efektywny wpływ na krótkoterminowe

\footnotetext{
${ }^{75}$ Raport roczny 1998, op. cit., s. 13-27.

${ }^{76}$ Sprawozdanie z wykonania założeń polityki pieniężnej w 1998 roku, op. cit., s. 27-28.
} 
stopy rynku międzybankowego (WIBOR). Bank centralny poprzez tę stopę miał pośrednio wpływ na oprocentowanie kredytów udzielanych przez banki komercyjne. W 1998 r. znacznie wzrosło saldo operacji otwartego rynku prowadzonych z bankami komercyjnymi, aż o 12,9 mld zł, głównie ze względu na zwiększenie emisji bonów pieniężnych NBP o 14,2 mld zł (saldo operacji warunkowych spadło o 1,3 mld zf) ${ }^{77}$. W sumie w 1998 r. przeprowadzono 164 przetargi na bony pieniężne NBP, sprzedając bankom bony o łącznej wartości 243 mld zt. ${ }^{78}$.

Instrumentem realizacji polityki pieniężnej była również rezerwa obowiązkowa wyliczana na podstawie średnich stanów depozytów złotowych oraz walutowych na koniec poszczególnych dekad miesiąca. W 1998 r. stopy rezerwy obowiązkowej były na stosunkowo wysokim poziomie, głównie ze względu na wysoką nadpłynność w systemie bankowym. Stopa rezerwy od depozytów złotowych a'vista wynosiła w tym czasie $20 \%$, od depozytów terminowych $11 \%$, natomiast od depozytów walutowych 5\%. 7 maja 1998 r. RPP wprowadziła zmiany dotyczące sposobu naliczania rezerwy obowiązkowej, która od 28 lutego 1999 r. miała być liczona jako średnia arytmetyczna środków na rachunkach bankowych podlegających naliczaniu rezerwy ze wszystkich dni miesiąca ${ }^{79}$.

Rok 1999 okazał się trudny, głównie ze względu na skutki rosyjskiego kryzysu finansowego, ogólnego spowolnienia rozwoju gospodarki światowej oraz wzrostu cen paliw na rynkach międzynarodowych. W rozliczeniu rocznym tempo wzrostu PKB ukształtowało się na poziomie $4,1 \%{ }^{80}$. Dodatkowo wprowadzono kosztowne reformy dotyczące funkcjonowania sektora publicznego: reformę administracyjną, reformę systemu emerytalnego i służby zdrowia oraz reformę szkolnictwa podstawowego i średniego. Zdarzenia te nie ułatwiały prowadzenia polityki gospodarczej. Deficyt na rachunku obrotów bieżących bilansu płatniczego wynosił 7,6\% PKB. Niepokojącym zjawiskiem było również przyspieszenie inflacji, która w porównaniu do grudnia $1998 \mathrm{r}$. wzrosła o 9,8\%. W związku z tym, że w pierwszych miesiącach roku 1999 inflacja spadała, RPP 21 stycznia postanowiła obniżyć podstawowe stopy procentowe. Decyzja ta była podyktowana tym, że na rynku utrzymywała się nadwyżka podaży (szczególnie artykułów żywnościowych), wynikająca głównie z ograniczenia eksportu na rynki wschodnie (kryzys rosyjski) ${ }^{81}$. Władze monetarne zdecydowały się złagodzić politykę pieniężną również ze względu na zapowiadany wzrost re-

${ }^{77}$ Raport o inflacji 1998 rok, op. cit., s. 91-92.

${ }^{78}$ Raport roczny 1998, op. cit., s. 13-27.

${ }^{79}$ W 1998 r., w momencie obowiązywania Ustawy o NBP, zrezygnowano z oprocentowania rezerwy obowiązkowej, od której odsetki przekazywano do Agencji Restrukturyzacji i Modernizacji Rolnictwa, [w:] Raport roczny 1998, op. cit., s. 26.

${ }^{80}$ Sprawozdanie z wykonania założén polityki pieniężnej w 1999 roku, Narodowy Bank Polski, Warszawa 2000, s. 6.

${ }^{81}$ Raport o inflacji 1999 rok, Narodowy Bank Polski, Warszawa, czerwiec 2000, s. 7. 
strykcyjności polityki fiskalnej. Zatem stopa kredytu lombardowego została obniżona z $20 \%$ do $17 \%$, stopa redyskonta weksli z 18,25\% do $15,5 \%$, z kolei wysokość stopy operacji otwartego rynku zmieniono z $15,5 \%$ na $13 \%$, co zostało przedstawione na wykresie $5.11 .^{82}$

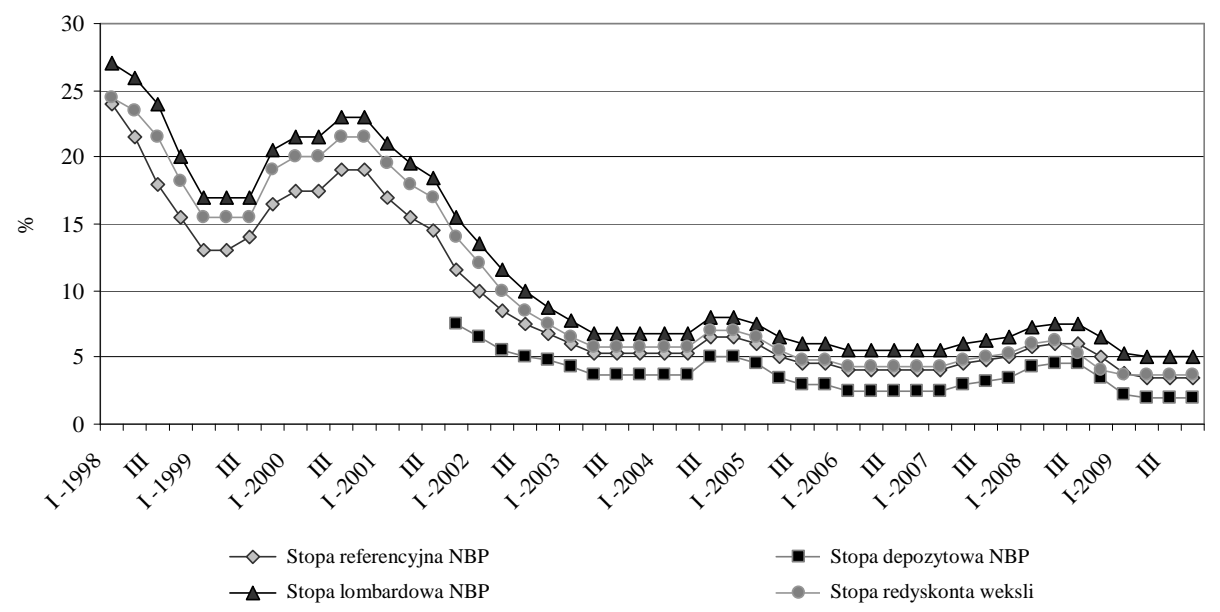

Wykres 5.11. Podstawowe stopy procentowe w Polsce w latach 1998-2009

Ź r ó d ł o: opracowanie własne na podstawie danych: Raporty roczne NBP z lat 1998-2009.

W drugiej połowie 1999 r. nastąpił gwałtowny wzrost ceny ropy naftowej na rynkach światowych, który w warunkach kłopotów finansowych budżetu oraz słabej konkurencji na rynku paliw, objawił się gwałtownym wzrostem cen. Dodatkowo zjawisko to było potęgowane przez podniesienie stawek celnych na niektóre produkty na rynku żywności i surowców dla przemysłu spożywczego, wprowadzono kontyngenty ilościowe oraz wzmocniono protekcję celną na rynku rolnym. Nadmiernie ekspansywna polityka fiskalna przejawiła się znacznym wzrostem popytu wewnętrznego ${ }^{83}$. Z kolei skutki mniej restrykcyjnej polityki monetarnej były widoczne we wzroście popytu na kredyty, głównie ze względu na spadek oprocentowania w ujęciu realnym. Efektem nadmiernego popytu krajowego był wzrost deficytu obrotów bieżących bilansu płatniczego oraz zwiększenie podatności waluty polskiej na zjawisko deprecjacji, która może być czynnikiem pogłębiającym inflację. W takich warunkach RPP postanowiła 23 września 1999 r. podnieść poziom stopy podstawowych operacji otwartego rynku o 1 punkt procentowy do $14 \%$. Następnie 18 listopada nastąpiła podwyżka stopy

\footnotetext{
${ }^{82}$ Raport roczny 1999, Narodowy Bank Polski, Warszawa 2000, s. 13-92.

${ }^{83}$ M. S o b o 1, Polityka..., op. cit., s. 162-163.
} 
lombardowej do $20,5 \%$, redyskonta weksli do $19 \%$, a stopy operacji otwartego rynku do 16,5\% (wykres 5.11). W 1999 r. NBP ograniczył emisję bonów pieniężnych, w rezultacie czego saldo operacji otwartego rynku spadło o 17,4 mld zł. Operacje te były wykorzystywane głównie w celu ograniczenia nadpłynności w sektorze bankowym ${ }^{84}$.

Od dnia 30 września RPP postanowiła ujednolicić stawkę rezerwy obowiązkowej od wszystkich depozytów do poziomu 5\%. Na rynku pojawiły się uwolnione z tego tytułu środki, które 67 banków ulokowało kupując wyemitowane przez bank centralny obligacje: 6-, 7-, 8-, 9- i 10-letnie. Takie odciążenie banków związane z rezerwą obowiązkową wpłynęło na wzrost konkurencyjności polskiego systemu bankowego. Był to proces zauważalny w wielu krajach Europy Środkowo-Wschodniej ${ }^{85}$.

W drugiej połowie $1999 \mathrm{r}$. widoczne symptomy spowolnienia gospodarczego przyczyniły się do wielu niekorzystnych tendencji, które miały miejsce również w 2000 r. Wśród nich były przede wszystkim: rosnący deficyt budżetowy, stopa bezrobocia (grudzień 2000 r. - 15\%) oraz słabsza dynamika wzrostu gospodarczego (tempo wzrostu PKB pod koniec 2000 r. wyniosło 2,4\%) ${ }^{86}$. W pierwszym kwartale 2000 r. relacja deficytu obrotów bieżących do PKB była wyższa od $8 \%$ w ujęciu rocznym. Dopiero w drugim kwartale zaobserwowano wzrost eksportu oraz osłabienie i ustabilizowanie importu, co w rezultacie spowodowało, że wspomniana wyżej relacja dla całego 2000 r. zatrzymała się na poziomie $6,3 \%{ }^{87}$.

Nie udało się zrealizować krótkookresowego celu polityki pieniężnej zapisanego w Założeniach polityki pieniężnej na $2000 \mathrm{r}$. Według tego dokumentu zamierzano obniżyć tempo wzrostu cen towarów i usług konsumpcyjnych do poziomu 5,4-6,8\% w grudniu 2000 r. Dwunastomiesięczny wskaźnik CPI na koniec roku wynosił $8,5 \%$. Co więcej, średnioroczna inflacja w 2000 r. wzrosła do $10,1 \%$ przekraczając poziom jednocyfrowy. Ten silny wzrost inflacji, który pojawił się już w końcu 1999 r., był przede wszystkim spowodowany zwiększającą się dynamiką popytu krajowego ${ }^{88}$. Wśród przyczyn wzrostu tego ostatniego upatruje się zbyt mało restrykcyjną politykę pieniężną. Niekorzystny wpływ na poziom inflacji w Polsce miały również zaburzenia na rynku paliw i żywności. Z powodu wzrostu cen ropy naftowej na rynkach światowych w II połowie $1999 \mathrm{r}$., na polskim rynku podwyższano cenę paliw aż 20 razy. Dodatkowym czynnikiem w tej kwestii był również proces dostosowań cen regulowanych typowy dla krajów próbujących likwidować lukę rozwojową powstałą w wyniku niższej wy-

${ }^{84}$ Raport roczny 1999, op. cit., s. 13.

${ }^{85}$ Ibidem, s. 12-13.

${ }^{86}$ Raport o stanie sektora matych i średnich przedsiębiorstw w Polsce $w$ latach 1999-2000, Polska Agencja Rozwoju Przedsiębiorczości, Warszawa 2001, s. 15.

${ }^{87}$ Raport roczny 2000, Narodowy Bank Polski, Warszawa 2001, s. 13.

${ }^{88}$ Raport o inflacji 2000 rok, Narodowy Bank Polski, Warszawa 2001, s. 89. 
dajności pracy w sektorze usług o rosnącym popycie, tzw. efekt Samuelsona-Balassy ${ }^{89}$. Pomimo zaostrzenia polityki pieniężnej w drugiej połowie $1999 \mathrm{r}$. skutki wcześniejszego rozluźnienia widoczne były jeszcze do połowy $2000 \mathrm{r}$. W lutym 2000 r., a następnie 31 sierpnia 2000 r. RPP zdecydowała się na podniesienie stóp procentowych. Stopa oprocentowania kredytu lombardowego została podniesiona z 20,5\% do $23 \%$, stopa redyskonta weksli z $19 \%$ do $21,5 \%$, natomiast stopa operacji otwartego rynku z 16,5\% do $19 \%$ w skali roku. Oficjalne stopy procentowe w okresie od września 1999 r. do sierpnia 2000 r. wzrosły o 6 punktów procentowych (wykres 5.11) ${ }^{90}$. W sierpniu $2000 \mathrm{r}$. odnotowano spadek inflacji do poziomu jednocyfrowego $\mathrm{w}$ ostatnim kwartale roku.

Ze względu na utrzymującą się nadpłynność w systemie bankowym NBP w 2000 r. przeprowadzał operacje absorbujące, emitując głównie 28-dniowe bony pieniężne, oddziałując przez to bezpośrednio na poziom jednomiesięcznej stopy procentowej na rynku międzybankowym. Saldo operacji otwartego rynku w 2000 r. wynosiło 18,4 mld zł wobec 21,4 mld w 1999 r. ${ }^{91}$.

Zgodnie z założeniami Średniookresowej strategii polityki pieniężnej na lata 1999-2003 ${ }^{92}$ oraz Założeń polityki pieniężnej na $2000 r^{93}$, kurs złotego przestał być instrumentem polityki pieniężnej. Rada Ministrów w porozumieniu z RPP zdecydowała o upłynnieniu kursu walutowego. Był to ostatni etap polityki uelastyczniania mechanizmu kursowego i kolejny element procesu przygotowania Polski do członkostwa w Unii Gospodarczo-Walutowej. W rezultacie wprowadzenie płynnego kursu walutowego przyczyniło się do zwiększenia autonomii polityki stóp procentowych banku centralnego ${ }^{94}$.

Rok 2001 to okres realizacji przez NBP zadań ujętych w Planie działalności na 2001 r. oraz w Zatożeniach polityki pieniężnej na rok 2001 ${ }^{95}$. Dążąc do osiągnięcia średniookresowego celu polityki pieniężnej, jakim było obniżenie inflacji poniżej 4\% do końca 2003 r., ${ }^{96}$ bank centralny przyjął w 2001 r. za cel krótkookresowy doprowadzenie tempa wzrostu cen towarów i usług konsumpcyjnych do poziomu $6-8 \%{ }^{97}$. W rezultacie roczna inflacja ukształtowała się nawet poniżej dolnej granicy celu inflacyjnego, osiągając na koniec 2001 r. poziom 3,6\%. Przyczyn takiego rozwoju zdarzeń upatruje się zarówno wśród czynników podażowych (korzystna sytuacja na rynku paliw i żywności) oraz czynników natury popytowej (niższy popyt zewnętrzny oraz wewnętrzny). Zauważalny

${ }^{89}$ Raport roczny 2000, op. cit., s. 25, 196.

${ }^{90}$ Sprawozdanie z wykonania założeń polityki pieniężnej w 2000 roku, Narodowy Bank Polski, Warszawa 2001, s. 15-16.

${ }^{91}$ Ibidem, s. 17-19.

${ }^{92}$ Średniookresowa strategia polityki pieniężnej na lata 1999-2003, op. cit., s. 6-13.

${ }^{93}$ Założenia polityki pieniężnej na 2000 rok, Narodowy Bank Polski, Warszawa 1999, s. 1-8.

${ }^{94}$ Raport roczny 2000, op. cit., s. 33-35.

${ }^{95}$ Założenia polityki pieniężnej na 2001 rok, Narodowy Bank Polski, Warszawa 2000, s. 1-8.

${ }^{96}$ Średniookresowa strategia polityki pieniężnej na lata 1999-2003, op. cit., s. 9-10.

${ }^{97}$ Założenia polityki pieniężnej na 2001 rok, Narodowy Bank Polski, Warszawa 2000, s. 6. 
spadek popytu inwestycyjnego hamujący wzrost poziomu inflacji był wynikiem pogarszającej się koniunktury zewnętrznej, restrykcyjnej polityki pieniężnej w 2000 r. oraz wcześniejszej ekspansji inwestycyjnej. Spadek inwestycji był również wynikiem pogorszenia koniunktury zewnętrznej i osłabienia dynamiki eksportu. Ponadto do niższego tempa wzrostu cen przyczynił się także wzrost wartości waluty polskiej ${ }^{98}$.

W 2001 r. RPP sześciokrotnie obniżała podstawowe stopy procentowe, łącznie o 750 punktów bazowych. Zapoczątkowane od 28 lutego obniżki stopy operacji otwartego rynku z 19\% osiągnęły 28 listopada poziom 11,5\%. Stopa kredytu lombardowego w ciągu roku zmieniona została z 23\% do 15,5\%, natomiast stopa redyskonta weksli z 21,5\% do 14\%. Od 28 listopada NBP wprowadził stopę depozytową na poziomie 7,5\%, jako cenę depozytów jakie banki komercyjne mogą zakładać w banku centralnym oraz jako dolne ograniczenie wahań stóp na rynku międzybankowym (co było krokiem w dostosowywaniu systemu operacyjnego do standardów EBC). W rezultacie tych decyzji nominalne stopy procentowe osiągnęły najniższy poziom od początku transformacji (wykres 5.11) ${ }^{99}$. Do powodów zmniejszania restrykcyjności polityki pieniężnej banku centralnego zaliczano między innymi szybki spadek dynamiki wzrostu gospodarczego i inflacji.

Jednomiesięczna stopa procentowa rynku międzybankowego WIBOR 1M spadała wraz z obniżkami minimalnej stopy rentowności 28-dniowych operacji otwartego rynku (wykres 5.12) ${ }^{100}$. Biorąc pod uwagę kontekst makroekonomiczny, obniżki stóp procentowych RPP z 2001 r. nie wpłynęły na poziom inflacji w danym okresie. Poprzez mechanizm transmisji impulsów polityki pieniężnej, zmiany te miały odzwierciedlenie w sferze realnej z opóźnieniem 7-9 kwartałów, natomiast na wzrost gospodarczy z opóźnieniem 4-6 kwartałów. NBP kształtując stopień restrykcyjności polityki pieniężnej brał pod uwagę przede wszystkim realizację celu średniookresowego ${ }^{101}$. W grudniu 2001 r. obniżono stopę rezerwy obowiązkowej z $5 \%$ do $4,5 \%{ }^{102}$. Dodatkowo wprowadzono w grudniu 2001 r. nowy instrument, jakim był nieoprocentowany kredyt techniczny (intraday credit), umożliwiający bankom zaciąganie kredytu w NBP i spłacanie go tego samego dnia ${ }^{103}$.

${ }^{98}$ Raport roczny 2001, Narodowy Bank Polski, Warszawa 2002, s. 3-18.

${ }^{99}$ Sprawozdanie z wykonania założeń polityki pieniężnej w 2001 roku, Narodowy Bank Polski, Warszawa 2002, s. 22-23.

${ }^{100}$ Raport o inflacji 2001 rok, Narodowy Bank Polski, Warszawa 2002, s. 101-102.

${ }^{101}$ Raport roczny 2001, op. cit., s. 20-28.

${ }^{102}$ Sprawozdanie z wykonania założeń polityki pieniężnej w 2001 roku, op. cit., s. 27.

${ }^{103}$ Raport roczny 2001, op. cit., s. 30-34. 


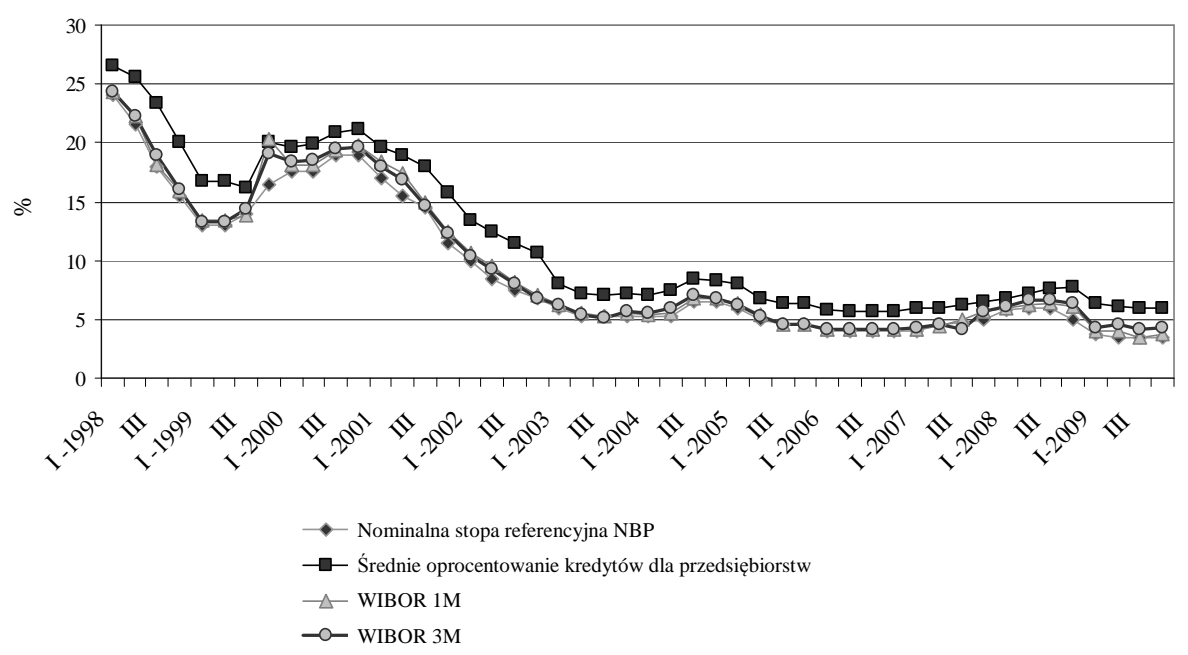

Wykres 5.12. Nominalna stopa referencyjna NBP, średnie oprocentowanie kredytów dla przedsiębiorstw oraz stopy rynku międzybankowego WIBOR 1M i WIBOR 3M w latach 1998-2009

Ź r ó d ł o: opracowanie własne na podstawie danych statystycznych zaczerpniętych z Raportów rocznych NBP z lat 1998-2009 oraz Biuletynów miesięcznych NBP z lat 1998-2009.

Rok 2002 nie przyniósł poprawy w gospodarce światowej. Sytuacja ekonomiczna krajów UE, które mają istotne znaczenie dla Polski ze względu na skalę powiązań gospodarczych, nie uległa znaczącej poprawie. Najważniejszy partner handlowy Polski, jakim są Niemcy, osiągnął w 2002 r. wzrost tempa PKB zaledwie o 0,2\%, co było najsłabszym wynikiem od $1993 \mathrm{r}$. W Polsce tempo wzrostu PKB wyniosło $1,3 \%$. Spadł również poziom inflacji, gdzie roczny wskaźnik CPI obniżył się do $0,8 \% \mathrm{w}$ grudniu 2002 r. w stosunku do poziomu 3,6\% w grudniu $2001 \mathrm{r}$. Wśród przyczyn obniżenia inflacji w tym czasie wymienia się wyraźny spadek popytu $\mathrm{w}$ gospodarce ${ }^{104}$. NBP realizując politykę pieniężną w 2002 r. uwzględnił również nierównowagę sektora finansów publicznych ${ }^{105}$. Sytuacja sektora finansów publicznych miała znaczenie w czasie podejmowania decyzji przez RPP dotyczących chociażby polityki stóp procentowych. Dokonano ośmiu obniżek stopy operacji otwartego rynku z $11,5 \%$ do $6,75 \%$. Stopa kredytu lombardowego została obniżona z poziomu $15,5 \%$ do $8,75 \%$, stopa redyskonta weksli z $11 \%$ do $7,5 \%$, natomiast depozytowa z 7,5\% do 4,75\% (wykres $5.11)^{106}$.

${ }^{104}$ Raport o inflacji 2002 rok, Narodowy Bank Polski, Warszawa 2003, s. 4.

${ }^{105}$ Raport roczny 2002, Narodowy Bank Polski, Warszawa 2003, s. 31-35.

${ }^{106}$ Sprawozdanie z wykonania założeń polityki pieniężnej w 2002 roku, Narodowy Bank Polski, Warszawa 2003, s. 4. 
W polskim systemie bankowym nadal występowała nadpłynność operacyjna. Sterylizowano ją wykorzystując emisję 28-dniowych bonów pieniężnych. Kolejną zmianą przybliżającą krajowy system bankowy do rozwiązań Eurosytemu było, począwszy od lutego 2002 r., ustalenie przeprowadzania emisji bonów pieniężnych NBP raz w tygodniu, w piątki ${ }^{107}$. Saldo operacji otwartego rynku w końcu 2002 r. spadło do 7,3 mld zł w porównaniu do końca 2001 r..$^{108}$

$\mathrm{W}$ Założeniach polityki pieniężnej na $2003 \mathrm{r}$. podkreślano, że będzie to czas niepewności prognoz czynników zewnętrznych, mających wpływ na wzrost gospodarczy i inflację. W rezultacie w UE zwiększył się import z krajów, które oferują tańsze produkty, w tym z Polski. Nastąpiła nominalna oraz realna deprecjacja złotego, a także szybszy wzrost wydajności pracy. NBP podejmując decyzje w zakresie polityki pieniężnej, starał się uwzględniać kroki podejmowane przez władze odpowiedzialne za politykę fiskalną. Drenaż oszczędności krajowych przez sektor publiczny nie stwarzał korzystnej sytuacji do obniżki stóp procentowych przez bak centralny. Ciągłe potrzeby pożyczkowe sektora publicznego, wynikające z utrzymującego się deficytu budżetowego $(4,5 \%$ PKB w 2003 r.), ograniczały pulę środków, które mogłyby być przeznaczone na finansowanie przedsiębiorstw. Sytuacja finansów publicznych była czynnikiem, który utrudniał stabilizację inflacji na niskim poziomie. Pomimo tych trudności w grudniu 2003 r. roczna stopa inflacji wynosiła 1,7\%, kształtując się poniżej krótkookresowego celu inflacyjnego na dany rok (wynosił on 3\%, z przedziałem wahań $+/-1$ punkt procentowy) ${ }^{109}$. W 2003 r. Rada Polityki Pieniężnej sześciokrotnie obniżała stopę podstawowych operacji otwartego rynku z poziomu $6,75 \%$ do $5,25 \%$ (wykres 5.12$)^{110}$.

Od stycznia 2003 r. skrócono zapadalność bonów pieniężnych emitowanych w ramach podstawowych operacji otwartego rynku z 28 do 14 dni. Od tamtej pory minimalna stopa rentowności 14-dniowych operacji otwartego rynku informowała o kierunku polityki pieniężnej oraz miała wpływ na oprocentowanie depozytów na rynku międzybankowym o dwutygodniowym terminie zapadalności. Decyzja ta miała zwiększyć efektywność mechanizmu transmisji polityki pieniężnej oraz zapewnić lepszy wpływ banku centralnego na stan płynności w sektorze bankowym ${ }^{111}$. Stopa oprocentowania kredytu lombardowego została zmieniona w ciągu roku z $8,75 \%$ do $6,75 \%$. Natomiast stopę redyskonta weksli obniżono z 7,5\% do 5,75\%, a stopę depozytową z 4,75\% do 3,75\% ${ }^{112}$. W 2003 r.

\footnotetext{
${ }^{107}$ Raport o inflacji 2002 rok, op. cit., s. 69.

${ }^{108}$ Raport roczny 2002, op. cit., s. 31-35.

${ }^{109}$ Raport o inflacji 2003 rok, Narodowy Bank Polski, Warszawa 2004, s. 14, 37-41.

${ }^{110}$ Sprawozdanie z wykonania założeń polityki pieniężnej w 2003 roku, Narodowy Bank Polski, Warszawa 2004, s. 21.

${ }_{111}$ Założenia polityki pieniężnej w 2003 roku, Narodowy Bank Polski, Warszawa 2002,

${ }^{112}$ Raport roczny 2003, Narodowy Bank Polski, Warszawa, 2004, s. 20-30.
} s. $8-10$. 
NBP wprowadził zmiany polegające na zmianie sposobu naliczania i utrzymywania rezerwy obowiązkowej. Pierwsza $\mathrm{z}$ nich zaczęła obowiązywać od 30 września i dotyczyła pomniejszania przez banki kwoty naliczonej rezerwy obowiązkowej o równowartość 500 tys. euro. W ramach drugiej zmiany 31 października obniżono stopę rezerwy obowiązkowej do $3,5 \%{ }^{113}$. W celu nadmiernych wahań stóp rynku międzybankowego, banki komercyjne przeprowadzały z NBP operacje depozytowo-kredytowe. Łączna kwota kredytu lombardowego wykorzystanego przez banki w ciągu roku wynosiła 11,6 mld zł, a depozytów złożonych w banku centralnym $39,8 \mathrm{mld} \mathrm{zl}^{114}$.

W roku 2004 przystąpienie Polski do Unii Europejskiej miało istotny wpływ na działalność banku centralnego. Narodowy Bank Polski stał się członkiem Europejskiego Systemu Banków Centralnych. Rok ten okazał się korzystny z punktu widzenia tempa wzrostu PKB, ponieważ zapoczątkowane w poprzednim roku ożywienie gospodarcze osiągnęło w 2004 r. poziom 5,4\%. W związku z przystąpieniem Polski do struktur UE, zaobserwowano wzrost wskaźnika CPI $(4,4 \% \text { w grudniu } 2004 \text { r. })^{115}$. Był to skutek przede wszystkim wzrostu cen żywności i ropy naftowej oraz większego popytu wewnętrznego i zewnętrznego na wybrane produkty krajowe. Wyższemu wskaźnikowi cen towarów i usług konsumpcyjnych towarzyszył również znaczny wzrost oczekiwań inflacyjnych. Na poziom inflacji istotny wpływ miał także sposób prowadzenia polityki fiskalnej (zbyt luźna skłania bank centralny do utrzymywania wyższych realnych stóp procentowych). W rezultacie deficyt całego sektora finansów publicznych wynosił w 2004 r. 4,8\% PKB, a dług publiczny 50,3\% PKB. Biorąc pod uwagę uwarunkowania gospodarcze, jak chociażby ożywienie gospodarcze, wzrost inflacji, potrzeby finansowe budżetu państwa oraz takie wydarzenia jak członkostwo Polski w UE i związane z tym transfery pieniężne mające wpływ na gospodarkę, NBP postanowił zmienić nastawienie w polityce pieniężnej. Rada Polityki Pieniężnej dążyła do tego, by inflacja nie przekraczała celu inflacyjnego wyznaczonego na poziomie $2,5 \%$ z przedziałem dopuszczalnych odchyleń $+/-1$ punkt procentowy. Było to założenie przyjęte $\mathrm{w}$ ramach nowej strategii, tzw. strategii bezpośredniego celu inflacyjnego i dotyczyło realizacji polityki monetarnej na 2004 r. $^{116}$ RPP zdecydowała się na trzykrotne podwyższenie stopy operacji otwartego rynku z poziomu 5,25\% do 6,5\%. Oprocentowanie stopy lombardowej zostało zmienione z $6,75 \%$ do $8 \%$, a stopy redyskonta weksli z 3,75\% do 7\%. Natomiast stopę depozytową podwyższono z 3,75\% do 5\% (wykres 5.11).

\footnotetext{
${ }^{113}$ Sprawozdanie z wykonania założeń polityki pieniężnej w 2003 roku, op. cit., s. 25-26.

${ }^{114}$ Raport roczny 2003, op. cit., s. 30.

${ }^{115}$ Raport o inflacji 2005 rok, Narodowy Bank Polski, Warszawa 2005, s. 3-9.

${ }^{116}$ Raport roczny 2004, Narodowy Bank Polski, Warszawa 2005, s. 30-35.
} 
Stawka WIBOR 2W, na którą bank centralny miał bezpośredni wpływ poprzez operacje otwartego rynku, utrzymywała się w okolicach stopy referencyjnej ${ }^{117}$.

W 2004 r. zmniejszyło się saldo podstawowych operacji otwartego rynku średnio o 1,8 mld zł, wynosząc w grudniu 2,3 mld zł. Było to spowodowane głównie ograniczeniem płynności sektora bankowego, wynikającym ze wzrostu salda złotowych środków budżetowych na rachunkach w NBP, przyrostu pieniądza gotówkowego w obiegu oraz wzrostu poziomu rezerwy obowiązkowej. Z dniem 1 maja 2004 r. wprowadzono zmiany dotyczące zasad utrzymywania i naliczania rezerwy obowiązkowej, z których pierwsza dotyczyła jej oprocentowania. RPP podjęła decyzję, że wysokość oprocentowania rezerwy obowiązkowej będzie na poziomie 0,9 stopy redyskontowej weksli ${ }^{118}$. Po drugie, zdecydowano, że od 30 czerwca środki uzyskane przez banki z tytułu sprzedaży papierów wartościowych typu repo będą oprocentowane zerową stopą rezerwy obowiązkowej $^{119}$. Był to krok ku poprawie konkurencyjności polskich banków wobec banków działających w strefie euro. W 2004 r. banki w mniejszym stopniu korzystały $\mathrm{z}$ kredytu lombardowego w porównaniu $\mathrm{z}$ rokiem poprzednim (w skali roku $8 \mathrm{mld} \mathrm{zl})^{120}$.

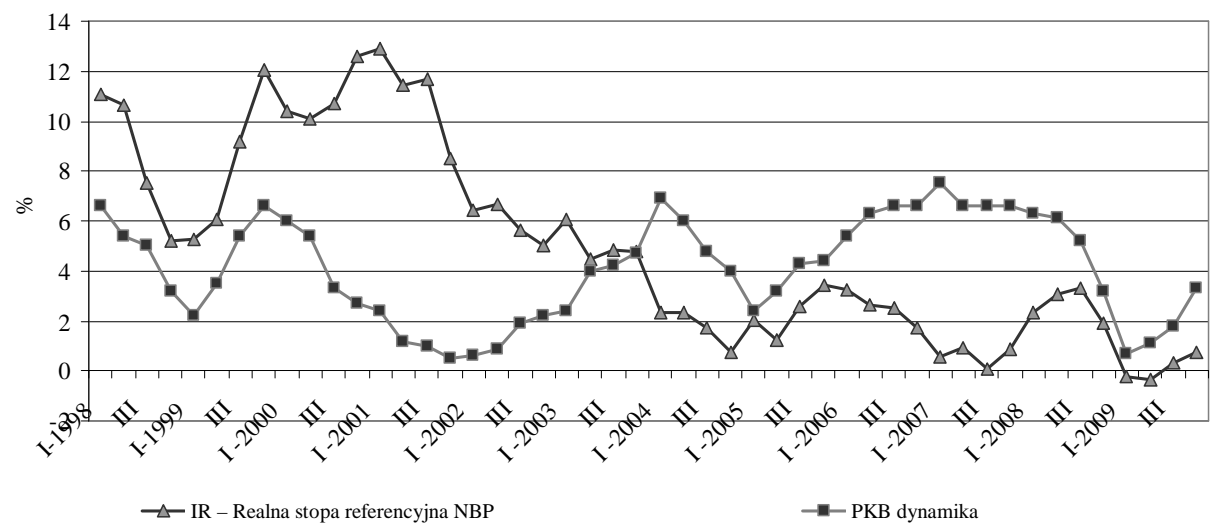

Wykres 5.13. Realna stopa referencyjna NBP oraz dynamika PKB w Polsce w latach 1998-2009

Ź r ó d ło: opracowanie własne na podstawie danych: Raporty roczne NBP z lat 1998-2009 oraz tabeli GUS - wybrane kwartalne wskaźniki makroekonomiczne.

${ }^{117}$ Sprawozdanie z wykonania założeń polityki pieniężnej w 2004 roku, Narodowy Bank Polski, Warszawa 2005, s. 28-29.

${ }^{118}$ Kwotę wynikającą z naliczonych odsetek od rezerwy obowiązkowej NBP rozdzielił w następujący sposób: $80 \%$ tej kwoty, tj. 334,7 mln zł, przekazano do Funduszu Poręczeń Unijnych, a pozostałe $20 \%$, czyli 83,7 mln zł otrzymały banki.

${ }^{119}$ Instrumenty polityki pieniężnej na tle ptynności sektora bankowego w 2004 roku, Narodowy Bank Polski, Warszawa 2005, s. 18.

${ }^{120}$ Raport roczny 2004, op. cit., s. 36-45. 
W 2005 r. kontynuowano założenia Strategii polityki pieniężnej po $2003 r{ }^{121}$ Bank centralny stosując strategię BCI prowadził w 2005 r. politykę monetarną w warunkach obniżającej się inflacji mierzonej wskaźnikiem CPI oraz inflacji netto (inflacja po wyłączeniu cen żywności i paliw). Średnioroczna inflacja wynosiła $2,1 \%$, a miesięczny wskaźnik CPI obniżył się z poziomu $3,7 \%$ w styczniu do $0,1 \% \mathrm{w}$ grudniu. Stopniowy proces wygasania wstrząsu akcesyjnego, tzw. spadek zagrożenia efektem unijnym, silna aprecjacja złotego, niższy od prognozowanego deficyt sektora finansów publicznych, aż w końcu spadek cen żywności i marż na rynku paliw, to najważniejsze przyczyny spadku inflacji w 2005 r. ${ }^{122}$ Wydarzenia te przekonały RPP do zmiany nastawienia w polityce pieniężnej na łagodne, w rezultacie czego NBP obniżył stopę operacji otwartego rynku z $6 \%$ do $4,5 \%$, stopę lombardową z $7,5 \%$ do $6 \%$, stopę redyskonta weksli z $6,5 \%$ do $4,75 \%$, a stopę depozytową z 4,5\% do 3\%. Rada Polityki Pieniężnej kierując się między innymi projekcją inflacji podejmowała decyzje biorąc pod uwagę fakt, że zmiany stóp procentowych w danym momencie będą oddziaływać na procesy inflacyjne $\mathrm{z}$ pewnym opóźnieniem. Generalnie łagodniejsza polityka pieniężna w 2005 r. sprzyjała większej aktywności gospodarczej (wykres 5.13$)^{123}$.

W 2005 r. bank centralny, zmierzając do przybliżenia systemu operacyjnego do standardów Eurosystemu, zmienił termin zapadalności emitowanych bonów pieniężnych z 14 do 7 dni. Krótkoterminowe stopy rynku międzybankowego zmniejszały się wraz ze zmianami oprocentowania stopy referencyjnej. Bank centralny miał bezpośredni wpływ poprzez operacje otwartego rynku na stawkę WIBOR SW ${ }^{124}$, która kształtowała się w okolicach poziomu wyznaczonego przez stopę referencyjną ${ }^{125}$. Od 2005 r. NBP publikował wysokość stawki POLONIA, która średnio w ciągu roku odchylała się od stopy referencyjnej o 26 punktów bazowych. W 2005 r. banki wykorzystywały możliwość zaciągania kredytu lombardowego, głównie w ostatnich dniach okresów utrzymywania rezerwy obowiązkowej. Łącznie w ciągu roku zaciągnęły 10 mld zł kredytu, w porównaniu do $8 \mathrm{mld}$ zł w $2004 \mathrm{r}$. W stosunku do roku poprzedniego spadła kwota depozytu na koniec dnia ze 113,6 mld zł do 56,9 mld zł w 2005 r. ${ }^{126}$

${ }^{121}$ Strategia polityki pieniężnej po 2003 roku, Narodowy Bank Polski, Warszawa 2003, s. 12.

${ }^{122}$ Raport roczny 2005, Narodowy Bank Polski, Warszawa 2006, s. 28-31.

${ }^{123}$ Sprawozdanie z wykonania założeń polityki pieniężnej na rok 2005, Narodowy Bank Polski, Warszawa 2006, s. 14-15.

${ }^{124}$ Stawka WIBOR SW (Warsaw Interbank Offer Rate Spot Week) - według tej stawki banki udzielają pożyczek na rynku międzybankowym na okres $7 \mathrm{dni}$, jest to średnia arytmetyczna z kwotowań przekazywanych przez uczestników tzw. fixingu, który przeprowadza się każdego dnia roboczego do godziny 11.00 .

${ }^{125}$ Instrumenty polityki pieniężnej Narodowego Banku Polskiego w 2005 roku. Ptynność sektora bankowego, Narodowy Bank Polski, Warszawa 2006, s. 16.

${ }^{126}$ Raport roczny 2005, op. cit., s. 33-36. 
Narodowy Bank Polski w 2006 r. mógł prowadzić działalność w warunkach zrównoważonego wzrostu gospodarczego, który mierzony rocznym tempem wzrostu PKB wynosił 6,1\%. W tym czasie zanotowano w gospodarce wzrost zatrudnienia i niski poziom inflacji. Wskaźnik CPI utrzymywał się przez cały rok poniżej celu inflacyjnego $2,5 \% \mathrm{i}$ w ujęciu średniorocznym wynosił $1 \%{ }^{127}$. Do osiągnięcia niskiego stanu inflacji przyczyniła się aprecjacja kursu złotego w latach 2004-2006, a także słaby wzrost popytu krajowego w 2005 r. Ponadto istotne znaczenie w kształtowaniu wskaźnika inflacji miała polityka stóp procentowych prowadzona w 2004 r., której skutki były zauważalne wyraźnie w 2006 r. RPP pomimo ożywienia w polskiej gospodarce, przyspieszenia popytu konsumpcyjnego, wzrostu popytu inwestycyjnego i rosnącej inflacji, postanowiła obniżyć stopy procentowe (wykres 5.11). Decyzje Rady zostały podjęte na podstawie oceny czynników kształtujących przyszłą inflację. Wykorzystano wykonaną w styczniu 2006 r. projekcję inflacji, która wskazywała, że prawdopodobieństwo, iż tempo wzrostu cen powyżej 2,5\% jest niższe niż prawdopodobieństwo, że ceny te ukształtują się poniżej celu inflacyjnego w danym horyzoncie czasowym $^{128}$. W ciągu roku dwukrotnie obniżono stopę rentowności 7-dniowych operacji otwartego rynku z 4,5\% do $4 \%$. Oprocentowanie kredytu lombardowego zmieniono z $6 \%$ do 5,5\%, a redyskonta weksli z 4,75\% do 4,25\%. Stopę depozytową obniżono z poziomu $3 \%$ do $2,5 \%$. W rezultacie tendencje wzrostowe $\mathrm{w}$ gospodarce umacniały się z miesiąca na miesiąc, dlatego RPP postanowiła nie obniżać stóp procentowych w najbliższym czasie (wykres 5.11) ${ }^{129}$.

W lipcu 2007 roku pojawiły się pierwsze symptomy kryzysu na rynku kredytów hipotecznych typu subprime w Stanach Zjednoczonych. Zaczęły rosnąć ceny żywności i surowców, wpływając na wzrost wskaźników inflacji na świecie. Zawirowania na rynku amerykańskim w szybkim tempie rozprzestrzeniały się na rynkach światowych i z miesiąca na miesiąc przybierały coraz poważniejszą formę. W Polsce pomimo zagrożeń zewnętrznych sytuacja gospodarcza pozostawała stabilna ${ }^{130}$. Inflacja w ujęciu średniorocznym wyniosła $2,5 \%$, mimo że wykazywała tendencję rosnącą i w grudniu osiągnęła poziom $4 \%$. Rada Polityki Pieniężnej, sugerując się między innymi projekcjami inflacji oraz oczekiwaniami inflacyjnymi, zdecydowała się na podwyżkę oficjalnych stóp podstawowych. Stopa operacji otwartego rynku w ciągu roku została podniesiona z $4 \%$ do 5\%, stopa lombardowa z 5,5\% do 6,5\%, redyskonta weksli z 4,25\% do 5,25\%, a stopa depozytowa z $2 \%$ do $3,5 \%$ (wykres 5.11$)^{131}$. W ślad za stopą referencyj-

${ }^{127}$ Raport roczny 2006, Narodowy Bank Polski, Warszawa 2007, s. 30-40.

${ }^{128}$ Raport o inflacji 2006 rok, Narodowy Bank Polski, Warszawa 2007, s. 5-14.

${ }^{129}$ Sprawozdanie z wykonania założeń polityki pieniężnej w 2006 roku, Narodowy Bank Polski, Warszawa 2007, s. 16-18.

${ }^{130}$ Raport roczny 2007, Narodowy Bank Polski, Warszawa 2008, s. 3.

${ }^{131}$ Instrumenty polityki pieniężnej Narodowego Banku Polskiego w 2007 roku. Ptynność sektora bankowego, Narodowy Bank Polski, Warszawa 2008, s. 18. 
ną podążała krótkoterminowa stopa WIBOR SW rynku międzybankowego, nieznacznie odchylając się od poziomu minimalnej stopy rentowności 7-dniowych operacji otwartego rynku. Odchylenia te wynikały głównie z oczekiwań dalszych podwyżek stóp procentowych oraz z zaburzeń płynnościowych na rynkach światowych i związanej z tym niechęci banków do ryzyka. Wzrosły również średnie odchylenia stawki POLONIA oraz WIBOR O/N od stopy referencyjnej, odpowiednio 23 i 16 punktów bazowych. W 2007 r. banki musiały utrzymywać w NBP większą o $21 \%$ kwotę rezerw obowiązkowych (prawie 17 mld zf) w stosunku do roku poprzedniego, ze względu na przyrost depozytów na rachunkach bankowych. W sektorze bankowym nadal utrzymywała się nadpłynność, choć prognozowano, że w kolejnych latach będzie się zmniejszać ${ }^{132}$.

Do września 2008 r. wyraźnie zaostrzył się kryzys finansowy na rynkach międzynarodowych. Do tego czasu dla NBP najistotniejszym wyzwaniem był podwyższony poziom inflacji, który w lipcu i sierpniu 2008 r. wyniósł 4,8\%. Czynniki, które przyczyniły się do wzrostu inflacji znajdowały się poza wpływem krajowej polityki pieniężnej. Były to wysokie ceny żywności i ropy naftowej na świecie. Dodatkowo podwyższone zostały w 2008 r. ceny administrowane, dotyczące głównie cen nośników energii (energii elektrycznej i gazu) oraz cen usług związanych z użytkowaniem mieszkań. W związku z podwyższonym poziomem inflacji w Polsce jak i na świecie, RPP prowadziła restrykcyjną politykę pieniężną podnosząc stopy procentowe czterokrotnie (łącznie o 1 punkt procentowy) do czerwca $2008 \mathrm{r}$. (wykres 5.11) ${ }^{133}$.

Jednak znaczące pogorszenie koniunktury gospodarczej na świecie w IV kwartale 2008 r. wywołane globalnym kryzysem finansowym, wpłynęło na zmianę decyzji NBP dotyczących kierunku polityki pieniężnej. W listopadzie 2008 r. Rada Polityki Pieniężnej zaczęła obniżać stopy procentowe. W drugim półroczu 2008 r. Rada obniżyła podstawowe stopy procentowe łącznie o 1 punkt procentowy. W rezultacie na koniec roku stopa operacji otwartego rynku wynosiła $5 \%$, lombardowa $6,5 \%$, a depozytowa $3,5 \%$ (wykres 5.11$)^{134}$. Nasilający się kryzys finansowy na świecie zaczął już od drugiej połowy 2008 r. wywierać wpływ na gospodarkę polską. Objawiło się to wzrostem awersji inwestorów do ryzyka i odpływem kapitałów z rynków wschodzących, co po okresie aprecjacji polskiej waluty objawiło się znaczną deprecjacją złotego. Dodatkowo we wrześniu 2008 r. ogłoszono upadek banku inwestycyjnego Lehman Brothers, który wpłynął na ograniczenie zaufania pomiędzy kontrahentami na rynkach światowych. Niepewność na rynkach finansowych oraz niestabilna sytuacja finansowa kredytobiorców zwiększyły ryzyko udzielania kredytów sektorowi niefinanso-

${ }^{132}$ Raport roczny 2007, op. cit., s. 37-40.

${ }^{133}$ Raport roczny 2008, Narodowy Bank Polski, Warszawa 2009, s. 3.

${ }^{134}$ Instrumenty Polityki Pieniężnej Narodowego Banku Polskiego w 2008 roku. Ptynność sektora bankowego, Raport NBP, Warszawa 2009, s. 5-20. 
wemu. Banki ograniczyły zatem akcję kredytową. Przedsiębiorstwa zmniejszyły swoje nakłady na inwestycje ze względu na pogorszenie ich oczekiwań co do przyszłego popytu na swoje dobra. Recesja w strefie euro, która dotknęła również Niemcy, będące ważnym partnerem handlowym Polski, przyczyniła się do spadku polskiego eksportu i produkcji przemysłowej, a przez to do spadku PKB $^{135}$.

Oprócz obniżenia stóp procentowych NBP postanowił zastosować jeszcze dodatkowe instrumenty dostarczające płynności finansowej. W celu uspokojenia sytuacji na rynku uruchomiono w październiku 2008 r. Pakiet zaufania, którego zadaniem miało być rozładowanie napięcia na rynku międzybankowym. Cele Pakietu zaufania sprowadzały się do umożliwienia bankom pozyskania środków złotowych na okresy dłuższe niż jeden dzień, a także środków walutowych. Ponadto rozszerzono zakres zabezpieczeń akceptowanych przez NBP w celu zwiększenia pozyskania płynności złotowej przez banki. Wydłużono okres zapadalności operacji otwartego rynku (operacje repo) do 3 miesięcy, uruchomiono operacje walutowe typu swap, akceptowano depozyty walutowe jako zabezpieczenie kredytu refinansowego, zmniejszono wartość zabezpieczeń dla kredytu lombardowego oraz wydłużono listę aktywów akceptowalnych jako zabezpieczenia $^{136}$. Łącznie od 17 października 2008 r. NBP zdecydował się w ramach Pakietu zaufania na przeprowadzenie czterech operacji dostrajających, wykorzystując do tego krótkoterminowe transakcje repo o terminach zapadalności 6, 14, 28 dni, a także długoterminowe transakcje repo o terminach zapadalności 91 dni. Operacje te zasiliły sektor bankowy w płynność na poziomie 34,33 mld zł. $\mathrm{Z}$ kolei w ramach operacji typu swap walutowy NBP mając możliwość kupna lub sprzedaży złotego za walutę obcą na rynku kasowym i jednoczesnej jego sprzedaży bądź kupna w transakcji terminowej w ustalonej dacie waluty, w 2008 r. przeprowadzał jedynie operację sprzedaży waluty obcej w transakcji pierwotnej. NBP dokonywał transakcji typu swap walutowy na parach walut EUR/PLN, USD/PLN, CHF/PLN o 7-dniowym terminie zapadalności i rozliczeniem w czasie $t+2$. Operacje te przeprowadzano również $\mathrm{z}$ innymi terminami zapadalności, tj. 6, 8, 10 i 84 dni. Średniorocznie operacje typu swap wpłynęły na ograniczenie płynności sektora bankowego w 2008 r. o $162 \mathrm{mln} \mathrm{z1}^{137}$.

Globalny kryzys finansowy przyczynił się do osłabienia dynamiki krajowego wzrostu gospodarczego. W rezultacie w 2008 r. tempo wzrostu PKB wyniosło $4,9 \%$ wobec $6,7 \%$ roku poprzedniego. Na ten spadek wpływ miało zmniejszenie się tempa wzrostu nakładów brutto na środki trwałe z 17,6\% w $2007 \mathrm{r}$. do $8,1 \%$ w 2008 r. Był to rezultat przewidywań podmiotów gospodarczych co

${ }^{135}$ Sprawozdanie z wykonania założeń polityki pieniężnej na rok 2008, Narodowy Bank Polski, Warszawa 2009, s. 9-10.

${ }^{136}$ Raport roczny 2008, op. cit., s. 50.

${ }^{137}$ Instrumenty polityki pieniężnej Narodowego Banku Polskiego w 2008 roku, op. cit., s. 22-24. 
do osłabienia popytu na ich produkty i ograniczony dostęp do kredytów bankowych $^{138}$. W IV kwartale $2008 \mathrm{r}$. widoczne było już znaczne ograniczenie kredytów dla przedsiębiorstw, co wynikało z wysokiej niepewności co do stanu koniunktury w przyszłości. Banki musiały ograniczać akcję kredytową z powodu nasilających się ograniczeń kapitałowych. Większość banków zdecydowała się podnieść marże kredytowe. Pomimo tego popyt przedsiębiorstw na kredyty nadal nieznacznie wzrastal ${ }^{139}$.

Podobnie w roku 2009, polityka pieniężna NBP prowadzona była w czasie recesji $\mathrm{w}$ gospodarce światowej $\mathrm{i} w$ warunkach zaburzeń na rynkach światowych. Dopiero od II kwartału 2009 r. tendencje recesyjne w gospodarce zaczynały ulegać osłabieniu, a kolejne kwartały przyniosły ponowny wzrost globalnego PKB. Następowała powolna stabilizacja sytuacji na rynkach finansowych, zaczęły wzrastać ceny aktywów finansowych oraz zaobserwowano aprecjację kursów walut gospodarek wschodzących. W dużej mierze do poprawy koniunktury gospodarczej przyczyniła się prowadzona w wielu krajach ekspansywna polityka makroekonomiczna, czyli polityka monetarna objawiająca się poprzez obniżki stóp procentowych i zasilanie rynku w płynność, jak również polityka fiskalna poprzez stymulowanie gospodarki. W 2009 r., w grupie krajów Europy Środkowo-Wschodniej tylko Polska osiągnęła dodatnie roczne tempo wzrostu PKB, które wyniosło 1,8\%. Roczny wskaźnik CPI obniżył się wobec 2008 r. o $0,7 \%$ i ukształtował się na poziomie $3,5 \%{ }^{140}$. W zaistniałych warunkach RPP postanowiła $\mathrm{w}$ ciągu roku obniżyć stopę operacji otwartego rynku z poziomu $4,25 \%$ do $3,5 \%$, lombardową z $5,75 \%$ do $5 \%$, a depozytową z $2,75 \%$ do $2 \%$ (wykres 5.11) $)^{141}$.

Kończąc opis uwarunkowań polityki pieniężnej w Polsce w latach 1998 -2009 , należy jeszcze podkreślić istotną rolę jaką pełni w gospodarce zależność uśrednionej stopy procentowej transakcji jednodniowych typu overnight na polskim rynku międzybankowym (POLONIA) od stopy referencyjnej NBP. Dla równowagi na rynku ważne jest, by stawka POLONIA utrzymywała się zasadniczo na poziomie zbliżonym do stopy referencyjnej NBP. W latach 2005-2007 średnia rynkowa stopa procentowa typu overnight kształtowała się w większości poniżej stopy referencyjnej NBP (wykres 5.14). Następnie od IV kwartału 2008 r. POLONIA była średnio nieznacznie wyższa od stopy referencyjnej NBP. Z kolei w czasie kryzysu w 2009 r. POLONIA notowała najczęściej wartości poniżej

${ }^{138}$ Raport o stanie sektora matych i średnich przedsiębiorstw w Polsce w latach 2007-2008, Polska Agencja Rozwoju Przedsiębiorczości, Wydawnictwo Naukowe Instytutu Technologii Eksploatacji - PIB, Radom 2009, s. 11.

${ }^{139}$ Sytuacja na rynku kredytowym, wyniki ankiety do przewodniczacych komitetów kredytowych, I kwartał 2009, Narodowy Bank Polski, Warszawa 2009, s. 1-2.

${ }^{140}$ Sprawozdanie z wykonania założeń polityki pieniężnej na rok 2009, Narodowy Bank Polski, Warszawa 2010, s. 7-12.

${ }^{141}$ Instrumenty polityki pieniężnej Narodowego Banku Polskiego w 2008 roku, op. cit., s. 25. 
stopy referencyjnej NBP. Zatem odchylenie stawki POLONIA od stopy referencyjnej NBP, w istotnym stopniu było skutkiem kryzysu finansowego, co wskazuje na to, że znaczne zmiany poziomu tej stawki mogą świadczyć o zaburzeniach na rynku międzybankowym.

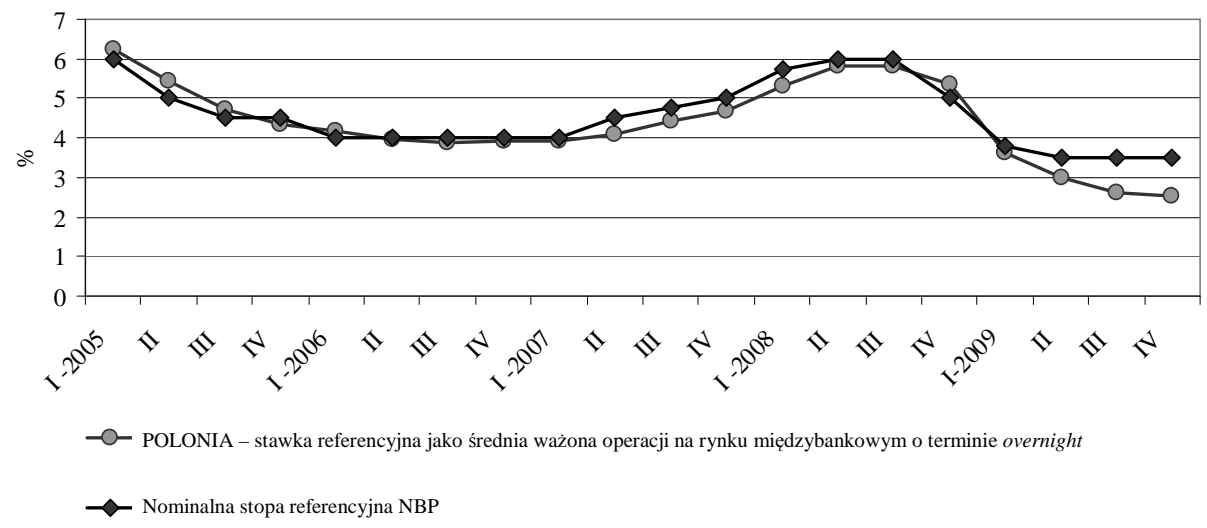

Wykres 5.14. Nominalna stopa referencyjna NBP oraz stawka POLONIA w Polsce w latach 2005-2009

Ź r ó d ł o: opracowanie własne na podstawie danych: Raporty roczne NBP z lat 2005-2009.

Warto podkreślić zależność polityki stóp procentowych banku centralnego od poziomu inflacji w gospodarce oraz uwarunkowań zewnętrznych i wewnętrznych mających wpływ na wskaźnik inflacji i decyzje banków ${ }^{142}$. Niełatwe jest zatem obranie kierunku polityki pieniężnej przez bank centralny oraz przewidzenie konsekwencji decyzji dotyczących polityki monetarnej w gospodarce.

\subsection{Zadłużenie kredytowe przedsiębiorstw w bankach komercyjnych oraz nakłady inwestycyjne podmiotów gospodarczych w Polsce w latach 1998-2009}

W 1998 r. sytuacja finansowa przedsiębiorstw uległa pogorszeniu, głównie z powodu wolniejszego wzrostu przychodów ze sprzedaży produktów i materiałów w stosunku do kosztów ich uzyskania. Zanotowano również szybszy spadek inflacji niż oprocentowania depozytów i kredytów bankowych, co sprzyjało

${ }^{142}$ W. Przybylska-Kapuścińska, Spory wokót polityki stóp procentowych $w$ Polsce, [w:] J. L. B ednarczyk (red.), Stopy procentowe a gospodarka. Dylematy Unii Gospodarczej $i$ Walutowej, Wydawnictwo Instytutu Technologii Eksploatacyjnej Państwowego Instytutu Badawczego, Radom 2006, s. 116. 
bardziej oszczędnościom niż zaciąganiu kredytów. Pomimo tego wysokie realne stopy procentowe nie wpłynęły na zmniejszenie rozmiarów kredytów udzielanych przedsiębiorstwom. Zadłużenie przedsiębiorstw w 1998 r. sięgnęło kwoty 114,5 mld zł, natomiast tempo wzrostu kredytów dla przedsiębiorstw wyniosło 21,5\% wobec 16,2\% w 1997 r. Nakłady inwestycyjne przedsiębiorstw wzrosły w 1998 r. o 20\%, z czego najszybszy wzrost aktywności inwestycyjnej zaobserwowano wśród nakładów na modernizację i rekonstrukcję parku maszynowego. Był to krok sprzyjający poprawie konkurencyjności sektora przedsiębiorstw ${ }^{143}$.

W roku 1999 tempo rozwoju przedsiębiorstw uległo osłabieniu, co przełożyło się także na wolniejszy udział przedsiębiorstw w wytwarzaniu PKB. Pomimo tego, wielkość nakładów inwestycyjnych głównie w małych przedsiębiorstwach charakteryzowała się silnym wzrostem. Warunki gospodarcze, w których funkcjonowały przedsiębiorstwa były niesprzyjające, ponieważ tempo wzrostu gospodarczego, pomimo że w 1999 r. oraz w 2000 r. wynosiło 4,1\%, to jednak wykazywało dynamikę malejącą (IV kwartał 2000 r. - 2,4\%). We wszystkich głównych sektorach gospodarki, jak: przemysł, budownictwo, handel i transport, rolnictwo, nastąpiło zwolnienie aktywności gospodarczej. Spadł popyt krajowy, zarówno konsumpcyjny jak i inwestycyjny. Czynnikiem, który ożywiał gospodarkę był popyt zewnętrzny, dlatego eksport stał się elementem wzrostu gospodarczego ${ }^{144}$. W 2000 r. sytuacja finansowa przedsiębiorstw znacznie się poprawiła. Uzyskały one wyższe przychody ze sprzedaży niż w 1999 r., wynik finansowy netto w 2000 r. wyniósł 6,2 mld zł w porównaniu do 1,6 mld zł w roku 1999. Sytuacja na rynku kredytowym nie sprzyjała jednak przedsiębiorstwom, ponieważ pomimo spadku inflacji w 2000 r. (8,5\% w porównaniu do 9,8\% w 1999 r.) $)^{145}$ rosło oprocentowanie kredytów oraz depozytów (wykres 5.15).

Wyższe oprocentowanie kredytów i depozytów było czynnikiem hamującym zaciąganie kredytów przez przedsiębiorstwa, a raczej stymulującym oszczędności. Mimo tego realny stan zadłużenia przedsiębiorstw utrzymał się na wysokim poziomie $135,5 \mathrm{mld}$ zł w 2000 r., wykazując tym samym wzrost o 7,4\% w porównaniu do $12,5 \% \mathrm{w} 1999 \mathrm{r}$. Malała w tym czasie dynamika inwestowania, która średnio w latach 1994-1998 wynosiła 16\%, w 1999 r. 6\%, a w 2000 r. wyniosła 2\%, spadając poniżej tempa wzrostu PKB. Takie wyniki wskazywały, że maleją zdolności inwestycyjne polskiej gospodarki oraz że słabną procesy restrukturyzacyjne i modernizacyjne przemysłu. To wpływa negatywnie na konkurencyjność gospodarki i wolniejszą likwidację luki technologicznej pomiędzy Polską i krajami bardziej rozwiniętymi gospodarczo.

${ }^{143}$ Raport o stanie sektora matych i średnich przedsiębiorstw w Polsce w latach 1997-1998, Polska Agencja Rozwoju Przedsiębiorczości, Warszawa 1999, s. 18-19.

${ }^{144}$ Raport o stanie sektora matych i średnich przedsiębiorstw w Polsce w latach 1999-2000, op. cit., s. 20-24.

${ }^{145}$ A. U rb ań s ka, Polityka monetarna: Wspótczesna teoria i analiza empiryczna dla Polski, „Materiały i Studia” 2002, z. 148, s. 1-104. 
Rola kredytów w finansowaniu inwestycji przedsiębiorstw oszacowana została na poziomie $13-17 \%{ }^{146}$.

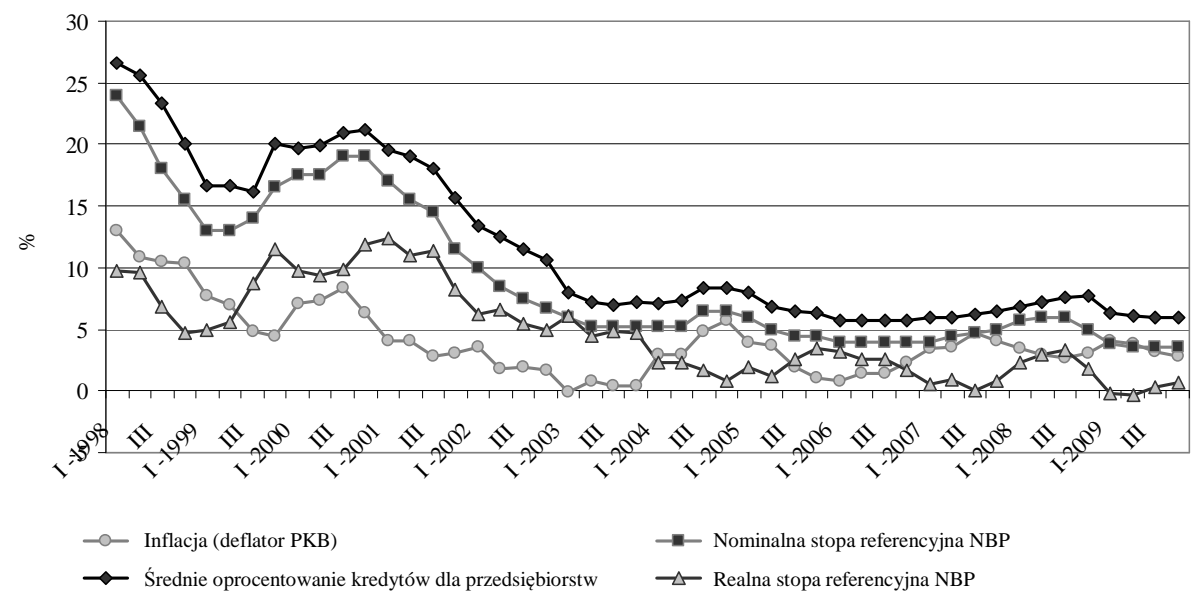

Wykres 5.15. Inflacja, nominalna stopa referencyjna NBP, realna stopa referencyjna NBP oraz średnie oprocentowanie kredytów dla przedsiębiorstw w Polsce w latach 1998-2009

Ź r ó d ł o: opracowanie własne na podstawie danych: Raporty roczne NBP z lat 1998-2009 oraz tabeli GUS - wybrane kwartalne wskaźniki makroekonomiczne.

Wraz z podstawowymi stopami banku centralnego, stopy rynku międzybankowego wykazywały w 2001 r. trend spadkowy pomimo trzykrotnych, przejściowych wzrostów w ciągu roku. Były one spowodowane silną deprecjacją złotego na początku lipca 2001 r., zaburzeniami o charakterze płynnościowym w listopadzie oraz wtórnym efektem tego zaburzenia w grudniu. Realna stopa referencyjna NBP w 2001 r. utrzymywała się na relatywnie wysokim poziomie (np. 12,9\% w I kwartale 2001 r., 8,5\% w IV kwartale tego roku) przy spadającej dynamice PKB w Polsce (np. 2,4\% w I kwartale 2001 r. do 0,5\% w IV kwartale tego roku), co mogłoby wskazywać na tłumiący wpływ wyższej stopy referencyjnej na wzrost gospodarczy (wykres 5.16).

Przyglądając się decyzjom banków komercyjnych reagujących na obniżenie w 2001 r. stopy referencyjnej NBP o 7,5 punktów procentowych, zauważamy, że oprocentowanie kredytów dla podmiotów gospodarczych spadło o 5,5 punktów procentowych (depozytów dla podmiotów gospodarczych o 5,9 pkt. proc.; 1- i 3-miesięczny WIBOR obniżył się w ciągu roku niemal w tym samym stopniu co stopy procentowe NBP, różnica 0,1 punktu procentowego).

${ }^{146}$ Raport o stanie sektora matych i średnich przedsiębiorstw w Polsce w latach 1999-2000, op. cit., s. 20-24. 


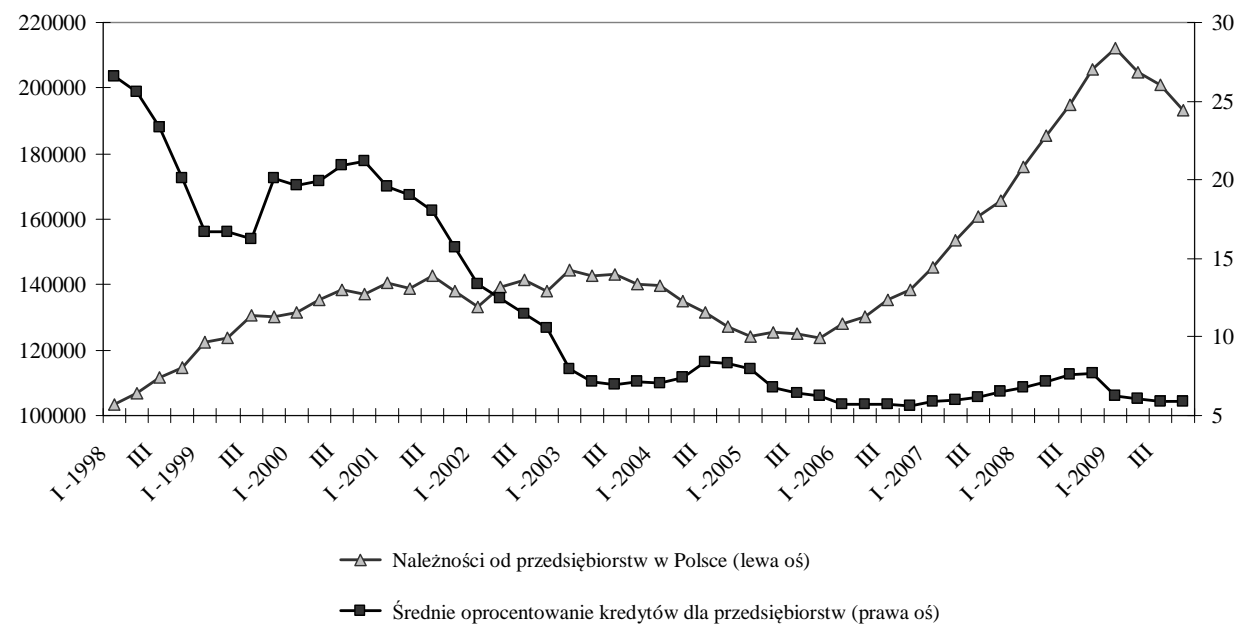

Wykres 5.16. Należności od przedsiębiorstw dla sektora bankowego (w mln zł) oraz średnie oprocentowanie kredytów dla przedsiębiorstw w Polsce w latach 1998-2009

Źr ó d ło: jak do wykresu 5.15.

Decyzje te spowodowane były także różnym podejściem banków do zabezpieczenia kredytów, ponieważ starały się wyeliminować kredytobiorców najbardziej ryzykownych. Było to związane z sytuacją gospodarczą w kraju, spadkiem tempa wzrostu PKB czy rosnącym bezrobociem. W 2001 r. tempo wzrostu należności od przedsiębiorstw dla sektora bankowego spadło o 1,7 punktu procentowego w stosunku do roku poprzedniego, odnotowując poziom $5,8 \%{ }^{147}$. Należności sektora przedsiębiorstw dla banków w 2001 r. osiągnęły poziom około 140 mld zł (wykres 5.16) ${ }^{148}$. Jednak od II kwartału 1999 r. roczne tempo zadłużenia kredytowego przedsiębiorstw ulegało zmniejszeniu ${ }^{149}$.

Nakłady inwestycyjne przedsiębiorstw ogółem w 2001 r. uległy obniżeniu wobec roku wcześniejszego o około 12,5\%. Realna wartość inwestycji ogółem wyniosła około $170 \mathrm{mld} \mathrm{zf}^{150}$ (wykres 5.17). Jedną z przyczyn tych spadków upatruje się w zmniejszeniu tempa budownictwa mieszkaniowego, co powodowało spadek ilości firm budowlanych i zatrudnienia w tej dziedzinie. W 65\%

${ }^{147}$ Raport o inflacji 2001 rok, op. cit., s. 101-110.

${ }^{148}$ Wartość urealniona do I kwartału 2005 r., natomiast wartość nominalna wynosiła około 125 mld zł.

${ }^{149}$ Ocena kondycji finansowej przedsiębiorstw w 2001 roku ze szczególnym uwzględnieniem zjawisk pieniężno-kredytowych (w świetle badań ankietowych i danych GUS), Narodowy Bank Polski, Warszawa, czerwiec 2002, s. 65.

${ }^{150}$ Nominalne nakłady inwestycyjne przedsiębiorstw w 2001 r. osiągnęły wartość 93,26 mld zł. 
podmioty gospodarcze finansowały inwestycje ze środków własnych, natomiast udział kredytów bankowych nie przekraczał w 2001 r. 18\%. Głównych przyczyn w osłabieniu procesów inwestycyjnych w tym czasie upatruje się w pogarszającej się koniunkturze w kraju i za granicą, gorszej sytuacji finansowej przedsiębiorstw i niedostatecznej ilości środków z zewnętrznych źródeł finansowania ${ }^{151}$.

Pomimo znacznych obniżek stóp NBP, banki komercyjnie dość ostrożnie prowadziły swoją politykę kredytowo-depozytową, głównie ze względu na pogarszającą się jakość portfela kredytów, czego miernikiem był wzrastający wskaźnik kredytów zagrożonych (z 17,0\% wzrósł do 20,5\%). W związku z tym banki musiały zwiększyć rezerwy celowe na pokrycie ewentualnych niespłaconych należności. Dodatkowo, skarbowe papiery wartościowe stanowiły dla banków zachętę do lokowania środków w bezpieczne instrumenty, w przeciwieństwie do bardziej ryzykownej w tym czasie działalności kredytowej ${ }^{152}$. Nominalne oprocentowanie kredytów dla podmiotów gospodarczych w 2002 r. obniżało się, chociaż w tempie wolniejszym niżby wynikało to z obniżki stóp procentowych NBP. Również realne oprocentowanie kredytów dla przedsiębiorstw zmalało. Wśród czynników, które wpływały w tamtym czasie na niespójność zmian oprocentowania kredytów dla podmiotów gospodarczych przez banki komercyjne ze ścieżką stóp procentowych NBP, wymienia się wysoką podaż obligacji skarbowych, duży udział kredytów zagrożonych w portfelu kredytowym banków, jak również niepewność co do rozwoju gospodarczego w przyszłości $^{153}$. W 2002 r., znaczenie kredytów i pożyczek bankowych w finansowaniu przedsiębiorstw zmniejszyło się. Łączne realne ${ }^{154}$ zadłużenie sektora przedsiębiorstw w bankach osiągnęło poziom 137 mld zł w grudniu 2002 r. $^{155}$ Nakłady inwestycyjne ${ }^{156}$ przedsiębiorstw w 2002 r. zmniejszyły się w stosunku do roku poprzedniego o niemal $23 \%$.

W roku 2003 nastąpił wzrost działalności inwestycyjnej, czemu sprzyjała poprawa sytuacji finansowej przedsiębiorstw, spadek stóp procentowych oraz podatków (wykres 5.17) ${ }^{157}$. Druga połowa 2003 r. to okres przyspieszonego wzrostu zadłużenia przedsiębiorstw, przede wszystkim z tytułu kredytów długoterminowych. W tym czasie zaobserwowano również dodatnie tempo wzrostu

${ }^{151}$ Raport o stanie sektora matych i średnich przedsiębiorstw w Polsce w latach 2001-2002, Polska Agencja Rozwoju Przedsiębiorczości, Warszawa 2003, s. 15, 48-52.

${ }^{152}$ Raport roczny 2002, op. cit., s. 30-31.

${ }^{153}$ Raport o inflacji 2002 rok, op. cit., s. 80.

${ }^{154}$ Wartość urealniona do I kwartału 2005 r., natomiast nominalna wartość wyniosła 124 mld zł.

${ }^{155}$ Ocena kondycji finansowej przedsiębiorstw w 2002 roku ze szczególnym uwzględnieniem zjawisk pieniężno-kredytowych (w świetle badań ankietowych i danych GUS), Narodowy Bank Polski, Warszawa, lipiec 2003, s. 67.

${ }^{156}$ Realne inwestycje ogółem w gospodarce osiągnęły poziom około $160 \mathrm{mld}$ zł.

${ }^{157}$ Raport o stanie sektora matych i średnich przedsiębiorstw w Polsce w latach 2002-2003, Polska Agencja Rozwoju Przedsiębiorczości, Warszawa 2004, s. 15. 
nakładów na środki trwałe. W grudniu 2003 r. realne zadłużenie ${ }^{158}$ przedsiębiorstw wobec banków osiągnęło poziom $140 \mathrm{mld}$ zł (nominalne $127 \mathrm{mld}$ zł w grudniu 2003 r. $)^{159}$.

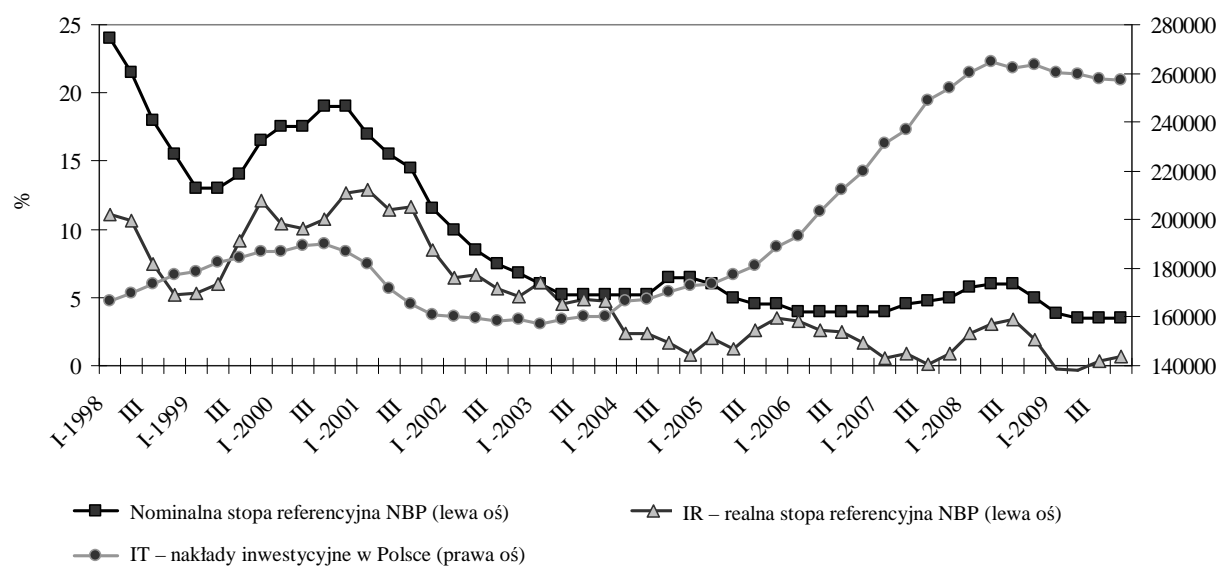

Wykres 5.17. Nominalna stopa referencyjna NBP, realna stopa referencyjna NBP oraz nakłady inwestycyjne (w mln zł) w Polsce w latach 1998-2009

Źródło: opracowanie własne na podstawie danych: OECD National Accounts (www.oecd.org) oraz Raporty roczne NBP z lat 1998-2009.

Na rynku kredytowym w I kwartale 2004 r. zaobserwowano wzrost popytu na kredyty związany ze wzrostem zapotrzebowania firm na finansowanie inwestycji i aktywów obrotowych w wyniku ożywienia gospodarczego ${ }^{160}$. Pomimo, że banki nie zmieniły warunków udzielania kredytów dla przedsiębiorstw, popyt na kredyty w IV kwartale 2004 r. nadal wzrastał w większym stopniu niż w III kwartale ${ }^{161}$. Generalnie średnie ważone oprocentowanie kredytów dla przedsiębiorstw na koniec 2004 r. ukształtowało się na poziomie 8,3\% (spadek w ostatnim kwartale roku o $0,1 \%)^{162}$. Według badań kondycji sektora przedsiębiorstw oraz stanu koniunktury w 2004 r., przeprowadzonych przez NBP, wyni-

${ }^{158}$ Zadłużenie przedsiębiorstw z tytułu kredytów i pożyczek wyniosło 114,6 mld zł, spadek o $1,4 \%$ wobec roku poprzedniego.

${ }^{159}$ Ocena kondycji finansowej przedsiębiorstw w 2003 roku w świetle danych GUS, Narodowy Bank Polski, Warszawa, maj 2004, s. 38-42.

${ }^{160}$ Sytuacja na rynku kredytowym, wyniki ankiety do przewodniczacych komitetów kredytowych, II kwartał 2004, Narodowy Bank Polski, Warszawa, maj 2004, s. 1.

${ }^{161}$ Sytuacja na rynku kredytowym, wyniki ankiety do przewodniczacych komitetów kredytowych, I kwartał 2005, NBP, Warszawa, styczeń 2005, s. 1.

${ }_{162}$ Biuletyn informacyjny 12/2004, Narodowy Bank Polski, Warszawa, maj 2005, s. 23. 
kało jednoznacznie, że w działalność inwestycyjną częściej angażowały się przedsiębiorstwa zainteresowane znacznym zwiększeniem poziomu kredytów ${ }^{163}$. Tak też w IV kwartale 2004 r. odnotowano wzrost popytu inwestycyjnego przedsiębiorstw, w tym nakłady brutto na środki trwałe w IV kwartale zwiększyły się o 7,7\% r/r wobec wzrostu $4 \% \mathrm{r} / \mathrm{r}$ w poprzednich trzech kwartałach ${ }^{164}$. Nakłady inwestycyjne przedsiębiorstw w 2004 r. w stosunku do roku poprzedniego wzrosły o 13,9\%. Realne nakłady inwestycyjne ogółem w 2004 r. osiągnęły poziom 169 mld zł (wykres 5.17) ${ }^{165}$.

W I kwartale 2005 r. pojawiła się tendencja do łagodzenia kryteriów udzielania kredytów dla przedsiębiorstw, między innymi poprzez zmniejszenie marży kredytowej. W tym czasie popyt na kredyty wśród przedsiębiorstw ciągle umiar-

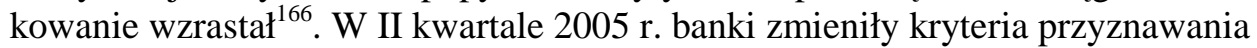
kredytów, łagodząc warunki głównie dla małych i średnich przedsiębiorstw. Banki zwiększały maksymalną kwotę kredytu, wydłużały okres kredytowania, łagodziły wymagania dotyczące zabezpieczeń oraz zmniejszały marżę kredytową $^{167}$. W ostatnim kwartale 2005 r. popyt, głównie na kredyty długoterminowe wśród dużych przedsiębiorstw, zaczął wzrastać. Było to spowodowane zwiększeniem zapotrzebowania na finansowanie inwestycji przez firmy ${ }^{168}$. Przedsiębiorstwa ogółem w 2005 r. poniosły nakłady inwestycyjne wyższe o 10,4\% wobec roku poprzedniego. $Z$ kolei urealnione nakłady inwestycyjne ogółem wynio-

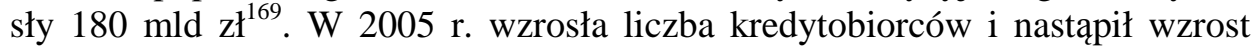
zainteresowania przedsiębiorców finansowaniem zewnętrznym. Na zadłużenie kredytowe przedsiębiorstw w latach 2004-2005 wpłynęło kilka czynników, takich jak: umocnienie kursu złotego wobec walut obcych i spadek części zadłużenia $\mathrm{z}$ tytułu kredytów walutowych, wyższy poziom akumulacji przedsiębiorstw, lepsze wskaźniki sprawności działania firm oraz wzrost zobowiązań z tytułu dostaw i usług ${ }^{170}$.

${ }^{163}$ Wstępna informacja o kondycji sektora przedsiębiorstw ze szczególnym uwzględnieniem stanu koniunktury w IV kw. 2004, Narodowy Bank Polski, Warszawa 2005, s. 62.

${ }^{164}$ Raport o inflacji 2005 rok, op. cit., s. 22.

${ }^{165}$ Raport o stanie sektora matych i średnich przedsiębiorstw w Polsce w latach 2005-2006, Polska Agencja Rozwoju Przedsiębiorczości, Warszawa 2007, s. 37-38.

166 Sytuacja na rynku kredytowym, wyniki ankiety do przewodniczacych komitetów kredytowych, II kwartał 2005, Narodowy Bank Polski, Warszawa, kwiecień 2005, s. 1.

${ }^{167}$ Sytuacja na rynku kredytowym, wyniki ankiety do przewodniczacych komitetów kredytowych, III kwartał 2005, Narodowy Bank Polski, Warszawa, lipiec 2005, s. 1-2.

${ }^{168}$ Sytuacja na rynku kredytowym, wyniki ankiety do przewodniczacych komitetów kredytowych, I kwartał 2006, Narodowy Bank Polski, Warszawa, styczeń 2006, s. 1-2.

${ }^{169}$ Raport o stanie sektora matych i średnich przedsiębiorstw w Polsce w latach 2005-2006, op. cit., s. 37-38.

${ }^{170}$ Ocena kondycji finansowej przedsiębiorstw w 2005 roku na podstawie danych F-01 GUS, Narodowy Bank Polski, Warszawa, sierpień 2006, s. 67. 
Właściwie przez cały 2006 r. oraz 2007 r. banki wykazywały wzrost popytu na kredyty ze strony przedsiębiorstw. W dalszym ciągu zwiększało się zapotrzebowanie firm na finansowanie inwestycji, zapasów oraz kapitału obrotowego. Rosnący popyt na kredyty długoterminowe wskazywał na przyspieszenie tempa inwestycji oraz spadek roli środków własnych $\mathrm{w}$ finansowaniu przedsięwzięć inwestycyjnych. Banki łagodziły kryteria przyznawania kredytów, głównie z powodu presji konkurencyjnej ze strony innych banków oraz niższego ryzyka związanego z sytuacją gospodarczą ${ }^{171}$. Nakłady inwestycyjne w 2006 r. rosły, co było oznaką ożywienia gospodarczego. Sprzyjała temu zjawisku poprawa sytuacji finansowej przedsiębiorstw, obniżenie stóp procentowych oraz podatków, jak również optymistyczne prognozy odnośnie sytuacji gospodarczej Polski w kolejnych latach (wykres 5.17) ${ }^{172}$. W 2006 r. nakłady inwestycyjne przedsiębiorstw ogółem wzrosły o 14,6\% wobec roku poprzedniego. Generalnie wyodrębniając tylko przedsiębiorstwa prywatne w 2006 r. tempo nakładów inwestycyjnych tych podmiotów osiągnęło poziom 21,3\%. Udział środków z kredytów i pożyczek krajowych wynosił $14,4 \%$, a dodając do tego $5,3 \%$ środków z zagranicy to udział nakładów finansowych pochodzenia obcego stanowił prawie $20 \%{ }^{173}$. Średnie oprocentowanie kredytów dla przedsiębiorstw obniżone zostało z poziomu około 8,5\% w 2004 r. do około 6\% w 2009 r. przy znacznym wzroście należności od przedsiębiorstw dla sektora bankowego (wykres 5.16).

Począwszy od IV kwartału 2007 r. banki zaczęły nieznacznie zaostrzać kryteria udzielania kredytów dla przedsiębiorstw. Podobna sytuacja utrzymywała się w I kwartale 2008 r., kiedy banki zdecydowały stopniowo podnosić marże kredytowe. Powyższe decyzje banków wynikały głównie z pogorszenia sytuacji kapitałowej banków, związanej z szybkim tempem wzrostu akcji kredytowej w ostatnich kwartałach. Wzrosło również ryzyko związane z sytuacją gospodarczą. Pomimo tego popyt na kredyty ze strony przedsiębiorstw nadal wzrastał ${ }^{174}$. W 2007 r. nakłady inwestycyjne przedsiębiorstw wzrosły wobec roku poprzedniego o 26,2\%. Nadal jednak największe źródło finansowania inwestycji stanowiły środki własne $-64 \%$, krajowe kredyty i pożyczki - $21 \%$ a środki zagraniczne $7 \%{ }^{175}$.

Przez cały 2009 r. banki w mniejszym lub większym stopniu zaostrzały kryteria udzielania kredytów przedsiębiorstwom, zmniejszając jednocześnie podaż

${ }^{171}$ Sytuacja na rynku kredytowym, wyniki ankiety do przewodniczacych komitetów kredytowych, I kwartał 2007, Narodowy Bank Polski, Warszawa, styczeń 2007, s. 1-2.

${ }^{172}$ Raport o stanie sektora matych i średnich przedsiębiorstw $w$ Polsce $w$ latach 2005-2006, op. cit., s. 12.

${ }^{173}$ Raport o stanie sektora matych $i$ średnich przedsiębiorstw w Polsce w latach 2006-2007, Polska Agencja Rozwoju Przedsiębiorczości, Warszawa 2008, s. 36-39.

174 Sytuacja na rynku kredytowym, wyniki ankiety do przewodniczacych komitetów kredytowych, II kwartał 2008, Narodowy Bank Polski, Warszawa, kwiecień 2008, s. 1-2.

${ }^{175}$ Raport o stanie sektora matych i średnich przedsiębiorstw w Polsce w latach 2006-2007, op. cit., s. 52-54. 
kredytów na rynku (pomimo spadku podstawowych stóp NBP) ${ }^{176}$. Dopiero w IV kwartale 2009 r. złagodzono tendencję zaostrzania polityki kredytowej. Banki nieznacznie obniżyły marże dla kredytów charakteryzujących się normalnym profilem ryzyka. Natomiast z badań ankietowych przeprowadzonych wśród przedsiębiorstw wynikało, że jednak w IV kwartale 2009 r. odsetek firm ubiegających się o kredyt spadł o 4,6 pkt proc. kw/kw i 2,3 pkt proc. r/r ${ }^{177}$.

Kryzys finansowy istotnie zachwiał trend wzrostowy PKB, który w I kwartale 2009 r. zanotował poziom $0,7 \%$. Z kolei podstawowa realna stopa referencyjna w czasie kryzysu również uległa obniżeniu (w I kwartale 2009 r. wyniosła $-0,2 \%$ ), w porównaniu do okresu sprzed kryzysu finansowego ${ }^{178}$. Od II kwartału 2009 r. zadłużenie przedsiębiorstw z tytułu kredytów inwestycyjnych i nieruchomości utrzymywało się na stabilnym poziomie. Rozpatrując popyt inwestycyjny w III kwartale 2009 r. zaobserwowano, że nakłady brutto na środki trwałe obniżyły się o 1,5\% r/r wobec spadku o 3\% w II kwartale 2008 r. W III kwartale 2009 r. nakłady inwestycyjne zostały ograniczone przez przedsiębiorstwa po raz pierwszy od $2002 \mathrm{r}$. (wykres 5.17) ${ }^{179}$.

\subsection{Podsumowanie}

Analizując decyzje banków centralnych dotyczące polityki pieniężnej, należy pamiętać o czynnikach, które mają istotny wpływ na gospodarkę światową oraz determinują decyzje władz monetarnych. Do takich czynników zaliczamy oprócz cen ropy naftowej, surowców, żywności czy popytu wewnętrznego również kryzysy finansowe. Przykładem jest chociażby ostatni kryzys, który od 2007 r. zakłócił wiele procesów gospodarczych. Niektórzy ekonomiści, jak J. B. Taylor, czy autorzy 79 rocznego raportu Banku Rozliczeń Międzynarodowych w Bazylei wskazują, że to zbyt luźna polityka pieniężna i niskie stopy procentowe przyczyniły się do poważnych zaburzeń na rynkach światowych. Dodatkowo J. B. Taylor wskazuje, że wpływ stopy funduszy federalnych FED na stopy EBC był statystycznie istotny, co świadczy o zbyt niskiej stopie procentowej w Eurosystemie, szczególnie w latach 2000-2006. Warto zauważyć, że

176 Sytuacja na rynku kredytowym, wyniki ankiety do przewodniczacych komitetów kredytowych, IV kwartał 2009, Narodowy Bank Polski, Warszawa, październik 2009, s. 1-2.

177 Sytuacja na rynku kredytowym, wyniki ankiety do przewodniczacych komitetów kredytowych, I kwartał 2010, Narodowy Bank Polski, Warszawa, styczeń 2010, s. 1-2.

${ }^{178}$ Realna stopa referencyjna od początku 2002 r. spadała aż do końca 2004 r., co mogło przyczynić się do wzrostu gospodarczego w tym okresie. Przy relatywnie niskiej realnej stopie referencyjnej NBP, w okresie od końca 2004 r. do początku 2008 r. (z niewielkimi wahaniami), zaobserwowano stosunkowo wysoki wzrost gospodarczy aż do III kwartału 2008 r.

${ }^{179}$ Raport o inflacji 2010 rok, Narodowy Bank Polski, Warszawa 2010, s. 25, 35-36. 
polityka stóp procentowych prowadzona przez NBP była w tym czasie w większym stopniu restrykcyjna, co prawdopodobnie uchroniło polską gospodarkę przed bardziej negatywnymi skutkami ostatniego kryzysu finansowego. Obserwując kształtowanie się wielkości makroekonomicznych w Polsce oraz w strefie euro w latach 1998-2009, można oczekiwać, że po wstąpieniu Polski do Eurosystemu zmianie ulegnie poziom stóp procentowych. Stopy EBC obowiązujące w strefie euro charakteryzują się niższym poziomem niż w Polsce, a w momencie wejścia Polski do UGiW na gospodarkę polską oddziaływać będą stopy procentowe ustalane przez EBC. Niższy poziom stóp procentowych może wpłynąć na niższy koszt kapitału, niższe oprocentowanie kredytów, co może oddziaływać na poszerzenie działalności inwestycyjnej. Na przestrzeni omawianych dwunastu lat, zarówno poziom oprocentowania kredytów, jak i stóp rynku międzybankowego w Polsce istotnie spadał w ślad za stopą referencyjną, podobnie jak w strefie euro. Wyniki gospodarcze w Polsce i strefie euro w latach 1998-2009 wskazują, że niski poziom stóp procentowych przyczyniał się do wzrostu nakładów inwestycyjnych, z różnym opóźnieniem wynikającym z mechanizmu transmisji impulsów polityki pieniężnej do sfery realnej gospodarki.

Podsumowując, poziom stóp procentowych powinien być zawsze dostosowany do warunków danej gospodarki. Natomiast w momencie przystąpienia Polski do strefy euro, poziom stóp procentowych EBC może okazać się zbyt niski do warunków polskiej gospodarki, dlatego należy dokładnie przygotować gospodarkę w celu uniknięcia zawirowań gospodarczych w czasie wejścia do UGiW. 


\section{Rozdział 6}

\section{ANALIZA ZALEŻNOŚCI INWESTYCJI OD STOPY REFERENCYJNEJ BANKU CENTRALNEGO NA PODSTAWIE BADAŃ EMPIRYCZNYCH W LATACH 1998-2009 - STUDIUM PRZYPADKU}

W celu zbadania wpływu stopy procentowej na poziom inwestycji w Polsce i strefie euro wykorzystano ekonometryczno-statystyczne metody badawcze. Poza analizą zależności stóp procentowych EBC oraz NBP, uwagę skoncentrowano również na empirycznym oddziaływaniu stóp referencyjnych banków centralnych na stopy rynku międzybankowego, a następnie tych ostatnich na ceny kredytów bankowych dla przedsiębiorstw. Oszacowano korelację pomiędzy poziomem kredytów udzielonych przedsiębiorstwom a wielkością nakładów inwestycyjnych w Polsce i strefie euro w celu określenia pośredniego wpływu stóp procentowych banku centralnego oraz rynku międzybankowego na sferę realną gospodarki.

\subsection{Metodyka badań empirycznych oraz specyfika metod badawczych}

Temat oddziaływania stóp procentowych banku centralnego na inwestycje w gospodarce jest kontrowersyjny. J. Taylor, M. Keynes twierdzili, że związek ten jest istotny. Tymczasem ekonomiści tacy jak: B. Bernanke, M. Gertler przekonywali o mniejszym znaczeniu kosztu kapitału dla przedsiębiorstw niż cen i płac w procesie podejmowania decyzji inwestycyjnych ${ }^{1}$. Badania wpływu stóp procentowych na inwestycje podejmowali: Ch. J. Erceg i A. T. Levin ${ }^{2}$,

\footnotetext{
${ }^{1}$ B. B ern an ke, M. Gert ler, Inside the Black Box: The Credit Channel of Monetary Policy Transmission, „Journal of Economic Perspectives” 1995, vol. 9, s. 27-37.

${ }^{2}$ Ch. J. Erceg, A. T. Le vin, Optimal Monetary Policy with Durable and Non-Durable Goods, referat przedstawiony na konferencji „International Research Forum on Monetary Policy”, ECB, 5-6.07.2002.
} 
K. N. Kuttner i P. C. Mosser, mierząc wpływ stóp procentowych na poszczególne składowe inwestycji. Ekonomiści ci wykazali, że stopy procentowe oddziałują silnie na budownictwo mieszkaniowe, a słabiej na inwestycje przedsiębiorstw ${ }^{3}$. Analiza zależności inwestycji od stopy procentowej była jednak utrudniona z powodu wielu czynników zakłócających bezpośredni wpływ banku centralnego poprzez kanał stóp procentowych na inwestycje przedsiębiorstw. Temat oddziaływania stóp procentowych na gospodarkę nabiera znaczenia w momencie dyskusji o przyjęciu Polski do strefy euro. Analiza zależności pomiędzy odpowiednimi zmiennymi umożliwiła sprawdzenie stopnia wpływu stopy referencyjnej banku centralnego na inwestycje przedsiębiorstw w Polsce i w strefie euro.

Zależność pomiędzy stopami procentowymi a inwestycjami przedsiębiorstw była przedmiotem badań wielu ekonomistów. Analizy te przeprowadzano dla różnych krajów o odmiennych uwarunkowaniach gospodarczych, poddanych działaniu wielu czynników strukturalnych. $\mathrm{Z}$ kolei te ostatnie miały istoty wpływ na poziom efektywności i czas przeniesienia impulsów polityki pieniężnej poprzez mechanizm transmisji i jego kanały do sfery realnej gospodarki ${ }^{4}$.

W badaniach empirycznych nie jest łatwo oddzielić wpływ polityki pieniężnej na inwestycje od oddziaływania innych czynników. Istotnym elementem, który ma znaczenie $\mathrm{w}$ procesie transmisji polityki pieniężnej banku centralnego, związanym z poziomem inwestycji jest koszt użytkowania kapitału (user cost of capital $)^{5}$. Ponadto często zmiany popytu inwestycyjnego oddziałują na poziom stóp procentowych, co jest trudne do rozróżnienia od wpływu stóp procentowych na inwestycje. Jak zauważa między innymi L. Mahadeva i P. Sinclair, wśród elementów utrudniających zbadanie zależności inwestycji od stóp procentowych istnieje między innymi fakt, że często składowe inwestycji (maszyny, akcje) kształtowane są również przez kursy walutowe oraz ich ceny zagraniczne ${ }^{6}$.

$\mathrm{W}$ związku z powyższym, w rozdziale tym przeprowadzono badania siły, kierunku oraz czasu opóźnień oddziaływania podstawowej stopy referencyjnej na gospodarkę, w tym głównie na inwestycje. W monografii założono, że stopa referencyjna banku centralnego wpływa odwrotnie proporcjonalnie na poziom inwestycji przedsiębiorstw, zarówno w Polsce jak i strefie euro. Przyjęto, że model ekonometryczny pozwoli zbadać, czy w okresie 1998-2009 odwrotnie proporcjonalny wpływ stóp procentowych na inwestycje znajduje potwierdzenie

${ }^{3}$ K. N. Kuttner, P. C. Moss er, The Monetar Transmission Mechanism: Some Answers and Further Questions, ,FRBNY Economic Policy Review” 2002, vol. 5, s. 15-26.

${ }^{4}$ R. Kokoszczyński, T. Łyziak, E. Wróbel, Czynniki strukturalne we wspótczesnych teoriach mechanizmów transmisji polityki pieniężnej, XXII Konferencja Naukowa NBP „Reformy strukturalne a polityka pieniężna”, Falenty 2002, s. 1-16.

${ }^{5}$ Ibidem, s. 3-7.

${ }^{6} \mathrm{~L}$. M a hadeva, P. S in clair, The transmission mechanism of monetary policy, materiał przygotowany na Central Bank Governors' Symposium, Bank Anglii, 08.06.2001, s. 54-64. 
w gospodarce polskiej oraz Eurosystemie. Ponadto uznano za interesujące zbadanie siły tego oddziaływania na rzeczywistość gospodarczą. W związku z tym, że omawiane zjawisko jest złożone, o wielu czynnikach zakłócających wpływ zmiennych objaśniających na zmienną objaśnianą, w celu uzyskania jak największej efektywności zastosowanej metody postanowiono wykorzystać metody oparte na modelu ekonometrycznym. Wybór tej metody został podyktowany faktem, że poprzez dodanie do równania regresji zaburzenia stochastycznego, zwanego inaczej składnikiem losowym (błędem losowym) powstaje możliwość ujęcia w badaniu sumarycznego oddziaływania na zmienną objaśnianą innych czynników pominiętych $\mathrm{w}$ równaniu. Z kolei sam błąd losowy może wynikać z niewłaściwej postaci równania matematycznego, z błędów pomiaru zmiennych lub z niepoprawności postawionych hipotez ${ }^{7}$.

Model ekonometryczny to uproszczone odwzorowanie związków zachodzących w wyróżnionej części rzeczywistości. W monografii skorzystano z jednorównaniowego modelu dynamicznego, ponieważ jedną ze zmiennych objaśniających jest zmienna opóźniona, a dokładniej jest nią opóźniona zmienna objaśniana, stąd model ten jest autoregresyjny ${ }^{8}$. Estymację parametrów modelu ekonometrycznego przeprowadzono metodą najmniejszych kwadratów. Do opisania zależności inwestycji od stopy referencyjnej banku centralnego zastosowano funkcję logarytmiczną. Przedstawiono kilka wariantów równania w celu zaobserwowania wpływu zestawu różnych zmiennych objaśniających na zmienną objaśnianą.

Według teorii neoklasycznej, w modelowaniu inwestycji istotna jest również ich opłacalność, czyli różnica pomiędzy zyskami a kosztami, które ponosi użytkownik inwestycji. Szczególne znaczenie przypisuje się tu kosztom obsługi kredytów lub opodatkowania (user costs). Właśnie D. W. Jorgenson zwrócił uwagę, że w funkcji inwestycji istotne są koszty inwestycji, na które składa się głównie kwota pożyczona w celu zakupu środka trwałego, powiększona o koszty oprocentowania kredytu wyrażone przez realną stopę procentową. Model inwestycji powinien również uwzględniać fakt, że z reguły cykle inwestycyjne są dłuższe od badanych okresów i dlatego należy uwzględniać towarzyszące tym procesom opóźnienia9 9

Przeprowadzono również badanie współczynnika korelacji Pearsona $\left(r_{x y}\right)$ oraz współczynnika determinacji $\left(R^{2}\right)$ pomiędzy odpowiednimi zmiennymi. Współczynnik korelacji liniowej Pearsona jest miarą siły i kierunku dla związków prostoliniowych. Jest to miara niemianowana i symetryczna. Współczynnik ten informuje o sile zależności pomiędzy cechami, gdzie: $r_{x y}=0$ oznacza, że występuje niezależność między zmiennymi, jeśli zaś współczynnik Pearsona

${ }^{7}$ B. R. Gó r e c ki, Podstawowy kurs nowoczesnej ekonometrii, [za:] zasoby witryny internetowej: http://uczelniawarszawska.pl/materialy/1197726936.pdf [02.12.2010].

${ }^{8}$ B. Gładysz, J. Mercik, Modelowanie ekonometryczne, studium przypadku, Oficyna Wydawnicza Politechniki Wrocławskiej, Wrocław 2007, s. 8-17.

${ }^{9}$ W. W e lf e, A. W e lf e, Ekonometria stosowna, PWE, Warszawa 2004, s. 123-131. 
mieści się w przedziale $0-0,33$, zależność między cechami jest słaba, jeśli znajduje się w przedziale $0,34-0,66$ to występuje średnia zależność między zmiennymi, a przedział 0,67-1 informuje o silnej, wyraźnej zależności stochastycznej między cechami, jeśli otrzymujemy $r_{x y}=1$, wtedy występuje funkcyjny związek dwóch cech. Z kolei o kierunku tej zależności wiemy obserwując wartość kowariancji: $C(X, Y)=0$ - brak zależności korelacyjnej, $C(X, Y)>0$ - zależność korelacyjna dodatnia, $C(X, Y)<0$ - zależność korelacyjna ujemna. Natomiast współczynnik determinacji informuje w ilu procentach zmiany zmiennej zależnej powodowane są przez zmiany zmiennej niezależnej ${ }^{10}$. Współczynnik korelacji liniowej Pearsona umożliwia określenie siły oraz kierunku związków pomiędzy dwiema cechami oraz pozwala ocenić mechanizm powiązań między zmiennymi. Z kolei współczynnik determinacji został użyty dodatkowo jako narzędzie informujące, $\mathrm{w}$ jakim stopniu zmienna niezależna oddziałuje na zmienną zależną ${ }^{11}$.

\section{2. Źródła danych wykorzystanych w badaniach empirycznych}

Poniżej przedstawiono opis oraz źródła danych użytych w modelach ekonometrycznych, obliczeniach statystycznych oraz wykorzystanych do wykonania wykresów zmiennych. Wartości liczbowe zostały zaczerpnięte między innymi z bazy OECD National Accounts (www.oecd.org). Dane przeliczono na wartości realne według poniższej formuły i przedstawiono w cenach z 2005q1: wolumen $*$ deflator $/ 100=$ nominal value (wartość nominalna), a następnie wykorzystano wzór: nominal value / deflator o podstawie $2005 \mathrm{q} 1$ = real value (2005q1).

IR - intrest rate - realna stopa referencyjna (urealniona przez deflator PKB) obliczona została na podstawie wzoru: realna stopa procentowa $=$ $=\left[\right.$ nominalna stopa procentowa $\left.-\left(P G D P_{t}-P G D P_{t-4}\right) / P G D P_{t-4}\right] /$ $/\left[100+\left(P G D P_{t}-P G D P_{t-4}\right) / P G D P_{t-4}\right] * 100$,

$S R E$ - nominalna stopa referencyjna NBP,

IT - (total investments - gross fixed capital formation) inwestycje całkowite realne (2005q1),

ITV - total investments value - wartość nominalna inwestycji całkowitych,

PIT - (gross fixed capital formation - total investments, deflator, market proces) - nakłady brutto na środki trwałe, deflator ceny rynkowe (wykorzystane jako cena inwestycji),

${ }^{10}$ M. S e j-Kolas a, A. Zi elińska, Excel w statystyce, Wydawnictwo Akademii Ekonomicznej im. Oskara Langego we Wrocławiu, Wrocław 2004, s. 61-72.

${ }^{11}$ B. P u ł a s k a - T u r y n a, Statystyka dla ekonomistów, Difin, Warszawa 2008, s. 274-284. 
$I T=I C O N($ gross fixed capital formation, construction, volume) + IMT (gross fixed capital formation, metal products and machinery, transport equipment, volume) - nakłady brutto na środki trwałe w budowie + nakłady brutto na środki trwałe, maszyny i urządzenia oraz środki transportu = inwestycje całkowite,

GDP - Gross Domestic Product, wartość realna PKB w cenach z 2005q1,

GDPV - Gross Domestic Product Value, wartość nominalna PKB,

PGDP - deflator PKB (2005q1).

Nakłady brutto na środki trwałe opracowane są według zaleceń ESA 95 (European System of Accounts). Są to nakłady zwiększające wartość majątku trwałego, obejmujące nakłady na: rzeczowe środki trwałe, wartości niematerialne i prawne, remonty środków trwałych. Do wartości nakładów na rzeczowe środki trwałe zalicza się nakłady na ich nabycie, nakłady na wytworzenie dla własnych potrzeb środków trwałych, nakłady na środki trwałe w budowie oraz na ulepszenia ${ }^{12}$. Stopa inwestycji w gospodarce to relacja nakładów brutto na środki trwałe do produktu krajowego brutto w cenach bieżących.

Nominalne stopy procentowe Narodowego Banku Polskiego zostały pobrane z Raportów Rocznych NBP z lat 1998-2009. Wykorzystano stopy nominalne NBP obowiązujące na koniec danego kwartału w kolejnych latach. Średnie oprocentowanie kredytów dla przedsiębiorstw zaczerpnięto z Raportów Rocznych NBP z lat 1998-2009, jako średnie ważone oprocentowanie kredytów złotowych w bankach komercyjnych oraz jako dane w ostatnim miesiącu danego kwartału. Stawki WIBOR 1M oraz WIBOR 3M zostały pobrane z Biuletynów miesięcznych NBP z poszczególnych lat w okresie 1998-2009, zanotowane w miesiącu na koniec danego kwartału. POLONIA - referencyjna stopa międzybankowych operacji depozytowych typu overnight pochodzi z bazy NBP, dane kwartalne opublikowane również w Biuletynach Miesięcznych NBP.

Nominalne stopy procentowe EBC zostały zaczerpnięte ze zbioru Statistical Data Warehouse, Reports, Monthly Bulletin, Euro Area Statistics Online, Monetary policy statistics, stan na listopad 2010 r. Do badań empirycznych wykorzystano stopy nominalne EBC, które obowiązywały na koniec danego kwartału poszczególnych lat ${ }^{13}$. Średnie oprocentowanie kredytów dla przedsiębiorstw zostało zaczerpnięte z Biuletynów Miesięcznych EBC, jako lending interest rate to enterprises powyżej 1 roku. Do danych kwartalnych użyto stopy oprocentowania kredytów obowiązującej w miesiącu kończącym dany kwartał ${ }^{14}$. Stawki

12 Informacja GUS o metodologii szacunków kwartalnych produktu krajowego, Rachunki Kwartalne Produktu Krajowego Brutto w latach 1995-2003, Główny Urząd Statystyczny, Warszawa 2004 oraz Glossary of Statistical Terms OECD, National Accounts, ESA [3.102-3.106], 2001.

${ }^{13}$ Zasoby oficjalnej witryny internetowej Europejskiego Banku Centralnego: http://sdw.ecb. europa.eu/reports.do?node=100000131 [25.11.2010].

${ }^{14}$ ECB Monthly Bulletin, tabele „Retail bank interest rates”, Lending interest rates, biuletyny miesięczne Europejskiego Banku Centralnego od 1998 do 2010 r., Frankfurt n. Menem. 
EURIBOR 1M oraz EURIBOR 3M również zaczerpnięto z Biuletynów Miesięcznych EBC, z tabel pt. Money market interest rates, jako 1-month deposits oraz 3-month depostits. Jako dane kwartalne wykorzystano stopy EURIBOR 1M oraz EURIBOR 3M zanotowane w miesiącu na koniec danego kwartału ${ }^{15}$. EONIA - referencyjna stopa międzybankowych operacji depozytowych typu overnight pochodzi z bazy Europejskiego Banku Centralnego Statistical Data Warehouse, dane kwartalne opublikowane również w Biuletynach Miesięcznych $E B C^{16}$.

Stopę nominalną wykorzystuje się w transakcjach zaciągania kredytu, lokowania kapitału w formie depozytów, czyli jest stopą, która widnieje w umowach między bankiem a klientem. Pomniejszając stopę nominalną o stopę inflacji uzyskuje się stopę realną. Realna stopa procentowa została obliczona według następującego wzoru ${ }^{17}: \operatorname{Ir}=[(1+I n) /(1+i)]-1$, gdzie $\operatorname{Ir}-$ realna stopa procentowa, In -nominalna stopa procentowa, $i$ - wskaźnik inflacji.

Dynamika PKB w Polsce, przedstawiona jako stopa wzrostu PKB w ujęciu kwartalnym, została zaczerpnięta $\mathrm{z}$ danych statystycznych GUS, wykorzystując jako ceny stałe - ceny średnioroczne roku poprzedniego (tabele: kwartalne mierniki gospodarcze - część III, Rachunki narodowe). Należności od przedsiębiorstw w skonsolidowanym systemie bankowym w ujęciu kwartalnym zaczerpnięto z danych statystycznych GUS w mln zł jako stan w końcu okresu (tabela: wybrane kwartalne wskaźniki makroekonomiczne - część II). Dane te urealniono wykorzystując deflator PKB.

Wskaźnik inflacji jako CPI (Consumer Price Index) pobrano z bazy danych statystycznych GUS, wykorzystując wskaźnik cen towarów i usług konsumpcyjnych, liczony jako analogiczny okres roku poprzedniego (tabela: wybrane kwartalne wskaźniki makroekonomiczne - część II). W pozostałych przypadkach inflacja w Polsce obliczona została przy wykorzystaniu deflatora PKB.

Zmiany procentowe PKB w strefie euro jako roczna stopa wzrostu PKB (gdzie dane kwartalne zostały sezonowo wyrównane), zaczerpnięto z danych opracowanych przez Eurostat dla EBC według ESA95 ${ }^{18}$. Kredyty dla przedsiębiorstw opisano za pomocą danych pochodzących z Biuletynów Miesięcznych $E B C$ (Biuletyny EBC od 1998 r. do 2009 r.), jako pożyczki MIFs monetarnych

${ }^{15}$ ECB Monthly Bulletin, tabele „Money market interest rates”, Euro Area, biuletyny miesięczne Europejskiego Banku Centralnego od 1998 do 2010 r., Frankfurt n. Menem.

${ }^{16}$ Zasoby witryny internetowej: European Central Bank - Statistical Data Warehouse, Money Market - Eonia rate: http://sdw.ecb.europa.eu/quickview.do?SERIES_KEY=143.FM.Q.U2. EUR.4F.MM.EONIA.HSTA [12.12.2010].

${ }^{17} \mathrm{Z}$. D r e s le r, Kontrowersje wokót polityki stopy procentowej, [w:] J. L. B e d narczy k (red.), Stopy procentowe a gospodarka, eseje z teorii i polityki pieniężnej, Wydawnictwo Politechniki Radomskiej, Radom 2004, s. 88.

${ }^{18}$ Zasoby oficjalnej witryny internetowej Europejskiego Banku Centralnego: http://sdw.ecb. europa.eu/quickview.do?SERIES_KEY=122.ICP.M.U2.N.000000.4.ANR\&periodSortOrder=ASC [10.01.2011]. 
instytucji finansowych dla przedsiębiorstw sektora niefinansowego, dane kwartalne na koniec okresu.

Wskaźnik inflacji HICP (Harmonised Indices of Consumer Prices) został pobrany z bazy EBC Statistical Data Warehouse jako roczna zmiana procentowa. Wartości wyrażone miesięcznie zostały zagregowane do wartości kwartalnych (średnia $\mathrm{z}$ trzech miesięcy danego kwartału jako dana kwartalna) ${ }^{19}$. Do obliczeń inflacji w strefie euro wykorzystano również deflator PKB, który jest wskaźnikiem inflacji rozumianym jako zmiana procentowa cen wszystkich dóbr, które wchodzą w skład PKB pomiędzy rokiem bazowym a bieżącym. Deflator ten uwzględnia ceny nie tylko dóbr konsumpcyjnych, ale również inwestycyjnych oraz stanowiących eksport netto.

Na potrzeby obliczeń wykonanych w pracy wykorzystano najszerszą miarę inflacji, czyli deflator PKB, który reprezentuje ceny wszystkich dóbr i usług finalnych. Zgodnie z metodologią SNA93 oraz opartą na niej ESA95, indeksy cen wykorzystywane w rachunkach narodowych liczone są na podstawie indeksów Fishera. W tym miejscu można podkreślić, że informacje dotyczące inflacji obliczanej na podstawie deflatora PKB są dostępne z pewnym opóźnieniem w porównaniu do danych inflacji $\mathrm{CPI}^{20}$. Dlatego inflacja CPI jest częściej wykorzystywana do porównań z celami inflacyjnymi banków centralnych oraz na rynkach finansowych. Jednak z punktu widzenia podmiotów gospodarczych podejmujących decyzje inwestycyjne uznano, że istotniejszą miarą inflacji będzie deflator PKB.

\subsection{Weryfikacja empiryczna wpływu stopy referencyjnej EBC na inwestycje w strefie euro - modelowanie ekonometryczne}

Polityka monetarna jako domena sfery regulacyjnej gospodarki oddziałuje na zachowania podmiotów gospodarczych w sferze realnej. Istotne jest podkreślenie faktu, że wpływ decyzji władz monetarnych na wielkość popytu globalnego w gospodarce uzależniony jest od stopnia wrażliwości inwestorów na zmiany w polityce pieniężnej. Weryfikując poruszony w monografii problem, że stopa referencyjna banku centralnego wpływa odwrotnie proporcjonalnie na poziom inwestycji przedsiębiorstw, zarówno w Polsce jak i strefie euro, przeprowadzono badanie przy wykorzystaniu jednorównaniowego modelu ekonometrycznego. Opracowano dwa modele dla strefy euro. W równaniach tych jako zmienną objaśnianą wykorzystano przyrosty logarytmów nakładów na środki trwałe brutto reprezentujące inwestycje w strefie euro. Wśród zmiennych objaśniających uży-

${ }^{19}$ Ibidem.

${ }^{20} \mathrm{P}$. B aranowski, Problem optymalnej stopy inflacji $w$ modelowaniu wzrostu gospodarczego, Wydawnictwo Biblioteka, Łódź 2008, s. 17, 103, 109. 
to przyrostów realnej stopy referencyjnej EBC, przyrostów logarytmów produktu krajowego brutto oraz w drugim modelu dodatkowo przyrostów logarytmów opóźnionych nakładów inwestycyjnych o dwa kwartały. Równanie regresji wykorzystane w modelu zostało przedstawione poniżej ${ }^{21}$ :

$$
\begin{gathered}
\text { Wzór 6.1. Równanie regresji } \\
y_{t=} \alpha_{0}+\alpha_{1} x_{1 t}+\alpha_{2} x_{2 t}+\ldots+\alpha_{n} x_{n t}+\varepsilon_{t}
\end{gathered}
$$

gdzie:

$y_{t} \quad-$ zmienna objaśniana,

$x_{1 t} \ldots x_{n t}-$ zmienne objaśniające,

$\varepsilon_{t} \quad-$ składnik losowy.

Otrzymane wyniki zbadano pod względem przydatności w wyjaśnieniu badanego problemu za pomocą testów statystycznych. Do weryfikacji istotności współczynników regresji wykorzystano test $t$-Studenta, natomiast do wykrycia autokorelacji posłużono się testem Durbina, Durbina-Watsona oraz LM. Zmienność wariancji resztowej zbadano testem White'a. Przeprowadzone zostało również badanie stacjonarności zmiennych. Analiza stacjonarności zmiennych została wykonana przy pomocy testu ADF. Zmienne testowane na poziomach wykazały, że są niestacjonarne. Dopiero test na pierwszych przyrostach tych zmiennych pozwolił na odrzucenie hipotezy $H_{0}$ o występowaniu pierwiastka jednostkowego (występowanie stacjonarności) na rzecz hipotezy $H_{1}$ o braku występowania pierwiastka jednostkowego, czyli stacjonarności zmiennych. Niniejsza analiza może być wykorzystana jako podstawa do dalszych badań związanych z tym tematem przy zastosowaniu bardziej zaawansowanych metod badawczych oraz bardziej aktualnych danych.

\subsubsection{Estymacja oraz weryfikacja statystyczna (model 1 dla strefy euro)}

\section{Postać modelu przed oszacowaniem MNK:}

$$
\Delta \ln I T_{t}=\alpha_{0}+\alpha_{1} \Delta I R_{t}+\alpha_{2} \Delta \ln G D P_{t}+\varepsilon_{t}
$$

gdzie:

$\Delta \ln I T_{t}-$ nakłady inwestycyjne (w cenach z 2005q1), przyrosty logarytmów,

$\Delta I R_{t} \quad-$ realna stopa referencyjna EBC (przyrosty),

$\Delta \ln G D P_{t}$ - wartość produktu krajowego brutto (w cenach z 2005q1), przyrosty logarytmów.

${ }^{21}$ B. Gładys z, J. Mercik, op. cit., s. 8-17. 


\section{Postać modelu po oszacowaniu MNK w programie GRETL:}

$$
\Delta \ln I T_{t}=-0,0055-0,0057 \Delta I R_{t}+2,1976 \Delta \ln G D P_{t}+\varepsilon_{t}
$$

Wartości parametrów modelu oszacowane zostały metodą najmniejszych kwadratów.

Estymacja KMNK, wykorzystane obserwacje 1999:2-2009:4 $(N=43)$

Zmienna zależna: $l d \_I T$ (model 1 dla strefy euro)

\begin{tabular}{|c|c|c|c|c|}
\hline Nazwa zmiennej & Współczynnik & Błąd standardowy & $t$-Studenta & Wartość $p$ \\
\hline const & $-0,00547209$ & 0,00112463 & $-4,866$ & $1,81 \mathrm{e}-05$ \\
\hline$d \_I R$ & $-0,00571850$ & 0,00252103 & $-2,268$ & 0,0288 \\
\hline$l d \_G D P$ & 2,19765 & 0,171723 & 12,80 & $1,00 \mathrm{e}-015$ \\
\hline \multicolumn{5}{|c|}{$\begin{array}{l}\text { Wsp. determ. } R \text {-kwadrat } 0,836994 \text { Skorygowany } R \text {-kwadrat } 0,828844 \\
F(2,40) 102,6949 \text { Wartość } p \text { dla testu } F 1,75 \text { e-16 Autokorel. reszt - rhol } 0,129498 \\
\text { Stat. Durbina-Watsona } 1,712269 \\
\text { Średn. aryt. zm. zależnej } 0,002259 \text { Odch. stand. zm. zależnej } 0,014797 \\
\text { Suma kwadratów reszt } 0,001499 \text { Błąd standardowy reszt } 0,006122\end{array}$} \\
\hline \multicolumn{5}{|c|}{$\begin{array}{l}\text { Test White'a: statystyka testu: } L M=3,62771 \\
\text { z wartością } p=P(\text { Chi-Square }(5)>3,62771)==0,604157 \\
\text { Test Doornika-Hansena }(1994)-\text { Statystyka testu: Chi-kwadrat }(2)=0,337874 \\
\text { Z wartością } p=0,844562\end{array}$} \\
\hline
\end{tabular}

Ź r ó d ło: opracowanie własne na podstawie danych OECD, przy użyciu programu GRETL.

Do weryfikacji istotności współczynników regresji wykorzystano test $t$-Studenta, natomiast do wykrycia autokorelacji posłużono się testem Durbina-Watsona oraz testem LM (Lagrange Multiplier - test mnożników Lagrange'a). Zmienność wariancji resztowej zbadano testem White'a. Przeprowadzone zostało również badanie stacjonarności zmiennych.

\section{Zmienność wariancji resztowej (test na homoskedastyczność) modelu 1}

W metodzie najmniejszych kwadratów zakłada się, że wariancja składnika losowego $\varepsilon_{i}$ jest stała dla wszystkich $i$, co przedstawia poniższa równośćc ${ }^{22}$ :

$$
D^{2}\left(\varepsilon_{i}\right)=\sigma^{2}, i=1,2, \ldots, n .
$$

${ }^{22}$ B. Borkowski, H. Dudek, W. Szczęsny, Ekonometria, wybrane zagadnienia, Wydawnictwo Naukowe PWN, Warszawa 2003, s. 93. 
Występowanie jednakowych wariancji składników losowych nazywa się homoskedastycznością, natomiast w przeciwnym razie mówi się o heteroskedastyczności składników losowych. Heteroskedastyczność jest zjawiskiem niepożądanym, ponieważ estymator MNK traci efektywność. W celu zbadania w modelu obecności heteroskedastyczności reszt zastosowano test White'a. Test White'a jest ogólnym testem wykrywającym obecność heteroscedastyczności (zmienność wariancji resztowej). Testujemy hipotezę ${ }^{23}$ :

Hipoteza zerowa: heteroskedastyczność reszt nie występuje:

$$
\begin{aligned}
& H_{0}: \sigma^{2}=\text { const } \\
& H_{1}: \sigma^{2} \neq \text { const }
\end{aligned}
$$

Statystyka $L M=n R^{2}$ ma asymptotyczny rozkład $\chi^{2} \mathrm{z}$ liczbą stopni swobody równą ilości zmiennych $w$ regresji bez stałej. Jeśli wartość statystyki testowej jest duża, a p-value nieznacznie różni się od zera, wobec tego odrzucamy hipotezę zerową o homoskedastyczności składnika losowego ${ }^{24}$. W modelu 1 odczytaliśmy wartość statystyki $L M=3,62771 \mathrm{z}$ prawdopodobieństwem jej otrzymania przy założeniu prawdziwości hipotezy zerowej o stałości wariancji równym $p=P($ Chi-Square $(5)>3,62771)=0,604157$, gdzie $(0,604157>0,05)$. Nie ma podstaw do odrzucenia hipotezy $H_{0}$ o stałości wariancji składników losowych (o homoskedastyczności składników losowych) na rzecz hipotezy alternatywnej $H_{1}$.

\section{Weryfikacja hipotez o normalności rozkładu reszt}

Sprawdzianem testu jest statystyka test Doornika-Hansena, który jest modyfikacją testu Jarque-Bera, gdzie $J B \sim \chi^{2}(2)$

$H_{0}$ : reszty mają rozkład normalny

$H_{1}$ : reszty nie mają rozkładu normalnego

W modelu 1 otrzymaliśmy wartość statystyki testu: Chi-kwadrat(2) = $=0,337874 \mathrm{z}$ prawdopodobieństwem jej otrzymania przy założeniu prawdziwości hipotezy zerowej o rozkładzie normalnym składnika losowego równym $p=0,844562$, gdzie $(0,844562>0,05)$. Nie ma podstaw do odrzucenia hipotezy $H_{0}$ o rozkładzie normalnym składnika losowego na rzecz hipotezy $H_{1}$. Wyniki wskazują, że nie ma podstaw do odrzucenia hipotezy zerowej o nor-

${ }^{23}$ Ibidem, 93-94.

${ }^{24}$ B. Gładys z, J. Mercik, op. cit., s. 8-17. 
malności rozkładu reszt, ponieważ wartość $p$, czyli $p$-value jest większa niż nominalny poziom istotności 0,05 .

\section{Weryfikacja hipotez o autokorelacji składnika losowego modelu 1}

$$
\begin{aligned}
& H_{0}: \rho=0 \quad \text { (brak autokorelacji składnika losowego) } \\
& H_{1}: \rho \neq 0
\end{aligned}
$$

Wartość krytyczna przy $n=43$ obserwacjach i $k=2$ liczbie zmiennych bez wyrazu wolnego wynosi $d_{L}=1,41$ oraz $d_{U}=1,60$ (wartości krytyczne odczytane $\mathrm{z}$ tablic dla testu Durbina). Zgodnie z formułą $d_{U}<d<4-d(1,60<1,71<2,29)$ można stwierdzić, że nie ma podstaw do odrzucenia hipotezy $H_{0}$, zatem w modelu nie występuje autokorelacja pierwszego rzędu ${ }^{25}$ (Statystyka Durbina-Watsona dla modelu $1, d=1,712269)$.

\section{Weryfikacja hipotez o istotności parametrów modelu 1}

$$
\begin{aligned}
& H_{0}: \alpha_{i}=0 \quad \text { (nieistotność parametrów regresji) } \\
& H_{1}: \alpha_{i} \neq 0
\end{aligned}
$$

Sprawdzianem hipotezy $H_{0}$ jest statystyka: $t\left(\alpha_{1}\right)=\frac{\alpha_{i}}{S\left(\alpha_{i}\right)}$

posiadająca rozkład $t$-Studenta o $(n-k)$ stopniach swobody.

Dla wyrazu wolnego (const) otrzymaliśmy wartość statystyki $t$-Studenta $=$ $t\left(\alpha_{0}\right)=-4,866$ oraz wartość prawdopodobieństwa jej uzyskania równą $p=1,81 \mathrm{e}-05(1,81 \mathrm{e}-05<0,05)$, co przy założeniu prawdziwości hipotezy zerowej o nieistotności parametrów regresji daje podstawy do odrzucenia hipotezy $H_{0}$ na rzecz hipotezy alternatywnej $H_{1}$. Oznacza to, iż parametr $\alpha_{0}$ różni się od zera w sposób statystycznie istotny, czyli z prawdopodobieństwem 0,95 przyjmujemy, że wyraz wolny ma istotny wpływ na zmienną objaśnianą $I T$ - nakłady inwestycyjne. Podobnie dla pozostałych zmiennych zweryfikowano istotność parametrów odrzucając hipotezę zerową $H_{0}$ rzecz hipotezy alternatywnej $H_{1}$

\footnotetext{
${ }^{25}$ Ibidem, s. 20-23.
} 
(o istotności parametrów). Dla poszczególnych zmiennych wartości statystyki $t$-Studenta wyniosły: $d \_I R, t\left(\alpha_{1}\right)=-2,268$ przy $p=0,0288(0,0288<0,05)$, dla zmiennej objaśniającej $l d \_G D P, t\left(\alpha_{2}\right)=12,80$ przy $p=1,00 \mathrm{e}-015(1,00 \mathrm{e} 015<0,05)$. Oznacza to iż parametry $\alpha_{1}, \alpha_{2}$ różnią się od zera w sposób statystycznie istotny, czyli z prawdopodobieństwem 0,95 przyjmujemy, że zmienne objaśniające $d \_I R, l d \_G D P$ istotnie wpływają na zmienną objaśnianą, czyli IT (nakłady inwestycyjne w strefie euro).

\section{Interpretacja parametrów funkcji logarytmicznej :}

- $\alpha_{1}=-0,00571850$, jeśli $\mathrm{z}$ okresu (kwartału) na okres (kwartał) stopa procentowa wzrastałaby o jedną jednostkę, czyli o 1 punkt procentowy, to nakłady inwestycyjne ceteris paribus z okresu (kwartału) na okres (kwartał) spadłyby o około $0,00571850 \%$.

- $\alpha_{2}=2,19765$, jeśli produkt krajowy brutto wzrośnie o $1 \%$, to ceteris paribus nakłady inwestycyjne w tym kwartale wzrosną o około $2,19765 \%$.

Współczynnik dopasowania modelu 1 wynosi $R^{2}=0,836994$, co oznacza, że model wyjaśnia $83,7 \%$ zmienności badanej cechy. Świadczy to o istotnym dopasowaniu modelu do danych empirycznych. Na podstawie testu $F$ Snedecora odrzucamy hipotezę $H_{0}$ o nieistotności układu współczynników regresji na rzecz hipotezy $H_{1}$. Zatem wyniki testu wskazują na zależność nakładów inwestycyjnych przynajmniej od jednego z czynników objaśniających uwzględnionych w modelu. W 83,7\% zmienność zmiennej objaśnianej IT jest objaśniona zmiennością zmiennych objaśniających $l d \_G D P, d \_I R$.

\subsubsection{Estymacja oraz weryfikacja statystyczna (model 2 dla strefy euro)}

\section{Postać modelu 2 przed oszacowaniem MNK:}

$$
\Delta \ln I T_{t}=\alpha_{0}+\alpha_{1} \Delta I R_{t}+\alpha_{2} \Delta \ln G D P_{t}+\alpha_{3} \Delta \ln I T_{t-2}+\varepsilon_{t}
$$

gdzie:

$\Delta \ln I T_{t}$ - nakłady inwestycyjne (w cenach z 2005q1), przyrosty logarytmów,

$\Delta I R_{t} \quad-$ realna stopa referencyjna EBC (przyrosty),

$\Delta \ln G D P_{t}$ - wartość produktu krajowego brutto (w cenach z 2005q1), przyrosty logarytmów,

$\Delta \ln I T_{t-2}$ - nakłady inwestycyjne opóźnione o dwa kwartały (w cenach z 2005q1), przyrosty logarytmów. 
wskazują, że nie ma podstaw do odrzucenia hipotezy zerowej o normalności rozkładu reszt, ponieważ wartość $p$, czyli $p$-value jest większa niż nominalny poziom istotności 0,05 .

\section{Weryfikacja hipotez o autokorelacji składnika losowego modelu 2}

W celu wykrycia autokorelacji wyższych rzędów zachodzących między zaburzeniami losowymi zastosowano test Breuscha-Godfrey'a zwany również testem $L M$. Zatem hipoteza $H_{0}: \rho_{1}=\rho_{2}=\ldots \rho_{p}=0$ o braku autokorelacji weryfikowana jest za pomocą statystyki $(T-p) R^{2}$. Jeśli $(T-p) R^{2}>\chi_{p}^{2}$ wtedy odrzucamy hipotezę $H_{0}$ na rzecz hipotezy alternatywnej o wystepowaniu autokorelacji danego rzędu ${ }^{26}$. W modelu $2 \mathrm{w}$ roli zmiennej objaśniającej wykorzystana została opóźniona zmienna objaśniana, $l d \_I T \_2$ (nakłady inwestycyjne opóźnione o 2 kwartały). Stąd do weryfikacji hipotezy o autokorelacji składnika losowego obliczona została statystyka testu $L M$, która wyniosła $T R^{\wedge} 2=$ 1,003345 natomiast wartość krytyczna $\chi^{2}=5,99$ przy poziomie istotności 0,05 i opóźnieniu drugiego rzędu. W związku z tym, że statystyka testu $L M$ jest niższa od $\chi^{2}$, to nie ma podstaw do odrzucenia hipotezy zerowej, zatem możemy uznać, iż w modelu nie występuje autokorelacja składników losowych drugiego rzędu.

\section{Weryfikacja hipotez o istotności parametrów modelu 2}

Dla wyrazu wolnego (const) otrzymaliśmy wartość statystyki $t$-Studenta $=$ $t\left(\alpha_{0}\right)=-4,990$ oraz wartość prawdopodobieństwa jej uzyskania równą $\mathrm{p}=1,29 \mathrm{e}-05(1,29 \mathrm{e}-05<0,05)$, co przy założeniu prawdziwości hipotezy zerowej o nieistotności parametrów regresji daje podstawy do odrzucenia hipotezy $H_{0}$ na rzecz hipotezy alternatywnej $H_{1}$. Oznacza to, iż parametr $\alpha_{0}$ różni się od zera w sposób statystycznie istotny, czyli z prawdopodobieństwem 0,95 przyjmujemy, że wyraz wolny ma istotny wpływ na zmienną objaśnianą $I T$ - nakłady inwestycyjne. Również dla pozostałych zmiennych zweryfikowano istotność parametrów odrzucając hipotezę zerową $H_{0}$ na rzecz hipotezy alternatywnej $H_{1}$ (o istotności parametrów). Dla poszczególnych zmiennych wartości statystyki $t$-Studenta wyniosły: $d \_I R, t\left(\alpha_{1}\right)=-1,947$ przy $p=0,0588(0,0588<0,10)$, dla zmiennej objaśniającej $l d \_G D P, t\left(\alpha_{2}\right)=11,16$ przy $p=1,05 \mathrm{e}-013(1,05 \mathrm{e}-013<0,05)$ oraz zmiennej objaśnianej opóźnionej o 2 kwartały, jako zmiennej objaśniającej, ld_IT_2, $t\left(\alpha_{2}\right)=2,336$ przy $p=0,0247 \quad(0,0247<0,05)$. Oznacza to iż parametr $\alpha_{1}$ różni się od zera w sposób statystycznie istotny, czyli z prawdopodobień-

\footnotetext{
${ }^{26}$ B. R. Górecki, op. cit. [11.11.2010].
} 
stwem 0,90 przyjmujemy, że zmienna objaśniająca $d \_I R$ istotnie oddziałuje na zmienną objaśnianą, czyli IT (nakłady inwestycyjne w strefie euro). Z kolei parametry $\alpha_{2}, \alpha_{3}$ również różnią się od zera w sposób statystycznie istotny, czyli z prawdopodobieństwem 0,95 przyjmujemy, że zmienne objaśniające ld_GDP, ld_IT_2, mają istotny wpływ na zmienną objaśnianą, czyli IT (nakłady inwestycyjne w strefie euro).

\section{Interpretacja parametrów funkcji logarytmicznej:}

- $\alpha_{1}=-0,00472766$, jeśli z okresu (kwartału) na okres (kwartał) stopa procentowa wzrosłaby o jedną jednostkę, czyli o 1 punkt procentowy, to nakłady inwestycyjne ceteris paribus $\mathrm{z}$ okresu (kwartału) na okres (kwartał) spadłyby o $0,00472766 \%$.

$-\alpha_{2}=2,01526$, jeśli produkt krajowy brutto w danym kwartale wzrośnie o $1 \%$ ceteris paribus to nakłady inwestycyjne w tym kwartale wzrosną o $2,01526 \%$

- $\alpha_{3}=0,157778$, jeśli opóźnione nakłady inwestycyjne sprzed dwóch kwartałów wzrosłyby o $1 \%$ to ceteris paribus bieżące nakłady inwestycyjne wzrosłyby o $0,157778 \%$

Współczynnik dopasowania modelu 2 wynosi $R^{2}=0,857007$, co oznacza, że model wyjaśnia $85,7 \%$ zmienności badanej cechy. Świadczy to o istotnym dopasowaniu modelu do danych empirycznych. Na podstawie testu $F$ Snedecora odrzucamy hipotezę $H_{0}$ o nieistotności układu współczynników regresji na rzecz hipotezy $H_{1}$. Ponadto hipoteza $H_{0}$ została odrzucona (w przypadku wszystkich współczynników) na rzecz hipotezy alternatywnej na podstawie testu $t$-Studenta o istotności parametrów. W 85,7\% zmienność zmiennej objaśnianej inw jest objaśniona zmiennością zmiennych objaśniających $l d \_G D P, d \_I R$ oraz $l d \_I T \_2$.

\subsubsection{Analiza stacjonarności}

Pojęcie stacjonarności zmiennej jest jednym z podstawowych pojęć w analizie szeregów czasowych. Ściślej ujmując zmienna stacjonarna to taka, której własności pozostają niezmienione wraz z upływem czasu. Przy testowaniu hipotez wyprowadza się rozkłady typowych statystyk testowych i wtedy założenie o stacjonarności zmiennych w modelu jest niezbędne, ponieważ występowanie w modelu zmiennych niestacjonarnych prowadzi zazwyczaj do błędnych wyników wnioskowania statystycznego ze względu na niestandardowe rozkłady asymptotyczne statystyk testowych. Dlatego badanie stacjonarności zmiennych modelu jest w pewnym sensie testem diagnostycznym, który pozwala na weryfi- 
kację prawdziwości założeń niezbędnych do tego, by standardowe procedury testowania hipotez były prawidłowe ${ }^{27}$.

Badanie stacjonarności zmiennych losowych przeprowadzone zostało przy użyciu rozszerzonego testu Dickey-Fullera. Hipoteza zerowa tego testu zakłada, że badany szereg jest niestacjonarny ze względu na występowanie pierwiastka jednostkowego, natomiast hipoteza alternatywna mówi o stacjonarności szeregu ${ }^{28}$.

$$
\Delta y_{t}=\delta y_{t-1}+\sum_{j=1}^{K} \alpha \Delta y_{t-j}+\varepsilon_{t}
$$

gdzie:

$y_{t}$ - to szereg obserwacji danej zmiennej,

$K$ - liczba opóźnionych wartości przyrostów zmiennej (dobrana tak by wyeliminować autokorelację składnika losowego),

$\delta, \alpha-$ parametry równania,

$\varepsilon_{t}-$ składnik losowy.

Test ADF (Augumented Dickey Fuller) - rozszerzony test pierwiastka jednostkowego na występowanie stacjonarności polega na weryfikacji hipotez:

$H_{0}: \delta=0$ - występowanie pierwiastka jednostkowego (zmienne niestacjonarne)

$H_{1}: \delta<0$ - brak występowania pierwiastka jednostkowego (zmienne stacjonarne)

Jeśli $p<0,05$, to odrzucamy hipotezę $H_{0}$ na rzecz hipotezy alternatywnej przy poziomie istotności $\alpha=0,05$. W przypadku zmiennych dla strefy euro testowanie na poziomach wykazało, że są one niestacjonarne, dlatego przeprowadzono test ADF tych zmiennych na pierwszych przyrostach i wtedy wyniki dla wszystkich zmiennych pozwoliły na odrzucenie hipotezy $H_{0}$ na rzecz hipotezy alternatywnej $H_{1}$ o występowaniu stacjonarności. To oznacza, że pierwsze przyrosty logarytmiczne zmiennych $\mathrm{w}$ tym przypadku są stacjonarne.

Podsumowując, wykorzystane dwa modele ${ }^{29}$ dla strefy euro okazały się istotne statystycznie oraz poprawne ekonomicznie.

${ }^{27}$ P. B a ran ow ski, Problem..., op. cit., s. 79-81.

${ }^{28}$ M. B or z y s zkow sk a, Analiza empiryczna wybranych zmiennych wchodzacych $w$ sktad funkcji popytu na pieniadz, X Ogólnopolskie Seminarium Naukowe, 4-6 września 2007 r. w Toruniu, Uniwersytet Mikołaja Kopernika, Toruń 2007, s. 300.

${ }^{29}$ Wykorzystano również w modelu jako zmienną objaśnianą realną stopę rynku międzybankowego EURIBOR 3M w celu sprawdzenia, w jakim stopniu odzwierciedla zależność inwestycji 


\subsection{Weryfikacja empiryczna wpływu stopy referencyjnej NBP na inwestycje w Polsce - modelowanie ekonometryczne}

W celu sprawdzenia prawdziwości założenia, że stopa referencyjna banku centralnego wpływa odwrotnie proporcjonalnie na poziom inwestycji przedsiębiorstw, zarówno w Polsce jak i strefie euro, oszacowane zostały trzy warianty modeli dla Polski. W równaniach tych jako zmienną objaśnianą zastosowano przyrosty logarytmów nakładów na środki trwałe brutto reprezentujące inwestycje w Polsce. Wśród zmiennych objaśnianych w modelu pierwszym użyto przyrostów realnej stopy referencyjnej NBP, przyrostów logarytmów produktu krajowego brutto, przyrostów logarytmów deflatora nakładów na środki trwałe brutto jako cenę inwestycji oraz przyrostów logarytmów opóźnionych nakładów inwestycyjnych o jeden oraz dwa kwartały.

\subsubsection{Estymacja oraz weryfikacja statystyczna (model 1 dla Polski)}

\section{Postać modelu 1 przed oszacowaniem MNK:}

$$
\begin{aligned}
& \Delta \ln I T_{t}=\alpha_{0}+\alpha_{1} \Delta I R_{t}+\alpha_{2} \Delta \ln G D P_{t}+\alpha_{3} \Delta \ln P I T+ \\
& +\alpha_{4} \Delta \ln I T_{t-1}+\alpha_{5} \Delta \ln I T_{t-2}+\varepsilon_{t}
\end{aligned}
$$

gdzie:

$\Delta \ln I T_{t} \quad$ - nakłady inwestycyjne (w cenach z 2005q1), przyrosty logarytmów,

$\Delta I R_{t} \quad$ - realna stopa referencyjna EBC (przyrosty),

$\Delta \ln G D P_{t}$ - wartość produktu krajowego brutto (w cenach z 2005q1), przyrosty logarytmów,

$\Delta \ln P I T \quad$ - deflator nakładów na środki trwałe brutto, ceny rynkowe (wykorzystany jako cena inwestycji), przyrosty logarytmów,

$\Delta \ln I T_{t-1}$ - nakłady inwestycyjne opóźnione o jeden kwartał (w cenach z 2005q1), przyrosty logarytmów,

$\Delta \ln I T_{t-2}$ - nakłady inwestycyjne opóźnione o dwa kwartały (w cenach z 2005q1), przyrosty logarytmów.

od nominalnej stopy rynku międzybankowego, jednak współczynnik określający tę zmienną EUR3M $(-0,0065)$ był nieznacznie większy od współczynnika określającego stopę referencyjną EBC, IR $(-0,0057)$ w modelu 1 . Z kolei wskaźnik dla realnego EUR3M wyniósł $(-0,00475)$ w modelu 2 przy $I R(-0,00472)$. W związku z tym, że celem pracy było zbadanie wpływu stopy referencyjnej a nie stopy rynku międzybankowego nie opisywano dokładniej pozostałych wyników tego modelu. 


\section{Postać modelu 1 po oszacowaniu MNK w programie GRETL:}

$$
\begin{aligned}
& \Delta \ln I T_{t}=-0,0074-0,0051 \Delta I R_{t}+1,4368 \Delta \ln G D P_{t}-0,8844 \Delta \ln P I T+ \\
& +0,3634 \Delta \ln I T_{t-1}+0,3747 \Delta \ln I T_{t-2}+\varepsilon_{t}
\end{aligned}
$$

Estymacja KMNK wykorzystane obserwacje 1998:2-2009:4 $(N=47)$

\begin{tabular}{|c|c|c|c|c|}
\hline Nazwa zmiennej & Współczynnik & Błąd standardowy & $t$-Studenta & Wartość $p$ \\
\hline const & $-0,00736122$ & 0,00332811 & $-2,212$ & 0,0326 \\
\hline$d \_I R$ & $-0,00512564$ & 0,00124580 & $-4,114$ & 0,0002 \\
\hline$l d \_G D P$ & 1,43677 & 0,296542 & 4,845 & $1,84 \mathrm{e}-05$ \\
\hline$l d \_P I T$ & $-0,884431$ & 0,235105 & $-3,762$ & 0,0005 \\
\hline ld_IT_1 & 0,363408 & 0,110663 & 3,284 & 0,0021 \\
\hline ld_IT_2 & 0,374719 & 0,0943090 & 3,973 & 0,0003 \\
\hline \multicolumn{5}{|c|}{$\begin{array}{l}\text { Wsp. determ. } R \text {-kwadrat } 0,818258 \text { Skorygowany } R \text {-kwadrat } 0,796094 \\
F(5,41) 36,91885 \text { Wartość p dla testu } F=78 \mathrm{e}-14 \text { Autokorel.reszt - rhol } 0,065562 \\
\text { Stat. Durbina } h 0,672905 \\
\text { Średn. aryt. zm. zależnej } 0,009272 \text { Odch. stand. zm. zależnej } 0,022540 \\
\text { Suma kwadratów reszt } 0,004247 \text { Błąd standardowy reszt } 0,010178\end{array}$} \\
\hline \multicolumn{4}{|c|}{$\begin{array}{l}\text { Test White'a : statystyka testu: } L M=26,0688 \\
\mathrm{z} \text { wartością } p=P(\text { Chi-Square }(20)>26,0688)=0,163551\end{array}$} & \\
\hline
\end{tabular}
Zmienna zależna: $l d \_I T$ (modelu 1 dla Polski)

Źr ód ło: jak do tab. 6.1 .

\section{Zmienność wariancji resztowej (test na homoskedastyczność) modelu 1 dla Polski}

W modelu 1 otrzymaliśmy wartość statystyki $L M=26,0688$ z prawdopodobieństwem jej otrzymania przy założeniu prawdziwości hipotezy zerowej o stałości wariancji równym $p=P($ Chi-Square $(20)>26,0688)=0,163551$, gdzie $(0,163551>0,05)$. Nie ma podstaw do odrzucenia hipotezy $H_{0}$ o stałości wariancji składników losowych (o homoskedastyczności składników losowych) na rzecz hipotezy alternatywnej $H_{1}$.

\section{Weryfikacja hipotez o normalności rozkładu reszt}

$\mathrm{W}$ modelu 1 otrzymaliśmy wartość statystyki testu: $C h i$-kwadrat $(2)=$ 3,82074 z prawdopodobieństwem jej otrzymania przy założeniu prawdziwości 
hipotezy zerowej o rozkładzie normalnym składnika losowego równym $p=0,148025$, gdzie $(0,148025>0,05)$. Nie ma podstaw do odrzucenia hipotezy $H_{0}$ o rozkładzie normalnym składnika losowego na rzecz hipotezy $H_{1}$. Wyniki wskazują, że nie ma podstaw do odrzucenia hipotezy zerowej o normalności rozkładu reszt, ponieważ wartość $p$ czyli $p$-value jest większa niż nominalny poziom istotności 0,05 .

\section{Weryfikacja hipotez o autokorelacji składnika losowego modelu 1}

$$
\begin{aligned}
& H_{0}: \rho=0 \quad \text { (brak autokorelacji składnika losowego) } \\
& H_{1}: \rho \neq 0
\end{aligned}
$$

W przypadku, kiedy w roli zmiennej objaśniającej występuje opóźniona zmienna objaśniana, to statystyka $d$ (statystyka Durbina-Watsona), będzie obciążona. Aby tego uniknąć, stosuje się statystykę w postaci ${ }^{30}$ :

$$
h=\left(1-\frac{d}{2}\right) \sqrt{\frac{n}{1-n \hat{\sigma}_{y}^{2}}}
$$

gdzie:

$d \quad$ - statystyka Durbina-Watsona, która jest określona wzorem ${ }^{31}$ :

$$
d=\frac{\sum_{t=2}^{n}\left(e_{t}-e_{t-1}\right)}{\sum_{t=1}^{n} e_{t}^{2}},
$$

$\hat{\sigma}_{y}^{2}$ - estymator wariancji estymatora parametru, związanego z opóźnioną zmienną objaśnianą,

$t-$ czas.

Statystka $h$ ma rozkład asymptotycznie normalny o wartości oczekiwanej równej zeru i jednostkowej wariancji. Wartość krytyczna dla poziomu istotności $\alpha=0,05$ wynosi $u_{\alpha}=1,96$. Ponieważ $H_{o b l}=|0,672905|<u_{\alpha}$, jest niższe od wartości krytycznej rozkładu normalnego równej 1,96, to nie mamy podstaw do odrzucenia hipotezy zerowej, zatem możemy uznać, iż w modelu nie występuje autokorelacja składników losowych.

\footnotetext{
${ }^{30}$ B. Gład y s z, J. Mercik, op. cit., s. 23.

${ }^{31}$ B. B orkows ki, H. Dudek, W. S zczęs ny, op. cit., s. 87.
} 


\section{Weryfikacja hipotez o istotności parametrów modelu 1}

Dla wyrazu wolnego (const) otrzymaliśmy wartość statystyki $t$-Studenta $=$ $t\left(\alpha_{0}\right)=-2,212$ oraz wartość prawdopodobieństwa jej uzyskania równą $p=0,0326(0,0326<0,05)$, co przy założeniu prawdziwości hipotezy zerowej o nieistotności parametrów regresji, daje podstawy do odrzucenia hipotezy $H_{0}$ na rzecz hipotezy alternatywnej $H_{1}$. Oznacza to, iż parametr $\alpha_{0}$ różni się od zera w sposób statystycznie istotny, czyli z prawdopodobieństwem 0,95 przyjmujemy, że wyraz wolny ma istotny wpływ na zmienna objaśnianą $I T$ - nakłady inwestycyjne. Podobnie dla pozostałych zmiennych zweryfikowano istotność parametrów odrzucając hipotezę zerową $H_{0}$ rzecz hipotezy alternatywnej $H_{1}$ (o istotności parametrów). Dla poszczególnych zmiennych wartości statystyki $t$-Studenta wyniosły: $d \_I R, t\left(\alpha_{1}\right)=-4,114$ przy $p=0,0002(0,0002<0,05)$, dla zmiennej objaśniającej $l d \_G D P, t\left(\alpha_{2}\right)=4,845$ przy $p=1,84 \mathrm{e}-05(1,84 \mathrm{e}-05<0,05)$, dla zmiennej objaśniającej $l d \_P I T, t\left(\alpha_{3}\right)=-3,762$ przy $p=0,0005(0,0005<0,05)$, dla zmiennej objaśniającej ld_IT_1, $t\left(\alpha_{4}\right)=3,284$ przy $p=0,0021(0,0021<0,05)$, dla zmiennej objaśniającej $l d \_I T \_2, t\left(\alpha_{5}\right)=3,973$ przy $p=0,0003(0,0003<0,05)$. Oznacza to, iż parametry $\alpha_{1}, \alpha_{2}, \alpha_{3}, \alpha_{4}, \alpha_{5}$ różnią się od zera w sposób statystycznie istotny, czyli z prawdopodobieństwem 0,95 przyjmujemy, że zmienne objaśniające $d \_I R, l d \_G D P, l d \_P I T, l d \_I T \_1, l d \_I T \_2$ istotnie wpływają na zmienną objaśnianą, czyli IT (nakłady inwestycyjne w Polsce).

\section{Interpretacja parametrów funkcji logarytmicznej}

$-a_{1}=-0,00500842$, jeśli z okresu (kwartału) na okres (kwartał) stopa procentowa wzrastałaby o jednostkę, czyli o 1 punkt procentowy, to tempo wzrostu nakładów inwestycyjnych ceteris paribus z okresu (kwartału) na okres (kwartał) spadłoby o $0,00500842 \%$,

$-a_{2}=1,45747$, jeśli w danym kwartale produkt krajowy brutto wzrośnie o $1 \%$, to ceteris paribus nakłady inwestycyjne w tym kwartale wzrosną o $1,45747 \%$,

$-a_{3}=-0,884431$, jeśli w danym kwartale ceny nakładów inwestycyjnych (deflator inwestycji) wzrosną o $1 \%$, to ceteris paribus nakłady inwestycyjne w tym kwartale spadłyby o $-0,884431 \%$,

$-a_{4}=0,363247$, jeśli nakłady inwestycyjne sprzed jednego kwartału (opóźnione o 1 okres) wzrosłyby o $1 \%$, to ceteris paribus bieżące nakłady inwestycyjne wzrosłyby o $0,363247 \%$,

$-a_{5}=0,371774$, jeśli nakłady inwestycyjne sprzed dwóch kwartałów (opóźnione o 2 okresy) wzrosłyby o $1 \%$, to ceteris paribus bieżące nakłady inwestycyjne wzrosłyby o $0,371774 \%$. 
Współczynnik dopasowania modelu 1 wynosi $R^{2}=0,818258$, co oznacza, że model wyjaśnia $81,8 \%$ zmienności badanej cechy. Świadczy to o istotnym dopasowaniu modelu do danych empirycznych. Na podstawie testu $F$ Snedecora odrzucamy hipotezę $H_{0}$ o nieistotności układu współczynników regresji na rzecz hipotezy $H_{1}$. Ponadto hipoteza $H_{0}$, została odrzucona (w przypadku wszystkich współczynników) na rzecz hipotezy alternatywnej na podstawie testu $t$-Studenta o istotności parametrów. W 88,1\% zmienność zmiennej objaśnianej ld_IT jest objaśniona zmiennością zmiennych objaśniających $l d \_I R, d \_G D P, l d \_P I T$ oraz ld_IT_1, ld_IT_2.

\subsubsection{Estymacja oraz weryfikacja statystyczna (model 2 dla Polski)}

\section{Postać modelu 2 przed oszacowaniem MNK:}

$\Delta \ln I T_{t}=\alpha_{0}+\alpha_{1} \Delta I R_{t}+\alpha_{2} \Delta \ln G D P_{t}+\alpha_{3} \Delta \ln P I T+\alpha_{4} \Delta \ln I T_{t-2}+\varepsilon_{t}$

gdzie:

$\Delta \ln I T_{t}$ - nakłady inwestycyjne (w cenach z 2005q1), przyrosty logarytmów,

$\Delta I R_{t} \quad-$ realna stopa referencyjna EBC (przyrosty),

$\Delta \ln G D P_{t}$ - wartość produktu krajowego brutto (w cenach z 2005q1), przyrosty logarytmów,

$\Delta \ln P I T$ - deflator nakładów na środki trwałe brutto, ceny rynkowe (wykorzystany jako cena inwestycji), przyrosty logarytmów,

$\Delta \ln I T_{t-2}$ - nakłady inwestycyjne opóźnione o dwa kwartały (w cenach z 2005q1), przyrosty logarytmów.

\section{Postać modelu 2 po oszacowaniu MNK w programie GRETL:}

$\Delta \ln I T_{t}=-0,0112-0,0050 \Delta I R_{t}+2,1979 \Delta \ln G D P_{t}-0,8625 \Delta \ln P I T+$ $+0,4558 \Delta \ln I T_{t-2}+\varepsilon_{t}$

\section{Zmienność wariancji resztowej (test na homoskedastyczność) modelu 2}

W modelu 2 otrzymaliśmy wartość statystyki $L M=23,0107$ z prawdopodobieństwem jej otrzymania przy założeniu prawdziwości hipotezy zerowej o stałości wariancji równym $p=P($ Chi-Square $(14)>23,0107)=0,0600957$, gdzie $(0,0600957>0,05)$. Nie ma podstaw do odrzucenia hipotezy $H_{0}$ o stałości wariancji składników losowych (o homoskedastyczności składników losowych) na rzecz hipotezy alternatywnej $H_{1}$. 
Estymacja KMNK, wykorzystane obserwacje 1998:2-2009:4 $(N=47)$

Zmienna zależna: $l d \_I T$ (model 2 dla Polski)

\begin{tabular}{|c|c|c|c|c|}
\hline Nazwa zmiennej & Współczynnik & Błąd standardowy & $t$-Studenta & Wartość $p$ \\
\hline const & $-0,0112134$ & 0,00345832 & $-3,242$ & 0,0023 \\
\hline$d \_I R$ & $-0,00530592$ & 0,00138198 & $-3,839$ & 0,0004 \\
\hline ld_GDP & 1,82665 & 0,301734 & 6,054 & $3,32 \mathrm{e}-07$ \\
\hline ld_PIT & $-0,620513$ & 0,243535 & $-2,548$ & 0,0146 \\
\hline$l d \_I T \_2$ & 0,568330 & 0,0817338 & 6,953 & $1,69 \mathrm{e}-08$ \\
\hline \multicolumn{5}{|c|}{$\begin{array}{l}\text { Wsp. determ. } R \text {-kwadrat } 0,770455 \text { Skorygowany } R \text {-kwadrat } 0,748593 \\
F(4,42) 35,24259 \text { Wartośc } p \text { dla testu } F=6,51 \mathrm{e}-13 \text { Autokorel. reszt }- \text { rhol } 0,141171 \\
\text { Stat. Durbina-Watsona } 1,703038 \\
\text { Statystyka testu: } T R^{\wedge} 2=2,907754 \text { z wartością } p=P(C h i \text {-kwadrat }(2)>2,90775)=0,234\end{array}$} \\
\hline \multicolumn{5}{|c|}{$\begin{array}{l}\text { Średn. aryt. zm. zależnej } 0,009272 \text { Odch. stand .zm. zależnej } 0,022540 \\
\text { Suma kwadratów reszt 0,005365 Błąd standardowy reszt } 0,011302\end{array}$} \\
\hline \multicolumn{5}{|c|}{$\begin{array}{l}\text { Test White'a : statystyka testu: } L M=23,0107 \\
\text { z wartością } p=P(\text { Chi-Square }(14)>23,0107)=0,0600957\end{array}$} \\
\hline
\end{tabular}

Źr ó d ło: jak do tab. 6.1.

\section{Weryfikacja hipotez o normalności rozkładu reszt modelu 2}

$\mathrm{W}$ modelu 2 otrzymaliśmy wartość statystyki testu: Chi-kwadrat(2) = 3,36664 z prawdopodobieństwem jej otrzymania przy założeniu prawdziwości hipotezy zerowej o rozkładzie normalnym składnika losowego równym $p=0,185756$, gdzie $(0,185756>0,05)$. Nie ma podstaw do odrzucenia hipotezy $H_{0}$ o rozkładzie normalnym składnika losowego na rzecz hipotezy $H_{1}$. Wyniki wskazują, że nie ma podstaw do odrzucenia hipotezy zerowej o normalności rozkładu reszt, ponieważ wartość $p$, czyli $p$-value jest większa niż nominalny poziom istotności 0,05 .

\section{Weryfikacja hipotez o autokorelacji składnika losowego modelu 2}

W modelu 2 dla Polski statystyka testu $L M$ wynosi $T R^{\wedge} 2=2,907754$ oraz wartość krytyczna $\chi^{2}=5,99$ przy poziomie istotności 0,05 i opóźnieniu drugiego rzędu. W związku z tym, że statystyka testu $L M$ jest niższa od $\chi^{2}$ to nie ma podstaw do odrzucenia hipotezy zerowej, zatem możemy uznać, iż w modelu nie występuje autokorelacja składników losowych drugiego rzędu. 


\section{Weryfikacja hipotez o istotności parametrów modelu 2}

Dla wyrazu wolnego (const) otrzymaliśmy wartość statystyki $t$-Studenta $=$ $t\left(\alpha_{0}\right)=-3,242$ oraz wartość prawdopodobieństwa jej uzyskania równą $p=0,0023(0,0023<0,05)$, co przy założeniu prawdziwości hipotezy zerowej o nieistotności parametrów regresji, daje podstawy do odrzucenia hipotezy $H_{0}$ na rzecz hipotezy alternatywnej $H_{1}$. Oznacza to, iż parametr $\alpha_{0}$ różni się od zera w sposób statystycznie istotny, czyli z prawdopodobieństwem 0,95 przyjmujemy, że wyraz wolny ma istotny wpływ na zmienną objaśnianą $I T$ - nakłady inwestycyjne. Podobnie dla pozostałych zmiennych zweryfikowano istotność parametrów odrzucając hipotezę zerową $H_{0}$ rzecz hipotezy alternatywnej $H_{1}$ (o istotności parametrów). Dla poszczególnych zmiennych wartości statystyki $t$-Studenta wyniosły: $d \_I R, t\left(\alpha_{1}\right)=-3,839$ przy $p=0,0004(0,0004<0,05)$, dla zmiennej objaśniającej ld_GDP, $t\left(\alpha_{2}\right)=6,054$ przy $p=3,32 \mathrm{e}-07(3,32 \mathrm{e}-07<0,05)$, dla zmiennej objaśniającej $l d \_P I T, t\left(\alpha_{3}\right)=-2,548$ przy $p=0,0146(0,0146<0,05)$, dla zmiennej objaśniającej $l d \_I T \_2, t\left(\alpha_{4}\right)=6,953$ przy $p=1,69 \mathrm{e}-08(1,69 \mathrm{e}-08<0,05)$. Oznacza to, iż parametry $\alpha_{1}, \alpha_{2}, \alpha_{3}, \alpha_{4}$ różnią się od zera w sposób statystycznie istotny, czyli z prawdopodobieństwem 0,95 przyjmujemy, że zmienne objaśniające $d \_I R, l d \_G D P, l d \_P I T, l d \_I T \_2$ istotnie wpływają na zmienną objaśnianą, czyli IT (nakłady inwestycyjne w Polsce).

\section{Interpretacja parametrów funkcji logarytmicznej}

$-a_{1}=-0,00530592$, jeśli z okresu (kwartału) na okres (kwartał) stopa procentowa wzrastałaby o jednostkę, czyli o 1 punkt procentowy, to nakłady inwestycyjne ceteris paribus z okresu (kwartału) na okres (kwartał) spadłyby o $0,00530592 \%$,

$-a_{2}=1,82665$, jeśli $\mathrm{w}$ danym kwartale produkt krajowy brutto wzrośnie o $1 \%$, to ceteris paribus nakłady inwestycyjne w tym kwartale wzrosną o $1,82665 \%$,

$-a_{3}=-0,620513$, jeśli $\mathrm{w}$ danym kwartale ceny nakładów inwestycyjnych (deflator inwestycji) wzrosną o $1 \%$, to ceteris paribus nakłady inwestycyjne w tym kwartale spadłyby o $0,620513 \%$,

$-a_{4}=0,568330$, jeśli nakłady inwestycyjne sprzed trzech kwartałów (opóźnione o 3 okresy) wzrosłyby o $1 \%$, to ceteris paribus bieżące nakłady inwestycyjne wzrosłyby o $0,568330 \%$.

Współczynnik dopasowania modelu 2 wynosi $R^{2}=0,770455$, co oznacza, że model wyjaśnia $77,0 \%$ zmienności badanej cechy. Świadczy to o istotnym dopasowaniu modelu do danych empirycznych. Na podstawie testu $F$ Snedecora 
odrzucamy hipotezę $H_{0}$ o nieistotności układu współczynników regresji na rzecz hipotezy $H_{1}$. Ponadto hipoteza $H_{0}$, została odrzucona (w przypadku wszystkich współczynników) na rzecz hipotezy alternatywnej na podstawie testu $t$-Studenta o istotności parametrów. W 77,0\% zmienność zmiennej objaśnianej $l d \_I T$ jest objaśniona zmiennością zmiennych objaśniających $l d \_I R$, d_GDP, ld_PIT oraz ld_IT_2.

\subsubsection{Estymacja oraz weryfikacja statystyczna (model 3)}

\section{Postać modelu 3 przed oszacowaniem MNK:}

$$
\Delta \ln I T_{t}=\alpha_{0}+\alpha_{1} \Delta I R_{t}+\alpha_{2} \Delta \ln G D P_{t}+\alpha_{3} \Delta \ln I T_{t-2}+\varepsilon_{t}
$$

gdzie:

$\Delta \ln I T_{t} \quad$ - nakłady inwestycyjne (w cenach z 2005q1), przyrosty logarytmów,

$\Delta I R_{t} \quad$ - realna stopa referencyjna EBC (przyrosty),

$\Delta \ln G D P_{t}$ - wartość produktu krajowego brutto (w cenach z 2005q1), przyrosty logarytmów,

$\Delta \ln P I T$ - deflator nakładów na środki trwałe brutto, ceny rynkowe (wykorzystany jako cena inwestycji), przyrosty logarytmów,

$\Delta \ln I T_{t-2}$ - nakłady inwestycyjne opóźnione o dwa kwartały (w cenach z 2005q1), przyrosty logarytmów.

\section{Postać modelu 3 po oszacowaniu MNK w programie GRETL:}

$\Delta \ln I T_{t}=-0,0146-0,0055 \Delta I R_{t}+1,8111 \Delta \ln G D P_{t}+0,5291 \Delta \ln I T_{t-2}+\varepsilon_{t}$

\section{Zmienność wariancji resztowej (test na homoskedastyczność) modelu 3}

W modelu 3 otrzymaliśmy wartość statystyki $L M=11,6499$ z prawdopodobieństwem jej otrzymania przy założeniu prawdziwości hipotezy zerowej o stałości wariancji równym $p=P($ Chi-Square $(9)>11,6499)=0,233775$, gdzie $(0,233775>0,05)$. Nie ma podstaw do odrzucenia hipotezy $H_{0}$ o stałości wariancji składników losowych (o homoskedastyczności składników losowych) na rzecz hipotezy alternatywnej $H_{1}$. 
Estymacja KMNK, wykorzystane obserwacje 1998:2-2009:4 $(N=47)$

Zmienna zależna: $l d \_I T$ (model 3 dla Polski)

\begin{tabular}{|c|c|c|c|c|}
\hline Nazwa zmiennej & Współczynnik & Błąd standardowy & $t$-Studenta & Wartość $p$ \\
\hline const & $-0,0146372$ & 0,00338397 & $-4,325$ & $8,89 \mathrm{e}-05$ \\
\hline$d \_I R$ & $-0,00552039$ & 0,00146486 & $-3,769$ & 0,0005 \\
\hline$l d \_G D P$ & 1,81114 & 0,320359 & 5,653 & $1,16 \mathrm{e}-06$ \\
\hline ld_IT_2 & 0,529162 & 0,0852476 & 6,207 & $1,83 \mathrm{e}-07$ \\
\hline \multicolumn{5}{|c|}{$\begin{array}{l}\text { Wsp. determ. } R \text {-kwadrat } 0,734973 \text { Skorygowany } R \text {-kwadrat } 0,716483 \\
F(3,43) 39,74926 \text { Wartość } p \text { dla testu } F 1,83 \mathrm{e}-12 \text { Autokorel. reszt }- \text { rhol } 0,065607 \\
\text { Statystyka Durbina-Watsona } 1,860620 \\
\text { Statystyka testu: } T R^{\wedge} 2=1,987266 \text { z wartością } p=P(\text { Chi-kwadrat }(2)>1,98727)=0,37\end{array}$} \\
\hline \multicolumn{5}{|c|}{ Średn. aryt. zm. zależnej 0,009272 Odch. stand. zm. zależnej 0,022540 } \\
\hline $\begin{array}{l}\text { Test White'a : stat } \\
\text { z wartością } p=P( \\
\text { Test Doornika-Har } \\
\text { z wartością } p=0,1\end{array}$ & $\begin{array}{l}\text { yka testu: } L M= \\
\text { i-Square }(9)>11 \\
\text { na }(1994)-\text { Stat } \\
649\end{array}$ & $\begin{array}{l}\text { 99) }=0,233775 \\
\text { ka testu: } \text { Chi-kwad }\end{array}$ & $=3,44466$ & \\
\hline
\end{tabular}

Źr ó d ło: jak do tab. 6.1.

\section{Weryfikacja hipotez o normalności rozkładu reszt modelu 3}

$\mathrm{W}$ modelu 3 otrzymaliśmy wartość statystyki testu: Chi-kwadrat(2) = 3,44466 z prawdopodobieństwem jej otrzymania przy założeniu prawdziwości hipotezy zerowej o rozkładzie normalnym składnika losowego równym $p=0,178649$, gdzie $(0,178649>0,05)$. Nie ma podstaw do odrzucenia hipotezy $H_{0}$ o rozkładzie normalnym składnika losowego na rzecz hipotezy $H_{1}$. Wyniki wskazują, że nie ma podstaw do odrzucenia hipotezy zerowej o normalności rozkładu reszt, ponieważ wartość $p$, czyli $p$-value jest większa niż nominalny poziom istotności 0,05 .

\section{Weryfikacja hipotez o autokorelacji składnika losowego modelu 3}

W modelu 3 dla Polski statystyka testu $L M$ wynosi $T R^{\wedge} 2=1,987266$ oraz wartość krytyczna $\chi^{2}=5,99$ przy poziomie istotności 0,05 i opóźnieniu drugiego rzędu. W związku z tym, że statystyka testu $L M$ jest niższa od $\chi^{2}$ to nie ma podstaw do odrzucenia hipotezy zerowej, zatem możemy uznać, iż w modelu nie występuje autokorelacja składników losowych drugiego rzędu. 


\section{Weryfikacja hipotez o istotności parametrów modelu 3}

Dla wyrazu wolnego (const) otrzymaliśmy wartość statystyki $t$-Studenta $=$ $t\left(\alpha_{0}\right)=-4,325$ oraz wartość prawdopodobieństwa jej uzyskania równą $p=8,89 \mathrm{e}-05(8,89 \mathrm{e}-05<0,05)$, co przy założeniu prawdziwości hipotezy zerowej o nieistotności parametrów regresji, daje podstawy do odrzucenia hipotezy $H_{0}$ na rzecz hipotezy alternatywnej $H_{1}$. Oznacza to, iż parametr $\alpha_{0}$ różni się od zera w sposób statystycznie istotny, czyli z prawdopodobieństwem 0,95 przyjmujemy, że wyraz wolny ma istotny wpływ na zmienną objaśnianą $I T$ - nakłady inwestycyjne. Podobnie dla pozostałych zmiennych zweryfikowano istotność parametrów odrzucając hipotezę zerową $H_{0}$ rzecz hipotezy alternatywnej $H_{1}$ (o istotności parametrów). Dla poszczególnych zmiennych wartości statystyki $t$-Studenta wyniosły: $d \_I R, t\left(\alpha_{1}\right)=-3,769$ przy $p=0,0005(0,0005<0,05)$, dla zmiennej objaśniającej $l d \_G D P, t\left(\alpha_{2}\right)=5,653$ przy $p=1,16 \mathrm{e}-06(1,16 \mathrm{e}-06<0,05)$, dla zmiennej objaśniającej $l d \_I T \_2, \mathrm{t}\left(\alpha_{3}\right)=6,207$ przy $p=1,83 \mathrm{e}-07(1,83 \mathrm{e}-07<0,05)$. Oznacza to, iż parametry $\alpha_{1}, \alpha_{2}, \alpha_{3}$, różnią się od zera w sposób statystycznie istotny, czyli z prawdopodobieństwem 0,95 przyjmujemy, że zmienne objaśniające $d \_I R, l d \_G D P, l d \_I T \_2$ istotnie wpływają na zmienną objaśnianą, czyli $I T$ (nakłady inwestycyjne w Polsce).

\section{Interpretacja parametrów funkcji logarytmicznej:}

$-a_{1}=-0,00552039$, jeśli z okresu (kwartału) na okres (kwartał) stopa procentowa wzrastałaby o jednostkę, czyli o 1 punkt procentowy, to nakłady inwestycyjne ceteris paribus z okresu (kwartału) na okres (kwartał) spadłyby o $-0,00552039 \%$,

$-a_{2}=1,81114$, jeśli $\mathrm{w}$ danym kwartale produkt krajowy brutto wzrośnie o $1 \%$, to ceteris paribus to nakłady inwestycyjne w tym kwartale wzrosną o $1,81114 \%$,

$-a_{4}=0,529162$, jeśli nakłady inwestycyjne sprzed jednego kwartałów (opóźnione o 1 okres) wzrosłyby o $1 \%$, to ceteris paribus bieżące nakłady inwestycyjne wzrosłyby $0,529162 \%$.

Współczynnik dopasowania modelu 3 wynosi $R^{2}=0,734973$, co oznacza, że model wyjaśnia $85,7 \%$ zmienności badanej cechy. Świadczy to o istotnym dopasowaniu modelu do danych empirycznych. Na podstawie testu $F$ Snedecora odrzucamy hipotezę $H_{0}$ o nieistotności układu współczynników regresji na rzecz hipotezy $H_{1}$. Ponadto hipoteza $H_{0}$ została odrzucona (w przypadku wszystkich współczynników) na rzecz hipotezy alternatywnej na podstawie testu $t$-Studenta o istotności parametrów. W 73,5\% zmienność zmiennej objaśnianej IT jest objaśniona zmiennością zmiennych objaśniających $l d \_I R, d \_G D P$ oraz $l d \_I T \_2$. 


\subsubsection{Analiza stacjonarności zmiennych}

Badanie stacjonarności zmiennych losowych przeprowadzone zostało przy użyciu rozszerzonego testu Dickey-Fullera. Hipoteza zerowa tego testu zakłada, że badany szereg jest niestacjonarny ze względu na występowanie pierwiastka jednostkowego, natomiast hipoteza alternatywna mówi o stacjonarności szere$\mathrm{gu}^{32}$. Test ten został dokładniej opisany powyżej w podpunkcie odnoszącym się do analizy stacjonarności zmiennych wykorzystanych w modelach ekonometrycznych dotyczących strefy euro. W tym przypadku zmienne testowane na poziomach były niestacjonarne, dlatego przeprowadzono test ADF tych zmiennych na pierwszych przyrostach i wtedy wyniki dla wszystkich zmiennych pozwoliły na odrzucenie hipotezy $H_{0}$ na rzecz hipotezy alternatywnej $H_{1}$ o występowaniu stacjonarności. To oznacza, że pierwsze przyrosty logarytmiczne zmiennych w tym przypadku są stacjonarne.

Podsumowując, wszystkie wykorzystane zmienne objaśniające w trzech modelach dla Polski okazały się istotne statystycznie oraz poprawne ekonomicznie. W modelach dla Polski zmieniano tylko skład zmiennych objaśniających, oczekując zwiększenia współczynnika stojącego przy zmiennej niezależnej - realnej stopie referencyjnej.

\subsection{Wnioski}

Na podstawie wyników uzyskanych po oszacowaniu dwóch modeli ekonometrycznych dla Eurosystemu (model 1,2 dla strefy euro) oraz trzech modeli ekonometrycznych dla Polski (model 1, 2, 3 dla Polski) potwierdzono, że stopa referencyjna banku centralnego wpływa odwrotnie proporcjonalnie na poziom inwestycji przedsiębiorstw, zarówno w Polsce jak i strefie euro. Bardziej zaawansowane modele ekonometryczne modelowania inwestycji ${ }^{33}$ uwzględniają wskaźniki wykorzystania mocy produkcyjnych, stopień wykorzystania środków trwałych, zagraniczne inwestycje bezpośrednie, koszty pracy czy koszty inwestycji. Należy wziąć pod uwagę fakt, że na poziom nakładów inwestycyjnych oddziałuje wiele czynników gospodarczych. Ponadto, cykle inwestycyjne zwykle wymagają czasu, dlatego uwzględnia się opóźnienia w ich realizacji. Stąd dopiero po wprowadzeniu do zmiennych w modelu opóźnień czasowych widoczny jest wzrost zależności nakładów inwestycyjnych od stopy referencyjnej banku centralnego. Model ekonometryczny wydaje się być zaawansowaną formą

\footnotetext{
${ }^{32}$ M. B orzyszkowska, op. cit., s. 300.

${ }^{33}$ W. Welfe, A. Welfe, op. cit., s. 123-127.
} 
mierzenia zjawisk w rzeczywistości gospodarczej, jednak należy podkreślić, że niesie za sobą wiele ograniczeń i możliwych błędów. Z drugiej strony jest bardziej precyzyjnym narzędziem niż proste metody statystyczne. Podsumowując, w dalszej perspektywie badań dotyczących wpływu polityki pieniężnej na poziom inwestycji interesująca wydaje się perspektywa przeprowadzenia prognozowania stopnia oddziaływania stopy referencyjnej NBP na nakłady inwestycje w Polsce, jako członka strefy euro.

W monografii zbadano również wpływ stopy referencyjnej na nakłady inwestycyjne przy wykorzystaniu współczynnika korelacji Pearsona dla badanych zmiennych. Współczynnik korelacji inwestycji od realnej stopy referencyjnej wyniósł dla Polski $(-0,54)$. Oznacza to, że zależność nakładów na środki trwałe brutto od stopy referencyjnej banku centralnego w Polsce jest umiarkowana. Z kolei w strefie euro zależność inwestycji od stopy referencyjnej była umiarkowana dopiero po 7-8 kwartałach (tab. 6.6).

T a b e 1 a 6.6

Współczynniki korelacji Pearsona pomiędzy inwestycjami a stopą referencyjną wraz z opóźnieniami w Polsce i strefie euro

\begin{tabular}{|l|c|l|c|}
\hline \multicolumn{1}{|c|}{ Współczynnik korelacji } & Polska & \multicolumn{1}{|c|}{ Współczynnik korelacji } & Strefa euro \\
\hline \hline Inwestycje a stopa referencyjna & $-0,543$ & Inwestycje a stopa referencyjna & 0,074 \\
\hline 1 kwartał opóźnienia & $-0,576$ & 1 kwartał opóźnienia & 0,086 \\
\hline 2 kwartał opóźnienia & $-0,609$ & 2 kwartał opóźnienia & 0,031 \\
\hline 3 kwartał opóźnienia & $-0,639$ & 3 kwartał opóźnienia & $-0,061$ \\
\hline 4 kwartał opóźnienia & $-0,669$ & 4 kwartał opóźnienia & $-0,187$ \\
\hline 5 kwartał opóźnienia & $-0,708$ & 5 kwartał opóźnienia & $-0,316$ \\
\hline 6 kwartał opóźnienia & $-0,755$ & 6 kwartał opóźnienia & $-0,424$ \\
\hline 7 kwartał opóźnienia & $-0,791$ & 7 kwartał opóźnienia & $-0,527$ \\
\hline 8 kwartał opóźnienia & $-0,813$ & 8 kwartał opóźnienia & $-0,622$ \\
\hline
\end{tabular}

Źródło: opracowanie własne w programie Microsoft Excel

Współczynnik korelacji Pearsona oparty jest na związku korelacyjnym między dwiema analizowanymi cechami, co czyni go miarą mniej skomplikowaną w porównaniu do modelu ekonometrycznego, który umożliwia badanie wpływu na zmienną objaśnianą większej liczby zmiennych objaśniających. W związku z tym, że na poziom inwestycji w gospodarce oddziałuje wiele czynników, model ekonometryczny jest narzędziem w większej mierze odzwierciedlającym rzeczywistość gospodarczą, a w tym również opisywane zjawisko wpływu stopy referencyjnej banku centralnego na inwestycje. 
Różne czynniki wpływają na politykę stóp procentowych banku centralnego, a następnie na oprocentowanie kredytów dla podmiotów gospodarczych. Reakcja banków na politykę pieniężną zależy w dużej mierze od ich płynności, konkurencji w sektorze usług finansowych, preferencji okresu zapadalności umów kredytowych, różnorodności stóp procentowych, premii za ryzyko lub kosztów administracyjnych. Generalnie wiele czynników ma wpływ na skuteczność działań polityki pieniężnej banku centralnego oddziałując jednocześnie na stopy kredytowe banków, a następnie na sferę realną gospodarki (w tym inwestycje). Zatem istotne jest badanie pośredniej zależności nakładów inwestycyjnych podmiotów gospodarczych od stopy referencyjnej banku centralnego.

W niniejszej monografii przedstawiono wyniki badań, które potwierdziły, że występuje wysoka zależność między stopą referencyjną banku centralnego a oprocentowaniem kredytów udzielanych przedsiębiorstwom przez banki komercyjne oraz że wielkość kredytów dla przedsiębiorstw wpływa w istotnym stopniu na inwestycje podmiotów gospodarczych, a także polityka stóp referencyjnych banku centralnego determinuje poziom stóp rynku międzybankowego, oddziałując przez to na poziom kredytów w gospodarce. Badanie to oparte zostało na współczynnikach korelacji Pearsona oraz współczynnikach determinacji $R^{2}$ pomiędzy odpowiednimi zmiennymi dla strefy euro (tab. 6.7).

T a b e l a 6.7

Wartości współczynnika korelacji liniowej Pearsona oraz współczynnik determinacji pomiędzy poniższymi zmiennymi w strefie euro w latach 1998-2009

\begin{tabular}{|c|c|c|c|c|c|}
\hline & $\begin{array}{c}\text { Nominalna stopa } \\
\text { referencyjna EBC } \\
\text { a oprocentowanie } \\
\text { kredytów dla } \\
\text { przedsiębiorstw }\end{array}$ & \begin{tabular}{|c|} 
Realna stopa \\
referencyjna EBC \\
a oprocentowanie \\
kredytów dla \\
przedsiębiorstw
\end{tabular} & $\begin{array}{c}\text { Kredyty dla } \\
\text { przedsiębiorstw } \\
\text { a nakłady } \\
\text { inwestycyjne }\end{array}$ & $\begin{array}{l}\text { Nominalna stopa } \\
\text { referencyjna EBC } \\
\text { a stopa rynku } \\
\text { międzybankowego } \\
\text { EURIBOR 3M }\end{array}$ & \begin{tabular}{|} 
Oprocentowanie \\
kredytów dla \\
przedsiębiorstw \\
a stopa rynku \\
międzybankowego \\
EURIBOR 3M \\
\end{tabular} \\
\hline $\begin{array}{c}\text { Współczynnik } \\
\text { korelacji } \\
\text { Pearsona } \\
\end{array}$ & 0,89 & 0,75 & 0,81 & 0,98 & 0,86 \\
\hline$R^{2}$ & 0,78 & 0,56 & 0,65 & 0,96 & 0,75 \\
\hline
\end{tabular}

Źr ód ło: opracowanie własne w programie Microsoft Excel na podstawie danych liczbowych OECD, ECB, Eurostat.

W przypadku pierwszej relacji pomiędzy nominalną stopą referencyjną EBC a oprocentowaniem kredytów dla przedsiębiorstw uzyskano wartość współczynnika korelacji $(0,89)$. Na tej podstawie można wyciągnąć wniosek o wysokiej zależności oprocentowania kredytów dla przedsiębiorstw od nominalnej stopy referencyjnej EBC. Wskaźnik determinacji $R^{2}$ informuje, że $78 \%$ zmienności oprocentowania kredytów dla podmiotów gospodarczych jest wyjaśnione zmianami stopy referencyjnej. Również wysoka jest wartość współczyn- 
nika korelacji $(0,75)$ pomiędzy realną stopą referencyjną a oprocentowaniem kredytów dla przedsiębiorstw w strefie euro. Wskazuje ona na to, że w istotnym stopniu realna stopa referencyjna wpływa na oprocentowanie kredytów. Współczynnik determinacji wskazuje, że 56\% zmienności oprocentowania kredytów jest wyjaśnione zmianami realnej stopy referencyjnej. Następnie zbadano wartość współczynnika korelacji Pearsona pomiędzy wielkością kredytów dla przedsiębiorstw a nakładami inwestycyjnymi w strefie euro. Otrzymana wartość $(0,81)$ wskazuje na wysoką zależność pomiędzy kredytami udzielonymi przedsiębiorstwom a nakładami inwestycyjnymi. Współczynnik determinacji oznacza w tym przypadku, że 65\% zmienności nakładów inwestycyjnych jest wyjaśnione zmianami wielkości kredytów dla podmiotów gospodarczych.

Otrzymane wyniki potwierdzają prawdziwość postawionych w badaniu założeń, że występuje wysoka zależność między stopą referencyjną banku centralnego a oprocentowaniem kredytów udzielanych przedsiębiorstwom przez banki komercyjne oraz wielkość kredytów dla przedsiębiorstw wpływa w istotnym stopniu na inwestycje podmiotów gospodarczych.

Kolejna analiza dotyczy wpływu nominalnej stopy referencyjnej EBC na stopy rynku międzybankowego EURIBOR 3M. Współczynnik korelacji Pearsona na poziomie $(0,98)$ świadczy o bardzo wysokiej zależności stopy EURIBOR 3M od podstawowej stopy referencyjnej EBC. Natomiast wskaźnik determinacji informuje, że $96 \%$ zmienności stopy rynku międzybankowego EURIBOR 3M jest wyjaśnione przez stopę podstawowych operacji refinansujących EBC. Następnie zbadano zależność pomiędzy stopą rynku międzybankowego EURIBOR $3 \mathrm{M}$ a oprocentowaniem kredytów dla podmiotów gospodarczych, otrzymując współczynnik korelacji na poziomie $(0,86)$. Świadczy to o tym, że oprocentowanie kredytów zależy w wysokim stopniu od poziomu stopy na rynku międzybankowym EURIBOR 3M. Współczynnik determinacji w tym przypadku oznacza, że 75\% zmienności oprocentowania kredytów dla przedsiębiorstw wyjaśnione jest przez zmianę stopy EURIBOR 3M. Uzyskane wyniki można uznać za potwierdzenie założenia, że polityka stóp referencyjnych banku centralnego determinuje poziom stóp rynku międzybankowego oddziałując przez to na poziom kredytów w gospodarce.

Podobne badanie współczynnika korelacji Pearsona oraz współczynnika determinacji $R^{2}$ pomiędzy odpowiednimi zmiennymi przeprowadzono również dla Polski (tab. 6.8).

Wartość współczynnika korelacji Pearsona dla pierwszej relacji pomiędzy nominalną stopą referencyjną EBC a oprocentowaniem kredytów dla przedsiębiorstw wyniosła $(0,99)$. Wskazuje to na istnienie wysokiej zależności oprocentowania kredytów dla przedsiębiorstw od nominalnej stopy referencyjnej NBP. $Z$ kolei wskaźnik determinacji $R^{2}$ dla tych dwóch zmiennych informuje, że $98 \%$ zmienności oprocentowania kredytów dla podmiotów gospodarczych jest wyjaśnione zmianami stopy referencyjnej. 
Wartości współczynnika korelacji liniowej Pearsona oraz współczynnik determinacji pomiędzy poniższymi zmiennymi w Polsce w latach 1998-2009

\begin{tabular}{|c|c|c|c|c|c|}
\cline { 2 - 6 } & $\begin{array}{c}\text { Nominalna stopa } \\
\text { referencyjna NBP } \\
\text { a oprocentowanie } \\
\text { kredytów dla } \\
\text { przedsiębiorstw }\end{array}$ & $\begin{array}{c}\text { Realna stopa } \\
\text { referencyjna NBP } \\
\text { a oprocentowanie } \\
\text { kredytów dla } \\
\text { przedsiębiorstw }\end{array}$ & $\begin{array}{c}\text { Kredyty dla } \\
\text { rzedsiębiorstw } \\
\text { a nakłady } \\
\text { inwestycyjne }\end{array}$ & $\begin{array}{c}\text { Nominalna stopa } \\
\text { referencyjna NBP } \\
\text { a stopa rynku } \\
\text { międzybankowego } \\
\text { WIBOR 3M }\end{array}$ & $\begin{array}{c}\text { Oprocentowanie } \\
\text { kredytów dla } \\
\text { przedsiębiorstw } \\
\text { a stopa rynku } \\
\text { międzybankowego } \\
\text { WIBOR 3M }\end{array}$ \\
\hline $\begin{array}{c}\text { Współczynnik } \\
\text { korelacji } \\
\text { Pearsona }\end{array}$ & 0,99 & 0,86 & 0,81 & 0,99 & 0,99 \\
\hline$R^{2}$ & 0,98 & 0,75 & 0,66 & 0,99 & 0,98 \\
\hline
\end{tabular}

Ź r ó d ł o: opracowanie własne na podstawie danych liczbowych OECD, NBP.

Wysoka jest również wartość współczynnika korelacji $(0,86)$ pomiędzy realną stopą referencyjną a oprocentowaniem kredytów dla przedsiębiorstw w Polsce. Oznacza to, że w istotnym stopniu realna stopa referencyjna wpływa na oprocentowanie kredytów. Natomiast współczynnik determinacji wskazuje, że 75\% zmienności oprocentowania kredytów jest wyjaśnione zmianami realnej stopy referencyjnej. W następnej kolejności obliczona została wartość współczynnika korelacji Pearsona pomiędzy wielkością kredytów dla przedsiębiorstw a nakładami inwestycyjnymi w Polsce. Otrzymana wartość $(0,81)$ wskazuje na wysoką zależność pomiędzy kredytami udzielonymi przedsiębiorstwom a nakładami inwestycyjnymi. Współczynnik determinacji oznacza w tym przypadku, że 66\% zmienności nakładów inwestycyjnych jest wyjaśnione zmianami wielkości kredytów dla podmiotów gospodarczych. Otrzymane wyniki potwierdzają, że występuje wysoka zależność między stopą referencyjną banku centralnego a oprocentowaniem kredytów udzielanych przedsiębiorstwom przez banki komercyjne oraz wielkość kredytów dla przedsiębiorstw wpływa w istotnym stopniu na inwestycje podmiotów gospodarczych.

Dalsza część analizy dotyczy wpływu nominalnej stopy referencyjnej NBP na stopy rynku międzybankowego WIBOR 3M. Współczynnik korelacji Pearsona na poziomie $(0,99)$ świadczy o bardzo wysokiej zależności stopy WIBOR 3M od podstawowej stopy referencyjnej NBP. Z kolei wskaźnik determinacji informuje, że 99\% zmienności stopy rynku międzybankowego WIBOR 3M jest wyjaśnione przez stopę podstawowych operacji refinansujących NBP. Badając zależność pomiędzy stopą rynku międzybankowego WIBOR 3M a oprocentowaniem kredytów dla podmiotów gospodarczych, otrzymano współczynnik korelacji na poziomie 0,99 . Świadczy to o tym, że oprocentowanie kredytów zależy w wysokim stopniu od poziomu stopy na rynku międzybankowym WIBOR 3M. Współczynnik determinacji w tym przypadku oznacza, że 98\% 
zmienności oprocentowania kredytów dla przedsiębiorstw wyjaśnione jest przez zmianę stopy WIBOR 3M. Uzyskane wyniki można uznać za potwierdzenie założenia, że polityka stóp referencyjnych banku centralnego determinuje poziom stóp rynku międzybankowego oddziałując przez to na poziom kredytów w gospodarce.

Podsumowując można zauważyć, że:

- Na podstawie dwóch modeli ekonometrycznych dla strefy euro można wnioskować, że zależność nakładów inwestycyjnych od stopy referencyjnej EBC jest odwrotnie proporcjonalna.

- W obu modelach dla strefy euro zauważono wysoki wpływ produktu krajowego brutto na nakłady inwestycyjne podmiotów gospodarczych.

- Na podstawie trzech modeli ekonometrycznych dla gospodarki polskiej ustalono, że nakłady inwestycyjne w Polsce zależą od stopy referencyjnej NBP w sposób odwrotnie proporcjonalny.

- W oparciu o trzy modele dla Polski wyciągnięto wniosek o relatywnie wysokim wpływie produktu krajowego brutto na inwestycje oraz wysokim poziomie współczynnika określającego oddziaływanie ceny inwestycji na wielkość tych inwestycji. 


\section{ZAKOŃCZENIE}

Stopa procentowa stanowi jeden z najważniejszych parametrów gospodarki rynkowej. Ostatnie kilkadziesiąt lat to okres zmian w strukturze rynków finansowych, które wpłynęły na poziomy i politykę stóp procentowych. Celem monografii było podkreślenie wpływu polityki stopy referencyjnej banku centralnego na inwestycje przy uwzględnieniu uwarunkowań zewnętrznych i wewnętrznych polityki pieniężnej w Polsce i strefie euro w latach 1998-2009. Ponadto w pracy założono, że stopa referencyjna banku centralnego wpływa odwrotnie proporcjonalnie na poziom inwestycji przedsiębiorstw, zarówno w Polsce jak i strefie euro. W związku z tym w pracy zaprezentowano rozważania na temat polityki pieniężnej, stóp procentowych i inwestycji przedsiębiorstw oraz przedstawiono dylematy dotyczące tej problematyki, wykorzystując literaturę krajową i zagraniczną. Pomimo wielu badań dotyczących wpływu polityki pieniężnej na gospodarkę, jego charakter i siła są wciąż przedmiotem dyskusji. W pracy dokonano charakterystyki stóp procentowych, które mają istotne znaczenie dla funkcjonowania gospodarki, oddziałując na nakłady inwestycyjne przedsiębiorstw. Jednym $\mathrm{z}$ wiodących problemów związanych ze stopami procentowymi jest ich udział w określaniu kosztu finansowania inwestycji, czy użytkowania kapitału, co powoduje m. in., że wskazane jest weryfikowanie efektywności i skuteczności działania banku centralnego, którego celem jest stabilizacja cen poprzez wykorzystanie dostępnego instrumentarium. W niniejszej książce skupiono uwagę na stopach referencyjnych banku centralnego w Polsce i strefie euro oraz ich oddziaływaniu na poziom inwestycji, co staje się szczególnie istotne w kontekście przystąpienia Polski do struktur strefy euro.

Badania rozpoczęto od teoretycznej weryfikacji zagadnienia, w ramach której ustalono, że istotnym elementem polityki gospodarczej jest polityka pieniężna realizowana przez bank centralny, sprowadzająca się do wyboru pieniężnych celów makroekonomicznych. W pracy wskazano, że ważnym atrybutem banku centralnego jest niezależność. Dla niezależnego banku centralnego główny priorytet to stabilność cen, co odzwierciedlają strategie EBC oraz NBP. Obserwując politykę pieniężną prowadzoną przez banki w strefie euro, a także w Polsce, 
można zauważyć, że niezależność banku centralnego sprzyja obniżaniu poziomu inflacji w gospodarce. Zgodnie ze strategią bezpośredniego celu inflacyjnego w Polsce i strefie euro, w momencie pojawienia się trwałych symptomów podwyższonej inflacji bank centralny podwyższa stopy procentowe, co hamująco oddziałuje na poziom inwestycji. Tym samym zauważono, że strategia bezpośredniego celu inflacyjnego przyczyniła się do niższego poziomu inflacji w gospodarce, co stymuluje podmioty gospodarcze do podejmowania decyzji inwestycyjnych.

W monografii podkreślono występowanie różnic między polityką stóp procentowych banku centralnego w strefie euro i w Polsce. Ustalono, że istniejące odmienne rozwiązania operacyjne mają podłoże rynkowe oraz źródło w różnej płynności sektora bankowego w Polsce i Eurosystemie. Nieznaczne są natomiast różnice dotyczące ustawodawstwa regulującego funkcjonowanie NBP w stosunku do wymogów obowiązujących w ESBC. NBP starając się spełnić wymogi akcesyjne do Unii Gospodarczej i Walutowej dąży do harmonizacji regulacji stosowanych w strefie euro. Występujące jednak między procesami gospodarczymi w Polsce i strefie euro różnice mają wpływ na decyzje podejmowane przez władze monetarne. Charakteryzująca Polskę, w przeciwieństwie do strefy euro, nadpłynność sektora bankowego determinuje stosowanie instrumentów polityki pieniężnej o przeciwnym w porównaniu do instrumentów Eurosystemu kierunku działania na system bankowy. Kraje strefy euro pozostają w różnych fazach cyklu koniunkturalnego, gdzie działanie polityki pieniężnej za pomocą wspólnej stopy procentowej i polityki kursowej jest utrudnione. Inaczej reagują na szoki asymetryczne, stąd w przypadku kryzysu wspólna polityka pieniężna ma utrudnione zadanie przeciwdziałania nierównomiernym szokom asymetrycznym. Ponadto w Polsce obserwuje się niższy wskaźnik monetyzacji gospodarki w porównaniu do państw Eurosystemu, wyższy wzrost wydajności pracy, wyższy poziom stóp procentowych oraz dynamiczniej rozwijającą się gospodarkę niż w krajach strefy euro. Istotna jest również różnica między poziomem nominalnych oraz realnych stóp procentowych w Polsce i strefie euro. W Polsce, która znajduje się w fazie konwergencji, obserwujemy wyższą dynamikę wydajności pracy, a co się z tym wiąże (efekt Balassy-Samulesona) większą dynamikę wynagrodzeń, która przyczynia się do presji inflacyjnej. Stąd bank centralny interweniuje poprzez podnoszenie poziomu nominalnych stóp procentowych. Do tego należy dodać różną percepcję ryzyka w Polsce i strefie euro. Premia za ryzyko znajduje odzwierciedlenie $\mathrm{w}$ wyższym poziomie rynkowych stóp procentowych w Polsce, jako emerging market.

Na podstawie przedstawionego $\mathrm{w}$ niniejszej pracy materiału analitycznego można określić następujące wnioski dotyczące strefy euro i funkcjonowania Europejskiego Banku Centralnego:

- EBC prowadził ekspansywną politykę pieniężną w latach 1998-2009, o czym świadczy niski poziom stopy referencyjnej EBC, która w 1999 r. wyno- 
siła 3\%, a w 2009 r. 1\%. Wobec tego można w tym przypadku określić politykę monetarną prowadzoną przez EBC jako stabilną.

- Wskaźnik inflacji HICP w strefie euro w badanym okresie (1998-2009) oscylował średnio wokół poziomu 2\% (od 1,1\% w I kwartale 1998 r., poprzez 3,8\% w III kwartale 2008 r., do 0,43\% w IV kwartale 2009 r.), przekraczając w pewnych okresach założony cel inflacyjny. Wraz ze wzrostem stopy referencyjnej poziom inflacji spadał, jednak to wzrost inflacji wywoływał decyzje EBC o podwyższeniu stopy referencyjnej. Wyższa stopa procentowa EBC skutkowała, z pewnym opóźnieniem (wynikającym z mechanizmu transmisji impulsów polityki pieniężnej do gospodarki), niższym poziomem PKB.

- Stopy rynku międzybankowego Eurosystemu w latach 1998-2009 podążały w ślad za stopą referencyjną EBC (np. EURIBOR 3M z około 3,9\% w $1998 \mathrm{r}$. do około $0,71 \% \mathrm{w} 2009$ r.). Stąd na przestrzeni 12 lat fluktuacje tych stóp były nieznaczne. Podobnie poziom oprocentowania kredytów dla przedsiębiorstw oscylował nieznacznie powyżej stopy referencyjnej. Oprocentowanie kredytów dla przedsiębiorstw w strefie euro wyznaczane było na podstawie stóp rynku międzybankowego (EURIBOR 1M, EURIBOR 3M), powiązanych z poziomem stopy referencyjnej.

- W strefie euro oprocentowanie kredytów dla firm miało wpływ na wielkość kredytów udzielanych przedsiębiorstwom przez banki. Wielkość kredytów udzielonych przedsiębiorstwom w strefie euro, sukcesywnie wzrastała od poziomu ponad 2400 mld euro w 1998 r. do około 4400 mld euro w 2009 r., przy średnim oprocentowaniu kredytów dla firm wahającym się od 6,19\% w 1998 r. do $3,35 \%$ w 2009 r.

- Realne nakłady inwestycyjne w strefie euro znalazły się w trendzie wzrostowym w analizowanym okresie 1999-2009, od poziomu 1371 mld euro w 1998 r. do 1591 mld euro w 2009 r. (osiągając w I kwartale 2008 r. nawet wielkość 1849 mld euro). Realne nakłady inwestycyjne w strefie euro wzrastały wraz ze spadkiem stopy referencyjnej z pewnym opóźnieniem wynikającym $\mathrm{z}$ mechanizmu transmisji impulsów polityki pieniężnej do sfery realnej gospodarki.

Biorąc pod uwagę rozważania zawarte w niniejszej pracy można zaprezentować następujące wnioski dotyczące Polski i prowadzenia polityki pieniężnej przez Narodowy Bank Polski:

- NBP prowadził ekspansywną politykę stóp procentowych w latach 1998 -2009 , obniżając stopę referencyjną z poziomu 24\% w 1998 r. do 3,5\% w 2009 r. W tym czasie nastąpił również znaczny spadek średniorocznej inflacji mierzonej wskaźnikiem CPI - z 11,8\% do 3,5\% w roku 2009. Był to bardzo istotny spadek stóp procentowych oraz poziomu inflacji. W Polsce $\mathrm{w}$ okresach podwyższonej inflacji stopa referencyjna była podnoszona, co skutkowało spadkiem inflacji i było zgodne $\mathrm{z}$ założonym celem inflacyjnym. W badanym okresie istotnie spadał poziom średniorocznej inflacji w Polsce, co świadczy o skuteczności strategii bezpośredniego celu inflacyjnego. 
- W Polsce, podobnie jak w strefie euro, stopa rynku międzybankowego (np. WIBOR 1M, WIBOR 3M) zmieniała się w tym samym kierunku, co stopa referencyjna banku centralnego. W badanym okresie (1998-2009) w ślad za istotnym spadkiem stopy referencyjnej NBP obniżano stopy rynku międzybankowego (np. WIBOR 3M z około 24,3\% w 1998 r. do około 4,23\% w 2009 r.) oraz średnie oprocentowanie kredytów dla przedsiębiorstw z 26,5\% w I kwartale 1998 r. do około 6\% w IV kwartale 2009 r.

- Średnie oprocentowanie kredytów dla przedsiębiorstw ulegało zmianom w ślad za stopą referencyjną NBP, a tym samym za stopami rynku międzybankowego. W latach 1998-2009, wraz ze spadkiem średniego oprocentowania kredytów dla przedsiębiorstw (z 26,56\% w 1998 r. do 5,9\% w 2009 r.), istotnie wzrastał poziom zadłużenia firm w bankach komercyjnych (z ponad $103 \mathrm{mld}$ zł w 1998 r. do ponad 193 mld zł w 2009 r.). Wydaje się, że spadek średniego oprocentowania kredytów dla przedsiębiorstw w Polsce istotnie wpływał na poziom zadłużenia firm w bankach komercyjnych.

- Spadek realnej stopy referencyjnej NBP oddziaływał na wzrost wielkości nakładów inwestycyjnych w Polsce mierzonych nakładami brutto na środki trwałe. Nakłady inwestycyjne przedsiębiorstw istotnie zmniejszały się w okresie spowolnienia gospodarczego oraz kryzysu finansowego, zarówno w Polsce jak i strefie euro. W analizowanym okresie 1998-2009, wraz ze spadkiem realnej stopy referencyjnej NBP, nakłady inwestycyjne w Polsce wzrosły z poziomu ponad 160 mld zł w 1998 r. do około 260 mld zł w 2009 r.

- Realna stopa referencyjna NBP była niższa od nominalnej stopy referencyjnej przez większą część badanego okresu (1998-2009), z wyjątkiem okresów spowolnienia gospodarczego oraz kryzysu finansowego, kiedy z powodu wzrostu inflacji różnica między tymi stopami zmniejszała się.

Biorąc pod uwagę powyższe wnioski można stwierdzić, że polityka stopy referencyjnej banku centralnego jest $\mathrm{w}$ wysokim stopniu skorelowana $\mathrm{z}$ poziomem stóp rynku międzybankowego, a następnie $\mathrm{z}$ poziomem oprocentowania kredytów dla przedsiębiorstw. Ponadto wielkość kredytów w istotnym stopniu wpływa na inwestycje w gospodarce.

Zmienne objaśniające takie jak: realna stopa referencyjna EBC, produkt krajowy brutto w strefie euro, nakłady inwestycyjne opóźnione o dwa okresy (czyli opóźniona zmienna objaśniająca) zastosowane w dwóch modelach dla strefy euro były istotne statystycznie oraz poprawne ekonomicznie.

W wyniku weryfikacji ekonometryczno-statystycznej potwierdzono, że zmienne objaśniające wykorzystane w trzech modelach dla Polski, czyli realna stopa referencyjna, produkt krajowy brutto, deflator inwestycji, jako cena nakładów inwestycyjnych, inwestycje opóźnione o 1 oraz o 2 kwartały, były istotne statystycznie oraz poprawne ekonomicznie. Oczekując zwiększenia współczynnika stojącego przy zmiennej niezależnej (realnej stopie referencyjnej) zmieniano skład zmiennych egzogenicznych (objaśniających). W rezultacie w modelach 
dla Polski wartość współczynnika stojącego przy stopie referencyjnej NBP była zbliżona. Zgodnie z oczekiwaniami wynikającymi z teorii ekonomii badana zależność nakładów inwestycyjnych od stopy referencyjnej w Polsce jest odwrotnie proporcjonalna. Wydaje się, że wpływ na uzyskany wynik ma różnorodność czynników (np. poziom ryzyka, stopa zwrotu, dostępność kapitału) determinujących decyzje przedsiębiorstw o poziomie inwestycji. Ponadto część nakładów inwestycyjnych jest realizowana pomimo podwyżek stóp procentowych ze względu na konieczność ich przeprowadzenia ${ }^{1}$. W przypadku inwestycji na środki trwałe brutto, istotna jest również rentowność tego przedsięwzięcia, dlatego cena kredytu w danym okresie nie zawsze jest głównym czynnikiem decydującym o zaciągnięciu zobowiązania w banku.

Podsumowując, przedstawiony w niniejszej monografii w rozdziale 6 materiał analityczny związany $\mathrm{z}$ wykorzystaniem modelownia ekonometrycznego umożliwił weryfikację postawionej hipotezy, że stopa referencyjna banku centralnego wpływa odwrotnie proporcjonalnie na poziom inwestycji przedsiębiorstw, zarówno w Polsce jak i w strefie euro oraz pozwolił na stwierdzenie, że:

- zależność nakładów inwestycyjnych od stopy referencyjnej banku centralnego zarówno w Polsce jak i w strefie euro, w latach 1998-2009 była odwrotnie proporcjonalna $\mathrm{i}$ istotna statystycznie (na podstawie modeli ekonometrycznych),

- zależność pomiędzy inwestycjami a realną stopą referencyjną w Polsce, w latach 1998-2009 była umiarkowana, natomiast w strefie euro przyjmowała wartości średnie dopiero po 7-8 kwartałach (na podstawie współczynnika korelacji).

Biorąc pod uwagę powyższe, wyciągnięto wnioski, że polityka stopy referencyjnej banku centralnego pozostaje istotnym elementem gospodarki i należy brać pod uwagę kierunek i siłę jej oddziaływania na poszczególne składniki PKB. Dokonując syntezy badań wykazano, że istnieje odwrotnie proporcjonalna zależność pomiędzy nakładami na środki trwałe w gospodarce a stopą referencyjną banku centralnego, zarówno w Polsce jak i strefie euro. W tym miejscu należy jednak podkreślić, że w badanym okresie 1998-2009 czynnikiem istotnie zakłócającym procesy gospodarcze był kryzys finansowy, który wpłynął na poziom badanych zmiennych. Koncentrując się na sile oddziaływania stopy referencyjnej banku centralnego na inwestycje nie udało się zbadać, które zmienne gospodarcze wykazują najbardziej istotny wpływ na poziom nakładów inwestycyjnych na środki trwałe brutto, zarówno w Polsce jak i w strefie euro.

Dokonany przegląd i charakterystyka modeli nie wyczerpują złożoności zagadnienia. Mimo iż w polskiej literaturze pojawia się coraz więcej opracowań na temat wpływu polityki pieniężnej na gospodarkę, to nadal odczuwa się niedosyt

${ }^{1}$ A. S z y m c z a k, Krótkookresowe i dtugookresowe efekty wptywu stopy procentowej na aktywność inwestycyjna przedsiębiorstw w Polsce, [za:] zasoby witryny internetowej: http://mikro. univ.szczecin.pl/bp/pdf/41/17.pdf. 
w zakresie ich implementacji. Przyczyn tego stanu jest wiele. Jedna z nich tkwi $\mathrm{w}$ braku kompleksowego spojrzenia na procesy podejmowania decyzji w zakresie polityki pieniężnej, uwzględniającego różne perspektywy konsekwencji tych decyzji. Wszystkie przedstawione modele są użyteczne oraz nadają badaniom oryginalności, ale $\mathrm{w}$ określonych obszarach procesu nie dostarczają odpowiedzi na wiele pytań. Analizując ich przydatność przez pryzmat pełnionych funkcji można uznać je za istotne narzędzie wspierające pracę. Najważniejszą ich zaletą jest możliwość uzyskiwania parametrów opisujących badane zjawisko w zależności od wielu czynników.

Biorąc pod uwagę dalsze prace badawcze z zakresu polityki pieniężnej i wykorzystania wpływu jej stóp procentowych na sektor otwarty, interesujące byłoby włączenie do rozważań badania większej grupy czynników mających wpływ na inwestycje oraz objęcie analizą różnic i podobieństw ich oddziaływania na inwestycje w Polsce i strefie euro, a także określenie implikacji tych badań dla władz monetarnych. Jednakże prowadzenie takiego typu analiz wymaga przygotowania odpowiedniej bazy informacyjnej, która posłużyłaby do zaawansowanego badania ekonometrycznego opartego na modelach wielorównaniowych oraz symulacyjnych. Ponadto, jest to materia niedająca się do końca przewidzieć ze względu na duże prawdopodobieństwo wystąpienia różnych zdarzeń mających wpływ na funkcjonowanie gospodarki, czynników nie tylko wynikających z uwarunkowań wewnętrznych-krajowych, ale także z faktu, że funkcjonujemy w warunkach globalizacji i jesteśmy poddani również na wpływy zagraniczne, nie tylko pochodzące ze strefy euro, ale także innych krajów, czego przykładem było przenoszenie się ostatniego kryzysu na rynkach finansowych.

Z perspektywy Polski ważne jest, aby w dłuższym okresie obserwować decyzje EBC, w celu chociażby przeprowadzenia symulacji stopnia oddziaływania polityki pieniężnej Eurosystemu na polską gospodarkę po ewentualnym przystąpieniu Polski do UGiW. W obliczu kryzysu finansowego oraz niestabilnej sytuacji w strefie euro powinno się wyciągnąć odpowiednie wnioski dotyczące przygotowań Polski do wstąpienia do Eurosystemu. Przede wszystkim należy starannie przygotować się do zmiany waluty poprzez wypełnienie kryteriów konwergencji w sposób trwały, rozpoczynając najważniejsze reformy strukturalne jeszcze przed uczestnictwem w mechanizmie ERM II. W celu uniknięcia szoku asymetrycznego w Polsce istotny będzie poziom deficytu strukturalnego, racjonalna polityka fiskalna, elastyczność rynku produktów i rynku pracy oraz skuteczność nadzoru finansowego. Wydaje się, że niestabilna sytuacja w strefie euro, niepewność na światowych rynkach finansowych oraz kryzys zbyt wysokich deficytów budżetowych odłoży w czasie wejście Polski do strefy euro. Stąd niemałym wyzwaniem dla Polski będzie realizacja kryteriów konwergencji przy współpracy władz odpowiedzialnych za politykę pieniężną i fiskalną w celu uchronienia polskiej gospodarki przed niedostosowaniem do warunków strefy euro. 


\section{BIBLIOGRAFIA}

Alt a villa C., Cic carelli M., Inflation Forecasts, Monetary Policy and Unemployment Dynamics. Evidence from US and the Euro Area, ,Working Paper Series” European Central Bank 2007, no. 725 .

A u gu st ynowicz P., Lending Activity of Polish Banks, [w:] H. Żu kow ska, M. Żu kow sk i (red.), The Banking System in Poland, Maria Curie-Skłodowska Press, Lublin 2008.

B a k a Wł., Bankowość centralna, funkcje - metody - organizacja, Biblioteka Menadżera i Bankowca, Warszawa 2001.

B aranowski P., Problem optymalnej stopy inflacji $w$ modelowaniu wzrostu gospodarczego, Wydawnictwo Biblioteka, Łódź 2008.

B aranowski P., Wykorzystanie danych typu real time do oszacowania parametrów reguty Taylora dla Polski, praca powstała w ramach projektu badawczego pt. Polityka fiskalna i monetarna w okresie akcesji do strefy euro- scenariusze $i$ wyzwania, finansowego ze środków na naukę w latach 2006-2008.

B arclay J. M., S mith C. W. Jr., The capital structure puzzle: Another look at the evidence, „Journal of Applied Corporate Finance”, Spring 1999, vol. 12, no. 1.

B arczyk R., Teoria i praktyka polityki antycyklicznej, Wydawnictwo Akademii Ekonomicznej w Poznaniu, Poznań 2004.

B arro R., Inflation and Economic Growth, „NBER Working Papers” 1995, no. 5326, Cambridge.

B arro R., Milton Friedman: Perspectives, Particularly on Monetary Policy, Harvard University, Harvard 2006.

B arteczko K., B ocian A., Modelowanie polityki makroekonomicznej, PWE, Warszawa 1996.

$\mathrm{B}$ e d $\mathrm{n}$ a r c z y k J. L. (red.), Finansowe determinanty wzrostu w gospodarce globalnej, Wydawnictwo Fachowe CeDeWu, Warszawa 2010.

B e d n arc zy k J. L. (red.), Stopy procentowe a gospodarka. Dylematy Unii Gospodarczej $i$ Walutowej, Wydział Ekonomiczny Politechniki Radomskiej, Radom 2006.

Bednarczyk J. L., Polityka pieniężna przeciw inflacji, Wydawnictwo Naukowe PWN, Warszawa 1990.

Bednarczyk J. L., Stopa procentowa jako narzędzie polityki banku centralnego, [w:] W. Przybylska-Kapuścińska (red.), Studia z bankowości centralnej i polityki pieniężnej, Difin, Warszawa 2009.

B ed $\mathrm{n}$ arc zy k J. L. (red.), Stopy procentowe a gospodarka, eseje z teorii i polityki stóp procentowych, Wydawnictwo Politechniki Radomskiej, Radom 2004. 
B e n n et t H., L o a y z a N., Policy biases when the monetary and fiscal authorities have different objectives, „Central Bank of Chile Working Papers” 2001, no. 66.

B erger A. N., Ude11 G. F., Small business credit availability and relationship lending: The importance of bank organizational structure, „Economic Journal” 2002, vol. 112, no. 477.

B erger H., Ehrmann M., Fratzscher M., Forecasting ECB monetary policy. Accuracy is (still) a matter of geography, Working Paper No. 578, EVB, 05/2006.

$\mathrm{B}$ ernanke B., B inder A., The federal fund rate and the channels of monetary transmission, „American Economic Review” 1992, vol. 82(4).

Bernanke B., Gertler M., Inside the Black Box: The Credit channel of Monetary Policy Transmission, ,Journal of Economic Perspectives” 1995, vol. 9.

B i é A., B i eń W., Kalkulacja ceny pieniądza w lokatach, pożyczkach i kredytach, Difin, Warszawa 1999.

Biuletyn informacyjny 12/2004, Narodowy Bank Polski, Warszawa, maj 2005.

Biuletyn miesięczny. 10 rocznica EBC, Europejski Bank Centralny, Frankfurt 2008.

B ł a s z z y k P., Stabilność cen - sposoby definicji oraz wyzwania dla polityki pieniężnej, „Materiały i Studia" 2010, z. 249.

Blinder A. S., Bankowość centralna $w$ teorii i praktyce, Wydawnictwo CeDeWu, Warszawa 2001.

B o ot A. W. A., Thak or A. V., Can relationship Banking survive Competition?, „The Journal of France" 2000, vol. 55, no. 2.

B o ot J. R., B o ot L. C., Loan Collateral Decisions and Corporate Borrowing Costs, „Journal of Money, Credit and Banking” 2006, vol. 38.

B o r i o C., L o w e P., Asset Proces, Financial and Monetary Stability: Exploring the Nexus, „BIS Working Papers" 2002, no. 114.

B orkowski B., Dudek H., S zc zęs ny W., Ekonometria, wybrane zagadnienia, Wydawnictwo Naukowe PWN, Warszawa 2003.

Borowski J., Podatność na szoki asymetryczne i proces przystapienia do Unii Monetarnej, „Bank i Kredyt” 2001, nr 11-12.

B or z y s zkow sk a M., Analiza empiryczna wybranych zmiennych wchodzacych $w$ skład funkcji popytu na pieniadz, X Ogólnopolskie Seminarium Naukowe, 4-6 września 2007 r. w Toruniu, Uniwersytet Mikołaja Kopernika, Toruń 2007.

B ożyk P., Mis ala J., Puła w ski M., Międzynarodowe stosunki ekonomiczne, PWE, Warszawa 1999.

Brzoza-Brzezina M., Lending booms in the new UE member states. Will euro adoption matter?, Working Paper Series No. 543, EBC, Frankfurt 2005.

Brzoza-Brzezina M., Makarski K., Credit Crunch in Small Open Economy, Narodowy Bank Polski, listopad 2009.

Brzoza-Brzezina M., Niedźwi edzińska J., Ekspansja kredytowa w nowych państwach członkowskich Unii Europejskiej a przystapienie do wspólnego obszaru walutowego, [w:] J. L. B e d narczy k (red.), Stopy procentowe a gospodarka. Dylematy Unii Gospodarczej $i$ Walutowej, Wydział Ekonomiczny Politechniki Radomskiej, Radom 2006.

Bukowska J., Polityka stóp procentowych Europejskiego Banku Centralnego a inflacja w obszarze euro w latach 1999-2008, [w:] M. Nog a (red.), Ponadnarodowa i narodowa polityka monetarna na świecie, CeDeWu, Warszawa 2009. 
B ukowski S., Stopy procentowe a ksztattowanie się kursu walutowego euro w latach 19992004, [w:] J. L. B e d n ar c z y k (red.), Stopy procentowe a gospodarka. Eseje z teorii i polityki stóp procentowych, Wydawnictwo Politechniki Radomskiej, Radom 2004.

Cendal M., Wptyw instrumentów banku centralnego na kształtowanie się krótkoterminowych stop procentowych rynku pieniężnego, [w:] J. L. B ednarczyk (red.), Stopy procentowe a gospodarka. Dylematy Unii Gospodarczej $i$ Walutowej, Wydawnictwo Instytutu Technologii Eksploatacyjnej Państwowego Instytutu Badawczego, Radom 2006.

Chądzyński M., Wptyw matych i średnich przedsiębiorstw na wzrost gospodarczy $w$ Polsce w latach 1995-2005, Stowarzyszenie Ekonomistów Rolnictwa i Agrobiznesu, Roczniki Naukowe, t. X, z. 3.

Chmielewski T., Bank Risk and Credit Rationing, „Quarterly Journal of Economics” 2005, vol. 74(2).

$\mathrm{Chmielewski} \mathrm{T.,} \mathrm{Interest} \mathrm{rate} \mathrm{pass-through} \mathrm{in} \mathrm{the} \mathrm{Polish} \mathrm{banking} \mathrm{sektor} \mathrm{and} \mathrm{bank-specific}$ financial disturbances, MPRA Paper No. 5133, 2003.

$\mathrm{C}$ iżkow ic z P., R y bińs ki K., The role of banking and financial policies in promoting micro, small, and medium enterprises, artykuł przygotowany na konferencję ,Macroeconomic Stability: Towards High Growth and Uneployment”, Bank Indonezji, Bali 2007.

Cottarelli C., Dell'Ariccia G., Vladkova-Hollar I., Early Birds, Late Riders, and Sleeping Beauties: Bank Credit Growth to the Private Sector in Central and Eastern Europe and the Balkans, „IMF Working Paper”, November 2003, s. 8, [w:] M. Iwanicz- Drozdowska, Wptyw zmian w regulacjach ostrożnościowych na dostęnność kredytów dla matych i średnich przedsiębiorstw. Wyniki badań ankietowych, „Bank i Kredyt”, marzec 2006.

Cox J. C., In gersoll J. E., R os s J r. S. A., The Theory of the Term Structure of Interest Rate, „Econometrica” 1985, vol. 53, no. 2.

Crossy R., Olofs son Ch., European SME Financing: An Overview, „Small Business Economics", Springer, 1997.

Cuki erman A., Central bank strategy, credibility, and independence, MIT Press, Cambridge 1992.

Czapaluk M., Racjonalne oczekiwania a polityka państwa, Uniwersytet Zielonogórski, nr 3, Zielona Góra 2002.

Czechowska I. D., Wykorzystanie bonów pieniężnych $w$ ramach polityki pieniężnej, [w:] J. L. B ednarczyk (red.), Stopy procentowe a gospodarka. Dylematy Unii Gospodarczej $i$ Walutowej, Wydawnictwo Instytutu Technologii Eksploatacyjnej Państwowego Instytutu Badawczego, Radom 2006.

Czubocha K., Pas zkowska M., Rola Europejskiego Banku centralnego w integracji walutowej krajów członkowskich Unii Europejskiej, „eFinanse - Finansowy Kwartalnik Internetowy" 2009, $\mathrm{nr} 4$.

Ć w i k liń s ki H., Polityka gospodarcza, Wydawnictwo Uniwersytetu Gdańskiego, Gdańsk 2004.

$\mathrm{D}$ a ch Z., Sektor matych i średnich przedsiębiorstw w perspektywie przystapienia do Unii Europejskiej, „Zeszyty Naukowe AE Kraków", 2001.

De Grauwe P., Unia walutowa. Funkcjonowanie i wyzwania, PWE, Warszawa 2003.

Dębski W., Rynek finansowy i jego mechanizmy. Podstawy teorii i praktyki, Wydawnictwo Naukowe PWN, Warszawa 2005. 
Dresler Z., Kontrowersje wokót polityki stopy procentowej, [w:] J. L. B e d narczyk (red.), Stopy procentowe a gospodarka, eseje z teorii i polityki pieniężnej, Wydawnictwo Politechniki Radomskiej, Radom 2004.

Ehrmann M., Gambacorta L., Martinez-Pages J., Sevesrte P., Worms A., Financial system and the role of banks in monetary policy transmission in the euro area, European Central Bank, Working Paper No. 105, 2001.

Erceg Ch. J., Levin A. T., Optimal Monetary Policy with Durable and Non-Durable Goods, referat przedstawiony na konferencji „International Research Forum on Monetary Policy”, ECB, 5-6.07.2002.

Fe d o r o wi c z Z., Polityka pieniężna, Poltext, Warszawa 1993.

Fedorowicz Z., Stopa procentowa $w$ polityce banku centralnego, [w:] J. Głuchowski, I. O hl (red.), Bankowe i pozabankowe źródta finansowania gospodarki, Konferencja Katedr Finansów - Ciechocinek 1995, Wydawnictwo Uniwersytetu M. Kopernika, Toruń 1997.

Fil a r D., Przymiarki do europejskich stóp, „Rzeczpospolita” 2005, nr 242, 14-15.10.2005.

F i s cher S., Modern Approach to Central Banking, ,NBER Working Paper” 1995, no. 5064.

Fi s ch er S., Modern central banking, [w:] F. C a pi e, Ch. God hart, S. Fi s h e r, N. S ch madt, The Future of Central Banking, Cambridge University Press, Cambridge 1994.

Fis cher S., Why Are Central Banks Pursuing Long-Run Price Stability, Federal Reserve Bank of Kansas City, 1996.

Fiszer J., Polska nie musi obniżać CIT jak inne kraje Unii Europejskiej, „Dziennik Gazeta Prawna", 07.11.2011.

For t in P., Can Monetary Policy Make a Difference for Economic Growth and Inequality, Canadian Institute for Advanced Research, Ottawa, January 2001.

Frenkel M., Nickel Ch., Schmidt G., Some Shocking Aspects of EMU Enlargement, Research Note No. 1999/99-4.

Frie d m an M., Fried man R., Wolny wybór, Wydawnictwo Kraków, Kraków 1988.

Frost S., The construction of price indexes for deposit and loan facilities, Australian Bureau of Statistics, Canberra 2001.

Galbraith J. K., The Collapse of Monetarism and the Irrelevance of the New Monetary Consensus, 25th Annual Milton Friedman Distinguished Lecture at Marietta College, Marietta, Ohio, 31 marzec 2008.

Gąt a rek D., M a ks y mi u k R., Krys i ak M., Witkow sk i Ł., Nowoczesne metody zarzadzania ryzykiem finansowym, WIG Press, Warszawa 2001.

Gemzik-Salwach A., Analiza komparatywna koncepcji czasowej struktury stóp procentowych. Podejście analityczne i krytyczne, „Finanse - Finansowy kwartalnik internetowy” 2010, vol. 6, no. 2.

Gi e rałtow ski P., Polityka pieniężna w unii walutowej, [w:] P. Kow al ew ski, W. Ko ziński (red.), Mechanizmy funkcjonowania strefy euro, Narodowy Bank Polski, Warszawa 2010.

Gładys z B., Mercik J., Modelowanie ekonometryczne, studium przypadku, Oficyna Wydawnicza Politechniki Wrocławskiej, Wrocław 2007.

Gó r s ki M., Rynkowy system finansowy, PWE, Warszawa 2007.

Gotz-Kozierkiewicz D., Polityka pieniężna a polityka fiskalna, „Bank i Kredyt”, lipiec -sierpień 2000. 
Grabek G., Kłos B., Kokoszczyński R., Łyziak T., Przystupa J., Wróbel E., Porównanie podstawowych cech mechanizmu transmisji monetarnej w Polsce $i w$ strefie euro, Narodowy Bank Polski, Warszawa, kwiecień 2008.

Gr a b o w s k i B., Fundamentalne problemy polityki pieniężnej NBP, „Bank i Kredyt” 1999, nr 7-8.

Grafe C., Wypłosz Ch., The Real Exchange Rate in Transition Economies, artykuł zaprezentowany na konferencji „Third Dubrovnik Conference on Transition Economies in Dubrovnik", Chorwacja, czerwiec 1997.

Gru szecki T., Teoria pieniądza i polityka pieniężna. Rys historyczny i praktyka gospodarcza, Oficyna Ekonomiczna, Kraków 2004.

Guiso L., Kashyap A. K., Panetta F., Terlizzese D., How Interest Sensitive is Investment?, [w:] R. Kokoszczyński, T. Łyziak, E. Wróbel, Czynniki strukturalne we wspótczesnych teoriach mechanizmów transmisji polityki pieniężnej, XXII Konferencja naukowa NBP „Reformy strukturalne a polityka pieniężna”, Falenty 2002.

Has s le r U., N a u c z D., On the Persistence of the Eonia Spread, Goethe University, Frankfurt 2007.

I acoviello M., House Prices, Borrowing Constraints and Monetary Policy in the Business Cycle, Boston College, Boston, 06.12.2004.

Inders R., Muelle r H. M., A Lender-Based Theory of Collateral, „Journal of Financial Economics" 2007.

Ir el an d P. N., The Monetary Transmission Mechanism, Boston College and NBER, 2005.

Is sing O., The ECB`s Monetary Policy Strategy: Why did we choose a two Pillar Approach?, $4^{\text {th }}$ ECB Central Banking Conference, Frankfurt, 10 November 2006, 06.11.10 EBC Conference.

Iwańczuk A., Zarządzanie ryzykiem $w$ banku jako przedmiot regulacji zewnętrznych, [w:] M. Marcinkowska, St. Wieteska (red.), Harmonizacja bankowości i ubezpieczeń w skali narodowej i europejskiej, Difin, Warszawa 2007.

I wa n ic z-Drozdow ska M., Integracja rynków finansowych w Unii Europejskiej od A do Z, Narodowy Bank Polski, Warszawa 2009.

J a ku bi a k M., Oszczędności, inwestycje, integracja finansowa i bezpośrednie inwestycje zagraniczne w Europie Środkowo-Wschodniej, [w:] B. Li b e rd a (red.), Determinanty oszczędzania w Polsce, Raport Centrum Analiz Społeczno-Ekonomicznych, CASE, nr 28, Warszawa 1999.

J anik W., Stopy procentowe a zapotrzebowanie na obce źródta finansowania przedsiębiorstw, [w:] J. L. B ednarczyk (red.), Stopy procentowe a gospodarka. Eseje z teorii i polityki stóp procentowych, Politechnika Radomska, Radom 2004.

Jare mko M., Wiśniew ski M., Wptyw polityki stóp procentowych na nadptynność sektora bankowego $w$ Polsce, [w:] W. Przybylska-Kapuścińska (red.), Polityka pieniężna i rynek, ,Zeszyty naukowe Akademii Ekonomicznej w Poznaniu” 2003, nr 26.

J a w or ski W. L. (red.), Wspótczesny bank, Poltext, Warszawa 2002.

J a w ors ki Wł. L., Z a w a z k a Z. (red.), Bankowość. Podręcznik akademicki, Poltext, Warszawa 2006.

Jaw orski Wł. L., Zawadzka Z., Bankowość. Zagadnienia podstawowe, Poltext, Warszawa 2004. 
Jimenez G., S a urin a J., Collateral, Type of Lender and Relationship Banking as Determinants of Credit Risk, Bank of Spain, Directorate - General of Banking Regulation, May 2003.

J oh n s on K., S mall D., Try on R., Monetary Policy and Price Stability (unpublished), Board of Governors of the Federal Reserve System, „International Finance Discussion Papers” 1999, No. 641.

K a me c ki Z., Pojecie i typy integracji gospodarczej, „Ekonomista” 1967, nr 1.

Kaźmi erczak A., Monetary policy in market economy, Szkoła Główna Handlowa, Warszawa 2004.

Kaźmierczak A., Polityka pieniężna w gospodarce otwartej, Wydawnictwo Naukowe PWN, Warszawa 2008.

Kaźmi erc zak A., Polityka pieniężna w gospodarce rynkowej, Wydawnictwo Naukowe PWN, Warszawa 2003.

Keynes J. M., Ogólna teoria zatrudnienia, procentu i pieniądza, [tłum.] M. Kalecki, St. Rą c zkow ski, Wydawnictwo Naukowe PWN, Warszawa 1985.

Knakiewicz Z. (red.), Wspótczesny pieniądz $w$ teorii i praktyce, Wydawnictwo Akademii Ekonomicznej w Poznaniu, Poznań 2006.

Kokoszczyński R., Łyziak T., Wróbel E., Czynniki strukturalne we wspótczesnych teoriach mechanizmów transmisji polityki pieniężnej, XXII Konferencja Naukowa NBP „Reformy strukturalne a polityka pieniężna”, Falenty 2002.

Ko ko s zc z yń s ki R., Wspótczesna polityka pieniężna w Polsce, PWE, Warszawa 2004.

Kokoszczyński R., Łyziak T., Pawłowska M., Przystupa J., Wróbel E., Mechanizm transmisji polityki pieniężnej - wspótczesne ramy teoretyczne, nowe wyniki empiryczne dla Polski, „Materiały i Studia” 2002, nr 151, Warszawa.

Korke a maki T. P., Rutherford M., Industry Effects and Banking Relationship as Determinants of Small Firm Capital Structure Decisions, Gonzaga University, Virginia Commonwealth University, 2006.

Kosztowniak A., Polityka stóp procentowych Europejskiego Banku Centralnego a problem wzrostu gospodarczego w krajach strefy euro, [w:] J. L. B ed narc zy k (red.), Stopy procentowe a gospodarka. Dylematy Unii Gospodarczej $i$ Walutowej, Wydział Ekonomiczny Politechniki Radomskiej, Radom 2006.

Kot A., Metody kwantyfikacji restrykcyjności polityki monetarnej, fiskalnej oraz Policy mix w krajach akcesyjnych, „Bank i Kredyt” 2003, nr 6.

Kowalak M., Jakościowe aspekty polityki wspótczesnego banku centralnego, „Bank i Kredyt” 2006, $\mathrm{nr} 3$.

Krajowy Fundusz Kapitałowy jako uzupetnienie systemu finansowania rozwoju sektora MSP, Ministerstwo Gospodarki i Pracy, Departament Polityki Regionalnej, Warszawa 2005.

K ru g m a n P., Stable Proces and Fast Growth: Just Say No, „The Economist”, 03.08.1996.

Krys i a k A. S., Stopy procentowe a polityka kredytowa wobec matych i średnich przedsiębiorstw $w$ Polsce, [w:] J. L. B e d n arczyk (red.), Stopy procentowe a gospodarka. Dylematy Unii Gospodarczej i Walutowej, Radom 2006.

Kryzys grecki - geneza i konsekwencje, Dokument uzupełniający do ram strategicznych Narodowego Planu Wprowadzenia Euro, Ministerstwo Finansów, Warszawa 2010. 
K u ch arski L., Polityka pieniężna a wzrost gospodarczy i bezrobocie w Polsce $w$ latach 19982009, [w:] J. L. B ed n ar c z y k (red.), Finansowe determinanty wzrostu w gospodarce globalnej, Wydawnictwo Fachowe CeDeWu, Warszawa 2010.

Kurowska M., Fundamentalne bariery rozwojowe sektora MSP, [w:] A. B ogu s, M. Wyp y ch (red.), Harmonizacja rynków finansowych i finansów przedsiębiorstw w skali narodowej i europejskiej, Difin, Warszawa 2007.

Kurows ka M., Ocena zdolności kredytowej matych i średnich przedsiębiorstw, Wydawnictwo Uniwersytetu Łódzkiego, Łódź 2005.

$\mathrm{K}$ u s a k A., Jak określić potrzeby finansowe firmy, „ABC finansów” - dodatek do Serwisu Finansowo-Księgowego $\mathrm{nr}$ 10(464), 9 marca 2004.

Kuttner K. N., Mosser P. C., The Monetary Transmission Mechanism: Some Answers and Further Questions, ,FRBNY Economic Policy Review” 2002, vol. 5.

Kuttn e r K. N., The Monetary - Fiscal Policy Mix: Perspectives from the U. S., „Bank i Kredyt” 2002, nr 11-12.

Lachiewicz B., Stopa procentowa NBP a stopy procentowe $w$ bankach komercyjnych, [w:] J. L. B ednarczyk (red.), Stopy procentowe a gospodarka. Dylematy Unii Gospodarczej $i$ Walutowej, Wydawnictwo Politechniki Radomskiej, Radom 2006.

Landreth H., Colander D. C., Historia myśli ekonomicznej, Wydawnictwo Naukowe PWN, Warszawa 2005.

La to s ze k E., Etapy integracji walutowej w Unii Europejskiej, [w:] W. Pacho (red.), Europejska Integracja Monetarna od A do Z, Narodowy Bank Polski, Warszawa 2009.

Łon E., Dlaczego Polska nie powinna wchodzić do strefy euro?, Wydawnictwo Fundacja im. Bolesława Chrobrego, Poznań 2007.

Łu c zka T., Kapitat obcy w matym i średnim przedsiębiorstwie, Wydawnictwo Naukowe PWN, Warszawa-Poznań 2001.

Lu t k o w s ki K., Od złotego do euro. Źródta obaw i nadziei, TWIGGER, Warszawa 2004.

Łyziak T., Przystupa J., W róbel E., Monetary Policy Transmission in Poland: A Study of the Importance of Interest Rate and Credit Channels, „SUERF Studies” 2008, no. 1.

Maddaloni A., Peydro J. L., Sopel S., Does Monetary Policy Affect Bank Credit Standards, European Central Bank, Frankfurt n. Menem 2008.

Mahadeva L., Sinclair P., The transmission mechanism of monetary policy, materiał przygotowany na Central Bank Governors' Symposium, Bank Anglii, 08.06.2001.

Manki w N. G., T a yl or M. P., Makroekonomia, PWE, Warszawa 2009.

Marciniak S. (red.), Makro- $i$ mikroekonomia. Podstawowe problemy, Wydawnictwo Naukowe PWN, Warszawa 2005.

Marszałek P., Zastosowanie teorii gier do badania koordynacji polityki pieniężnej i polityki fiskalnej, [w:] W. Przybylska-Kapuścińska (red.), Studia z bankowości centralnej, „Zeszyty Naukowe Akademii Ekonomicznej w Poznaniu” 2005, nr 56.

Mesjasz Cz., Mesjasz L., Wycena kredytu dla przedsiębiorstwa - zatożenia teoretyczne i przeglad metod, „Bank i Kredyt”, wrzesień 2000.

Mikołajczyk B., Krawc zyk M., Sektor przedsiębiorstw mikro, matych i średnich w krajach Unii Europejskiej, „Studia Europejskie” 2006, nr 2.

Mile w ski R. (red.), Podstawy ekonomii, Wydawnictwo Naukowe PWN, Warszawa 1999.

Mir a F. S., On Capital Structure in the Small and Medium Enterprises: The Spanish Case, Universidad Cardenal Herrera, Elche 2001. 
Mis al a J. (red.), Proces integracji gospodarczej Polski z krajami członkowskimi Unii Europejskiej w świetle teorii, Wydawnictwo Politechniki Radomskiej, Radom 2001.

Mishkin F. S., Ekonomika pieniądza, bankowości i rynków finansowych, Wydawnictwo Naukowe PWN, Warszawa 2002.

Mish kin F. S., The Cause and Propagation of Financial Instability: Lessons for Policymakers, Federal Reserve Bank of Kansas City, 1997.

M i s h k in F. S., The Channels of Monetary Transmission. Lessons for Monetary Policy, „National Bureau of Economic Research Working Paper" 1996, no. 5464.

M is z t al P., Teoria parytetu stóp procentowych a ksztattowanie się kursu złotego w latach 1995 -2002, [w:] J. L. B e d n a r c z y k (red.), Stopy procentowe a gospodarka. Eseje z teorii i polityki stóp procentowych, Wydawnictwo Politechniki Radomskiej, Radom 2004.

Mroczek W., Wptyw wprowadzenia euro na stopień otwartości i zmiany strukturalne w handlu krajów strefy euro, [w:] Raport na temat uczestnictwa Rzeczypospolitej Polskiej w trzecim etapie Unii Gospodarczej i Walutowej, Projekty badawcze część IV, Narodowy Bank Polski, Warszawa 2009.

Mu cha-Les zko B., Strefa euro. Wprowadzenie. Funkcjonowanie. Międzynarodowa rola euro, Wydawnictwo Uniwersytetu Marii Curie-Skłodowskiej, Lublin 2007.

Munde11 R. A., A Theory of Optimum Currency Areas, „The American Economic Review” 1961, vol. 9.

Musielak-Linkowska M., Cel inflacyjny w Polsce. Założenia i realizacja, Wydawnictwo Fachowe CeDeWu, Warszawa 2007.

Narodowy Bank Polski, Wydawnictwo NBP, Warszawa 2005.

N a ro żn y T., Czynności kredytowe banku, Biblioteka Menedżera i Bankowca, Warszawa 2000.

No g a M. (red.), Makroekonomia, Akademia Ekonomiczna im. Oskara Langego, Wrocław 1995.

Oręziak L., Polityczne i ekonomiczne uwarunkowania ustanowienia $i$ funkcjonowania Unii Gospodarczej i Walutowej, „Bank i Kredyt” 1998, nr 12.

Ost a z e w s ki J., Finanse, Difin, Warszawa 2008.

Padoa-Schioppa T., Accession Countries on the Way to Euro: A Central Banker's View, speech at the conference on „Economic Policy Directions in the OECD Countries and Emerging Markets: Analysing the Experiences", Warszawa 21.07.2002.

Paulin G., Credibility with Flexibility: The Evolution of Inflation - Targeting Regimes, 1990 -2006, „Bank of Canada Review” 2006.

Pawłowicz L., Wierzba R. (red.), Finanse przedsiębiorstw wobec procesów globalizacji, Gdańska Akademia Bankowa, Gdańsk-Jurata 2003.

Pe e k J., R o s e n g re en E., The Evaluation of Small Business Lending, „New England Economic Review” 1998, Federal Reserve Bank of Boston, [w:] I. Ty moczko, M. Pawłowska, Uwarunkowania dostępności kredytu bankowego - analiza polskiego rynku, „Bank i Kredyt", czerwiec 2007.

Peers man G., S mets F., The Industry Effects of Monetary Policy in the Euro Area, Working Paper No. 165, European Central Bank, Frankfurt 2002.

Petersen M. A., Rajan R. G., The Benefis of Lending Relationships: Evidence from Small Business Data, ,The Journal of Finance” 1994, vol. 49, no. 1.

Peters en M. A., R aj a n R. G., The Effect of Credit Market Competition on Lending Relationships, „The Quarterly Journal of Economics” 1995, vol. 110(2). 
P i e tr y k a I., Harmonizacja instrumentów NBP ze standardami europejskimi - rezerwa obowiąkowa, [w:] M. Noga (red.), Ponadnarodowa i narodowa polityka monetarna na świecie, CeDeWu, Warszawa 2009.

Pietrzak B., Polański Z., Woźniak B., System finansowy w Polsce, Wydawnictwo Naukowe PWN, Warszawa 2008.

Pohulak-Żołęd ow ska E., Zastosowanie ulg i zwolnień w podatkach dochodowych a rozwój MSP ocena, prezentacja wyników badań, [w:] D. Kop y cińska (red.), Funkcjonowanie gospodarki polskiej w warunkach integracji i globalizacji, Katedra Mikroekonomii Uniwersytetu Szczecińskiego, Szczecin 2005.

P op ow T., Badanie wiarygodności kredytowej przedsiębiorstw przez bank, [w:] A. K o p c z y k (red.), Wiarygodność ekonomiczna przedsiębiorstwa - ocena i ksztattowanie, Wyższa Szkoła Finansów i Zarządzania, Białystok 2004.

Posen A. S., Why central bank independence does not cause low inflation: There is no institutional fix for policy, Finance and the International Economy, Oxford University Press, Oxford 1993.

Procesy restrukturyzacji dużych przedsiębiorstw, Instytut Nauk Ekonomicznych PAN, Warszawa 1998.

Proczek M., Polityka pieniężna w strefie euro. Europejska integracja monetarna od A do Z, „Bank i Kredyt” 2008, nr 6.

Przybylska-Kapuścińska W. (red.), Polityka pieniężna. Cele, strategie i instrumenty, Wydawnictwo Akademii Ekonomicznej w Poznaniu, Poznań 2002.

Przybylska-Kapuścińska W. (red.), Wspótczesna polityka pieniężna, Difin, Warszawa 2008.

Przybylska-Kapuścińska W., Operacje otwartego rynku w absorpcji nadptynności, [w:] W. Pr zybylska-Ka puścińska (red.), Studia z bankowości centralnej, Wydawnictwo Akademii Ekonomicznej w Poznaniu, Poznań 2005.

Przybylska-Kapuścińska W., Polityka stóp procentowych w Polsce i makroekonomiczne skutki, [w:] P. Karpuś, J. W ęcławski (red.), Problemy rozwoju rynku finansowego w aspekcie wzrostu gospodarczego, Wydawnictwo Uniwersytetu Marii Curie-Skłodowskiej, Lublin 2007.

Przybylska-Kapuścińska W., Spory wokót polityki stóp procentowych w Polsce, [w:] J. L. B ednarczyk (red.), Stopy procentowe a gospodarka. Dylematy Unii Gospodarczej $i$ Walutowej, Wydawnictwo Instytutu Technologii Eksploatacyjnej Państwowego Instytutu Badawczego, Radom 2006.

P u ł a s k a - T u r y n a B., Statystyka dla ekonomistów, Difin, Warszawa 2008.

P s zc zółk a I., Zmiany cen akcji poszczególnych branż w strefie euro a polityka pieniężna Europejskiego Banku Centralnego, [w:] J. L. B ed narczyk (red.), Stopy procentowe a gospodarka. Dylematy Unii Gospodarczej $i$ Walutowej, Wydział Ekonomiczny Politechniki Radomskiej, Radom 2006.

Pyka I., Bank centralny na wspótczesnym rynku pieniężnym, dyscyplina regulacyjna, skuteczność, instrumenty, Wydawnictwo C. H. Beck, Warszawa 2010.

Realizacja polityki pieniężnej w strefie euro. Dokumentacja ogólna instrumentów i procedur polityki pieniężnej w Eurosystemie, European Central Bank, Frankfurt, luty 2005.

Rola Narodowego Banku Polskiego w procesie integracji europejskiej, Narodowy Bank Polski, Warszawa 2003. 
Ró żań s ki J. (red.), Inwestycje rzeczowe i kapitałowe, Difin, Warszawa 2006.

R y b ińs s i K., Globalizacja w trzech odstonach, offshoring - globalne nierównowagi - polityka pieniężna, Difin, Warszawa 2007.

Rybiński K., The Euro adoption: Assessing benefits and costs, Narodowy Bank Polski, Warszawa 2007.

S ch a al P., Pieniądz i polityka pieniężna, PWE, Warszawa 1996.

Schardax F., Realna konwergencja, realne kursy walutowe oraz inflacja $w$ krajach Europy Środkowo-Wschodniej, referat przygotowany na konferencję „Polska droga do euro”, Oesterreichische Nationalbank, październik 2001.

S cheller H. J., European Central Bank - history, role and functions, European Central Bank, Frankfurt n. Menem 2004.

Sej-Kolas a M., Zielińska A., Excel w statystyce, Wydawnictwo Akademii Ekonomicznej im. Oskara Langego we Wrocławiu, Wrocław 2004.

Sierpińska M., Jachna T., Ocena przedsiębiorstwa wedtug standardów światowych, Wydawnictwo Naukowe PWN, Warszawa 2004.

S k olk a J., Input - output structural decompsition analysis for Austria, „Journal of Policy Modeling" 1989.

Skowronek-Mielczarek A., Małe i średnie przedsiębiorstwa. Źródta finansowania, Wydawnictwo C. H. Beck, Warszawa 2003.

Sławiński A., O siński J., Operacje otwartego rynku banku centralnego, Fundacja Edukacji i Badań Bankowych, Warszawa 1995.

Sławiński A., Znaczenie czynników ryzyka towarzyszących wchodzeniu Polski do ERM2 i do strefy euro, Kongres Ekonomistów Polskich, Warszawa 29-30 listopad 2007.

S obol M., Dostosowanie ram operacyjnych polityki pieniężnej NBP do wymogów Eurosystemu, [w:] J. L. B e d n arc z y k (red.), Stopy procentowe a gospodarka. Dylematy Unii Gospodarczej $i$ Walutowej, Wydział Ekonomiczny Politechniki Radomskiej, Radom 2006.

S obol M., Polityka pieniężna Narodowego Banku Polskiego $w$ drodze do euro, Wydawnictwo Fachowe CeDeWu, Warszawa 2008.

S o snow ski M., Podatkowe instrumenty polityki fiskalnej państwa a rozwój przedsiębiorczości, [w:] D. Ko p y c ińska (red.), Funkcjonowanie gospodarki polskiej w warunkach integracji i globalizacji, Katedra Mikroekonomii Uniwersytetu Szczecińskiego, Szczecin 2005.

Strategia polityki pieniężnej po 2003 roku, Narodowy Bank Polski, Warszawa 2003.

S tryjek J., Konwergencja nominalna a konwergencja realna - kiedy będzie możliwe wprowadzenie euro?, Informator Euro w Polsce w roku 20??. Ekonomiczne, polityczne i społeczne aspekty rezygnacji waluty narodowej, Szkoła Główna Handlowa, Warszawa.

S u m mer s L., How Should Long-Term Monetary Policy de Determined?, „Journal of Money, Credit and Banking" 1991, vol. 13.

Survey on the access to finance of small and medium-sized enterprises in the euro area: Second half of 2009, European Central Bank, February 2010.

S vensson L. E., Monetary Policy and Real Stabilization, Stockholm University, „National Bureau of Economic Research Working Paper" 2003, W9486.

Ś widerski J., Finanse banku komercyjnego, wydanie drugie, nowe regulacje, standardy, przepisy, Biblioteka Menedżera i Bankowca, Warszawa 1999.

Ś wi ęt oń M., Terminowa struktura dochodowości skarbowych papierów wartościowych w Polsce w latach 1998-2001, „Materiały i Studia” 2002, z. 150. 
S z c ze p a ń s k a O., Operacje otwartego rynku jako element systemu operacyjnego EBC i banków centralnych w krajach kandydujących do Unii Europejskiej, „Bank i Kredyt” 2002, nr 4.

S zczęsna A., Ryzyko i mechanizm dźwigni $w$ działalności przedsiębiorstwa, [w:] Zarzadzanie finansami. Wspótczesne tendencje $w$ teorii i praktyce, Uniwersytet Szczeciński, Szczecin 2000.

Szeląg K., Integracja walutowa w Europie Zachodniej w okresie powojennym, „Materiały i Studia” 2003, nr 166.

Szelągowsk a A., Interest rates as a factor impacting the price of basic bank products, [w:] J. L. B ednarczyk (red.), Stopy procentowe a gospodarka. Eseje z teorii i polityki stóp procentowych, Wydawnictwo Politechniki Radomskiej, Radom 2004.

T a y 1 o r J. B., Zrozumieć kryzys finansowy, Wydawnictwo Naukowe PWN, Warszawa 2010.

Taylor J., Low Inflation, Deflation, and Policies for Future Price Stability, „Monetary and Economic Studies" 2001, vol. 2 (Special Edition).

T a yl o r J., Monetary Transmission Mechanism: An Empirical Framework, „Journal of Economic Perspectives" 1995, vol. 9.

Te mpert on P., Felberg S. J. A. (red.), Euro Wspólna Waluta, Warszawa 2001.

The Implementation of Monetary Policy in the Euro Area. General Documentation on Eurosystem Monetary Policy Instruments and Procedures, European Central Bank, Frankfurt n. Menem 2008.

The Monetary Policy of the ECB, European Central Bank, Frankfurt n. Menem 2004.

Tre mb iń s k a J., Polityka pieniężna i jej wptyw na gospodarkę w Polsce po 1990 roku w warunkach nadptynności sektora bankowego, [w:] M. M a r cin kow ska, St. Wiet e s ka (red.), Harmonizacja bankowości i ubezpieczeń w skali narodowej i europejskiej, Difin, Warszawa 2007.

Trichet J.-C., The euro after two years, ,Journal of Common Market Studies” 2001, vol. 39, no. 1.

Ty moczko D., Ewolucja systemu finansowego a skuteczność instrumentów polityki pieniężnej, Narodowy Bank Polski, „Bank i Kredyt” 2002, nr 3, Warszawa.

Ty moczko D., Reakcje wybranych banków centralnych (FED i EBC) na kryzys, [w:] J. O s ińs ki (red.), Banki centralne wobec kryzysu ekonomicznego, Szkoła Główna Handlowa, Warszawa 2010.

U rb ań s ka A., Polityka monetarna: Wspótczesna teoria i analiza empiryczna dla Polski, „Materiały i Studia" 2002, z. 148.

V and en berg P., Micro, Small and Medium-sized Enterprises and the Global Economic Crisis, Impact and Policy Responses, International Labour Organization, 2009.

$\mathrm{Vlad}$ O., The use of the monetary policy instruments by central banks under globalization, Alexandru Ioan University, Iasi - Romania 2008.

W ą s o w s ki W., Ekonomika i finanse banku komercyjnego, Difin, Warszawa 2004.

W at a n abe W., How Do Relationship Lenders Price Loans to Small Firms?, „Hold-up” Costs, Transparency, and Private and Public Security, Faculty of Business and Commerce, Keio University, September 2007.

W d ow ińs ki P., Ekonometryczna analiza popytu na kredyt w polskiej gospodarce, Urząd Komisji Nadzoru Finansowego, Warszawa 2011/DAR/A/J/2011/00.

W elf e W., Welf e A., Ekonometria stosowana, PWE, Warszawa 2004. 
Wieczorkiewicz A., Dąbrowska K., Gruszczyński M., Integracja walutowa Polski w ramach Europejskiego Systemu Walutowego na tle doświadczeń unijnych, ,Studia Europejskie" 2005, nr 1, Centrum Europejskie Uniwersytetu Warszawskiego.

Wi erzba R., Euro - dziesięć lat funkcjonowania, [w:] W. Przybylska-Kapuścińska (red.), Studia z bankowości centralnej i polityki pieniężnej, Difin, Warszawa 2009.

Wi erzba R., Europejski Bank Centralny, [w:] R. Kokoszczyński, B. Pietrzak (red.), Bankowość centralna od A do Z, Narodowy Bank Polski, Warszawa 2006.

W i ęznow ski A., Monetarne przyczyny kryzysu finansowego w USA 2007/2008, [w:] M. Nog a, M. K. S t a wi ck a (red.), Ponadnarodowa i narodowa polityka monetarna na świecie, CeDeWu, Warszawa 2009.

Wilc zyńs ki W., Rynek i polityka pieniężna w Polsce u progu XXI wieku, Wydawnictwo WSB, Poznań 2001.

Wójcik C., Źródta zmian cen relatywnych i dynamiki realnego kursu walutowego - przegląd badań teoretycznych, ,Bank i Kredyt” 2005, nr 9.

Wojtyna A., Ewolucja keynesizmu a główny nurt ekonomii, Wydawnictwo Naukowe PWN, Warszawa 2000.

W oj t y n a A., Kontrowersje wokót skuteczności polityki pieniężnej, „Bank i Kredyt” 2000, nr 7-8.

Wojtyna A., Skuteczność polityki pieniężnej w warunkach niskiej inflacji: Problem zerowej granicy nominalnych stop procentowych, „Bank i Kredyt” 2001, nr 7.

Wojtyn a A., Szkice o niezależności banku centralnego, Wydawnictwo Naukowe PWN, Warszawa-Kraków 1998.

W o j t y n a A., Szkice o polityce pieniężnej, PWE, Warszawa 2004.

Wróbel E., Pawłowska M., Monetary transmission in Poland: Some evidence on interest rate and credit channles, „Materiały i Studia” 2002, nr 24.

Wstęna informacja o kondycji sektora przedsiębiorstw ze szczególnym uwzględnieniem stanu koniunktury w IV kw. 2004, Narodowy Bank Polski, Warszawa 2005.

Wypłosz Ch., Do We Know, [w:] Z. Knakiewicz (red.), Wspótczesny pieniądz w teorii i praktyce, Wydawnictwo Akademii Ekonomicznej w Poznaniu, Poznań 2006.

W y р с h M. (red.), Finanse przedsiębiorstwa $z$ elementami zarzadzania $i$ analizy, Absolwent, Łódź 2000.

\section{Raporty i sprawozdania}

79 Annual Report, 1 April 2008-31 March 2009, Basel, 29 June 2009. Annual Report 1999, European Central Bank, Frankfurt n. Menem 2000. Annual Report 2000, European Central Bank, Frankfurt n. Menem 2001. Annual Report 2001, European Central Bank, Frankfurt n. Menem 2002. Annual Report 2002, European Central Bank, Frankfurt n. Menem 2003. Annual Report 2003, European Central Bank, Frankfurt n. Menem 2004. Annual Report 2004, European Central Bank, Frankfurt n. Menem 2005. Annual Report 2005, European Central Bank, Frankfurt n. Menem 2006. Annual Report 2006, European Central Bank, Frankfurt n. Menem 2007. Annual Report 2007, European Central Bank, Frankfurt n. Menem 2008. Annual Report 2008, European Central Bank, Frankfurt n. Menem 2009. Annual Report 2009, European Central Bank, Frankfurt n. Menem 2010. 
Annual Report on the Euro Area 2006, „European Economy” 2006, No. 3, European Commission, Luxembourg 2007.

Annual Report on the Euro Area 2009, „European Economy” 2009, No. 6, European Commission, Luxembourg 2009.

BIS Working Party on Monetary Policy in Central and Eastern Europe, Mimeo 2003.

Działalność przedsiębiorstw niefinansowych w 2012 roku, Główny Urząd Statystyczny, Warszawa 2013.

ECB Monthly Bulletin, biuletyny miesięczne Europejskiego Banku Centralnego od 1998 r. do 2010 r., Frankfurt n. Menem.

Informacja po posiedzeniu Rady Polityki Pieniężnej w dniach 26-27 października 2010, Narodowy Bank Polski, Rada Polityki Pieniężnej, Warszawa, październik 2010.

Informacja z posiedzenia Rady Polityki Pieniężnej w dniach 27-28 listopada 2001, Narodowy Bank Polski, Warszawa 2001.

Instrumenty polityki pieniężnej na tle ptynności sektora bankowego w 2004 roku, Narodowy Bank Polski, Warszawa 2005.

Instrumenty polityki pieniężnej Narodowego Banku Polskiego w 2005 roku. Ptynność sektora bankowego, Narodowy Bank Polski, Warszawa 2006.

Instrumenty Polityki Pieniężnej Narodowego Banku Polskiego w 2006 roku. Ptynność sektora bankowego, Raport NBP, Warszawa 2006.

Instrumenty polityki pieniężnej Narodowego Banku Polskiego w 2007 roku. Ptynność sektora bankowego, Narodowy Bank Polski, Warszawa 2008.

Instrumenty Polityki Pieniężnej Narodowego Banku Polskiego w 2008 roku. Ptynność sektora bankowego, Raport NBP, Warszawa 2009.

Komunikat Komisji Europejskiej: Komunikat bankowy, DzU C 270 z 25 października 2008 r.

Komunikat Komisji Europejskiej: Komunikat o dokapitalizowaniu, DzU C z 10 i 15 stycznia 2009 r.

Komunikat Komisji Europejskiej: Komunikat w sprawie aktywów o obniżonej wartości, DzU C 72 z 26 marca 2009 r.

Komunikat Komisji Europejskiej: Komunikat w sprawie przywrócenia rentowności i oceny środków restrukturyzacyjnych stosowanych w sektorze finansowym, DzU C 195 z 19 sierpnia 2009 r.

Komunikat Narodowego Banku Polskiego w sprawie przyczyn utrzymywania się na wysokim poziomie stóp rynku pieniężnego w okresie 26.10.2001-22.11.2001, Narodowy Bank Polski, Warszawa.

Monetary policy transmission in the euro area, a decade after the introduction of the euro, „Monthly Bulletin” 2010, vol. 5, European Central Bank.

Monetary policy transmission in the euro zone, „EBC Monthly Bulletin” 2000, vol. 7.

Monthly Bulletin 10. anniversary EBC, European Central Bank, Frankfurt n. Menem 2008.

Monthly Bulletin August 2008, European Central Bank, Frankfurt n. Menem, August 2009.

Ocena kondycji finansowej przedsiębiorstw w 2001 roku ze szczególnym uwzględnieniem zjawisk pieniężno-kredytowych ( $w$ świetle badań ankietowych i danych GUS), Narodowy Bank Polski, Warszawa, czerwiec 2002.

Ocena kondycji finansowej przedsiębiorstw w 2002 roku ze szczególnym uwzględnieniem zjawisk pieniężno-kredytowych ( $w$ świetle badań ankietowych i danych GUS), Narodowy Bank Polski, Warszawa, lipiec 2003.

Ocena kondycji finansowej przedsiębiorstw w 2003 roku w świetle danych GUS, Narodowy Bank Polski, Warszawa, maj 2004.

Ocena kondycji finansowej przedsiębiorstw w 2005 roku na podstawie danych F-01 GUS, Narodowy Bank Polski, Warszawa, sierpień 2006.

Rachunki Kwartalne Produktu Krajowego Brutto w latach 1995-2003, Główny Urząd Statystyczny, Warszawa 2004.

Raport na temat petnego uczestnictwa Rzeczypospolitej Polskiej w trzecim etapie Unii Gospodarczej $i$ Walutowej, Narodowy Bank Polski, Warszawa 2009. 
Raport na temat uczestnictwa Rzeczypospolitej Polskiej w trzecim etapie Unii Gospodarczej

$i$ Walutowej, Projekty badawcze część IV, Narodowy Bank Polski, Warszawa 2009.

Raport o inflacji 1998 rok, Narodowy Bank Polski, Warszawa, czerwiec 1999.

Raport o inflacji 1999 rok, Narodowy Bank Polski, Warszawa, czerwiec 2000.

Raport o inflacji 2000 rok, Narodowy Bank Polski, Warszawa 2001.

Raport o inflacji 2001 rok, Narodowy Bank Polski, Warszawa 2002.

Raport o inflacji 2002 rok, Narodowy Bank Polski, Warszawa 2003.

Raport o inflacji 2003 rok, Narodowy Bank Polski, Warszawa 2004.

Raport o inflacji 2005 rok, Narodowy Bank Polski, Warszawa 2005.

Raport o inflacji 2006 rok, Narodowy Bank Polski, Warszawa 2007.

Raport o inflacji 2010 rok, Narodowy Bank Polski, Warszawa 2010.

Raport o stabilności systemu finansowego czerwiec 2009, Narodowy Bank Polski, Warszawa, czerwiec 2009.

Raport o stanie sektora matych i średnich przedsiębiorstw w Polsce w latach 1997-1998, Polska

Agencja Rozwoju Przedsiębiorczości, Warszawa 1999.

Raport o stanie sektora matych i średnich przedsiębiorstw w Polsce w latach 1999-2000, Polska

Agencja Rozwoju Przedsiębiorczości, Warszawa 2001.

Raport o stanie sektora matych i średnich przedsiębiorstw w Polsce w latach 2001-2002, Polska

Agencja Rozwoju Przedsiębiorczości, Warszawa 2003.

Raport o stanie sektora matych i średnich przedsiębiorstw w Polsce w latach 2002-2003, Polska

Agencja Rozwoju Przedsiębiorczości, Warszawa 2004.

Raport o stanie sektora matych i średnich przedsiębiorstw w Polsce $w$ latach 2005-2006, Polska

Agencja Rozwoju Przedsiębiorczości, Warszawa 2007.

Raport o stanie sektora matych i średnich przedsiębiorstw w Polsce w latach 2006-2007, Polska

Agencja Rozwoju Przedsiębiorczości, Warszawa 2008.

Raport o stanie sektora małych i średnich przedsiębiorstw w Polsce w latach 2007-2008, Polska

Agencja Rozwoju Przedsiębiorczości, Wydawnictwo Naukowe Instytutu Technologii Eks-

ploatacji - PIB, Radom 2009.

Raport o stanie sektora małych i średnich przedsiębiorstw w Polsce w latach 2008-2009, Polska

Agencja Rozwoju Przedsiębiorczości, Warszawa 2010.

Raport o stanie sektora matych $i$ średnich przedsiębiorstw w Polsce $w$ latach 2011-2012, Polska

Agencja Rozwoju Przedsiębiorczości, Warszawa 2013.

Raport roczny 1998, Narodowy Bank Polski, Warszawa 1999.

Raport roczny 1999, Narodowy Bank Polski, Warszawa 2000.

Raport roczny 2000, Narodowy Bank Polski, Warszawa 2001.

Raport roczny 2001, Narodowy Bank Polski, Warszawa 2002.

Raport roczny 2002, Narodowy Bank Polski, Warszawa 2003.

Raport roczny 2003, Narodowy Bank Polski, Warszawa 2004.

Raport roczny 2004, Narodowy Bank Polski, Warszawa 2005.

Raport roczny 2005, Narodowy Bank Polski, Warszawa 2006.

Raport roczny 2006, Narodowy Bank Polski, Warszawa 2007.

Raport roczny 2007, Narodowy Bank Polski, Warszawa 2008.

Raport roczny 2008, Narodowy Bank Polski, Warszawa 2009.

Raport Roczny 2009, Europejski Bank Centralny, Frankfurt n. Menem 2010.

Raport roczny 2009, Narodowy Bank Polski, Warszawa 2010.

Raport roczny Ptynność sektora bankowego. Instrumenty polityki pieniężnej NBP, Narodowy Bank Polski, Warszawa 2009.

Real Interest Rate: Movements and Determinants, „Deutsche Bundesbank Monthly Report” 2001, No. 7.

Sprawozdanie z działalności NBP w 2004 r., Narodowy Bank Polski, Warszawa 2004.

Sprawozdanie z wykonania założeń polityki pieniężnej na rok 2005, Narodowy Bank Polski, Warszawa 2006. 
Sprawozdanie z wykonania zatożeń polityki pieniężnej na rok 2008, Narodowy Bank Polski, Warszawa 2009.

Sprawozdanie z wykonania założeń polityki pieniężnej na rok 2009, Narodowy Bank Polski, Warszawa 2010.

Sprawozdanie z wykonania założeń polityki pieniężnej w 1998 roku, Narodowy Bank Polski, Warszawa 1999.

Sprawozdanie z wykonania założeń polityki pieniężnej w 1999 roku, Narodowy Bank Polski, Warszawa 2000.

Sprawozdanie z wykonania zatożeń polityki pieniężnej w 2000 roku, Narodowy Bank Polski, Warszawa 2001.

Sprawozdanie z wykonania założeń polityki pieniężnej w 2001 roku, Narodowy Bank Polski, Warszawa 2002.

Sprawozdanie z wykonania założeń polityki pieniężnej w 2002 roku, Narodowy Bank Polski, Warszawa 2003.

Sprawozdanie z wykonania założeń polityki pieniężnej w 2003 roku, Narodowy Bank Polski, Warszawa 2004.

Sprawozdanie z wykonania założeń polityki pieniężnej w 2004 roku, Narodowy Bank Polski, Warszawa 2005.

Sprawozdanie z wykonania założeń polityki pieniężnej w 2006 roku, Narodowy Bank Polski, Warszawa 2007.

Średniookresowa strategia polityki pieniężnej na lata 1999-2003, Rada Polityki Pieniężnej, Narodowy Bank Polski, Warszawa, wrzesien 1998.

Sytuacja na rynku kredytowym, wyniki ankiety do przewodniczacych komitetów kredytowych, II kwartał 2004, Narodowy Bank Polski, Warszawa, maj 2004.

Sytuacja na rynku kredytowym, wyniki ankiety do przewodniczacych komitetów kredytowych, I kwartał 2005, NBP, Warszawa, styczeń 2005.

Sytuacja na rynku kredytowym, wyniki ankiety do przewodniczacych komitetów kredytowych, II kwartał 2005, Narodowy Bank Polski, Warszawa, kwiecień 2005.

Sytuacja na rynku kredytowym, wyniki ankiety do przewodniczacych komitetów kredytowych, III kwartał 2005, Narodowy Bank Polski, Warszawa, lipiec 2005.

Sytuacja na rynku kredytowym, wyniki ankiety do przewodniczacych komitetów kredytowych, I kwartał 2006, Narodowy Bank Polski, Warszawa, styczeń 2006.

Sytuacja na rynku kredytowym, wyniki ankiety do przewodniczacych komitetów kredytowych, I kwartał 2007, Narodowy Bank Polski, Warszawa, styczeń 2007.

Sytuacja na rynku kredytowym, wyniki ankiety do przewodniczacych komitetów kredytowych, II kwartał 2008, Narodowy Bank Polski, Warszawa, kwiecień 2008.

Sytuacja na rynku kredytowym, wyniki ankiety do przewodniczacych komitetów kredytowych, I kwartał 2009, Narodowy Bank Polski, Warszawa 2009.

Sytuacja na rynku kredytowym, wyniki ankiety do przewodniczacych komitetów kredytowych, IV kwartał 2009, Narodowy Bank Polski, Warszawa, październik 2009.

Sytuacja na rynku kredytowym, wyniki ankiety do przewodniczacych komitetów kredytowych, I kwartał 2010, Narodowy Bank Polski, Warszawa, styczeń 2010.

Zalecenie Rady Prezesów EBC w sprawie udzielania gwarancji państwa dla zadtużenia banków z 20 października $2008 \mathrm{r}$.

Zalecenie Rady Prezesów EBC w sprawie ustalania cen środków stużących dokapitalizowaniu z 20 listopada $2008 r$.

Założenia polityki pieniężnej na 2000 rok, Narodowy Bank Polski, Warszawa 1999.

Założenia polityki pieniężnej na 2001 rok, Narodowy Bank Polski, Warszawa 2000.

Założenia polityki pieniężnej na 2002 rok, Narodowy Bank Polski, Warszawa 2001.

Założenia polityki pieniężnej na 2003 rok, Narodowy Bank Polski, Warszawa 2002.

Założenia polityki pieniężnej na 2004 rok, Narodowy Bank Polski, Warszawa 2003. 


\section{Akty prawne}

Council Decision (98/317/EC) of 3 May 1998 in Accordance with Article 109(4) of the Treaty, Official Journal of the European Communities L 139, 11 May 1998.

Council Regulation (EC) concerning the application of minimum reserves by the European Central Bank, Official Journal of the European Communities, No. 2531/98 of 23 November 1998;

Konstytucja Rzeczpospolitej Polskiej dnia 2 kwietnia 1997 r., DzU 1997, nr 78, poz. 483 z późn. $\mathrm{zm}$.

Protocol on the Convergence Criteria Referred to in Article 109j of the Treaty Establishing European Community, Official Journal of the European Communities C 191, 29 July 1992.

Protocol on the Excessive Deficit Procedure, Official Journal of European Communities C 191, 29 July 1992.

Protocol on the Statute of the European Central Bank System and of the European Central Bank, Official Journal of the European Communities C 191, 29 July 1992.

Regulation (EC) No 1745/2003 of the European Central Bank of 12 September 2003 on the application of minimum reserves, Official Journal of the European Communities, 2 October 2003.

Rekomendacja Komisji Europejskiej nr 2003/361/EC z 6 maja 2003 r., OJ L 124 z 20.05.2003.

Rozporzadzenie EBC w sprawie rezerw minimalnych $n r$ 2818/98, DzU L 356, 30.12.1998.

Treaty on European Union, ECSC-EEC-EAEC, Brussels, Luxemburg 1992.

Uchwata nr 15/2004 Zarzadu Narodowego Banku Polskiego z dnia 13 kwietnia 2004 r. w sprawie zasad i trybu naliczania oraz utrzymywania przez banki rezerwy obowiazkowej, nr 3, poz. 4.

Uchwała nr 9/2009 Rady Polityki Pieniężnej z dnia 27 maja 2009 r. zmieniająca uchwate w sprawie stóp rezerwy obowiązowej banków $i$ wysokości oprocentowania rezerwy obowiązowej, DzU NBP nr 10, Warszawa 2009.

Uchwała Rady Polityki Pieniężnej z dnia 29 września 1998 r. w sprawie założeń polityki pieniężnej na 1999 r., Monitor Polski z 1998 r., nr 36.

Uchwała Rady Polityki Pieniężnej z dnia 30 września 2009 r. w sprawie ustalenia założeń polityki pieniężnej (M.P. z dnia 17 września 2007 r.), zmiany w tekście jednolitym w DzU 2005, nr 167, poz. 1398; DzU 2006, nr 157, poz. 1119 oraz DzU 2007, nr 25, poz. 162 i nr 61, poz. 410.

Uchwała Zarzadu Narodowego Banku Polskiego z dnia 13 października 2008 r. zmieniająca uchwate $w$ sprawie wprowadzenia „Regulaminu refinansowania banków kredytem lombardowym przez Narodowy Bank Polski”, DzU NBP nr 16, 15 października 2008 r.

Ustawa z dnia 21 lipca 2006 r. o nadzorze nad rynkiem finansowym, DzU 2006, nr 157, poz. 1119.

Ustawa z dnia 29 sierpnia 1997 r. o Narodowym Banku Polskim, tekst ujednolicony - stan na dzień 22 czerwca $2010 \mathrm{r}$.

Ustawa z dnia 29 sierpnia 1997 r. Prawo bankowe, DzU 2009, nr 18, poz. 97; nr 42, poz. 341; nr 65 , poz. 545.

\section{Zasoby internetowe}

B a las s a B., The theory of economic integration, George Allen and Unwin, London 1964, [za:] zasoby witryny internetowej: http://www.questia.com/PM.qst?a=o\&d=34589359.

B arc zy k R., Rola pieniężnej polityki stabilizacji w procesie wchodzenia Polski do Unii Gospodarczej i Walutowej, [za:] zasoby witryny internetowej:

http://mikro.univ.szczecin.pl/bp/pdf/61/9.pdf. 
Bernanke B. S., Friedman's Monetary Framework: Some Lessons, On Milton Friedman's Ninetieth Birthday, University of Chicago, Chicago 2002, [za:] zasoby witryny internetowej: www.federalreserve.gov/boarddocs/speeches/2002/20021108/default.htm.

$\mathrm{B}$ og u sła w s k a W., Instrumenty polityki pieniężnej NBP w kontekście dostosowań do wymogów $E S B C$, Uniwersytet Szczerski, Szczecin, [za:] zasoby witryny internetowej: www.konferencja.edu.pl/ref8/pdf/pl/Boguslawska-Szczecin-polski.pdf.

$\mathrm{Chmielewski} \mathrm{T.,} \mathrm{Interest} \mathrm{rate} \mathrm{pass-through} \mathrm{in} \mathrm{the} \mathrm{Polish} \mathrm{banking} \mathrm{sektor} \mathrm{and} \mathrm{bank-specific}$ financial disturbances, MPRA Paper No. 5133, 2003, [za:] zasoby witryny internetowej: http://mpra.ub.uni-muenchen.de/5133/.

Duliniec A., Determinanty polityki finansowej przedsiębiorstwa, eFinanse - finansowy kwartalnik internetowy, [za:] zasoby witryny internetowej: www.e-finanse.com.

Gó re c ki B., Podstawowy kurs nowoczesnej ekonometrii, [za:] zasoby witryny internetowej: uczelniawarszawska.pl/materialy/1197726936.pdf.

Houben E., Nip pel P., The Role of Credit Rationing and collateral in Debt Financing, 2001, s. 1-5, [za:] zasoby witryny internetowej: www.bwl.uni-kiel.de/FiWi/pdf2/collateral.pdf.

Kowalski M., Wptyw polityki pieniężnej na inwestycje przedsiębiorstw, [za:] zasoby witryny internetowej: http://Kowalski_2003_Wplyw\%20NBP\%20na\%20inwestycje.pdf.

Kowalski M., Analiza źródet finansowania inwestycji przedsiębiorstw w Polsce, [za:] zasoby witryny internetowej: http://www.wsei.edu.pl/ mkowalski/Kowalski_2004_Analiza\%20Zrodel\%20Finansowania\%20Inwestycji.pdf.

Ł a ch K., Rozwój sektora matych $i$ średnich przedsiębiorstw $w$ Polsce i determinanty tego rozwo$j u$, [za:] zasoby witryny internetowej: www.univ.gda.pl/mikro/konferencja/pdf/Lach.pdf.

Monetary Policy, Transmission mechanism of monetary policy, EBC, [za:] zasoby witryny internetowej: http://www.ecb.europa.eu/mopo/intro/transmission/html/index.en.html.

Narodowy Bank Polski 2001-2006, Narodowy Bank Polski, Warszawa, [za:] zasoby witryny internetowej: http://www.nbp.pl/Home.aspx?f=publikacje/plan_dzialalnosci/nbp_0106.html.

No g a M., Inflacja a wzrost gospodarczy - ujęcie teoretyczne i zastosowania w polityce makroekonomicznej, [za:] zasoby witryny internetowej: http://mikro.univ.szczecin.pl/bp/pdf/88/6.pdf.

Oficjalna witryna internetowa Narodowego Banku Polskiego: www.nbp.pl/statystyka/Pieniezna_i_bankowa/DWN/Zmiany_definicyjne.pdf.

P alu s zak G., Spór o stabilność cen w euroobszarze, [za:] zasoby witryny internetowej: www.konferencja.edu.pl/ref8/pdf/pl/Paluszak-Poznanpolski.pdf

Pi etr zy k G., Nadptynność krajowego sektora banków komercyjnych w roli czynnika zakłócajacego transmisję impulsów polityki pieniężnej do sfery realnej, Akademia Ekonomiczna w Katowicach, ,eFinanse - finansowy kwartalnik internetowy”, [za:] zasoby witryny internetowej: www.e-finanse.com.

Rubrycka-Dettlaff A., Polityka stóp procentowych narodowego banku polskiego i jej implikacje makroekonomiczne w latach 1999 - 2004, [za:] zasoby witryny internetowej: http://pecunia.ue.poznan.pl/pien_ryn_inw/7_A.Rubrycka.pdf.

S z c ze pań s k a O., Instrumenty polityki pieniężnej Eurosystemu, Euro od A do Z, [za:] zasoby oficjalnej witryny internetowej Narodowego Banku Polskiego: www.nbp.pl.

S z y m c zak A., Krótkookresowe i dtugookresowe efekty wptywu stopy procentowej na aktywność inwestycyjna przedsiębiorstw w Polsce, [za:] zasoby witryny internetowej: http://mikro.univ.szczecin.pl/bp/pdf/41/17.pdf.

Wolański R., Wspieranie inwestycji prowadzonych przez mate i średnie przedsiębiorstwa, [za:] zasoby witryny internetowej: http://ekonom.univ.gda.pl/mikro/konferencja/pdf/Wolanski.pdf.

Wój ci k C., Przestanki wyboru reżimu kursu walutowego $w$ teorii i badaniach empirycznych, [za:] zasoby witryny internetowej: http://akson.sgh.waw.pl/ cwojcik/research/Wybor\%20 rezimu.pdf. 
Wstęna informacja o kondycji sektora przedsiębiorstw ze szczególnym uwzględnieniem stanu koniunktury w IV kwartale 2006 roku, [za:] zasoby oficjalnej witryny internetowej Narodowego Banku Polskiego:

http://www.nbp.pl/home.aspx?f=publikacje/koniunktura/koniunktura.html.

Zasoby oficjalnej witryny internetowej Narodowego Banku Polskiego, Warszawa 2007:

http://www.nbp.pl/Home.aspx?f=publikacje/plan_dzialalnosci/nbp_0106.html.

Zasoby oficjalnej witryny internetowej Ministerstwa Gospodarki:

http://www.mg.gov.pl/Przedsiebiorcy/Specjalne+strefy+ekonomiczne.

Zasoby oficjalnej witryny internetowej Stowarzyszenia ACI POLSKA (Stowarzyszenie Rynków Finansowych ACI POLSKA): http://www.acipolska.pl/polonia.html.

Zasoby oficjalnej witryny internetowej Europejskiego Banku Centralnego: http://sdw.ecb.europa.eu/quickview.do?SERIES_KEY=122.ICP.M.U2.N.000000.4.ANR\&pe riodSortOrder=ASC.

Zasoby oficjalnej witryny internetowej Europejskiego Banku Centralnego: http://sdw.ecb.europa.eu/quickview.do?SERIES_KEY=119.ESA.Q.I5.S.0000.B1QG00.1000 .TTTT.L.U.R\&periodSortOrder=ASC.

Zasoby witryny internetowej: European Central Bank - Statistical Data Warehouse, Money Market - Eonia rate: http://sdw.ecb.europa.eu/quickview.do?SERIES_KEY=143.FM.Q.U2. EUR.4F.MM.EONIA.HSTA

Zasoby oficjalnej witryny internetowej Europejskiego Banku Centralnego: http://sdw.ecb.europa.eu/reports.do?node $=100000131$.

Zasoby oficjalnej witryny internetowej Eurostat:

http://epp.eurostat.ec.europa.eu/portal/page/portal/sector_accounts/documents/Charts\%20and \%20Tables_EN_271010_wo_oldS13.xls\#'S11-4'!A1.

Zasoby oficjalnej witryny internetowej Banku PKO BP:

http://www.pkobp.pl/index.php/id=oferta/grupa=5/podgrupa=5/section=misp.

Ży ży ń s ki J., Problemy polityki pieniężnej, [za:] zasoby witryny internetowej: www.wydawnictwo.wz.uw.edu.pl/wpdownload.php?file=workingpaper022005.pdf\&paper=3. 


\section{SPIS TABEL}

1.1. Wady i zalety strategii BCI .........................................................................

1.2. Zakładana i rzeczywista stopa inflacji CPI w Polsce w latach 1998-2009 ............... 35

2.1. Progi oddziaływania polityki pieniężnej na produkt krajowy brutto ................................ 61

2.2. Mechanizm transmisji zmian polityki pieniężnej na gospodarkę w wersji ,koszt i dostępność kredytu" ....................................................................................... $\quad 70$

2.3. Operacje otwartego rynku w Eurosystemie i w Polsce ................................................ 79

2.4. Rezerwa obowiązkowa w Eurosystemie i w Polsce (stan na lipiec 2013 r.) .............. 87

4.1. Nakłady inwestycyjne przedsiębiorstw w Polsce w latach 1998-2012 w mln zł, ceny bieżące ................................................................................................... 139

6.1. Estymacja KMNK, wykorzystane obserwacje 1999:2-2009:4 $(N=43)$ Zmienna zależna: $l d \_I T$ (model 1 dla strefy euro)

6.2. Estymacja KMNK, wykorzystane obserwacje 1999:2-2009:4 $(N=43)$ Zmienna zależna: $l d \_I T$ (model 2 dla strefy euro)

6.3. Estymacja KMNK wykorzystane obserwacje 1998:2-2009:4 $(N=47)$ Zmienna zależna: $l d \_I T$ (modelu 1 dla Polski)

6.4. Estymacja KMNK, wykorzystane obserwacje 1998:2-2009:4 $(N=47)$ Zmienna zależna: $l d \_I T$ (model 2 dla Polski)

6.5. Estymacja KMNK, wykorzystane obserwacje 1998:2-2009:4 $(N=47)$ Zmienna zależna: $l d \_I T$ (model 3 dla Polski)

6.6. Współczynniki korelacji Pearsona pomiędzy inwestycjami a stopą referencyjną wraz z opóźnieniami w Polsce i strefie euro

6.7. Wartości współczynnika korelacji liniowej Pearsona oraz współczynnik determinacji pomiędzy poniższymi zmiennymi w strefie euro w latach 1998-2009

6.8. Współczynniki korelacji Pearsona pomiędzy inwestycjami a stopą referencyjną wraz z opóźnieniami w Polsce i strefie euro 


\section{SPIS RYSUNKÓW}

2.1. Mechanizm transmisji impulsów stóp procentowych polityki pieniężnej EBC ......... 64

3.1. Konsekwencje realizowanej polityki pieniężnej w modelu IS-LM ......................... 92

3.2. Efekty polityki pieniężnej przy średnim nachyleniu linii LM i płaskiej lub stromej linii IS

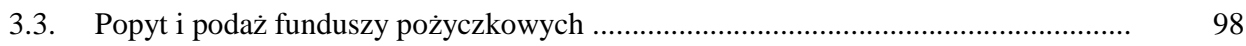

3.4. Podstawowe kształty krzywej dochodowości ............................................................ 99

3.5. Skutki zmian stopy procentowej ........................................................................ 110

3.6. Wpływ podstawowej stopy banku centralnego na wielkości ekonomiczne .............. 113

3.7. Macierz gry monetarno-fiskalnej (dylemat więźnia) ................................................. 119

3.8. Redukcja stopy procentowej jako narzędzie przeciwdziałania pogłębianiu się recesji gospodarczej ......................................................................................... 129

4.1. Podstawowe czynniki determinujące inwestycje trwałe przedsiębiorstw .................. 137 


\section{SPIS WYKRESÓW}

5.1. Podstawowe stopy procentowe EBC w latach 1998-2009

5.2. Poziom inflacji, tempo wzrostu PKB w strefie euro oraz stopa referencyjna EBC w latach 1998-2009

5.3. Stopa referencyjna EBC, średnie nominalne oprocentowanie kredytów dla przedsiębiorstw w strefie euro, EURIBOR 3M oraz EURIBOR 1M w latach 1998-2009 ...

5.4. Stopa referencyjna EBC oraz EONIA w strefie euro w latach 1999-2009

5.5. Kredyty przedsiębiorstw $w$ mld euro oraz średnie nominalne oprocentowanie kredytów dla przedsiębiorstw w strefie euro w latach 1998-2009

5.6. Nominalna i realna stopa referencyjna EBC oraz średnie oprocentowanie kredytów dla przedsiębiorstw i inflacja w strefie euro w latach 1998-2009

5.7. Nominalna i realna stopa referencyjna EBC oraz realne nakłady inwestycyjne w mld euro, w strefie euro w latach 1998-2009

5.8. Wzrost inwestycji przedsiębiorstw w strefie euro w latach 2000-2009

5.9. Stopa inwestycji w strefie euro w latach 2000-2009

5.10. Inflacja CPI, dynamika PKB, stopa referencyjna NBP w latach 1998-2009

5.11. Podstawowe stopy procentowe w Polsce w latach 1998-2009

5.12. Nominalna stopa referencyjna NBP, średnie oprocentowanie kredytów dla przedsiębiorstw oraz stopy rynku międzybankowego WIBOR $1 \mathrm{M}$ i WIBOR 3M w latach 1998-2009

5.13. Realna stopa referencyjna NBP oraz dynamika PKB w Polsce w latach 1998-2009...

5.14. Nominalna stopa referencyjna NBP oraz stawka POLONIA w Polsce w latach 2005-2009

5.15. Inflacja, nominalna stopa referencyjna NBP, realna stopa referencyjna NBP oraz średnie oprocentowanie kredytów dla przedsiębiorstw w Polsce w latach 1998-2009...

5.16. Należności od przedsiębiorstw dla sektora bankowego (w mln zł) oraz średnie oprocentowanie kredytów dla przedsiębiorstw w Polsce w latach 1998-2009

5.17. Nominalna stopa referencyjna NBP, realna stopa referencyjna NBP oraz nakłady inwestycyjne (w mln zł) w Polsce w latach 1998-2009 


\section{SPIS SCHEMATÓW}

2.1. Kanał stopy procentowej ............................................................................... 52

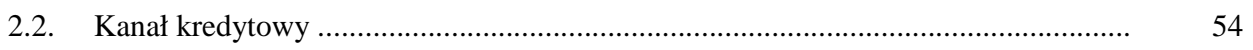

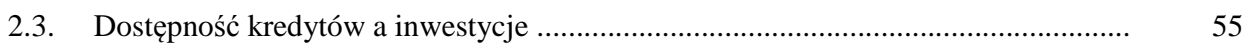

2.4. Kanał bilansowy związany z ceną kapitału ........................................................... 56

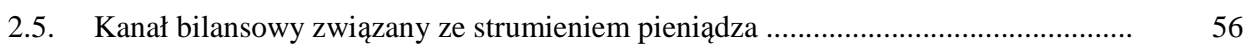

2.6. Kanał bilansowy przedsiębiorstw związany z ogólnym poziomem cen ..................... 57

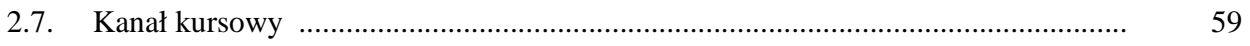

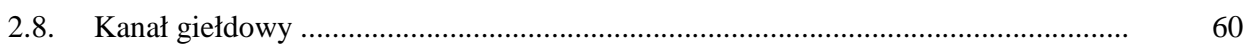




\section{SPIS WZORÓW}

3.1. Zależność między stopami o różnym stopniu terminowości (1) ……........................ 100

3.2. Zależność między stopami o różnym stopniu terminowości (2) ................................ 102

3.3. Reguła Taylora ...................................................................................... 111

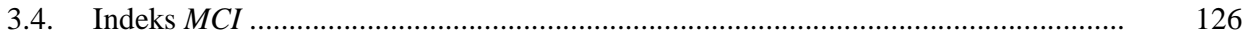

3.5. Wskaźnik MCI - ratio .......................................................................................... 127

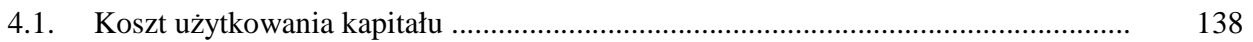

4.2. Przyrost dochodu narodowego ................................................................................

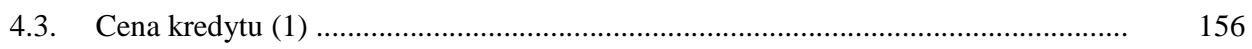

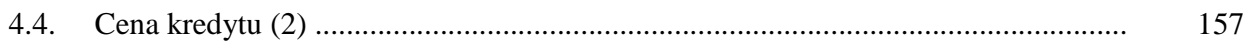

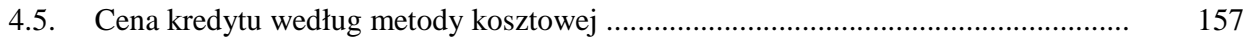

6.1. Równanie regresji ........................................................................................ 218 